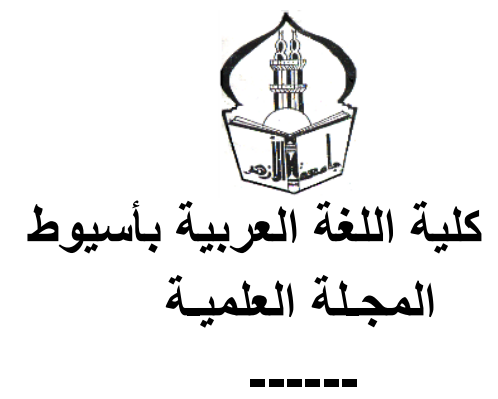

\title{
نصل المقال
}

\section{في الغريب هن الأقوال النهوية والتصريفية}

إعداد

د / عبدالرعوف ثابت أحمد عبد الله

أستاذ اللغويات المساعد في كلية البنات الإسلامية بأسيوط

( العدد الرابع والثلاثون - الجزء الثاني 1 • ب م ) 
فصل المقال في الغريب من الأقوال النحوية والتصريفية د / عبدالرعوف ثابت أحمد عبدالله

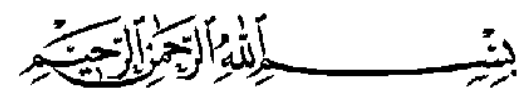

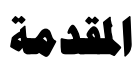

الحمد الله الأي شرف العرب برسوله محمد صلى الله عليه وسلم ، كما شرف العربية بأن جعلها لغة كتابه الكريم ، فهو أحد الأصول السماعية التي اعتمد عليها النحاة في جمع قواعد النحو والتصريف ، بالإضافة إلى كلام النبي صلى الله عليه وسلم ، وكلام العرب قبل بعثته، وفي زمنه، ويعده ، إلى أن فسدت الألسنة بكثرة المولاين نظماً ونثراً.

\section{0}

فإن من المعروف لكل علم قواعد وأصول يعتمد عليه ، ولهذه القواعد

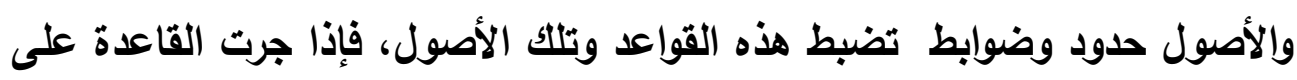
هذه الحدود والأقيسة التي قاسوها، وكثر استعمالها، وسموها بالمطرَّدة، فإذا قل هل استعمالها سواء أكاتت مخالفة للقياس أو موافقة له، وسموها بالقتة أو التدور، ونبهوا على حفظها كما وردت، وعدم القياس عليها لاحتمال أن تكون لغة من لغات العرب الموثوق بعربيتهم.ومن المعلوم أن القليل دون الكثير، والنادر أقل من القليل. أما إذا خالفت الحدود والأقيسة المتعارف عليها من غير نظر إلى قلة وجوده ، وكثرته وسموها بالشذوذ .

وقد تنسحب هذه المعاني على الأقوال والآراء ، فما جرى على ما تعارف عليه النحاة، ووافق الجمهور، والمعنى المذكور فيه يعضده، وسموه بالقوي، أو الصحيح، أو الراجح ، إما إذا لم يصل إلى هذا الحد، وسموه بالمرجوح، أو الضعيف ، فإن انفرد به صاحبه، ولم يقل به أحد من المتقدمين وسموه بالغريب، وأحياناً يطلقون هذا الوصف على ما خالف جمهور النحويين، أو ما خالف جمهور 
فصل المقال في الغريب من الأقوال النحوية والتصريفية د / عبدالرعوف ثابت أحمد عبدالله

البصريين، وأحياناً يطلقونه على الثاذ ، أو النادر، أو القليل، والغالب عليه هو الأول، وهو مااتفرد به صاحبه، ولم يعرفه باقي النحويين، ولقد شد انتباهي خلال مطالعتي لكتب النحو،والتصريف، والتفسير- أمثال: التذييل والتكميل، والجنى الداني ، ومغتي اللبيب، وهمع الهوامع، والبحر المحيط، والدر المصون ، واللباب في علوم الكتاب وغيرها - كثير من الأقوال النحوية والتصريفية الموسومة بالغريب ، وحينئ بدأت أبحث عَمّن كَتَبَ ، أو كُتببَ في هذا الموضوع فلم أقفت فيما وقع تحت يدي من مصادر على أحد قيماً أو حديثاً تناول ظاهرة الآراء الغريبة في كتب النحو والتصريف، فاستخرت الله وعزمت على جمعها ، وييان وجه الغرابة فيها، ودراستها ، ومناقشتها ، وهل هذه الآراء غريبة حقاً أم أنها يمكن أن تحمل على القليل ، أو الشاذ ، أو الضعيف ، أم أنها آراء فريدة انفرد بها أصحابها، ولا وجه للغرابة فيها غير أن الناعت لم يطلع على ما كتبه العلماء في هذه القضية ، وخاصة لو كان صاحب هذا القول مما له وزنه وقدره في العربية وسميتها :

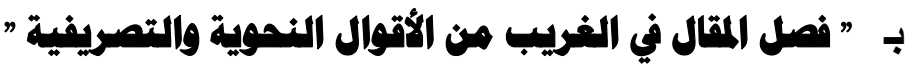
وقد اقتضت طبيعة البحث أن يأتي في مبحثين تسبقهما مقدمة وتمهيد، وتتبعهما خاتمة، وفهرس لأهم المصادر والمراجع، وآخر لموضوعات البحث . أما الاقدمة : فتحدثت فيها عن أهمية الموضوع ، والدافع إلى اختياره، والمنهج الذي سرث عليه

وأها التمهيد : فتحثث فيه عن مفهوم الغريب ، وعلاقته ببعض المصطلحات التي لها صلة وثيقة به أمثال : المطرد، والثاذ، والنادر، والضعيف، والضرورة. وأها المبمث الأهول : فنكرت فيه الأقوال والآراء النحوية الغريبة. وأما المبمث الثاني: فذكرت فيه الأقوال والآراء التصريفية الغريبة وأما الخاتمة: فتحدثت فيها عن أهم النتائج التي توصلت إليها . 
فصل المقال في الغريب من الأقوال النحوية والتصريفية د / عبدالرعوف ثابت أحمد عبدالله

وأخيرا: ذيلت البحث بفهرس لأهم المراجع والمصادر، وأخر لموضوعات البحث. ولقد اتبعت في هذا البمث المنهم التالي :

أولاً : وضعت عنواناً لكل قول أو رأي يتناسب مع موضوعه. ثانيا : ذكرت النص الذي يشير إلى أن هذا القول أو الرأي غريب. ثالث) : أظهرت وجه الغرابة من وجهة نظر ناعته بالغريب. رابعك : قمت بدراسة ومناقشة القول من كتب النحو، والتصريف ، واللغة ، ومعاني

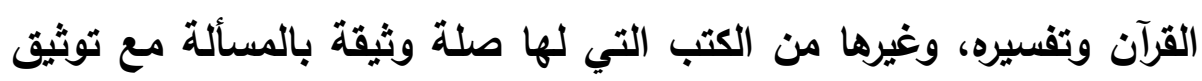
الآراء التي ذكرتها من كتب أصحابها ، وإلا فمن الكتب المهتمة بجمع الآراء. خامسك: خرجت الآيات القرآنية ، فنكرت اسم السورة، ورقم الآية.

سادسك) : خرجت القراءات القرآنية من كتب القراءات، والتفسير، ومعاني القرآن. سابهك : خرجت الأحاديث النبوية من كتب الصحاح، والسنن ، والمسانيد . ثامنا : وثثت الأمثال الواردة من كتب الأمثال. تاسعك : حققت الثواهد الثعرية والأرجاز، فنكرت بحر البيث، وقائله، وموطنه في ديوان صاحبه ، وإلا فمن الكتب المتخصصة في الشعر، والثاهد فيه، ويعض مواضعه في كتب التحو والتصريف ، واللغة .

\section{9}

فهذا بحثي بألت فيه قصارى جهدي من جمع ومناقشة ما تيسر لي جمعه ، فإن أكن قد وفقت فيما قصدت فلله الفضل والمنة ، وإن تكن الأخرى فحسبي أنتي اجتهدت والله من وراء القصد، فإنه نعم المولى ونعم النصير.

\section{נكتهر}

\section{عبدالرورف ثابت أهمد عبدالاله}

أستاذ الغويات المساعد في كلية البنات الإسلامية بأسيوط. 
فصل المقال في الغريب من الأقوال النحوية والتصريفية د / عبدالرعوف ثابت أحمد عبدالله

\section{التمهمهيد \\ مفهوم الغريب}

الغريب من الكلام إنما هو الغامضُ (1) البعيدُ من الفهرِ ، كالغريبٍ من الناسِ ، إنما هو البعيدُ عن الوطن المنقطع عن الأهل ، ومنه قوللك للرجلِ إذا نحَّبِتهُ

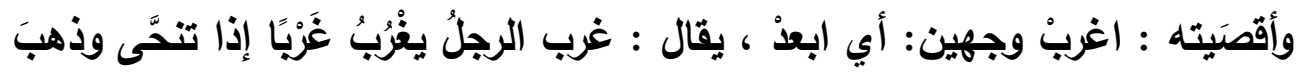

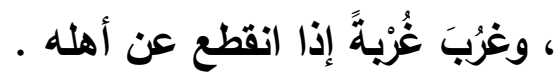

قال أبو سليمان محمد الخطابي(r) : في شرح معنى الغريب واشتقاقه: إن الغزيب من الكلام إنما هو الغامض البعيد من الفهم كالغزيب من الناس ، وقال: إن الغريب من الكلام يستعمل على وجهين : "أحدهما: أن يراد أنه بعيد المعنى غامضه لا يتتاوله الفهم إلا عن بعد ومعاناة فكر. والوجه الآخر: أن يراد به كلام من بعدت به الدار من شواذ قبائل العرب فإذا وقعت إلينا الكلمة من لغاتهم استغريناها ". ويناءً على هذا المعنى فقد أطلق مصطلح الغريب على كل لفظة وردث في القرآن الكريم قد بعُد معناها ، ولم يكن واضحاً عند العامة من الناس ، بل وضوحه اقتصر على خاصتهم فقط ، هذا ما أشار إليه الزجاجي - في معرض حديثه عن

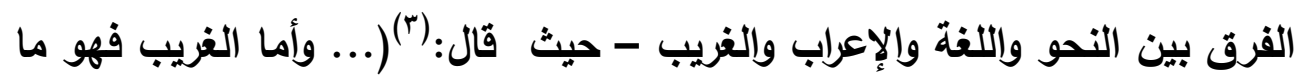
قل استماعه في اللغة ، ولم يلر في أفواه العامة كما دار في أفواه الخاصة، كقولهم : صكمت الرجل، أي: لكمته ، وكقولهم للشمس : يوح ،....إلى أن قال: وهذا وما أشبهه، وإن كان غريباً عند قوم، فهو معروف عند العلماء، وليس كل العرب

$$
\begin{aligned}
& \text { (1) ينظر تهذيب اللغة : 1 / } 110 \text { ( غرب) . }
\end{aligned}
$$

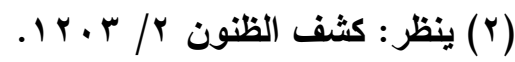

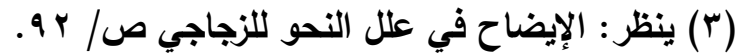


فصل المقال في الغريب من الأقوال النحوية والتصريفية د البدالرعوف ثابت أحمد عبدالله

يعرفون اللغة كلها غريبها وواضحها ومستعملها وشاذها، بل هم في ذلك طبقات يتفاضلون فيها ، كما أنه ليس كلهم يقول الشعر، ويعرف الأنساب كلها، إذ إنما هو في بعض دون بعض، وأما اللغة الواضحة المستعملة سوى الشاذ والنوادر فهم فيها شرع واحد). فعلم غريب القرآن هو العلم المختص بتفسير الألفاظ الغامضة في القرآن

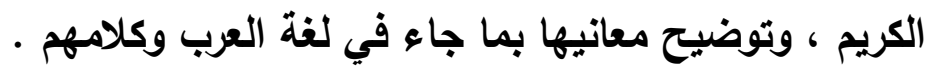
فقد سئل ابن عباس رضي الله تعالى عنه عن معنى قوله: "وأباً " من قوله

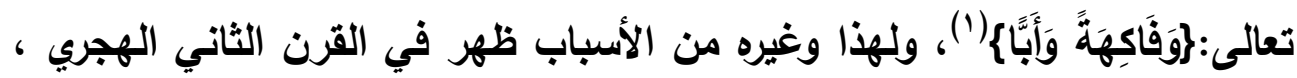
وما تلاه الكثير من المصنفات في غريب القرآن وييان معانيه أمثال : غريب القرآن لمؤرج السدوسي المتوفي (09 19ه) (r)، وغريب القرآن ليحيى بن المبارك بن المغيرة أبومحمد اليزيلي (r r r هـ) (r)، وتفسير غريب القرآن لابن قتيبة الاينوري

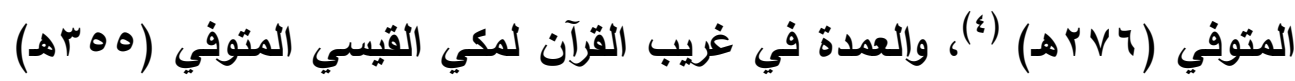

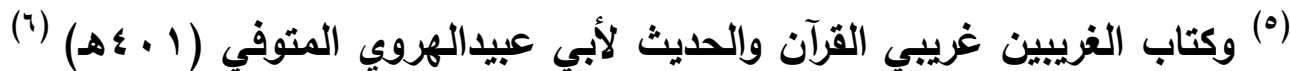

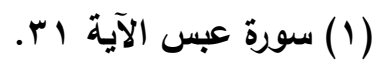

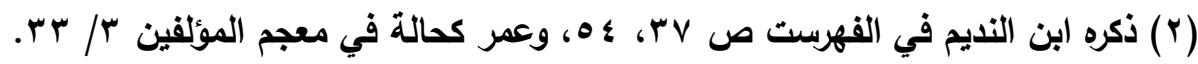

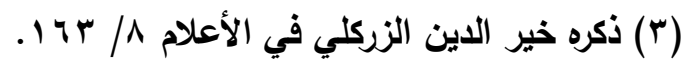

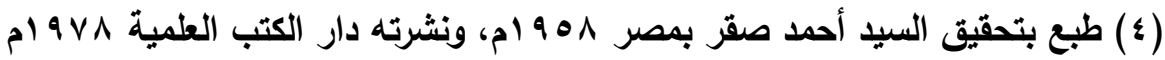

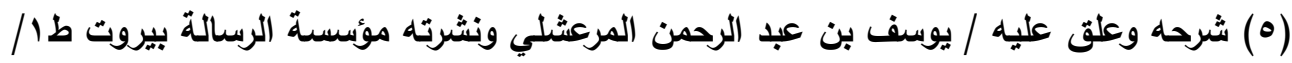

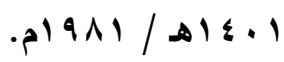
(†) طبع بتحقيق الأستاذ/محمود محمد الطناحي ونشره المجلس الأعلى للشئون الإسلامية

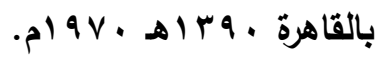


فصل المقال في الغريب من الأقوال النحوية والتصريفية د / عبدالرعوف ثابت أحمد عبدالله

ومفردات غريب القرآن للراغب الأصفهاني المتوفي (r 0هـ)، (') ، وغرائب التفسير

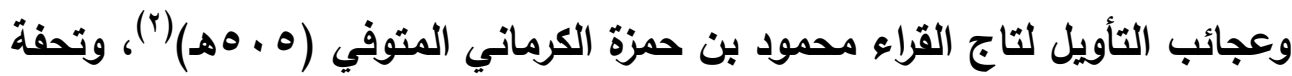
الأريب بما في القرآن من الغريب لأبي حيان الأندلسي المتوفي( والعمدة في تفسير أشرف الألفاظ للسمين الحلبي المتوفي( ؟ ه Vه)(؛)، وغير ذلك. وقا نهج هذا النهج جماعة من المحثثين ، فصنفوا في غريب الحديث

أمثال: غريب الحديث لأبي عبيد القاسم بن سلام الهروي المتوفي ؟ ؟ Y"هـ).(•) وغريب الحديث لإبراهيم بن إسحاق بن إبراهيم بن بشير البغدادي الحَرْبي المتوفي

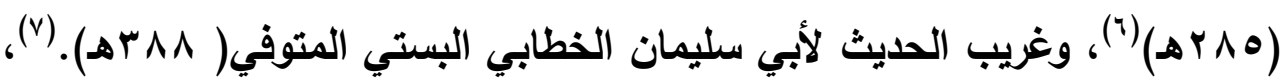

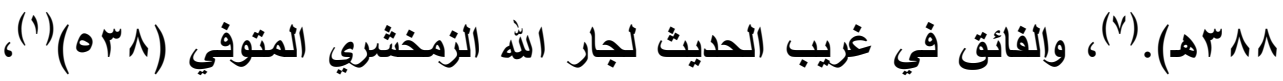

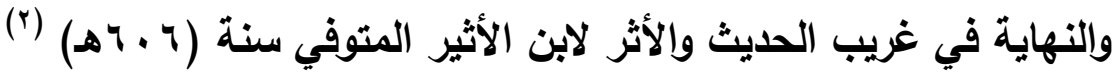

(1) طبع مراراً ومنها طبعة ، ضبط ومراجعة / محمد خليل عيتاني ونشرته دار المعرفة بيروت

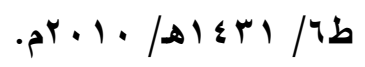

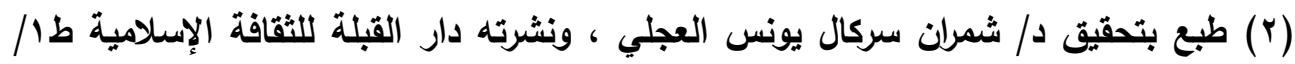

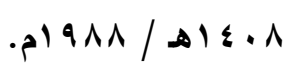

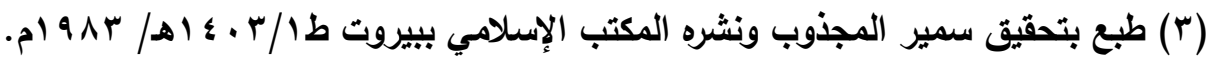

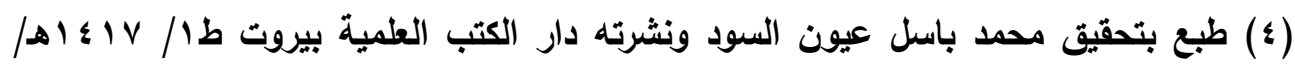
. 1997

(ه) طبع تحت مراقبة د/ محمد عبدالمعين خان ونشرته دار المعارف الإسلامية بحيدر آباد الدكن

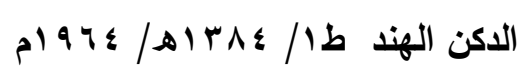

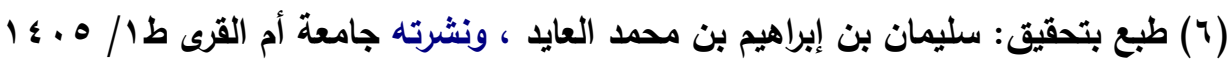

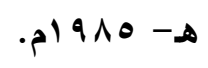

، طبع بتحقيق عبد الكريم إبراهيم العزياوي ونشرته جامعة أم القرى - مكة المكرمة (V) 
فصل المقال في الغريب من الأقوال النحوية والتصريفية د / عبدالرعوف ثابت أحمد عبدالله

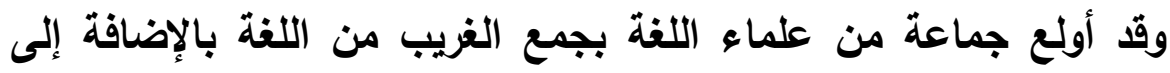

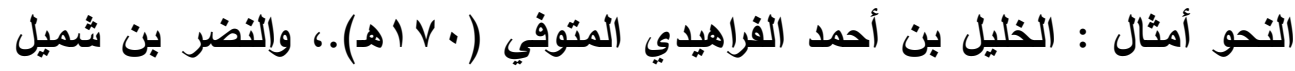

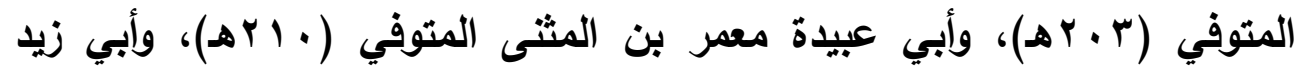

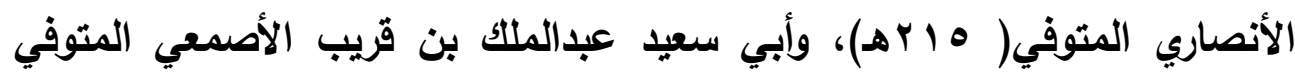

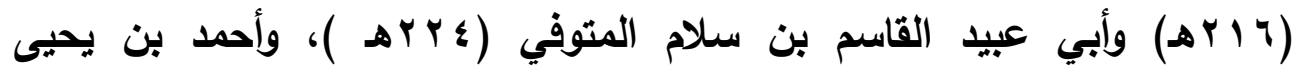

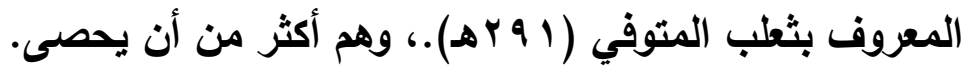

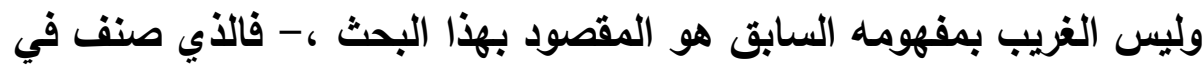
غريب القرآن، أو في غريب الحديث، أو الغريب في اللغة، عني به الألفاظ الغريبة

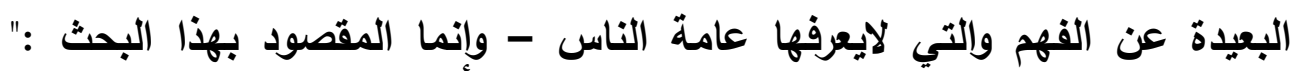
الغريب من الأقوال النحوية، أو التصريفية المنتشرة في كتب النحو، والتصريف ، واللغة ، ومعاني القرآن وتفسيره " ، والتي يطلقونها على التالي:

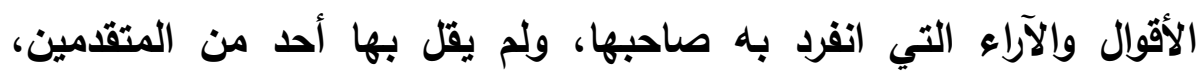
وأحياناً يطلقون هذا الوصف على ما خالف جمهور النحويين، أو ما خالف جمهور

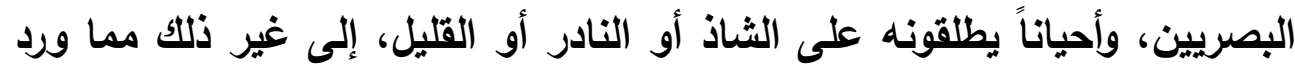
في هذا البحث ، ومن أمثثة ذلك :

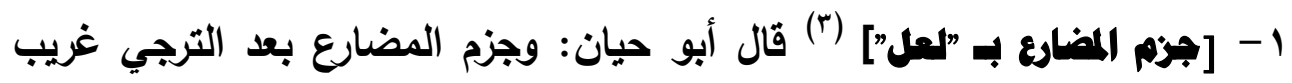

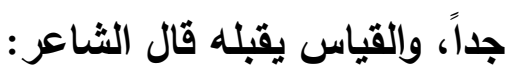

(1) طبع مرار ، ومنها طبعة بتحقيق/محمد أبوالفضل إبراهيم، ومحمدعلي البيجاوي، مطبعة

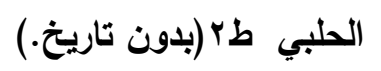

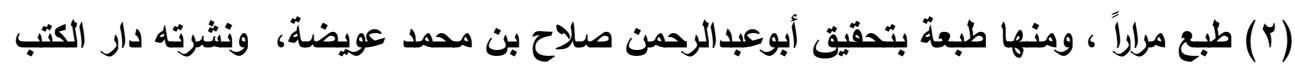

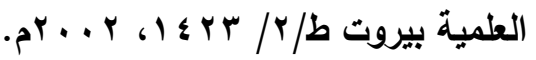

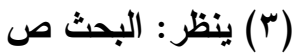


فصل المقال في الغريب من الأقوال النحوية والتصريفية د / عبدالرعوف ثابت أحمد عبدالله

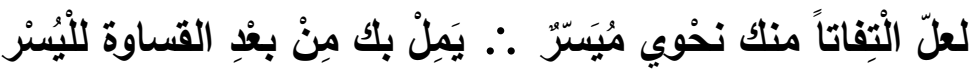
هذا القول نقله أبو حيان، وابن هثام، وناظر الجيش عن ابن مالكك ،

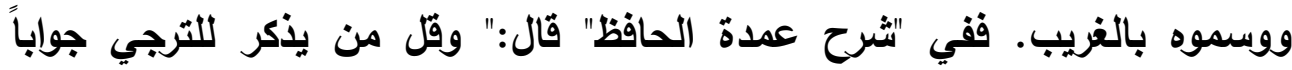

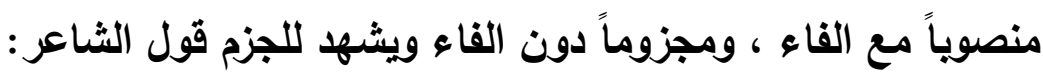

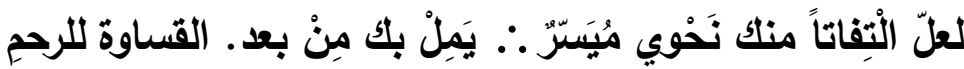
ووجه غرابته كما قال البذادي: إنه لا يعرف لغير (بن مالك ... ويالبحث

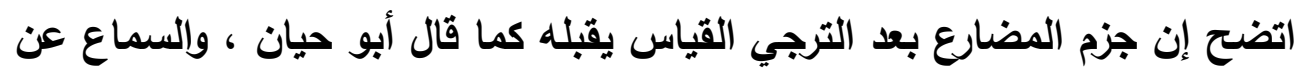
العرب يشهل له، والغرابة فيه انفراد ابن مالكك به، وهذا يعد من بدائع ابن مالك رحمة الله عليه --. r - [الفاء لا تغيد الترتيب والواو تفيده]. (') نقل عن الفراء أنه قال: إن الفاء لا تفيل الترتيب مطلقاً، قال ابن هشام: " وهذا غريب مع قوله : إن الواو تفيد الترتيب". ووجه غرابته أن الفراء بذلك خالف جمهور النحويين الذين يرون أنساء العاطفة تفيل الترتيب، كما أن الواو لا تفيد ترتيباً وإنما هي لمطلق الجمع بين

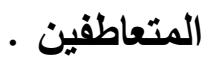

واحتج الفراء على صحة قوله "إن الفاء لا تفيد الترتيب مطلقاً" بقوله تعالى:

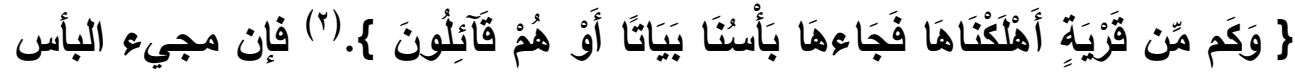
قبل الهلاك، وليس مترتباً عليه.

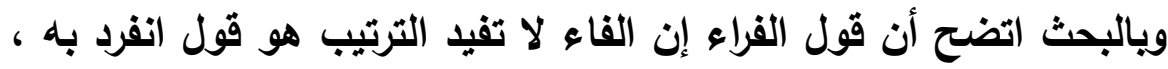
وخالف به جمهور النحويين، وما استدل به يشهر بصحة قوله، فذهبه ليس بغريب، فالفراء حجة يحتج بقوله كما سيأتي بيانه في دراسة المسألة .

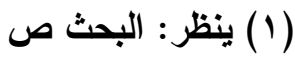

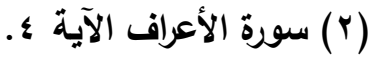


r- [هجيs "الفاء" بمعنى "إلى"] (1) نقل عن بعض البذاديين أن الفاء قد تأتي

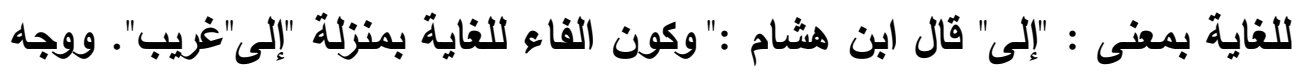

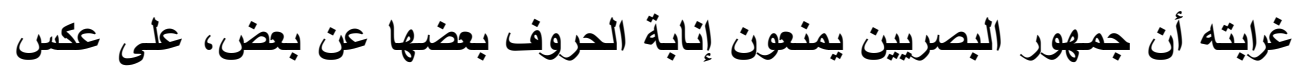
الكوفيين الذين يقولون بإنابة الحروف بعضها عن بعض، وهو مشهور في حروف به

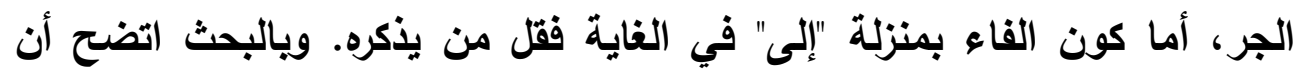

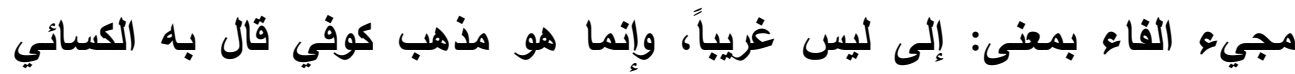

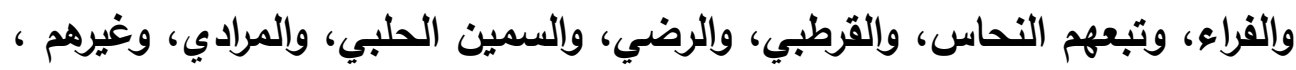
وحكاه العسكري ، وإين هشام عن بعض البغداديين.

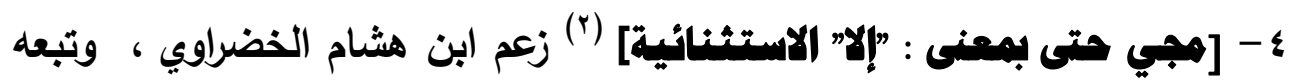
ابن مالك أن حتى تكون بمعنى: "إلا" الاستثنائية كقوله:

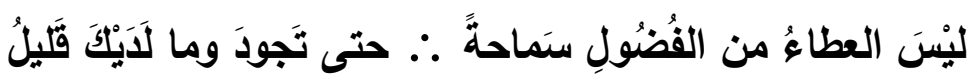
أي: إلا تجود، وهو - أي أن تجود - استثناء منقطع؛ لأن الجود في حالة قلة الماله المال ليس من جنس المستثنى منه ، وهو العطاء في حالة الكثرة .

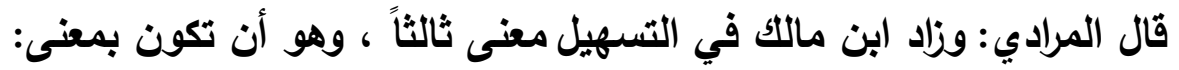
إلا أن، فتكون بمعنى الاستثناء المنقطع. كقول الثاعر :

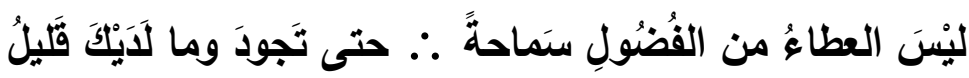
وهو معنى غريب، ذكره ابن هشام، وحكاه في البسيط عن بعضهم....

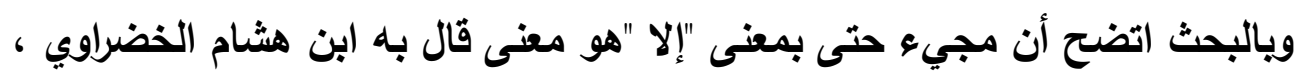

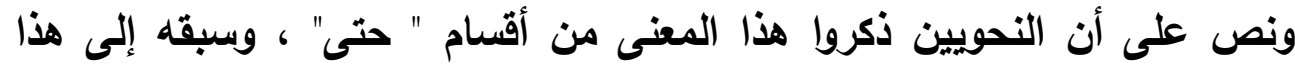

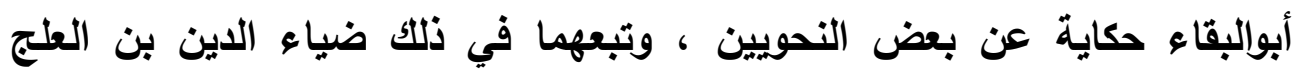

$$
\text { (1) ينظر : بنظر : البحث ص البحث ص }
$$


فصل المقال في الغريب من الأقوال النحوية والتصريفية د / عبدالرعوف ثابت أحمد عبدالله

صاحب البسيط ، وجمال الدين بن مالك، ونص عيله أبوحيان ‘والسمين الحلبي ، وابن هشام الأنصاري، وابن عادل الحنبلي “والثيخ خالد الأزهري، والسيوطي “ولم ينص أحد منهم على غرابته ، وهو الظاهر من عبارة سيبويه، وارتضاه البغدادي في

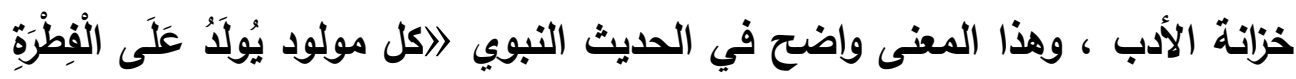

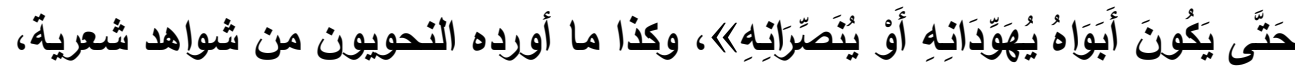
وأما في الآية التي ذكرها أبوالبقاء العكبري فهو رأي مرجوح ، ويناء على هذا أقول : إن هذا المعنى يضاف إلى معاني "حتى" ولا غرابة فيه. وهذا هو ما رجحه الامامينى، والثمني، في كتابيهما على مغتي اللبيب، قال الشمني:" يعني أن الراجح في هذا البيث أن تكون للاستثناء المنقطع ، ويحتمل الغاية احتمالاً مرجوحاً بأن يكون المعنى أن انتفاء كون إعطائك معدوداً من السماحة ممتداً إلى زمن عطائك في حال قلة مالك فإذا أعطيت في تلك الحالة تثبت سماحتك...." . . والله أعلم. ه - [ جواب " لو" فمل تعبب مقرونك باللام، أو همدر بـ"رب" أو ماضي مقرونك "بقد"] (1) قال أبوحيان: "ومن غريب ما وقع جواب "لو" فعل تعجب بصيغة " أفعل"مقروناً بالكلام قال الشاعر: فلو متُّ في قومي ولم آتِ عجزةً . يضعقني فيها امروٌٌ غيرَ عادلِ

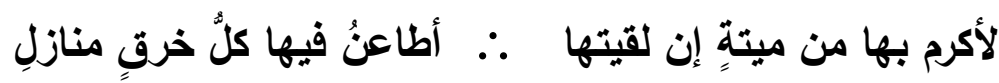
وَربَّ مقروناً باللام قال الثاعر:

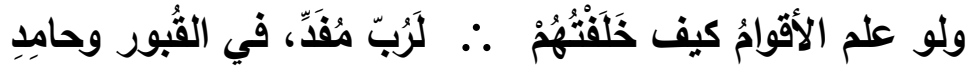
وقال ابن هشام: " وقد ورد جواب لو الماضي مقروناً بقد ، وهو غريب كقول جرير:

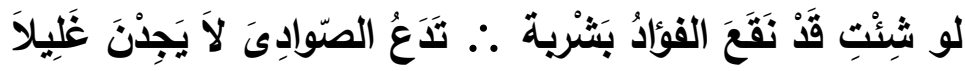

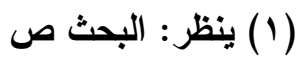


فصل المقال في الغريب من الأقوال النحوية والتصريفية د البدالرعوف ثابت أحمد عبدالله

ووجه الغرابة في هذه الأجوية ؛ قلة الاستعمال وندرته ، ولهذا عدَّها السيوطي في "الكهمع " من باب النادر.

ويالبحث اتضح أن مجيء جواب "لو" فعل تعجب بصيغة "أفعل" مقروناً باللام،

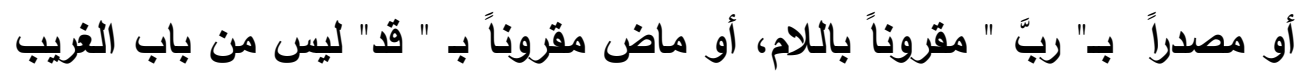
وإنما هو من باب القليل النادر الأي يحفظ ولا يقاس عليه . צ- [ فَعيلة فمن الصيغ قليلة الاستعمال] (1) قال الزمخشري عند تعرضه لقراعة أبي

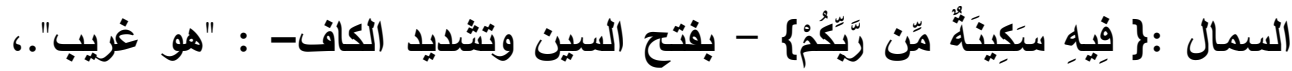
ووجه غرابته ؛ أن صيغة ( فَمَّيلة) من الصيغ قليلة الاستعمال في لغة العرب ، ولم تسمع " فَمَّلة " إلا في لغة حكاها أبوزيد الأنصارى في نوادره ـ ويالبحث اتضح أن تثديد العين في "فعيلة " ليس غريباً، وإنما هو لغة من لغات العرب قرأ بها أبو السمال ، وحكاها أبو زيد الأنصاري وهو ثقة يحتج بقوله في اللغة، وحكاها أيضاً ثعلب عن الفراء ، كما حكاها أبو الحسن الأخفش. צ- [الجر بـ" لعل] (ז) قال أبو حيان: ومن غرائب المنقول أن الفراء ذهب إلى جواز الخفض بـ "لعل"، وإجازة نصب الخبر ورفعه: والأصل: لعاً لعبدِ الله. قال: فمن نصب قال: لا يكون الاسم مخفوضاً، وفعله مرفوع. ونصبه عنده على التفسير كقولك : ما

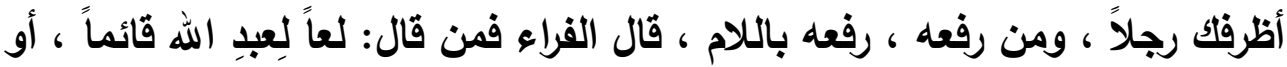

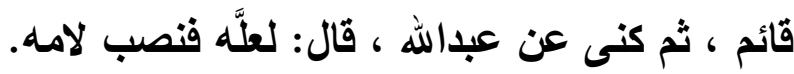
وهذا عند البصريين خطأ، لأنه إن أراد أن يخفض بـ " لعل" جاء بخلاف ما

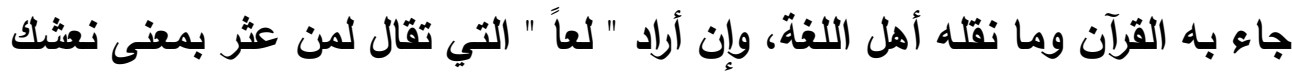
الله ، ضد تعساً ، فلا معنى لها هنا ، ولا لأكرها مع إن وأخواتها ."

$$
\text { (1) ينظر : بنظر : البحث ص البحث ص }
$$


فصل المقال في الغريب من الأقوال النحوية والتصريفية د / عبدالرعوف ثابت أحمد عبدالله

ووجه الغرابة كما زعم أبوحيان أن الجر بها لم يقع في القرآن ، ولم ينقل

عن العرب، كما أنه لابد للجار والمجرور من متعلق ، ولا متعلق لها هنا...ويالبحث

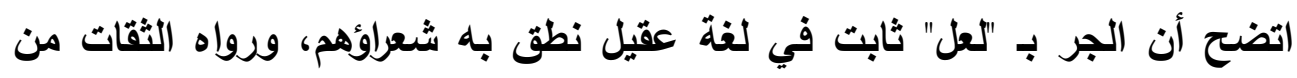

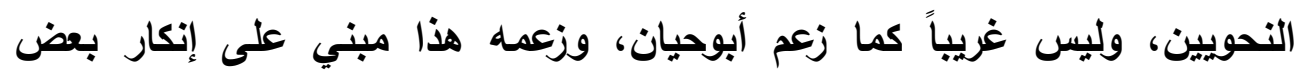

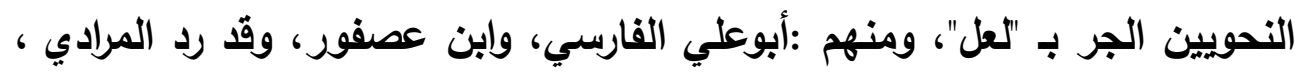

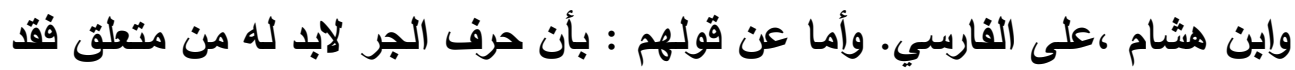
ذكر ابن هثام في الباب الثالث من المغتي مالا يتعلق بشيء من حروف الجر

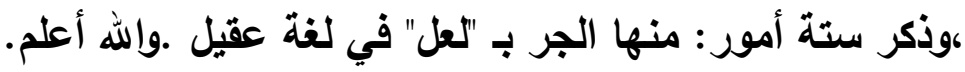
إلى غير ذلك من تعليقات للنحويين تفيد أن المقصود من الغريب من فن النه الأقوال النحوية أو التصريفية هو : ما انفرد به صاحبه .

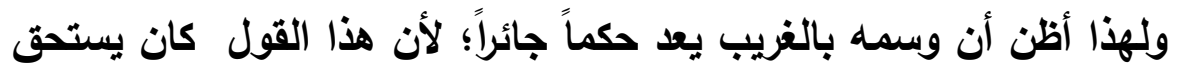

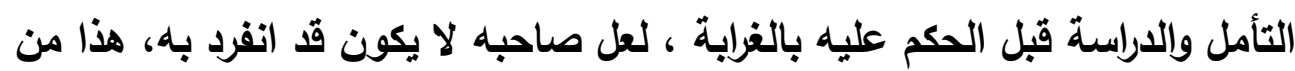

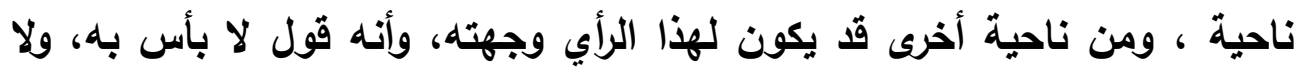
غبار عليه، واجتهاد محمود من صاحبه ، وانفراد بديع قـ يضيف جديداً ؛ فلماذا

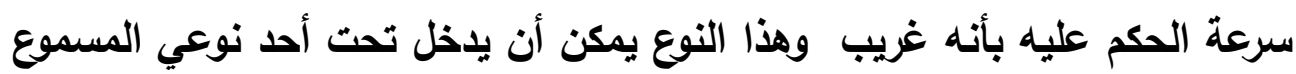

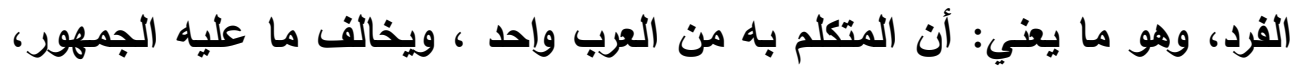

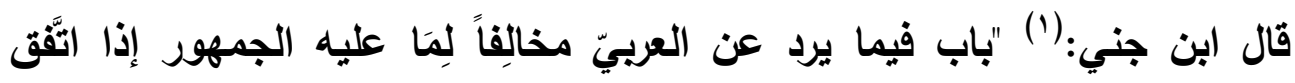

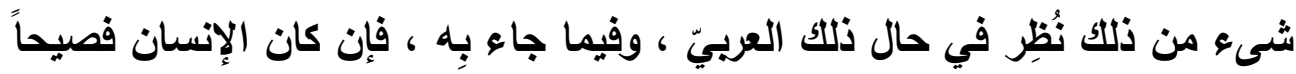

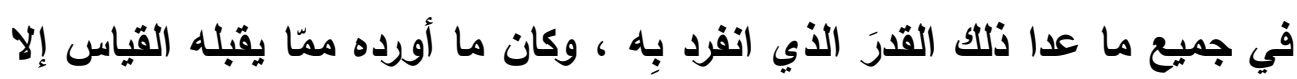

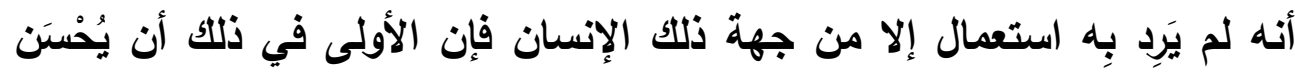

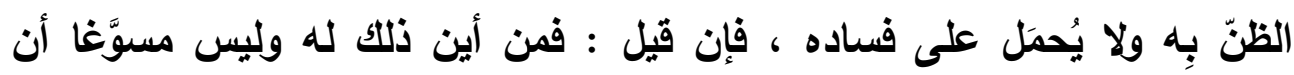

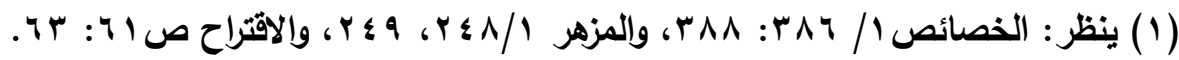


فصل المقال في الغريب من الأقوال النحوية والتصريفية د / عبدالرعوف ثابت أحمد عبدالله

يرتجل لغة لنفسه ؟ قيل : قد يمكن أن يكون ذلك وقع إليه من لغةٍ قديمةٍ قـ طال عهذُها، وعفا رسمها، وتأبَّبت معالمها... إلى أن قال: "فإِاذا كان الأمر كذلك لم نقطع على الفصيح يُسمَع منه ما ما يخالف الجمهور بالخطأ ما وُجد طريق إلى تقبّل ما يورِده إذا كان القياس يعاضده ، فإن لم يكن القياس مسوّغاً له كرفع المفعول، وجرّ الفاعل، ورفع المضاف إليه فينبغي أن يُردّ؛ وذلك لأنه جاء مخالفاً للقياس والسماع جميعاً، فلم يبق له عِصنمة

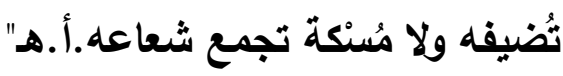
ويناءً على هذا يكون القول أو الرأي الأي انفرد به صاحبه يكون بليعاً فصيحاً وخاصة إذا لم يوجد فيه ما يضعفه، وكذا إذا ثبت أنه لم ينفرد به، بل قال بقوله جماعة من العلماء الثقات كما أثبتت الدراسة ذلك مع كثير من هذه الأقوال والآراء التي أوردتها في هذا البحث ، فهو يستحق بذلك أن يخرج من دائرة الغريب

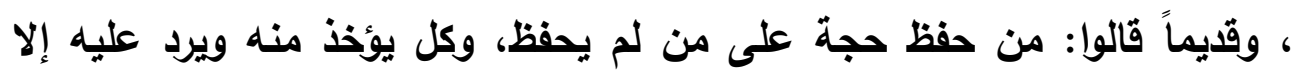

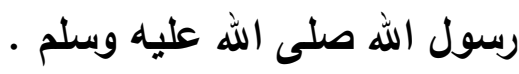

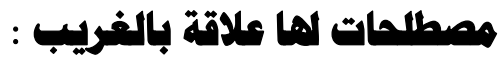
بما أن الغريب خلاف المطرد ، فقد يطلق أحياناً على الثاذ ، أو النادر، أو القليل، أو الضرورة ، أو الضعيف ، فقررث أن أقدم نبذة مختصرة عن مفهوم هذه المصطاح لتكتمل الفائدة . أورةً : الإطود.

الاطراد معناه: التتابع والاستمرار، يقال: اطرَّرَ الثيعُ ، أي تبعَ بعضُه بعضاً

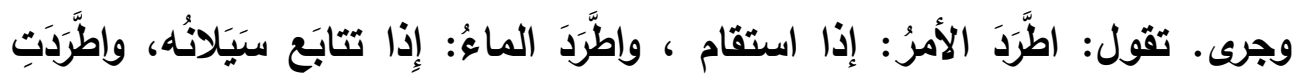

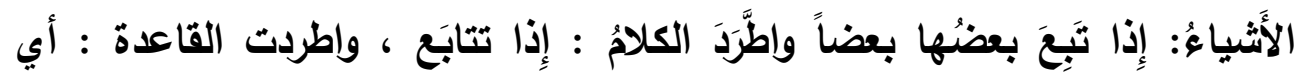


فصل المقال في الغريب من الأقوال النحوية والتصريفية د / عبدالرعوف ثابت أحمد عبدالله

انتشرث ، وكثر استعمالها، وجرى الكلام على القياس المعهود ـ قال الرماني : (1) "المطرد الجاري على النظائر.

قانيا: البشاذ.

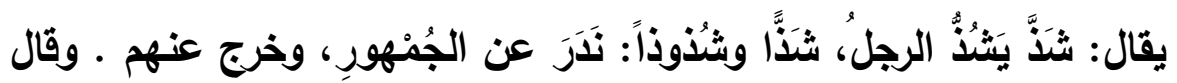

الليث: (ץ) "شذ الرجل، إذا انفرد عن أصحابه، وكذالك كل شيع منفرد فهو شاذ.، وفي لسان العرب(ז) " وسمى أهل النحو ما فارق ما عليه بقية بابه." وَالثَّاذٌ فِي

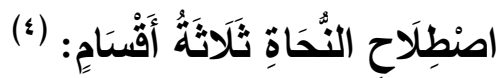

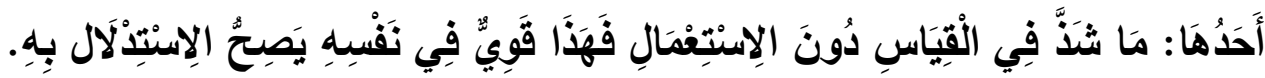

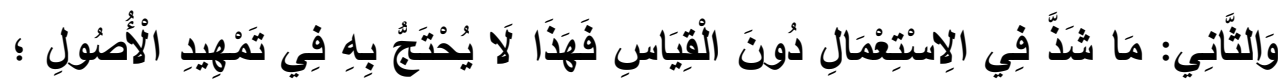

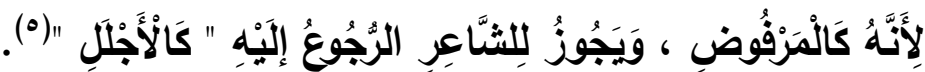

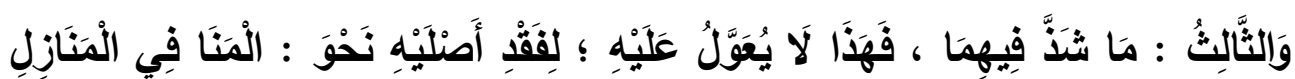

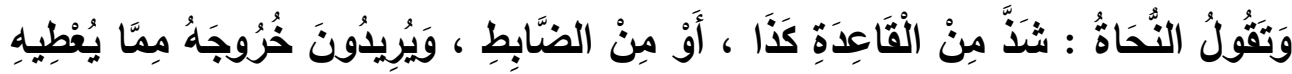

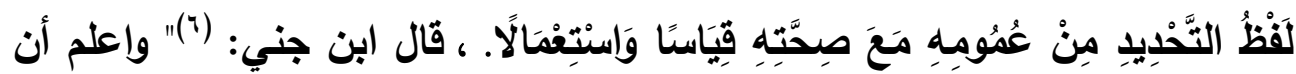

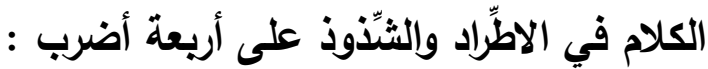

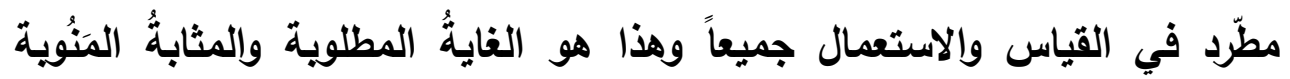
وذلك نحو: قام زيد ، وضريت عمراً ، ومررث بسعيد .

(1) ينظر : الحدود للرماني ص ع ؛.

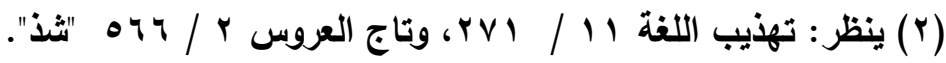

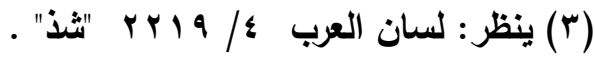

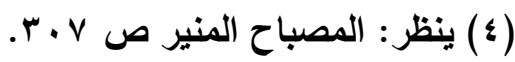
(ه) ينظر : إلى قول الراجز * الحمدُ لله العلي الأجلَلِ * يريد الأَجَلَّ، فأظهر التضعيف ضرورةً.

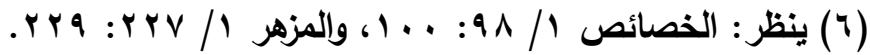


فصل المقال في الغريب من الأقوال النحوية والتصريفية د / عبدالرعوف ثابت أحمد عبدالله

ومطرّد في القياس شاذّ في الاستعمال وذلك نحو : الماضي من يَََر، ويَََع ، ويََع وكذلك قُولهم : مَكانُ مُبقِل هذا هو القياس ، والأكثر في السماع بأقل والأوّل

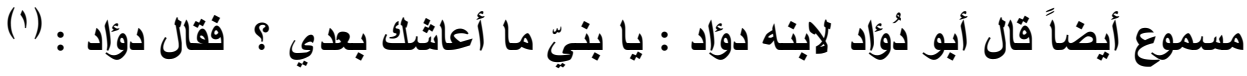
أعاشني بعدك وادٍ مُبْقِلْ . وقد حكى أيضاً أبو زيد في كتاب (حيلة ومحالة) : مَكانُ مُبْقلِل ،

ومما يقوى في القياس ويضعف في الاستعمال مفعول عسى أُسمْاً صَرِيحاً نحو قولك :عسى زيا قائماً ، أو قياماً ، هذا هو القياس غير أن السماع ورد بحَظْره والاقتصار على ترك استعمال الاسم ههنا وذلك قولهم : عسى زيد أن يقوم، و\}

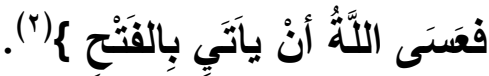

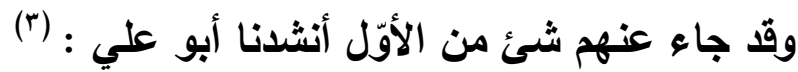

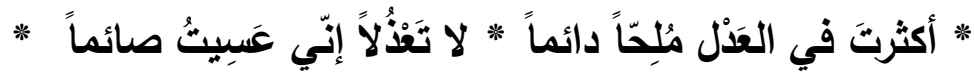

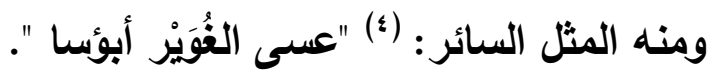

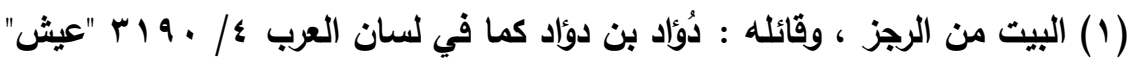

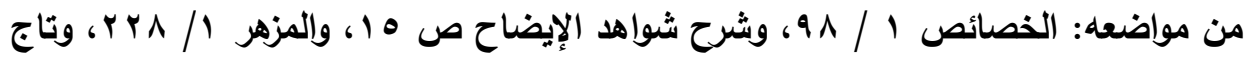

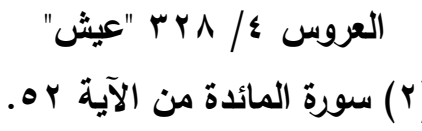

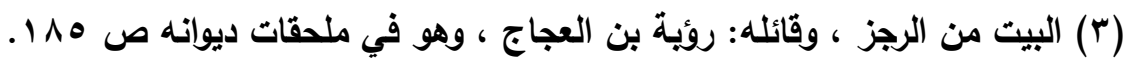

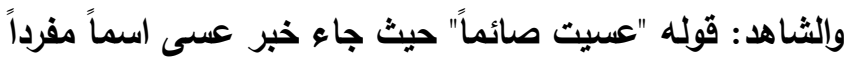

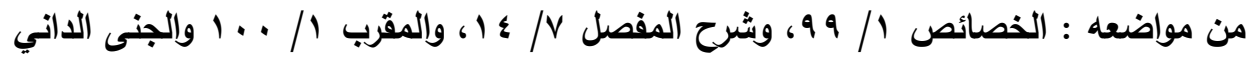

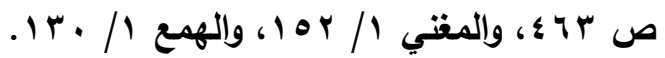

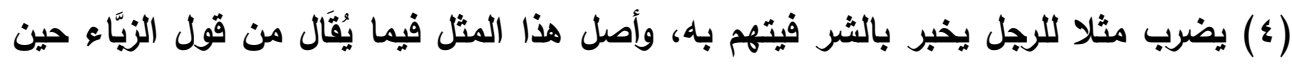

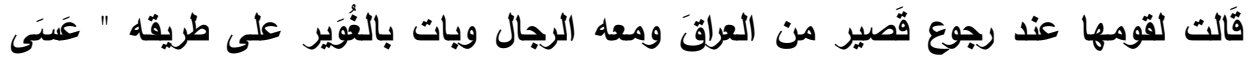


فصل المقال في الغريب من الأقوال النحوية والتصريفية د / عبدالرعوف ثابت أحمد عبدالله

والثالث : المطّرد في الاستعمال الثاذّ في القياس نحو: قولههم : أخوْص الرِمْتث ، وإستصويت الأمر. أخبرنا أبو بكر محمد بن الحسن عن أحمد بن يحيى قال : يقال:

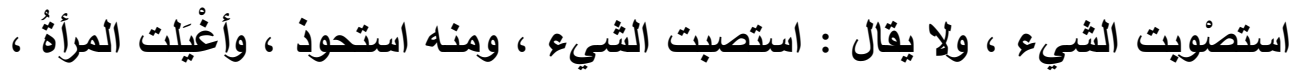

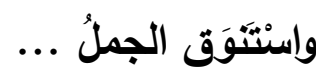
والرابع : الثاذّ في القياس والاستعمال جميعاً ، وهو كتتميم مفعول فيما عينه واو

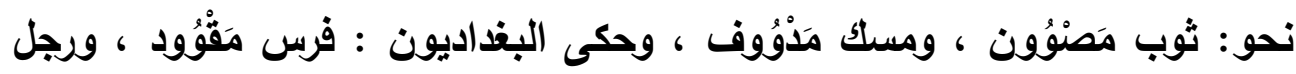

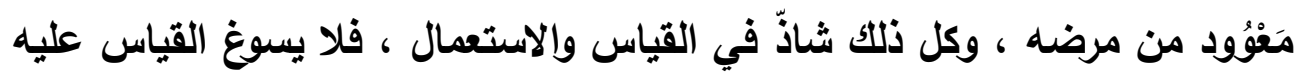

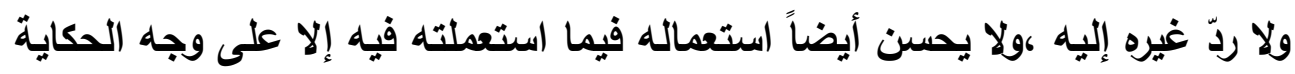

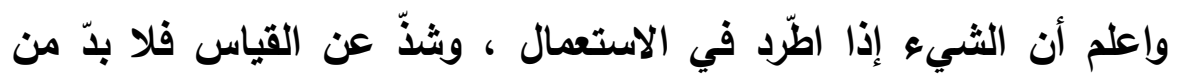

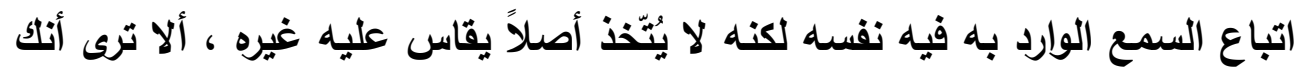

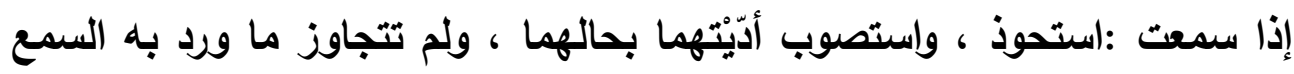

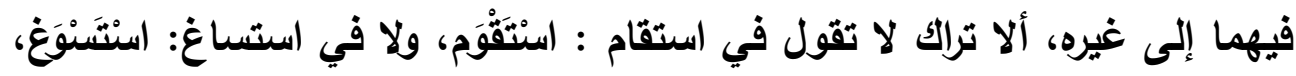

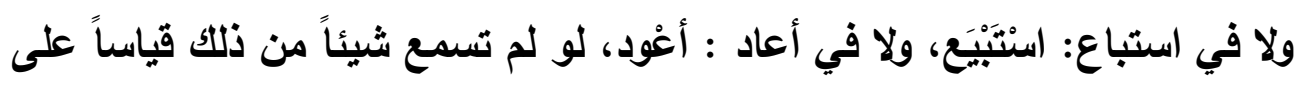

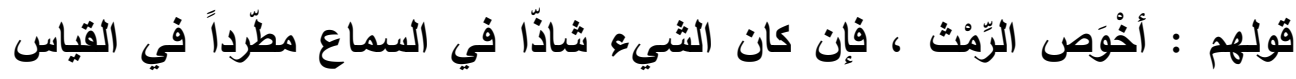

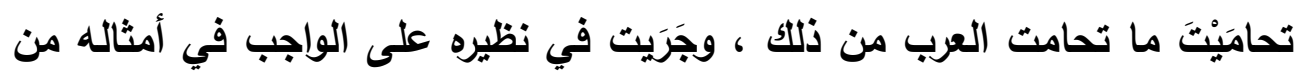

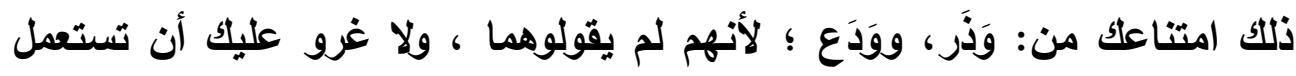

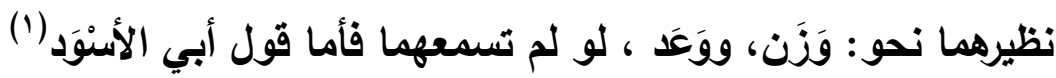

الغُويُُ أبؤسا " أي لعل الثُرَّ يأتيكم من قبل الغار - ينظر مجمع الأمثال r/ اء؟ب رقم: . $r \leqslant r_{0}$

(1) البيت من من الرمل ، وقائله: أبوالأسود الدؤلي وهو في ملحقات ديوانه . هr.

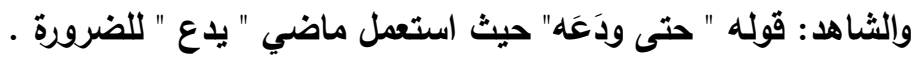


فصل المقال في الغريب من الأقوال النحوية والتصريفية د / عبدالرعوف ثابت أحمد عبدالله

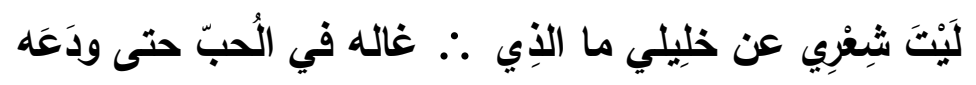

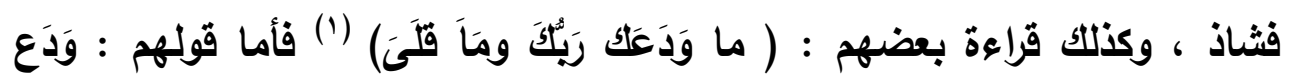

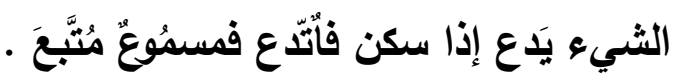

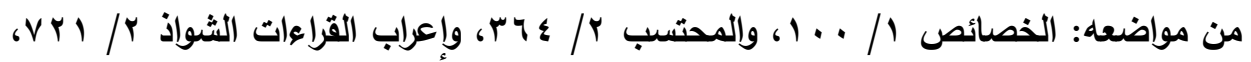

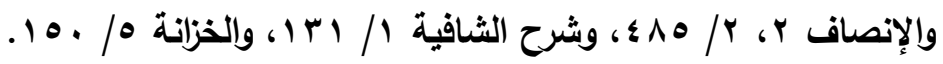

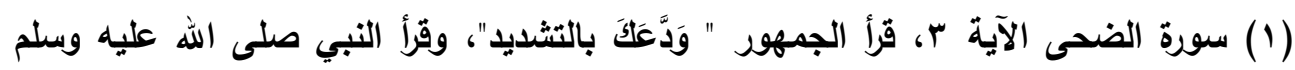

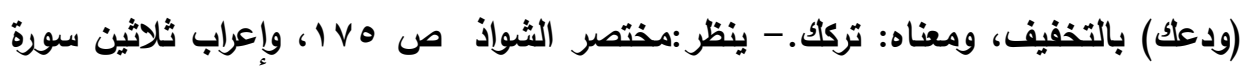

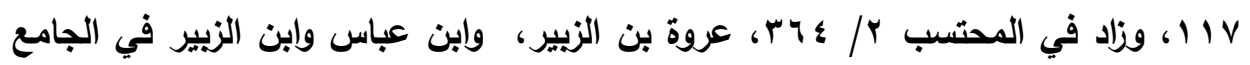

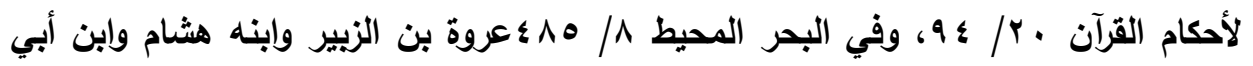

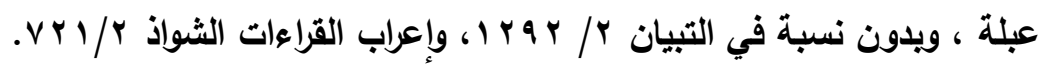


فصل المقال في الغريب من الأقوال النحوية والتصريفية د / عبدالرعوف ثابت أحمد عبدالله

ثالثما : النادر .

هو ما قل وجوده سواء أكان مخالفاً للقياس أو موافقاً له، وقال الرماني: (1)

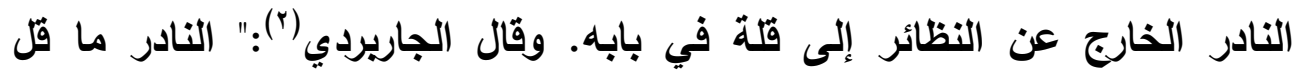

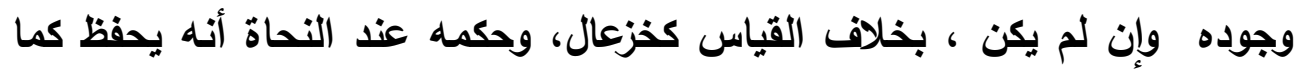

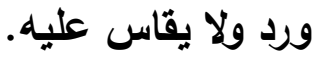

قال سييويه (") في باب "بناء الأفعال المتعدية" : "..فإنما هذا الأقل نوادر

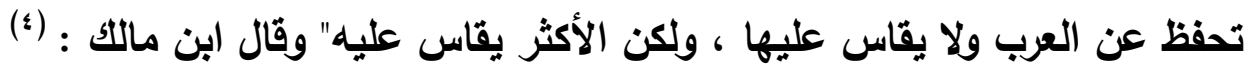

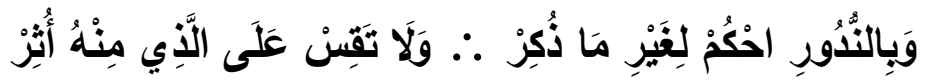

الضعيف هو الذي بصل حكمه إلى الثبوت ، قال الجاريردي في شرح الثافية : (•) الضعيف ما في ثبوته كلام ، كقرطاس ، بالضم في قرطاس بكسرها.

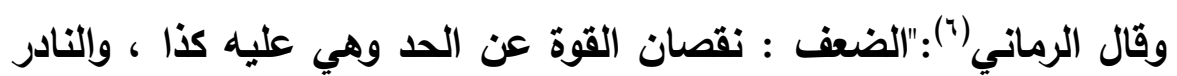

أضعف من المطرد في البيان".

قال ابن جماعة(v) في العلاقة بين الثناذ، والنادر، والضعيف- : " . . . ،

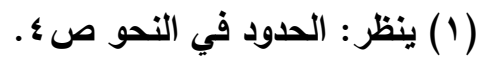

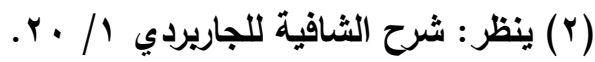

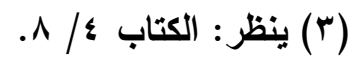

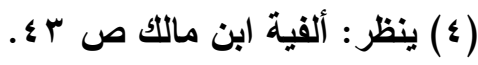

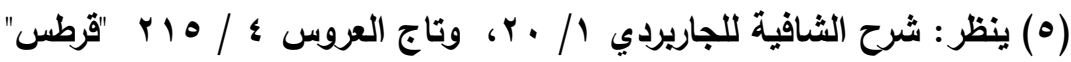

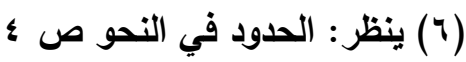

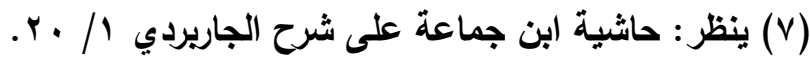


فصل المقال في الغريب من الأقوال النحوية والتصريفية د/ عبدالرعوف ثابت أحمد عبدالله

بين الشاذ والنادر عموماً من وجه فما خالف القياس وقل وجوده شاذ ونادر، وما خالف وكان كثيراً شاذ فقط ، وما قل ولم يخلف نادر فقط، وأن الضعيف وجن

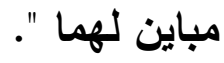

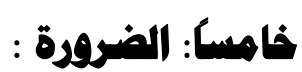

جمهور النحويين على أن الضرورة الشعرية هي: ما وقع في الشعر مما لم

يقع في مثله في الكلام ، أي: النثر، سواء اضطر إليه الثاعر أو لا.(') وهو ظاهر

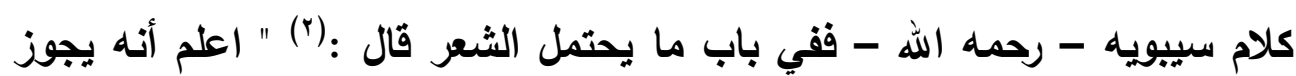
في الثعر ما لا يجوز في الكلام....، إلى أن قال: وليس شيء يضطرون إليه إلا مالا وهم يحاولون به وجهاً . وما يجوز في الثعر أكثر من أن أذكره للك ها هنا ؛ لأن

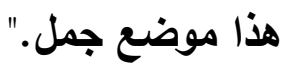

أما ابن مالك فيرى أن الضرورة الشعرية هي : ما ليس للشاعر عنه

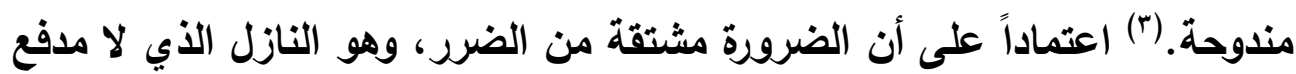
مدفع له. وضعف مذهبه هذا بأنه يكاد يسد باب الضرورة ، إذ كل ما يدعى أنه ضرورة يمكن أن يدعى تمكن الثاعر من تغييره بنظم تركيب آخر. وقد بسطت القول في هذه القضية في كتابي المسمى بـ "' الضرورة الشعرية بين الأخفش وابن مالك دراسة موازنة موثقة " والله وأعلم.

\section{البمشث الأول \\ الأقوال والآراء النموية الغريبة}

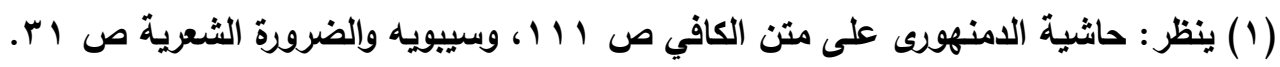

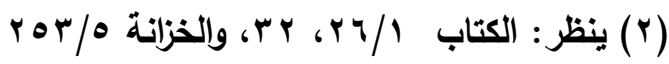

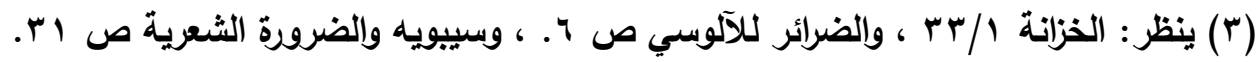


فصل المقال في الغريب من الأقوال النحوية والتصريفية د / عبدالرعوف ثابت أحمد عبدالله

\section{ا - تجريد التاء الاسمية عن الفطاب}

قال ابن هشام: (1) "ومن غريب أمر التاء الاسمية أنها جردت عن الخطاب ، والتزم فيها لفظ التذكير والإفراد في: أرأيتكما ، وأرأيتكم ، وأرأيتك ، وأرأيتك ، وأرأيتكن ، إذ لو قالوا : أرئيتماكما جمعوا بين خطابين. ووجه الغرابة أن التاء هنا خلصت للاسمية وتجردت عن الخطاب كما خلصت الكاف للخطاب وتجردت عن الاسمية.، وقد نبه على ذلك من قبل ابن جني(ץ) - رحمه الله- ففي الخصائص" ...وللتاء موضع تخلُص فيه للاسميّة البتة

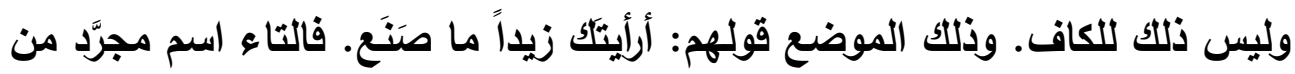
الخطاب، والكاف حرف للخطاب مجرَّد من الاسمية. هذا هو المذهب ـ ولذلك لزمت

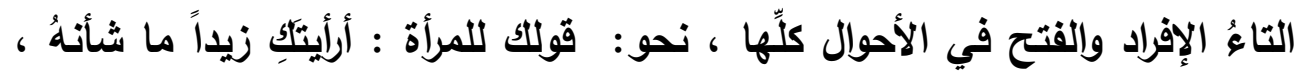
وللاثنين وللاثتين: أرليتكما زيداً أين جلس، ولجماعة المذكَّر والمؤنَّث: أرائتكم زيداً

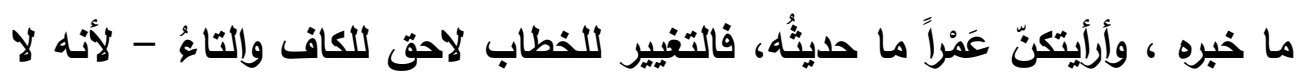
خطاب فيها- على صورة واحدة لأنها مخلَصة اسماً." واعلم أن للعرب في "أرأيت"، لغتين ومعنيين، أحدُهما: روئيةٌ العين، فإذا أردت هذا عَدَّيْتَ الروئية بالضمير إلى المخاطب، ويتصرَّف تصرُّفَ سائرِ الأفعال ،

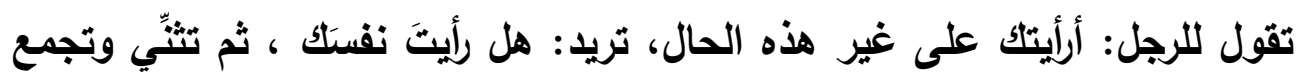
فتقول: أرأيتماكما ، أرأيتموكم ، أرأيتكنَّ ، والمعنى الآخر : أن تقول: أرأيتك وأنت تريد

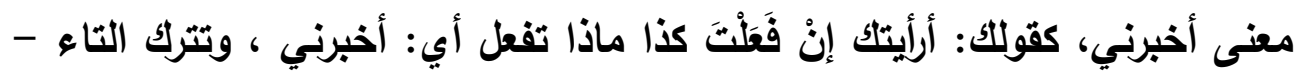
إذا أردت هذا المعنى - موحدةً على كل حال تقول: أرأيتكما، أرأيتكم ، أرأيتكنَّ، وإنما

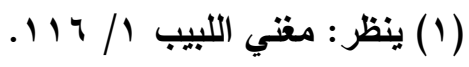

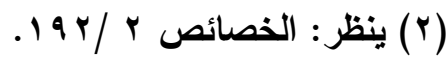


فصل المقال في الغريب من الأقوال النحوية والتصريفية د / عبدالرعوف ثابت أحمد عبدالله

تركَتِ العربُ التاءَ واحدةً ؛ لأنهم لـ يريدوا أن يكون الفعل واقعاً من المخاطب على نفسه فاكتفوا من علامة المخاطب بذكره في المكان ، وتركوا التاء على التذكير

والتوحيد إذا لم يكن الفعل واقعاً. (1)

قال أبوالبقاء: (ץ)"..والتاء في جميع ذلك مفتوحة ، والكاف حرف للخطاب

وليست اسماً ، واللاليل على ذلك أنها لو كانتا اسماً لكاتت إما مجرورة وهو باطل ؛ إذ لا جار هنا ، أو مرفوعة وهو باطل أيضاً لأمرين: أحدهما: أن الكاف ليست من ضمائر المرفوع. والثاني: أنه لا رافع لها إذ ليست فاعلاً؛ لأن التاء فاعل ولا يكون لفعل واحد فاعلان، وإما أن تكون منصوية وذلك باطل لثلاثنة أوجه: أحدها: أن هذا الفعل يتعدى إلى مفعولين كقولك : أرأيت زيداً ما فعل، فلو فأوله

جعلت الكاف مفعولاً لكان ثالثاً ، والثثاني أنه لو كان مفعولاً لكان هو الفاعل في المعنى ، وليس المعنى على ذللك إذ ليس الغرض أرأيث نفسك، بل أرأيت غيرك ، ولألك قلت: أرأيتك زيداً ، وزيد غير المخاطب ولا هو بلدل منه . والثالث : أنه لو

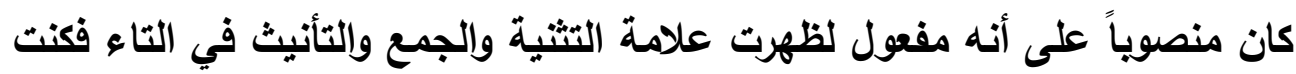
تقول: أرأيتماكما وأرايتموكم ، وأرأيتكن ، وقد ذهب الفراء إلى أن الكاف اسم مضمر منصوب في معنى المرفوع وفيما ذكرناه إبطال لمذهبه." ويعد هذه الدراسة - حقاً - تجد نفسك أمام أمر غريب انفردت به التاء الاسمية في لغتنا ـ والله أعلم.

\section{r- تقديم الضميز على منسره}

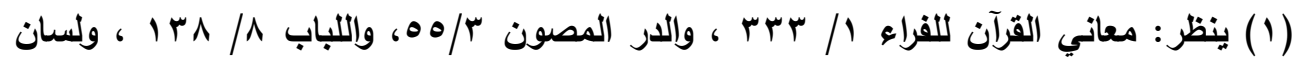

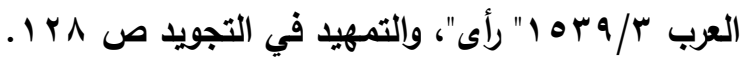

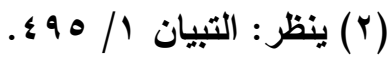


فصل المقال في الغريب من الأقوال النحوية والتصريفية د البدالرعوف ثابت أحمد عبدالله

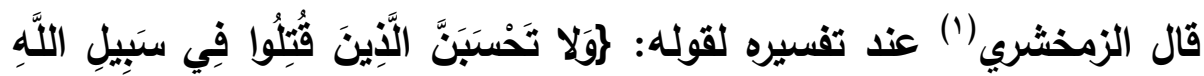

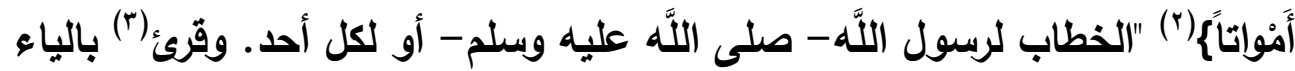
على: \}ولا يحسبنّ\{ رسول اللَّه (ص) أو \}ولا يحسبنّ حاسب. ويجوز أن يكون

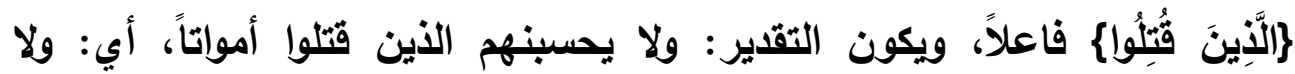
يحسبن الأين قتلوا أنفسهم أمواتاً. قلت: كيف جاز حذف المفعول الأوّل؟ قلت: هو في الأصل مبتدأ، فحذف كما حذف المبتدأ في قوله: أَحْياءُ." ، وردَّ عليه أبو حيان (؛) بأن هذا التقديرَ يؤدي إلى تقديم الضمير على مفسره، وذلك لا يجوز إلا في أبواب محصورةٍ (ه) ليس هذا منها."، وما اعترض به أبو حيان نعته تلامذته بالتحامل أو بالغريب.، فقي الدر المصون(؟) "..ورََّّ عليه الثيخ بأنَّ هذا التقديرَ يؤدي إلى تقديمٍ الضميرِ على مفسَّره ، وذلك لا يجوزُ إلا في أبوابٍ محصورةٍ ، وعدَّ

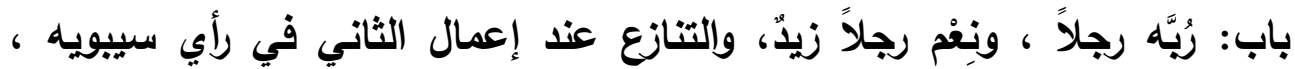
والبدلُ على خلاف فيه، وضمير الأمر. قال:" وزاد بعضُ أصحابنا أن يكون الظاهر المفسِّر خبراً، ويأنّ حَذْفَ أحد مفعولي "ظن " اختصاراً إنما يتمشى له عند الجمهور

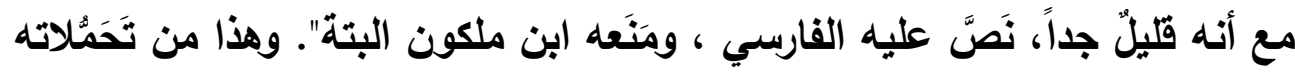
عليه. أمَّا قولُه :" يؤدي إلى تقديم المضمر إلى آخره "، فالزمخشري لم يقدِّره

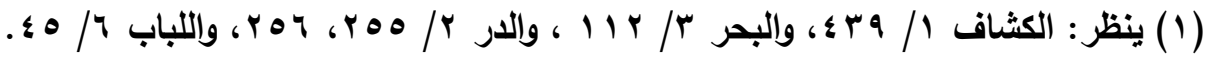

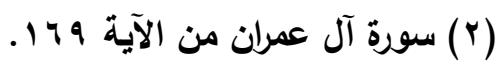

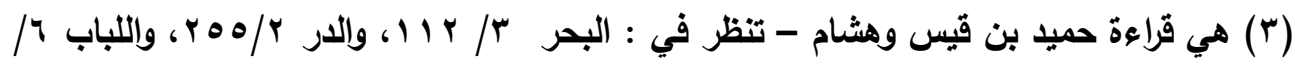

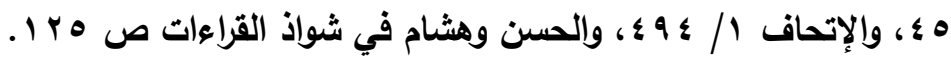

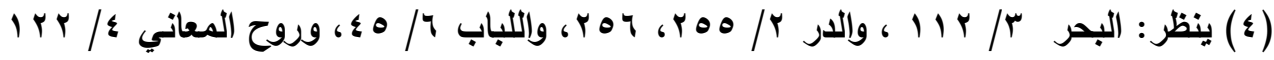
(0) حصرها ابن هشام في كتاب مغتي اللبيب الباب الرابع- في سبعة مواضع تحت عنوان "

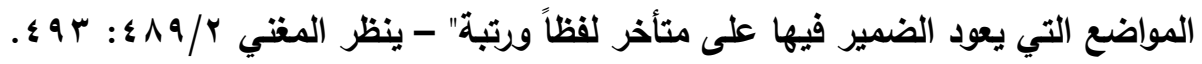

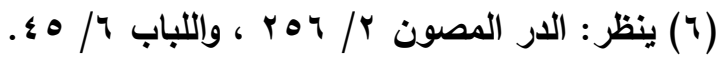


فصل المقال في الغريب من الأقوال النحوية والتصريفية د البدالرعوف ثابت أحمد عبدالله

صناعةً، بل إيراداً للمعنى المقصود ، ولذلك لَمَّا أراد أن يُقَََّر الصناعة النحويةَّة قََّره

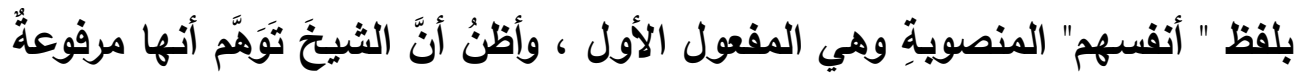
تأكيدٌ للضمير في " قُتُلوا "، ولم ينتبه أنه إنما قََََرها مفعولاً أولَ منصويةًَ. وأمَّا تمشيتُه قولَهله على مذهب الجمهور فيكفيه ذلك ، وما عليه من ابنِ مَلْكون؟ وستأتي مواضع يَضْطَرُ هو وغيرُه إلى حَذَفِ أحد المفعولين كما ستقف عليه قريباً." وفي روح المعاني(1) نقلاً عن السفاقسي:"واعترضه أبو حيان بشيء آخر أيضاً، وهو أن فيه تقديم المضمر على مفسره وهو محصور في أماكن ليس هذا منها، ورده السفاقسي بأنه وإن لم يكن هذا منها لكن عود الضمير على الفاعل لفظاً جائز؛ لأنه مقدم معنى، وتعدي أفعال القلوب إلى ضمير الفاعل جائز، وق نص السيرافي وغيره على جواز ظنه زيد منطلقا، وظنهما الزيدان منطلقين، وهذا نظيره ما ذكره هذا البعض، فالاعتراض عليه في غاية الغرابة.

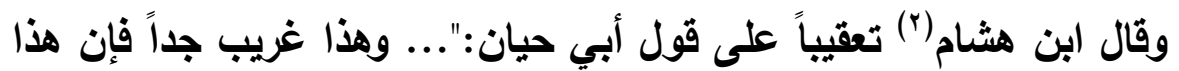
المؤخر مقدم في الرتبة ، ووقع له نظير هذا في قول القائل: مررت برجل ذامل ذاهبة

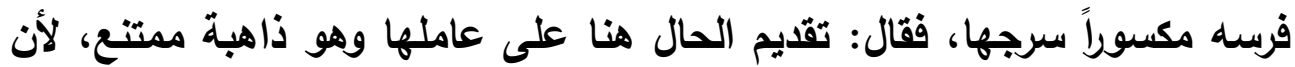
فيه تقديم الضمير على مفسره ، ولا شك أنه لو قدم لكان كقولك: غلامهه ضرب زيل فيل ، ووقع لابن مالك سهو في هذا المثال من وجه غير هذا، وهو أنه منع من التقديم

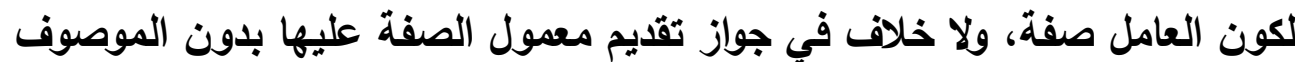
، ومن الغريب أن أبا حيان صاحب هذه المقالة وقع له أنه منع عود الضمير إلى هولى

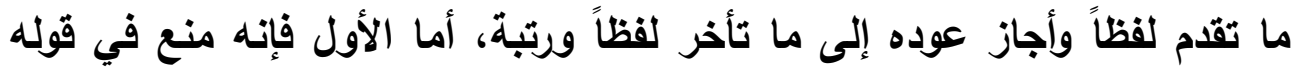

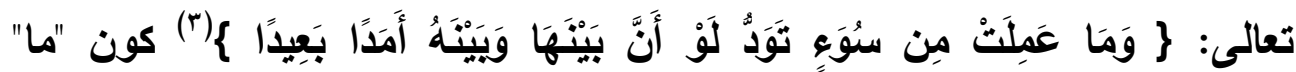

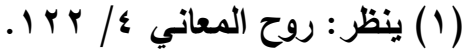

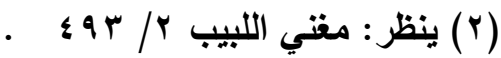

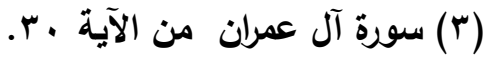


شرطية؛ لأن "تود" حينئ يكون دليل الجواب لا جواباً، لكونه مرفوعاً فيكون في نية

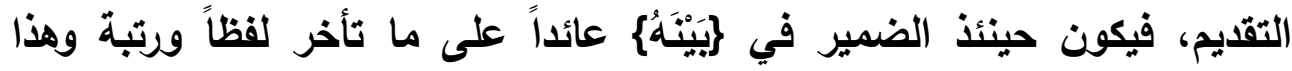

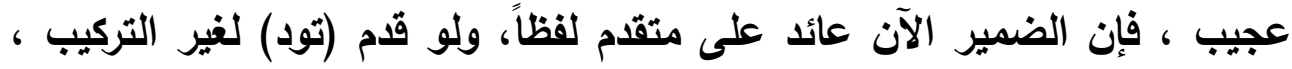

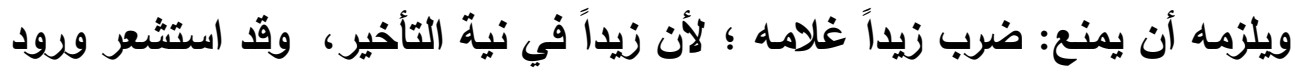

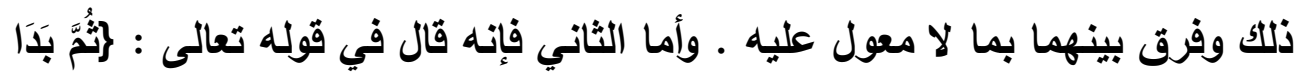

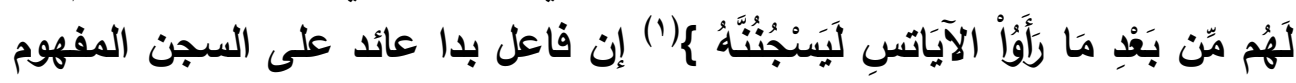

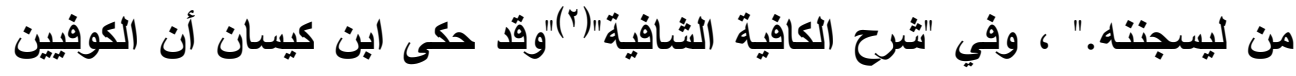

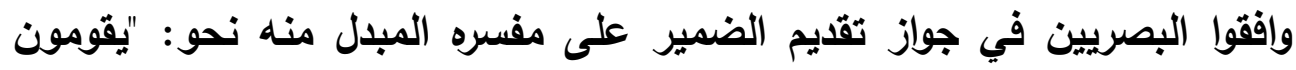

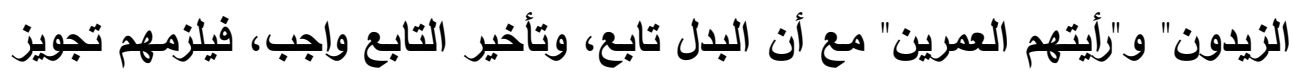

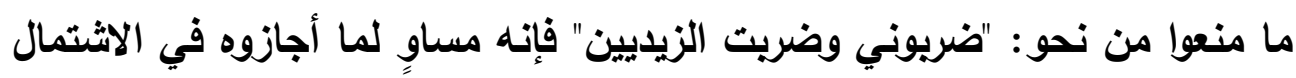

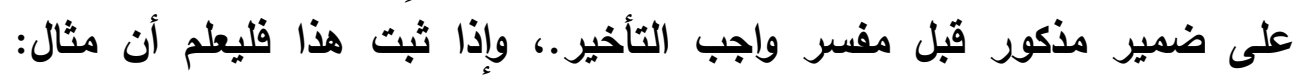

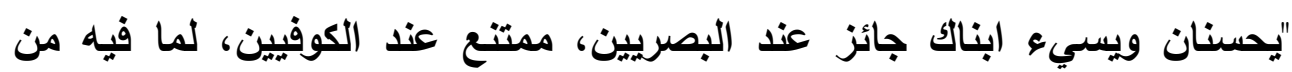

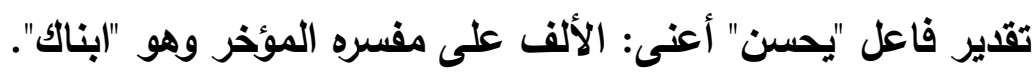

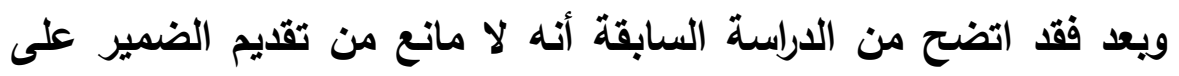

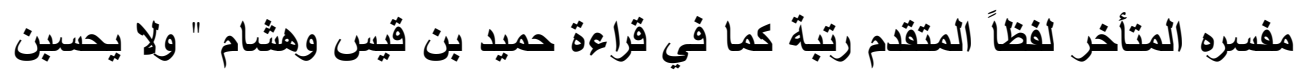

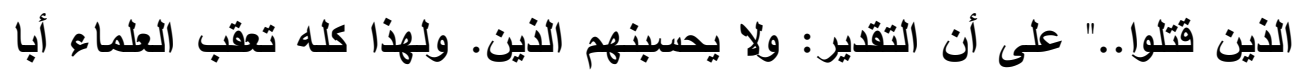
حيان في رده على الزمخشري ونعتوه بالغريب ـ والله أعلم.

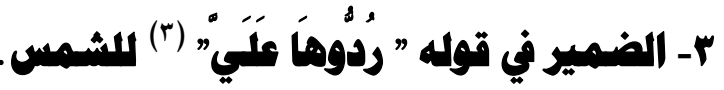

$$
\begin{aligned}
& \text { (1) سورة يوسف من الآية هب. }
\end{aligned}
$$

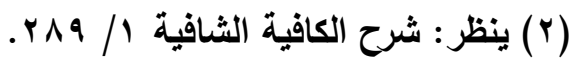

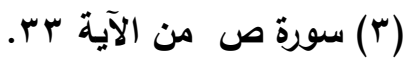


فصل المقال في الغريب من الأقوال النحوية والتصريفية د / عبدالرعوف ثابت أحمد عبدالله

قال أبو حيان:(')"ومن غريب القول أن الضمير في ردوها عائد على

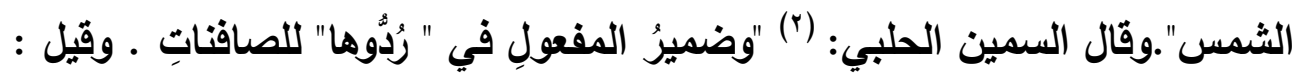
للشمس ، وهو غريبٌ جداً ". ووجه غرابته أنه لم يتقدم ذكر للشمس. وقا سبقهما إلى استبعاد هذا الوجه الفخر الرازي(ّ) وتبعه ابن عاشور(؛)، قال الرازي:" أقول الضمير في قوله :

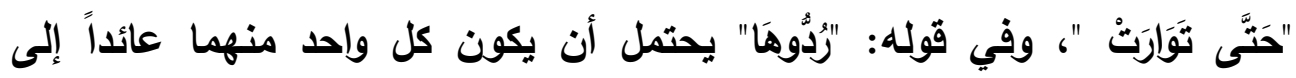
الشمس لأنه جرى ذلك ماله تعلق بها وهو العشي، ويحتمل أن يكون كل واحد منهما عائداً إلى الصافنات، ويحتمل أن يكون الأول: متعلقاً بالشمس، والثاني : بالصافنات، ويحتمل أن يكون بالعكس من ذلك فهذه احتمالات أربعة لا مزيد عليها: فالأول:أن يعود الضميران معاً إلى الصافنات كأنه قال: حتى ثوارث الصافن الصنات بالحجاب ردوا الصافنات علي.

والاحتمال الثاني: أن يكون الضميران معاً عائدين إلى الثمس كأنه قال حتى توارت الشمس بالحجاب ردوا الشمس ، وروي أنه - صلى الله عليه وسلم - لما اشتغل

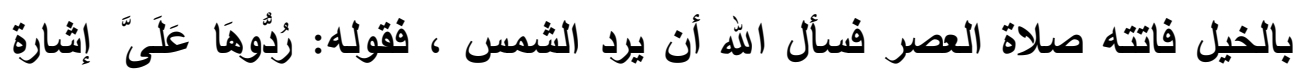
إلى طلب رد الثمس وهذا الاحتمال عندي بعيد ، والذي يدل عليه وجوه :

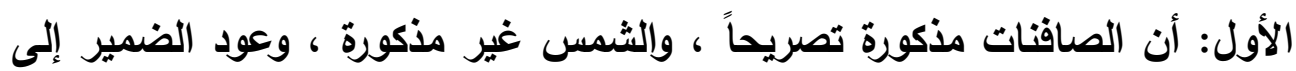
المذكور أولى من عوده إلى المقدر.

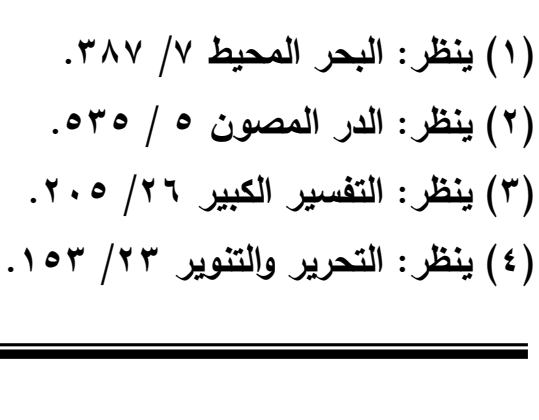


فصل المقال في الغريب من الأقوال النحوية والتصريفية د البدالرعوف ثابت أحمد عبدالله

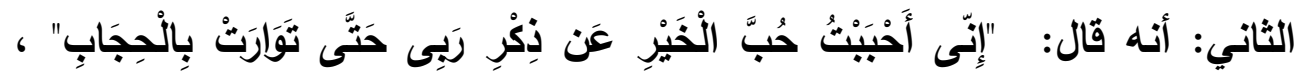
وظاهر هذا اللفظ يدل على أن سليمان عليه السلام كان يقول إني أحبيث حب الخير عن ذكر ريب ، وكان يعيد هذه الكلمات إلى أن توارت بالحجاب، فلو قلنا : المراد حتى توارت الصافنات بالحجاب كان معناه أنه حين وقع بصره عليها حال جريها كان يقول هذه الكلمة إلى أن غابت عن عينه وذلك مناسب ولو قلنا المراد حتى توارت الشمس بالحجاب كان معناه: أنه كان يعيد عين هذه الكلمة من وقت العصر إلى وقت المغرب وهذا في غاية البعد. الثالث: أنا لو حكمنا بعود الضمير في قوله: "حتى توارت" إلى الثمس وحملنا اللفظ على أنهه تركَ صلاة العصر كان هذا منافياً لقوله: "أَحْبَبتُ حُبَّ الْخَيَرِ عَنْ ذِكْرِ رَبِى" ، فإن تلك المحبة لو كاتت عن ذكر الله لما نسي الصلاة ولما ترك ذكر الله. الرابع : أنه بتقدير أنه عليه السلام بقي مشغولاً بتلك الخيل حتى غريت الشمس وفاتت صلاة العصر فكان ذلك ذنباً عظيماً وجرماً قوياً فالأليق لهذه الحالة التضرع والبكاء والمبالغة في إظهار التوبة، فأما أن يقول على سبيل التهور والعظمة لإله العالم ورب العالمين: ردوها علي، بمثل هذه الكلمة العارية عن كل جهات الأدب عقيب ذلك الجرم العظيم فهذا لايصدر عن أبعد الناس عن الخير فكيف يجوز إسناده إلى الرسول المطهر [المكرم] ('). الخامس: أن القادر على تحريك الأفلاك والكواكب هو الله تعالى فكان يجب أن يقول

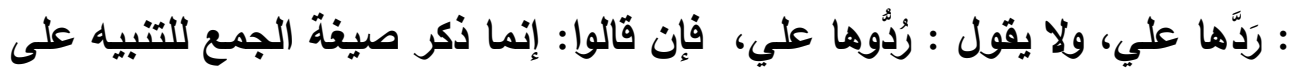

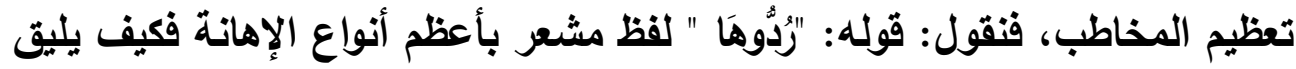
بهذا اللفظ رعاية التعظيم.

(1) في في إحدى نسخ المطبوع " المكرا " وفي الأخرى " المكر ! " . 
فصل المقال في الغريب من الأقوال النحوية والتصريفية د / عبدالرعوف ثابت أحمد عبدالله

السادس: أن الثمس لو رجعت بعد الغروب لكان ذلك مشاهداً لكل أهل الانيا ، ولو كان الأمر كذللك لتوفرث الدواعي على نقله وإظهاره وحيث لـ يقل أحد ذللك علمنا فساده.

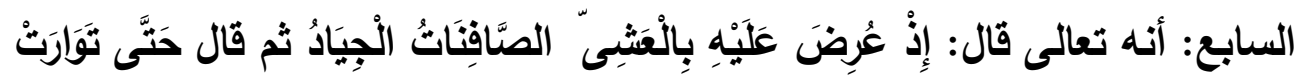

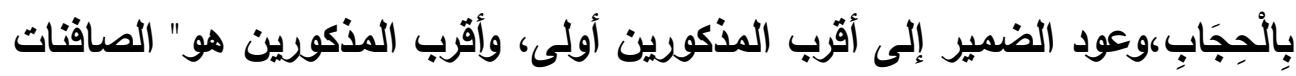

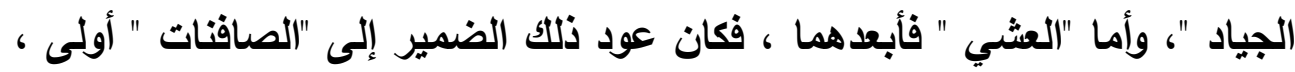

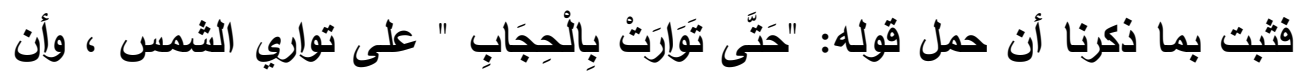

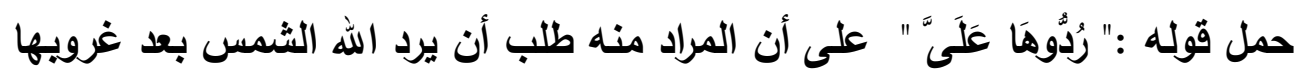
كلام في غاية البعد عن النظم".

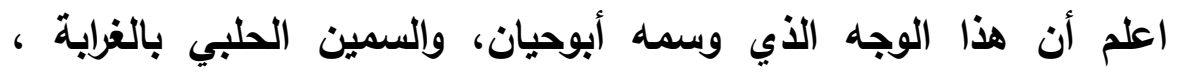

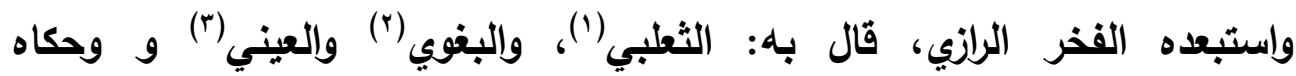

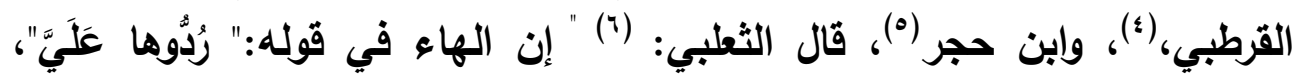

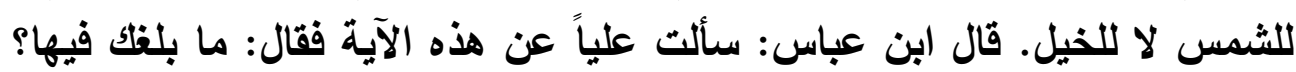

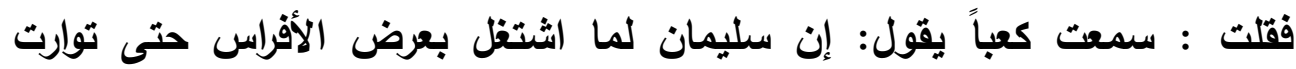

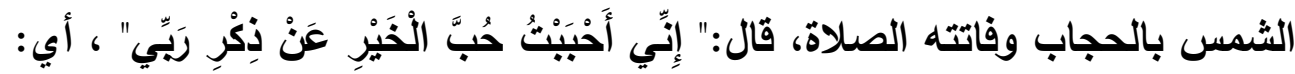

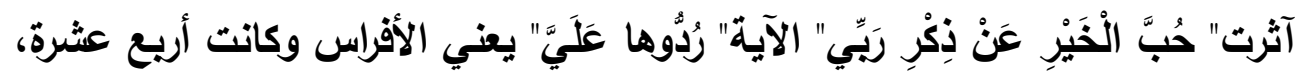

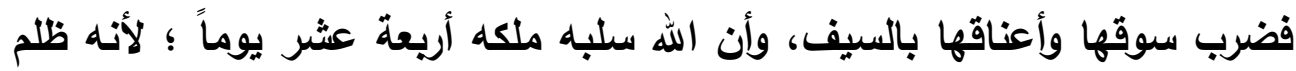

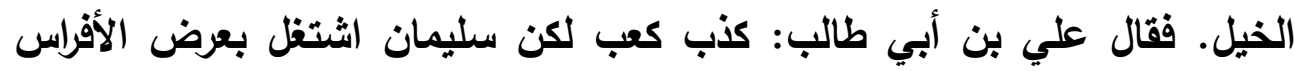

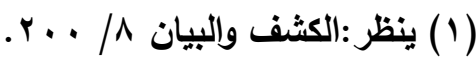

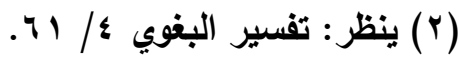

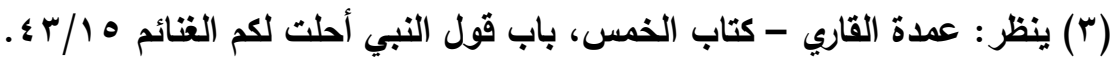

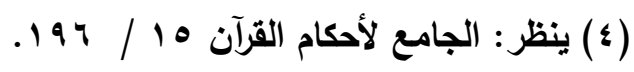

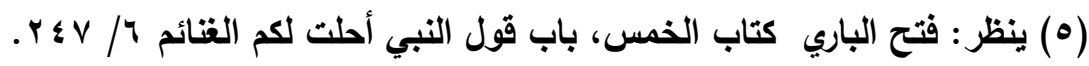

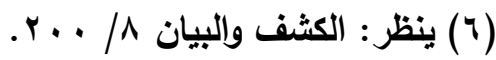


فصل المقال في الغريب من الأقوال النحوية والتصريفية د / عبدالرعوف ثابت أحمد عبدالله

للجهاد حتى توارت أي:غريت الشمس بالحجاب، فقال: بأمر الله للملائكة الموكلين بالشمس: "رُدُوهُوها"، يعني: الشمس، فردوها حتى صلى العصر في وقتها، وأن أنبياء

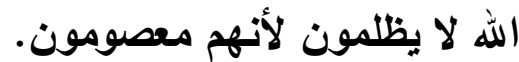

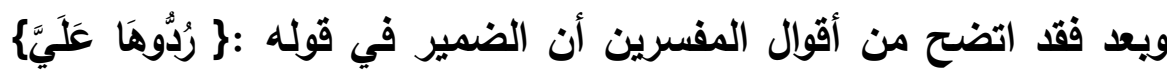
يحتمل أن يكون لـ "الصافنات "، ويحتمل أن يكون دل "الثمس " وإن لم يتقدم لها

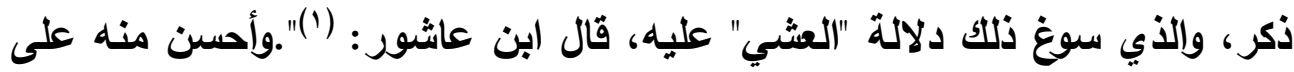

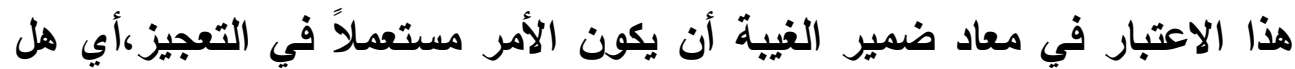

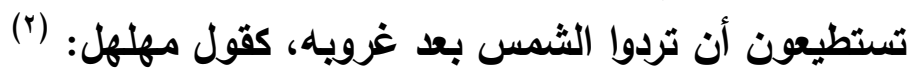

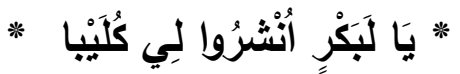

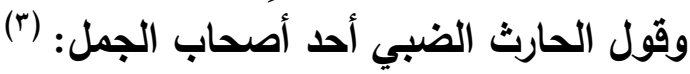

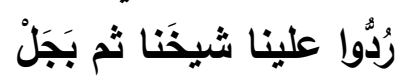
يريد:عثمان بن عفان - رضي الله عنه-، فلا استبعاد في هذا المحمل." والله أعلم. ع- إظهار متعلق الظرف والجار والمجرود

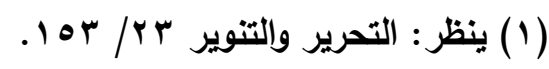

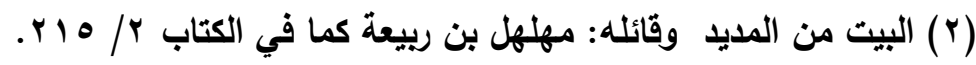

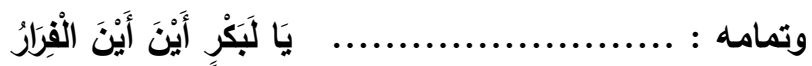

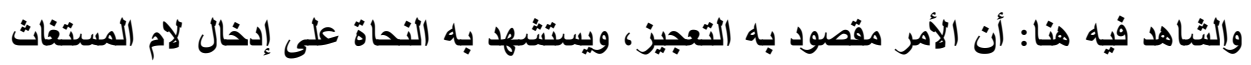
مفتوحة على بكر للقرق بينها ويين المستغاث من أجله.

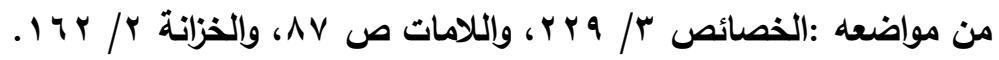

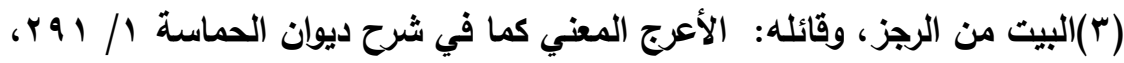

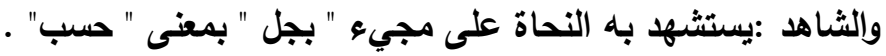

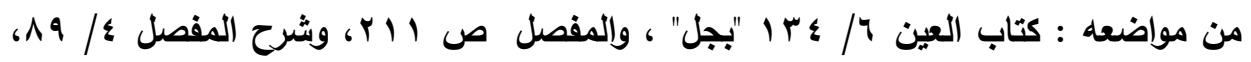

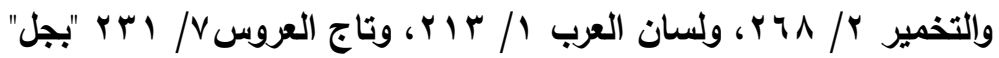


قال ابن يعيش:(') عند الدديث عن متعلق الظرف والجار والمجرور الواقع

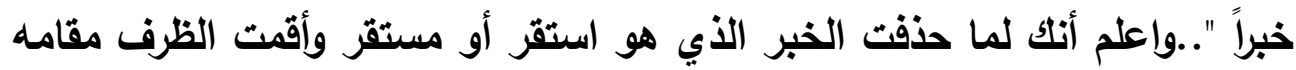

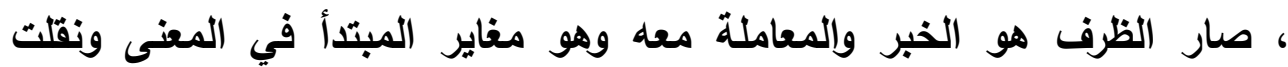

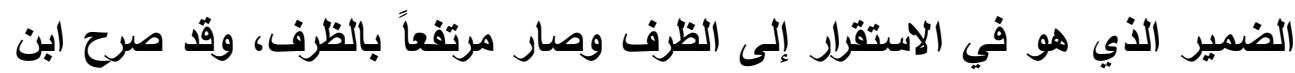

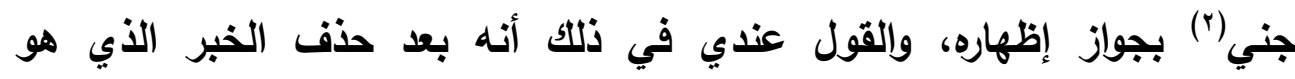
الاستقرار ونقل الضمير إلى الظرف لا يجوز إظهار ذلك المدذف ؛ لأنه قد صار

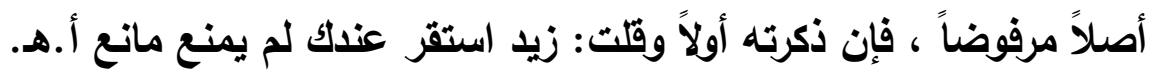

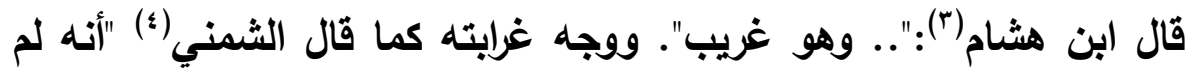
يقل به غيره." أو لأنه صرح بأصل مرفوض.

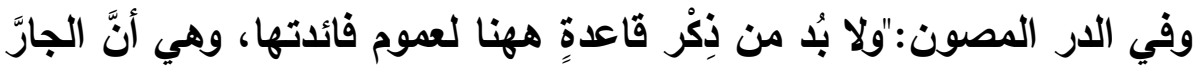

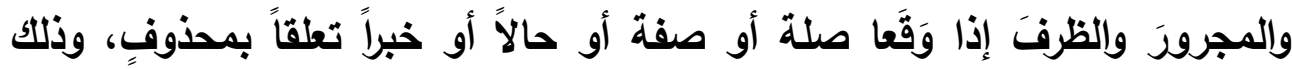

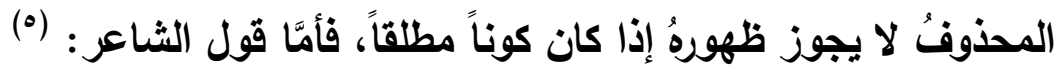

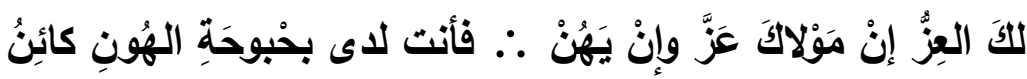

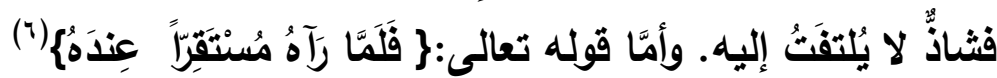

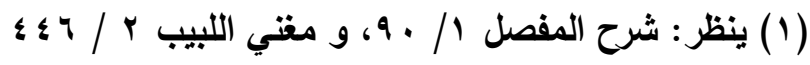

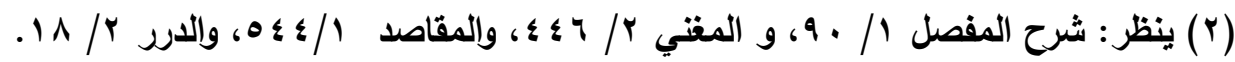

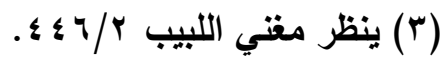

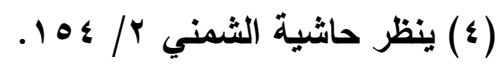

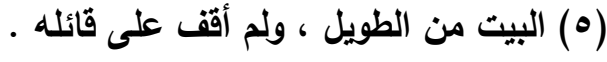
والثاهد: قوله " كائن" حيث صرح بمتعلق الظرف " لدى" وهو شاذ والقياس حذفه.

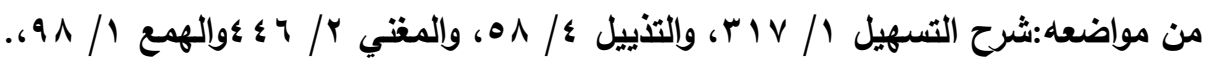

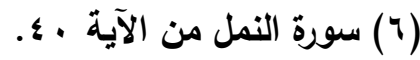


فصل المقال في الغريب من الأقوال النحوية والتصريفية د البدالرعوف ثابت أحمد عبدالله

فلم يَقْصِدْ جَعْلَ الظرفِ ثابتاً فلذلك ذكرَ المتعلِّقَ به. ثم ذلك المحذوفُ يجوز تقديرُه باسم أو فعل إلا في الصلة فإنه يتعيَّن أن يكون فعلاً ، وإلاًّ في الصورتين المذكورتين فإنه يتعيَّنُ أَنْ يكونَ اسماً. واختلفوا: أبيٌ التقديرين أولى فيما عدا الصورَ المستثناةَ ؟ فقوم رجَّحوا تقديرَ الاسمح، وقومُ رجَّحوا تقديرَ الفعلِ." (1 ) قال شيخ مشايخنا(؟) - رحمة الله عليه- :"والذي يتجه عندي وذكره كثير من أكابر العلماء أن " كائناً، واستقر " قد يراد بهما مجرد الحصول والوجود فيكون كل منهما كوناً عاماً واجب الحذف، وقد يراد بهما حصول مخصوص كالثبات وعدم قبول التحول والانتقال ونحو ذلك فيكون كل منهما كوناً خاصاً، وحينئ يجوز ذكره ، و" ثابت " و" ثبت " بهذه المنزلة، فقد يراد بهما الوجود المطلق الذي هو ضد الانتقال فيكونان عامين، وقد يراد بهما القرار وعدم قابلية الحركة مثلاً، وحينئ يكونان خاصين، ويهذا يرد على ابن جنى ما ذهب إليه، ويهذا - أيضاً- يتجه ذكر "كائن" في هذا البيت وذكر "مستقر" في نحو قوله تعالى: (فلما رآه مستقرا عنده)، لأن المعنى أنه لما رآه ثابتاً كما لو كان موضعه بين يايه من أول الأمر.، ويعد فقد

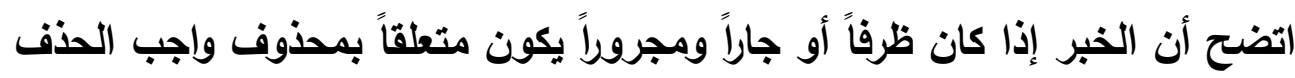
نحو: زيد عندك، وزيد في الار، والأصل: زيد استقر عندك أو استقر في الدار، أو مستقر على الوجهين، وإبرازه كما في البيت المذكور شاذ، وأما تصريح ابن جني بجواز إظهاره لكونه أصلاً فهو أصل مرفوض لا يجوز إظهاره وهو وجه الغرابة فيه. ويمكن أن يقال: إنه من الآراء التي انفرد بها ابن جني. والله أعلم.

\section{ه- مرفية كان وأخم|تما}

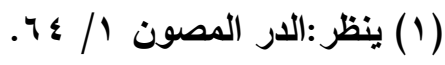

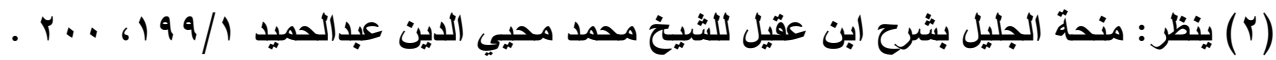


قال ابن هشام في "حواشي التسهيل: (1) "الخلاف في (عسى وليس ) شهير،

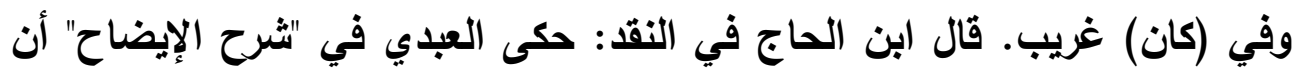

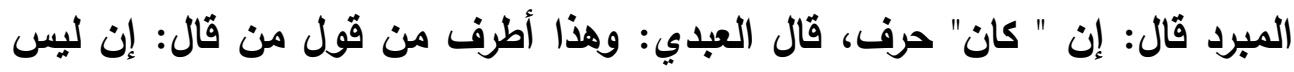

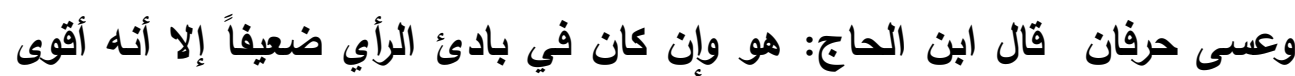

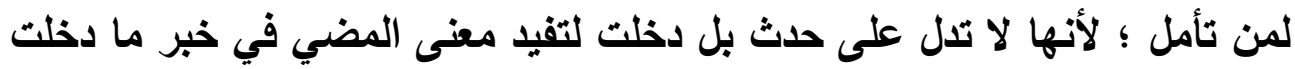
عليه"

المشهور من مذهب الجمهور أن "كان وأخواتها" أفعال ؛ لاتصال ضمائر

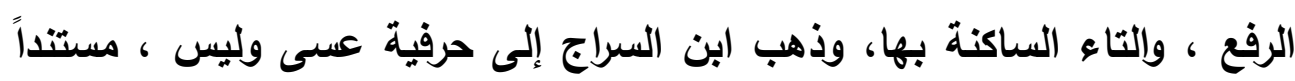

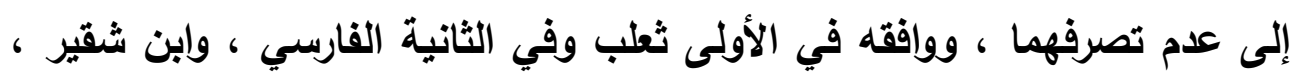

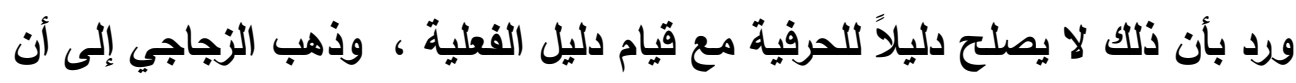

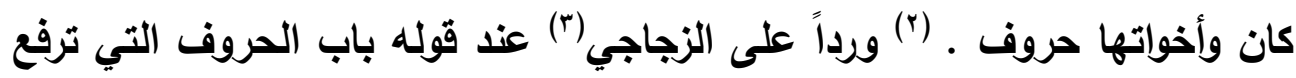

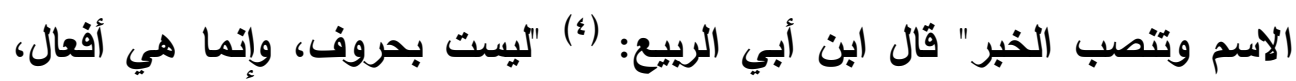

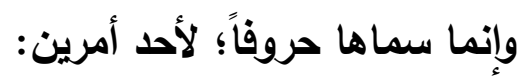
أحدهما: أن يريد بالحروف الكلم فكأنه قال باب الكلم التي ترفع الاسم وتنصب الخبر

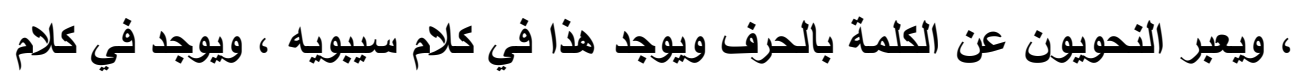

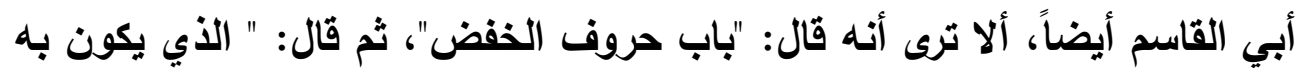

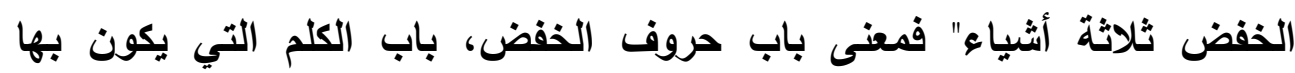
الخفض .

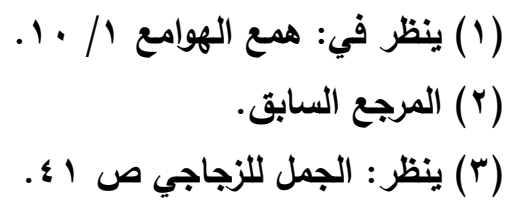

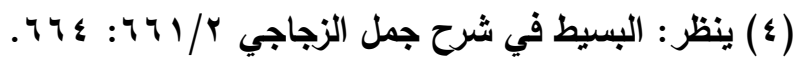


فصل المقال في الغريب من الأقوال النحوية والتصريفية د البدالرعوف ثابت أحمد عبدالله

الثاني: أن يكن سماها حروفاً؛ لضعفها من أمرين :

الأول: أن كل فعل يستقل بمرفوعه وأنت بالخيار في منصويه فتقول: ضرب زيا عمراً، فأنت بالخيار في عمرو إن شئت جئت به، وإن شئت لم تأت به، ولايجوز أن تقول: كان زيل، وتسكت، لابد أن تقول: كان زيا منطلقاً، وتأتي بخبره، وإنما كان ذلك في كان وأخواتها؛ لأنها قد تدخل على المبتدأ والخبر، ترفع الاسم تشبيهاً بالفاعل، وتنصب الخبر تثبيهاً بالمفعول، فكما لايجوز أن تأتي بالمبتدأ دون الخبر ولا بالخبر دون المبتدأ، لا تأتي باسم كان دون خبرها ولا بخبرها دون اسمها ... الضعف الثاني: أن جميع الأفعال تؤكد بالمصدر ويتبين مصدرها ، فتقول : ضرب زيا عمراً ضرياً، إذا أردت أن تؤكد المصدرها وتقول: ضرب زيد عمراً ضرياً شديداً، إذا أردت بيان النوع ، وضريتين إذا أردت بيان العدد ، وهكذا جميع الأفعال، ولايجوز للك ذلك في (كان) الناقصة وأخواتها، لاتقول: كان زيد قائماً كوناً، ولا كان زيدٌ قائماً كونتين، وكذلك جميع أخواتها ولا أعلم في ذلك خلافاً.أ.هد" وفي "الغيث المسجم" (1) عند إعراب قول الطغرائي: (r) ما كنت أوثز أن يمتد بي زمني . قال الصفدي:"كان ترفع الاسم وتتصب الخبر وهي فعل، وهو مذهب الأكثرين، وقال بعضهم: بل هي حرف، لأنها لا مصدر لها ولو كاتت فعلاً لالت على المصدر، ولما احتيج أن يعقد لها باباً يخصها، وليس ذلك بشيء. قال الشيخ بهاء الاين بن النحاس في "كان وأخواتها" لم يختلف أحد في فعلية شيء منها إلا " ليس" فإن أبا

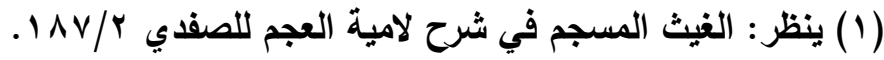

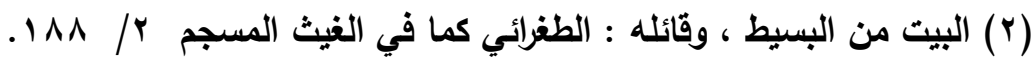

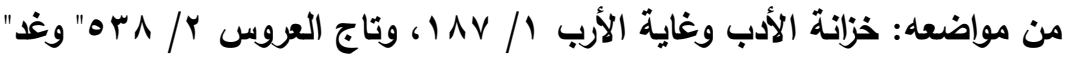


فصل المقال في الغريب من الأقوال النحوية والتصريفية د / عبدالرعوف ثابت أحمد عبدالله

علي ذكر في "المسائل الحلبيات"(1) أن "ليس" حرف وطول في الاستدلال على ذلك، وكذلك استدل أيضاً على حرفيتها في أول "الإيضاح الشعري"(r) له وكذلك فعل ابن السراج (ץ) أنه قال بفعلية " ليس" تقليداً، وفي كلام سيبويه إثارة إلى حرفيتها محتملة للتأويل، وهو قوله في باب حروف أجريت مجرى حروف الاستفهام، هذا بعض كلام الشيخ بهاء الدين ".

قال أبوالبقاء الكفوي:(؛) "والمختار أن كانن\{ حرف إن اعتبر القصد الأصلي في دلالة الفعل على معناه ، وإلا فهو فعل بلا شبهة". ويعد فقد اتضح أن القول بحرفية "كان" لأنها لو كاتت فعلاً لالت على لهل المصدر، ولما احتيج أن يعقد لها باباً يخصها، قول ضعيف، وذلك لضعف الاليل.

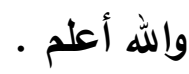

\section{1- إعمال ليس ثمع اقتران فبرها بإلا}

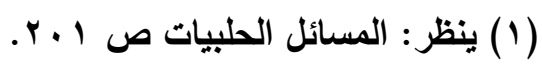

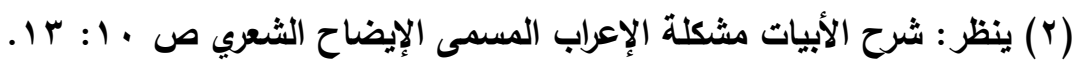

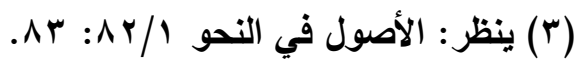

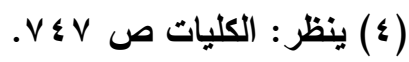


فصل المقال في الغريب من الأقوال النحوية والتصريفية د / عبدالرعوف ثابت أحمد عبدالله

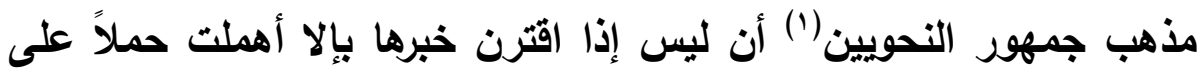

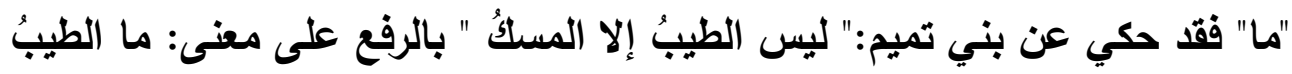

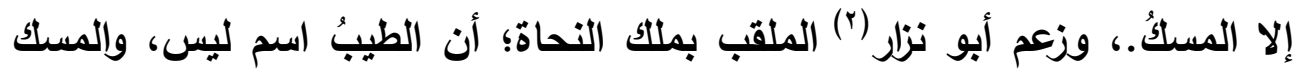

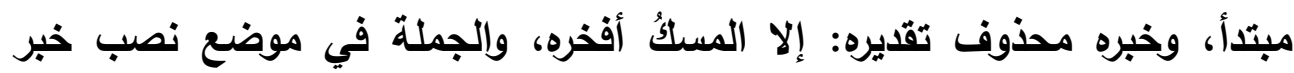

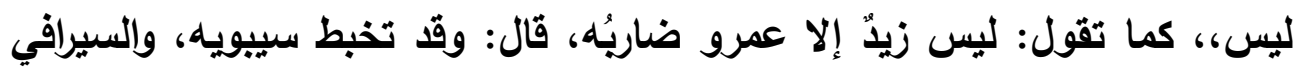

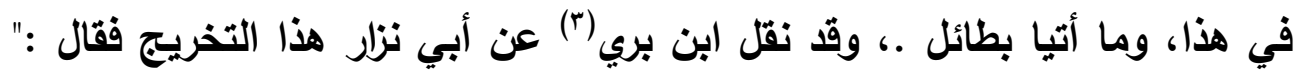

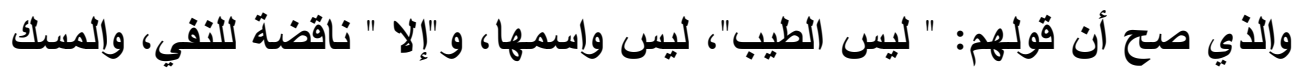
مبتأ وخبره محذوف تقديره : ليس الطيب إلا المسك أفخره، والجملة من المبتدأ

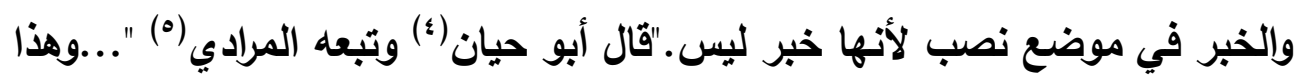

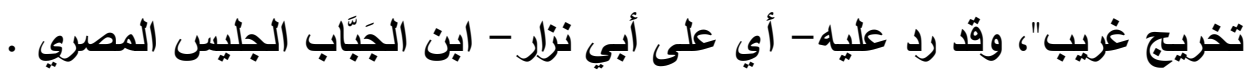

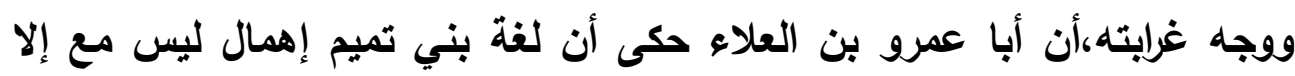
حملاً على "ما "كقولهم: ليس الطيب إلا المسك بالرفع على الإهمال ولا ضمير فئها. قال أبو حيان: (†) وإذا ثبت أن ذلك لغة الته فلا يمكن التأويل ، لأن التأويل

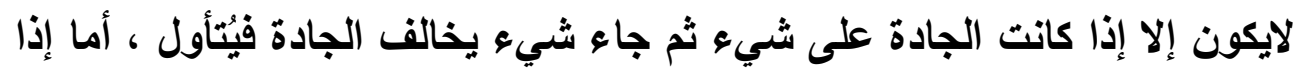
كانت لغة طائفة من العرب لم تتكلم إلا بها فلا تأول ".

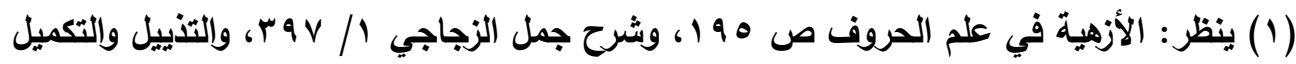

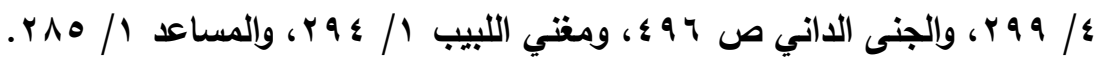

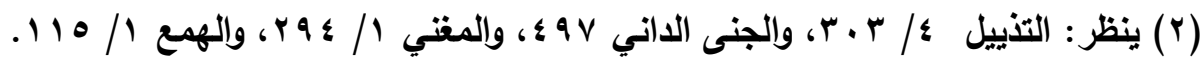

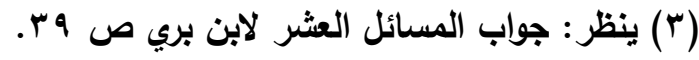

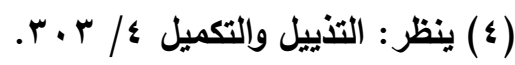

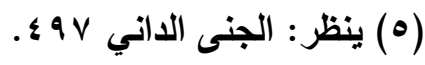

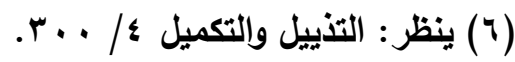


فصل المقال في الغريب من الأقوال النحوية والتصريفية د / عبدالرعوف ثابت أحمد عبدالله

واعلم أن النحويين (') اختلفوا في توجيه قولهم :" ليس الطيبُ إلا المسكُ" برفع

المسك على خمسة أقوال:

الأول: هو مذهب جمهور النحويين، والثاني: ما قاله أبونزار الملقب بملك النحاة.

والثالث: ما ذهب إليه الأخفش(؟) وتبعه أبوعلي الفارسي(؟) من أن اسم ليس ضمير الأمر والثأن، والطيب مبتدأ والمسك خبره ، والجملة من الطيب والمسك في محل نصب خبر ليس .

قال التيلي: (๕)"والصحيح ما ذكره الأخفش في المسائل الكبيز، وعول عليه الفارسي في الحلبيات ، أن في "ليس" ضمير الشأن والقصة، ويرفع "المسك" بأنه خبر المبتدأ الذي هو " الطيب" ، والمبتدأ وخبره جملة في محل نصب خبر ليس".

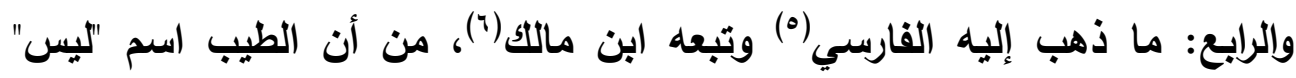
وخبرها محذوف وإلا المسك بلد من اسم ليس كأنه قيل: ليس الطيب في الوجود إلا المسك.

قال ابن مالك:"ويمكن في "ليس الطيبُ إلا المسكُ "إبقاء العمل على وجه لا محذور فيه، وهو أن يجعل "الطيب" اسم "ليس" و" المسك بدل منه، وإلخبر محذوف ، والتقدير: ليس الطيب في الوجود إلا المسك ويكون الاستغناء هنا بالبدل عن الخبر كالاستغتاء به في نحو : لا فتى إلا عليٌّ ، ولا سيف إلا ذو الفقار".

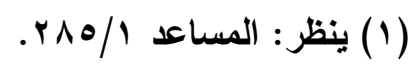

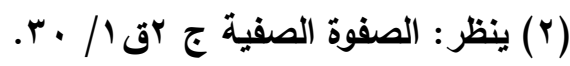

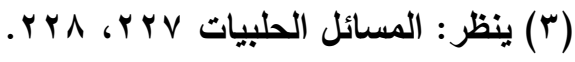

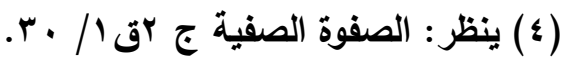

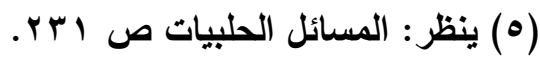

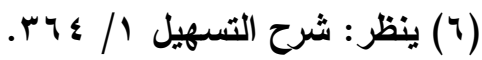


فصل المقال في الغريب من الأقوال النحوية والتصريفية د / عبدالرعوف ثابت أحمد عبدالله

الخامس ما ذهب إليه الفارسي" (') أيضاً من أن "الطيب" اسم "ليس" و" إلا المسك" نعت لهو والخبر محذوف، كأنه قيل: ليس الطيب الذي هو غير المسك طيباً في الوجود".

واعلم أن ما ذكرته لك من أقوال وتوجيهات في هذه المسألة إنما هو جار

على لغة بني تميم " ليس الطيبُ إلا المسكُ" برفع الطيب والمسك، أما أهل الحجاز فيرفعون الأول وينصبون الثاني حملاً على المطرد فيقولون: ليس الطيبُ إلا بلاب المسكَ"، وق جرى بين أبي عمرو بن العلاء وعيس بن عمر الثقفي حكاية في هذه المسألة،(ץ) فقد كان عيسى بن عمر ينكر الرفع بينما كان أبو عمرو بن العلاء ينكر النصب فلما اجتمع قال له أبو عمرو: نمت يا أبا عُمَر وأدلج الناس ، ليس ليس في الأرض حجازي إلا وهو ينصب ، ولا تميمي إلا وهو يرفع. ثم قال أبو عمرو لليزيلي ، ولخلف الأحمر: اذهبا إلى أبي مهدي فلقتاه الرفع فإنه لا يرفع ، وإلى إلى المنتجع التميمي فلقتاه التصب فإنه لا ينصب، فأتياهما وجها بكل منهما أن يرجع عن لغته فلم يفعل، وأخبرا أبا عمرو وعيسى عنده، فأخرج عيسى خاتمه من أصبعه ورمى باه إلى أبي عمرو وقال : هو للك بهذا فقت الناس . ويعد فقد اتضح أن ما ذكره الفارسي وأبونزار من توجيهات لإعمال ليس في لغة بني تميم الأين هم في الأصل يهملونها قول ضعيف ـ والله أعلم.

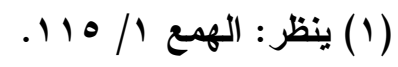

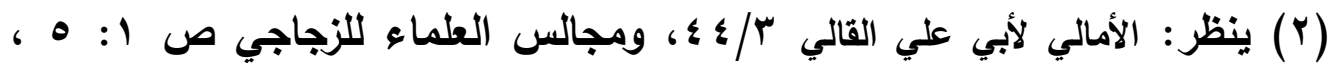
وشرح التسهيل / / V

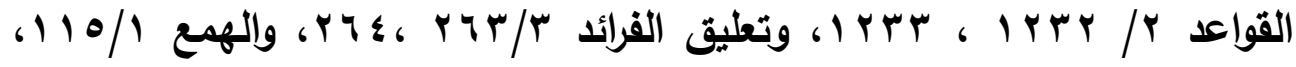

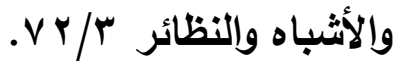


فصل المقال في الغريب من الأقوال النحوية والتصريفية د/ عبدالرعوف ثابت أحمد عبدالله

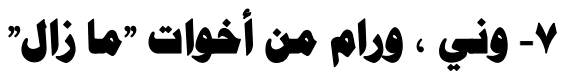

عد ابن مالك- رحمه الله- "وني"، "ورام" من أخوات زال ، ثم وصفهما بأنهما غريبتان، ولا يكاد النحويون يعرفونهما ، إلا من عني باستقراء الغريب ففي التسهيل

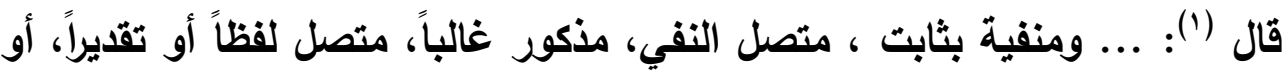
مطلوية النفي : زال ماضي يزال، وإنفك، ويرح ، وفتئ ، وفتأ، وأفتأ ، ووني ، ورام

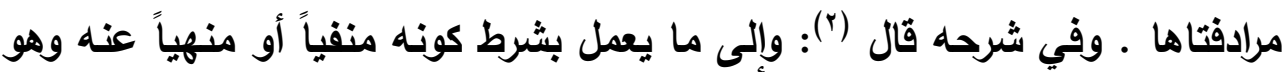
أربعة أفعال مشهورة ملحق بها اثنان. فالأربعة : زال ، وإنقك ، ويرح ، وفتئ ، وقد يقال : فتأ وأفتأ ، والملحقات بهن : وني ، ورام ، التي مضارعها يريم ... ثم قال : وقيد : ونى ورام ، الملحقتان بهن بمرادفتهما لهن ، احترازاً من وني بمعنى : فتر ، كمان ، ومن رام بمعنى حاول ويمعنى تحول ، ومضارع التي بمعنى: حاول : يروم ، ومضارع التي بمعنى: تحول: بريم، وهكذا مضارع المرادفة زال ، وهي ووني بمعنى زال غريبتان، ولا يكاد النحويون يعرفونهما، إلا من عني باستقراء الغريب، ومن شواهد استعمالها قول الثاعر (r):

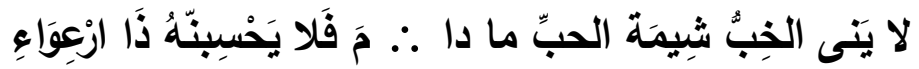
وقال آخر في إعمال (يريم) المشار إليه: (؛)

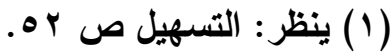

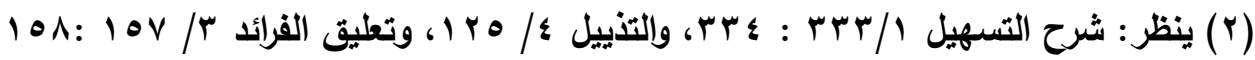
(r) البيت من الخفيف ، ولم أقف على قائله. وإلشاهل : قوله" لايني" حيث استعمله بمغنى : "لايزال".

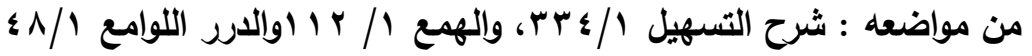
( ) البيت من الطويل ، ولم أقف على قائله.

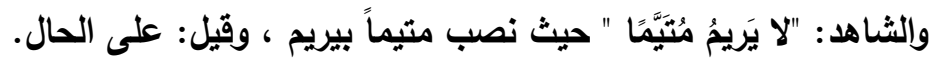

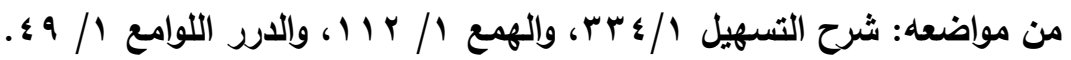




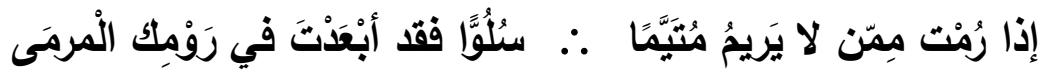
وما نعته ابن مالك بالغرابة، وعدم معرفة النحويين له؛ لم يسلم من اعتراض،

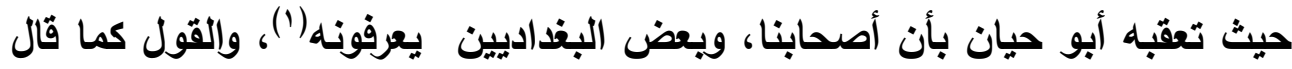

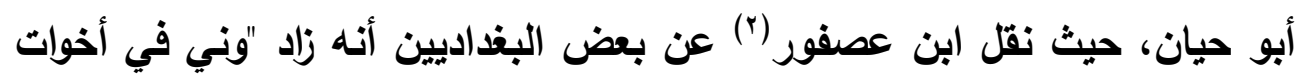

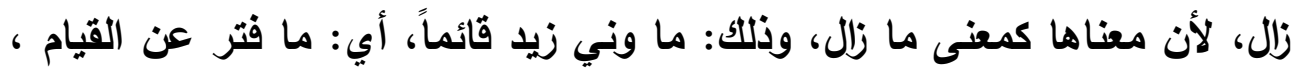

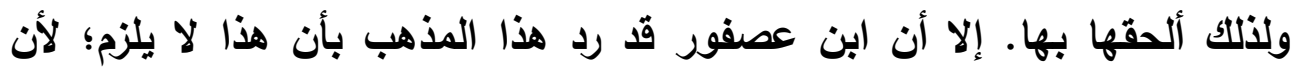
الفعل قد يكون بمعنى فعل آخر ولا يكون حكمه كحكمه. ألا ترى أن ظل زيل قان هائماً،

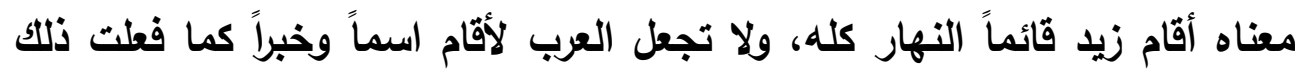

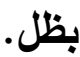

ومما يال على أنها ليست من أخوات كان أنه لا يقال : ما وني زيد القائم ،

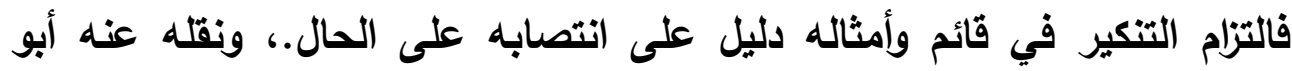

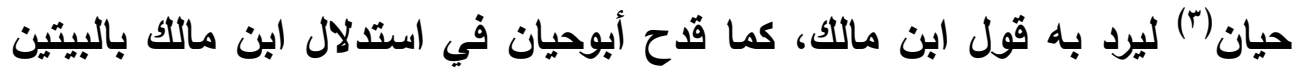

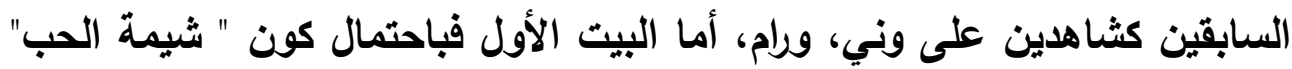
منصوياً على إسقاط الخافض، والأصل:عن شيمة الحب، وأما البيت الثاني الثاني فباحتمال

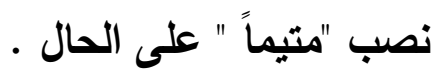
ويعد فبما ذكره ابن عصفور عن بعض البذاديين من أنه زاد وني على

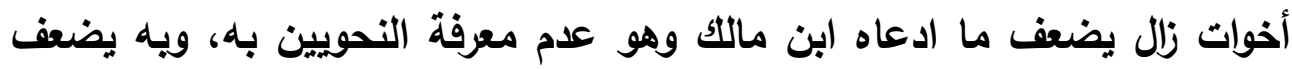

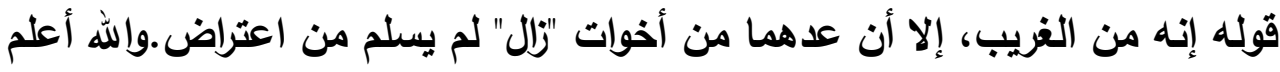
ه- هجيs خبر عسى اسمك صربها

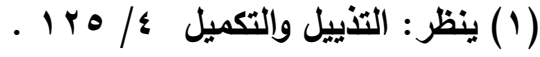

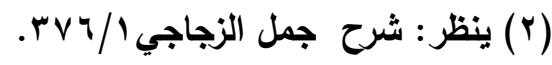

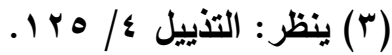


فصل المقال في الغريب من الأقوال النحوية والتصريفية د/ عبدالرعوف ثابت أحمد عبدالله

المشهور في "عسى" أنه فعلٌ ماضٍ نُقِل إلى إنشاءِ الترجِّي والإشثفاق. وهو

يرفعُ الاسمَ ويَنْصِبُ الخَبَر، ولا يكونُ خبرُها في الغالب إلا فعلاً مضارعاً مقروناً بـ إِ

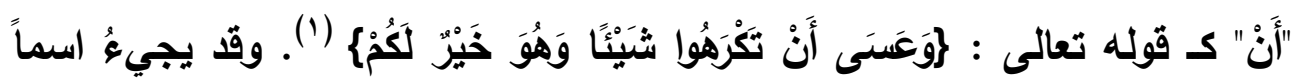

صريحاً كقوله : (r)

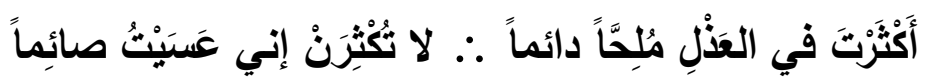

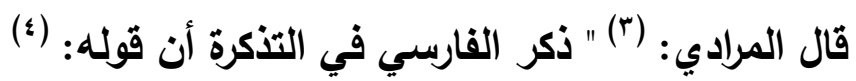

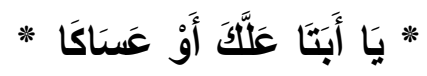

على حد "إني عسيت صائماً"، في أن الفاعل مضمر في الفعل، والكاف هو الخبر، كما أن صائماً هو الخبر، وإن خالفه في أنه معرفة وصائماً نكرة. وهذا تخريح غريب.أ.هـ.

ووجه غرابته كما تري أنه خَََّج الخبر على القليل؛ لأن المشهور في كلام العرب أن "عسى" إذا اتصل بها ضمير لايكون إلا بصورة المرفوع ، وقد يأتي بصورة

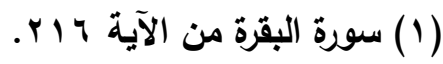

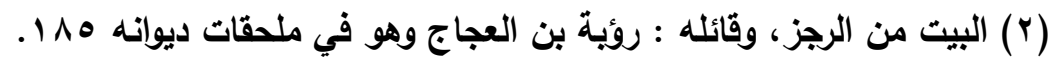

والثاهد: مجيء خبر " عسى " وهو قوليه صائماً مفرداً.

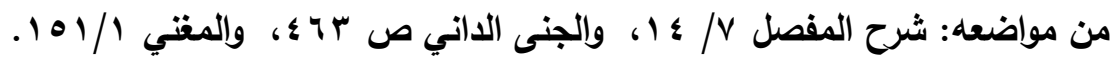

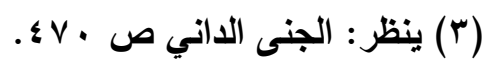

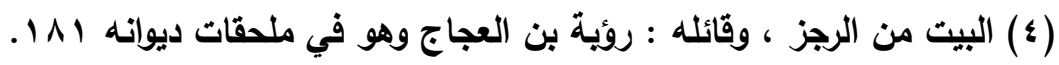

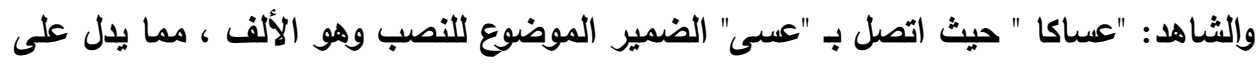
أن "عسى" حرف بمعنى "لعل"، وقيل الكاف خبر منصوب المحل، واسم "عسى" ضمير الصعل مستتر .

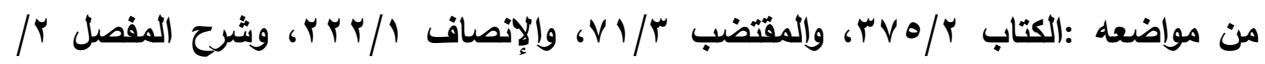

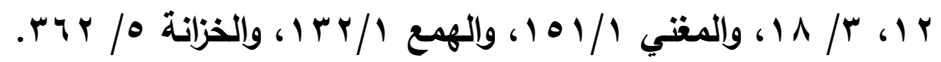


فصل المقال في الغريب من الأقوال النحوية والتصريفية د البدالرعوف ثابت أحمد عبدالله

المنصوب المتصل، قال السيوطي:(') "حق عسى إذا اتصل بها ضمير أن لا يكون إلا بصورة المرفوع هذا هو المشهور في كلام العرب، ويه نزل القرآن ومن العرب

من يأتي به بصورة المنصوب المتصل فيقال:عساني وعساك وعساه قال: (ץ)

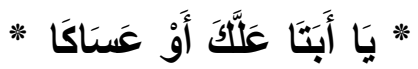

فمذهب سيبويه إقرار المخبر عنه والخبر على حاليهما من الإسناد السابق إلا

أن الخلاف وقع في العمل فعكس العمل بأن نصبت الاسم ورفعت الخبر حملاً لها

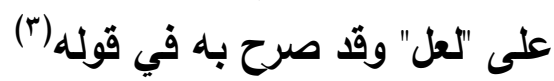

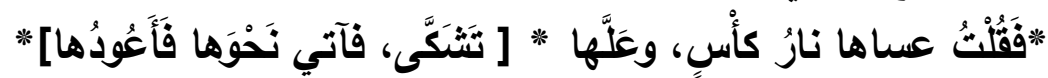
برفع نار، ومذهب المبرد، والقارسي عكس الإسناد إذ جعلا المخبر عنه خبراً

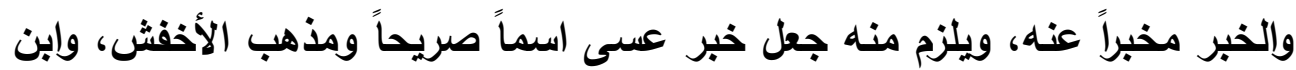

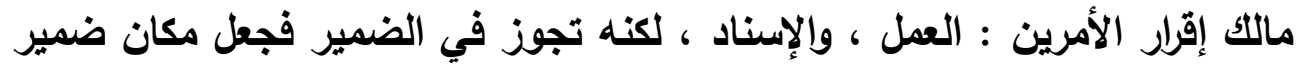
الرفع ضمير التصب وهو في محل رفع نيابة عن المرفوع ، كما ناب ضمير الرفع

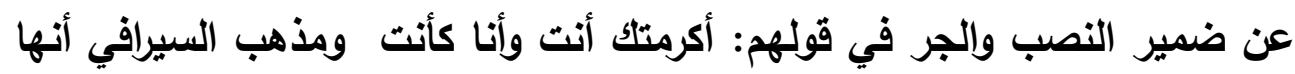
حينئذ حرف ك "لعل" وقد يقتصر والحالة هذه على الضمير المنصوب كالبيت

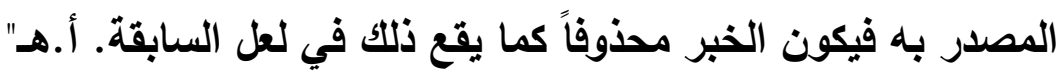

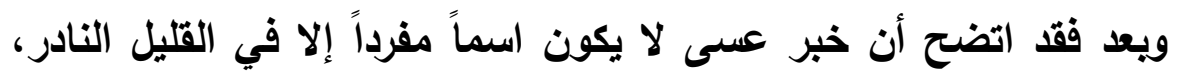

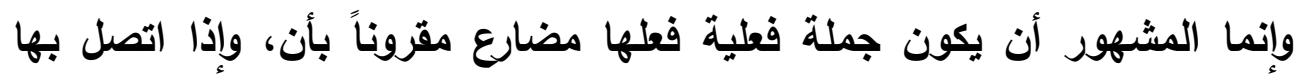
ضمير يكون في صورة المرفوع،وإذا ورد في صورة المنصوب يخرج على وجوه

$$
\begin{aligned}
& \text { (1) ينظر: همع الهوامع // بrاI. } \\
& \text { (r) سبق تحقيقه. }
\end{aligned}
$$

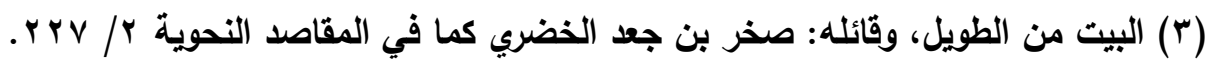

والثاهد: حيث جاءت عسى بمعنى "لعل" واسمها الضمير المتصل بها في محل نصب.

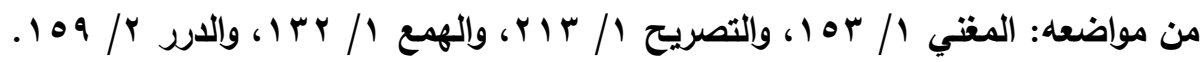


فصل المقال في الغريب من الأقوال النحوية والتصريفية د / عبدالرعوف ثابت أحمد عبدالله

الأول : أن الياء وأخواتها في موضع نصب اسماً لها ، وأن والفعل في موضع رفع خبراً لها ، وهو مذهب سيبويه.

الثاني :أن عسى باقية على أصلها ولكن انعكس الإسناد فجعل المخبر عنه خبراً لـ

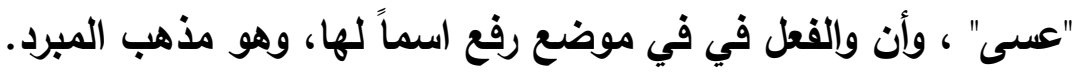

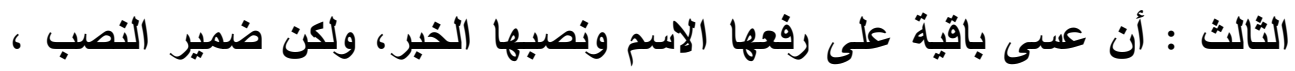

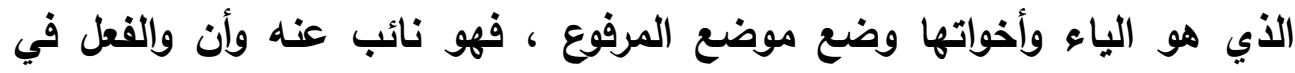

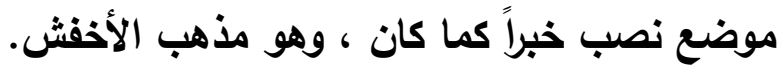

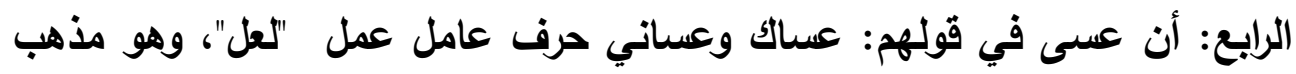

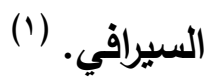

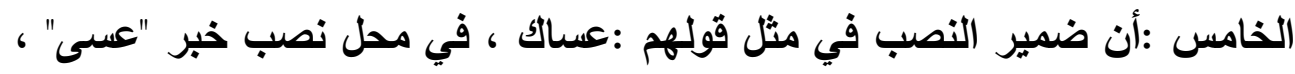

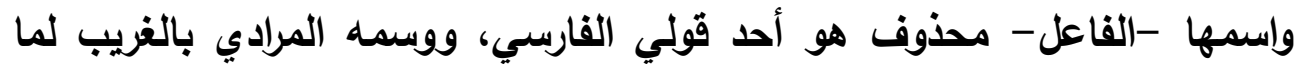

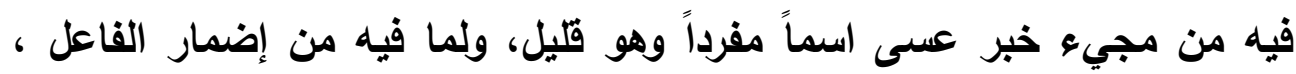

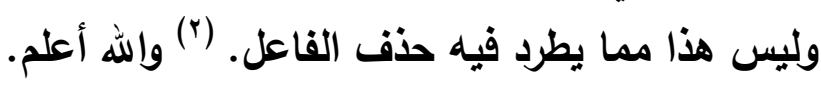

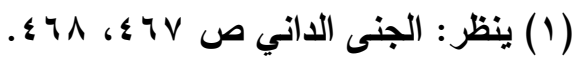

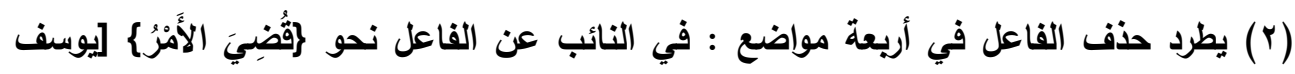

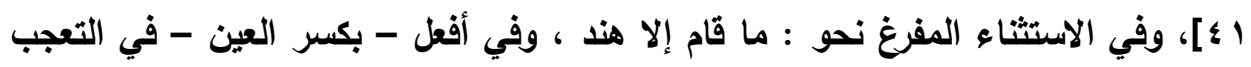

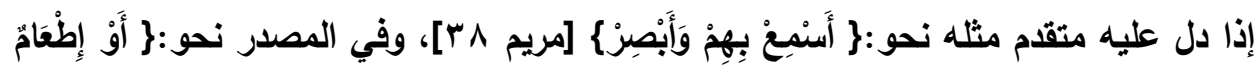

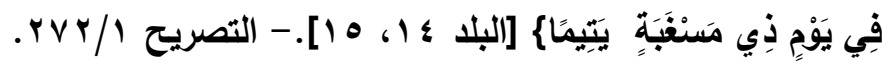


فصل المقال في الغريب من الأقوال النحوية والتصريفية د / عبدالرعوف ثابت أحمد عبدالله

\section{9 - "لكن" هركبة من قلالث كلمات}

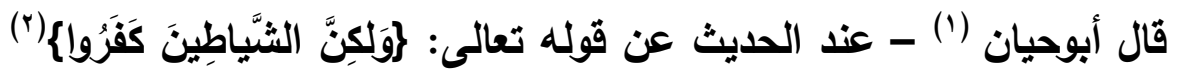

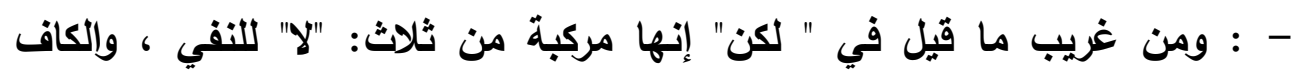
للخطاب، و" أن" التي للإثبات والتحقيق ، وأن الهمزة حذفت ؛ للاستثقال ، وهو قول فاسد ، والصحيح أنها بسيطة.أ.هـ. ووجه غرابته تركيب ثثلاثة أشياء وجعلها حرفاً واحداً ، كما أن كاف الخطاب أنهاب

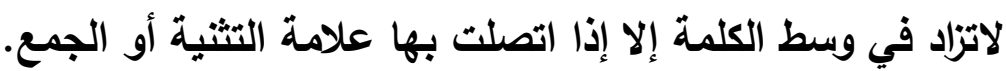

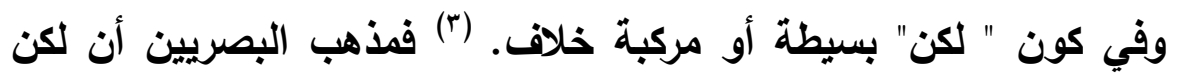
بسيطة. وأنها منتظمة من خمسة أحرف، وهو أكثر ما جاء عليه الحرف، وهو

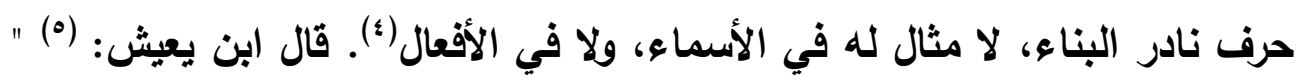
وألفه أصل، لأنا لا نعلم أحداً، يؤخذ بقوله ذهب الهاءل إلى أن الألفات في الحروف زائدة.

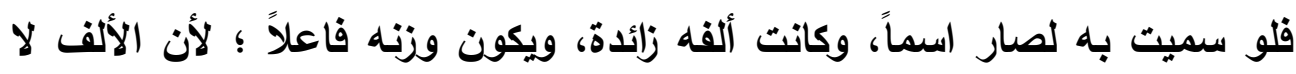
تكون أصلاً في ذوات الأربعة، من الأسماء والأفعال.

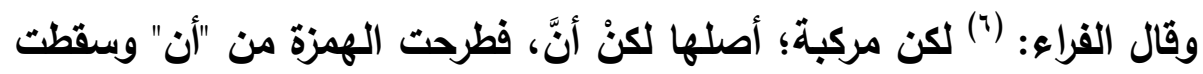
نون " لكن" حيث استقبلن ساكناً.

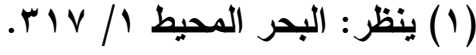

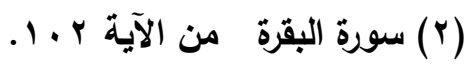

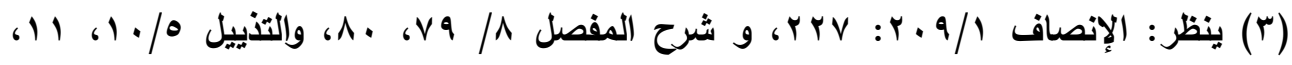

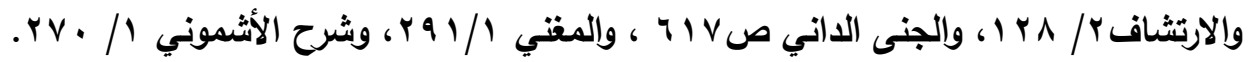

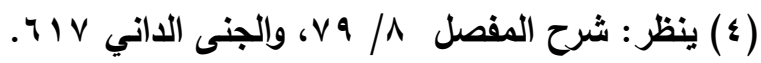

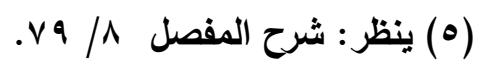

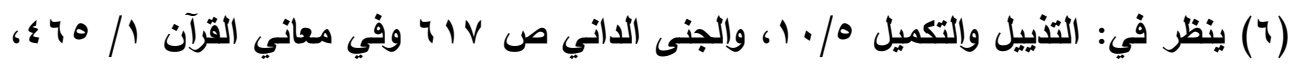

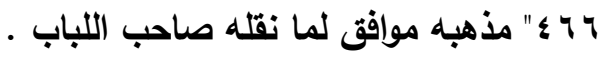


فصل المقال في الغريب من الأقوال النحوية والتصريفية د / عبدالرعوف ثابت أحمد عبدالله

ونقل صاحب اللباب(1)، عن الكوفيين، أنها مركبة من " لا " و "إن"، والكاف

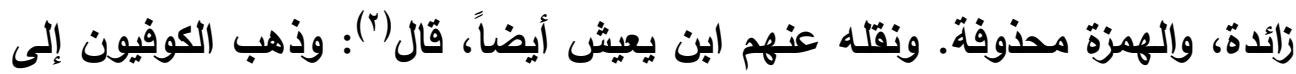
أنها مركبة، وأصلها: "إن" زيدت عليها "لا"، والكاف. وهو قول حسن، لندرة ولنه البناء، وعدم النظير. ويؤيده دخول اللام في خبره، كما تلخل في خبر إن، على مذهبهم.

ومنه: (r)

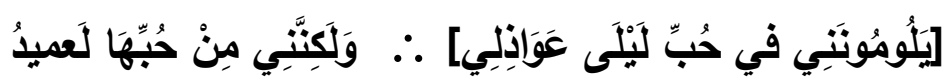

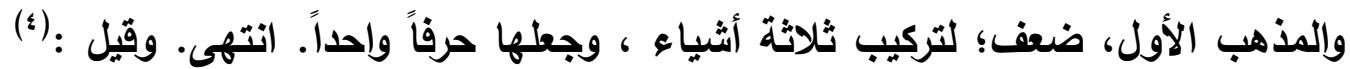

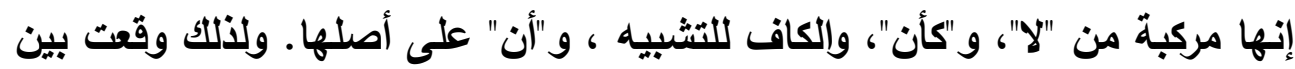

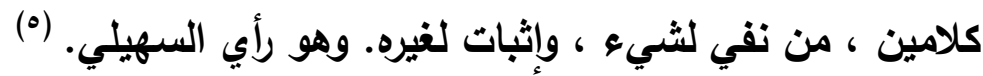
ويعد، فإن القول بتركيب " لكن" من ثُلاثة أشياء قريب من القئ القول الأي نقله أبو البقاء العكبري في اللباب ، وابن يعيش في شرح المفصل عن الكوفيين بأن

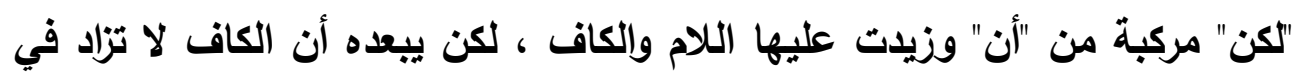

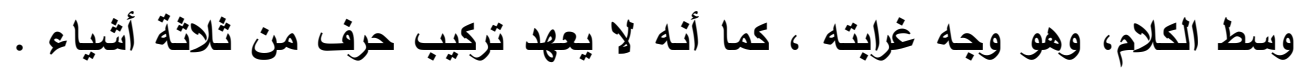
والله أعلم. وسطم

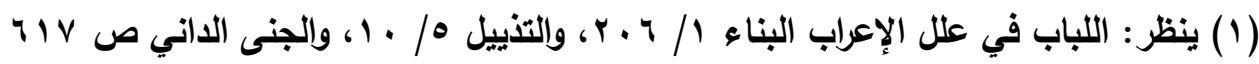

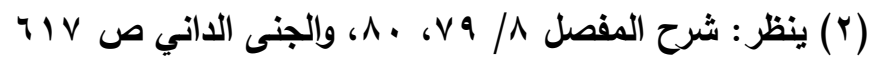
(r) البيت من الطويل ، ولم أقف على قائله. والثشاهد: قوله لعميد " أدخل اللام على خبر " لكن "عند الكوفيين.

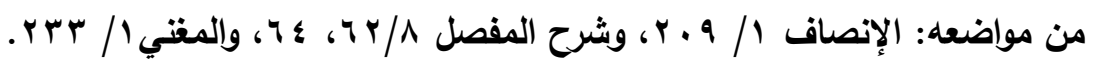

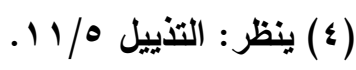

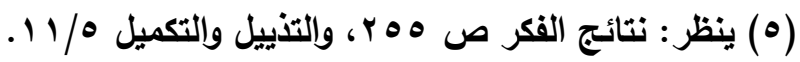


فصل المقال في الغريب من الأقوال النحوية والتصريفية د / عبدالرعوف ثابت أحمد عبدالله

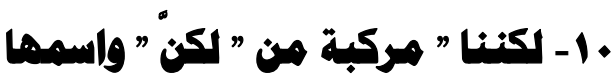

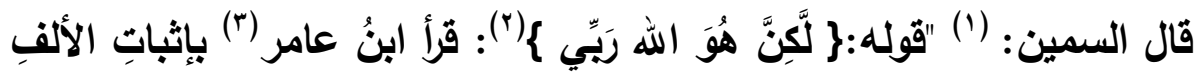

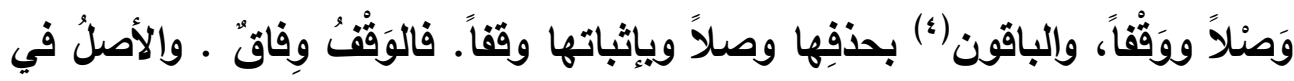

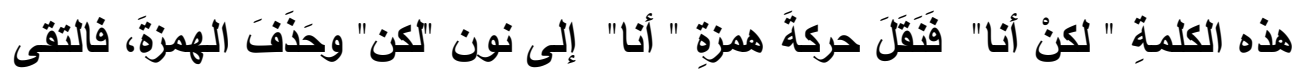
مِثْلان فَأدغم • وهذا أحسنُ الوجهين في تخريجِ هذا. وقيل: حَذَفَ هزةةَ "أنا" اعتباطاً

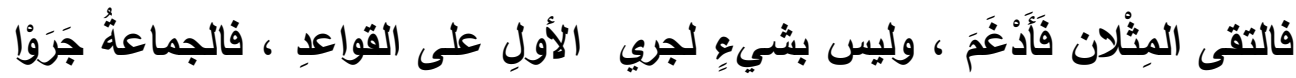

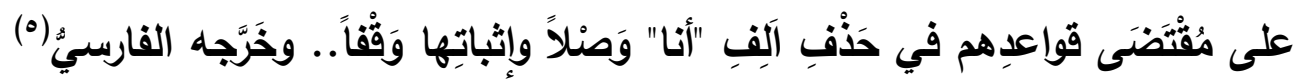

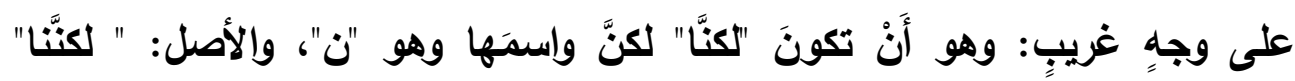

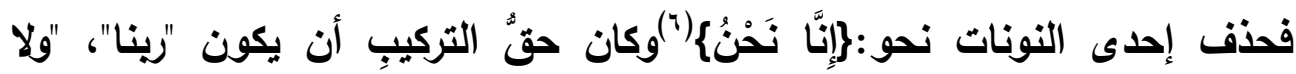
نُشرك بريّنا" قال : "ولكنه اعتبر المعنى فأفرد". وهو غريب جداً .أ.هـ ووجه غرابته على هذا التخريج أن الضمير العائد على "لكنَّا " مفرد والقياس أن يجمع ، فيقال: لكِنَّا هو الله رينا، ولكن حمله على المعنى . قال الفسوي: (v) "..ويجوز أن تكون كلمة "لكنْ" المخفقة قد لحقها النون ، والألف التي في نحو : ضرَبَنَّا، فاجتمع نون لكن الساكنة مع نون الضمير فأدغمت أندان

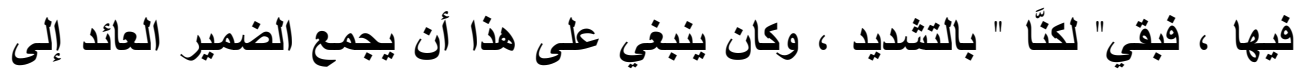

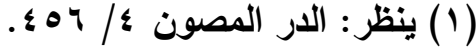

$$
\begin{aligned}
& \text { (r) سورة الكهف من الآية مبـ (r) }
\end{aligned}
$$

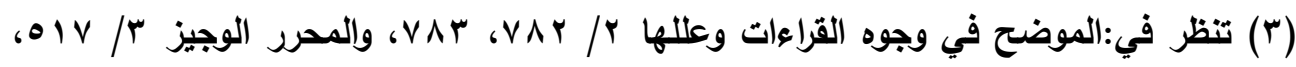

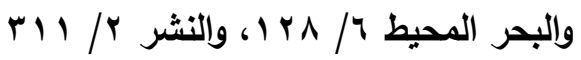

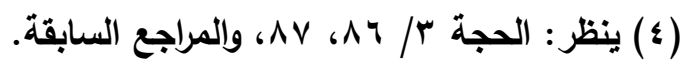

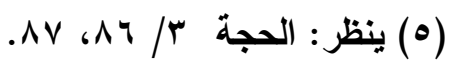

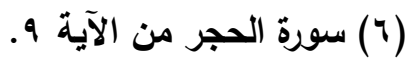

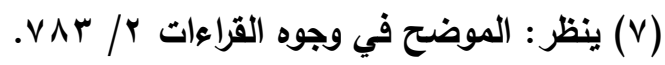


فصل المقال في الغريب من الأقوال النحوية والتصريفية د البدالرعوف ثابت أحمد عبدالله

ضمير " لكِنَّا " فيقال : لكِنَّا هو الله ربنا ، لكنه حمله على المعنى، لأن الرجل الواحد قد يقول : فعلنا وهو وحده فَعَلَهُ " وقال ابن عطية: (') ويتوجه في " لكنا" أن تكون لكن لحقتها نون الجماعة التي في : "خرجنا، وضرينا"، ووقع الإدغام لاجتماع المثلين، ثم وحد في \}يبئ على المعنى ، ولو اتبع اللفظ لقال: رينا ، ذكره أبو علي ، ويترجح بهذا التعليل قول من أثبت الألف في حال الوصل، والوقف ، ويتوجه في:\} لكنا \{ أن تكون المشهورة من أخوات "إن" ، المعنى : لكن قولي: هو \} الله ربي\{ ، أما "أني" لا أعرف من يقرأ بها وصلاً ووقةاً ، وذلك يلزم من يوجه هذا الوجه ". قال أبو حيان:(') "وأجاز أبو علي أن تكون لكن لحقتها نون الجماعة التي في خرجنا، وضرينا، ووقع الإدغام؛ لاجتماع المثلين، ثم وحد في رَبِّي على المعنى، ولو اتبع اللفظ لقال: رينا انتهى. وهو تأويل بعيد". ثم ذكر نص ابن عطية ، وتوقفه في القراءة ، ثم قال :" وذكر أبو القاسم يوسف بن عليّ بن جبارة الهذلي في كتاب الكامل في القراءات من تأليفه ما نصه: يحذفها في الحالين يعني ؛ الألف في الحالين ، يعني الوصل والوقف: حمصي ، وابن عتبة ، وقتيبة غير الثقفي ، ويونس عن أبي عمر · ويعني بحمصي : ابن أبي عبلة ، وأبا حيوة ، وأبا بحرية..."

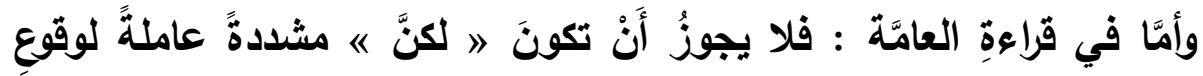

الضمير بعدها بصيغةِ المرفوع .

ويعد فإن كان الأصل هو مراعاة اللفظ والمعنى، إلا أن الحمل على المعنى فقط، ليس غريباً وقد أفرد له تلميذ الفارسي ابن جني مبحثاً خاصاً في كتابه

$$
\begin{aligned}
& \text { (1) ينظر : المحرر الوجيز س/ / VIV. }
\end{aligned}
$$

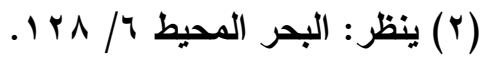


فصل المقال في الغريب من الأقوال النحوية والتصريفية د / عبدالرعوف ثابت أحمد عبدالله

الخصائص(') حيث قال :" فصل في الحمل على المعنى" اعلم أن هذا الشرج غور من العربية بعيد ، ومذهب نازح فسيح ـ قد ورد به القرآن وفصيح الكلام منثوراً ومنظوماً كتأنيث المذكر، وتذكير المؤتث ، وتصور معنى الواحد في الجماعة ، والجماعة في الواحد ، وفي حمل الثاني على لفظ قد يكون عليه الأول أصلاً كان ذللك اللفظ ، أو فرعاً ، وغير ذلتك. والله أعلم. 
قال أبو حيان: (') "ومن غريب المنقول ما وقع في( النُّت التي على إيضاح الفارسي) تأليف أبي علي الحسن بن علي بن حمدون الأسدي المعروف بالجَلُوليّ

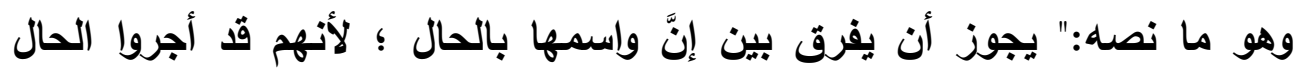

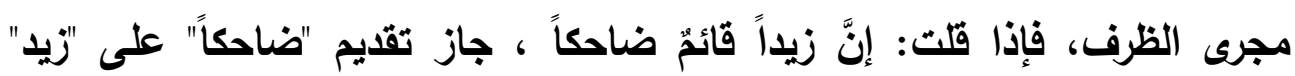
فتقول: إنَّ ضاحكاً زيداً قائم. فإن قيل: إذا قدمت "ضاحكاً" وهو متعلق بقائم صرت كأتثك قدمت بعض فض الخبر.

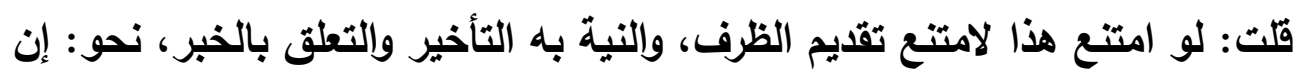

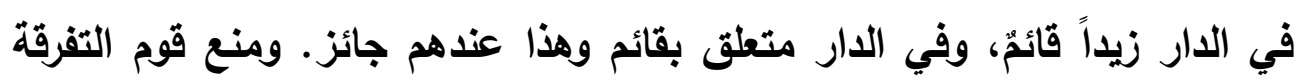
بين إن واسمها بالحال" انتهى كلامه.

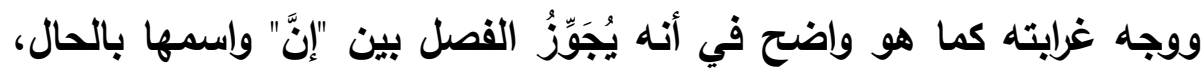
والنحاة يمنعون ذلك ، ولايجيزون الفصل إلا بالظرف.

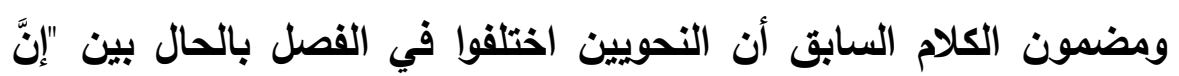
واسمها، ولم أقف عليه لأحد من النحاة ، وهو ما دعى أبا حيان إلى القول بغرابته.

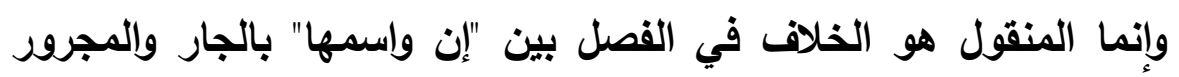

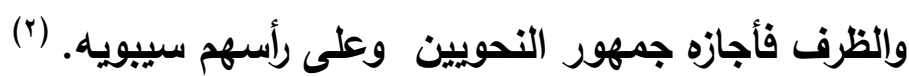
حيث قال في باب الحروف الخمسة التي تعمل فيما بعدها كعمل الفعل فيما

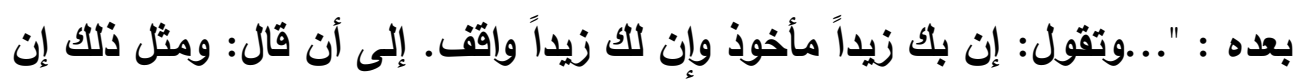
فيك زيداً لراغبّ. قال الثاعر: (َ)

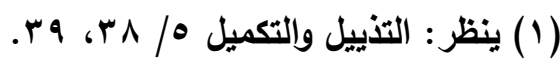

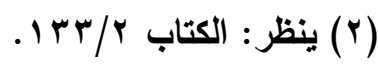
(r) البيت من من الطويل ، ولم أقف على قائله . 
فصل المقال في الغريب من الأقوال النحوية والتصريفية د البدالرعوف ثابت أحمد عبدالله

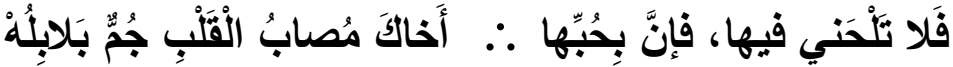

كأنك أردت: إن زيداً راغب، وإن زيداً مأخوذ، ولم تذكر بك ولا فيك فألغيتا هنا كما

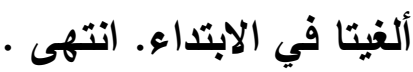

وفي "إيضاح الشعر" قال الفارسي" (') :" الظرف قد استجيز فيه من الاتساع ما لم يستجز في غيره ، ألا ترى أنه قد جاء" فَلا تَلْحَني فيها " البيت ... ، قفصل بقوله: "بحبها" بين إن واسمها. ولو كان مكان الظرف غيره لم يجز ذلك.والظرف متعلق بالخبر كأنه قال: إن أخاك مصاب القلب بحبها ، وقال ابن هشام في المغتي: (r) "(لقاعدة التاسعة إنهم يتسعون في الظرف والمجرور ما لا يتسعون في غيرهما فلذلك فصلوا بهما بين الحرف الناستخ ومنسوخه نحو قوله:

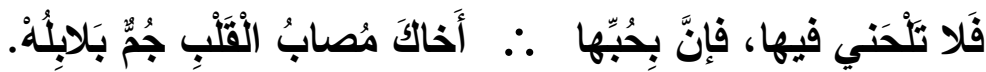
ويعد فقد اتضح أن القول بالفصل بين إن واسمها بالحال تثبيهاً للحال بالظرف هو قول انفرد به الحسن بن علي الجلولي وهو مخالف لما أجمع عليه النحاة. والله أعلم.

والثَاهد: "فإِنَّ بِحُبِّها ... أَخاكَّ" حيث فصل بقوله : "بحبها" بين إن واسمها.

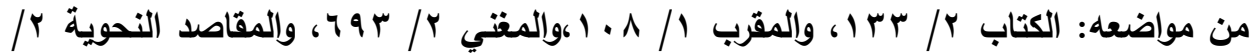

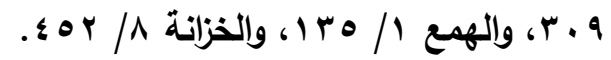

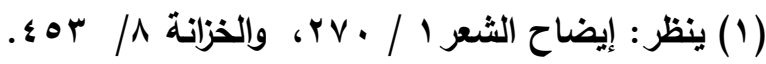

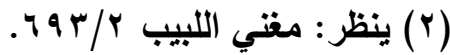


فصل المقال في الغريب من الأقوال النحوية والتصريفية د/ عبدالرعوف ثابت أحمد عبدالله

\section{rا بإل إعمال "إن" الداخلة على " مها " الزراندة}

قال ابن الناظم ('): "...وذكر ابن برهان: (ז) أن الأخفش روى: إنما إنما زيداً

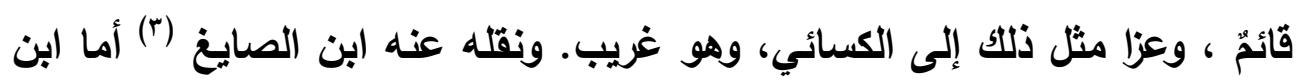

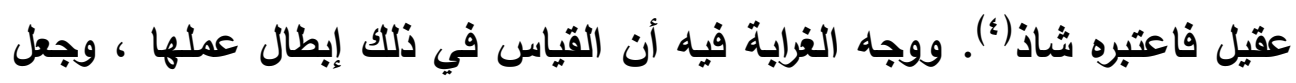

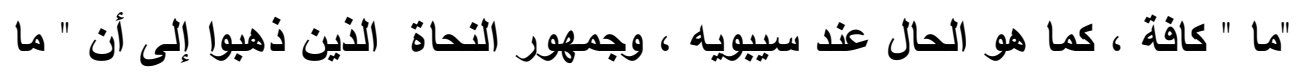
" الزائدة " تلخل على إن وأخواتها ، فتكفها عن العمل ، إلا ليت فقيها وجهان، تقول: إنما زيد قائم، وكأنما خالد أسد ، ولكنما عمرو جبان ، ولعلما أخوك ظافر. ولا سبيل إلى الإعمال ؛ لأن "ما " قـ أزالت اختصاص هذه الأحرف بالأسماء، فوجب

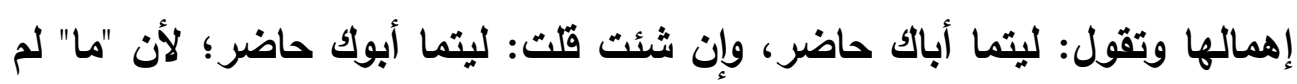

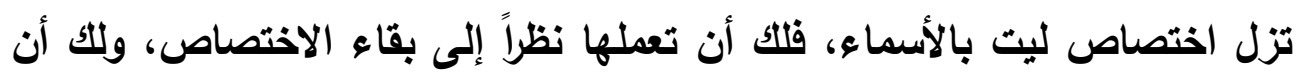

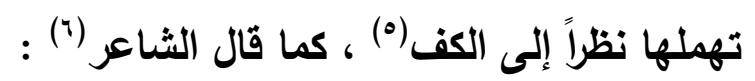

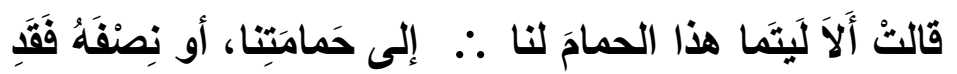
يروى بنصب الحمام، ورفعه. وهذا ما صححه ابن الحاجب(v)، وابن عصفور

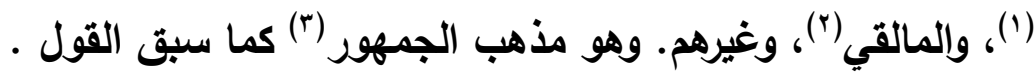

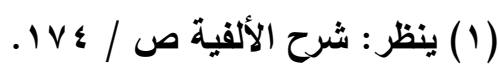

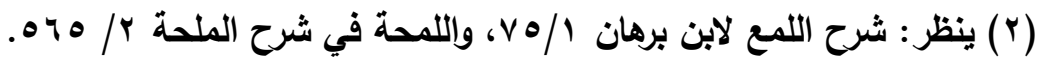

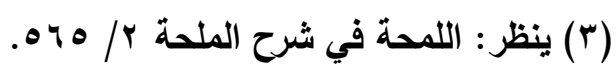

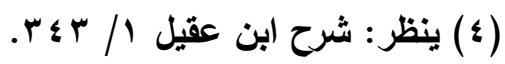

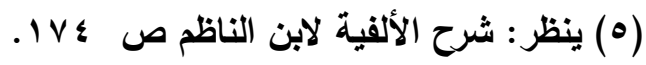

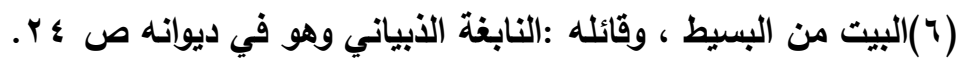
والثاهد فيه : جواز إعمال " ليت" التي اتصلت بـ "ما " وعدم إعمالها.

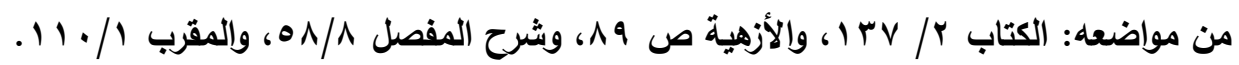

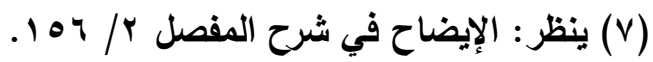


فصل المقال في الغريب من الأقوال النحوية والتصريفية د/ عبدالرعوف ثابت أحمد عبدالله

وأما ما رواه الأخفش عن العرب من إعمال "إن" مع اتصالها بـ "ما" الزائدة وعزاه إلى الكسائي فقد قال به طائفة من النحاة ، أمثال: الرماني، والزجاج ، وابن السراج

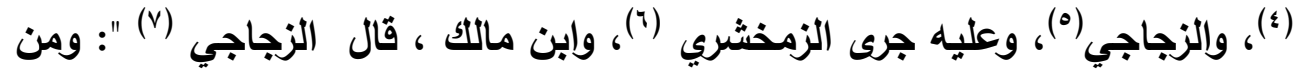
العرب من يقول: إنما زيداً قائم ، ولعلما بكراً قائم ، فيلغى "ما" وينصب بأن، وكذلك الك أخواتها." واختار هذا المذهب ابن مالك في شرح التسهيل(^) حيث قال :" .. وذكر

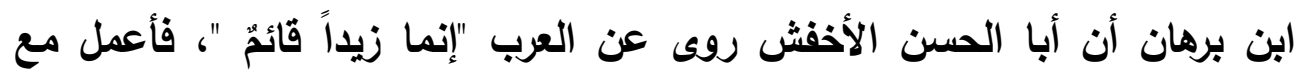
زيادة " ما"، وعزا مثل ذلك إلى الكسائي عن العرب. وهذا النقل الأي نقله ابن برهان - رحمه الله- يؤيد ما ذهب إليه ابن السراج من إجراء عوامل هذا الباب على سنن واحد قياساً ، وإن لم يثبت سماع في إعمال جميعها ـ ويقوله أقول في هذه المسألة • ومن أجل ذلك قلت: القياس سائغ. وفي الألقية قال (9):

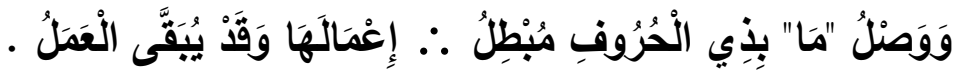

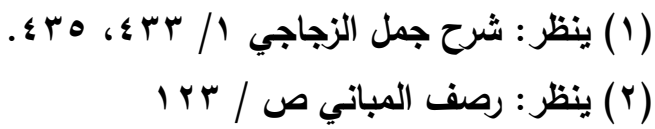

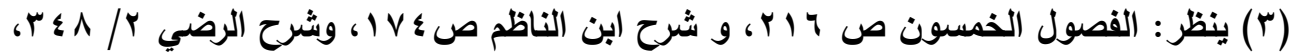

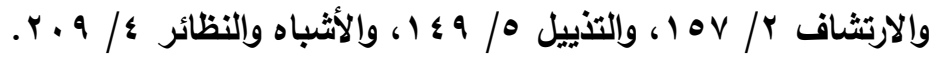

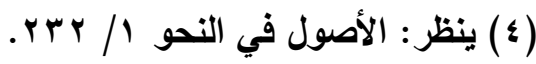

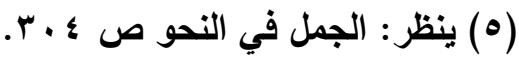

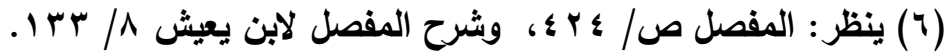

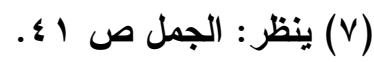

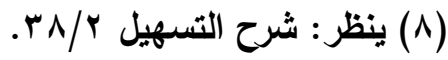

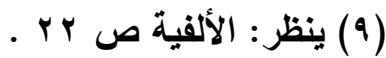


فصل المقال في الغريب من الأقوال النحوية والتصريفية د / عبدالرعوف ثابت أحمد عبدالله

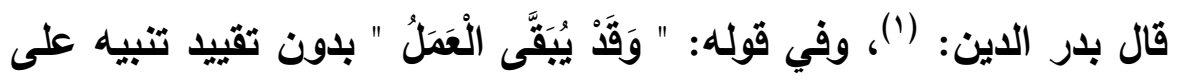
مجيء مثله، فلعلهم يرون أنه يكفي في صحة، الإعمال الاختصاص بحسب الأصل، ولا يضر عروض زواله، ولذلك نظائر كثيرة، كجواز إعمال أن المخفقة من الثقيلة، وغير ذلك، ومنهم من يرى أن هذا يكون مع ليت، ولعل، وكأن ، دون إن ، وأن ، ولكن، وهو مذهب الزجاج ، وابن السراج.

أما أبوالبقاء فلم ير الإعمال في الجميع حتى ليت، لما فيه من زوال

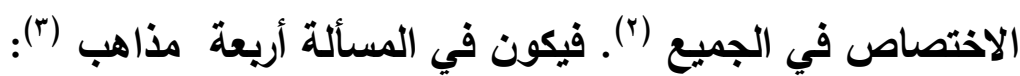
ويعد فقد اتضح أن ما رواه الأخفش - ومن تبعه- عن العرب من إعمال "إن" إذا اتصلت بما الزائدة ليس غريباً كما قال ابن الناظم وابن الصايغ ، وإنما رواه الثقات عن العرب ، وتناقّه العلماء كابراً عن كابر، وها هو أبو جعفر النحاس يجيزه

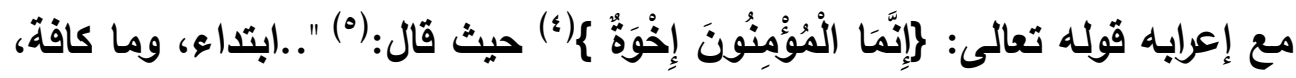
كافة، ويجوز في القياس النصب ومنعه سيبويه." والله أعلم.

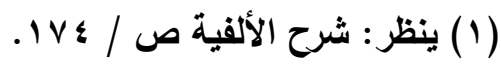

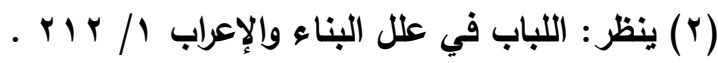

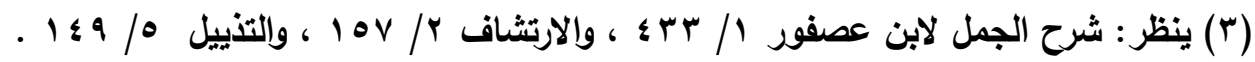

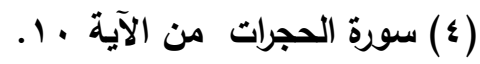

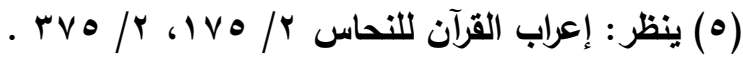


فصل المقال في الغريب من الأقوال النحوية والتصريفية د / عبدالرعوف ثابت أحمد عبدالله

\section{rا - وقوع " أن" الافففة بمد فمل التمنهي}

قال ابن مالك:(1) "لا تقع "أن" المخففة- غالبًا- إلا بعد علم أو ظن فلألك قلت : وقبل "أن" ذي علم أو ظن لزم هـ ويشذوذ ما سوى هذا وسم

فمن الشاذ قول كثير: (r)

تمنيك نفس أن ستدنو ولو دنت دنت

وقول الفرزقد: (ז)

أبيت أمني النفس أن سوف نلتقي . وهل هو مقدور لنفسي لقاؤها

فأوقعا "أن" المخفقة بعد فعل التمني - وهو غريب. أ.هـ "

ووجه غرابته أنَّ "أنْ" هذه معمولة لما قبلها، وأن معناها التأكيا والتحقيق ،

مجراها في ذلك مجرى المكسورة فيجب أن يكون الفعل الذي تبنى عليه مطابقاً لها في المعنى بأن يكون من أفعال العلم واليقين ونحوهما مما معناه الثبوت والاستقرار؛ ليطابق معنيا العامل والمعمول ولا يتناقضا، وحكم المخففة من الثقيلة في التأكيا والتحقيق حم المثقلة فلألك لا ياخل عليها من الأفعال إلا ما ياخل على المثقلة . ولهزا اشترط النحويون ألا يقع قبلها شيء من أفعال الطمع والإثفاق نحو: اشتهيث، وأردت ، وأخاف، لأن هذه الأفعال يجوز فيها أن يوجد ما بعدها وأن لا يوجد، فلذلك لا يقع بعدها إلا أن المخفقة الناصبة للأفعال ؛ لأنه لا تأكيد فيها ولا

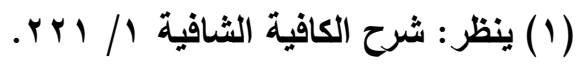

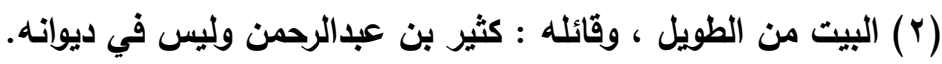

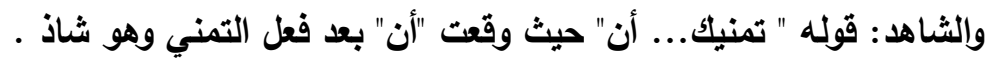

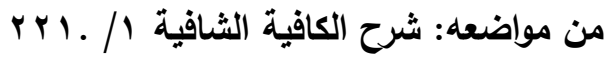

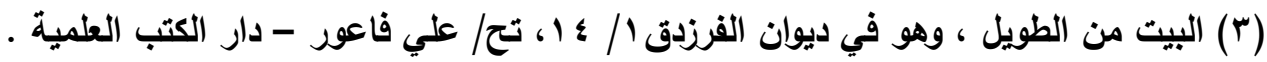

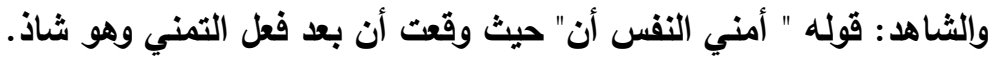

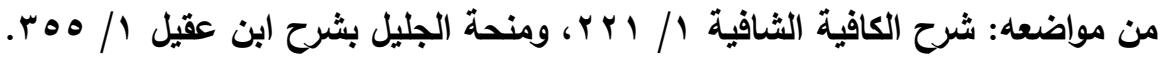


فصل المقال في الغريب من الأقوال النحوية والتصريفية د / عبدالرعوف ثابت أحمد عبدالله

مضارعة لما فيه تأكيا فتقول: أرجو أن تحسن إليَّ، وأخاف أن تسيء إليَّة، قال

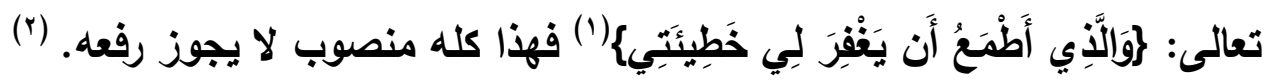
ويذلك يكون ما ورد من وقوع "أن" بعد فعل التمني من باب الغريب الثاذ

الأي يحفظ ولا يقاس عليه .والله أعلم .

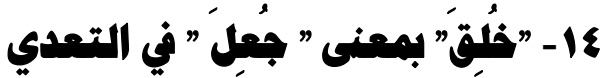

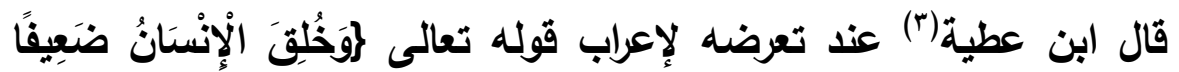
\{('): الإنسان" رفع على ما لم يسم فاعله، و" ضعيفاً" حال، وقرأ ابن عباس ومجاهد

$$
\begin{aligned}
& \text { (1) سورة الثعراء من الآية r. 1). }
\end{aligned}
$$

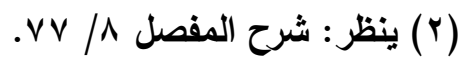

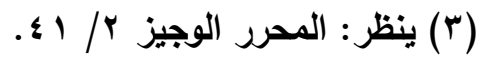


فصل المقال في الغريب من الأقوال النحوية والتصريفية د/ عبدالرعوف ثابت أحمد عبدالله

:(") وخَلقَ الإنسانه على بناء الفعل للفاعل و "ضعيفاً" حال أيضاً على هذه القراعة ، ويصح أن يكون " خلق " بمعنى جعل ، فيكسبها ذلك قوة التعدي إلى الهى مفعولين ، فيكون قوله " ضعيفاً " مفعولاً ثانياً .أ.هـ وتعقبه السمين الحلبي (َّ) حيث

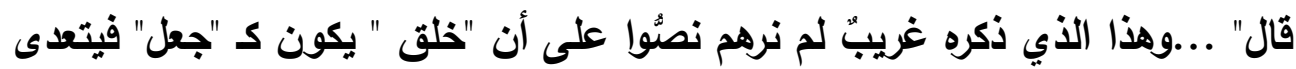
لاثنين مع حَصنهم للأفعال المتعدية لاثنين ، بل أليناهم يقولون: إن "جعل" إذا كانت بمعنى " خلق " تَعَََّتْ لواحد ". ووجه غرابته عند السمين ؛ أنه لم يقل به غير ابن عطية وهو ما صرح به أبوحيان(؛) في البحر حيث قال :"وانتصاب ضعيفاً على الحال. وقيل : انتصب على التمييز. لأنه يجوز أن يقدر بمن ، وهذا ليس بشيء. وقيل : انتصب على إسقاط حرف الجر، والتقدير : جعل من شيع ضعيف، أي من طين، أو من نطفة وعلقة ومضغة. ولما حذف الموصوف والجار انتصبت الصفة بالفعل نفسه. قال ابن عطية:(ه) ويصح أن يكون خلق بمعنى: جعل، فيكسبها ذلك قوّة التعدي إلى

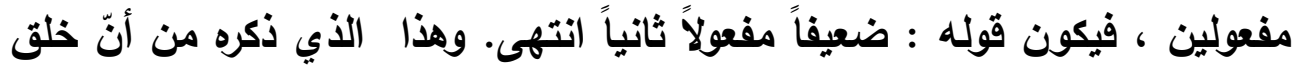
يتعدى إلى اثين بجعلها بمعنى جعل ، لا أعلم أحداً من النحويين ذهب إلى ذلك ، بل الأي ذكر الناس أنّ من أقسام جعل أن يكون بمعنى : خلق ، فيتعدّى إلى

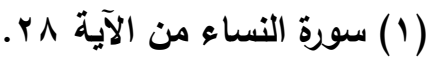

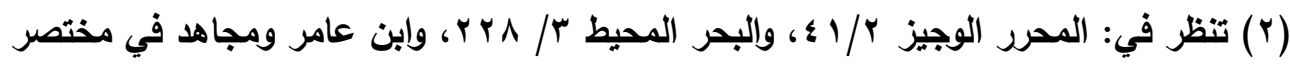

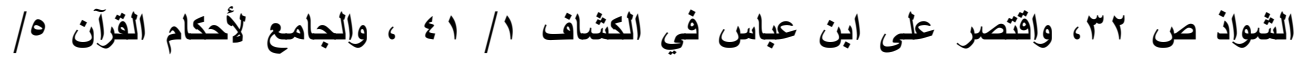

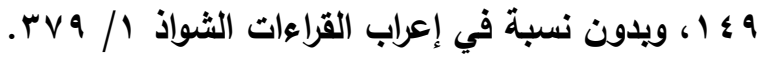

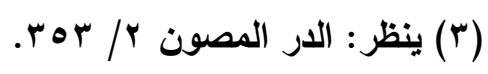

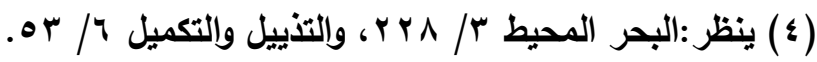

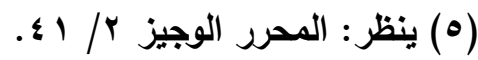


فصل المقال في الغريب من الأقوال النحوية والتصريفية د / عبدالرعوف ثابت أحمد عبدالله

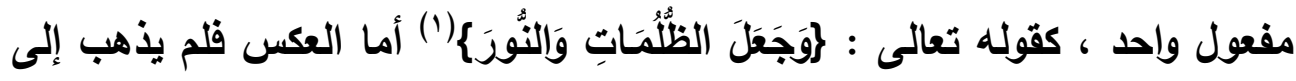
ذلك أحد فيما علمناه ، والمتأخرون الذين تتبعوا هذه الأفعال لم يذكروا ذلك.أ.هـ قال السيوطي: (r) "وألحق هشام بأفعال هذا الباب ؛عرف ، وأبصر وألحق بها ابن درستويه ؛ أصاب، وصادف، وغادر، وألحق بها بعضهم خلق بمعنى: جعل كقوله: \}وخلق الإنسان ضعيفا\{(") والجمهور أنكروا ذلك، وجعلوا المنصوب الثاني في الجميع حالاً، وزعم جماعة من المتأخرين منهم : خطاب الماردي، أنه قد يجوز تضمين الفعل المتعدي إلى واحد معنى صير، ويجعل من هذا الباب ، فأجاز حفرت

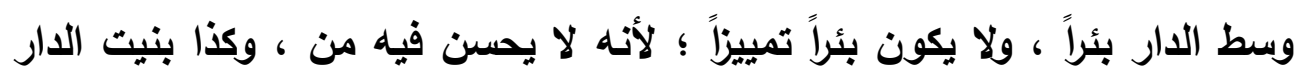

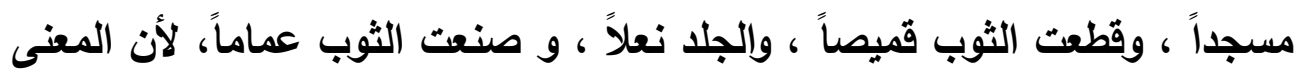
فيها: صيرت ، قال أبو حيان:" والصحيح أن هذا كله من باب التضمين الذي يحفظ ولا يقاس عليه" وذكر السكاكي في المفتاح فيما يتعدى إلى اثنين توهمت، و تيقتت، و شعرت، و دريت، وتبينت، و أصبت، و اعتقدت، و تمنيت، و وددت، وهب

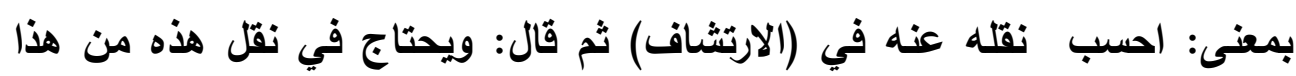
الباب إلى صحة نقل عن العرب..."

ويعد فإن ما قاله ابن عطية ونعته السمين الحلبي بالغريب ، وقال أبوحيان:

لا أعلم أحداً من النحويين ذهب إلى ذلك "، وجدت العلامة القرطبي نص عليه في ونيه موضعين ، ونسب أحدهما إلى إمام النحويين ، فعند الحديث عن قوله تعالي: رُرَبَّنَا

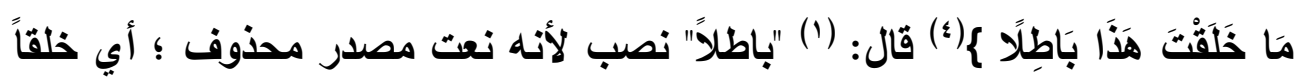

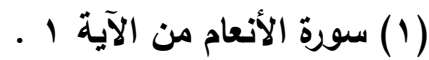

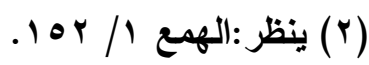

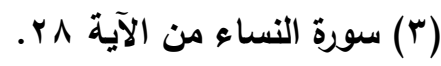

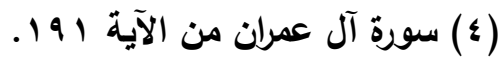


فصل المقال في الغريب من الأقوال النحوية والتصريفية د/ عبدالرعوف ثابت أحمد عبدالله

باطلاً وقيل: انتصب على نزع الخافض، أي ما خلقتها للباطل. وقيل: على المفعول

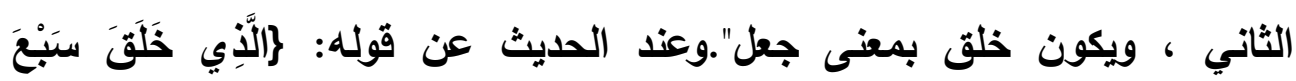

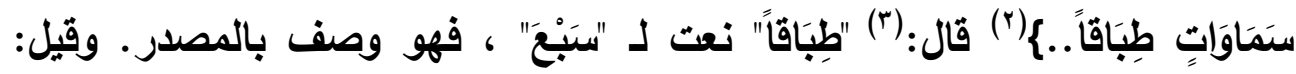
مصدر بمعنى المطابقة ؛ أي خلق سبع سموات وطبقها تطبيقاً أو مطابقة. أو على طويقت طباقاً. وقال سبيويِه : نصب" طِبَاقَاً لأنه مفعول ثان. قلت : فيكون "خَلَقَ " بمعنى جعل وصير".

ويذلك يكون ما ذكره ابن عطية ليس غريباً ، ولم ينفرد به إذا صح نقل القرطبي عن سيبويه ، وللأمانة لم أقف عليه في كتاب سيبويه ولعله فهمه من موضع آخر • والله أعلم .

\section{0 - الاشتخفال باسم الإشمارة}

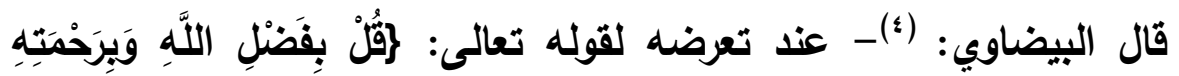

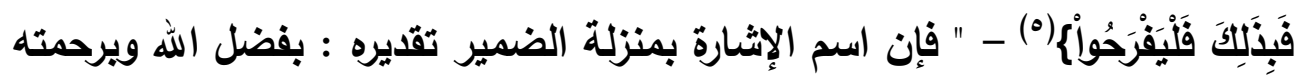

$$
\begin{aligned}
& \text { (1) ينظر : الجامع لأحكام القرآن \& / ج اسب. }
\end{aligned}
$$

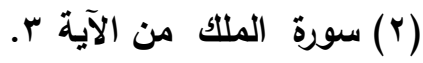

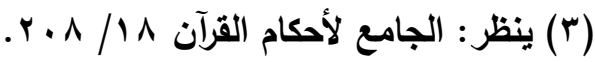

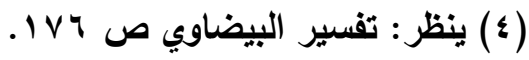

$$
\begin{aligned}
& \text { (•) سورة يونس من الآية ^هـ. }
\end{aligned}
$$


فليعتنوا أو فليفرحوا فبذلك.."، وعلق الشهاب الخفاجي(') على ذلك بقوله :" يعني أنه من باب الاثتغال، وشرطه اشتغال العامل بضمير المعمول واسم الإثارة يقوم مقام الضمير فاشتغاله به بمنزلة الاثتغال بضميره وذلك إثارة إليهما باعتبار ما

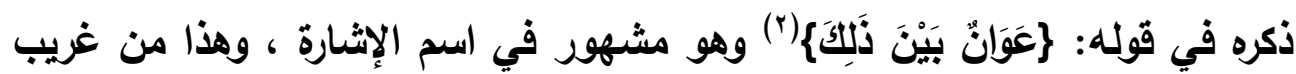
العربية فإن المعروف في الاثتغال اشتثاله بالضمير، وكونه باسم الإشارة لم يأكره التحاة." ونص على هذا أيضاً الشهاب الآلوسي في روح المعاني (َ) ووجه غرابته أن المعروف في شرط الباب اشتغال العامل بضمير المعمول ، ولم يذكر أحد من النحويين اشتغاله باسم الإشارة إليه. من المعهود لاى النحاة أن اشتغال العامل عن المعمول يكون إما بضميره ، وإما بشيء مضاف إلى ضميره فإذا قلت: زيداً ضريته، فهنا اشتغل بضميره ، وإذا قلت :زيداً ضربت غلامه ،فهو مشتغل بمضاف إلى ضميره، وكلام ابن مالك في

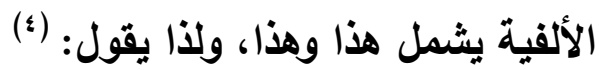

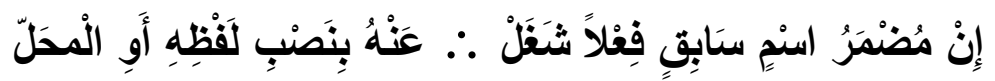
وأما كون العامل يشتغل باسم الإشارة لقيامه مقام الضمير فشيع لم بـإكره التحاة ، ولم أقف عليه فيما وقع تحت يدي من كتب النحو، إلا في حاشية الشهاب الخفاجي على تفسير البيضاوي، وتبعه الشهاب الآلوسي في روح المعاني، ولهذا فهو حق يعد من بدائع العربية ـ والله أعلم.

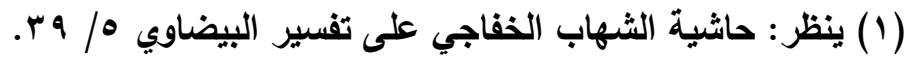

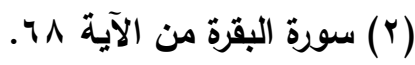

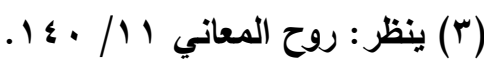

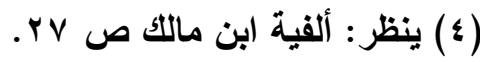


فصل المقال في الغريب من الأقوال النحوية والتصريفية د / عبدالرعوف ثابت أحمد عبدالله

\section{7 - مذف الاقول وبقاء القول}

قال ابن هشام(1) في صدد حديثه عن حذف المفعول : "ومن غريبه حذف

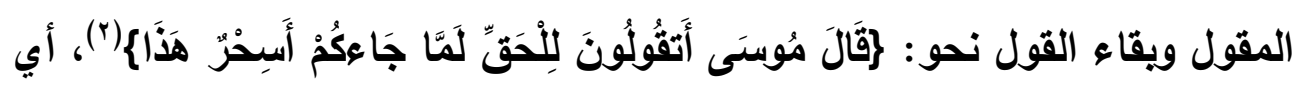
هو سحر، بدليل

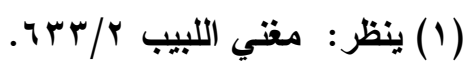

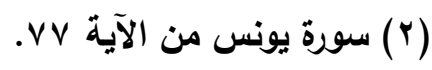


فصل المقال في الغريب من الأقوال النحوية والتصريفية د / عبدالرعوف ثابت أحمد عبدالله

ووجه غرابته أن حذف المفعول يكثر بعد فعل المثيئة والإرادة ، ونفي العلم

، والعائد الموصول والعائد المخبر عنه دونهما ، ويقل حذفه بعد القول ، وأما

عكسه وهو حذف القول ويقاء المقول فكثير أيضاً حتى قال أبو علي الفارسي(') : "حذف القول حديث البحر قل ولا حرج ".

واعلم أن ما ذكره ابن هشام ووسمه بالغريب سبق وأن ذكره الزجاجي ،

والزمخشري، وأبوالبقاء العكبري ، والقرطبي ، وابن جزي الكلبي، وأبوحيان ولم يسمه

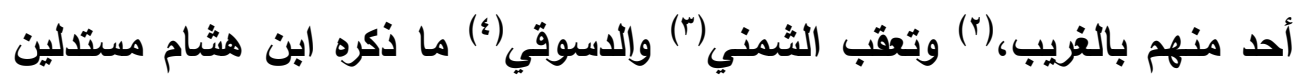
على ذلك بما ذكره الزمخثري.، قال الشمني: ما ذكره ابن هشام هو أحد أوجه ذكرها

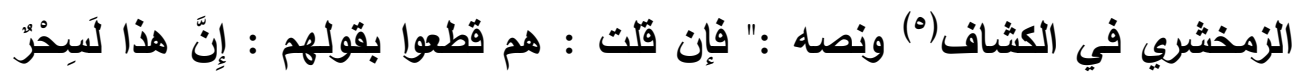
مُبِينٌ على أنه سحر ، فكيف قيل لهم : أتقولون أسحر هذا ؟ قلت: فيه أوجه: أن

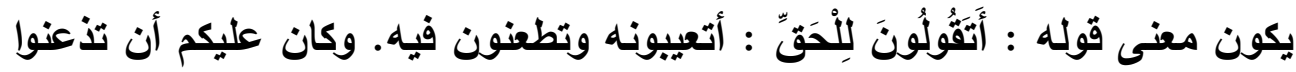
له وتعظموه، من قولهم: فلا يخاف القالة، وبين الناس تقاول إذا قال بعضهم لبعض

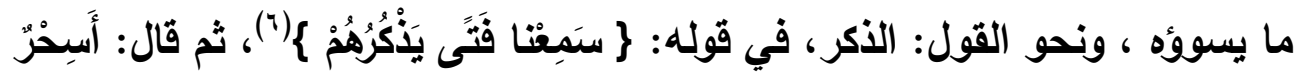
هذا فأنكر ما قالوه في عيبه والطعن عليه، وأن يحذف مفعول أتقولون وهو ما دل

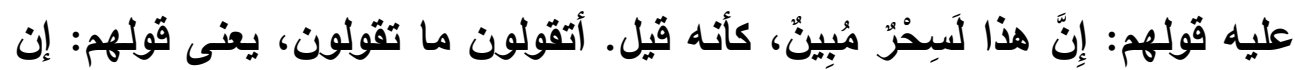

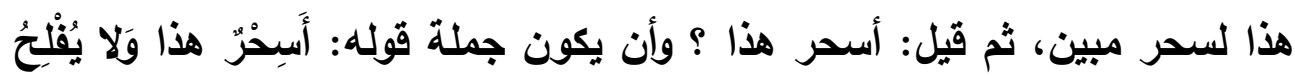

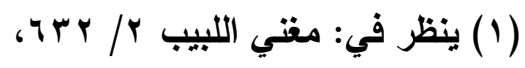

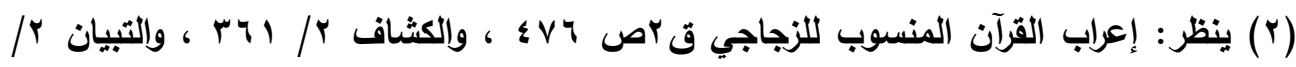

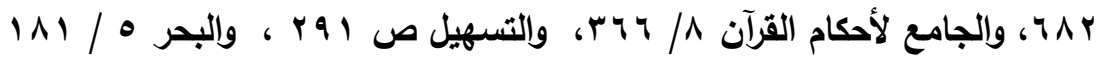

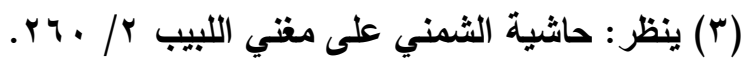

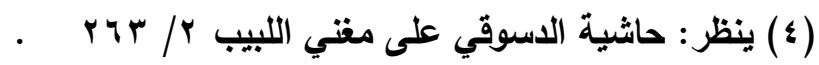

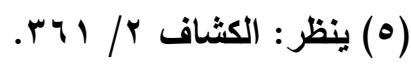

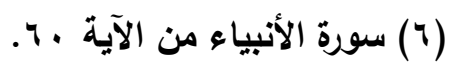


فصل المقال في الغريب من الأقوال النحوية والتصريفية د البدالرعوف ثابت أحمد عبدالله

السَّاحرُونَ ، حكاية لكلامهم، كأنهم قالوا: أَجئتما بالسحر تطلبان به الفلاح وَلا يُفْلَحُ

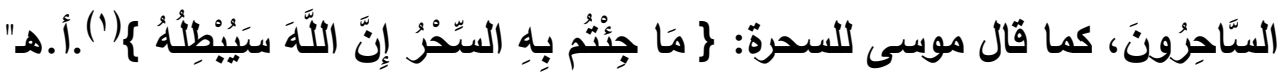

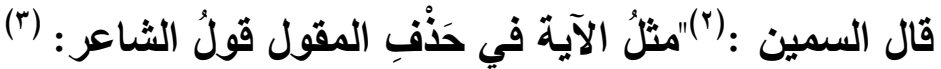

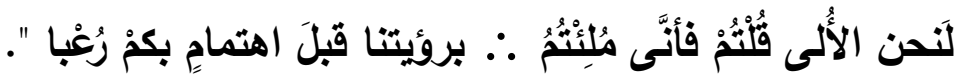

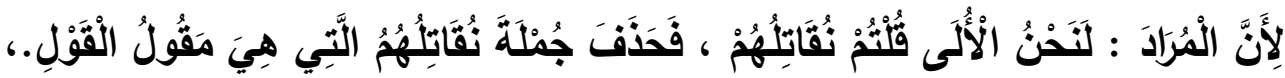

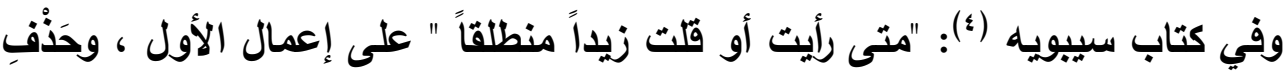
وحَذْفِ معمولِ القول

ويذلك اتضح لنا أن حذف المقول ويقاء القول ليس غريباً كما قال ابن هشام ؛ بلاليل الآية ، والبيت السابقين ، وإنما هو قليل في لغة العرب ، وعكسه هو

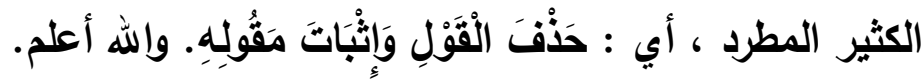

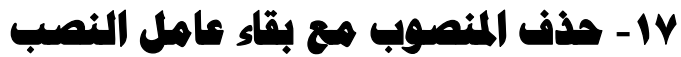

قال ابن هشام (ه) في المغتي بعد أن حكى عن الكوفيين أن كي ناصبة دائماً

دائماً قال: ويرده قولهم: كيمه كما يقولون لمه ، وأجابوا بأن التقدير: كي تفعل ماذا ، ويلزمهم كثرة الحذف، وإخراج ما الاستفهامية عن الصدر، وحذف ألفها في غير الجر ، وحذف الفعل المنصوب مع بقاء عامل النصب، وكل ذلك لم يثبت. نعم وقع

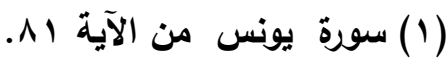

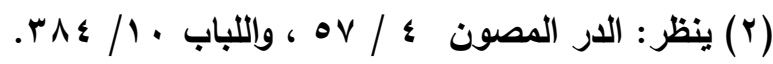
(r) البيت من الطويل ، ولم أقف على قائله.

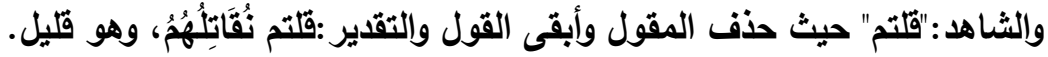

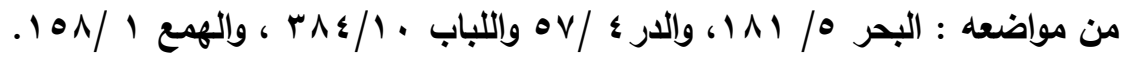

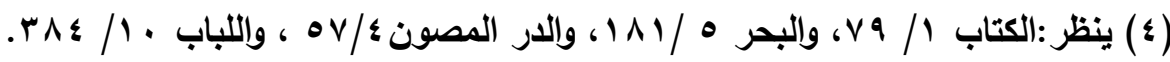

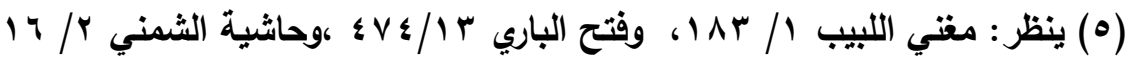


فصل المقال في الغريب من الأقوال النحوية والتصريفية د / عبدالرعوف ثابت أحمد عبدالله

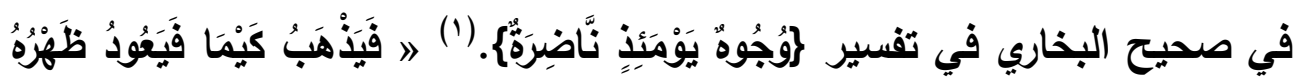

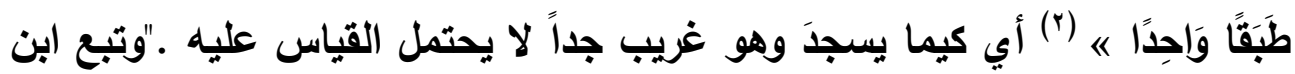

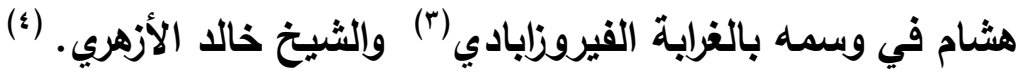
ووجه غرابته كما ترى أنه حذف الفعل المنصوب مع بقاء عامل النصائل

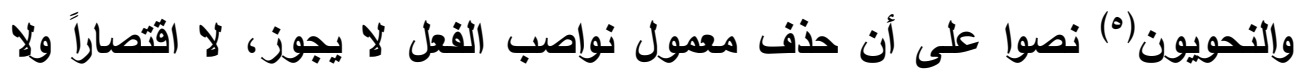

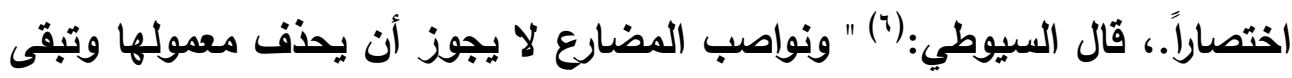

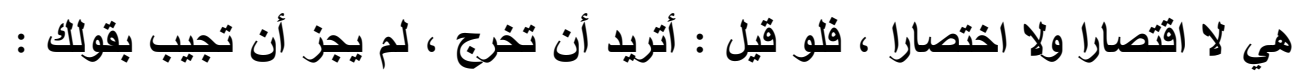

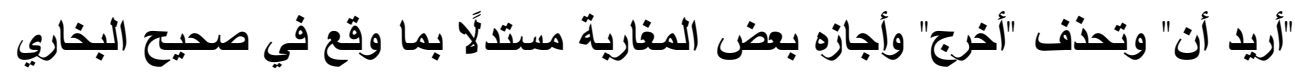

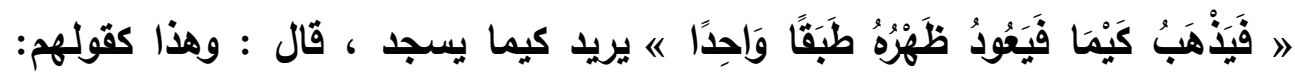

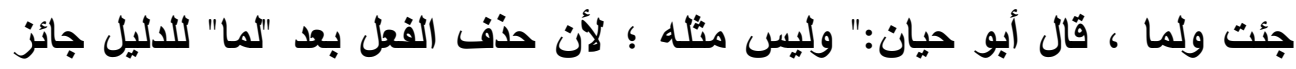
منقول في فصيح الكلام ولم ينقل من نحو هذا شيء من من كلام العرب. وفي شرح

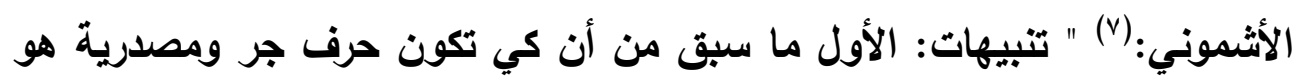
مذهب سيبويه وجمهور البصريين، وذهب الكوفيون إلى أنها ناصبة للفعل دائماً ،

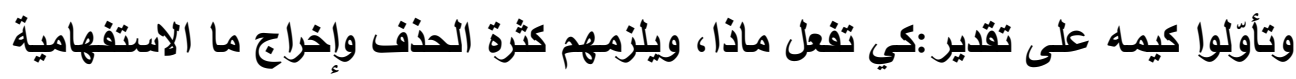

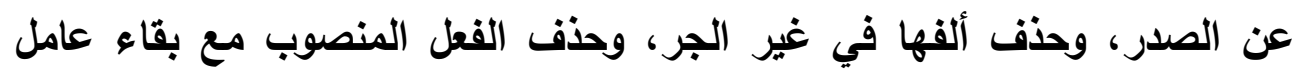

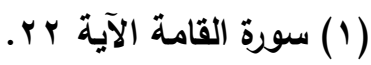

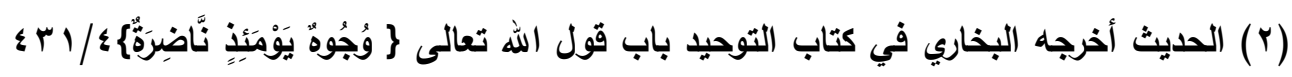

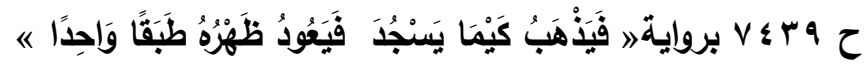

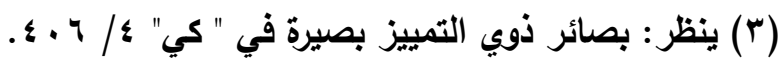

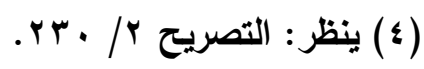

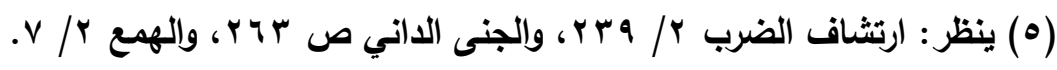

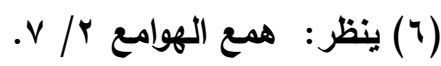
(V) 
فصل المقال في الغريب من الأقوال النحوية والتصريفية د / عبدالرعوف ثابت أحمد عبدالله

النصب، وكل ذلك لم يثبت." وتعقيباً على كلام ابن هشام قال ابن حجر(1) " وكأنه وقعت له نسخة سقطت منها هذه اللفظة لكنها ثابتة في جميع النسخ التي وققت عليها حتى إن ابن بطال ذكرها بلفظ "كي يسجد" بحذف ما ، وكلام ابن هشام يوهم أن البخاري أورده في التفسير ، وليس كذلك بل ذكرها هنا فقط ، قلت : ما ذكره ابن

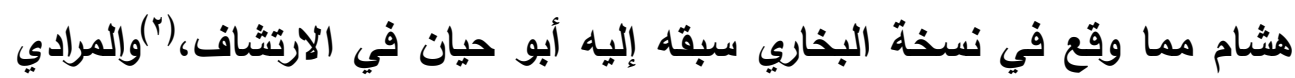

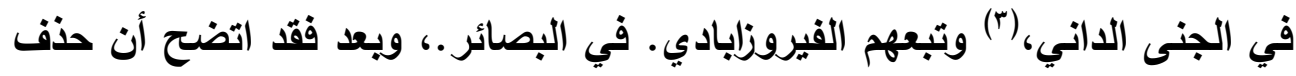
الفعل المنصوب ويقاء الناصب مخالف لما اتفق عليه النحويون، ويشهر لمذهبه الرواية التي تثبت المنصوب وعلى صحة الرواية التي ذكرها أبوحيان وابن هثام ومن تبعهما ، يكون من باب النادر الذي يحفظ ولا يقاس عليه. علماً بأني اجتهات في البحث عن الرواية المستشه بها في كتب التحو فلم أقف عليها. والله أعلم.

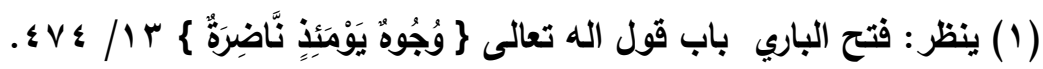

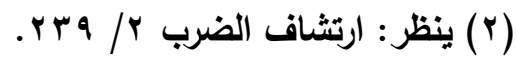

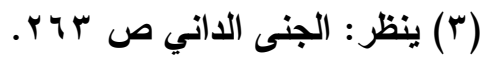


فصل المقال في الغريب من الأقوال النحوية والتصريفية د / عبدالرعوف ثابت أحمد عبدالله

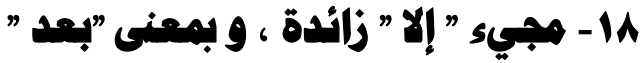

أثبت الأصمعي(') وابن جني لـ" إلِّا " معنى الزيادة قال ابن جني(؟) عند

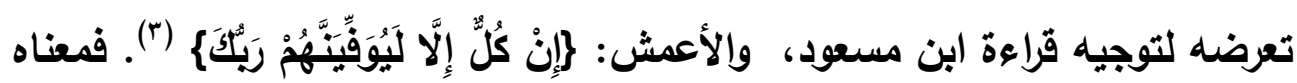
: ما كُلّ إلا والله ليوفينهم، كقولك: ما زيد إلا لأضرينه؛ أي : ما زيد إلا مستحق لأن يقال فيه هذا، ويجوز فيه وجه ثانٍ؛ وهو أن تكون "إن" مخففة من الثقيلة، وتجعل

"إلا" زائدة، وقد جاء عنهم ذلك قال: (؛)

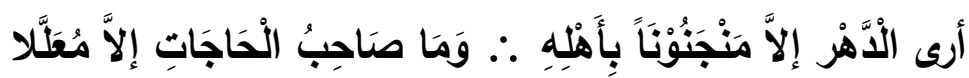

أي : أرى الاهر منجنونًا بأهله يتقلب به ، فتارة يرفعهم، وتارة يخفضهم. وعلى ذلك

أيضًا تأولوا قول ذي الرمة: (•)

$$
\begin{aligned}
& \text { (1) ينظر في " المغتي / / ل }
\end{aligned}
$$

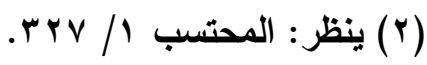

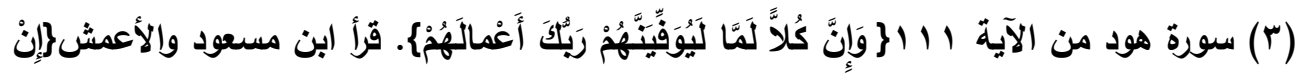

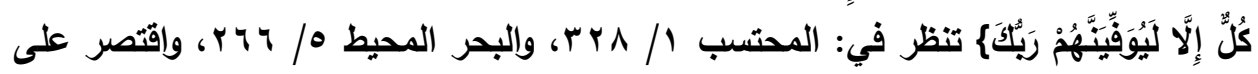

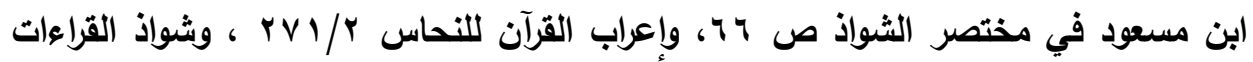

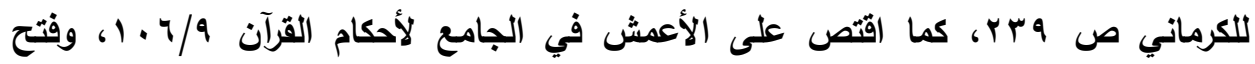

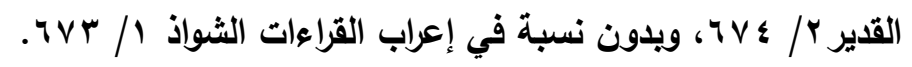

( ) البيت من الطويل ، ولم أقف على قائله.

والثاهد:" أرى الدهر إلا مجنوناً " حيث زيدت "إلإل" ويروى " ما فا الدهر إلا مجنوناً" وعليه فلا شاهد ، ويروى " إلا معذبا " كما في بعض المضان المصادر.

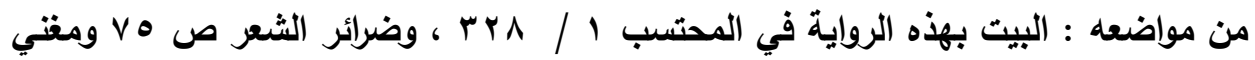

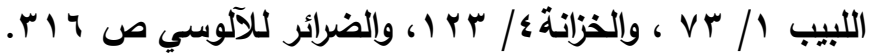

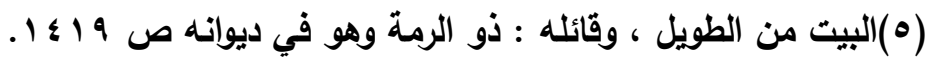

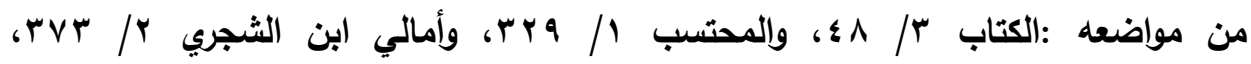

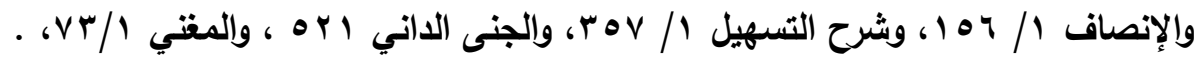


فصل المقال في الغريب من الأقوال النحوية والتصريفية د / عبدالرعوف ثابت أحمد عبدالله

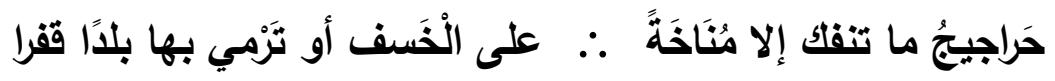
أي : ما تنفك مناخة، و "إلا" زائدة.". قال المرادي: (') "هذا قسم غريب، قال به الأصدمع، وابن جني، في قول الشاعر:

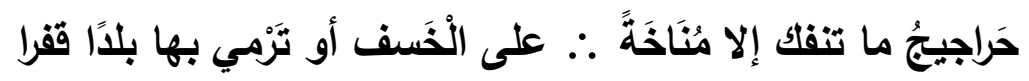

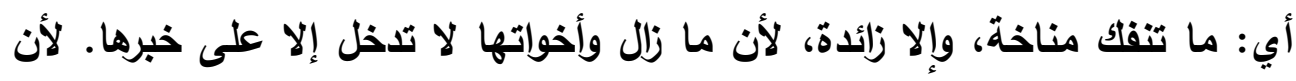

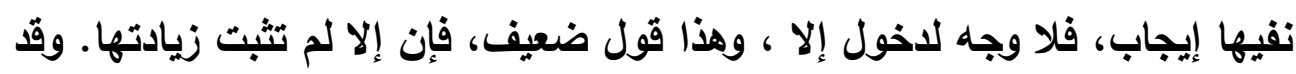

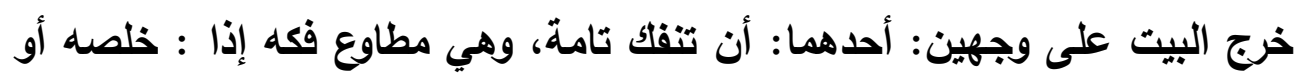

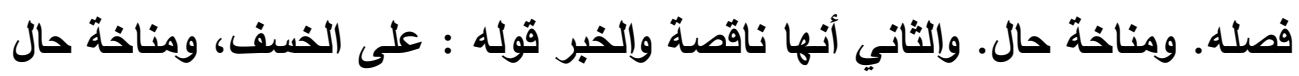
من الضمير المستكن في الجار. وهذا قول الفراء.

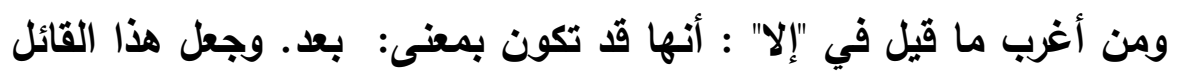

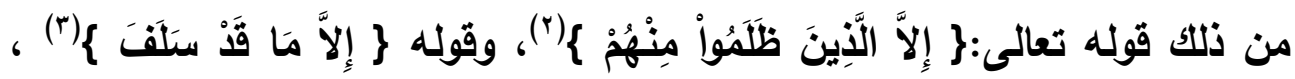

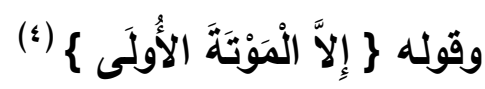
ووجه غرابة زيادة " إلا" من وجهة نظر المرادي أنه لم يثبت زيادتها فهو قول

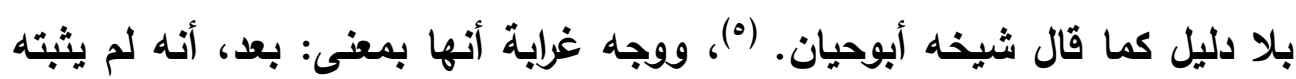

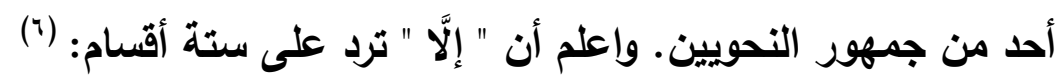

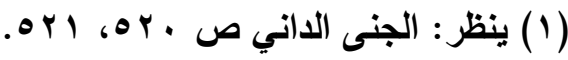

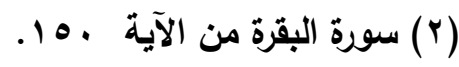

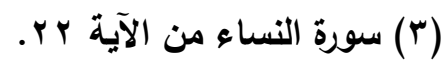

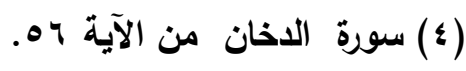

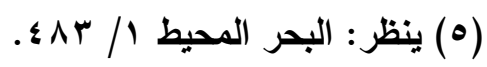

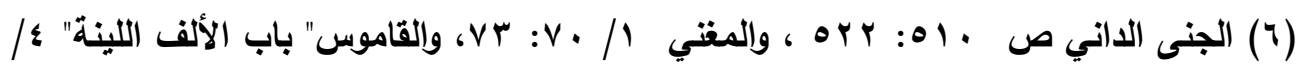

$$
\text { . \&.. ، } 499 / \varepsilon
$$


فصل المقال في الغريب من الأقوال النحوية والتصريفية د البدالرعوف ثابت أحمد عبدالله

الأول: أن تكون للاستثناء- وهو أشهر معانيها- نحو: قام القوم إلا زيداً، ومنه

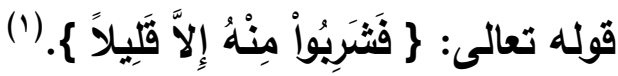

الثاني: أن تكون صفة بمعنى "غير" ، فيوصف بها ويتاليها جمع منكر أو شبهه،

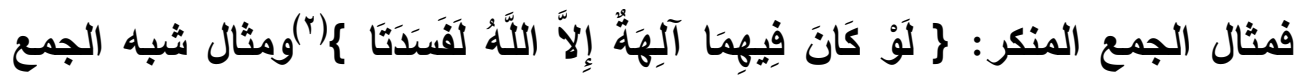
قوله : (r)

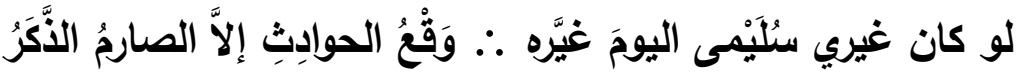
فإلا الصارم صفة لغيري ، ومقتضى كلام سييويه أنه لا يشترط كون الموصوف

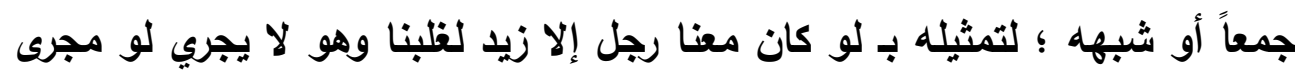
النفي كما يقول المبرد. الثالث : أن تكون عاطفة بمنزلة الواو في التشريك في اللفظ والمعنى ذكره الأخفش

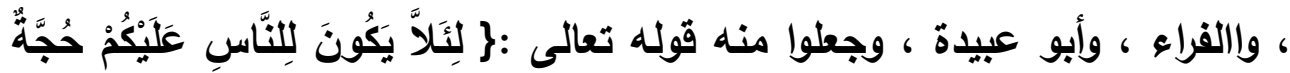

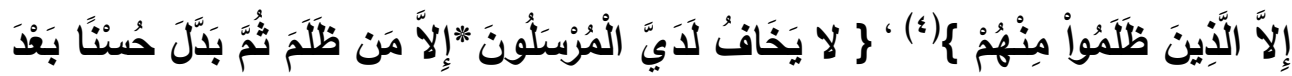
بَعْدَ سُوِْ|ح(ه) أي ولا الأين ظلموا ولا من ظلم وتأولهما الجمهور على الاستثناء المنقطع. الرابع: أن تكون زائدة ، والخامس : أن تكون بمعنى :" بعد". ووسمهما المرادي بالغرابة الترابة

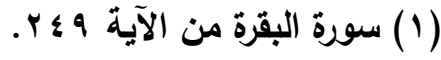

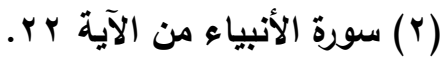

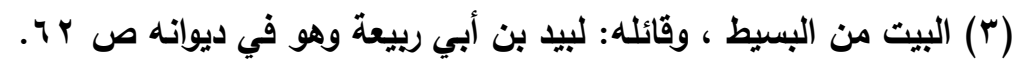

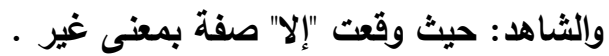

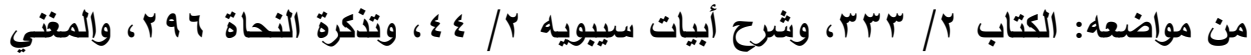

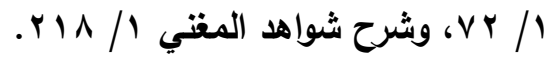

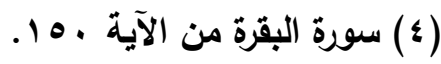

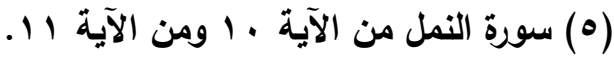


فصل المقال في الغريب من الأقوال النحوية والتصريفية د / عبدالرعوف ثابت أحمد عبدالله

أما كونها زائدة فقد قاله الأصمعي ، والمازني(') ، والفارسي(؟) وابن جني،

وجمال الدين ابن مالك في شرح التسهيل(ّ) والقيرزابادي في القاموس (؛)، كما نص عليه ابن عصفور في ضرائر الشعر:حيث قال : (0)" ومنها - أي من ضرائر الشعر

الثعر - زيادة "إلا " نحو قول الثاعر : (؟)

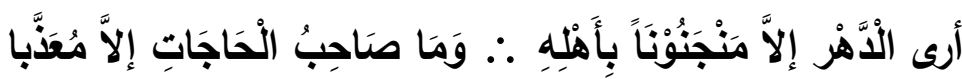

هكذا رواه المازني ، يريد: أرى الدهر مجنوناً بأهله، وكذا جعلها في قول الآخر: (v)

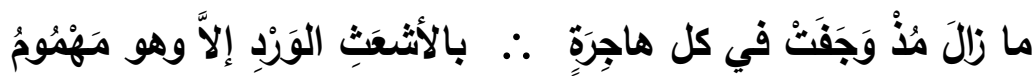

يريد هو مهموم. فزاد "إلا " والواو في خبر زال، وفي قول الآخر: (^) وكلهم حاشاك إلا وجدته . . كعين الكذوب جدها واحتفالها.

(1) ينظر في : ضرائر الشعر لابن عصفور ص ه V، والضرائر للآلوسي ص 1 اس.

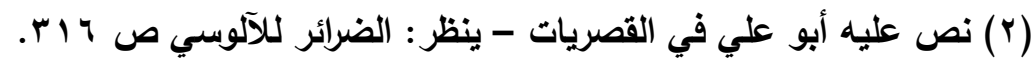

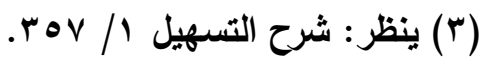

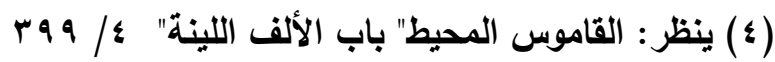

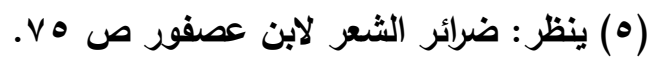

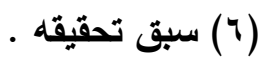

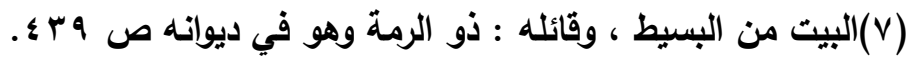

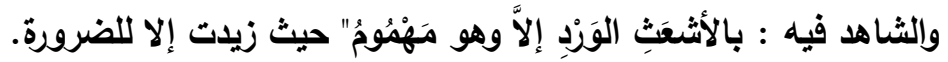

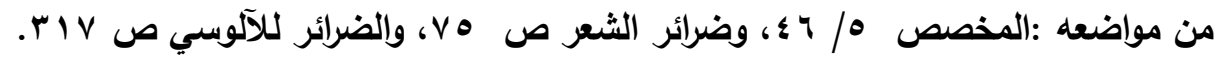
(^)(البيت من الطويل ، ولم أقف على قائله. والثاهد فيه : "حاشاك إلا وجلته" حيث زيدت إلا للضرورة.

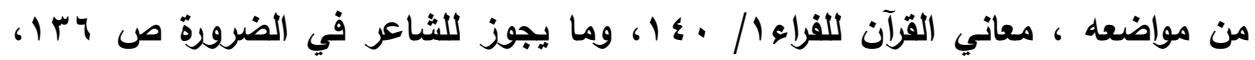

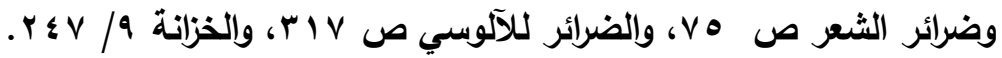


فصل المقال في الغريب من الأقوال النحوية والتصريفية د البدالرعوف ثابت أحمد عبدالله

$$
\text { يريد: كلهم حاشاك وجدته وفي قول ذي الرمة : }
$$

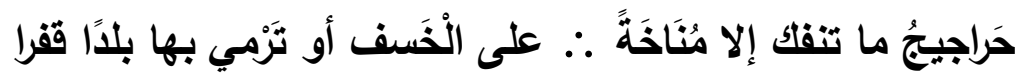
يريد: ما تنقك مناخة، وهذه الأبيات كلها تحتمل "إلا" فيها أن تكون غير زائدة إلا البيث الأول فإنها لاتكون فيه إلا زائدة ، وذلك بأن تحمل "زال" و" تنفك" تامتين ،

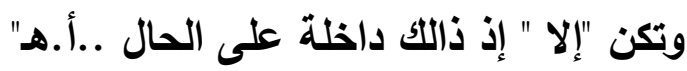
كما نص عليه الكرماني عند تعرضه لحديث البخاري "مَنْ فَارَقَ الْجَمَاعَةَ شِبْرًا

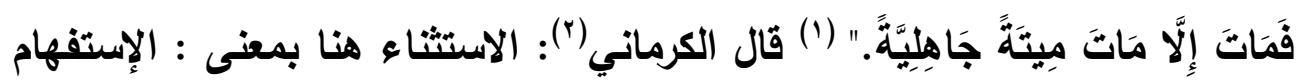
الإنكاري أي ما فارق الجماعة أحد إلّال جرى له كذا، أو حذفت "ما" فهي مقدرة ، أو "إلَّا" زائدة ، أوعاطفة على لأي الكوفيين" وفي تحفة الأحوذي (َ) عند تعرضه لحديث"

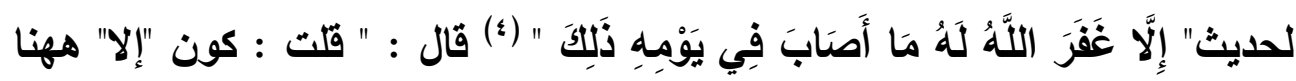
زائدة هو الظاهر وقد صرح صاحب القاموس(ه) بأنها تكون زائدة . ووسمه بالضعف كل من أبي البقاء(`) وأبي حيان(V)، وردَّه السمين

الحلبي (^)

(1) أخرجه الإمام البخاري في كتاب الفتن، باب قول النبي صلى الله عليه وسلم " ستون بعدي

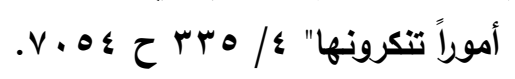

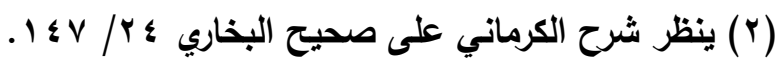

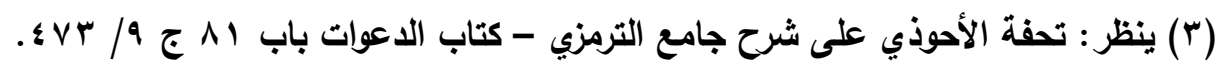

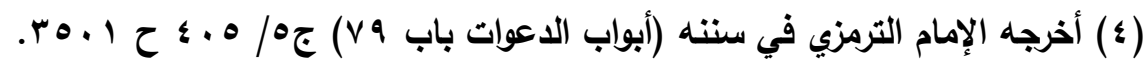

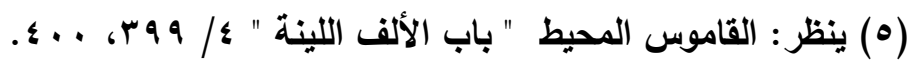

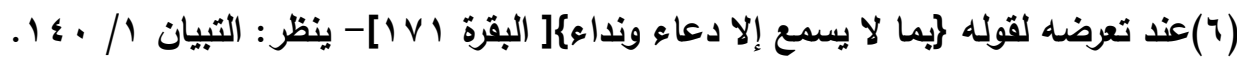

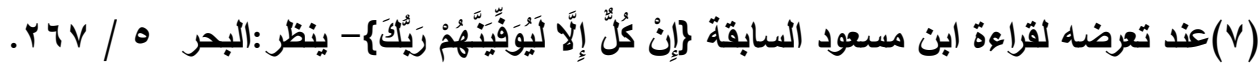

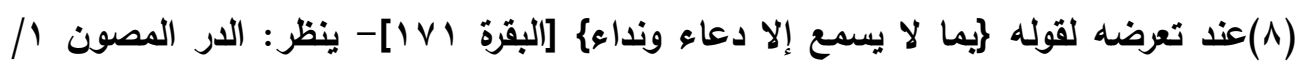


فصل المقال في الغريب من الأقوال النحوية والتصريفية د البدالرعوف ثابت أحمد عبدالله

\section{وابن عادل الحنبلي (1)}

وأما كون إلا بمعنى: "بعد" فلم أقف على من نص عليه من النحويين ، وإنما قال به

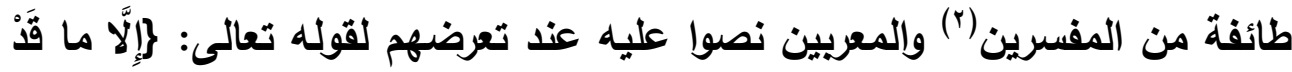

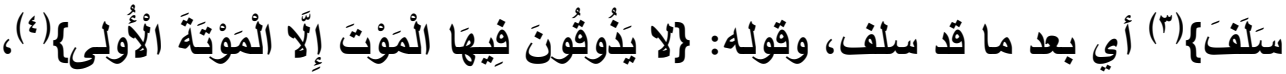

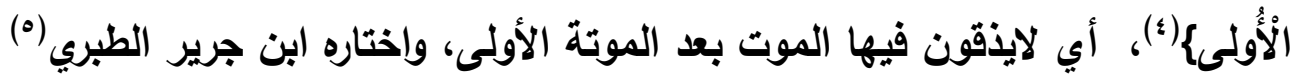

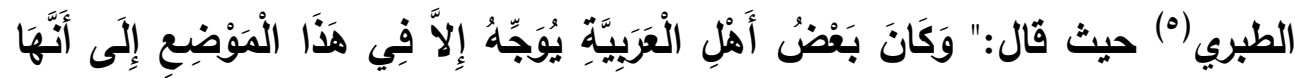

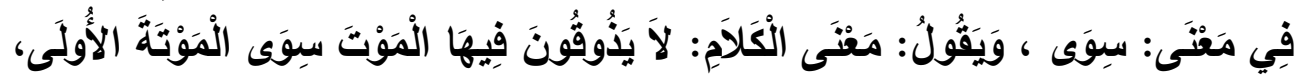

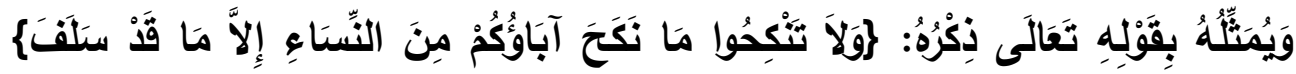

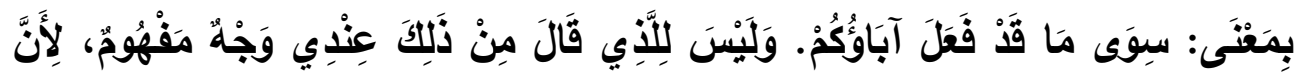

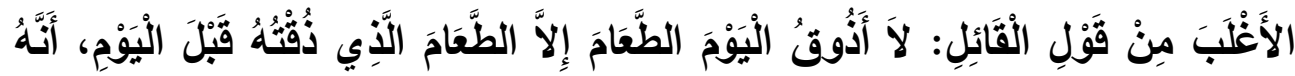

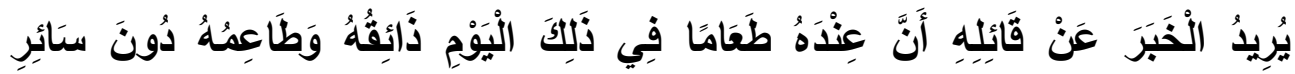

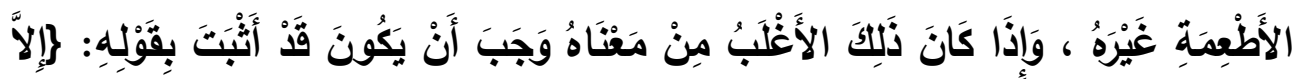

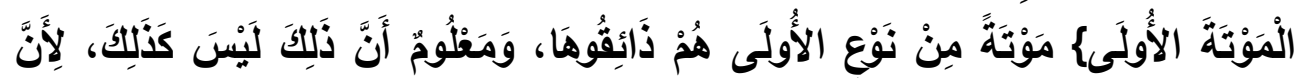

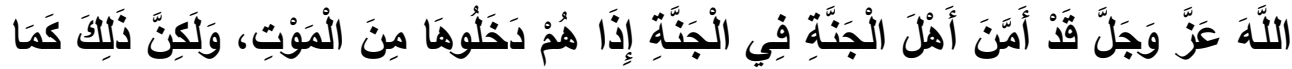

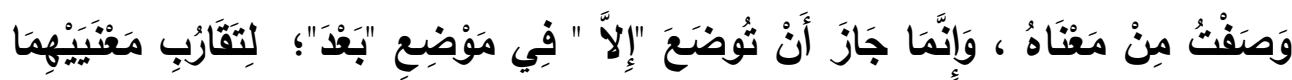

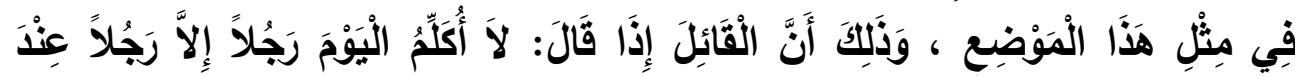

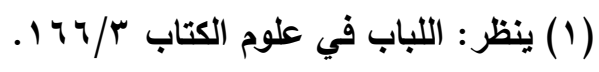

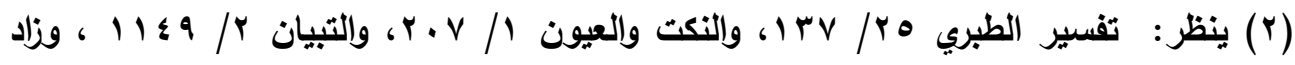

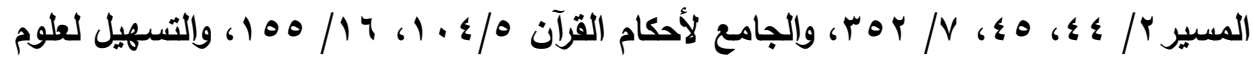

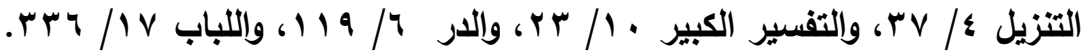

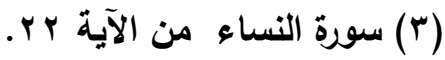

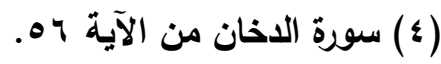

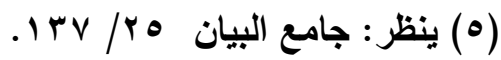


فصل المقال في الغريب من الأقوال النحوية والتصريفية د / عبدالرعوف ثابت أحمد عبدالله

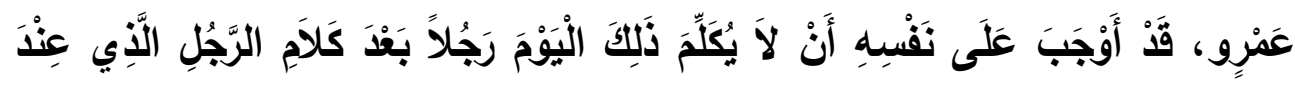

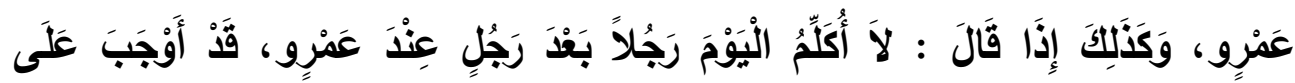

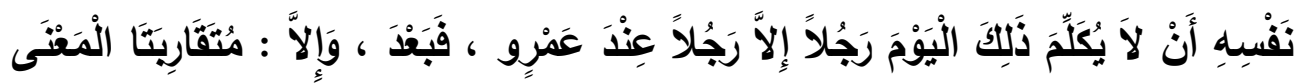

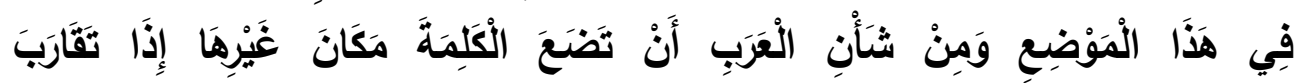

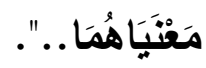

ويعد، فإني أري أن القول بزيادة "إلا " ليس غريباً كما قال المرادي ، فقراعة

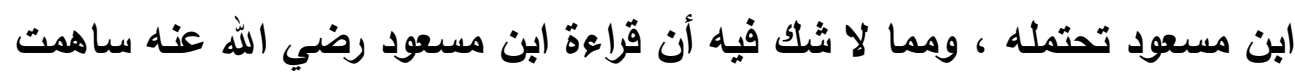

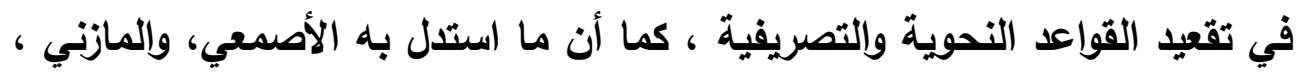

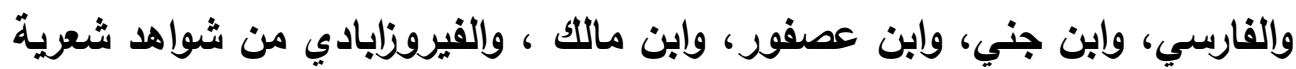

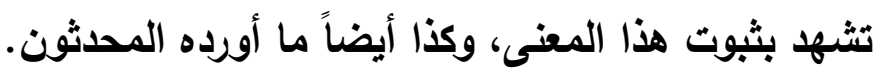

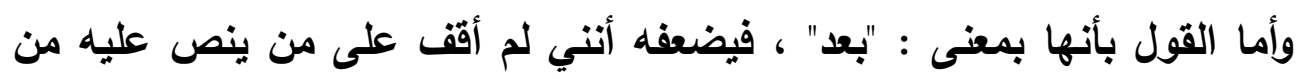

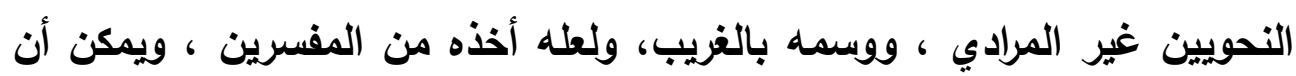

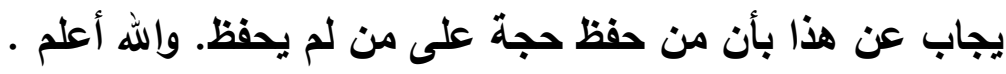


فصل المقال في الغريب من الأقوال النحوية والتصريفية د / عبدالرعوف ثابت أحمد عبدالله

\section{9 - زيادة "لا" في "لا سيما"}

قال أبوحيان:(1)"ومن غريب القول ما حكاه صاحب "البديع"(ז) وهو أن من

النحويين من زعم أن " لا " في " لاسيما " زائدة .

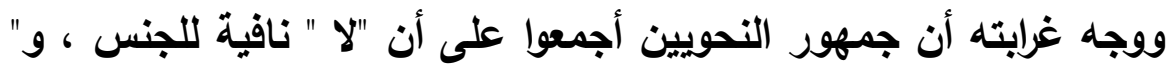

سي" اسم " لا " منصوب ، وخبرها محذوف لفهم المعنى، فِاذا قةت : " قام القوم لاسيّما زيدٌ " فالتقدير : لا مثلَ قيام زيدٍ قيامُ لهم.، وذهب الأخفش إلى أنَّ الخبر "ما" من "لاسيّما " وهي اسم موصول بمعنى "الَّني". ، ويناء على هذا يكون القول بأن " لا " من لاسيما زائدة قول انفرد به صاحبه ، ولم أقف على القائل بذلك ، ولعل وجه زيادتها عنده أنه ورد حذقها في كلام الأدباء المولدين . واعلم أن النحويين مختلفون في حذف " لا " من "لاسيما". فمن التّحاة من

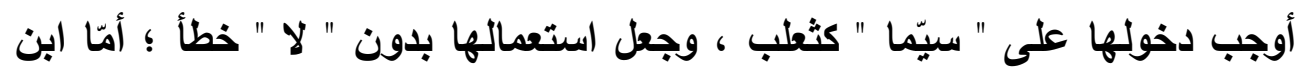
يعيش (ז) فقد ذهب إلى أنه لا يجوز الاستثناء بها حتى تأتي "لا"، قال:" ولا يُستثنى

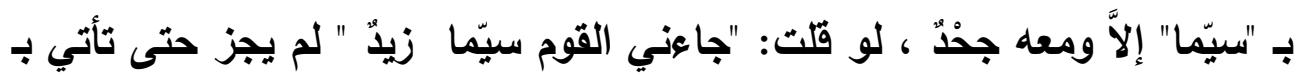

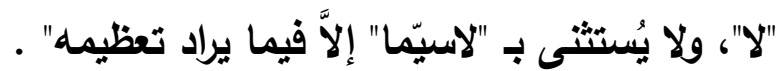

وذهب بعض النّحويين إلى جواز حذفها؛ وذلك لكثرة استعمالهم لها فتصرّفوا فيها

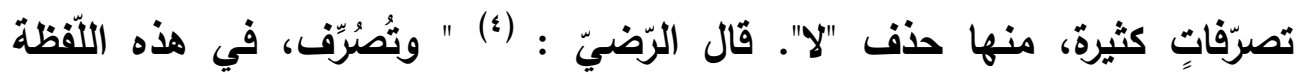
تصرّفات كثيرة ؛ لكثرة استعمالها ، فقيل : "سيّما" بحذف "لا" و "لاسيَما" بتخفيف هي

(1) ينظر: التذييل والتكميل ر/ צ

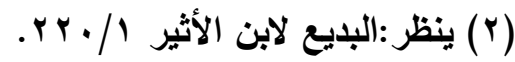

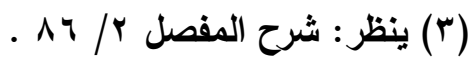

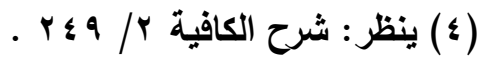


فصل المقال في الغريب من الأقوال النحوية والتصريفية د / عبدالرعوف ثابت أحمد عبدالله

"الياء" مع وجود "لا" وحذفها" . كوجعل أبو حيّان(') حذف "لا" غريباً ، وأنه يوجد في كلام الأدباء المولَّدين، قال: وكذلك حذف "لا" من "لاسيّما" إنّما يوجد في كلام الأدباء المولَّين، لا في كلام من بحتجّ بكلامه"، وفي المصباح:"ريما حذفت "لا " في الشعر وهي مرادة للعلم بها." قلت: وقد وردت في شعر من يحتج بقوله قال الحطيئة:

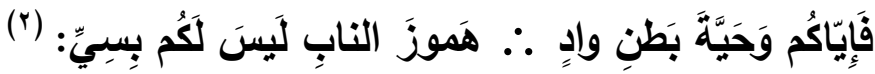

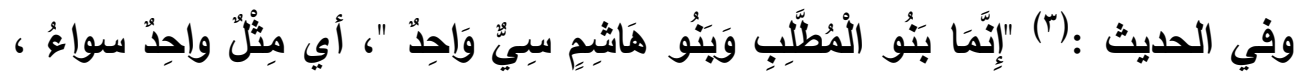

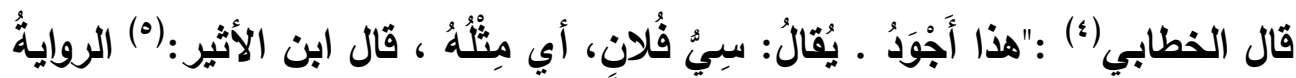

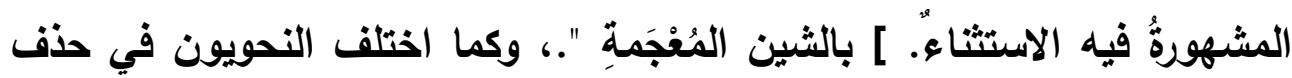

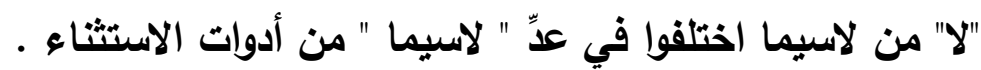
فمذهب الكوفيين وجماعة من التّحويين كالأخفش، وأبي حاتم، والفارسيّ، والنّحاس، والزّجّاج، وابن مضاء، والزّمخشريّ، وابن يعيش، أنها من أدوات

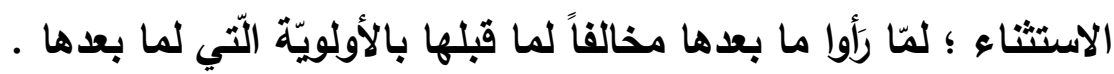
وذهب جماعة من التّحويين إلى أنها ليست من أدوات الاستثناء.

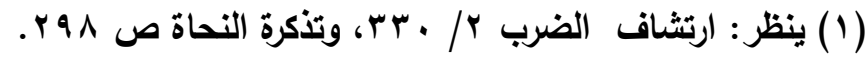

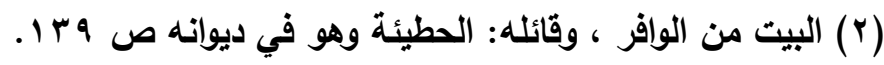

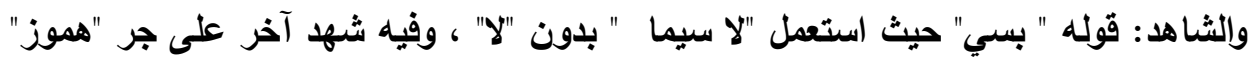

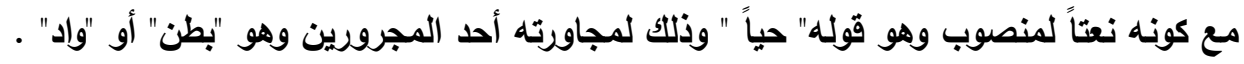

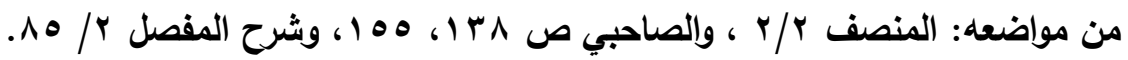

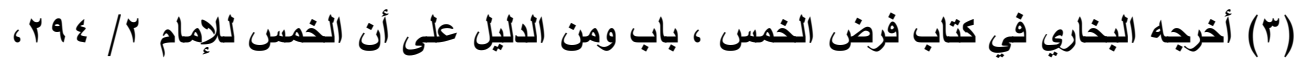

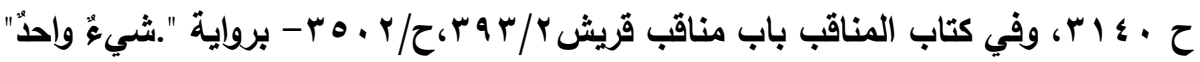

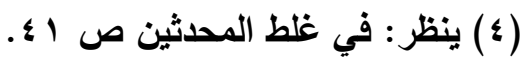

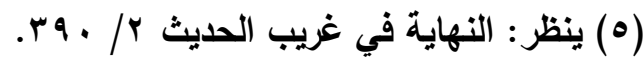


فصل المقال في الغريب من الأقوال النحوية والتصريفية د / عبدالرعوف ثابت أحمد عبدالله

قال القرافي: (1) " وأما" لاسيما" فليست بمعنى "إلا"، ولا هي من هذا الباب

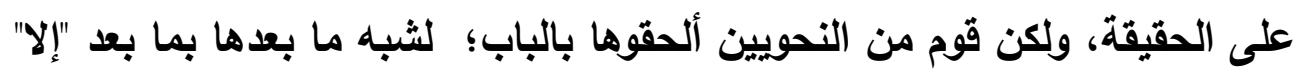

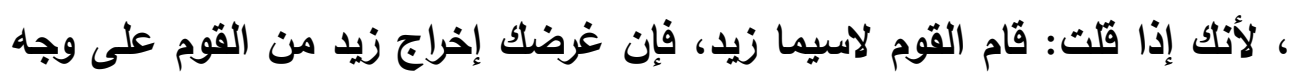

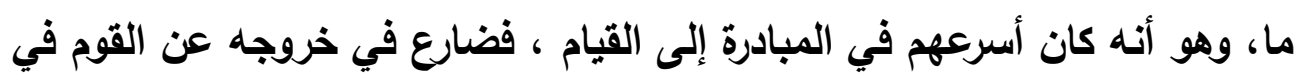

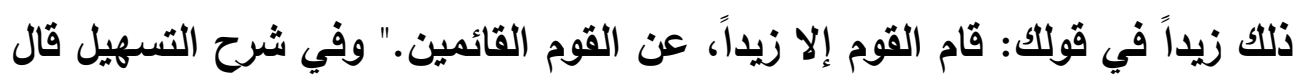

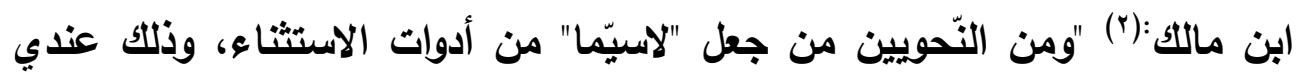

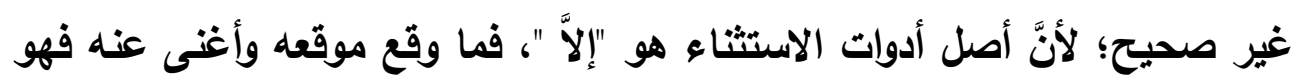

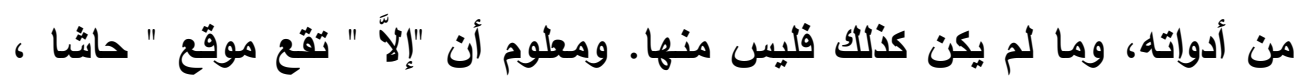

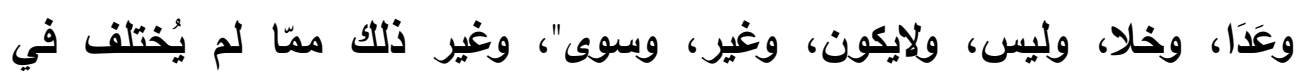

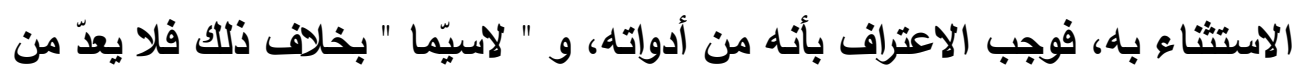

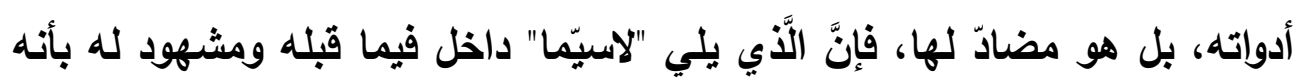

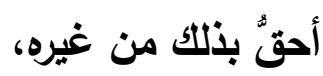

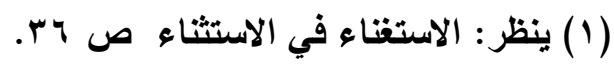

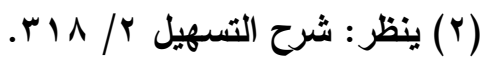


فصل المقال في الغريب من الأقوال النحوية والتصريفية د / عبدالرعوف ثابت أحمد عبدالله

وهذا المعنى مفهوم بالبديهة من قول امرئ القيس : (')

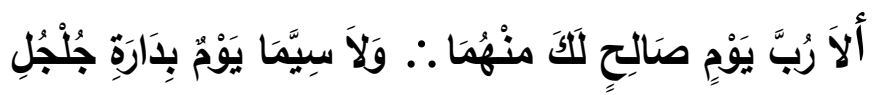

ويعد فإن ما حكاه صاحب "البديع" عن بعض النحويين من أن " لا " في " لا سيما " زائدة ـ لم أقف على قائله أو من يناصره في ذلك مما يدل على أنه مذهب مقصور على قائلة .والله أعلم.

(1) البيت من الطويل هو في ديوانه ص (1)

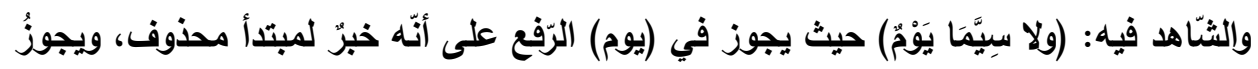

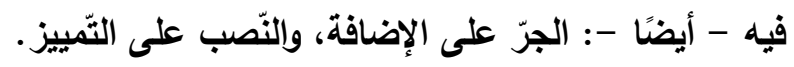

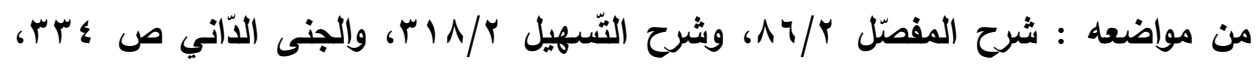

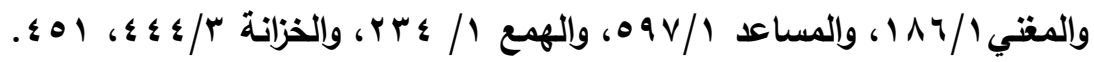


فصل المقال في الغريب من الأقوال النحوية والتصريفية د / عبدالرعوف ثابت أحمد عبدالله

\section{• r- انتصاب الضمير على الهال}

نقل ابن هشام في المغني(')عن ابن الحاجب أنه جوز النتصاب الضمير

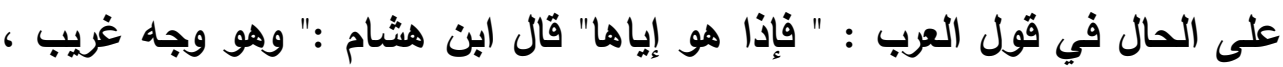

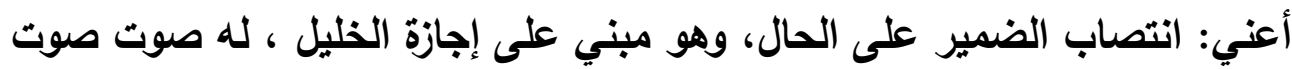

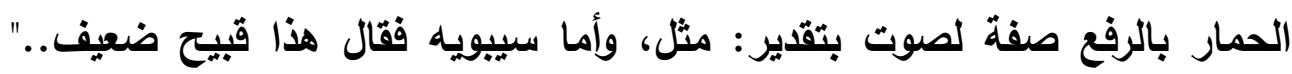

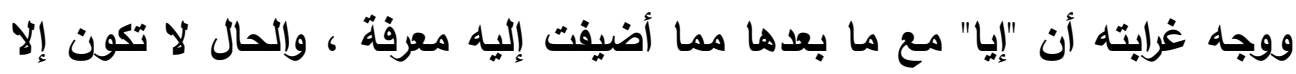

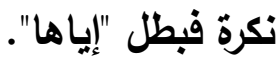

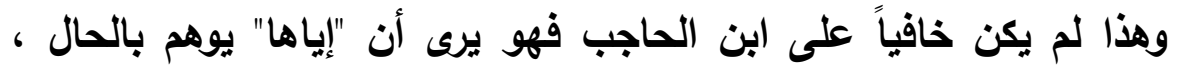

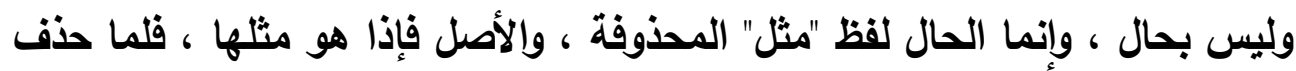

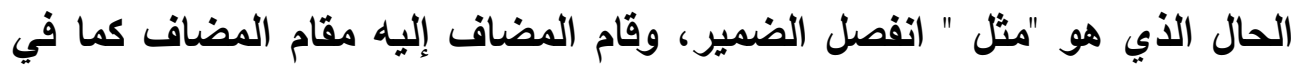

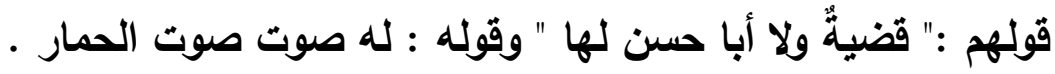

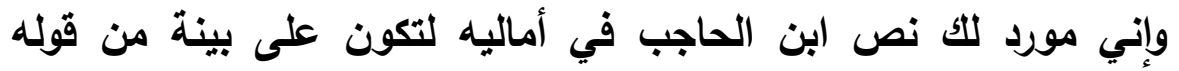

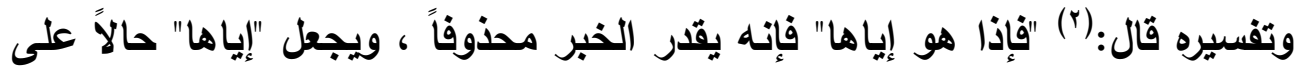

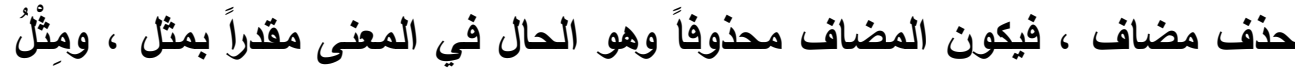

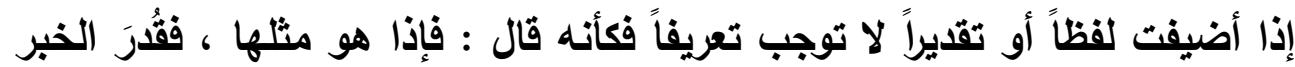

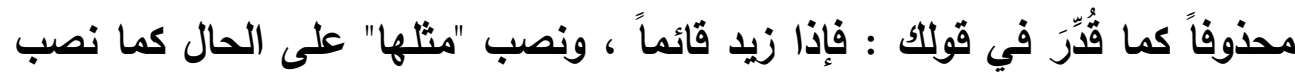

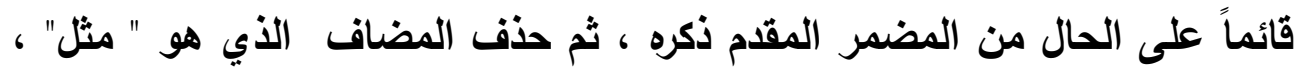

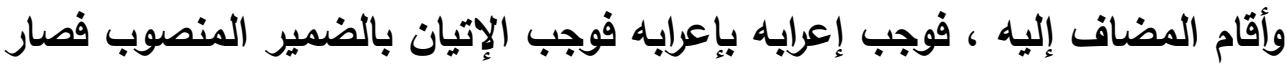

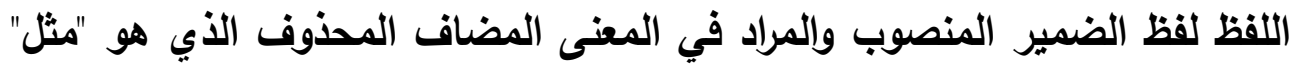

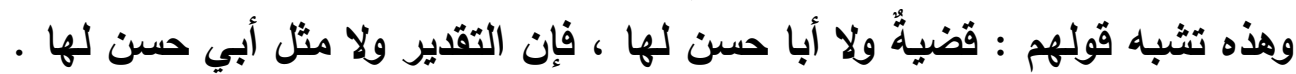

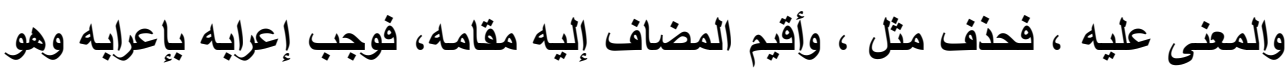

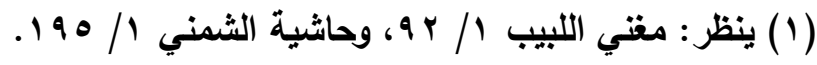

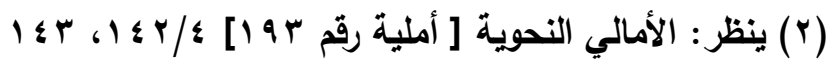


فصل المقال في الغريب من الأقوال النحوية والتصريفية د / عبدالرعوف ثابت أحمد عبدالله

النصب، فانتصب لانتصاب المضاف المحذوف لأنه معمولٌ دـ "لا" مباشرٌ فيتوهم

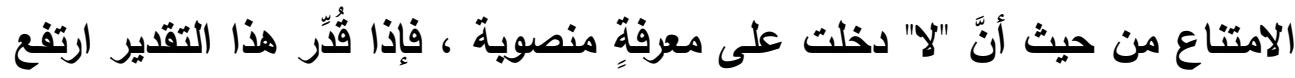

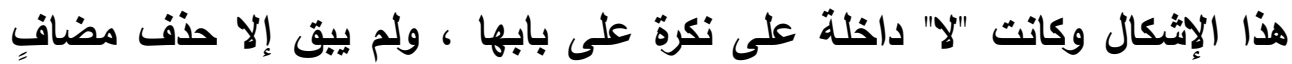
وإبقاء المضاف إليه مقامه. ولا بأس بذلك إذا كان ذلك معلوماً فكذلك ها هنا يتوهم

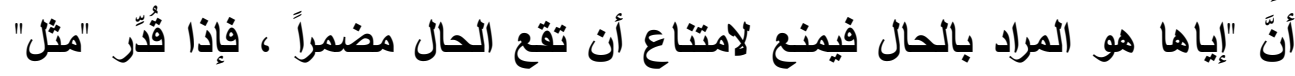

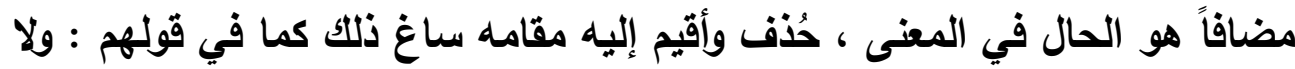

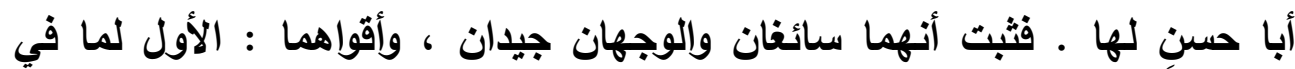
الثاني من كثرة التقديرات والخروج عن الظاهر.انتهى. فكلام ابن الحاجب ظاهر مقدر بمثل المحذوفة وإياها قائم مقامه.

وللكوفين توجيه آخر في هذه العبارة فقا نقل عن أبي العباس ثُعلب(') أنهانه

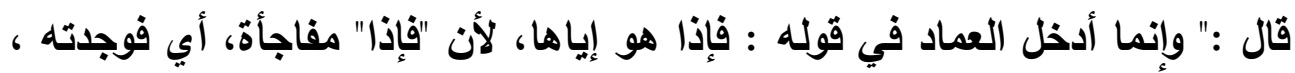
ورأيته. ووجدت ورأيت تتصب شيئين، ويكون معه خبر، فلزلك نصبت العرب.

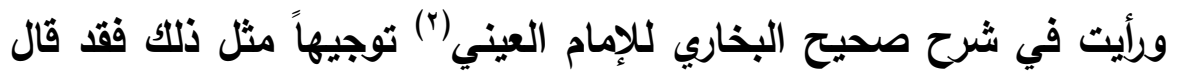

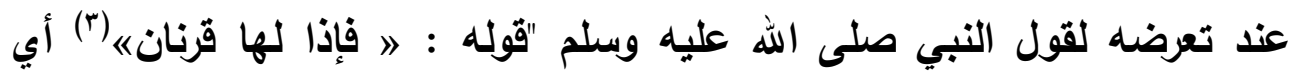
جانبان ، وقرنا الرأس جانباه ـ ويقال القرنان منارتان عن جانبي البئر تجعل عليهما

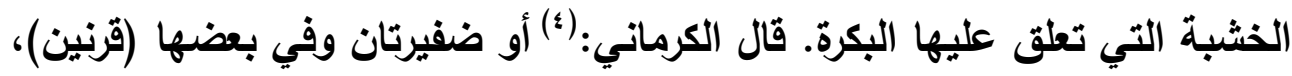

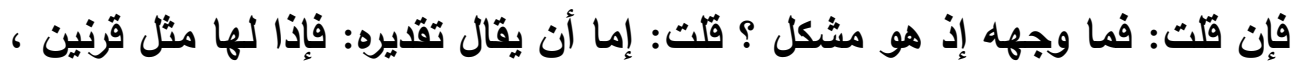

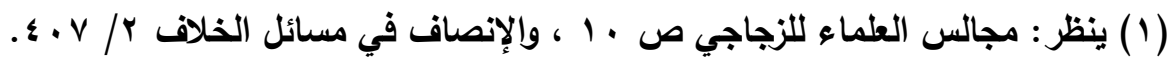

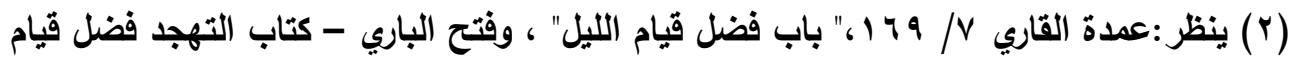

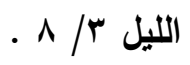

(r) الحديث أخرجه البخاري في كتاب فضائل الصحابة باب مناقب عبدالله بن عمر بن الخطاب rVMA ح $\varepsilon 0 \cdot / r$

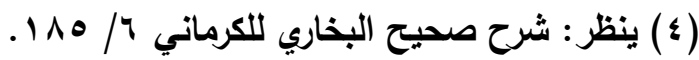


فصل المقال في الغريب من الأقوال النحوية والتصريفية د/ عبدالرعوف ثابت أحمد عبدالله

فحذف المضاف وترك المضاف إليه على إعرابه وهو كقراءة \}والله يريد الآخرة\{(1)

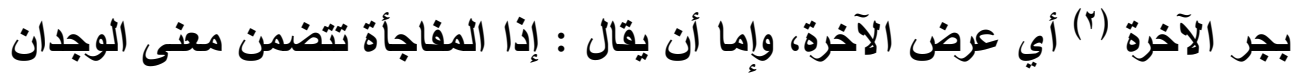
فكأنه قال فإذا وجدت لها قرنين كما يقول الكوفيون في قولهم:" كنت أظن العقرب

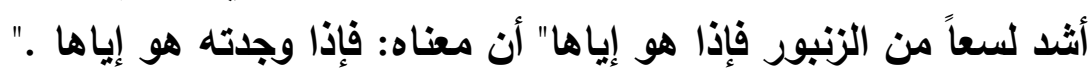

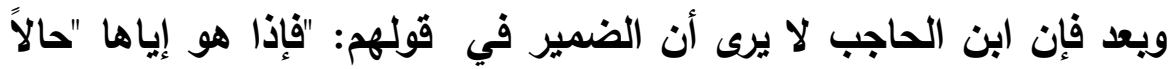

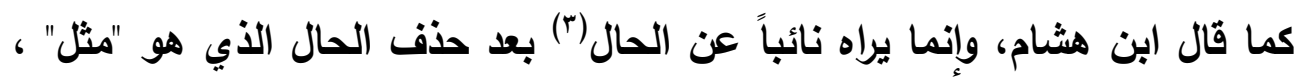

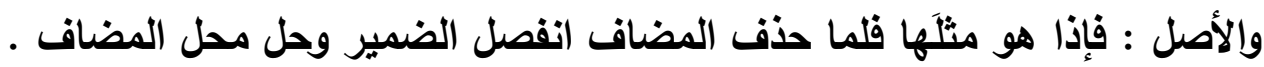

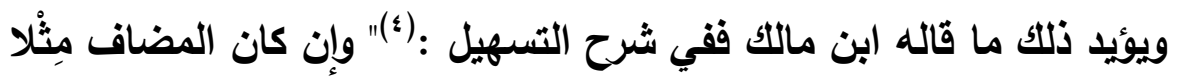

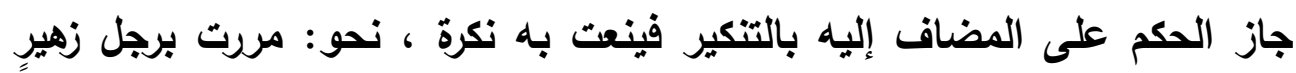

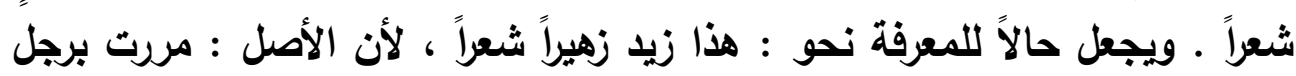

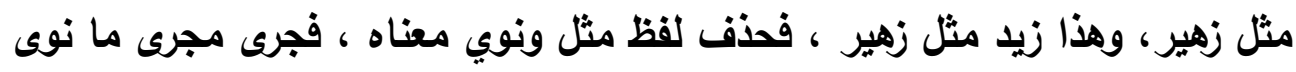

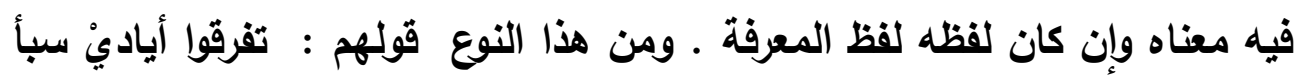
، فجعلوه حالاً، وهو في اللفظ معرفة لأنهم أرادوا : مثل أيادي ، فحذف مثنل، وأقيم

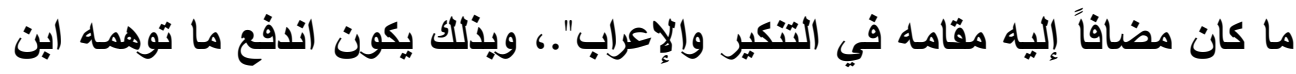

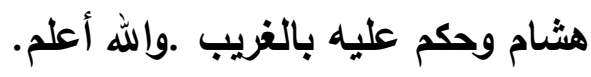

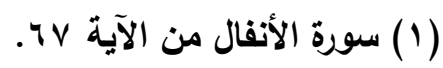

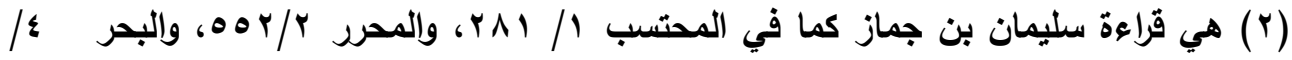

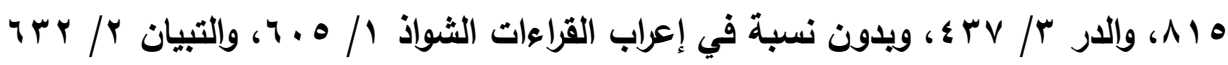

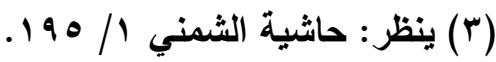

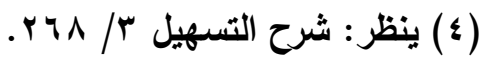


فصل المقال في الغريب من الأقوال النحوية والتصريفية د / عبدالرعوف ثابت أحمد عبدالله

\section{ا إ- التمييز المهول عن المبتدأ}

نص أبوحيان- في البحر المحيط في موضعين-على أن التمييز المنقول

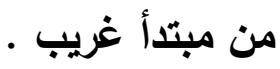

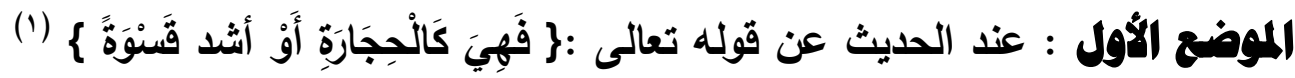

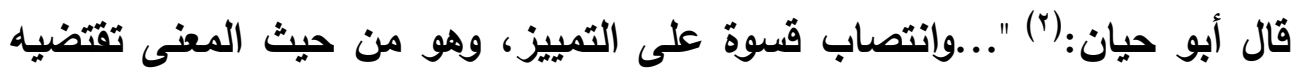
الكاف ويقتضيه أفعل التفضيل ، لأن كلاً منهما ينتصب عنه التمييز. تقول: زيد

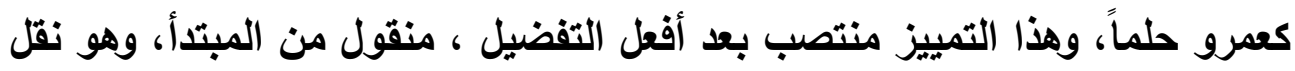

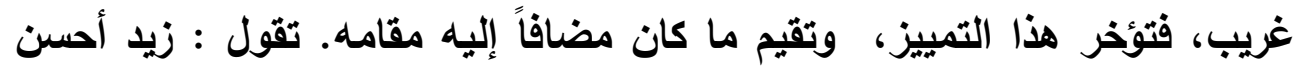

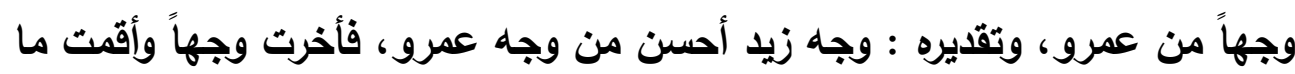

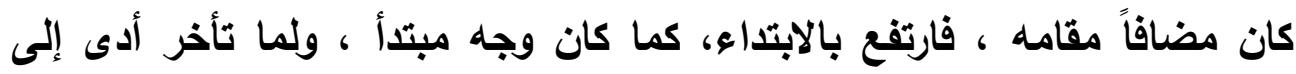

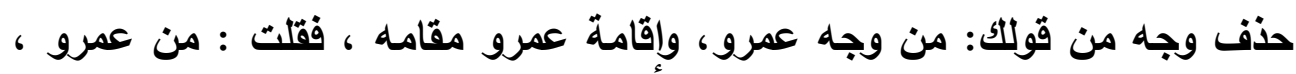
وإنما كان الأصل ذللك، لأن المتصف بزيادة الحسن حقيقة ليس الرجل إنما هو هو هونه

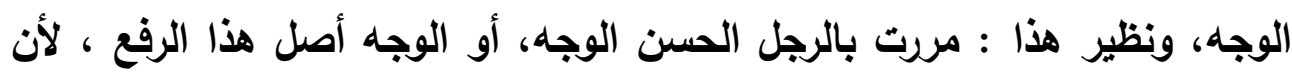

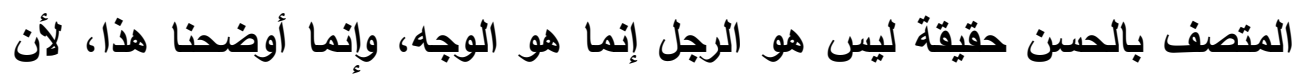

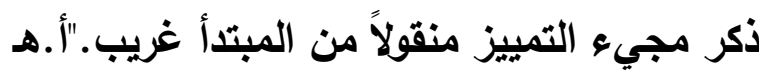

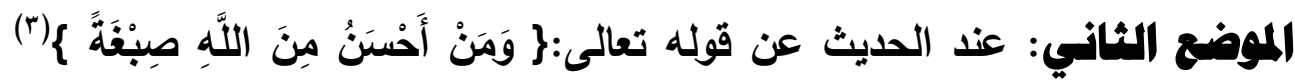

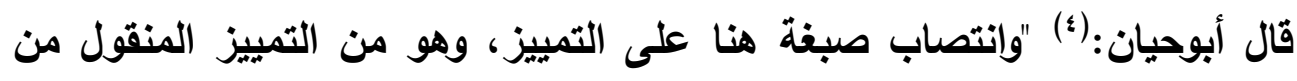
المبتأ. وقد ذكرنا أن ذلك غريب، أعني نص النحويون على أن من التمييز المنقول

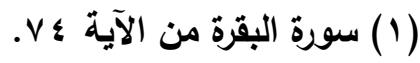

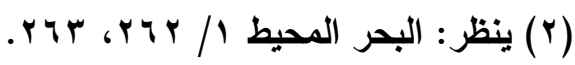

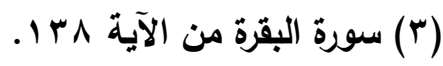

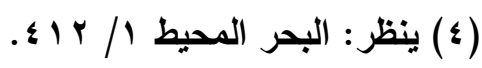


فصل المقال في الغريب من الأقوال النحوية والتصريفية د/ عبدالرعوف ثابت أحمد عبدالله

تمييزًا نقل من المبتأ، والتقدير: ومن صبغته أحسن من صبغة اللّه. فالتفضيل إنما يجري بين الصبغتين، لا بين الصابغين." وتبعه في هذا الموضع السمين الحلبي(') وابن عادل الحنبلي.(^) وفي التحرير والتنوير: (ّ)" وقد تأتى بهذا التحويل في التمييز إيجاز بايع إذ حذف كلمتان بدون لبس ، فإنه لما أسندت الأحسنية إلى من جاز دخول من التفضيلية على اسم الجلالة بتقدير مضاف، لأن ذلك التحويل جعل ما أضيفت إليه صبغة هو المحكوم عليه بانتفاء الأحسنية فعلم أن المفضل عليه هو المضاف المقدر، أي ومن أحسن من صبغة الله." أ.هـ. ووجه غرابته أنه قل من يذكره من التحويين. ومع قلته وجدت المعربين والمفسرين ومنهم أبوحيان قـ نصوا عليه في أريعة مواضع أخرى في كتاب الله ، ولم يسموه بالغرابة .

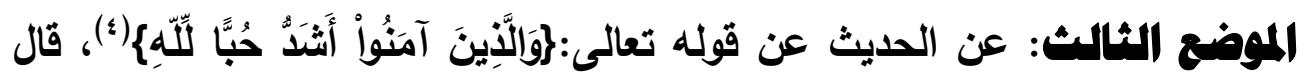
أبو حيان:(ه) "..وإنتصاب حباً على التمييز ، وهو من التمييز المنقول من المبتدأ تقديره : حبهم الله أثد من حب أولئك لله، أو لأندادهم على اختلاف القولين."

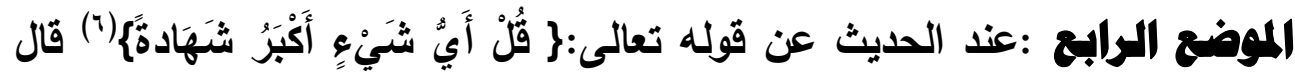

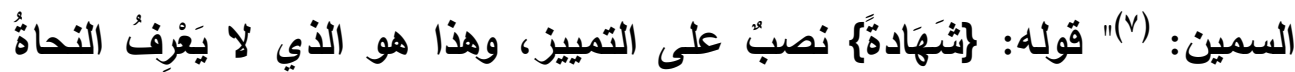

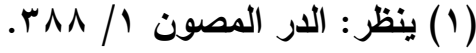

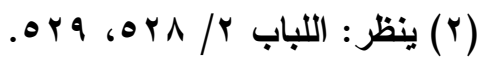

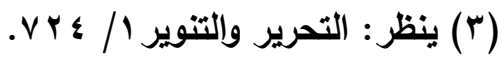

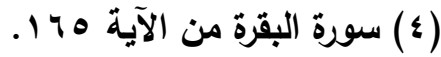

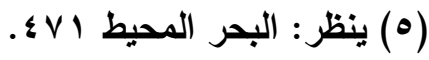

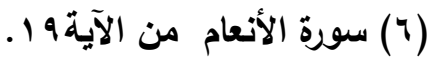

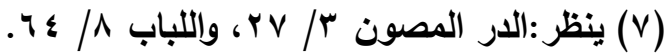


فصل المقال في الغريب من الأقوال النحوية والتصريفية د/ عبدالرعوف ثابت أحمد عبدالله

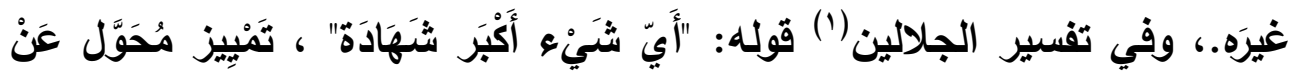
الْمُبْتَدَأَ ".

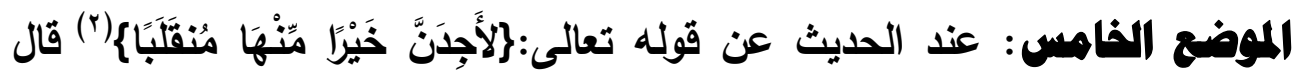

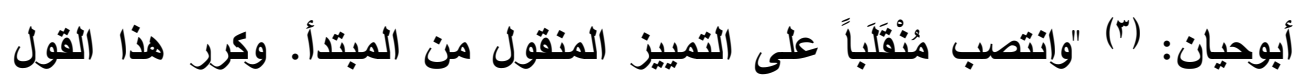

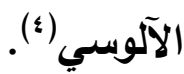

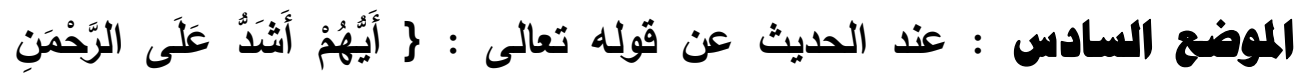

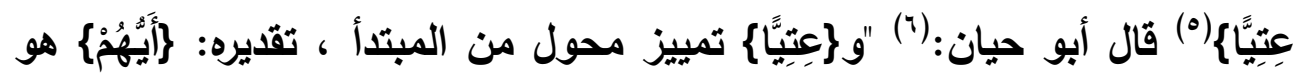

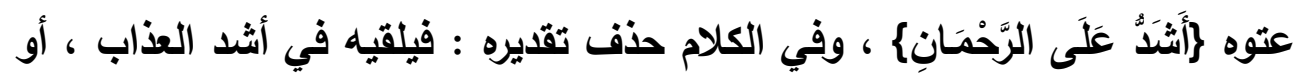
فيبدأ بعذابه ، ثم بمن دونه إلى آخرهم عذاباً.."

واعلم أن تمييز النسبة نوعان :الأول : تمييز محول. وهو ثثلاثة أقسام:

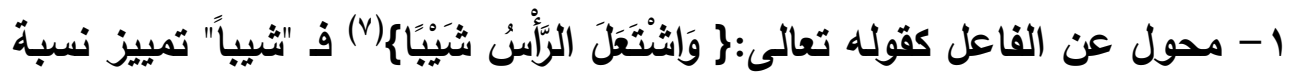
محول عن الفاعل لأن أصله: واشتتعل شيب الرأس.

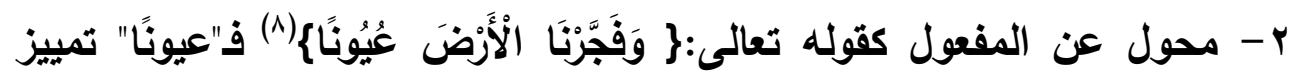
نسبة محول عن المفعول؛ لأن تقديره: وفجرنا عيون الأرض.

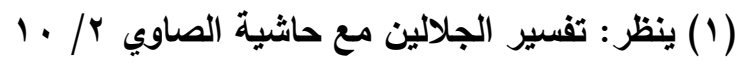

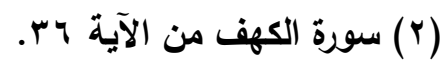

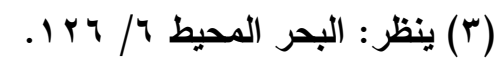

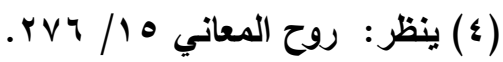
(0) سورة مريم من الآية 99.

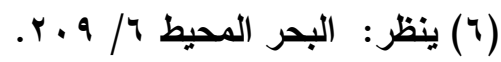
سورة مريم من الآية ع ع. (V)

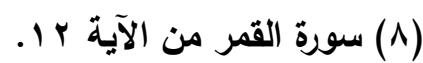


فصل المقال في الغريب من الأقوال النحوية والتصريفية د / عبدالرعوف ثابت أحمد عبدالله

r- محول عن غيرهما كالمحول عن المبتدأ، وذلك بعد اسم التفضيل الصالح

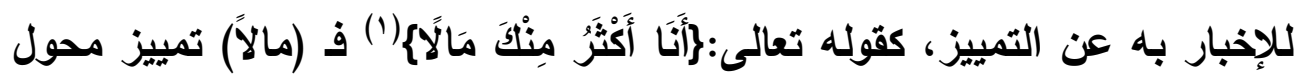
عن المبتدأ، وأصله: مالي أكثر من مالك. لكن.

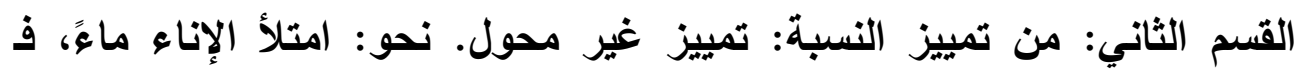
(ماءً) تمييز غير محول عن شيء، بل هو تركيب وضع ابتداء هكذا. ومنه قولهم: فيزيز

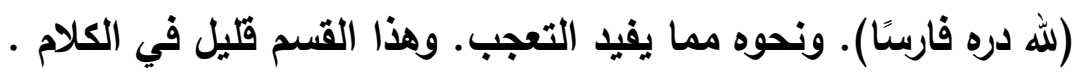

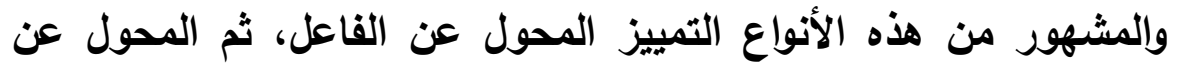
المفعول، وأما المحول عن المبتدأ فقل من يذكره من النحويين ، وقد نص عليه

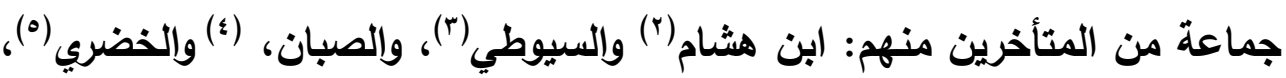

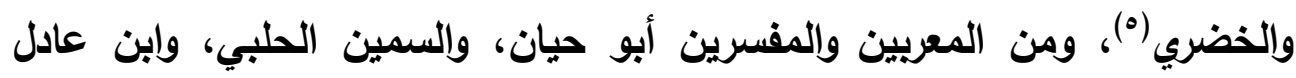

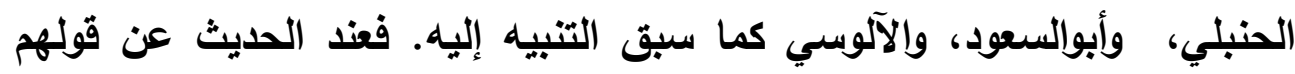

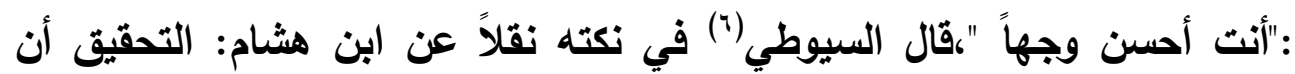

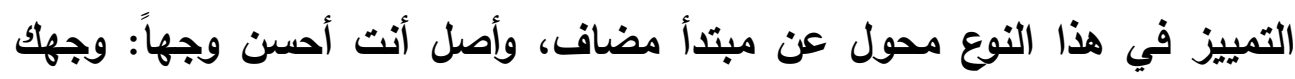
أحسن، فجعل المضاف تمييزاً ، والمضاف إليه مبتأ فانفصل وارتفع ، ولا يريد المصنف بقوله : الفاعل المعنى أن هذا النوع محول عن الفاعل كما فهم بعضهم ؛ لأنك إذا قلت : حسن وجهك لم يستفد التفضيل فكيف يكون أنت أحسن وجهاً محولاً

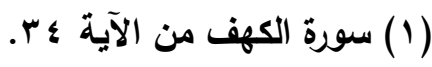

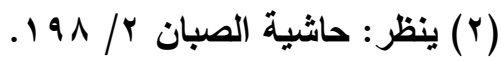

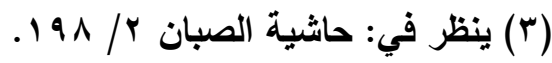

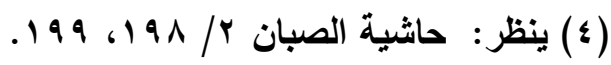

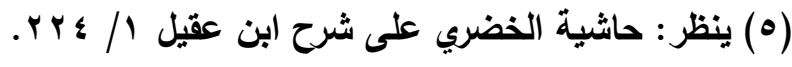

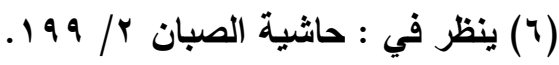


فصل المقال في الغريب من الأقوال النحوية والتصريفية د / عبدالرعوف ثابت أحمد عبدالله

عن حسن وجهك، وإنما يريد أن هذا التمييز هو المنسوب إليه ذلك المعنى. أ.هـ. ملخصا.

ويعد ف"تفسه" توكيداً للتمييز الواقع بعد أفعل التفضيل ، يعده القدماء من أن

التمييز المحول عن الفاعل في الصناعة ، ففي مثل قولهم: أنت أعلا منزلاً، فمنزلاً محول عن فاعل أفعل التفضيل صناعة والأصل: أنت أعلى منزلك وإن كان رفعه الظاهر قليلاً ، أو عن فاعل الفعل والأصل: أنت علا منزلك، أي علا علواً زائلاً على علو منزل غيرل، فلا يرد أنه إذا قيل: علا منزلك فات التفضيل مع أنه قد يمنع ضرر فواته ، ويعده بعض المتأخرين من التحويين من التمييز المحول عن المبتدأ ،كما سبق النقل عن ابن هشام، ونقل الصبان(1) هيضاً عن كتاب التوضيح للأشموني: أن التمييز في مثل هذا محول عن المبتدأ حيث قال:" وفي التوضيح أنه محول عن المبتدأ ، والأصل : منزلك أعلى، فجل المضاف تمييزاً ، والمضاف إليه مبتدأ ، فارتفع وانفصل بعد أن كان متصلاً مجروراً وهو أيضاً صحيح. قال شارح الجامع : لا منافاة بين كونه فاعلاً في المعنى ، ومحولاً عن المبتدأ في الصناعة ؛ لأن ما صلح لأن يخبر بالتفضيل عنه صلح لأن يكون فاعلاً في المعنى." ويناءً على هذا فلا غرابة في التمييز المحول عن المبتدأ. والله أعلم. 
فصل المقال في الغريب من الأقوال النحوية والتصريفية د / عبدالرعوف ثابت أحمد عبدالله

\section{"}

قال أبو حيان: (') ومن غرائب المنقول أن الفراء ذهب إلى جواز الخفض بـ

" لعل" ، وإجازة نصب الخبر ورفعه : والأصل : لعاً لعبدِ الله. قال : فمن نصب قال:

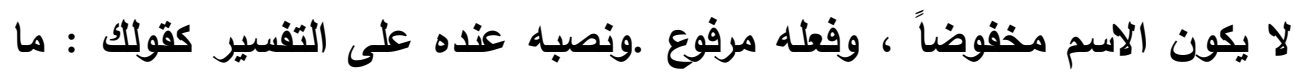

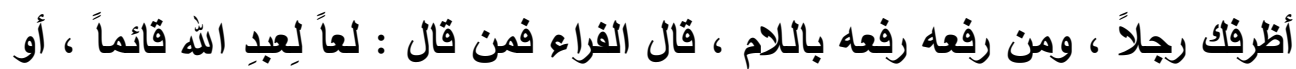
قائم ، ثم كنى عن عبد الله ، قال: لعلَّه فنصب لامه. وهذا عند البصريين خطأ ، لأنه إن أراد أن يخفض بـ " لعل" جاء بخلاف ما جاء به القرآن وما نقله أهل اللغة

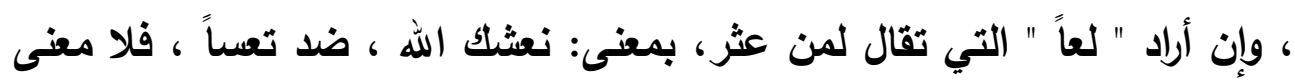
لها هنا ، ولا لأكرها مع "إن وأخواتها ". ووجه الغرابة كما زعم أبوحيان أن الجر بها لم يقع في القرآن ، ولم ينقل عن العرب، كما أنه لابد للجار والمجرور من متعلق ، ولا متعلق لها هنا، أما قوله

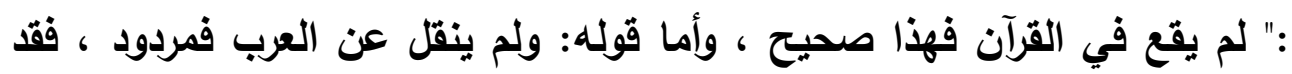
حكي أبو زيد الأنصاري ، والأخفش، وأبوعبيدة من البصريين ، والفراء من الكوفيين أن الجر بـ"لعل" لغة عُقيل، وقد نص على ذلك ابن جني (؟)، وابن سيده(ب)

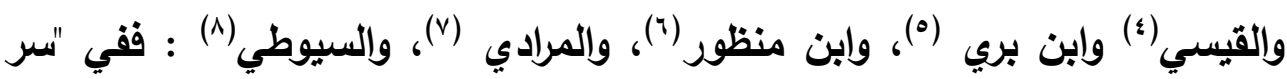

(1) ينظر : التذييل والتكميل م/ 1/1).

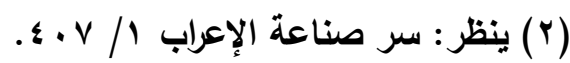

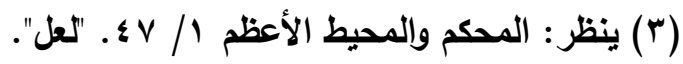

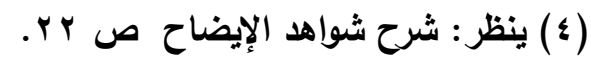

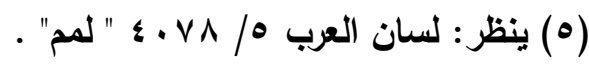

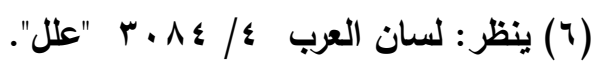

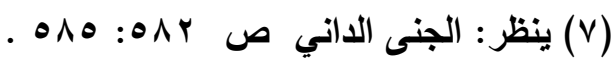
(^) ينظر: همع الهوامع r/r) 
فصل المقال في الغريب من الأقوال النحوية والتصريفية د / عبدالرعوف ثابت أحمد عبدالله

صناعة الإعراب(1) " وحكى أبو زيد أن لغة عقيل : لعلِ زيدٍ منطلق ، بكسر اللام

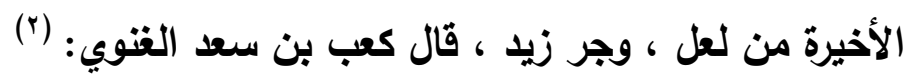

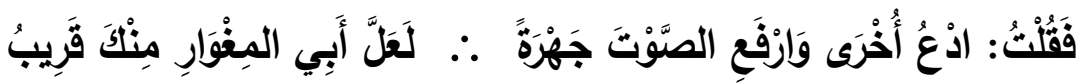
وقال أبو الحسن الأخفش: ذكر أبو عبيدة أنه سمع لام لعل مفتوحة ، في لغة من

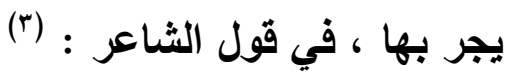

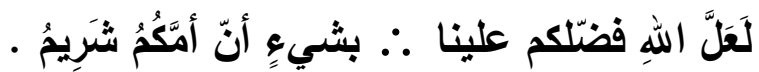
وقال المرادي:(؛) "القسم الثاني: أن تكون حرف جر، في لغة عقيل. يقولون: لعل زيل قائم. والجر بـ "لعل" مراجعة أصل مرفوض، لأن أصل كل حرف اختص بالاسم، ولم يكن كالجزء منه، أن يعمل الجر، كما تقدم في صدر الكتاب. وإنما خرجت إن وأخواتها، عن هذا الأصل، فعملت النصب والرفع، لشبهها بالفعل. ولذلك الك قال الجزولي: وقد جروا بلعل منبهة على الأصل. وروى الجر بها، عن العرب، أبوزيد، والفراء، والأخفش، وغيرهم من الأئمة.

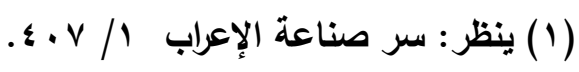

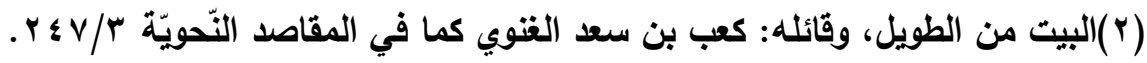

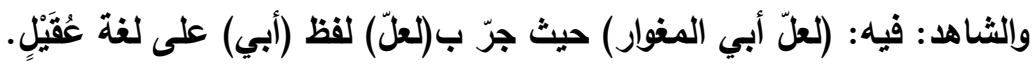

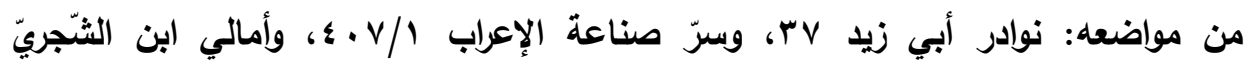

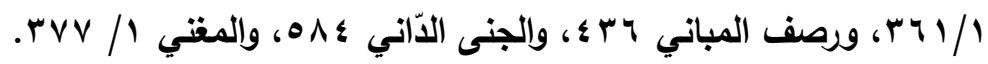
(r) (البيت من الوافر ، ولم أقف على قائله.

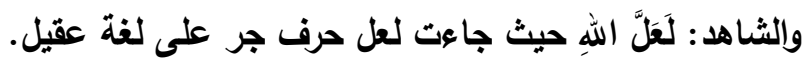

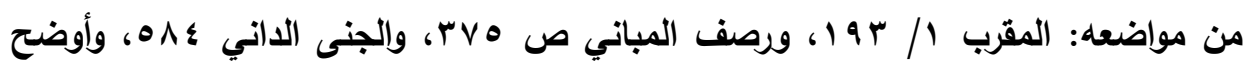

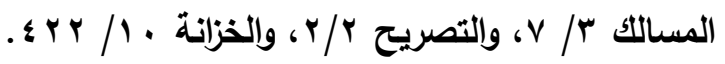

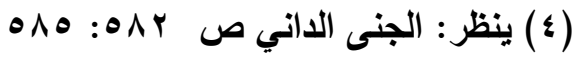


فصل المقال في الغريب من الأقوال النحوية والتصريفية د / عبدالرعوف ثابت أحمد عبدالله

\section{ومن ذلك قول الثاعر: (1)}

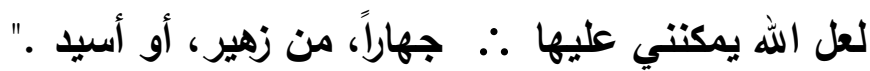

ويذلك يكون قد اتضح أن الجر بلعل ثابت في لغة عقيل نطق به شعراؤهم ،

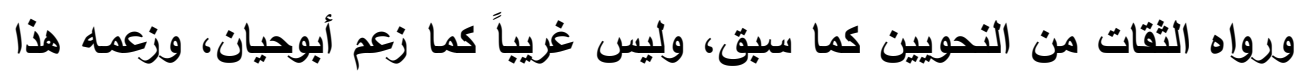
مبني على إنكار بعض النحويين الجر بلعل ، ومنهم: أبوعلي الفارسي(؟)، وابن

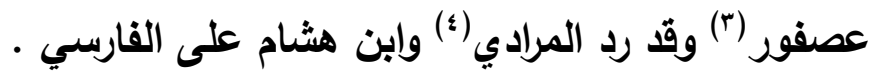
وأما عن قولهم بأن حرف الجر لابد له من متعلق فقد ذكر ابن هشام في الباب الثالث من المغني(•) مالا يتعلق بشيء من حروف الجر ، وذكر ستة أمور: منها الجر بلعل في لغة عقيل .والله أعلم.

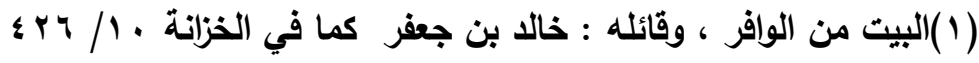

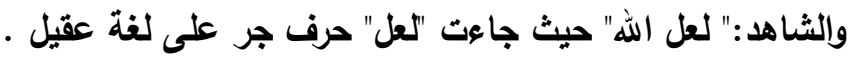

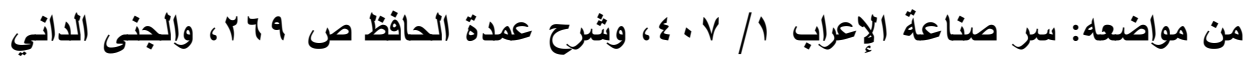

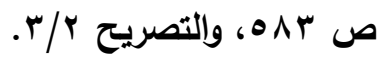

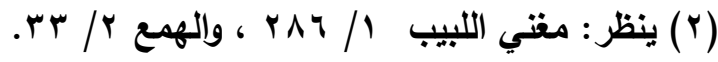

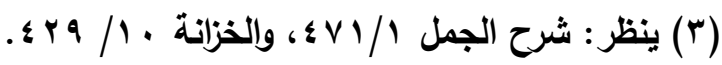

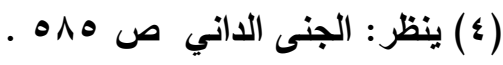

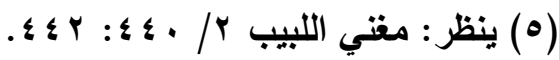




\section{rا - هجيs اللام بمعنى البلاs}

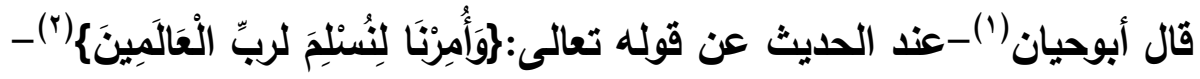
"..وقيل : اللام بمعنى : الباء ، كأنه قيل : وأمرنا بأن نسلم ، ومجيء اللام بمعنى

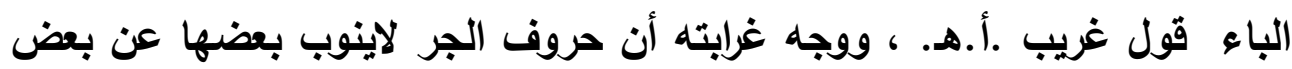
بقياس ، كما أن حروف الجزم، والنصب كذلك، وما أوهم ذلك فهو إما مؤول عند جمهور البصريين تأويلاً يقبله اللفظ، وإما على تضمين الفعل معنى فعل آخر، كتضمين: شرين معنى: روين.، ومذهب الكوفيين، وابن قتيبة، وإبن سبده، ووافقهم ابن مالك، وكثير من المعربين، والمفسرين ، جواز إنابة حروف الجر بعضها عن بعض.، والمعهود لدي أن اتجاه أبي حيان أنه بصري- وإن صرح في البحر بعدم التقييد بأحد المذهبين - وهذا الذي دعاه إلى القول بأن مجيء اللام بمعنى الباء غريب، وهو من المعاني التي يندر ذكرها في كتب النحاة .

ويالبحث اتضح أن هذا المعنى قال به الفراء(ّ)، قال القرطبي: (؛) قال الفراء:

والمعنى: أمرنا بأن نسلم ؛ لأن العرب تقول : أمرتك لتذهب ويأن تذهب بمعنى"أ.هـ. كما أجازه السمين الحلبي(•)، وابن عادل الحنبلي(ّ). وحكاه أبو البقاء العكبري(v)؛

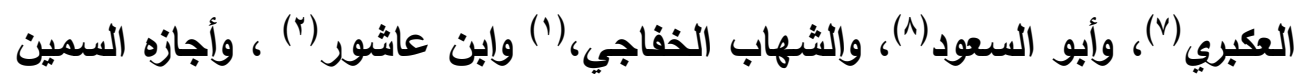

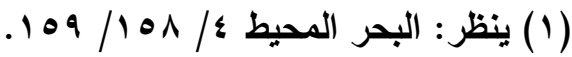

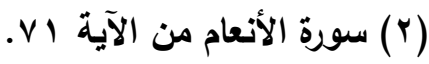

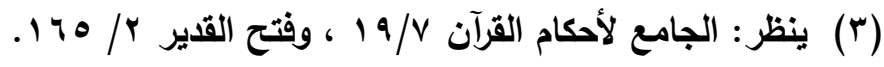

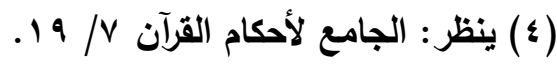

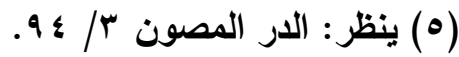

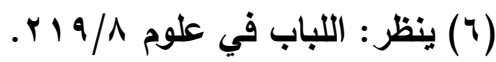

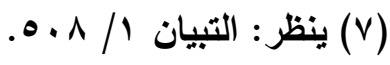

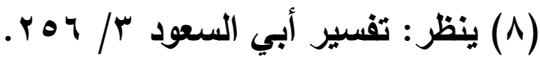


فصل المقال في الغريب من الأقوال النحوية والتصريفية د/ عبدالرعوف ثابت أحمد عبدالله

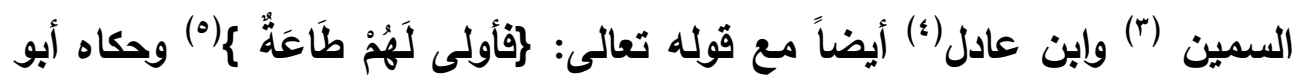

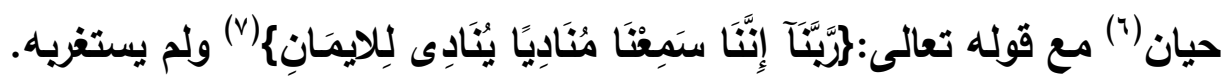
ومن الآيات التي احتملت أن تكون اللام بمعنى الباء(^) قوله تعالى:\}

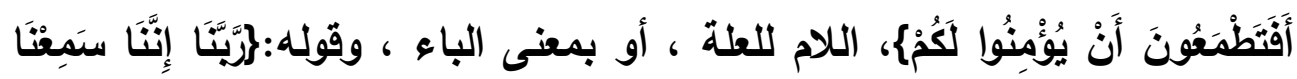

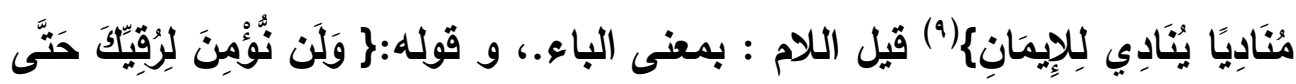

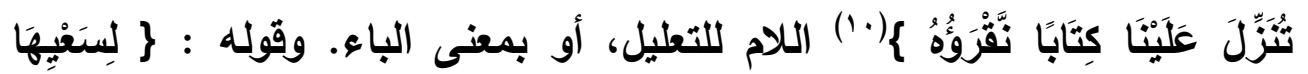

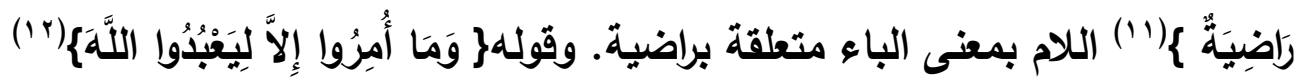
ويذلك يكون ورود اللام بمعنى الباء ليس غريباً ، والله أعلم.

\section{عץ- هن معاني الكاف المبادرة}

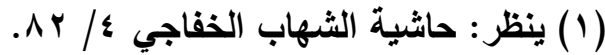

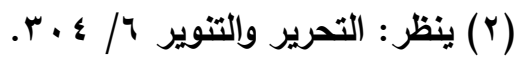

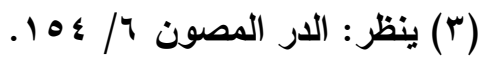

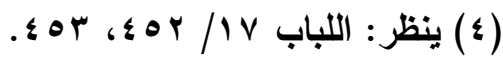

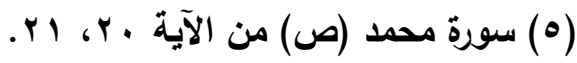

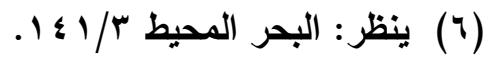

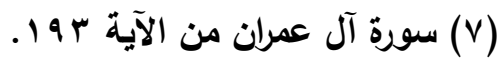

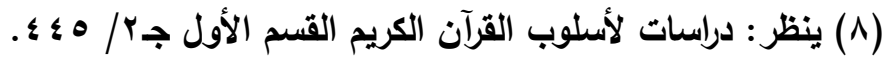

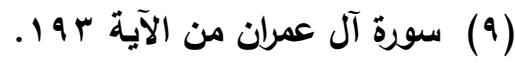

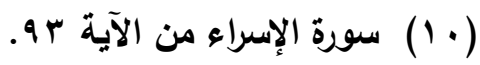

(11) (11) سورة الغاشية الآية 9.

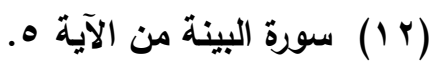


فصل المقال في الغريب من الأقوال النحوية والتصريفية د / عبدالرعوف ثابت أحمد عبدالله

قال ابن هشام في المغني(') : والمعنى الرابع:- أي من معاني الكاف -

المبادرة وذلك إذا اتصلت بما في نحو: سلم كما تلخل ، وصل كما ياخل الوقت ، ذكره ابن الخباز في النهاية ، وأبو سعيد السيرافي وغيرهما ، وهو غريب جدًا.

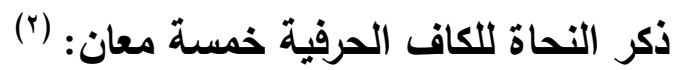

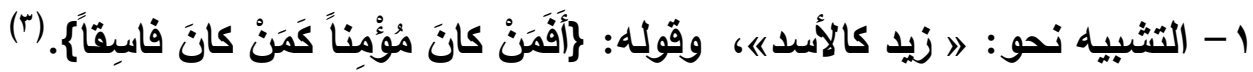

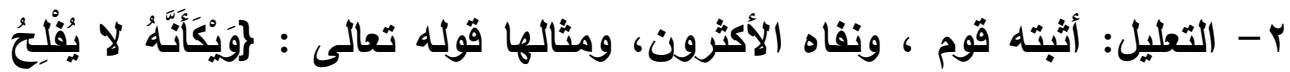

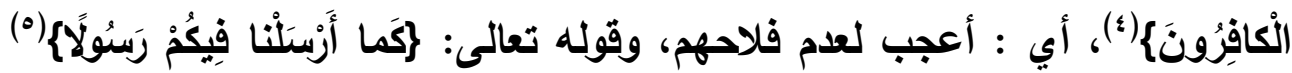
قال الأخفش : لأجل إرسالي فيكم رسولا. r- الاستعلاء: ذكره الأخفش والكوفيون، وأن بعضهم قيل له: كيف أصبحت؟ فقال: كخير، أي على خير. وقيل المعنى: بخير، وقيل: هي للتشبيه على حذف مضاف، أي كصاحب خير. ع - المبادرة: وذلك إذا اتصلت بـ (ما) في نحو: (سلم كما تلخل) (وصلّ كما ياخل الوقت)

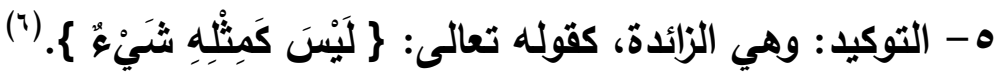
ويعد فإن المبادرة معنى من المعاني التي ذكرها النحاة للكاف الحرفية قال الشهاب الخفاجي:(')وهذه الكاف تسمى كاف المفاجأة وكاف القرآن، وقد نقلها

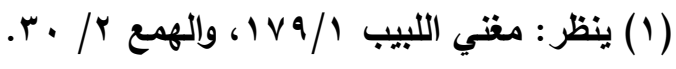

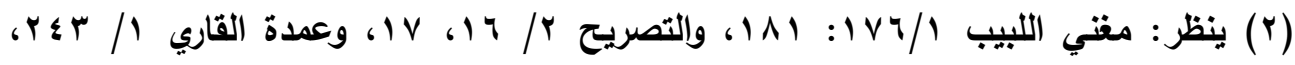

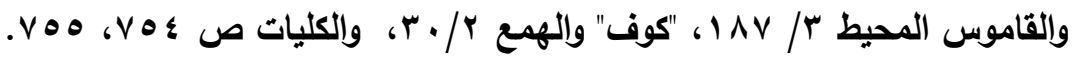

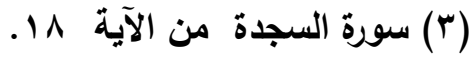

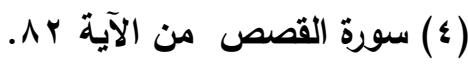

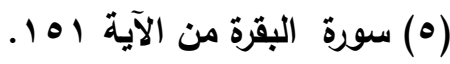

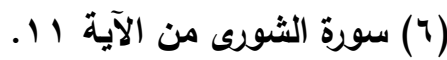


فصل المقال في الغريب من الأقوال النحوية والتصريفية د/ عبدالرعوف ثابت أحمد عبدالله

النحاة كصاحب المغتي ووقت في كلام العرب والفقهاء نحو: سلم كما تدخل ، وصل كما ياخل الوقت، وهي كاف التشبيه في الأصل كأنه شبه وقت أحد الحدثين المتجاورين بوقت الآخر أو أحدها بالآخر لوقوعهما في زمن واحد ولكونه خلاف المعروف فيها قال في المغتي : إنه معنى غريب جداً ". قال الصبان:(ץ) يمكن تخريجهما على زيادة الكاف، وجعل ما مصدرية وقتية ، أي سلم وقت دخولك، وصل وقت دخول الصلاة فتستفاد المبادرة. وق نص على هذا المعنى غير ما ذكرث صاحب القاموس(ז) وأبوالبقاء الكفوي في الكليات(؛)، والعيني في عمدة القاري(ه)، والثيخ خالا الأزهري في

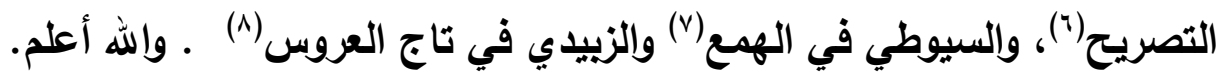

\section{Y - زيادة الباء بين "عن" ومجموردها زليادة الباء في السم ليسى}

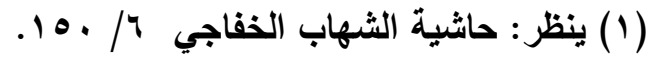

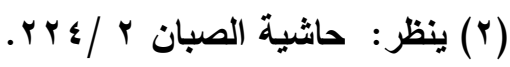

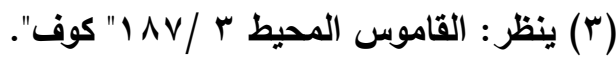

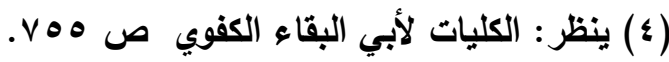

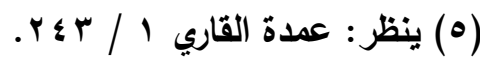

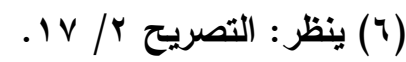

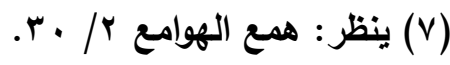

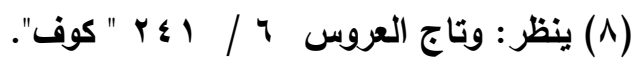


فصل المقال في الغريب من الأقوال النحوية والتصريفية د / عبدالرعوف ثابت أحمد عبدالله

1 - (1)

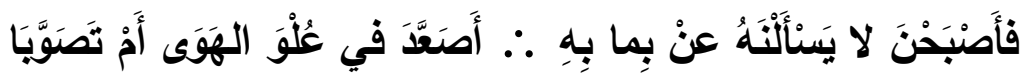
قال ابن جني: (ז) "فإنه زاد الباء وفصل بها بين عن وما جرته ، وهذا من وهن غريب مواضعها ـ فأما قولهم : سميته زيداً ويزيد ، وكنيته أبا عبد الله ويأبي عبد الله ، فليست الباء فيه زائدة وإنما أوصلوا بها الفعل تارة إلى المفعول ، وأوصلوه تارة أخرى بنفسه كما قالوا : جئته ، وجئت إليه." وتبع ابن جني في ذلك ابن سيده في المحكم(ז)، والرضي في شرح

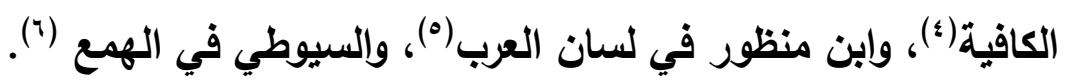
ووجه غرابته أنها لم ينص أحد من النحاة على زيادة الباء بين عن ومجرورها ضمن المواضع التي تزاد فيها الباء . وجعل الفراء(') الزيادة في البيث للضرورة حيث قال:" فكرر الباء مرتين. فلو قال: لا يسلنه عما به، كان أبين وأجود. ولكن الثاعر ريما زاد ونقص ليكمل الثعر..

(1) البيت من الطويل ، وقائله : الأسود بن يعفر وهو في ديوانه ص الب.

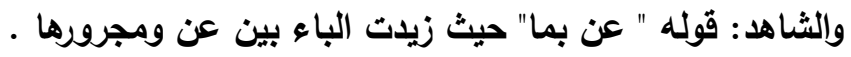

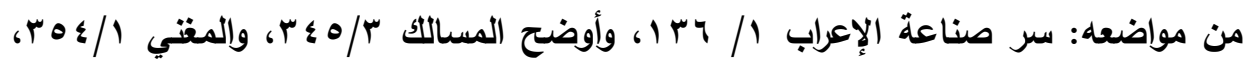

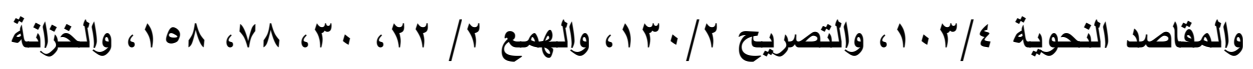

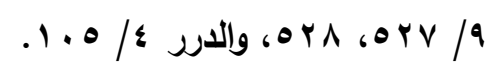

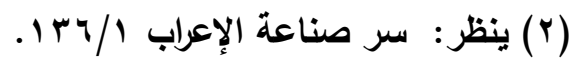

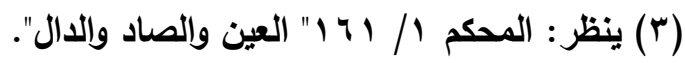

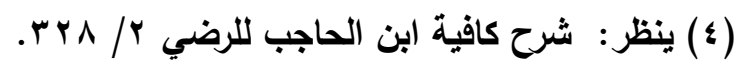

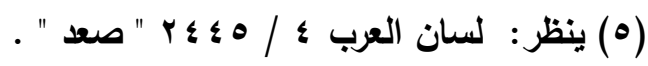

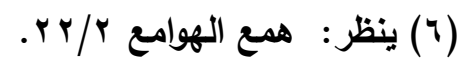


فصل المقال في الغريب من الأقوال النحوية والتصريفية د / عبدالرعوف ثابت أحمد عبدالله

ץ - قال ابن هشام: (r)" تتبيه: من الغريب أنها زيدت فيما أصله المبتدأ وهو:

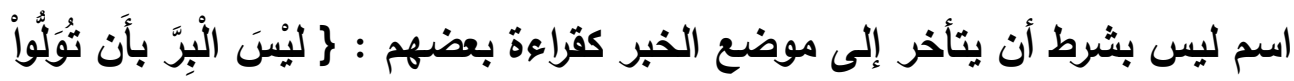

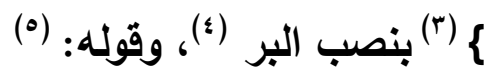

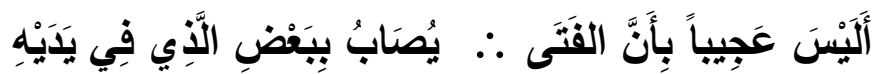

ووجه الغرابة أنه لـ يعهد دخول الباء على اسم "ليس" وإنما المعهود دخولها على الخبر.، قال أبو حيان:(؟) " أدخل الباء على اسم ليس، وإنما موضعها الخبر، وحسَّنَ ذلك في البيت ذكرُ العجيب مع التقرير الأي تفيده الهززة، وصار معنى الكلام: أعجب بأن الفتى، ولو قلت أليس قائماً بزيد لم يجز . واعلم أن الباء تزاد في المواضع التالية: (v) (ل)

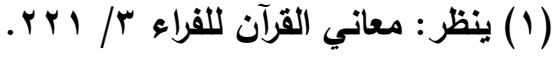

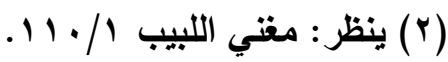

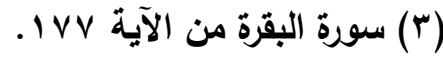

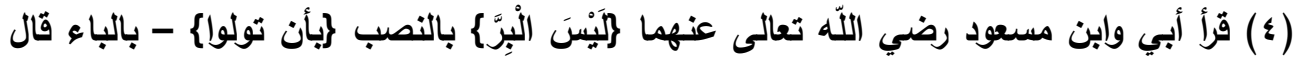

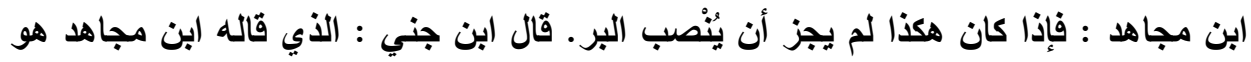
الظاهر في هذا؛ لكن قد يجوز أن يُنْصب مع البَ الباء، وهو أن تجعل الباء زائدة؛ كقولهم : كفي

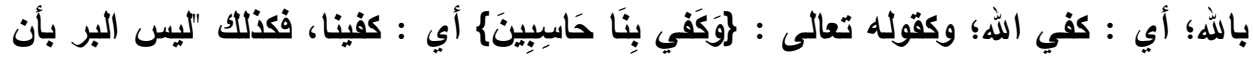

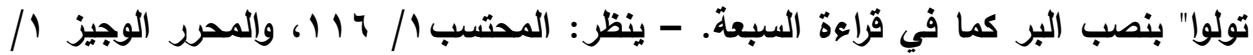

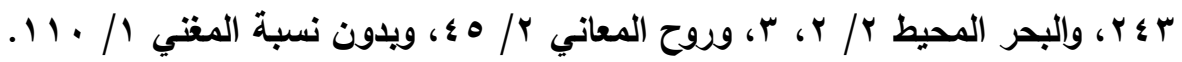

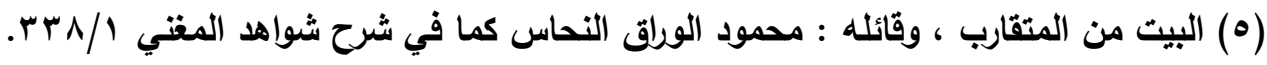
والتمثيل به في قوله: " بأن الفتى" حيث زيدت الباء في اسم "ليس" المتأخر عن الخبر .

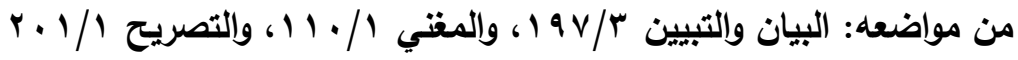

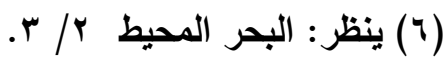

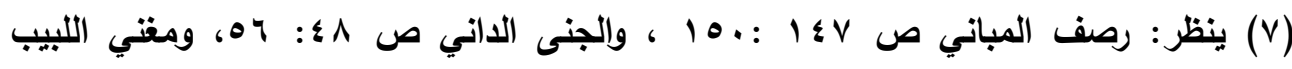

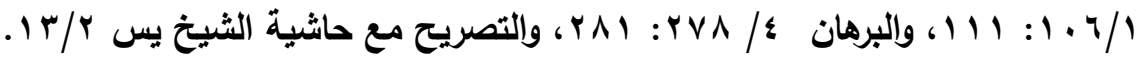


فصل المقال في الغريب من الأقوال النحوية والتصريفية د / عبدالرعوف ثابت أحمد عبدالله

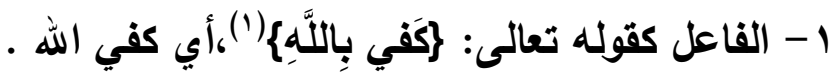

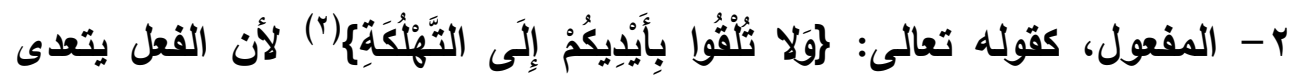

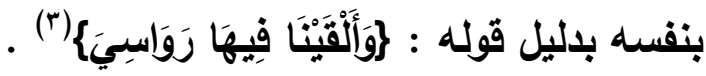

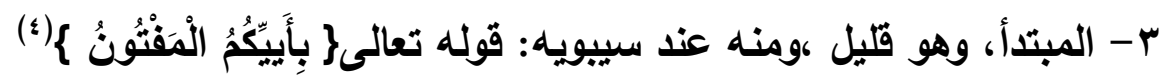

ع - خبر المبتدأ، كقوله تعالى

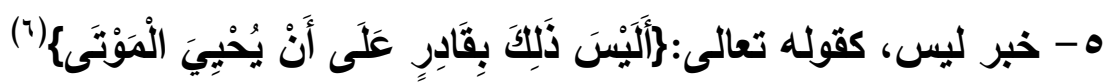

(v) : الحال المنفي عاملها كقوله

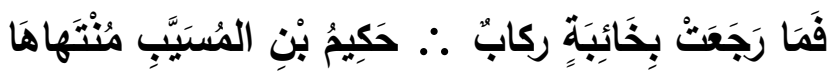

- التوكيد بالنفس والعين نحو : جاء زيل بنفسه ويعينه. وقال ابن عصفور في "(المقرب"(^) : وتزاد في نادر كلام لا يقاس عليه، كقوله

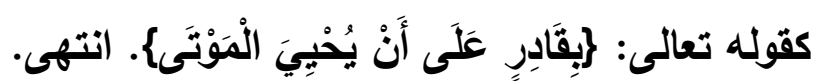

(1) سورة النساء من الآية 179

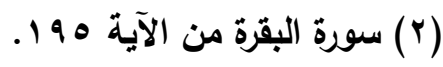

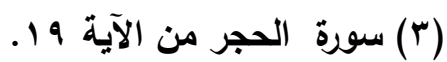

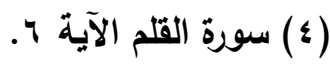

(0) سورة يونس من الآية VV.

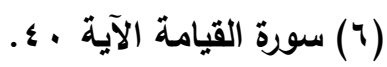

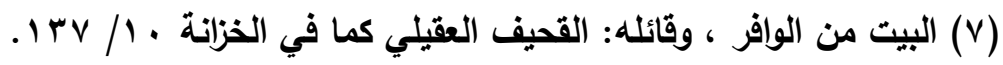

والثاهد: قوله " بخائبة حيث زاد الباء في الحال المنفي عاملها.

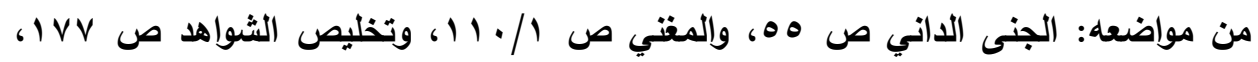

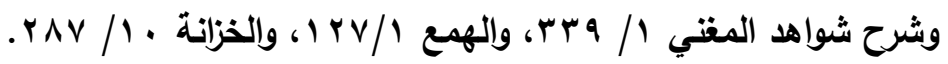

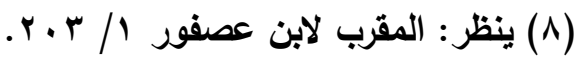


فصل المقال في الغريب من الأقوال النحوية والتصريفية د / عبدالرعوف ثابت أحمد عبدالله

ويبقى القول بأن زيادة الباء بين عن ومجرورها مما لم يعه عند النحاة ،

وأما ورودها في البيت فضرورة كما قال الفراء .

وأما زيادة الباء في اسم " ليس" وإن لم يكن معهوداً فيكفي لرفع غرابته ؛

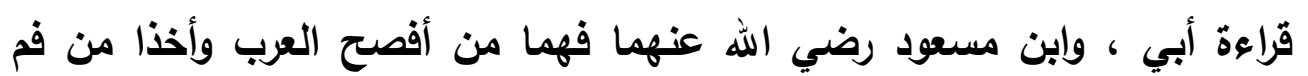
النبي صلى الله عليه وسلم. والله أعلم .

\section{7 - هذف التنوين من "كل" وبنانها على الضم.}

قال أبو حيان: (') "ومن غريب المنقول ما ذهب إليه محمد بن الوليد (1)

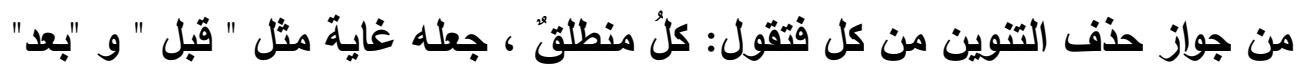
(1) ينظر: همع الهوامع / / • 1 ، ، وتاج العروس ^/ . . 1 ـ " كلل" 
فصل المقال في الغريب من الأقوال النحوية والتصريفية د / عبدالرعوف ثابت أحمد عبدالله

• حكاه عنه أبو جعفر النحاس ، وأنكر عليه علي بن سليمان ؛ لأن الظروف قـ خصت بعلة ليست في غيرها.أ.هـ

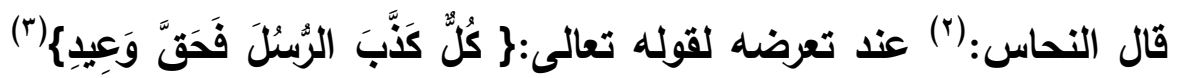

التقدير عند سيبويه: كلهم، ثم حذف لالالة كل، وأجاز النحويون جميعاً (كل) منطلق) بمعنى: كلهم ، قال أبو جعفر: سمعت محمد بن الوليا يجيز حذف التنوين فيقول: كل منطلق بمعنى: كلهم يجعله غاية ، مثل : قبل ، ويعد، قال علي بن سليمان: هذا كلام من لم يعرف لم بني قبل ويعد ، ونظير هذا من الألفاظ ؟ لأن النحويين قد خصوا الظروف للعلة التي فيها ليست في غيرها، قال أبو جعفر: وهذا

كلام بين عند أهل العربية صحيح. ووجه الغرابة فيه أن لفظ " كل" من الألفاظ الملازمة للإضافة ، فإذا حذف هلف

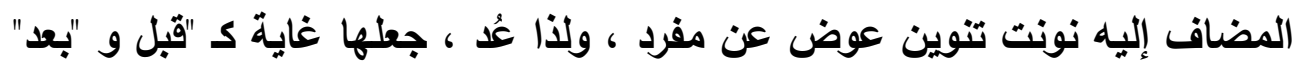
مع تجريدها عن الإضافة والتنوين ويناءها على الضم غريباً؛ لأن الظروف قد خصت بعلة ليست في غيرها وما بني من الظروف المذكورة فإنه لا يتصرف . قال ابن مالك: (؛) ".. وأما "كل" غير الواقع توكيداً ولا نعتاً فإنه لازم الإضافة هئة معنى لا لفظاً، لكنه لا يجرد عن الإضافة لفظاً إلا وهو مضاف معنى ، فلذلك لا

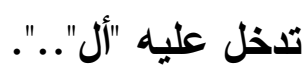

( ) هو / أحمد بن محمد بن الوليد بن محمد التميمي الملقب بابن ولاد المصري نحوي ابن نحوي

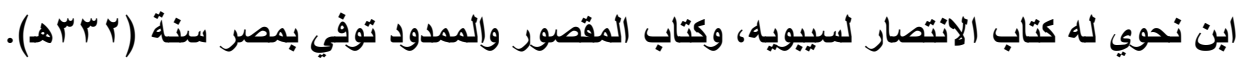

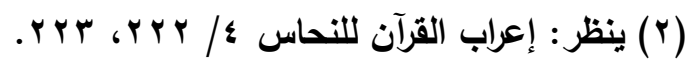

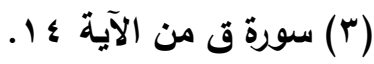

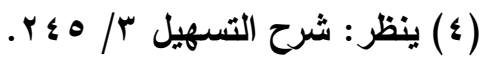


فصل المقال في الغريب من الأقوال النحوية والتصريفية د / عبدالرعوف ثابت أحمد عبدالله

ويعد فإن حذف التنوين من "كل" ويناءها على الضم تثبيهاً بـ"قبل" و"بعد" هو رأي انفرد به محمد بن الوليد بن محمد التميمي الملقب بابن ولاد المصري نقله عنه أبو جعفر النحاس ، وأبو حيان، والسيوطي ، والزبيدي، وحكاه مكي القيسي(') حيث قال:"أجاز بعض النحويين " كل منطلق"، فبنى كلاً على الضم لحذف ما أضيف إليه جعله كقبل ، ويعد " . والله أعلم.

\section{r r - عمل "فعيل" ، و"فعل" من صيخ المبالغة}

قال أبو حيان:(r)" ...، ومن غريب النقل ما ذهب إليه بعض النحويين من أن فعيلاً إذا كان من متعد جاز أن يعمل، فتقول: هذا شريب مسكر، عما أعملوا

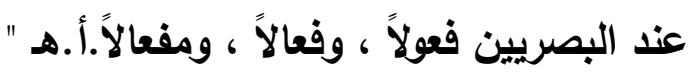

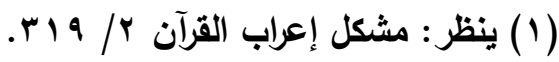

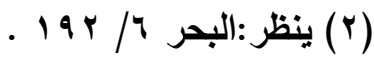


ومن هؤلاء النحويين: ابن ولاد ،وابن خروف ففي التذييل قال: (1) "وذهب

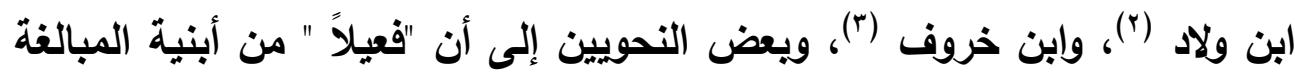

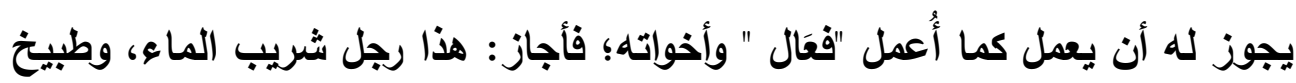

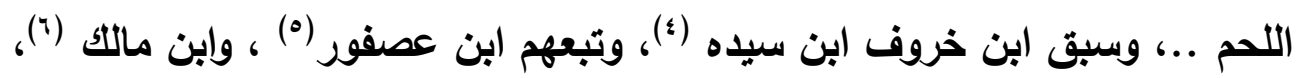
وأبو حيان في أحد قوليه (V) أما وجه غرابة النقل عند أبي حيان فمنها: أن فعيل، وفَعِل نحو : لبيس الثياب

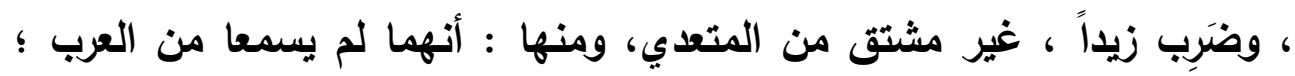

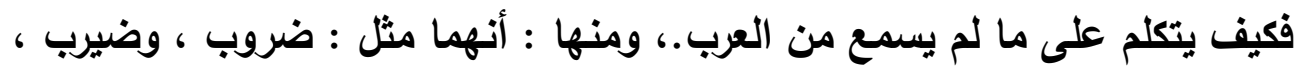

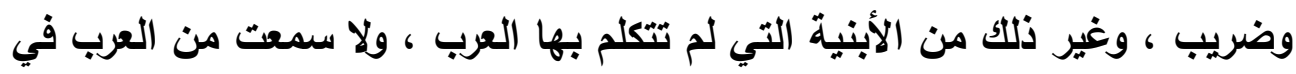

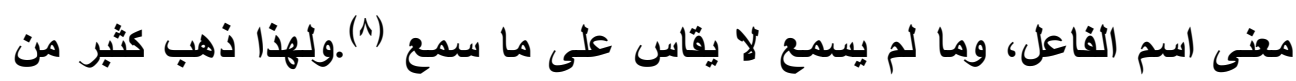

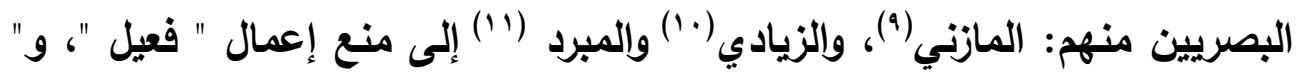

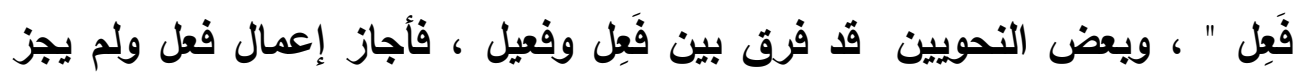

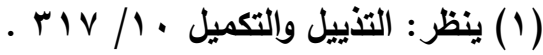

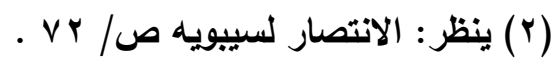

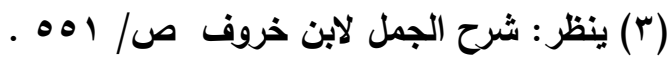

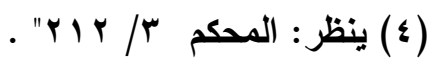

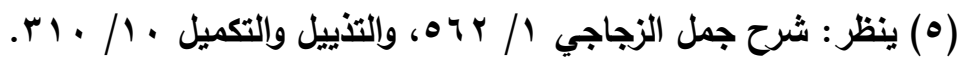

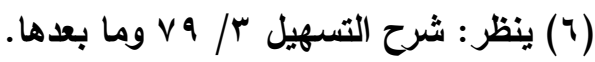

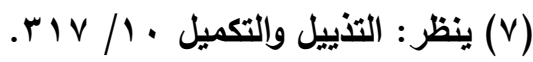

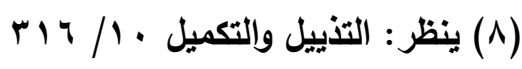

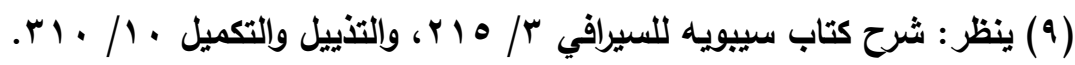

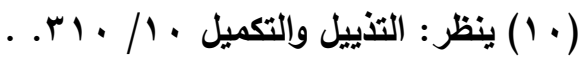

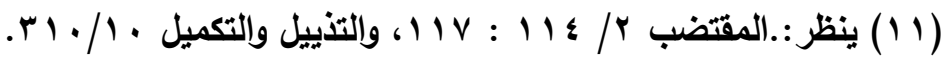


فصل المقال في الغريب من الأقوال النحوية والتصريفية د / عبدالرعوف ثابت أحمد عبدالله

إعمال فعيل ومنهم : الجرمي(")، وأبو عمرو(r): على ضعف العمل عنده في فعل .

أما الكوفيون فقد ذهبوا إلى عدم إعمال جميع صيغ المبالغة ، فهي لا تعمل عندهم ؛ لأنها لما جاءت للمبالغة زادت معنى على الفعل ؛ لأن أفعالها لا مبالغة

فيها ، فلا يجوز إعمالها (َ). أما سييويه فقد نسب له جواز الإعمال في جميعها، أما فعول ومفعال وفعال فباتفاق بينه ويين باقي البصريين، وأما فعيل ، وفعل فعنده فقط ، قال الرضي(؛) : قال سيبويه: فاعل إذا حول إلى فعيل، أو فعل عمل أيضاً ...، ومنع ذلك غير

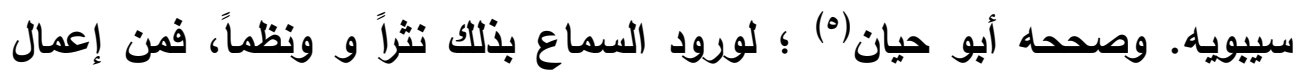
فعول ما رواه الكسائي عن العرب من قولهم: أنت غيوظ ما علمت أكباد الرجال ، وقال الشاعر (י):

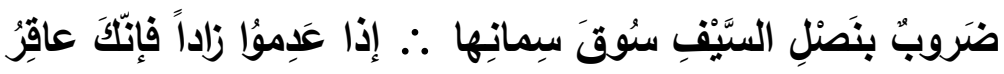

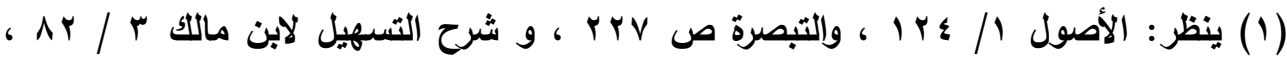

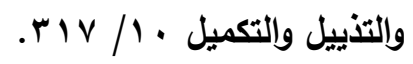

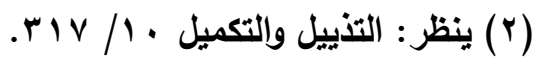

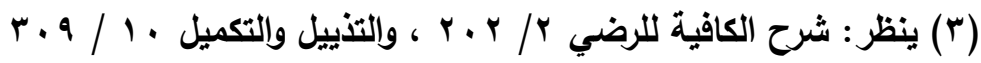

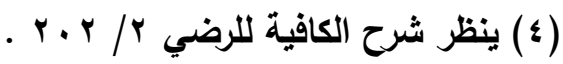

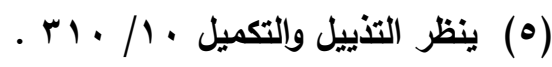

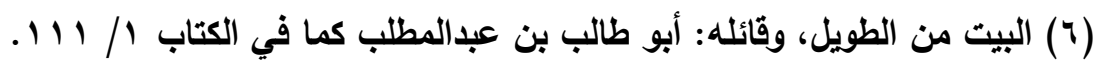

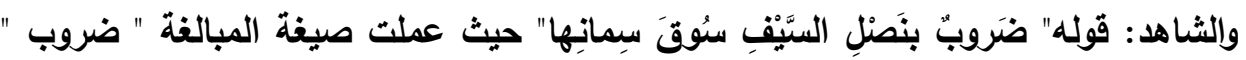
عمل الفعل فرفعت الفاعل وهو الضمير المستتر فيه ونصبت المفعول وهو قوليه " سوق".

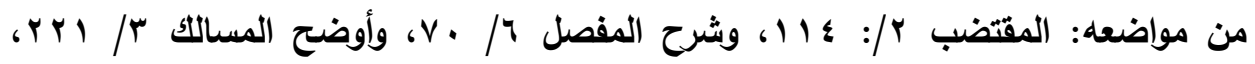

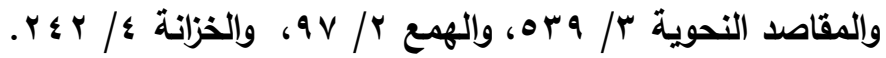


فصل المقال في الغريب من الأقوال النحوية والتصريفية د/ عبدالرعوف ثابت أحمد عبدالله

ومن إعمال فعال قول من سمعه سيبويه: أما العسل فأنا شراب، وقال

(الثاعر: (1)

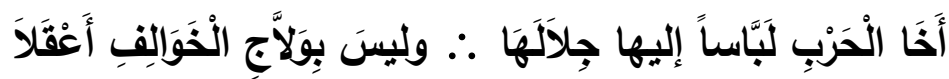

ومن إعمال مفعال قول بعض العرب: إنه لمنحار بوائكها ، وقال الشاعر (r):

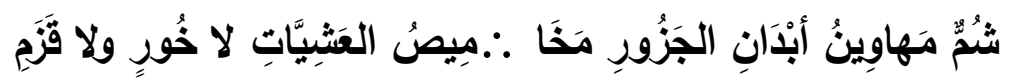

(1) البيت من الطويل ، وقائله القلاخ بن حزن كما في المقاصد النحوية ب/ هـ هـه

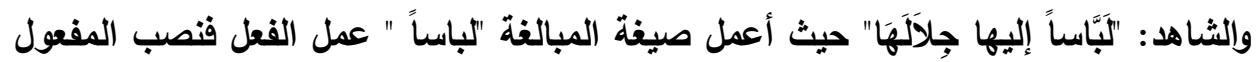

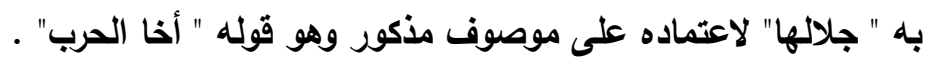

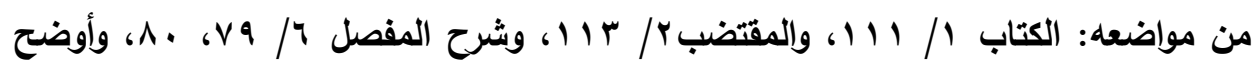

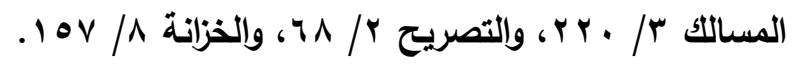

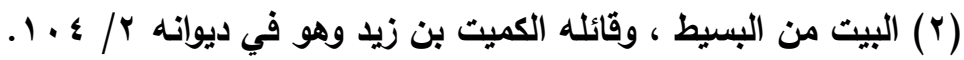

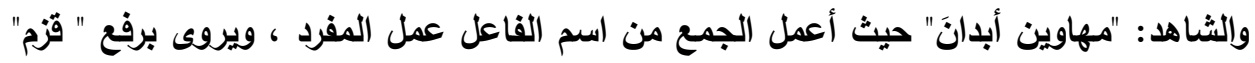

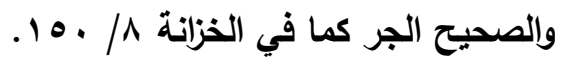

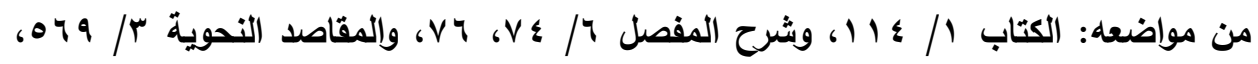
والهمع من مون/ 
فصل المقال في الغريب من الأقوال النحوية والتصريفية د / عبدالرعوف ثابت أحمد عبدالله

$$
\text { ومن إعمال فعل قول زيد الخيل ('): }
$$

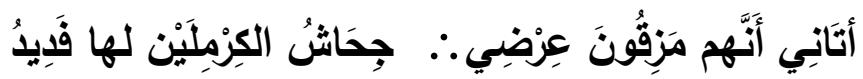

ومن إعمال فعيل قول بعض العرب: إن الله سميع دعاء من دعاه. قال ابن

مالك : رواه بعض الثقات ، وقالوا : هو حفيظ علمه وعلم غيره . ونقله عنه أبو

$$
\text { حيان (ז) وقال الشاعر(r): }
$$

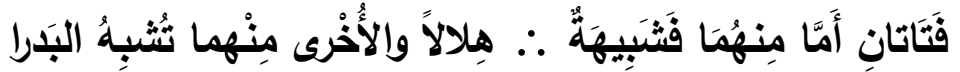

ومما أنشده سيبويه لإعمال فعيل أيضاً قول ساعدة بن جوئية (؛) :

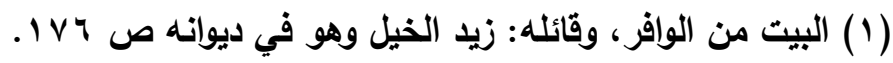
والثاهد: قوله " مزقون عرضي " حيث أعمل جمع صيغة المبالغة فنصب به اله المفعول به وهو قوله " عرضي".

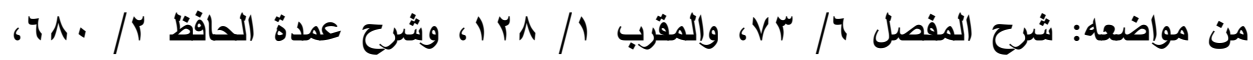

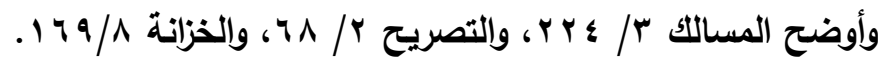

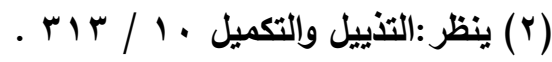

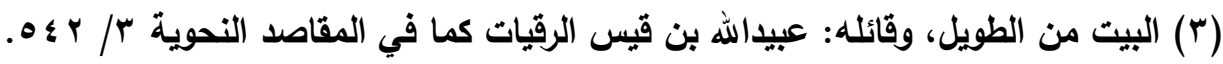

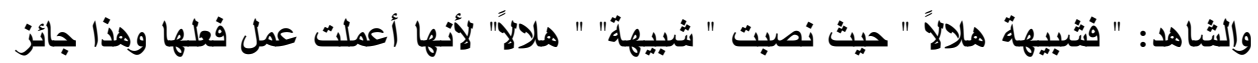
خلافاً لجماعة من البصريين.

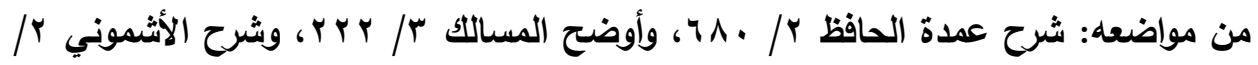
- rav

(؛) البيث من البسيط، وقائله: ساعدة بن جوئة الهذلي كما في شرح أشعار الهذليين ب// $.11 r 9$ والثاهد: قوله " كليلٌ موهناً " حيث نصب موهناً بكليل لأنه بمعنى مُكِّل وفعيل بمعنى مفعل كثير

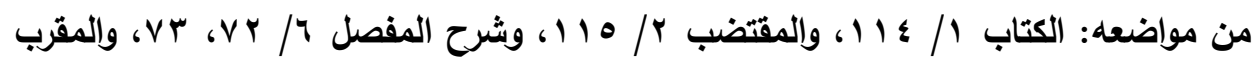

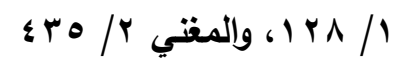


فصل المقال في الغريب من الأقوال النحوية والتصريفية د / عبدالرعوف ثابت أحمد عبدالله

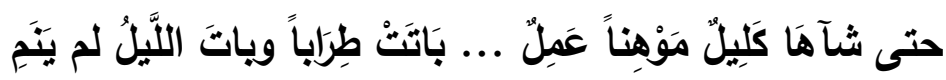
فكليل بمعنى : مكل، وقد نصب موهنا على أنه مفعول به، أي يكل أوقات الليل من فئل

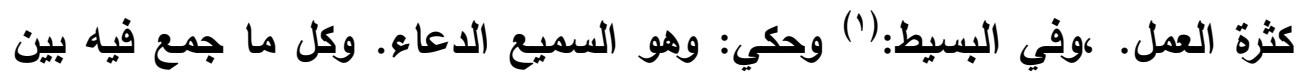

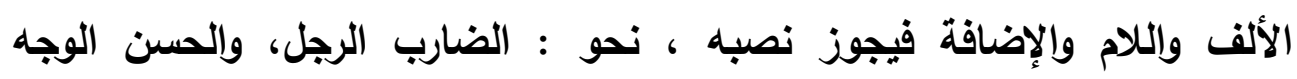

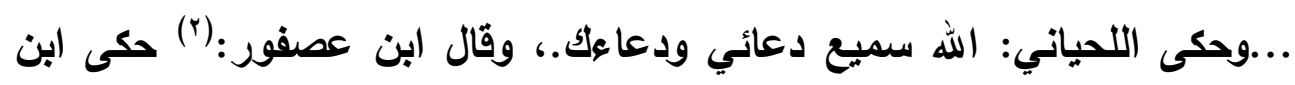

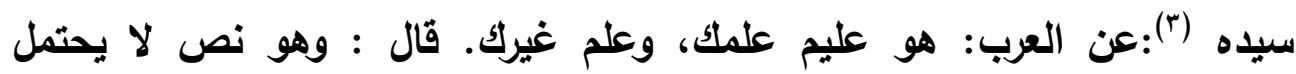
التأويل .

ويعد: فقي قول ابن مالك ، وأبي حيان في قولهم : إن الله سميع دعاء من

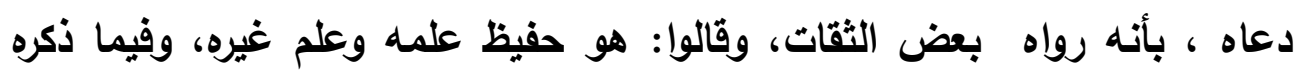

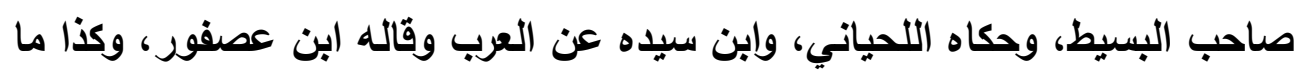

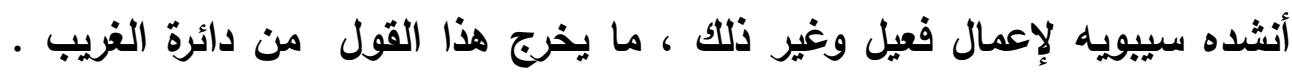
والله أعلم . الفلده

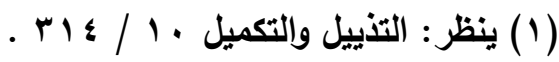

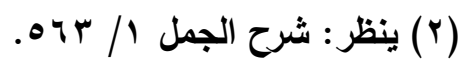

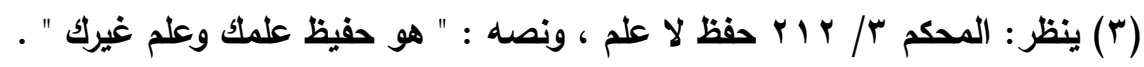


فصل المقال في الغريب من الأقوال النحوية والتصريفية د / عبدالرعوف ثابت أحمد عبدالله

\section{1ץ- إعراب المنصوب الواقع بعد حبذا}

قال ضياء الدين بن العلج في"البسيط"(1): يجوز في الاسم المنصوب الواقع بعد "حبذا" أن يعرب مفعولاً به لفعل محذوف تقديره: أعني ، ووصفه أبو حيان(r) بأنه قول غريب ، ولعل وجه غرابته ؛ أنه لم يقف عليه لغيره .

واعلم أن النحويين اختلفوا في الاسم المنصوب بعد "حبذا" على خمسة مذاهب: (r)

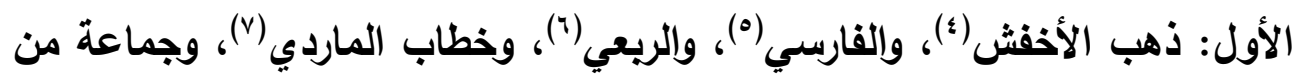
البصريين إلى أنه منصوب على الحال لا غير، سواء أكان جامداً أم مشتقاً . الثاني: ذهب أبو عمرو بن العلاء(^) إلى أنه منصوب على التمييز لا غير سواء أكان جامداً أم مشتقاً. ومشى عليه ابن السراج(") ، وابن جني(·')، وابن الناظم(1) وقد استدل ابن جني على أنه تمييز بلخول من عليه قال : وتقول : حبذا رجلاً زيد ، أي: من رجل ، فتتصبه على التمييز .

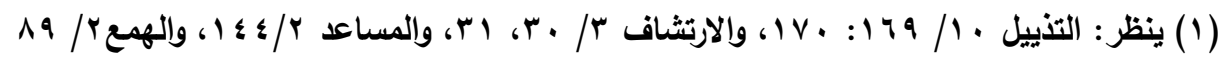

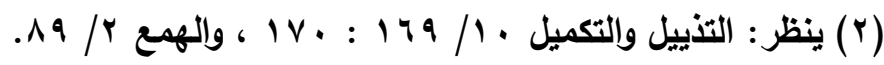

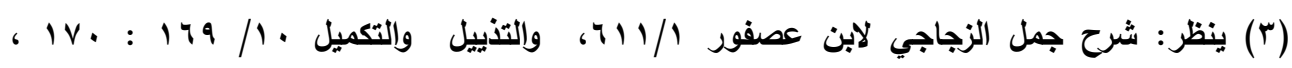

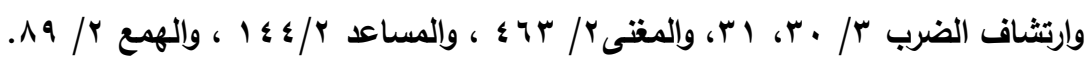

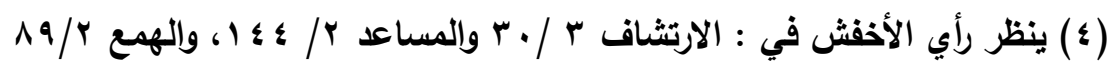

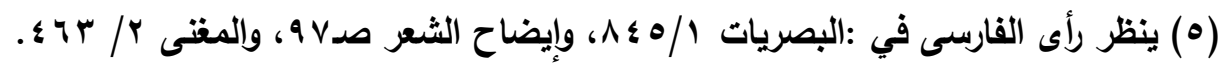

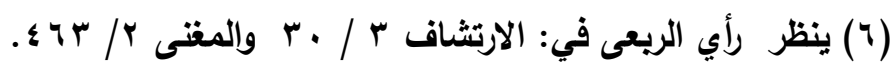

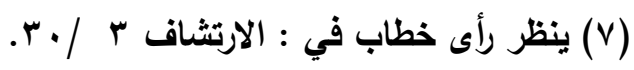

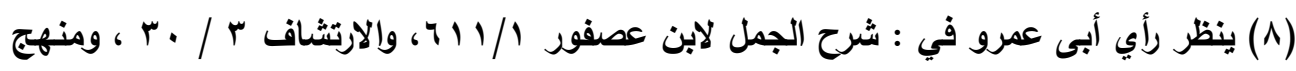

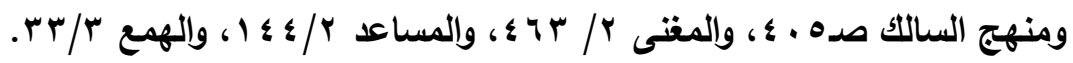

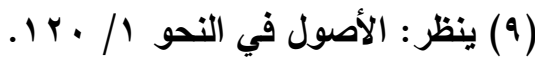

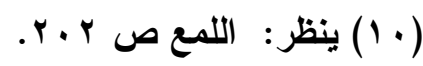

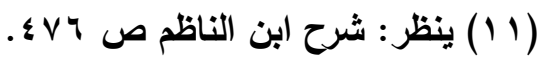


فصل المقال في الغريب من الأقوال النحوية والتصريفية د/ عبدالرعوف ثابت أحمد عبدالله

الثالث: مذهب الكوفيين، ويعض البصريين أنه منصوب على التمييز. الرابع: التفصيل وهو مذهب ابن أبي الربيع حيث قال: "إذا كان المنصوب جامدًا كان

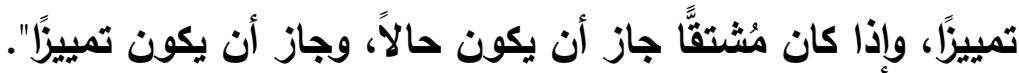
قال أبو حيان: (') "والذي يظهر أنه إن كان جامداً كان تمييزاً، وإن كان مشتقاً مشتقاً فمقصدان للمتكلم:فإن أراد تقييد المبالغة في مدح المخصوص بوصف كان ذلك المنصوب حالاً، ولا يصح دخول من عليه إذ ذاك.، وإن أراد عدم التقييد، بل تبيين جنس المبالغ في مدحه كان ذلك المنصوب تمييزاً ، مثال الأول: حبّا هندّ هُ مواصِلَةَ، أي: في حال مواصلتها. ومثال الثاني: حبّّا زيدٌٌ راكِبًا، وهذا الذي تدخل

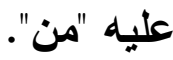
الخامس: جواز نصب هذا المنصوب بإضمار "أعني" قاله صاحب البسيط. قال أبو حيان:" فلا يكون إذ ذاك لا تمييزاً، ولا حالاً، بل هو مفعول بهذا الفعل المضمر،

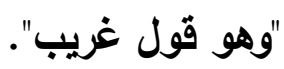
ويعد فقد اتضح أن القول بأن الاسم المنصوب بعد "حبذا " منصوب على أنى أنه مفعول به لفعل محذوف تقديره: أعنى، هو قول انفرد به صاحب البسيط ضياء الاين بن العلج، فلم أقف عليه لغيره .والله أعلم. 
فصل المقال في الغريب من الأقوال النحوية والتصريفية د / عبدالرعوف ثابت أحمد عبدالله

\section{q - حذف العاثد المبرود هع الجار دفعة واحدة}

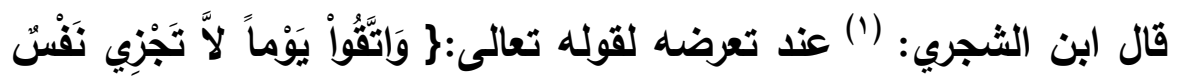

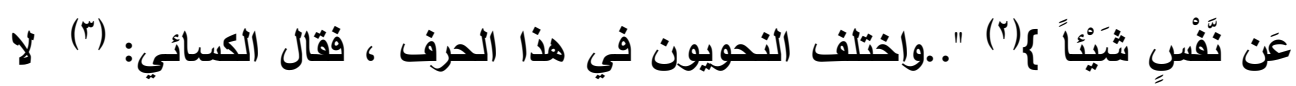

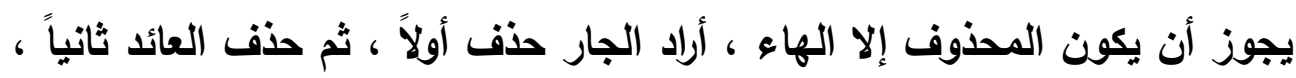

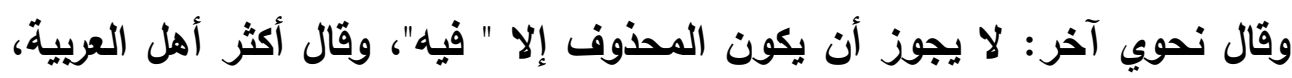

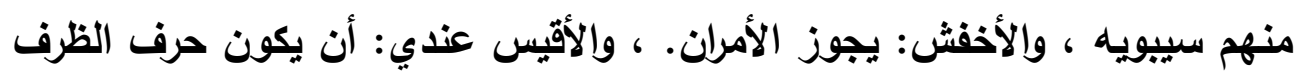

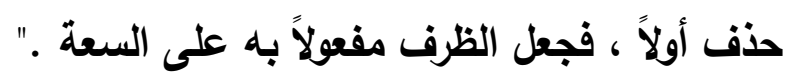

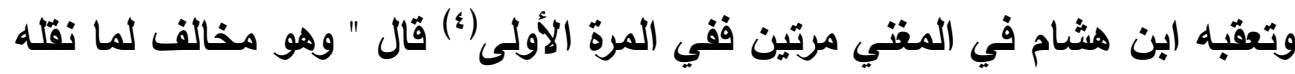

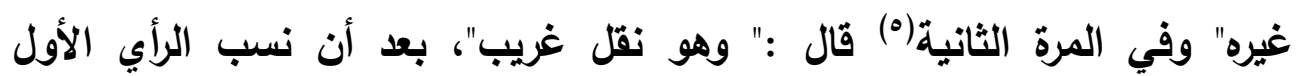

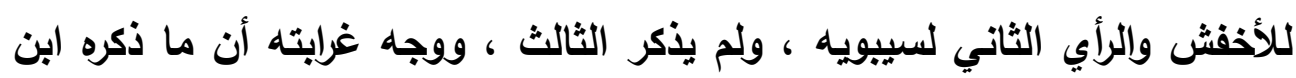
هشام هو المشهور في كتب النحو. وسأورد لك خلاصة ما وققت عليه في هذه وله

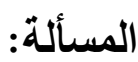

الأول: مذهب جمهور البصريين وعلى رأسهم سيبويه أن الجار والمجرور في مثل

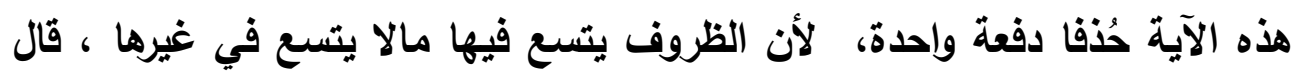

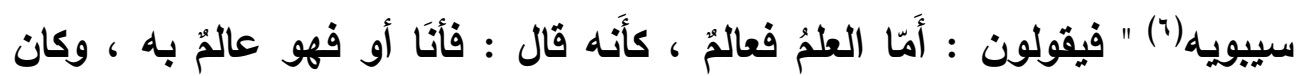

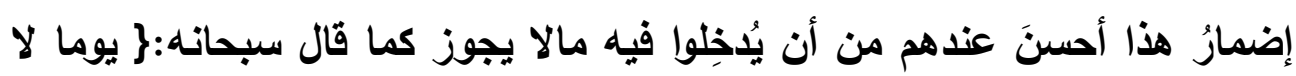

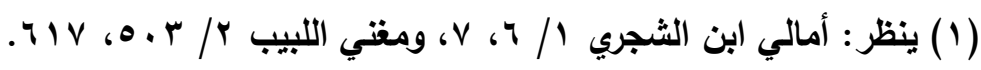

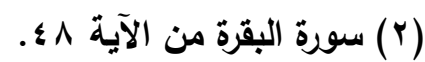

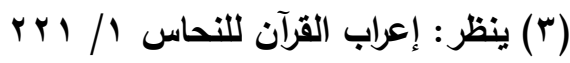

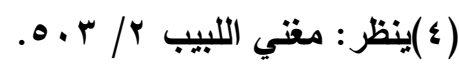

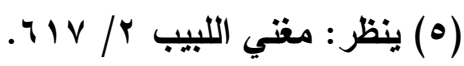

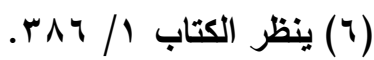


فصل المقال في الغريب من الأقوال النحوية والتصريفية د / عبدالرعوف ثابت أحمد عبدالله

تجزي نفس\{ أَضمر "فِيهِ" وظاهر كلام سييويه هنا أنه حذف الجار والمجرور دفعة واحدة. وهو ما نص عيه ابن هشام وغيره . الثاني : أن حرف الجر حذف أولاً ، ثم اتصل الضمير بالفعل ، ثم حذف أي على ملى التدريج ، وعزاه الكثير من النحويين للأخفش ، ورجح ابن جني هذا المذهب فقي المحتسب(1) قال: "... ولهذا أنكر ابن هشام على ابن الشجري نسبة هذا المذهب للكسائي ".

والحق أن هذا هو مذهب الكسائي أيضاً نص على ذلك الفراء(؟) وثعبب(r)

وأبو منصور الأزهري (؛)، والقرطبي، واختاره ابن الشجري كما سبق، قال القرطبي(•) القرطبي(•) عند تعرضه للآية السابقة :"قال البصريون: التقدير : يوما لا تجزى فيه نفس عن نفس شيئاً ثم حذف فيه كما قال: (؟)

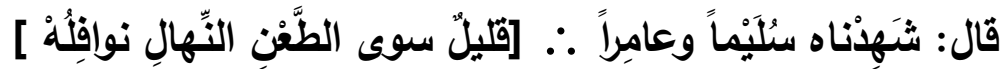
أي شهدنا فيه، وقال الكسائي هذا خطأ لا يجوز حذف" فيه" ولكن التقدير: واتقوا يوماً لا تجزيه نفس ، ثم حذف الهاء ، وإنما يجوز حذف الهاء لأن الظروف عنده

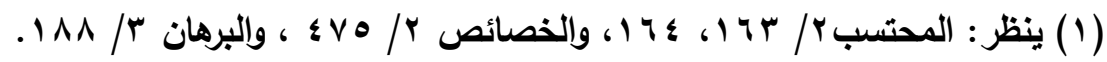

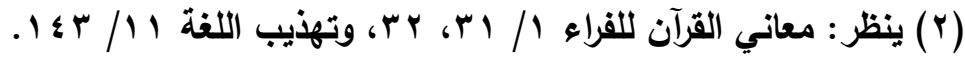

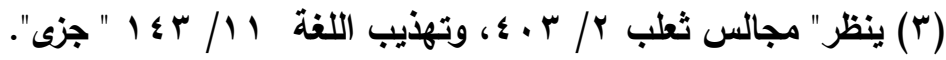

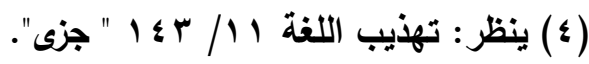

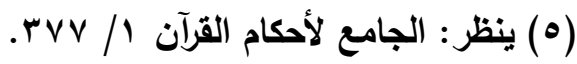

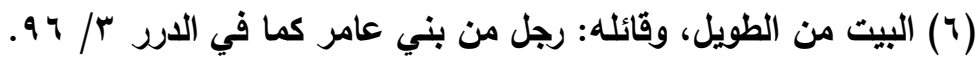

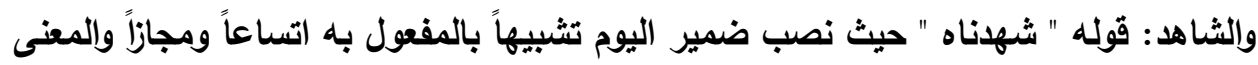
شهرنا فيه

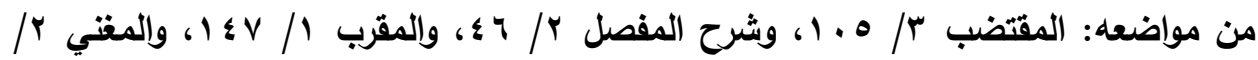

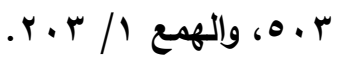


فصل المقال في الغريب من الأقوال النحوية والتصريفية د/ عبدالرعوف ثابت أحمد عبدالله

لا يجوز حذفها ـ قال : لا يجوز أن تقول: هذا رجلاً قصدت ، ولا رأيت رجلاً أرغب ، وأنت تريد: قصدت إليه ، وأرغب فيه، قال: ولو جاز ذلك لجاز الذي تكلمت زيد التال

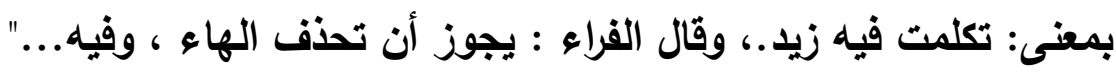

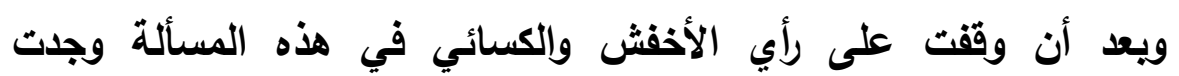

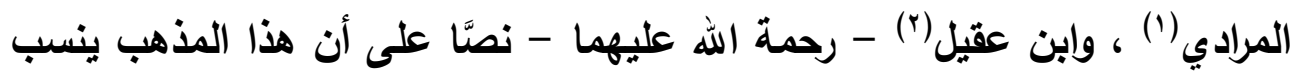

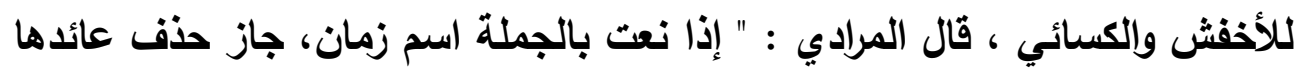

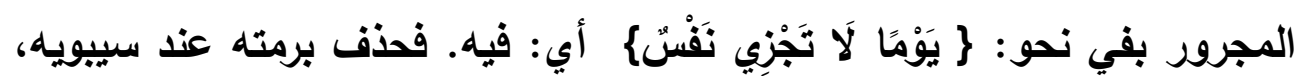
ويتدريج عند الكسائي ، والأخفش. المذهب الثالث : حكى المهلوي أن الوجهين جائزان عند سيبويه والأخفش والزياج

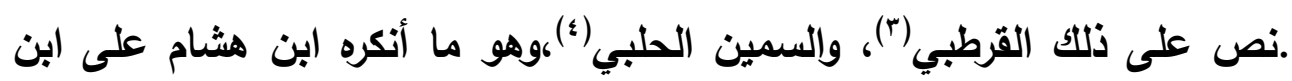
• الثجري

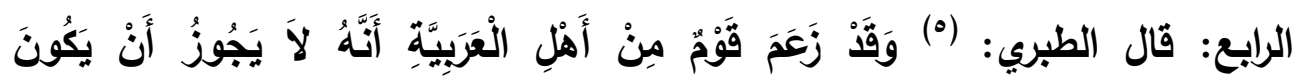

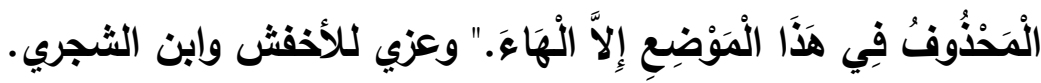

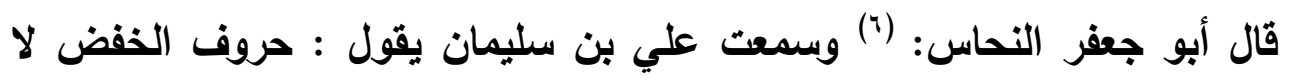

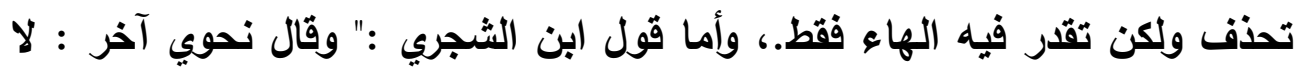

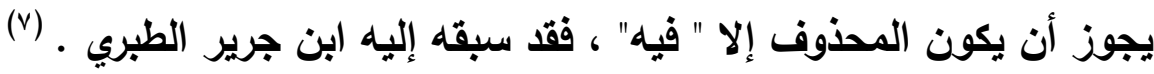

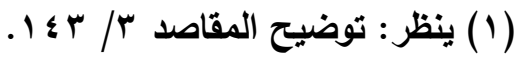

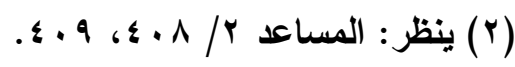

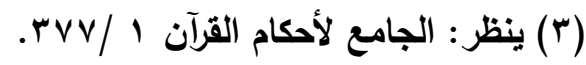

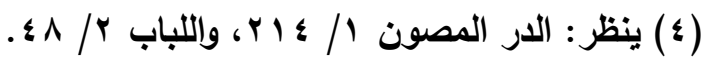

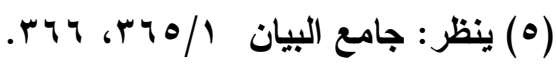

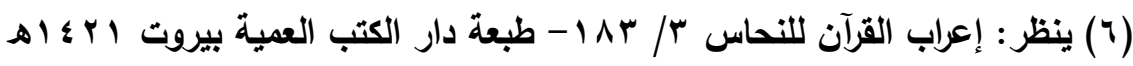
(V) 
فصل المقال في الغريب من الأقوال النحوية والتصريفية د / عبدالرعوف ثابت أحمد عبدالله

ويعد فإن ما نسبه ابن الشجري للكسائي من أن الأصل "لا تجزيه" فحذف

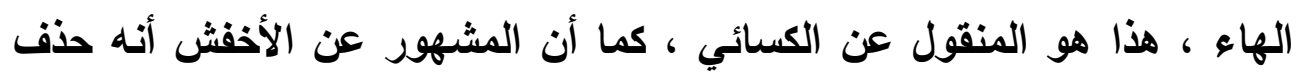
حرف الجر أولاً فاتصل الفعل بالضمير، ثم حذف الضمير وهذا ما أقره ابن هثام ، وقد سوى بعض النحويين - ومنهم ابن الشجري - بين المذهبين وجعهما مذهباً واحداً علماً بأن الكسائي لا يقدر حذف الجار لأن الظروف عنده لا يجوز حذفها قال: لا يجوز أن تقول هذا رجلاً قصدت، ولا أيت رجلاً أرغب ، وأنت تريد قصدت إليه وأرغب فيه ، قال: ولو جاز ذلك لجاز الأي تكلمت زيد بمعنى تكلمت فيه زيد. ولعل هذا الخلط هو ما دفع ابن هشام إلي القول بغرابة النقل ، وكذا أيضاً ما نسبه ابن الشجري إلى سييويه و الأخفش من جواز الحذف دفعة وإحدة أو على إنى

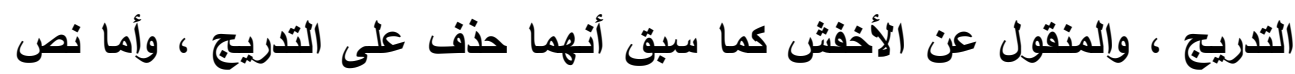
سيبويه في الكتاب فغير صريح في أنهما حذفا دفعة واحدة أم على التدريج ، فالنص يحتملهما، وهو ما نص عليه المهدوي، وابن الشجري ، ونقله القرطبي ، والسمين الحلبي • والله أعلم.

• r- إعراب "نفغسه" توكيدأ لـ " من سفهه"

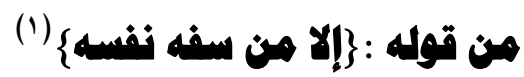

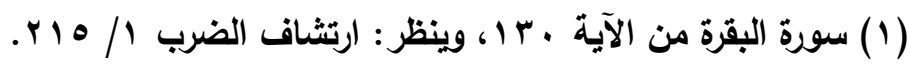


فصل المقال في الغريب من الأقوال النحوية والتصريفية د/ عبدالرعوف ثابت أحمد عبدالله

اختلف النحويون في إعراب " نفسه " من قَوله تعالى : \} وَمَنْ يَرْغَبُ عَن مِّلَّةِ

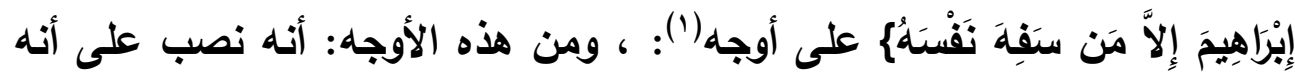
توكيد لـ "مَنْ سفه" ، أو بلال منه ، لأنه في محل نصب على الاستثناء ، في أحد

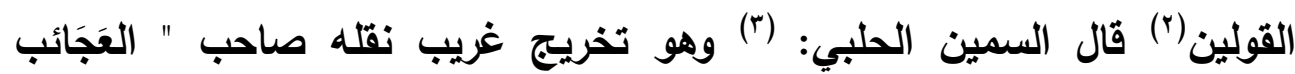
والغَرَأبب"(؛). ووجه غرابته أنه خرجه على الوجه المرجوح وليس الراجح كما سيأني. والثثاني- من الأوجه-:أن يكون مفعولاً به؛ لأنه حكي أن "سَفِهَة " بكسر الفاء يتعدّى بنفسه كما يتعدى " ستَفَّه " بفتح الفاء والتشثديد ، قال السمين وهو المختار . الثالث: أنه مفعول به ولكن على تضمين "سفه لمعنى فعل يتعدى ، فقدره الزجاج(ه) وابن جني بمعنى : "جهل"، وقدره أبو عبيدة بمعنى: "أهلك ". الرابع: أنه منصوب على إسقاط حرف الجَرّ تقديره : سَفِهَ في نَفْسه. الخامس: توكيد لمؤكد محذوف تقديره: سفه قولَّه نفسه، فحذف المؤكد قياساً على النعت والمنعوت، حكاه مكّي.، قال أبو حيان: (־) "وأما كونه توكيداً وحذف مؤكده

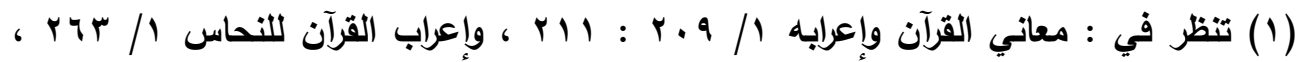

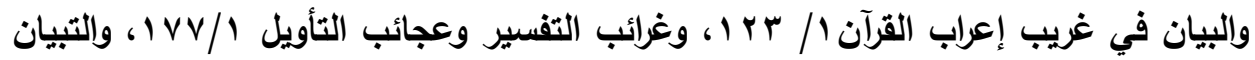

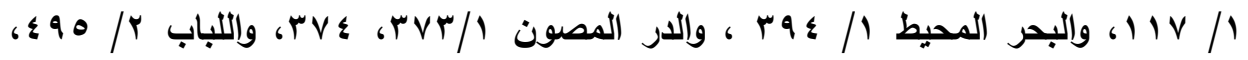

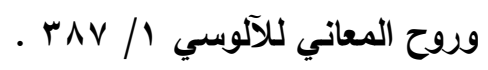

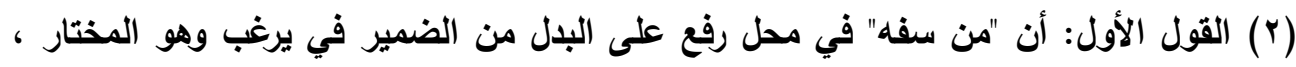

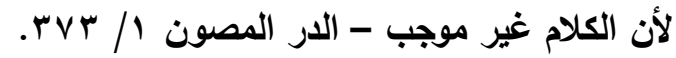

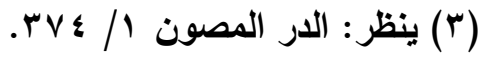

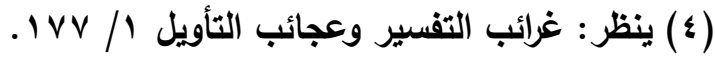

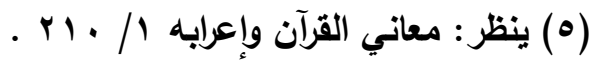

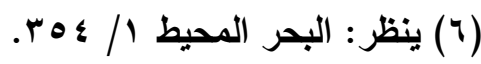


فصل المقال في الغريب من الأقوال النحوية والتصريفية د / عبدالرعوف ثابت أحمد عبدالله

فقيه خلاف. وقد صحح بعضهم أن ذلك لا يجوز أعني: أن يحذف المؤكد ويبقى التوكيد.

السادس: أنه تمييز، وهو قول الكوفيين. قال الزمخشري:(') ويجوز أن يكون في

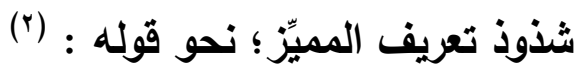

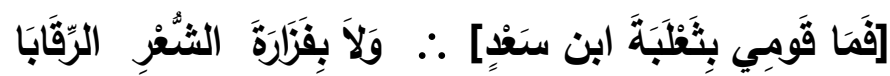

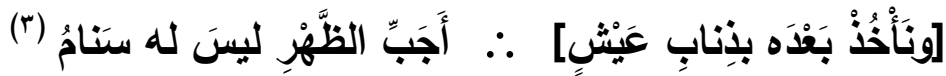

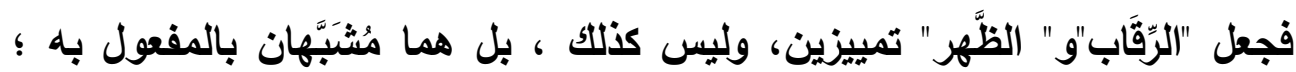

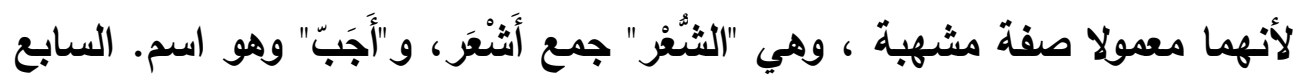
: أنه مشبه بالمفعول وهو قول بعض الكوفيين، واختار السمين الحلبي(؛) الثاني من هذه الوجوه وقال؛ لأن التضمين لا ينقاس، وكذلك حرف الجر. وأما حذف ولف المؤكد وإبقاء التوكيذ فالصحيح لا يجوز.، وأما التمييز فلا يقع معرفة، وما ورد نادر أو متأول. وأما التصب على التثبيه بالمفعول، فلا يكون في الأفعال إنما يكون في الصّفات المشبهة خاصة.

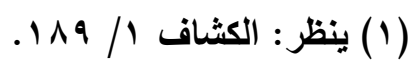

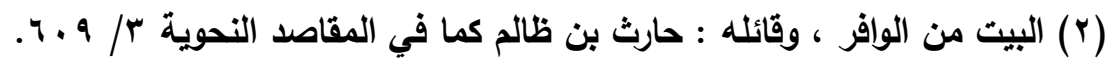
والثاهد قوله "الرقابا" حيث نصبه على التمييز على مذهب الكوفيين في جواز كون التمييز معرفة ، والمشهور أنه منصوب على التشبيه بالمفعول به.

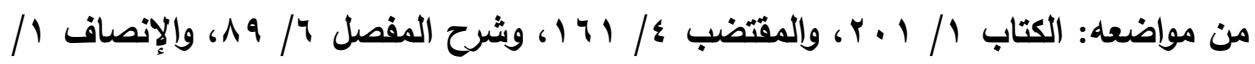
$.1 \%$

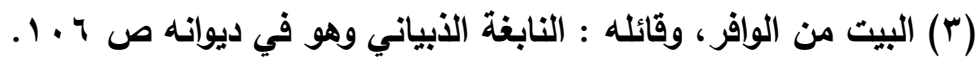

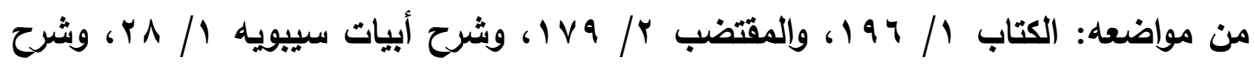

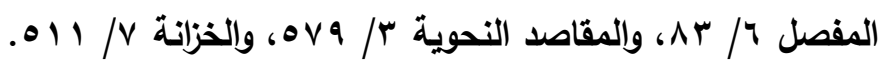

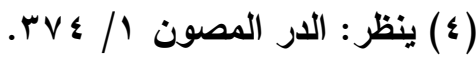


فصل المقال في الغريب من الأقوال النحوية والتصريفية د/ عبدالرعوف ثابت أحمد عبدالله

واعلم أن ما نقله السمين الحلبي عن الكرماني ووسمه بالغريب قال به ابن

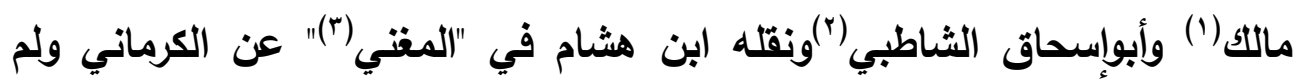
يسمه أحد منهم بالغريب.

قال الثاطبي:(؛) "ذكر لي الفقيه الأستاذ الفاضل أبو عبد الله محمد بن البكا عن بعضهم ، وحكاه ابن مالكك في شرح التسهيل أنه أعرب نفسه من قوله تعالى:

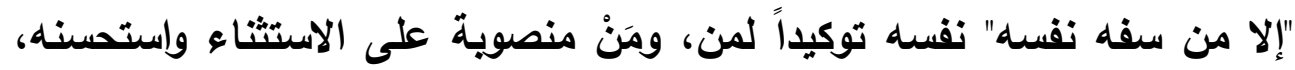
لأن الناس اختلفوا فيه اختلافاً كثيراً. فقلت له: إن المعنى على الرفع والتقريغ. فقال لي: أتسلم أن في يرغب ضميراً هو فاعله؟ فقلت نعم، لولا أن المعنى ما يرغب عن ملة الإسلام إلا من سفه نفسه فوقف الكلام هاهنا، ثم دلني الأستاذ الكبيز أبو

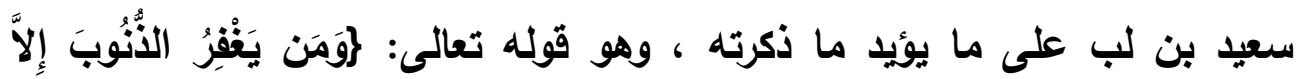

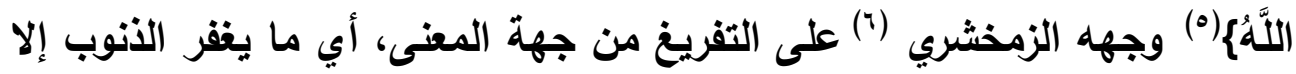
الله.، قال الأستاذ : إلا أن النصب يجوز في نحو هذا على ضعف.، وفي المقاصد الثافية(v) "...أن الاستثناء بإلا بعد النفي أو ما أثبه النفي يختار فيه الإتباع للأول فيجري على حكمه في الإعراب، إن كان مرفوعاً ارتفع ، وإن كان منصوياً انتصب ، وإن كان مجروراً انجر وذلك إذا كان الاستثناء متصلاً نحو قولتك: ما قام إن إن

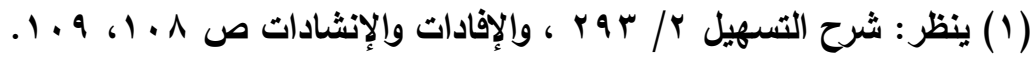

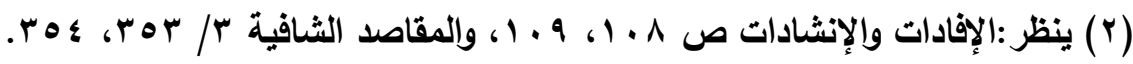

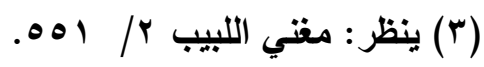

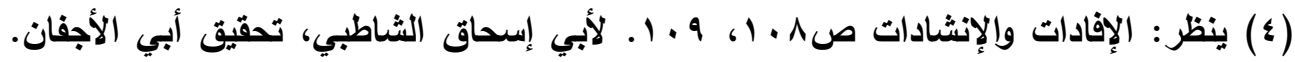

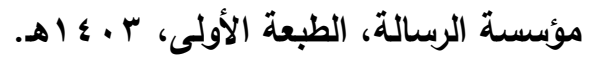

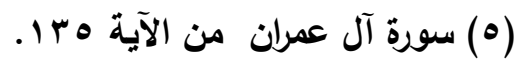

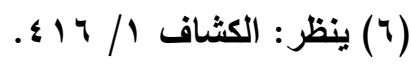

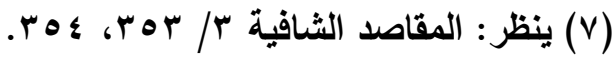


فصل المقال في الغريب من الأقوال النحوية والتصريفية د / عبدالرعوف ثابت أحمد عبدالله

القوم إلا زيدٌ ، وما رأيت القوم إلا زيداً على الإتباع لا على الاستثناء، وما مررت

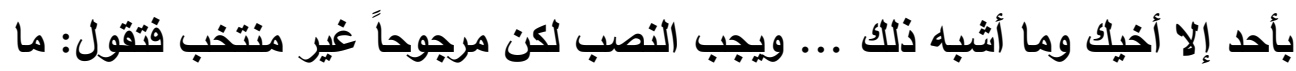

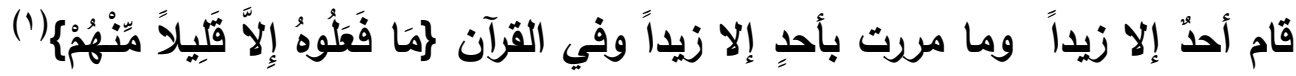

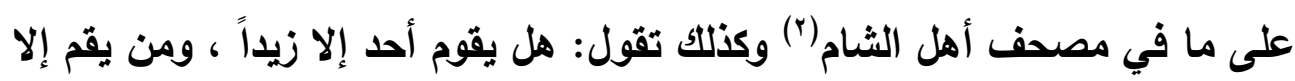

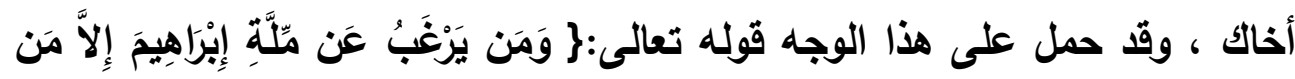

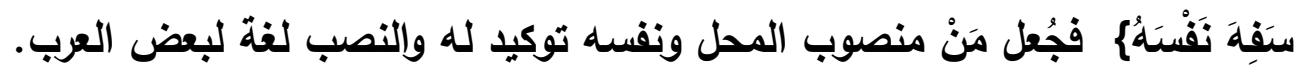

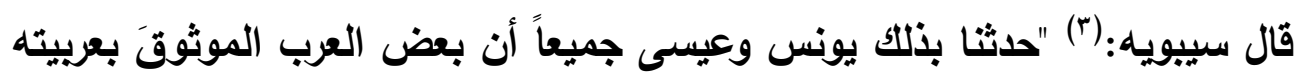

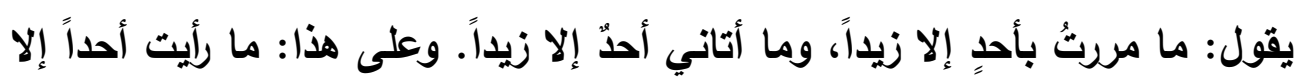
زيداً، فينصب زيداً على غير رأيت؛ وذلك أنك لم تجعل الآخر بدلاً من الأول، ولكنتك

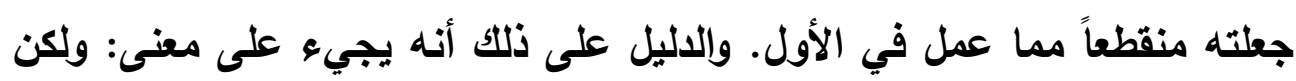
زيداً، ولا أعني زيداً. وعمل فيه ما قبله كما عمل العشرون في الارهم إذا قلت : عشرون درهماً.". ويعد فقد اتضح أن إعراب " نفسه" توكيد لقوله "من سفه" الذي هو في

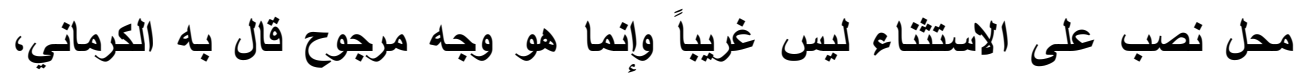

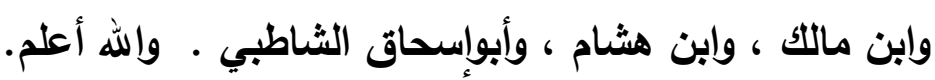

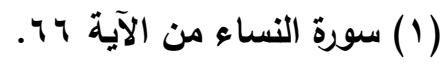

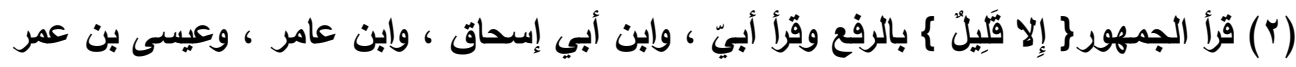

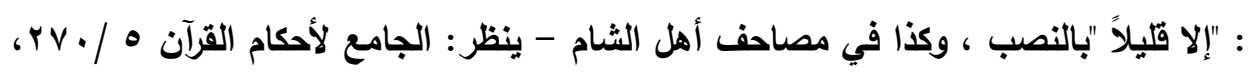

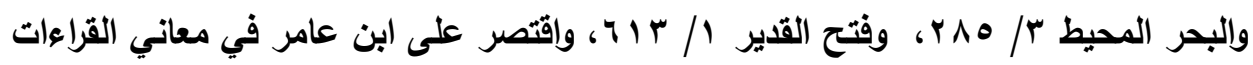

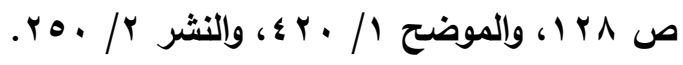

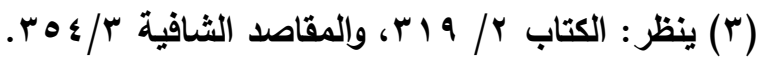


فصل المقال في الغريب من الأقوال النحوية والتصريفية د / عبدالرعوف ثابت أحمد عبدالله

\section{اس- الفاء لا تفيد التزتيب والهاو تفيده}

نقل عن الفراء(') أنه قال: إن الفاء لا تفيد الترتيب مطلقاً، قال ابن هشام(؟) : وهذا غريب مع قوله: إن الواو تفيد الترتيب". ووجه غرابته أن الفراء بذلك خالف جمهور النحويين الذين يرون أن الفاء العاطفة تفيد الترتيب، كما أن الواو لا تفيد ترتيباً، وإنما هي لمطلق الجمع بين - المتعاطفين واحتج الفراء على صحة قوله "إن الفاء لا تفيد الترتيب مطلقاً" بقوله تعالى:

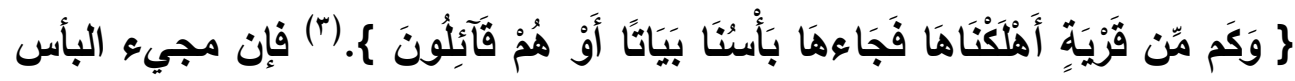
قبل الهلاك، وليس مترتباً عليه. وفي معاني القرآن(๕) "يقال: إنما أتاها البأس من فئ قَبْل الإهلاك، فكيف تقدم الهلاك؟ قَت: لأن الهلاك والبأس يقعان معا؛ كما تقول: أعطيتنى فأحسنت، فلم يكن الإحسان بعد الإعطاء ولا قبله: إنما وقعا معا، فاستجيز ذلك." ومن ذلك أيضاً حديث 》 توضأ فغسل وجهه ويديه ومستح رأسه ورجليه (0) قال الثيخ خالد:(؟) " فإن غسل الأعضاء الأربعة متقدم في المعنى ومتأخر في الحديث ، فلو كانت الفاء للترتيب لما حسن ذلك "

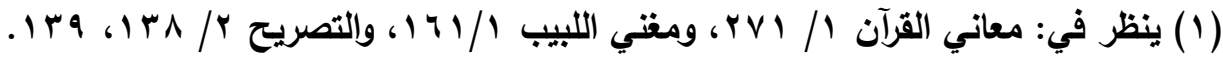

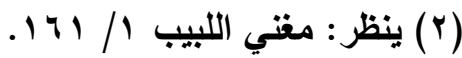

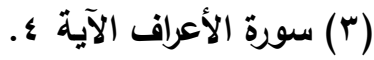

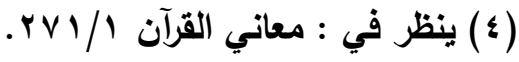

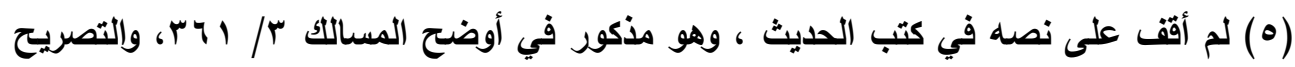

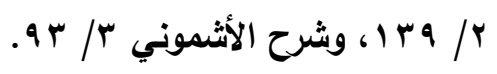

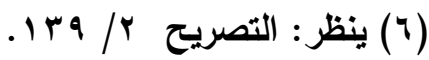


فصل المقال في الغريب من الأقوال النحوية والتصريفية د / عبدالرعوف ثابت أحمد عبدالله

وأجاب الجمهور عن قول الفراء بوجهين('): الأول:أن المعنى في الآية على إضمار الإرادة والتقدير : أردنا إهلاكها فجاءها بأسنا بياتاً فمجيء البأس مترتب على بـى الإرادة ، وفي الحديث أنه أراد الوضوء فغسل وجهه ...إلخ ، ففسل الأعضاء الأربعة مترتب على إرادة الوضوء، الثاني: أن الفاء فيهما للترتيب الأكري لا المعنوي. والحاصل أن الجمهور يقولون بإفادتها للترتيب مطلقاً، والفراء يمنع ذلك مطلقاً، وفصل القول في ذلك أبو عمرو الجرمي(r) إن الفاء لا تفيد الترتيب في البقاع، ولا في الأمطار ، واستثل على ذلك بقول امرئ القيس:(َ)

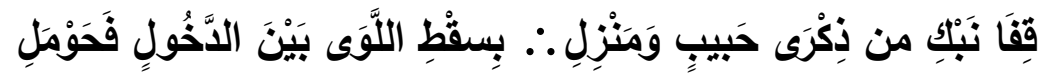
وقولهم : مطرنا مكان كذا فمكان كذا، إذا كان وقوع المطر فيهما في وقت وإحد. قال الأمير:(؛) "ووجه عدم الترتيب في البيث أن "بين" إنما تضاف لمتعدد، والترتيب يقتضي إضافتها للأول على حدة، ثم الثاني".

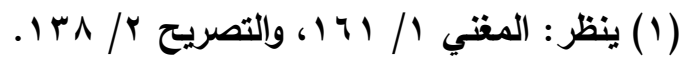

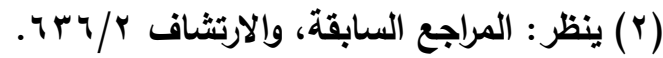

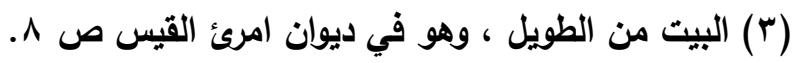
والثااهد قوله " فحومل" حيث جاءت الفاء بمعنى الواو فلم تفل تربئياً.

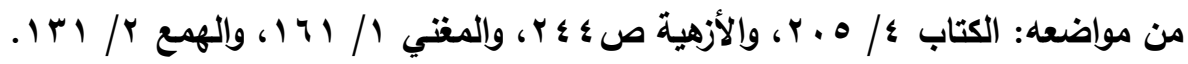

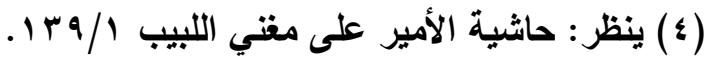


فصل المقال في الغريب من الأقوال النحوية والتصريفية د / عبدالرعوف ثابت أحمد عبدالله

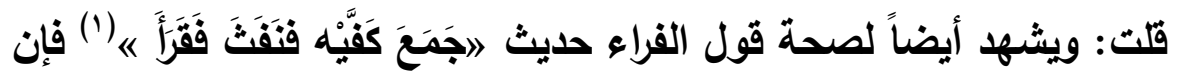

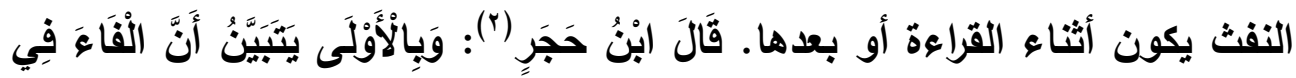

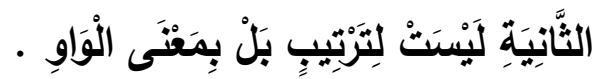

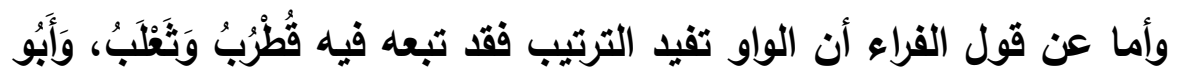

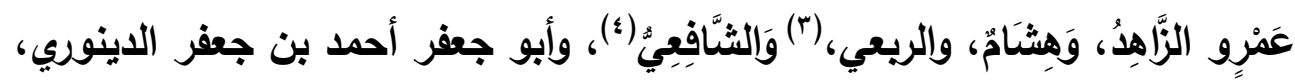

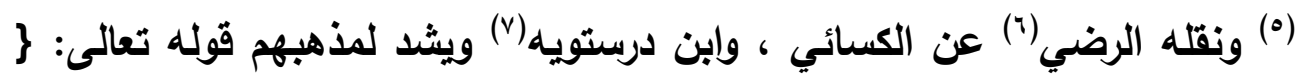

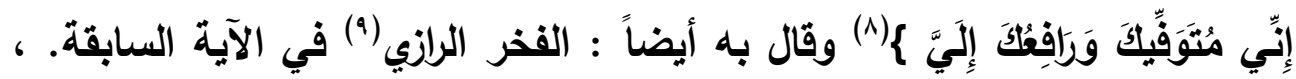

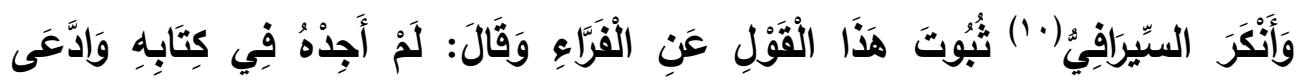

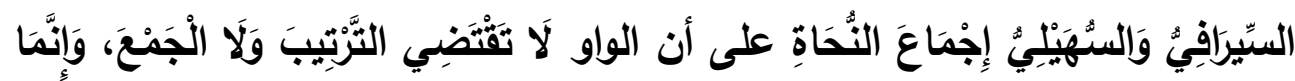

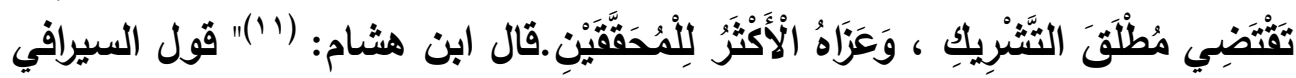
إن النحويين واللغويين أجمعوا على أنها لا تفيد الترتيب مردودويذلك اتضح أن قول

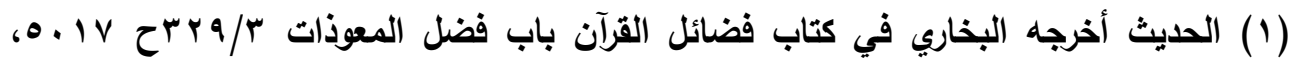

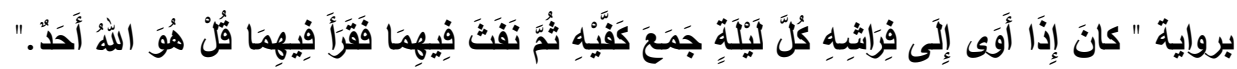

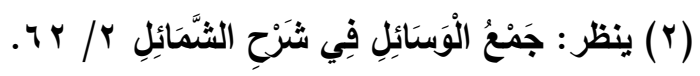

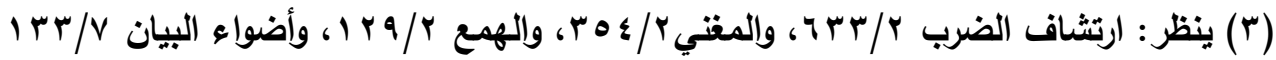

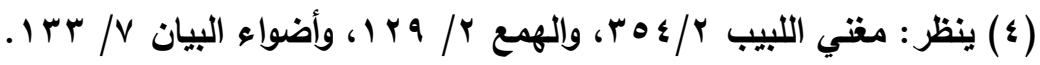

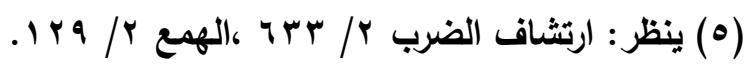

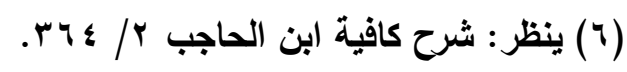

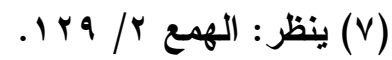

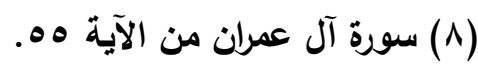

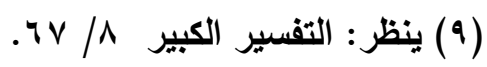

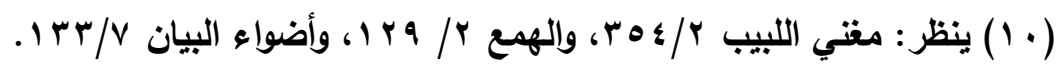

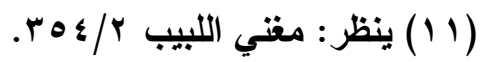


فصل المقال في الغريب من الأقوال النحوية والتصريفية د/ عبدالرعوف ثابت أحمد عبدالله

الفراء إن الفاء لا تفيد الترتيب هو قول انفرد به وخالف فيه جمهور التحويين، وما استدل به يشها بصحة قوله، فمذهبه ليس بغريب، فالفراء حجة يحتج بقوله.

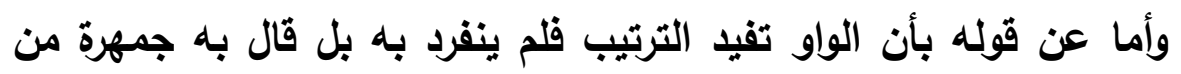
النحويين. والله أعلم. 
فصل المقال في الغريب من الأقوال النحوية والتصريفية د/ عبدالرعوف ثابت أحمد عبدالله

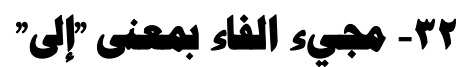

نقل عن بعض البغداديين أن الفاء قد تأتي للغاية بمعنى : "إلى" قال ابن

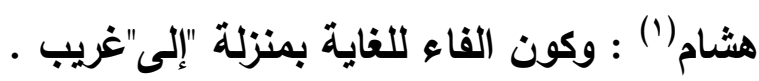

ووجه غرابته أن جمهور البصريين يمنعون إنابة الحروف بعضها عن بعض إض

، على عكس الكوفيين الأين يقولون بإنابة الحروف بعضها عن بعض وهو مشهور

في حروف الجر ، أما كون الفاء بمنزلة "إلى" في الغاية فقل من يذكره .

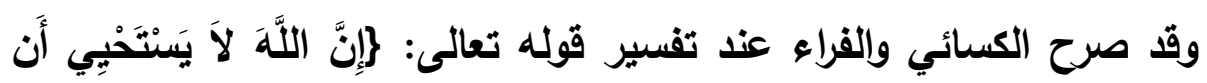

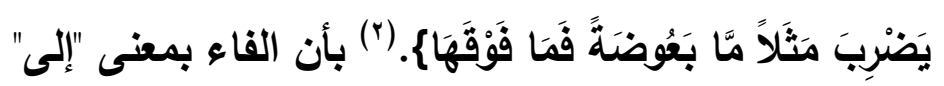

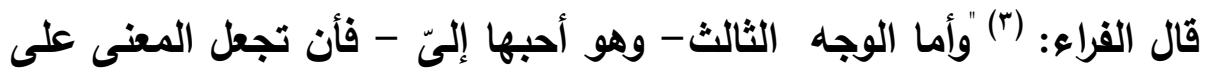

: إن اللّه لا يستحيى أن يضرب مثلا ما بين بعوضة إلى ما فوقها. والعرب إذا ألقت

״بين" من كلام تصلح 》إلى" في آخره نصبوا الحرفين المخفوضين اللأين خفض

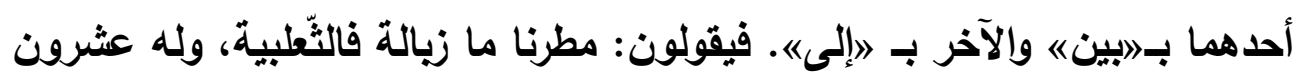
ما ناقة فجملا، وهى أحسن الناس ما قرنا فقدما. يراد به ما بين قرنها إلى قدمها." وقال التحاس: (؛)" الوجه الثالث قول الكسائي والفراء قالا : التقدير: أن يضرب مثثلا ما بين بعوضة حذفت "بين" وأعريت "بعوضة " بإعرابها والفاء بمعنى "إلى" أي إلى ما فوقها..".

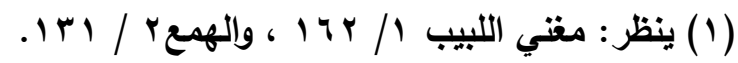

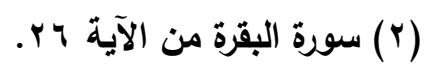

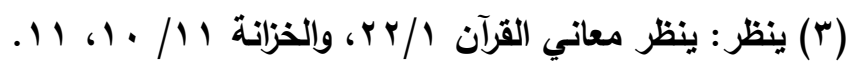

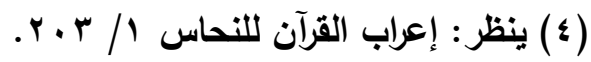


فصل المقال في الغريب من الأقوال النحوية والتصريفية د / عبدالرعوف ثابت أحمد عبدالله

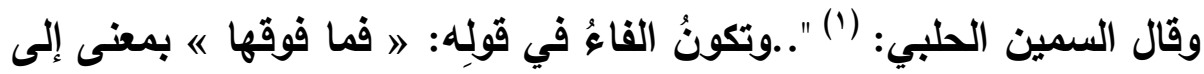
، أي : إلى ما فوقها ، ويُزْى هذا للكسائي والفراء وغيرِهم من الكوفيين." وهو قولٌ

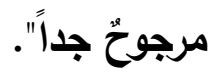

وفي"الجنى الداني" قال المرادي)(؟):" وتكون بمعنى إلى. ذكره بعض الكوفيين،

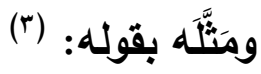

هو أحسن الناسِ ما بين قرنٍ فقدمِ . أي: إلى قدم. وأجاز بعضهم في قولهم: "بين الاخول فحومل" أن تكون الفاء

بمعنى إلى. وهذا ضعيف، والقاء في ذلك عاطفة،، وصرح به الرضي (؛) عند تعرضه

لقول الشاعر: (0)

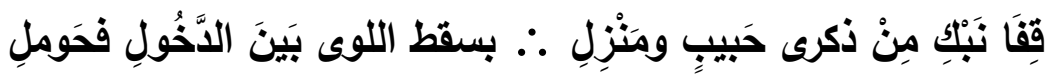

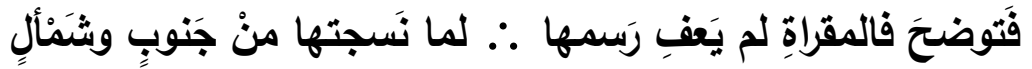

حيث قال: الفاء فيه بمعنى (إلى)، أي: منازل بين الاخول إلى حومل، إلى توضح إلى المقراة، فإن قلت: كيف هذا ؟ وأنت لا تقول: خرجت إلى زيل إلى عمرو؟ ، إذ إذ إنى الفعل لا يتعلق به حرفا جر بمعنى واحد، كما مر، بلا عطف، قلت: يستعمل في

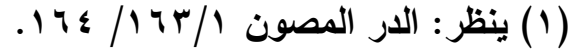

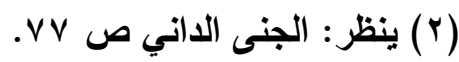

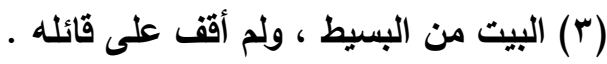

والثاهد قوله:" قرن فقدم" حيث جاعت البيط ، وفم اعاء بمغنى "إلى". ويروى "إلى قدم".

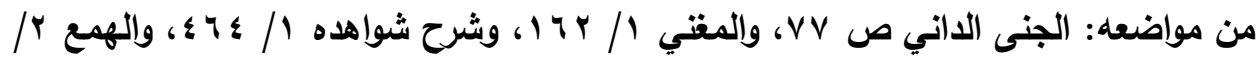

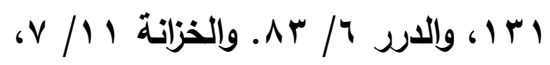

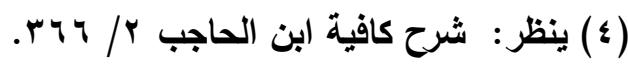
(0) سبق تحقيقه. 
فصل المقال في الغريب من الأقوال النحوية والتصريفية د / عبدالرعوف ثابت أحمد عبدالله

تحديد الأماكن، نحو قولك: اشتريت ما بين الموضع الفلاني، إلى دار زيد، إلى دار عمرو، إلى دار خالد، بحذف الواو تخفيفاً، لالالة الكلام عليه ." مأل ويعد فقد اتضح أن مجيء الفاء بمعنى "إلى" ليس غريباً، وإنما هو مذهب دأب كوفي، قال به الكسائي، والفراء، وتبعهم: النحاس، والقرطبي، والرضي، والسمين، الحلبي ، والمرادي، وغيرهم وحكاه العكري(') ، وابن هشام عن بعض البغداديين.

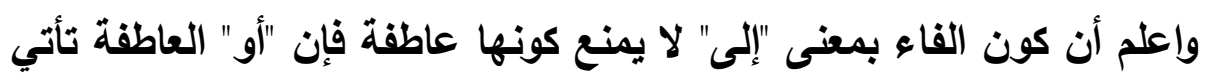
بمعنى "إلى" ويمعنى "إلا" ولم يقل أحد إنها مجردة من العطف فيهما والعطف بها لحأ واقع قطعاً. (r). والله أعلم.

rr- "أم" بهمنى همهزة الاستفهام

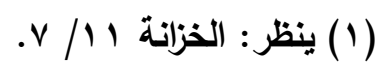

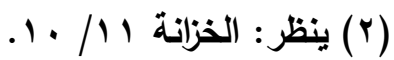


فصل المقال في الغريب من الأقوال النحوية والتصريفية د / عبدالرعوف ثابت أحمد عبدالله

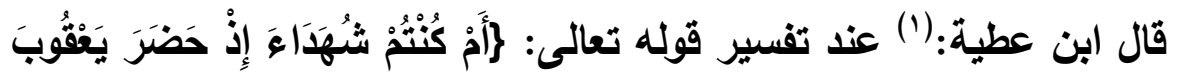

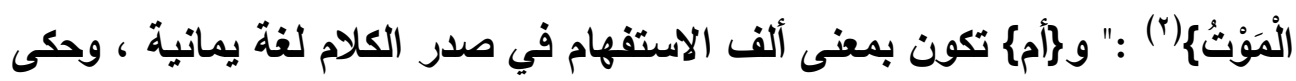

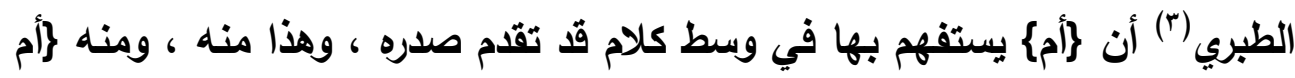

يقولون افتراه \{(ان

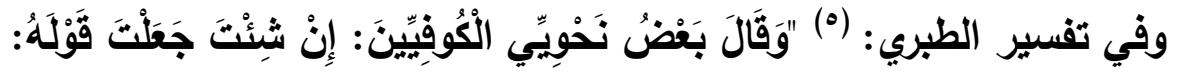

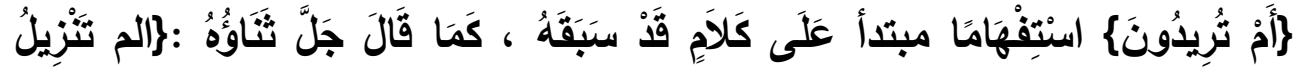

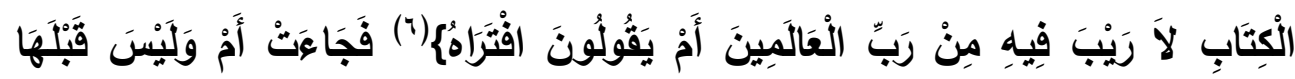

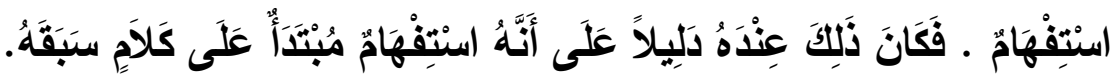

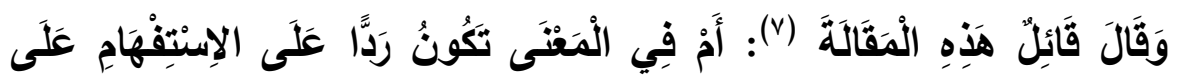

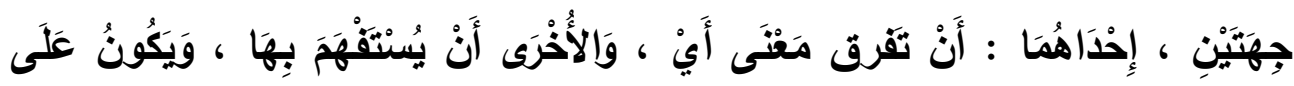

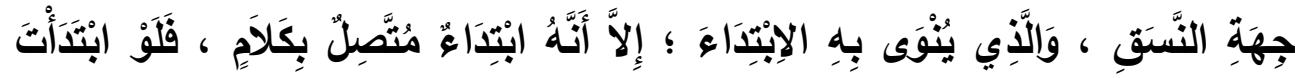

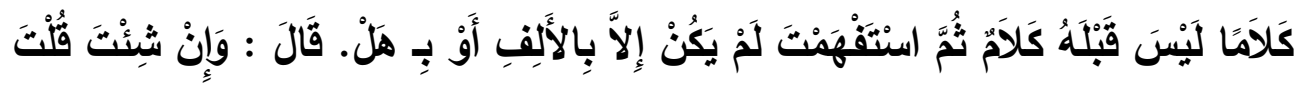

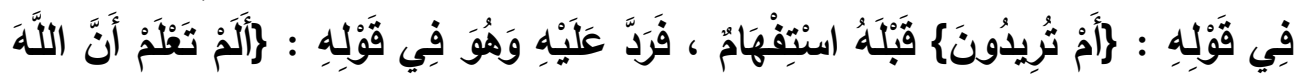

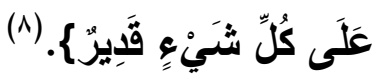

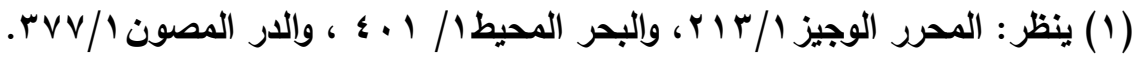

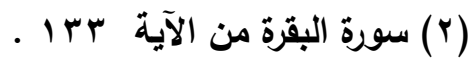

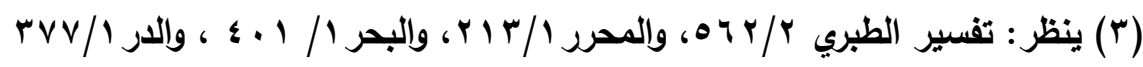

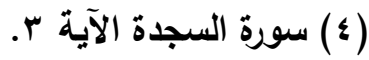

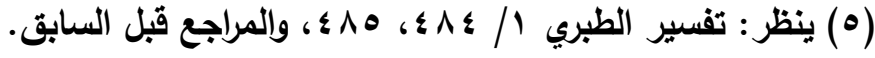

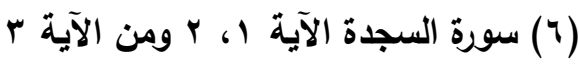

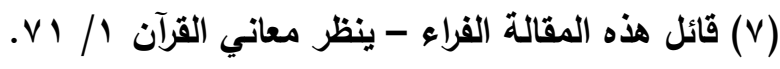

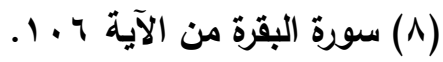


فصل المقال في الغريب من الأقوال النحوية والتصريفية د / عبدالرعوف ثابت أحمد عبدالله

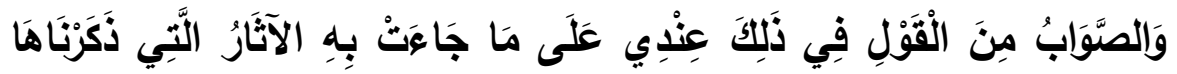

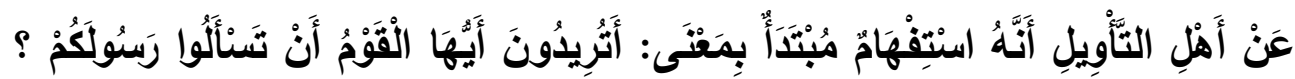

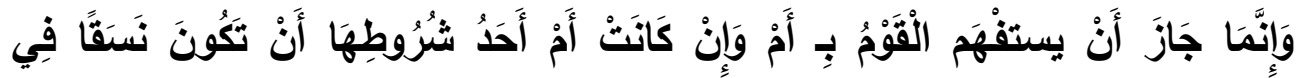

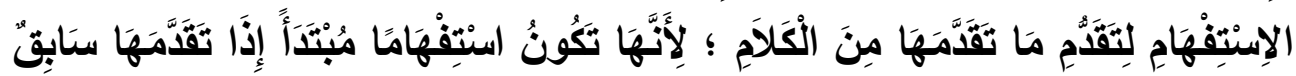

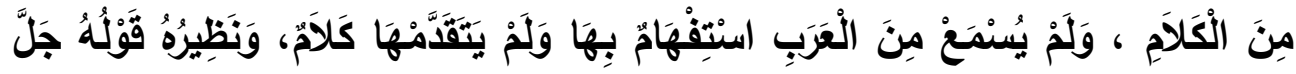

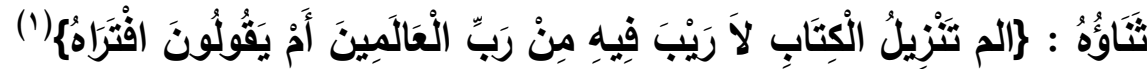

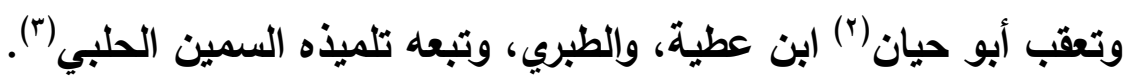

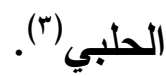
قال أبو حيان:" ولم أقف لأحد من النحويين على أن أم يستفهم بها في

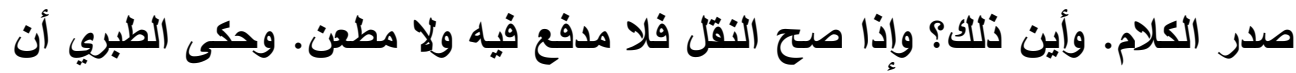

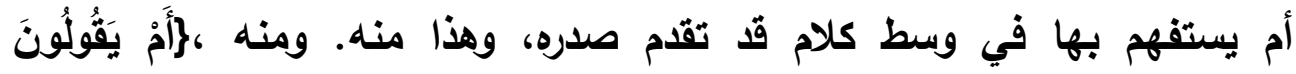

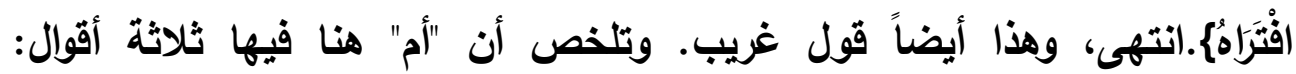
المشهور أنها هنا منقطعة بمعنى بل والثهزة. الثاني: أنها للإضراب فقطة، بمعنى بل. الثالث: بمعنى همزة الاستفهام فقط... أ.هـ." التها أما عن كون " أم" تأتي بمغنى همزة الاستفهام في ابتذاء الكلام فقد صرح

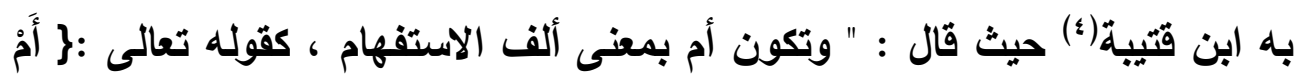

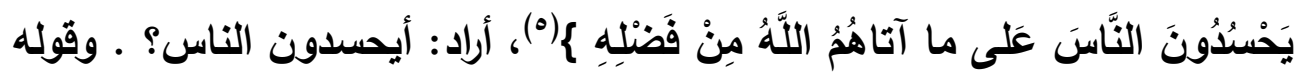

(1) سورة السجدة الآية ا، ب ومن الآية r.

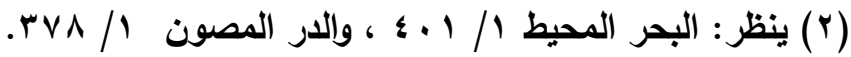

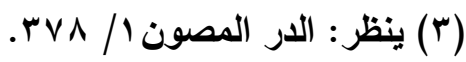

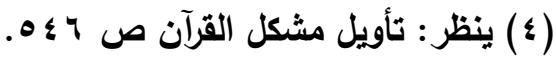

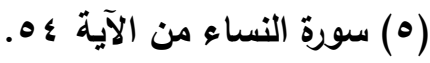


فصل المقال في الغريب من الأقوال النحوية والتصريفية د/ عبدالرعوف ثابت أحمد عبدالله

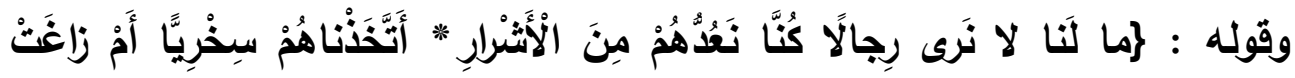

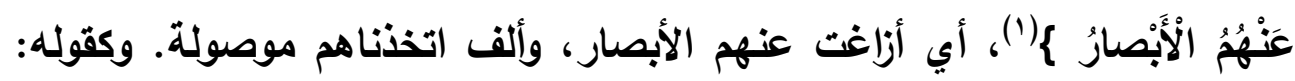

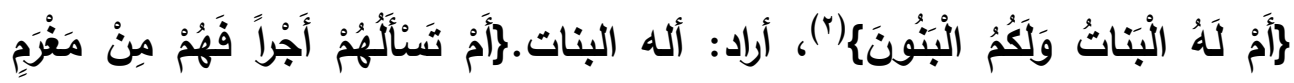

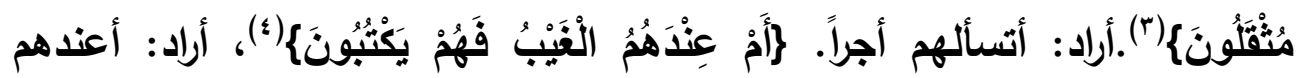

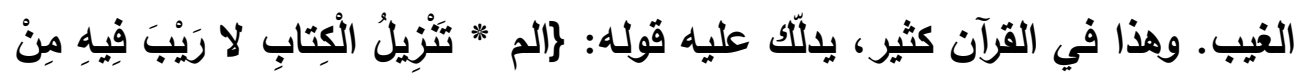

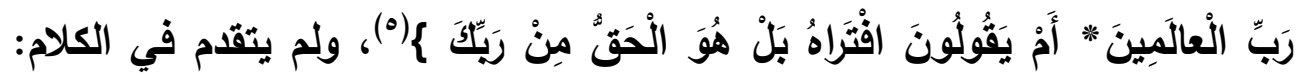

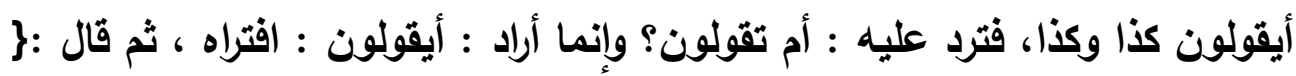

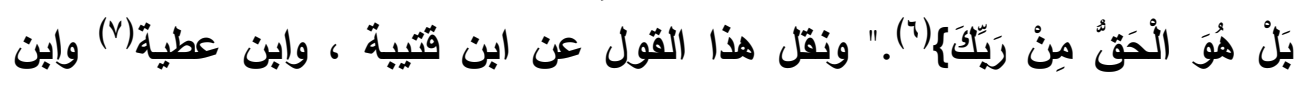

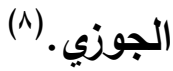

وفي "الأزهية"(9) قال الهروي: "الموضع الرابع: تكون بمعنى همزة الاستفهام

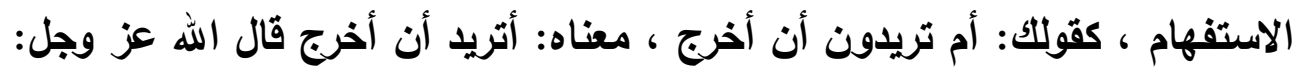

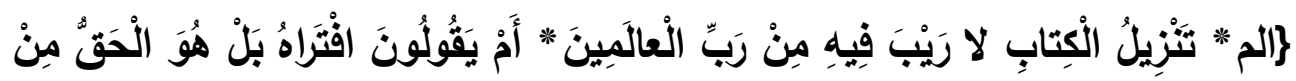

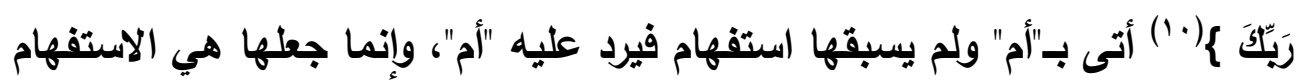

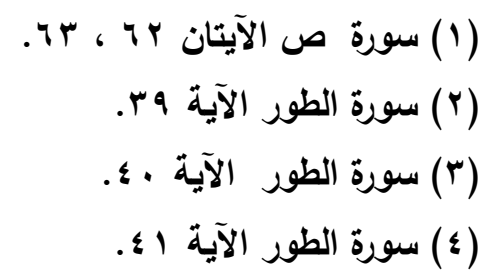

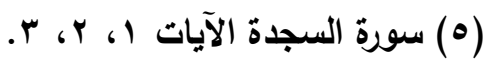

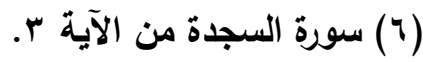

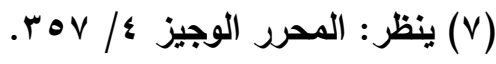

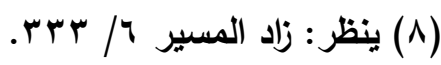

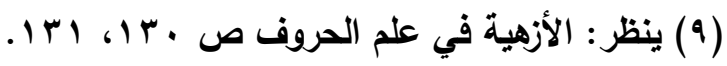

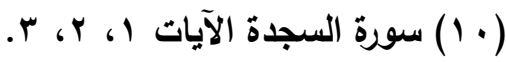


فصل المقال في الغريب من الأقوال النحوية والتصريفية د / عبدالرعوف ثابت أحمد عبدالله

بمعنى: أم تقولون افتراه جعل " أم" بمعنى ألف الاستفهام، وكذلك قولهه: [أَمْ تُرِيدُونَ

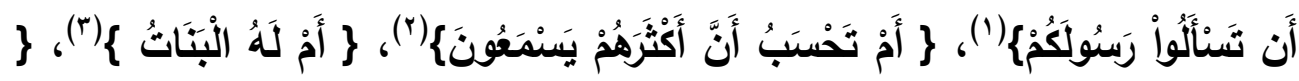

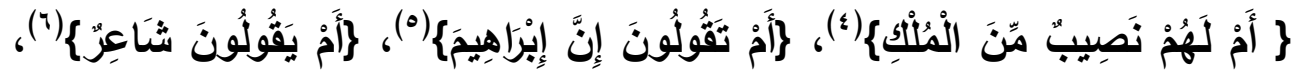

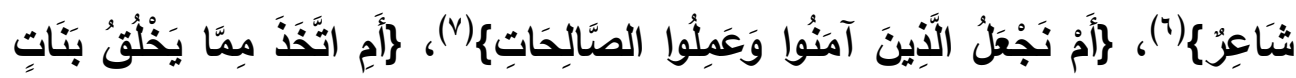

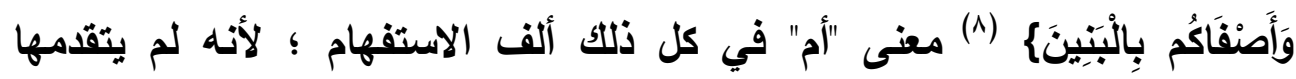
استفهام ، ونحو ذلك في القرآن كثير ".

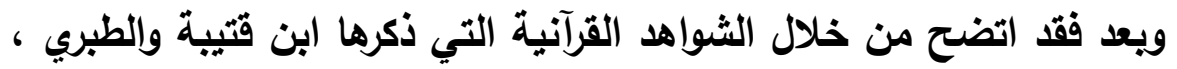

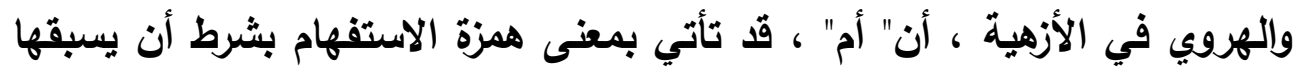

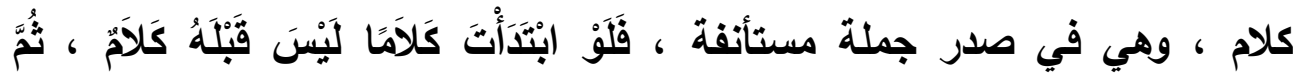

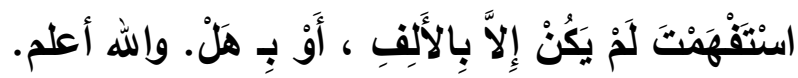

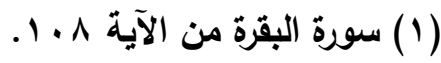

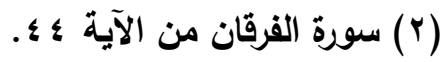

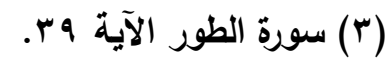

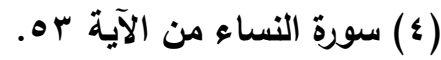

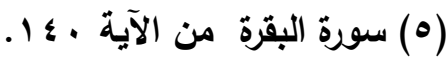

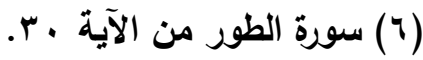

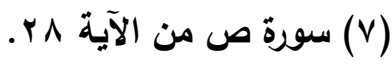

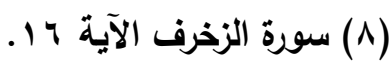


فصل المقال في الغريب من الأقوال النحوية والتصريفية د / عبدالرعوف ثابت أحمد عبدالله

\section{ع - عطف الهرف على الهرف}

اختلف التحويون في "إما" الثانية في مثل قولهم": جاعني إما زيد وإما

عمرو"، قال ابن هشام: (1)"وإما عاطفة عند أكثرهم أعني إما الثانية في نحو قولك : جاءني إما زيل وإما عمرو، وزعم يونس والفارسي وابن كيسان أنها غير عاطفة كالأولى ، ووافقهم ابن مالك(؟) ؛ لملازمتها غالباً الواو العاطفة ... ونقل ابن عصفور () الإجماع على أن "إما" الثاتية غير عاطفة كالأولى قال: وإنما ذكروها في في باب العطف لمصاحبتها لحرفه . وزعم بعضهم أن إما عطقت الاسم على الاسم ، والواو عطقت "إما" على "إما • وعطف الحرف على الحرف غريب، ولا خلاف أن "إما" الأولى غير عاطفة ؛ لاعتراضها بين العامل والمعمول في نحو: قام إما زيد وإما عمرو، ويين أحد معمولي الفعل ومعموله الآخر في نحو: رأيت إما زيداً وإما عمراً ، ويين المبال منه إماله

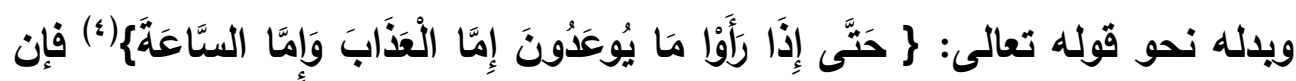

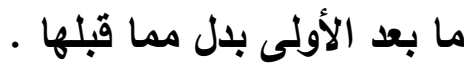
ووجه الغرابة في هذا الموضع أنه لم يسمع من لسان العرب عطف الحرف على الحرف. وإن أجازه ابن الحاجب و الأندلسي. قال الاماميني: (•) "وهذا القول حكاه ابن الحاجب (؟) وجوزه وقال لايبعد.

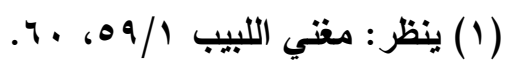

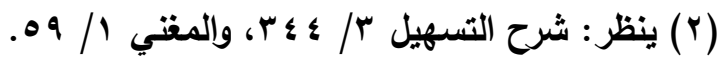

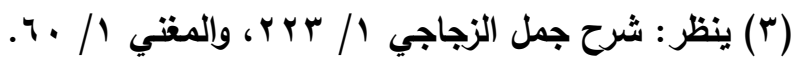

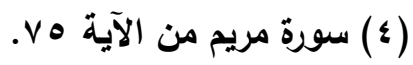

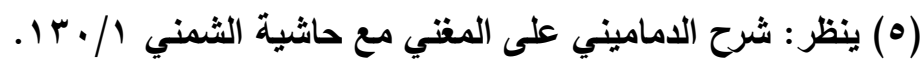

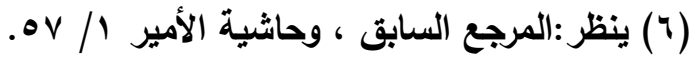


وحكى ابن الحاجب :(') عن الأندلسي: "(إما" الأولى مع الثانية حرف عطف،

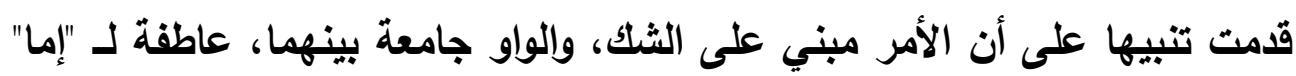

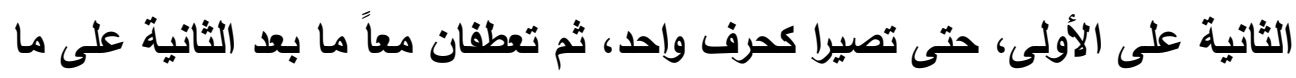

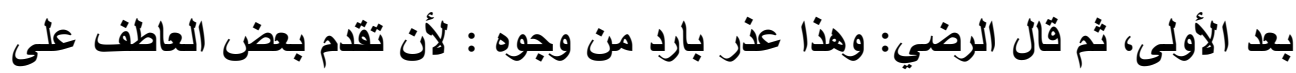

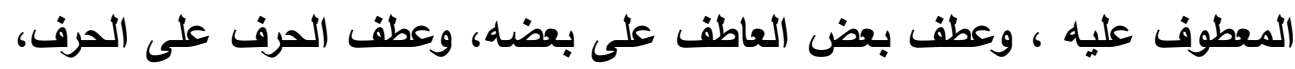

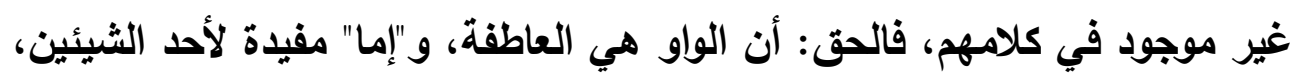

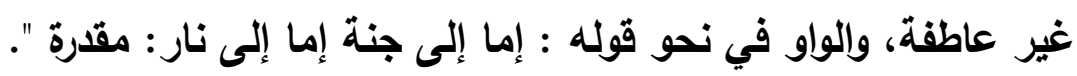

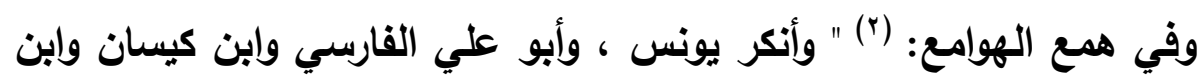

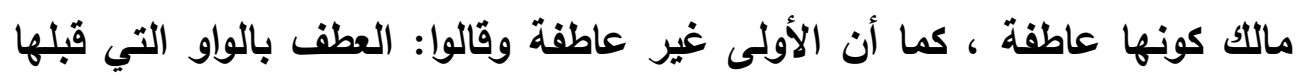

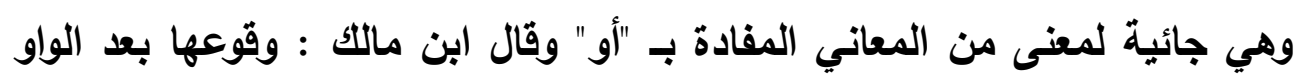

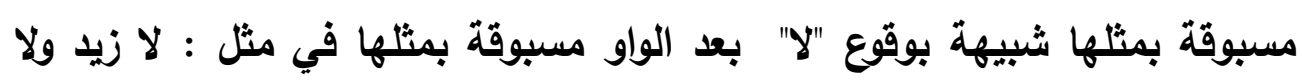

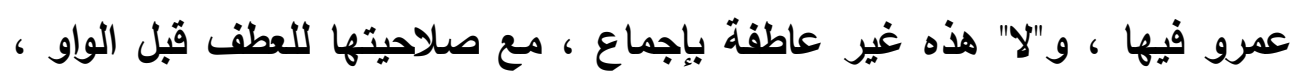

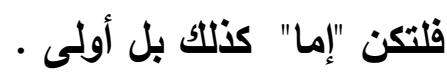
ويعد فقد اتضح أنه لم يسمع من كلام العرب عطف الحرف على الحرف . والله أعلم.

\section{ب- إبدال الظاهر من الضمير المتكن في الظرف}

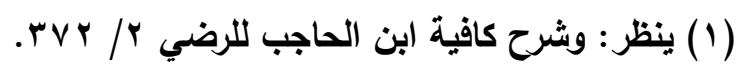
(T) ينظر :همع الهوامع هب آ. 
فصل المقال في الغريب من الأقوال النحوية والتصريفية د / عبدالرعوف ثابت أحمد عبدالله

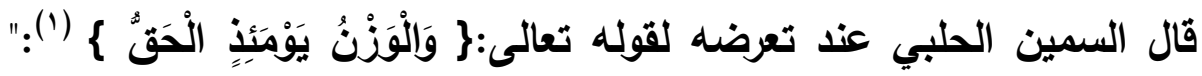
الوزنُ مبتدأ، وفي الخبر وجهان ()، أحدها: هو الظرفُ أي : الوزن كائنٌ أو مستقر يومئذ أي: يوم إذ نسأل الرسل والمرسل إليهم. فحذف الجملةً المضافَ إليها

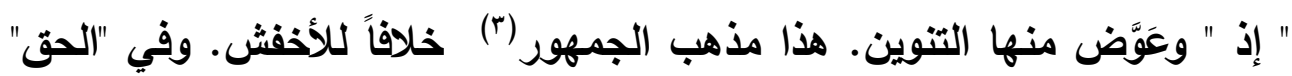
على هذا الوجهِ ثلاثةُُ أوجه:

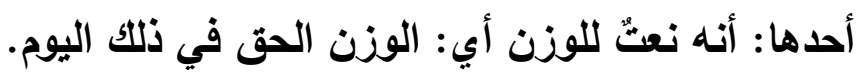
والثاني: أنه خبرُ مبتدأ محذوف كأنه جوابُ سوأل مقدر مِنْ قائل يقول: ما ذلك الوزنُ؟ فَقيل: هو الحق لا الباطل. والثالث: أنه بدلّ من الضمير المستكنّ في الظرف. وهو غريب ذكره مكي".(؛) ولعل وجه غرابته عند السمين الحلبي انفراد مكي بن أبي طالب به.

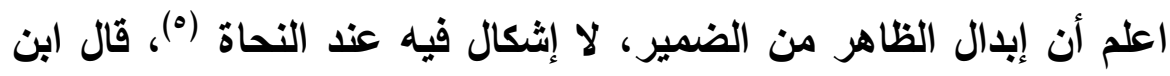
يعيش:(؟) اعلم أن البدل يتجاذبه شبهان شبه بالنعت ، وشبه بالتأكيا ، فكما أن المضمرات تؤكد ، فكذلك يبلل منها فهو في ذلك كالمظهر ...، وهو في ذلك على ثثلاثة أضرب : بلد مظهر من مضمر، ومضمر من مظهر، ومضمر من مضمر،

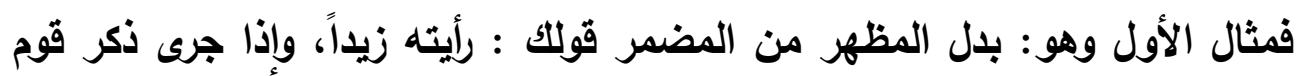

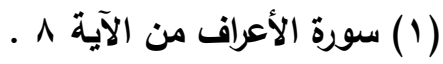

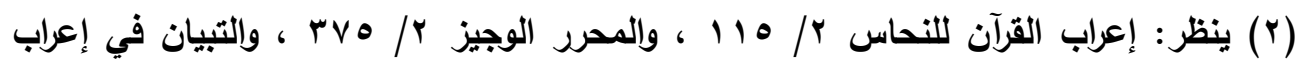

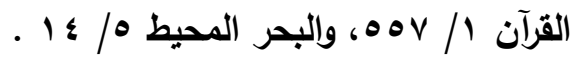

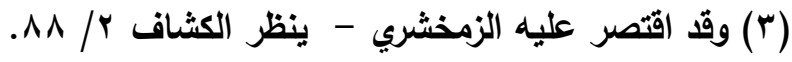

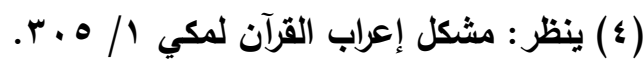

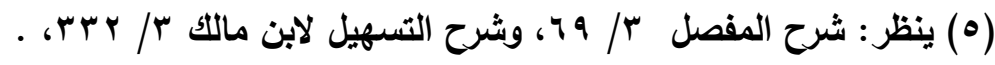

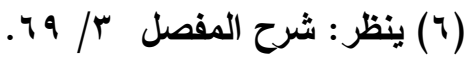




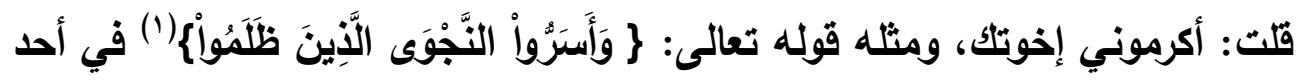

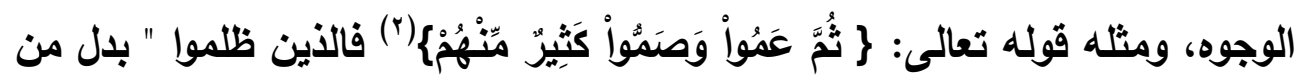
المضمر، وكذلك كثير ، وهذا من بدل الثيء من الشيء وهما لعين واحدة، وتقول : صرفت وجوهها أولها ، فأولها بدل من المضمر المجرور الذي أضفت الوجوه إليه ، وهذا من بلد البعض من الكل ؛ لأن الأول بعض وجوه الإبل ، ومما جاء في

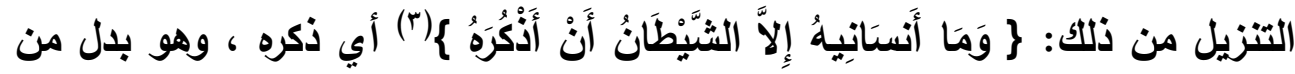
الهاء في أنسانيه ، والمعنى: وما أنساني ذكره إلا الشيطان ، ... وأما كون مكي بن أبي طالب انفرد بهذا القول، فأقول: إنه لم ينفرد به ، فقد سبقه إليه الزجاجي(؛)، وتبعه وأقره ابن الأنباري (•)، وشيخ الإسلام زكريا

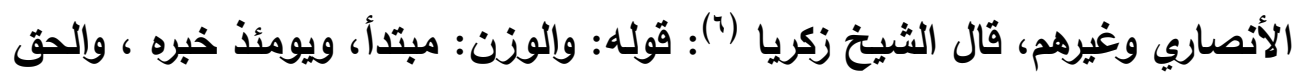
والحق صفة للوزن، أو خبر مبتدأ مذذف؛ أو بالاً من الضمير المستكن في

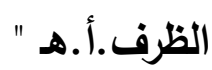
ويذلك يتضح أن ما قاله مكي بن أبي طالب القيسي من إبدال الظاهر من

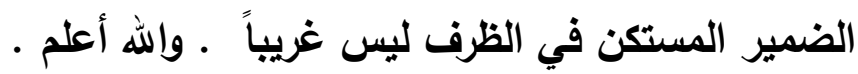

\section{بr- وقوع الهمـزة للنداء في القرآن}

(1) سورة الأنبياء من الآية ب.

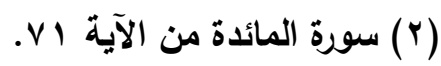

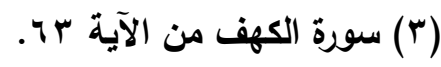

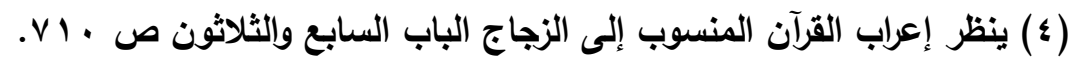

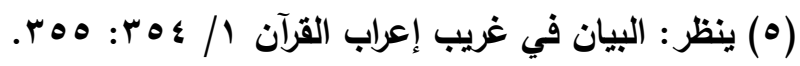

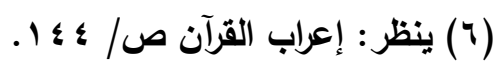


فصل المقال في الغريب من الأقوال النحوية والتصريفية د / عبدالرعوف ثابت أحمد عبدالله

قال ابن إياز (1) في شرح الفصول:"القرآن المجيد مع كثرة النداء فيه لم يأت

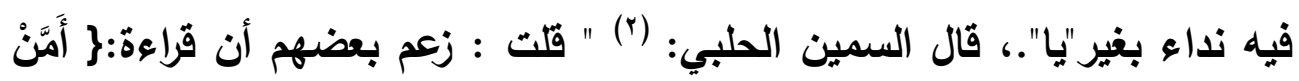

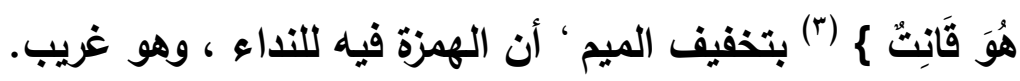

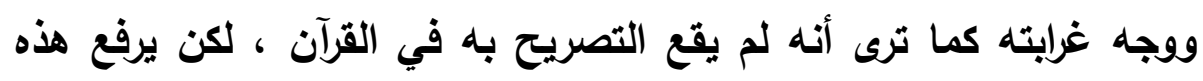

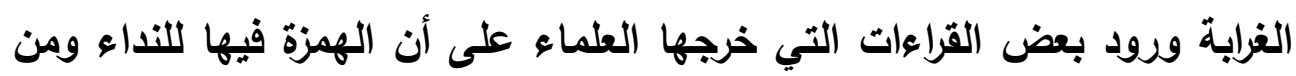
ذزلك : (घ)

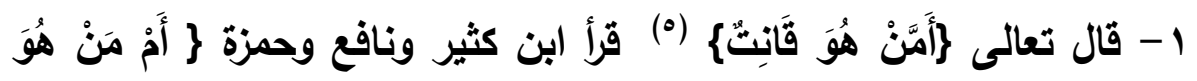

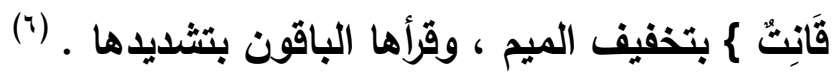

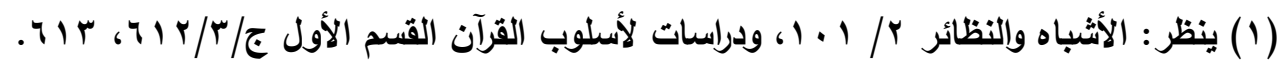

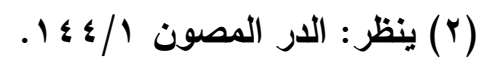

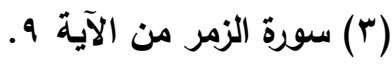

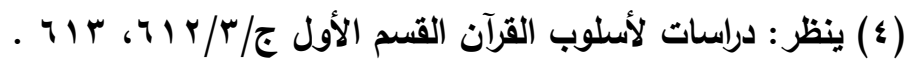

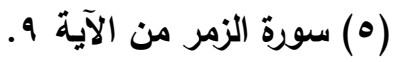

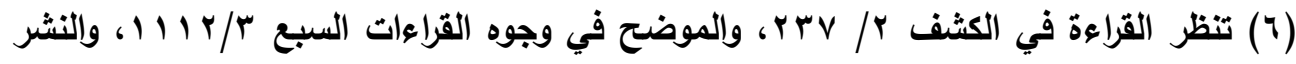

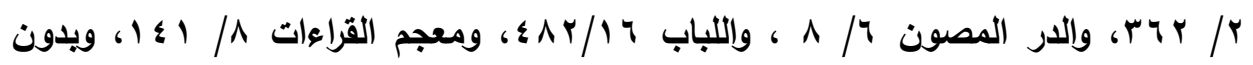

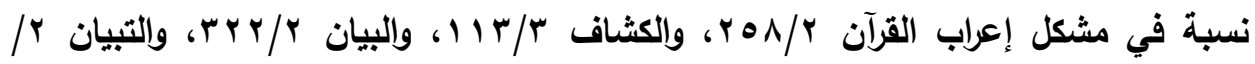

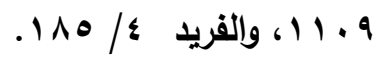


فصل المقال في الغريب من الأقوال النحوية والتصريفية د / عبدالرعوف ثابت أحمد عبدالله

قال الفراء: (') قرأها يحيى بن وثًاب() بالتخفيف. وذكر ذلك عن نافع وحمزة،

وفسروها يريد: يا من هو قانت. وهو وجه حسن، العرب تدعو بألف، كما ياعون بـ

"يا". فيقولون: يا زيد أقبل، وأزيد أقبل.

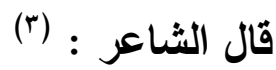

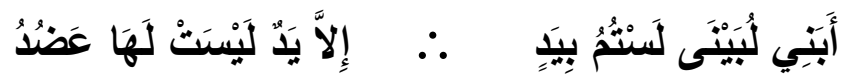

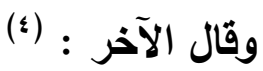

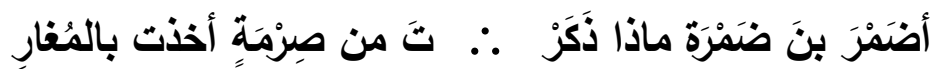

وهو كثير في الشعر". وقال النحاس : (•) " وحكى أبو حاتم عن الأخفش قال

: من قرأ في الزمر: (أمن هو) بالتخفيف، فقراعته ضعيفة ؛ لأنه استفهام ليس معه

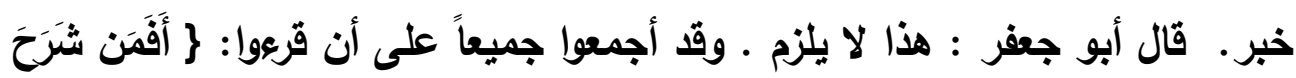

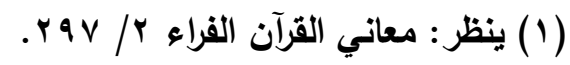

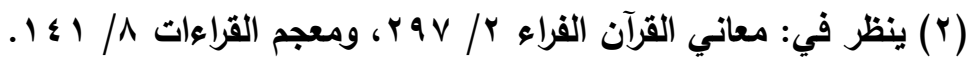

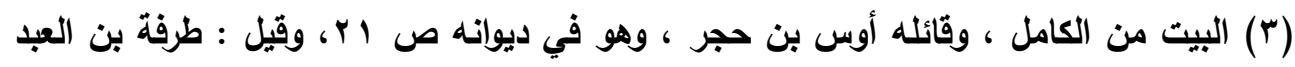

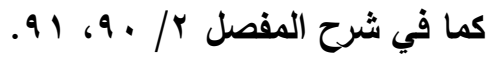

والشاهد قوله :" أبني لبينى" حيث استعمل الهمزة للنداء ، وفيه شاهد آخر على خفض يد

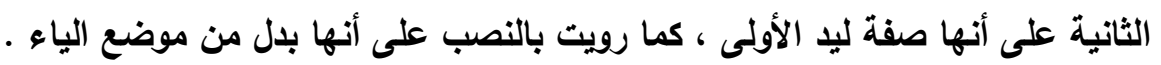

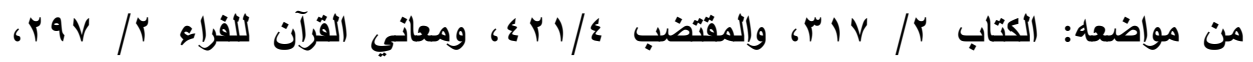

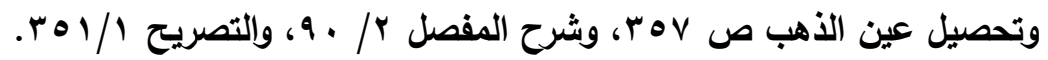

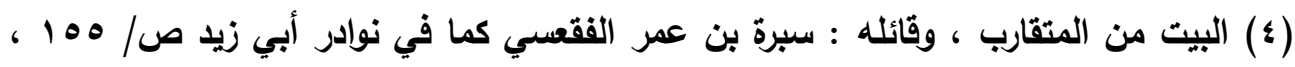

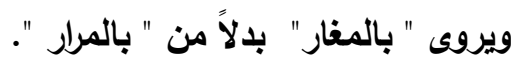

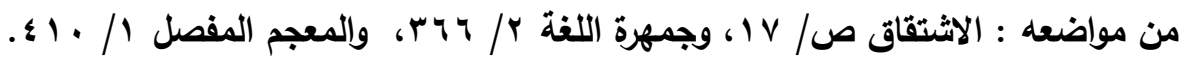

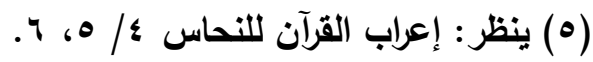


فصل المقال في الغريب من الأقوال النحوية والتصريفية د / عبدالرعوف ثابت أحمد عبدالله

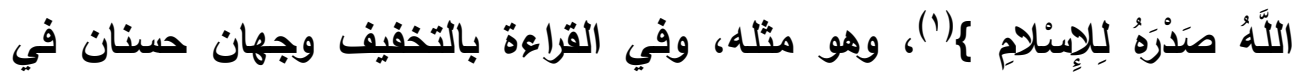
العربية، وليس في القراءة الأخرى إلا وجه واحد ، فأحد الوجهين: أن يكون نداء ، كما يقال: يا زيد أقبل ، ويقال : أزيد أقبل ، حكى ذلك سييويه (ז) ، وجميع النحويين

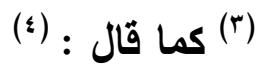

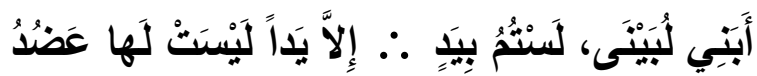

وكما يقال : فلان لا يصلي ولا يصوم، أمن يصلي ويصوم أبشر والوجه الآخر: أن يكون في موضع رفع بالابتداء ، والمعنى معروف ، أي: أمن هو قاتت آناء الليل أفضل أم من جعل الله أندادا ، والتقدير : الأي هو قاتت." وفي البحر المحيط: (ه) " وقال الفراء: الهمزة للنداء، كأنه قيل: يا من هو هو هوله قانت، ويكون قوله: (قلج)") خطاباً له، وهذا القول أجنبي مما قبله وما بعده. وضعف هذا القول الفارسي(v)، ولا التفات لتضعيف الأخفش وأبي حاتم هذه

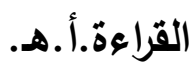

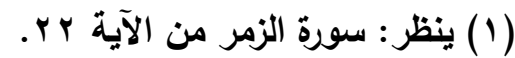

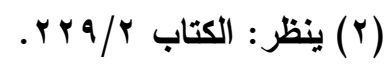

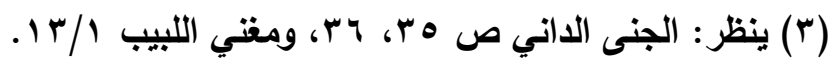
( ) ( ) سبق تحقيقه.

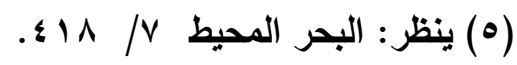

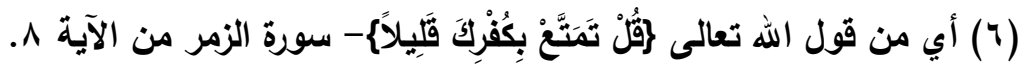

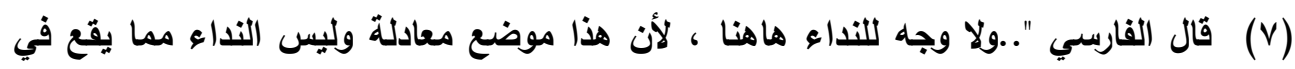

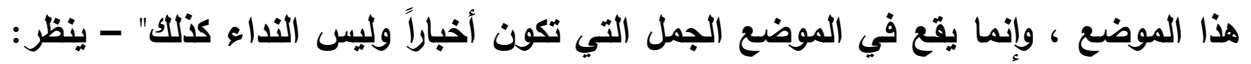

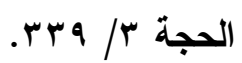


فصل المقال في الغريب من الأقوال النحوية والتصريفية د / عبدالرعوف ثابت أحمد عبدالله

قال ابن هشام: (1) "وكون الهمزة فيه للنداء هو قول الفراء ، ويبعده أنه ليس في التزيل نداء بغير "يا"، ويقربه سلامته من دعوى المجاز، إذ لا يكون الاستفهام منه تعالى على حقيقته، ومن دعوى كثرة الحذف إذ التقدير عند من جعلها للاستفهام: أمن هو قاتت خير أم هذا الكفار أبي المخاطب بقوله تعالى: رقَّلْ تَمَتَّعْ

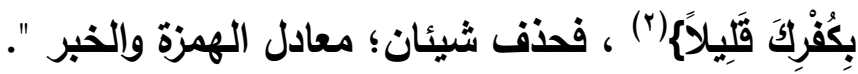
وقال البغوي: (") "وقيل: الألف في "أمن" بمعنى حرف النداء، تقديره : يا من هو قانت ، والعرب تنادي بالألف كما تنادي بالياء، فتقول: أبني فلان ويا بني فلان ، فيكون معنى الآية : قل تمتع بكفرك قليلاً إنك من أصحاب النار، يا من هو قاتت

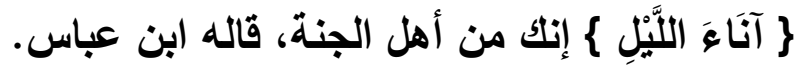

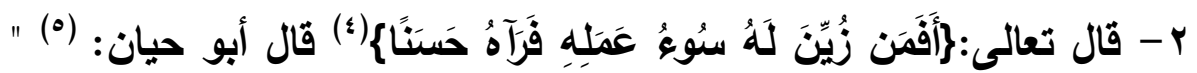

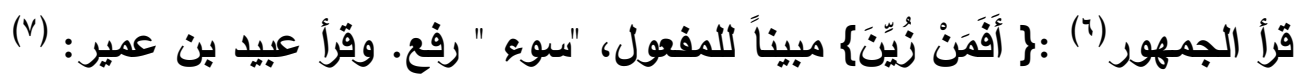

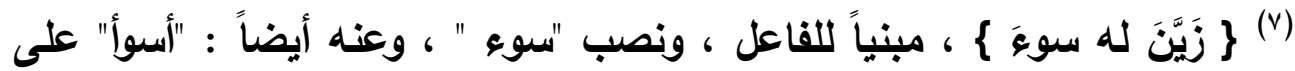
وزن : أفعل منصوياً ، وأسوأ عمله : هو الشرك. وقراءة طلحة(^): \}أمن\{ بغير فاء ، قال صاحب اللوامح: للاستخبار بمعنى العامة للتقريز، ويجوز أن يكون بمعنى حرف النداء ، فحذف التمام كما حذف من المشهور الجواب.انتهى. ويعني

$$
\begin{aligned}
& \text { (1) ينظر: مغتي اللبيب / 1 1 إ. }
\end{aligned}
$$

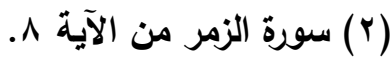

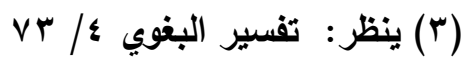

$$
\begin{aligned}
& \text { (؛) سورة فاطر من الآية } 1 .
\end{aligned}
$$

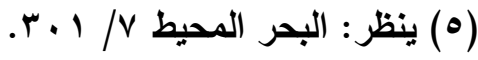

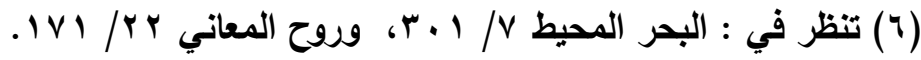

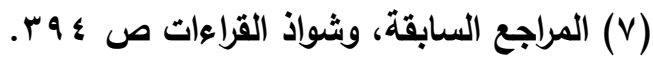$$
\text { (^) (المراجع السابقة (ل) }
$$ 
فصل المقال في الغريب من الأقوال النحوية والتصريفية د / عبدالرعوف ثابت أحمد عبدالله

بالجواب: خبر المبتدأ، ويالتمام: ما يؤدي لأجله، أي تفكر، وارجع إلى اللّه ، [فَّانََّّ

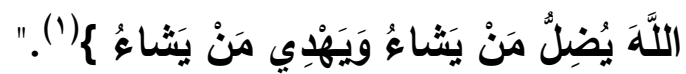

ويعد فقد اتضح أنه لا غرابة في وقوع الهمزة للنداء ، وإن لم يصرح به في مفي

القرآن، فقد احتملته بعض القراعات، والقراعة سنة عن النبي صلى الله عليه وسلم،

وهو أفصح العرب، وقد صرح بورودها أئمة النحاة، ومنهم: الفراء، وأبوجعفر

النحاس، وتبعهما كثير من المعربين والمفسرين.

وأما عن تضعيف أبي حاتم للقراعة فقد رددنا عليه في بحثنا الموسوم بـ" الرد

على أبي حاتم في تخطئة القراء "().والله أعلم .

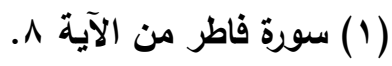

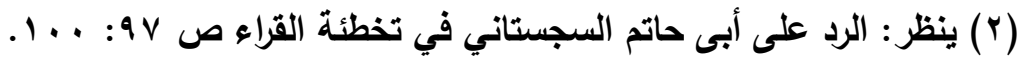


فصل المقال في الغريب من الأقوال النحوية والتصريفية د / عبدالرعوف ثابت أحمد عبدالله

\section{ry - مذف حرف النداs مع فيز الصلم}

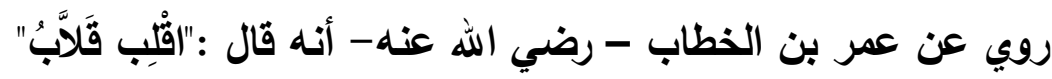

قال الزمخشري|(') وتبعه (بن الأثير:(r) "هذا مثل يُضْرب لمن تكون منه

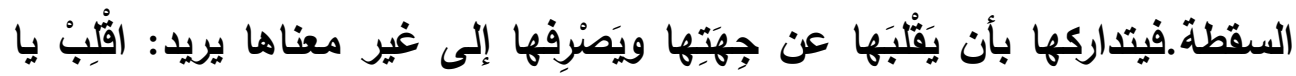

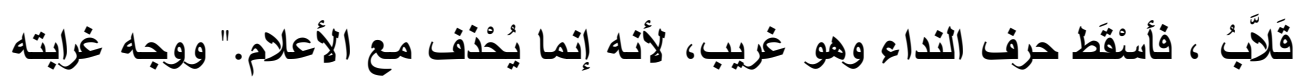
أنه أسقط حرف النداء مع غير العلم وهو مقصور على الضرورة عند البصريين،

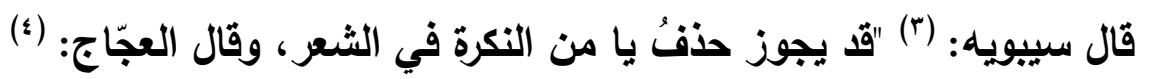

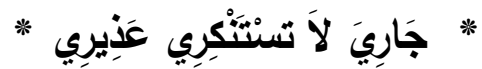

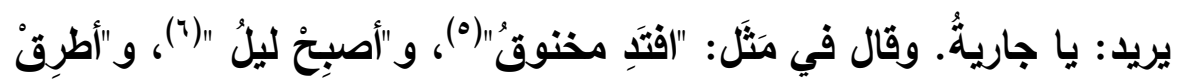
كَرا". (v) وليس هذا بكثير ولا بقويّ.، وفي المحتسب(^) "ومن ذلك قراءة أبي جعفر:

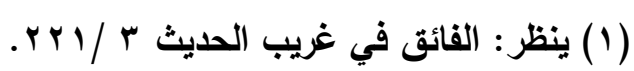

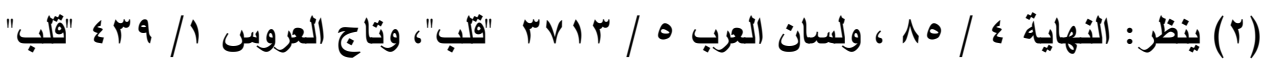

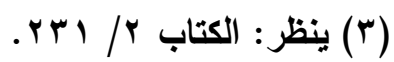

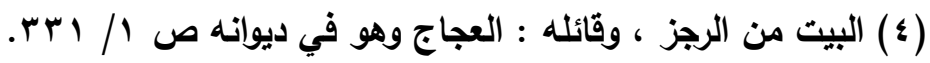

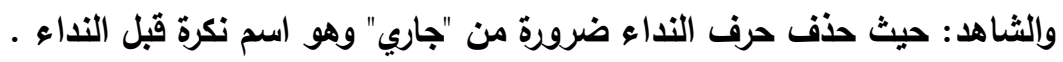

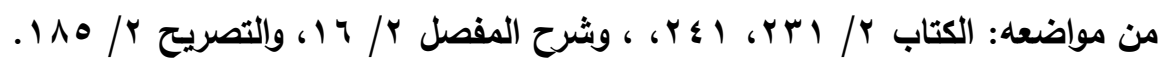

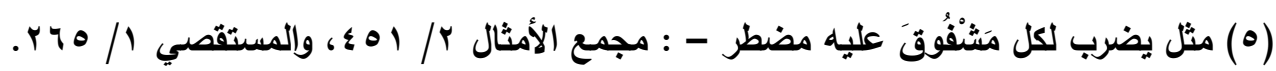

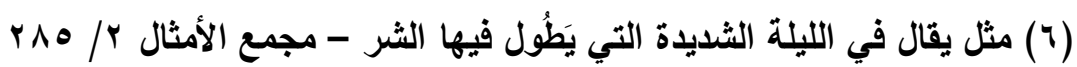

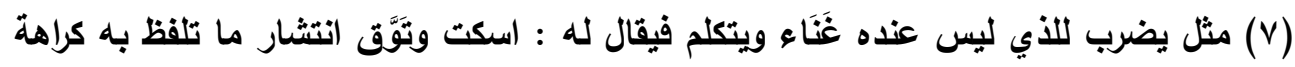

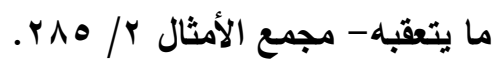

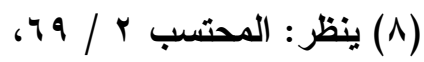


فصل المقال في الغريب من الأقوال النحوية والتصريفية د/ عبدالرعوف ثابت أحمد عبدالله

\}قُلْ رَبُّ احْكُمُْ (') بضم الباء، والألف ساقطة على أنه نداء مفرد.، قال أبوالقتح: هذا عند أصحابنا ضعيف، أعني: حذف حرف النداء مع الاسم الذي يجوز أن يكون وصفًا لأي. ألا تراك لا تقول: رجل أقبل؛ لأنه يمكنك أن تجعل الرجل وصفاً لأي. فتقول: يأيها الرجل؟ ولههذا ضعف عندنا قول من قال في قوله تعالى : جهَوُلاعِ بَتَاتِي

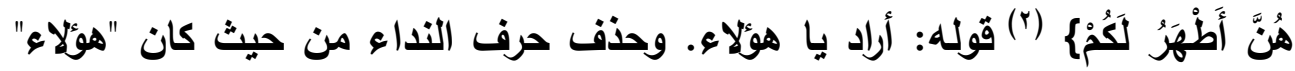

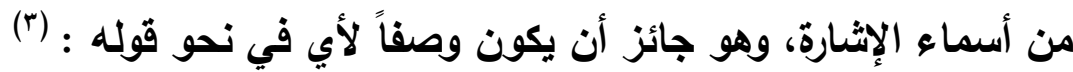

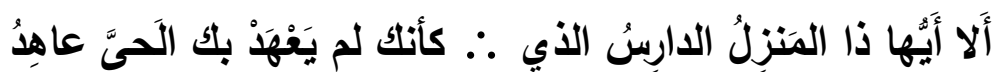

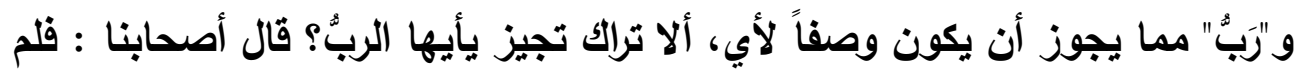

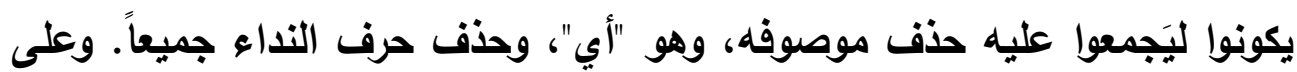

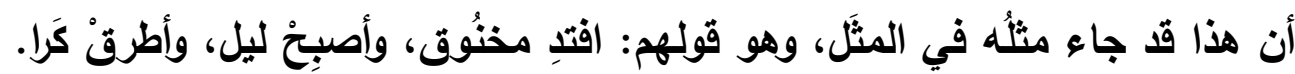

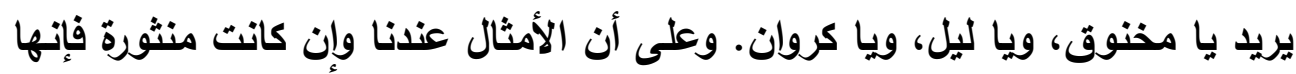

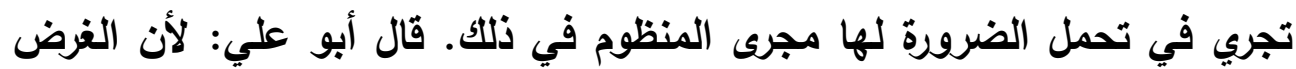

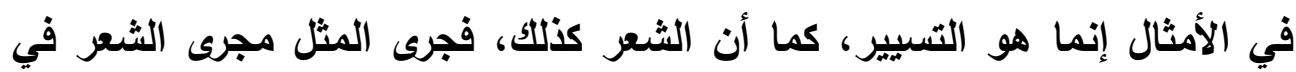
تجوز الضرورة فيه.." خلافاً للكوفيين فقد أجازوا حذف حرف الامتال النداء من اسم الإثارة ، واسم الجنس ، واستدلوا على صحة مذهبهم بما ورد عن العرب من الأمثلة

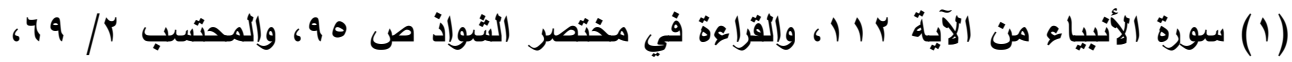

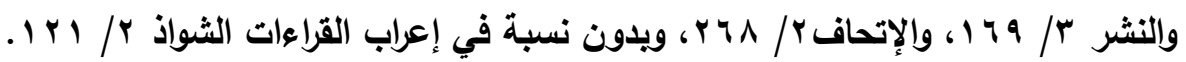

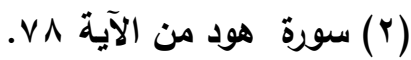

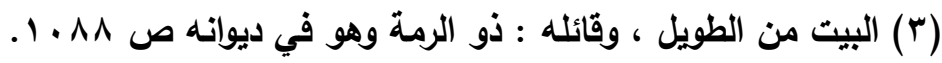

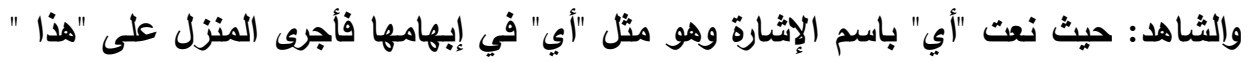
لأنه مفرد مثله .

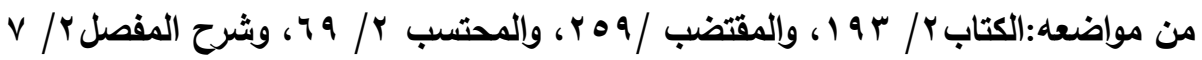


فصل المقال في الغريب من الأقوال النحوية والتصريفية د / عبدالرعوف ثابت أحمد عبدالله

السابقة، وهو الراجح، وقد صرح ابن مالك بموافقتهم في اسم الجنس ففي شرح

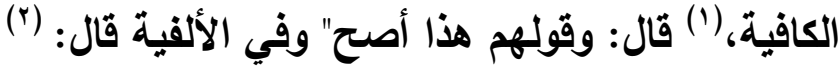

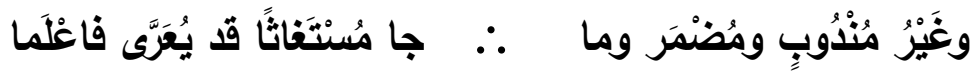

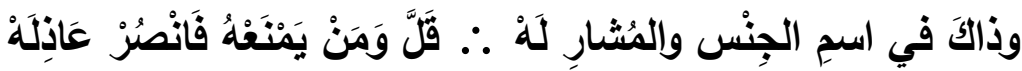

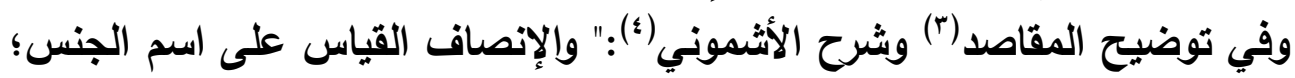

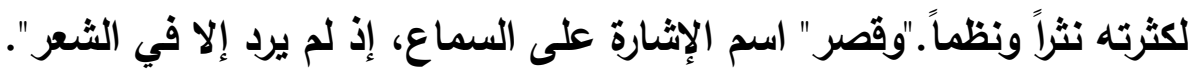

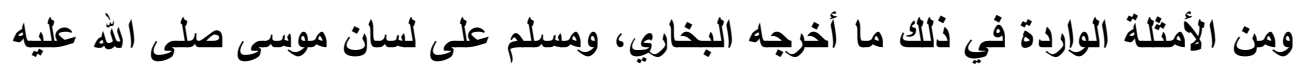

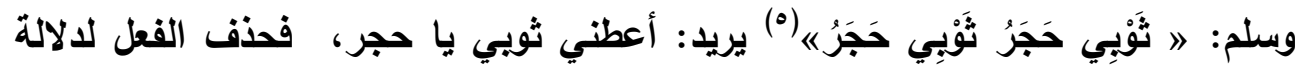

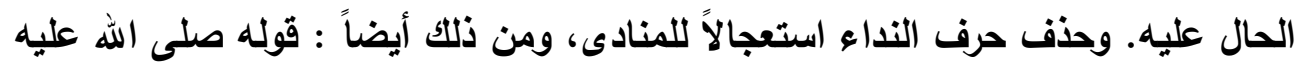

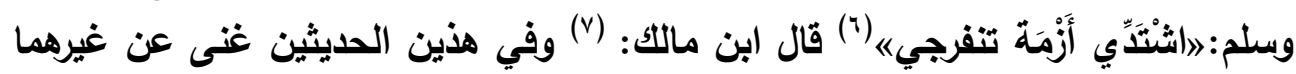

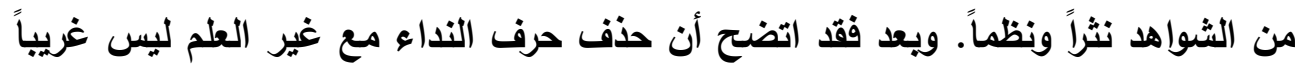

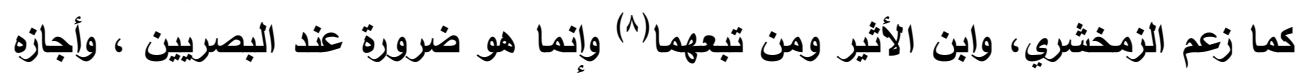
الكوفيون ومن تبعهم، وهو المختار ـ والله أعلم.

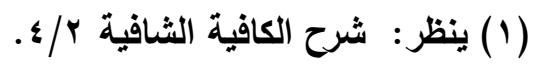

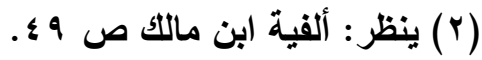

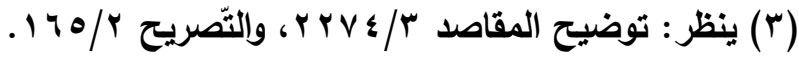

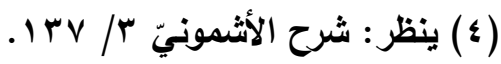

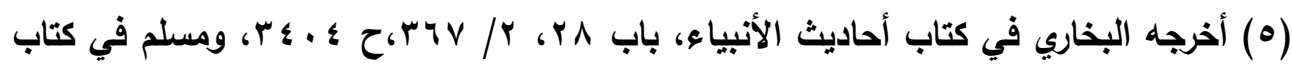

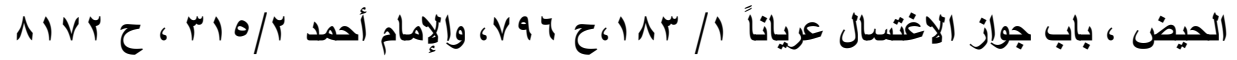

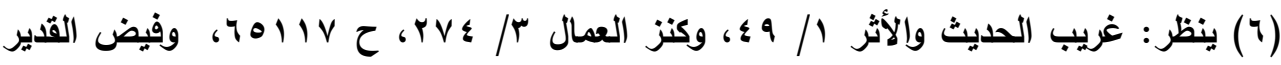

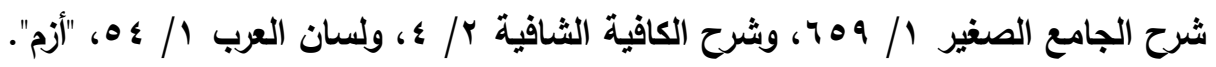

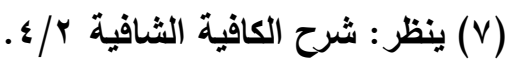

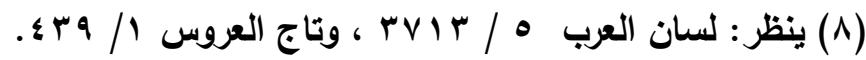


فصل المقال في الغريب من الأقوال النحوية والتصريفية د / عبدالرعوف ثابت أحمد عبدالله

\section{גr- بناء فداء على الكسر هم التنوين}

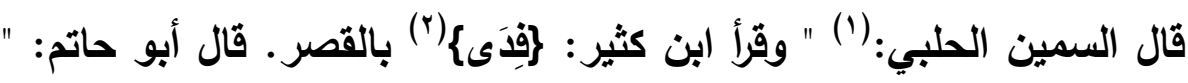

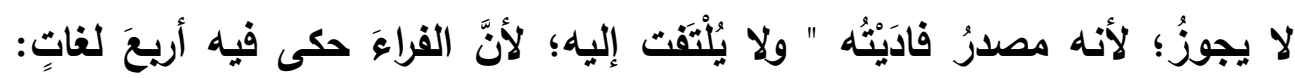

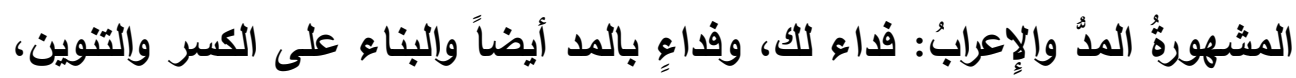

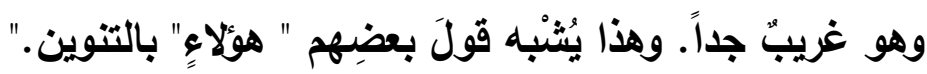

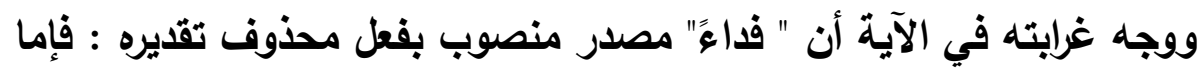

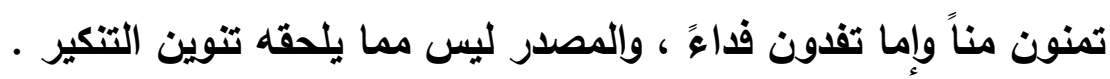

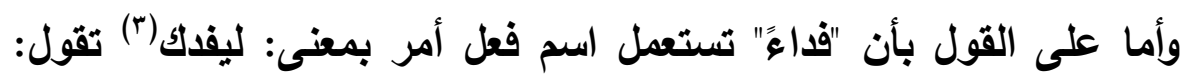

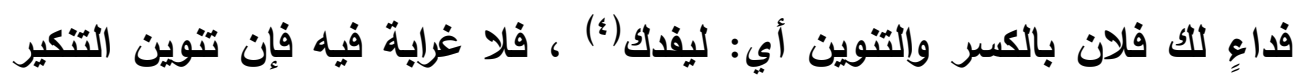

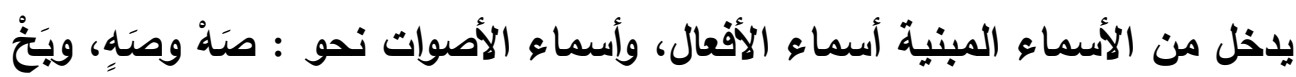

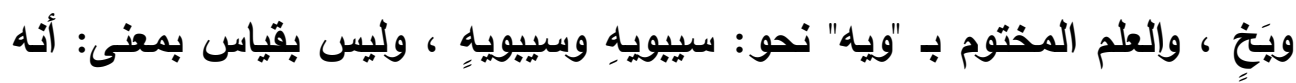

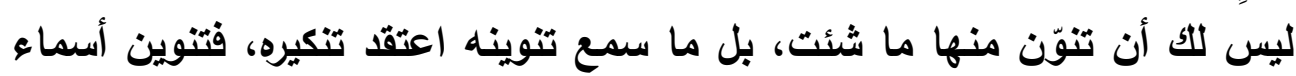
الأفعال والأصوات سماع وتنوين العلم المختوم بويه قياس. ودخول التنوين فيها دال على التنكير، وخروجه دال على التعريف.

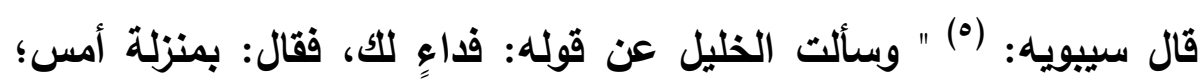
لأنهَّا كثرت في كلامهم، والجرُ كان أخفَّ عليهم من الرفع إذ أكثروا استعمالهم إيَّاه،

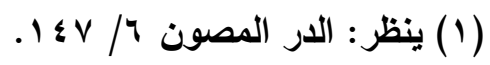

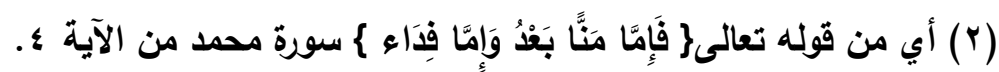

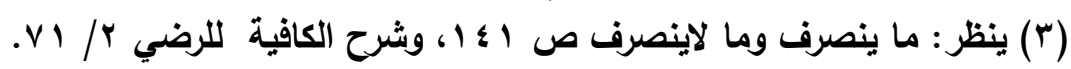

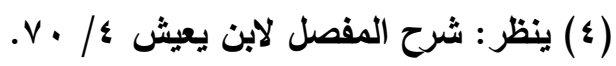

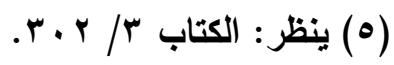


فصل المقال في الغريب من الأقوال النحوية والتصريفية د / عبدالرعوف ثابت أحمد عبدالله

وشبّهوه بأمس، ونوّن لأنهّ نكرة. فمن كلامهم أن يشبِّهوا الشيء بالشيء وإن كان ليس مثله في جميع الأشياء ". وقال:(1) "فداء للك" موضوع موضع الدعاء والأمر، فلذلك كسر لالتقاء

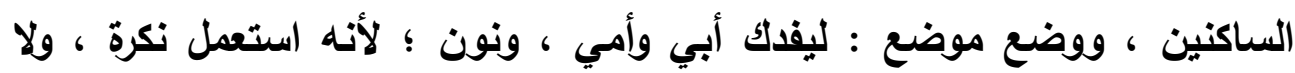

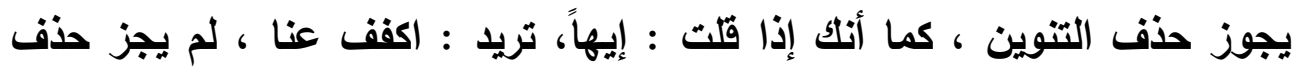
التنوين ..." وقال الجوهري: (ז) "(لفداء إذا كسر أوله يمد ويقصر، وإذا فتح فهو مقصور، يقال: قم فدى للك أبي. ومن العرب من يكسر "فاءع" بالتنوين إذا جاور لام الجر خاصة، فيقول: فداء للك، لأنه نكرة يريدون به معنى الدعاء"

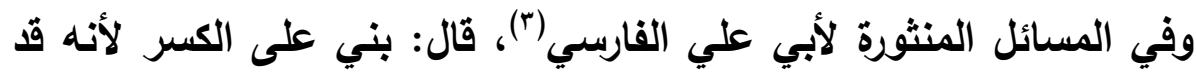
تضمن معنى الحرف، وهو لام الأمر". ثم نقل عن ابن المستوفي قوله: "يستعمل مكسوراً منونـاً ، وغير منون، حملاً على إيه وإيهِه". وقال القيسي: (๕) "..ويجوز "فاء" بكسر الهمزة والمد والتتوين، وإنما جاز للك ذلك ؛ لأنها كثرت في الاستعمال، ووقعت موقع فعل الدعاء، فبنيت، ودخلها التتوين مع البناء، كما دخل "إيه" وما أشبهها فرقاً بين المعرفة والنكرة. وقد نقل الثقات في "فداء" خمس لغات قال الثهاب الخفاجي(•): ".. فيه أربع أربع لغات: الفتح والكسر مع المد والقصر، ولغة خامسة البناء مع الكسر كما حكاه الثقات. هذا والله أعلم.

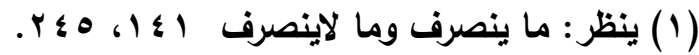

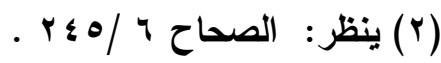

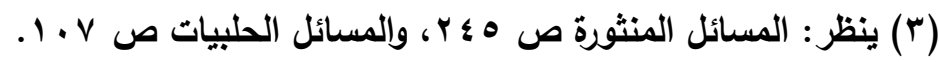

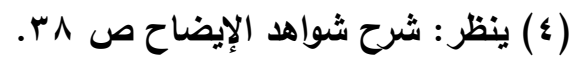

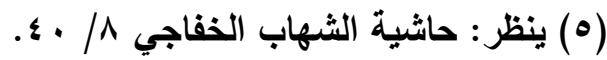


فصل المقال في الغريب من الأقوال النحوية والتصريفية د / عبدالرعوف ثابت أحمد عبدالله

\section{q- هن معاني "قد" النفي و التكثير}

قال ابن سبده:(1) " وتكون "قد" بمنزلة "ما " فيُنْي بها سُمِحَ بعض الفصحاء

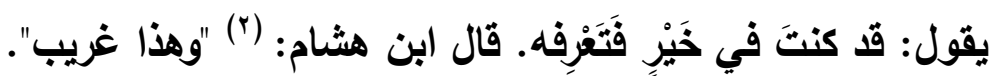

ووجه غرابته أنه لم يقل به أحد من المتقدمين غير ابن سيده .

وتبع ابن سيده في هذا جمال الدين ابن مالك(ّ) والفيروزابادي(ء) وأبو البقاء

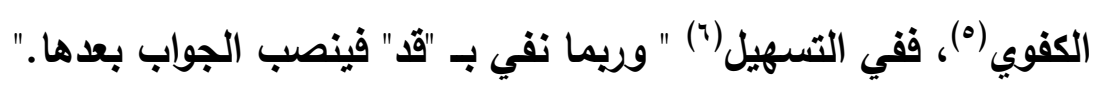

وق نقله عن ابن سيده جمع من العلماء منهم: بلر الاين ابن مالك، (v)

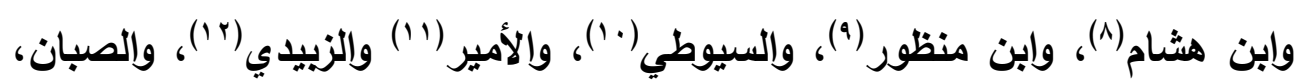

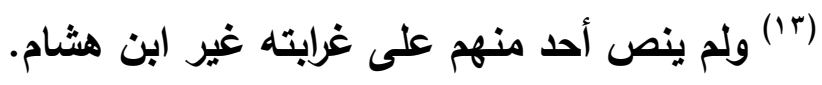

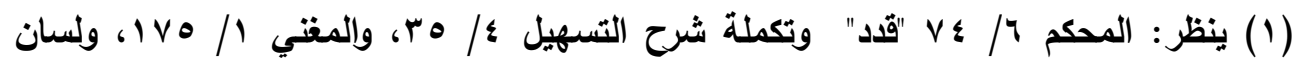

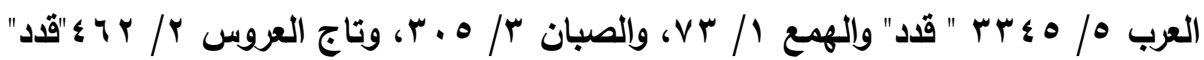

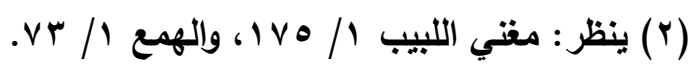

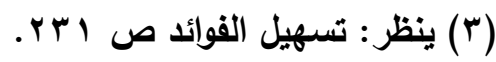

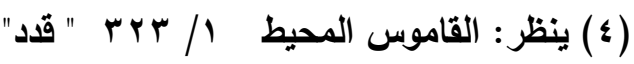

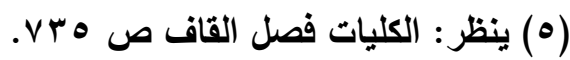

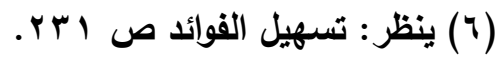

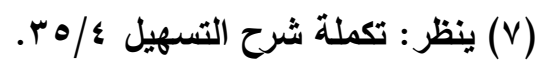

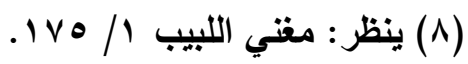

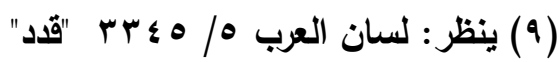

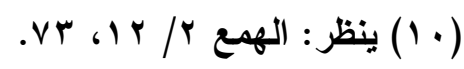

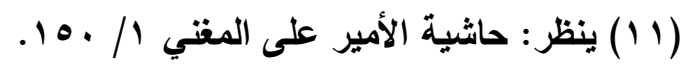

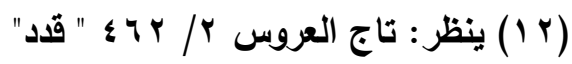

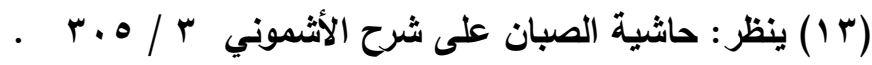


فصل المقال في الغريب من الأقوال النحوية والتصريفية د / عبدالرعوف ثابت أحمد عبدالله

وأما التكثير. فقال المرادي: (1) " هو معنى غريب. وقد ذكره جماعة، من النحويين،

وأنشدوا عليه قول الشاعر: (r)

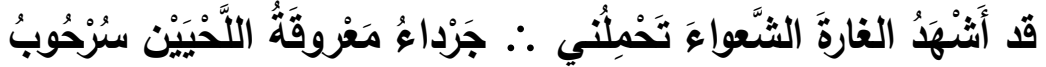

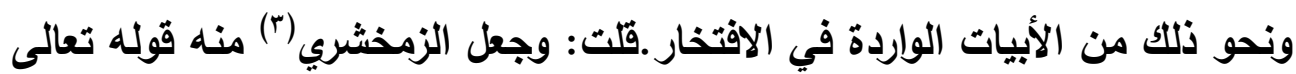

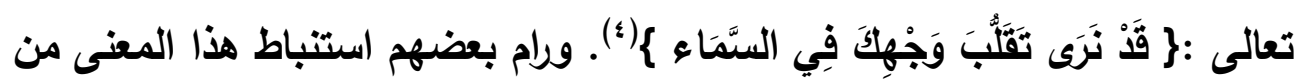
من كلام سيبويه(ه). فإنه قال: وأما "قد" فجواب لقوله: لما يفعل. ثم قال: وتكون "

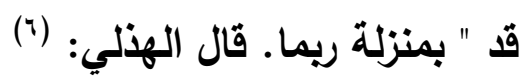

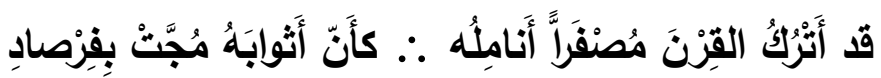

كأنه قال: ريما. هذا نصه. فتشبيهه بـ "ريما" يدل على أنها للتكثير. وعكس ذلك

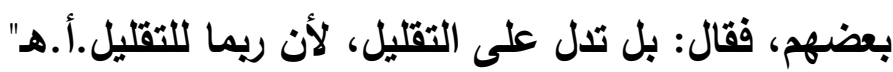

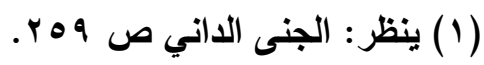

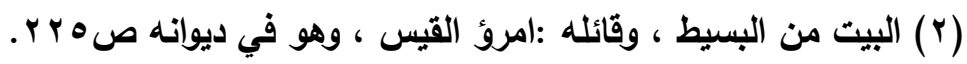

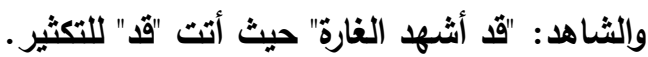

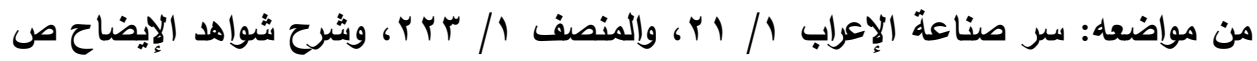

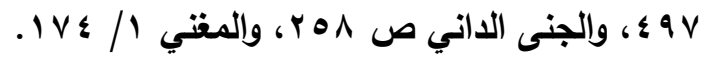

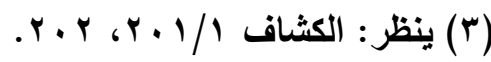

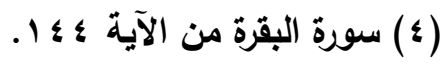

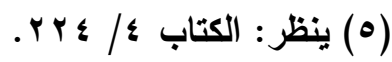

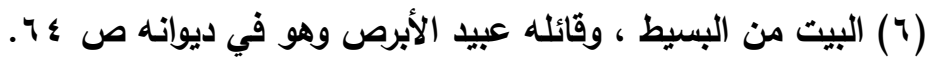

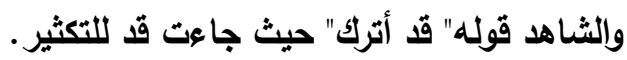

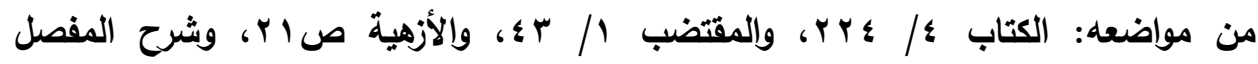

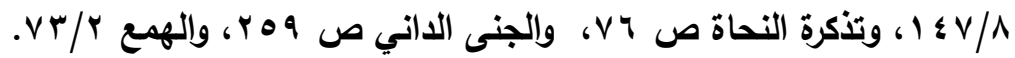


فصل المقال في الغريب من الأقوال النحوية والتصريفية د البدالرعوف ثابت أحمد عبدالله

ووجه غرابة هذا المعنى أنهم شبهوها بـ "ربما"، وريما على مذهب المحققين

من النحويين، إنما تكون لتقليل الثيع في نفسه ، أو لتقليل نظيره. قال أبو حيان(') عند تعرضه لقوله تعالى

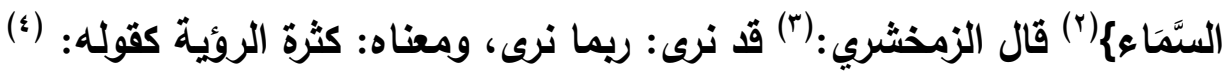

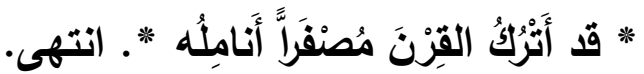

وشرحه هذا على التحقيق، لأنه شرح قد نرى بريما نرى. ورب، على مذهب المحققين من التحويين ، إنما تكون لتقليل الثيء في نفسه ، أو لتقليل نظيره. ثم قال : ومعناه كثرة الروئية ، فهو مضادّ لمدلول رب على مذهب الجمهور. ثم هذا المعنى الأي ادّعاه ، وهو كثرة الروئية ، لا يدل عليه اللفظ ، لأنه لم يوضع لمعنى الكثرة. هذا التركيب، أعني تركيب قد مع المضارع المراد منه الماضي ، ولا غير المضي ، وإنما فهمت الكثرة من متعلق الروئة، وهو التقب، لأن من رفع بصره إلى لى السماء مرة واحدة، لا يقال فيه: قلب بصره في السماء ، وإنما يقال : قلب إذا ردّد. فالتكثير، إنما فهم من التقلب الأي هو مطاوع التقليب، نحو: قطعته فتقطع، وكسرته فتكسر، وما طاوع التكثير فقيه التكثير . وتبين من هذا أن الزمخشري وأبا حيان يقولان بدلالة قد على التكثير وقا فهما هذا من كلام سييويه . قال الشهاب الخفاجي: (')" والأصل الأغلب في قد أن تشتعمل للتقليل ، وفهمه (بن مالك من قول سييويه وتكون قد بمنزلة ريما قال الهزلي : (r)

$$
\begin{aligned}
& \text { (1) ينظر: البحر المحيط / / عV ع. }
\end{aligned}
$$

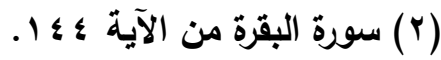

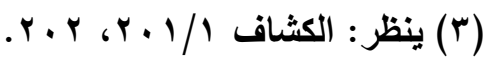

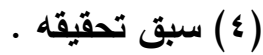


فصل المقال في الغريب من الأقوال النحوية والتصريفية د / عبدالرعوف ثابت أحمد عبدالله

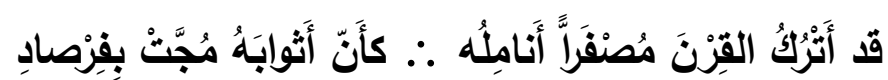

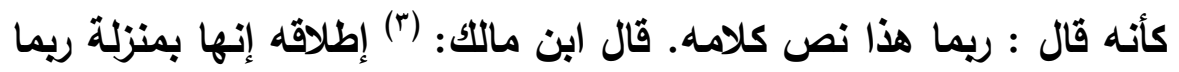

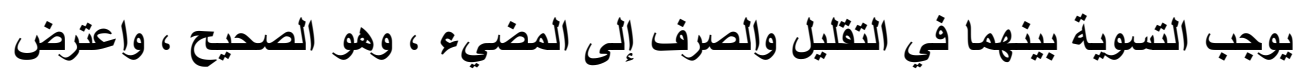

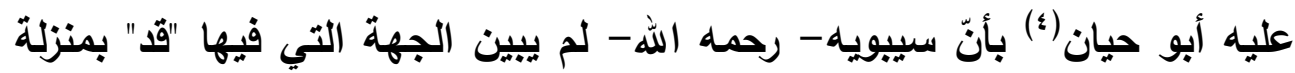

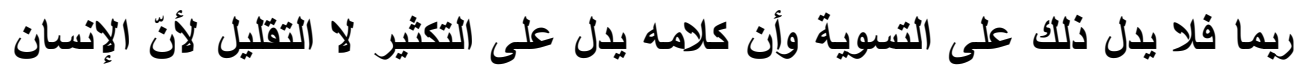

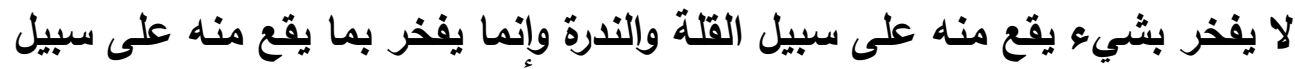

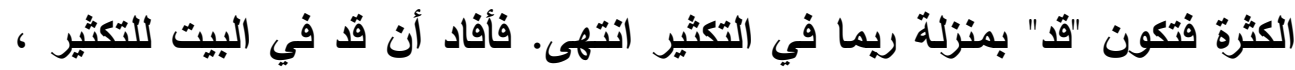

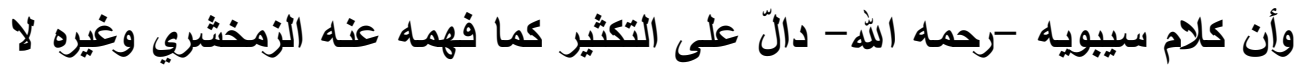

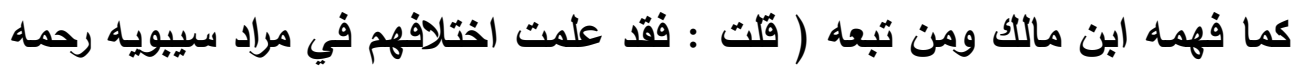

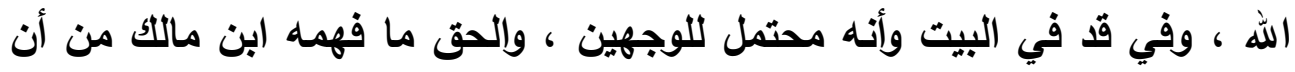

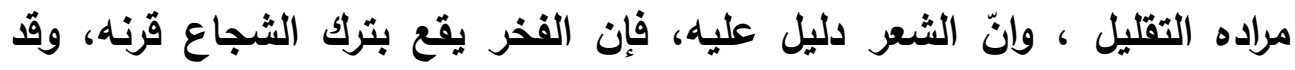

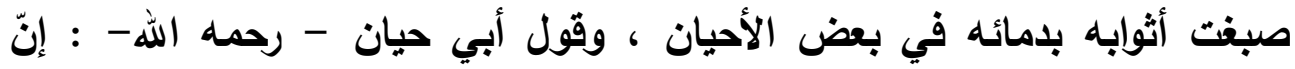

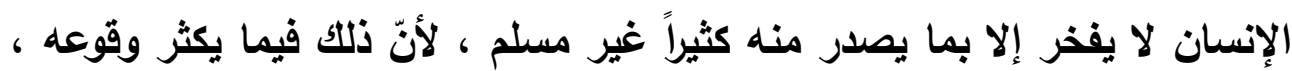

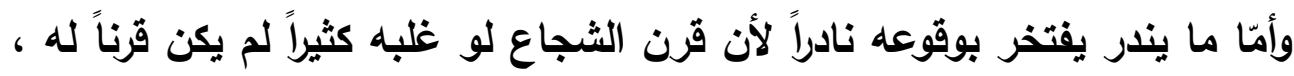

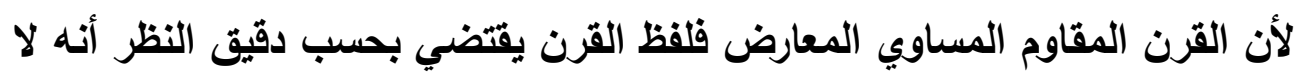

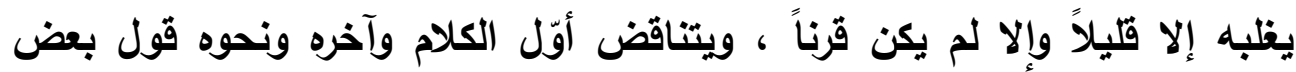

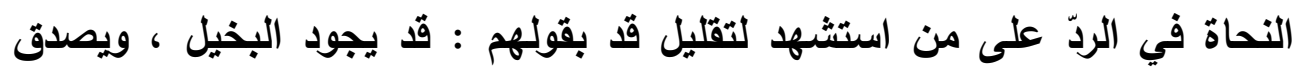

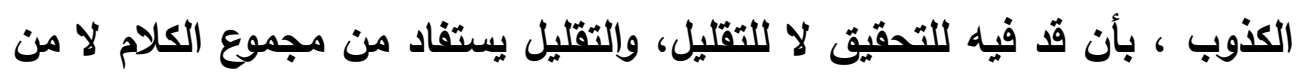

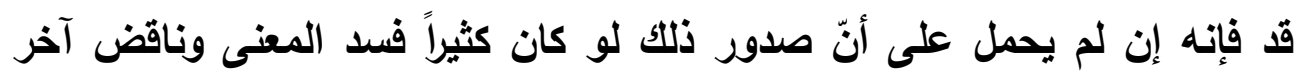

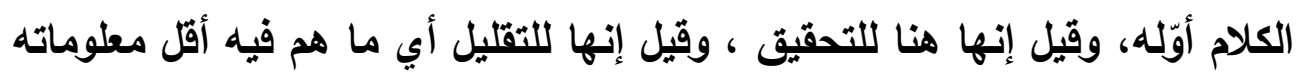

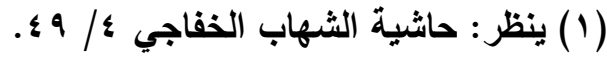

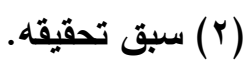

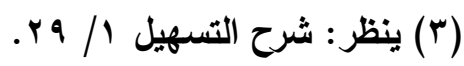

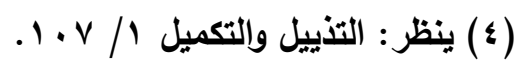


فصل المقال في الغريب من الأقوال النحوية والتصريفية د / عبدالرعوف ثابت أحمد عبدالله

، وإذا استعملت للتكثير فهل هو بطريق الوضع أو استعارة أحد الضدين للآخر

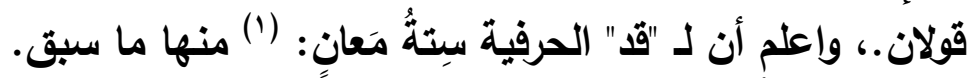

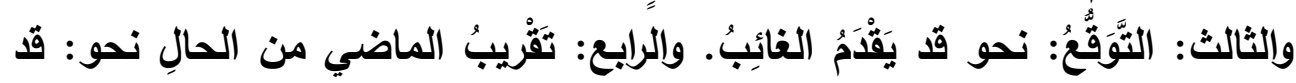

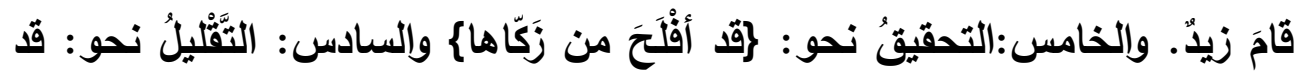

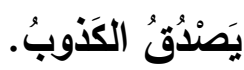

ويعد فقد اتضح أن دلالة قد على النفي كما قال ابن سيده ليس غريباً فابن

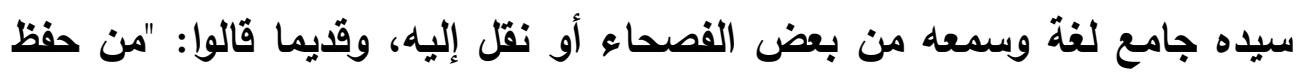

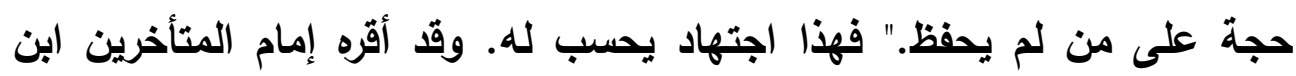
مالك- رحمه الله- ، وأما دلالتها على التكثير فقد نص عليه طائفة من المعربين

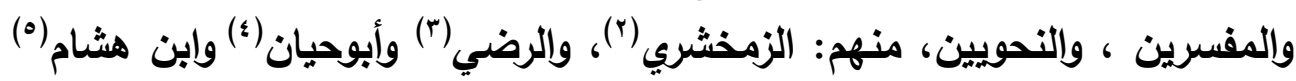

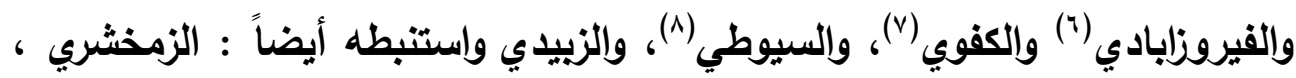

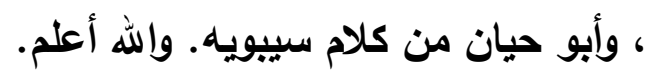

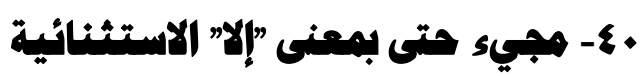

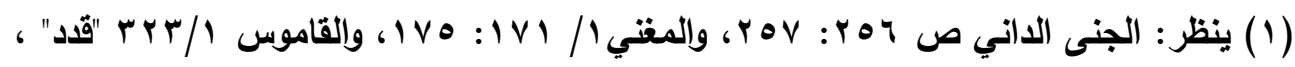

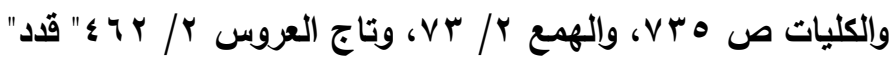

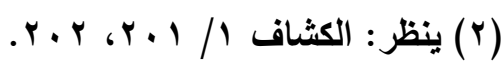

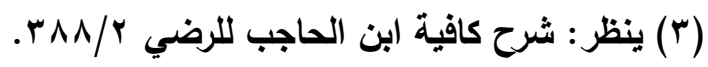

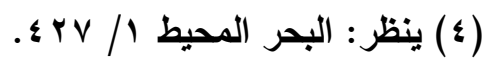

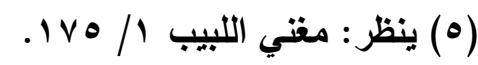

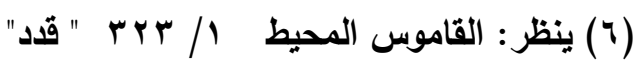
ينظر : الكليات فصل القاف ص هr) (N)

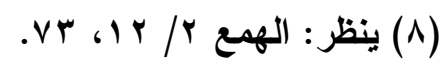


فصل المقال في الغريب من الأقوال النحوية والتصريفية د / عبدالرعوف ثابت أحمد عبدالله

زعم ابن هشام الخضراوي(')(بتعه (بن مالك(r) أن "حتى" تكون بمعنى "إلا"

الاستثنائية كقوله: (r)

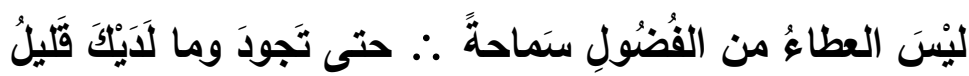
أي إلا تجود، وهو أي: أن تجود استثاء منقطع ؛ لأن الجود في حالة قلة المال ليس من جنس المستثنى منه وهو العطاء في حالة الكثرة . قال المرادي:(๕) وزاد ابن مالك في التسهيل(ه) معنى ثالثاً، وهو أن تكون بمعنى :إلا أن، فتكون بمعنى الاستثناء المنقطع. كقول الشاعر:

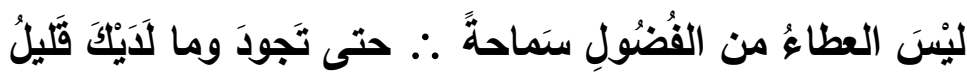

وهو معنى غريب، ذكره ابن هشام، وحكاه في البسيط (ا) عن بعضهم. وقول سيبويه(V) في قولهم: لا أفعل كذا إلا أن تفعل: والمعنى: حتى أن تفعل، ليس نصاً على أن حتى إذا انتصب ما بعدها تكون بمعنى: إلا أن، لأن ذلك تفسير معنى. ولا

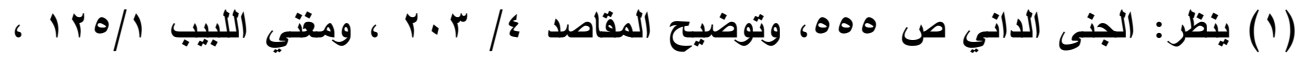

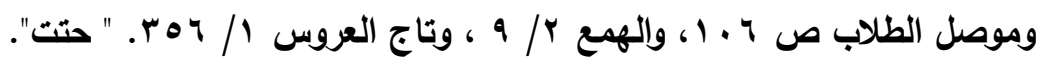

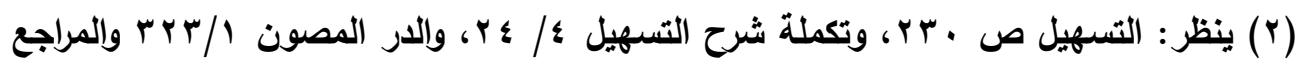
والمراجع السابقة .

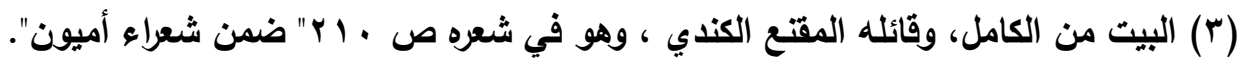

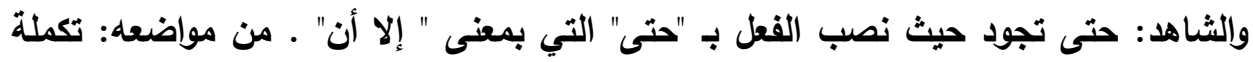

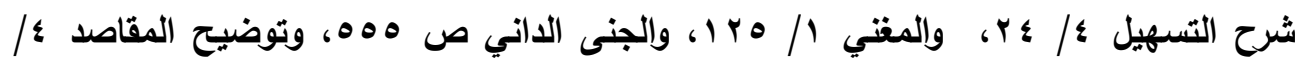

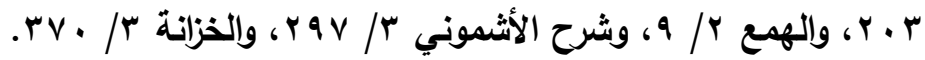

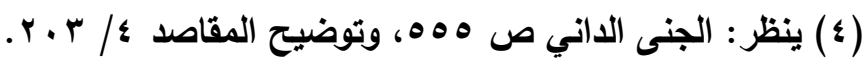

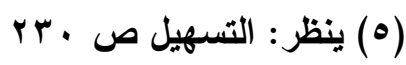

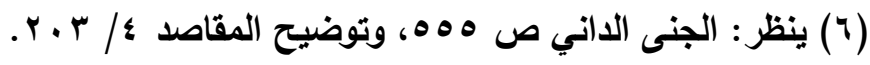

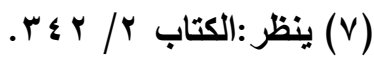


فصل المقال في الغريب من الأقوال النحوية والتصريفية د/ عبدالرعوف ثابت أحمد عبدالله

حجة في البيت، لإمكان جعلها فيه بمعنى إلى." ولعل وجه غرابته في نظر المرادي

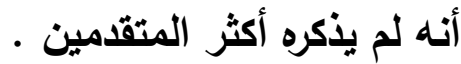

نص ابن هشام الخضراوي على هذا المعنى عند تعرضه لحديث: \ا كل مولود يُولَدُ

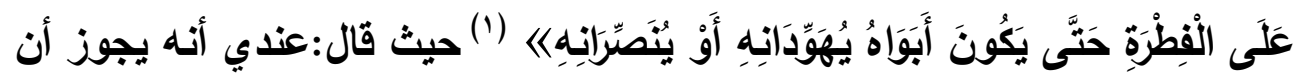
يكون ( على الفطرة ) حالاً من الضمير، ويولد في موضع خبر، و"حتى" بمعنى "إلا

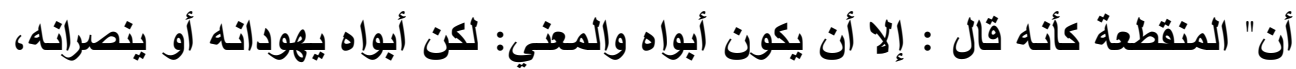

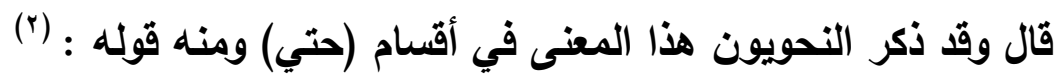

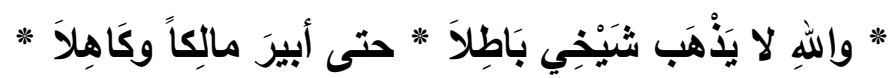
المعني : إلا أن أبير ، وهو منقطع بمعنى : لكن أبير انتهى. وفي مغتي اللبيب:() " دـ "حتى" الداخلة على المضارع المنصوب ثلاثة

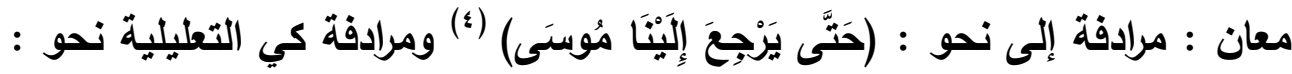

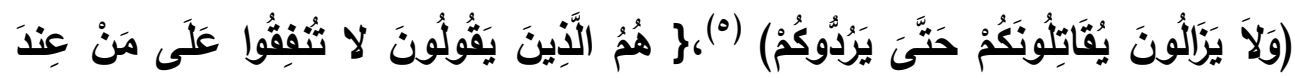

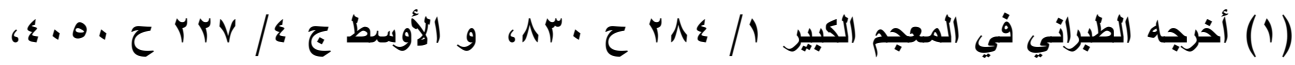

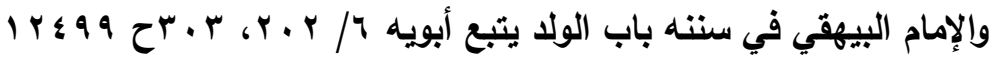

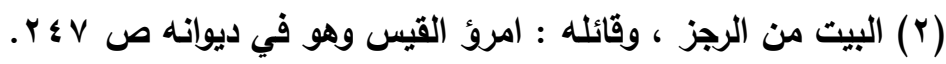
والثاهد: "حتى أبير "حيث جاءت حتى بمعنى إلا أن. : أن.

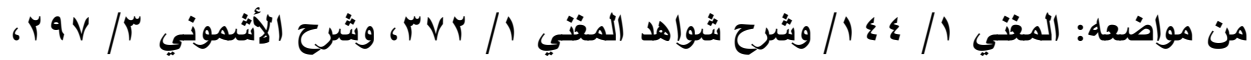

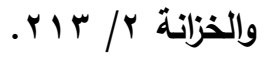

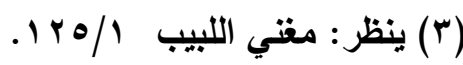

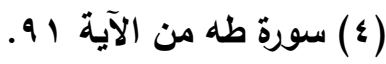

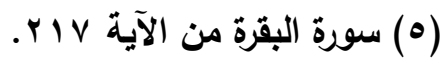




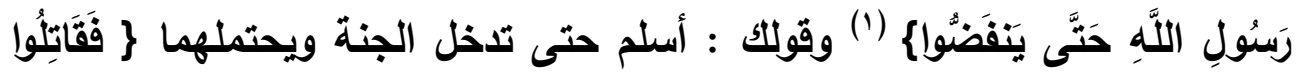

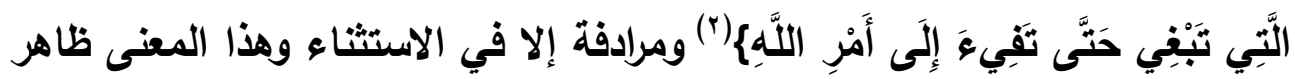

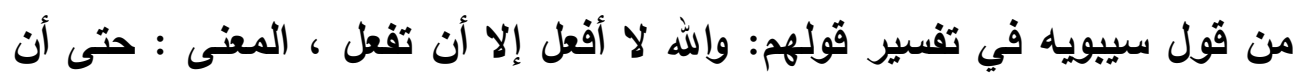

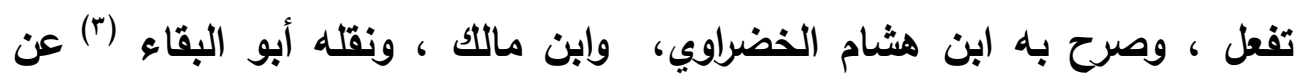

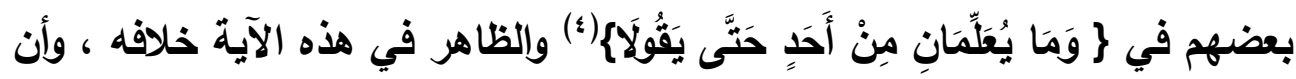

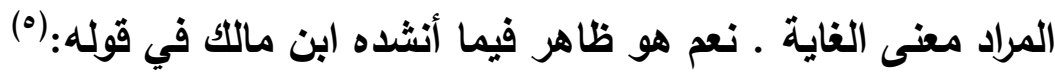

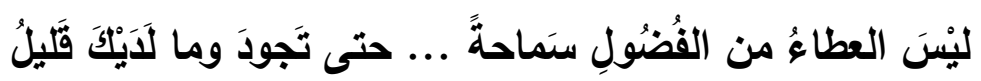

وفي قوله: (†)

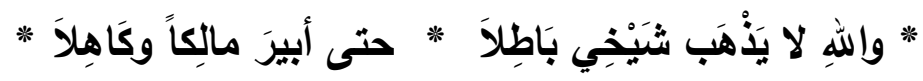

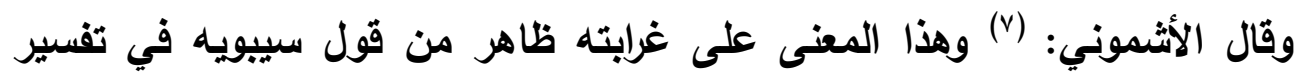

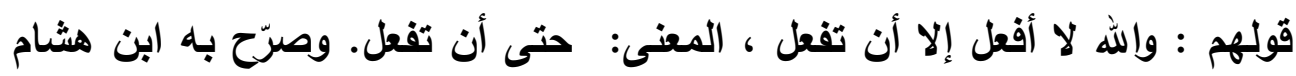

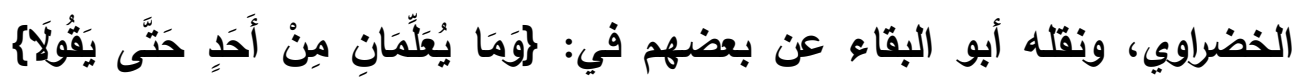

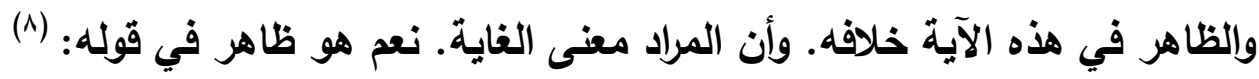

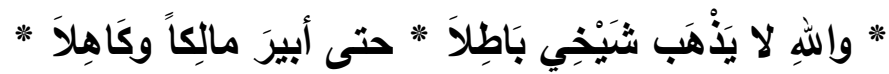

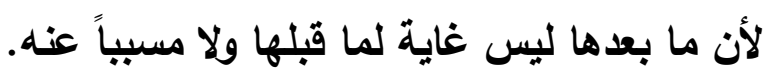

(1) سورة المنافقون من الآية v.

(r) سورة الحجرات من الآية 9.

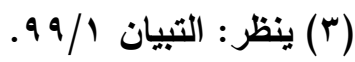

(؛) سورة البقرة من الآية r ـ 1.

(1) سبق تحقيقه.

(ף) (ף ) سبق تحقيقه.

rqv / نيظز : شرح الأثموني (V)

(^) سبق تحقيقه. 
ويعد فقد اتضح أن مجيء حتى بمعنى "إلا "هو معنى قال به ابن هشام

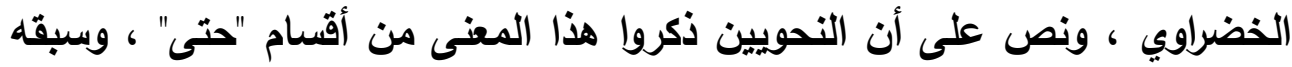

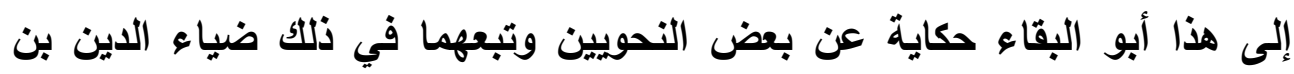

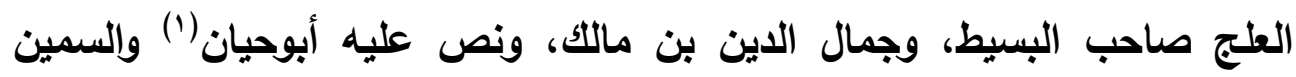

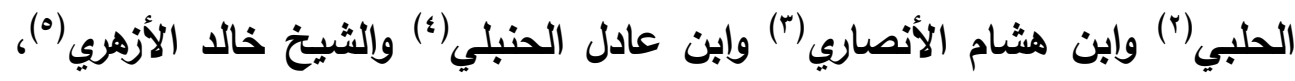

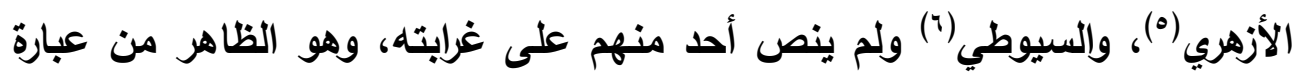

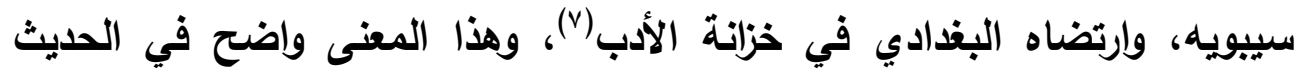

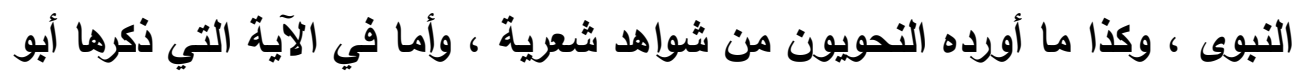

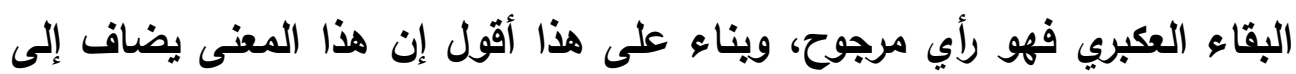

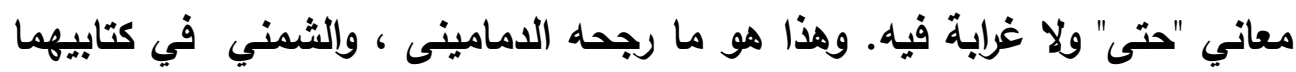

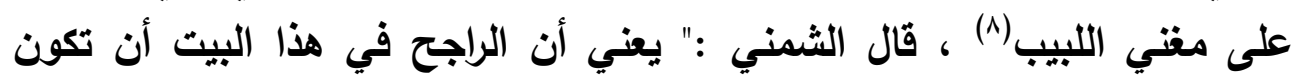

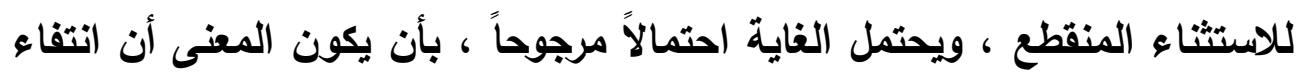

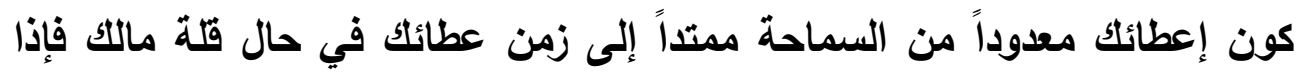

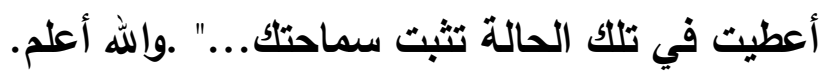

$$
\begin{aligned}
& \text { (1) ينظر:البحر المحيط / / • بr. }
\end{aligned}
$$

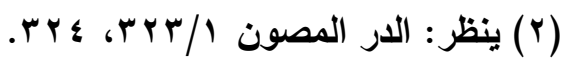

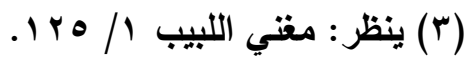

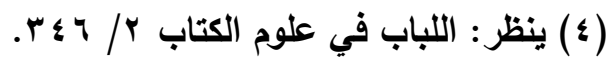

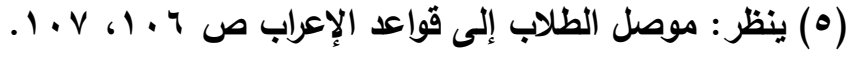

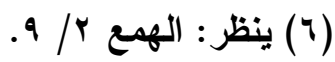

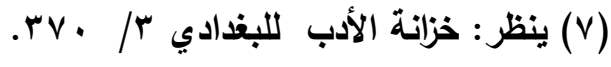

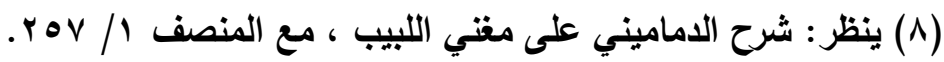


فصل المقال في الغريب من الأقوال النحوية والتصريفية د البدالرعوف ثابت أحمد عبدالله

\section{اع- عالة الجزم بـ "الم" مشمابهة "لالا" النافية}

قال أبو حيان: (1) " وفي كتاب ابن عطية(؟) تعليل غريب لعمل " لم " الجزم،

قال: وجزمت "لم" ؛ لأنها أشبهت "لا" في التبرئة في أنهما ينفيان، فكما تحذف " لا " تتوين الاسم ، كذلك تحذف " لم" الحركة ، أو العلامة من الفعل. ما نسبه أبو حيان إلى ابن عطية من علة الجزم بـ "لم" سبقه إليه الأخفش، ونقله عنه أبوجعفر النحاس، قال النحاس:(ّ) " قال الأخفش سعيد:"إنما جزموا بلم ؛ ؛ لأنها نفي، فأشبهت "لا " في قولك: لا رجل في الار، فذذت بها الحركة، كما حذفت التنوين من الأسماء، وقال غيره: جزمت بها ؛ لأنها أشبهت "إن" التي للشرط ؛ لأنها ترد المستقبل إلى الماضي، كما ترد "أن"، فنحتاج إلى جواب، فأثبهت الابتداء، والابتداء يلحق به الأسماء الرفع، وهو أولى بالأسماء." ، وقال أبو البقاء:

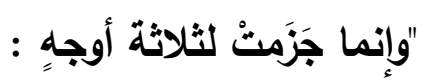

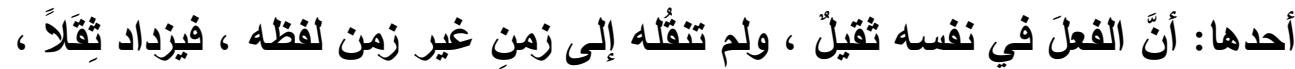

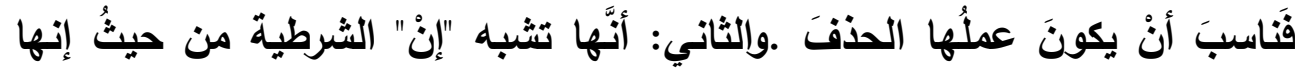

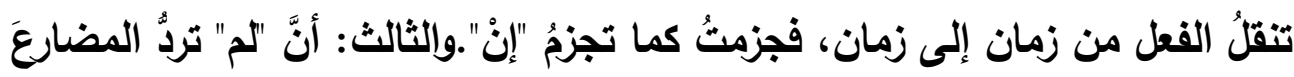
إلى معنى المضيّ، فالفعلُ باعتبارِ لفظه يستحقُّ الحركةَّة الإعرابية، وياعتبار معناه

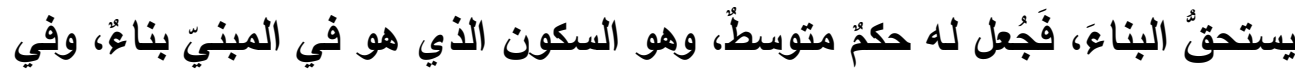

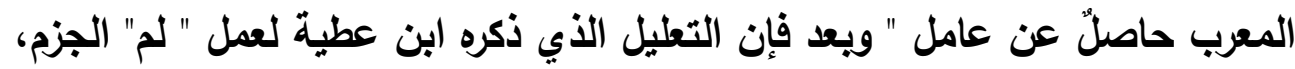

لم ينفرد به ، وإنما سبقه إليه الأخفش ، وتبعه أبو جعفر النحاس. والله أعلم .

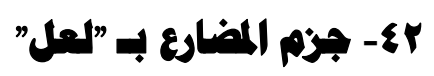

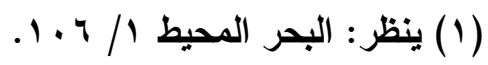

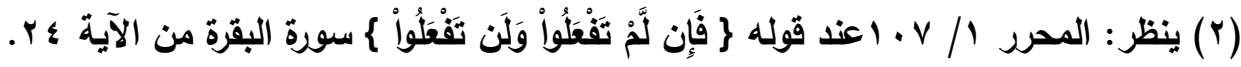

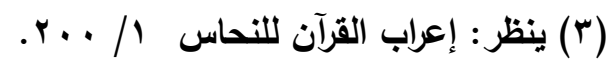

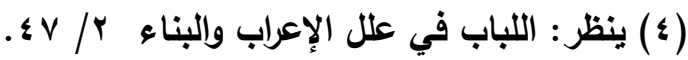


فصل المقال في الغريب من الأقوال النحوية والتصريفية د/ عبدالرعوف ثابت أحمد عبدالله

قال أبوحيان:(')وجزم المضارع بعد الترجي غريب جداً،والقياس يقبله قال الثاعر(؟)

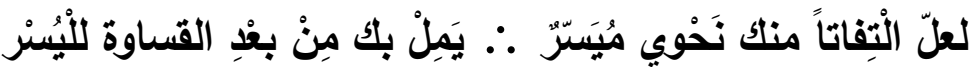
هذا القول نقله أبو حيان، وابن هشام، (־) وناظر الجيش(؛)عن ابن مالك، ووسموه بالغريب. ففي "شرح عمدة الحافظ"(ه)، قال:" وقل من يذكر للترجي جواباً منصوياً مع ائ الفاء ، ومجزوماً دون القاء ويشهر للجزم قول الثاعر:

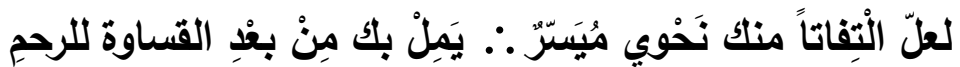
ووجه غرابته كما قال البغدادي(؟): إنه لا يعرف لغير ابن مالك، ولكن صريح كلام الرضي(v) يشمله فإنه قال:" اعلم أن كل ما يجاب بالقاء فينتصب المضارع بعد بعد الفاء، يصح أن يجاب بمضارع مجزوم، إلا النفي، لأن غير النفي منها: طلب، والنفي خبر محض، والطلب أظهر في تضمن معنى الثرط، إذا ذكر بعده ما يصلح للجزاء من الخبر."، ألحق الفراء الترجّي بالتمني، فأجاز نصب الفعل المضارع

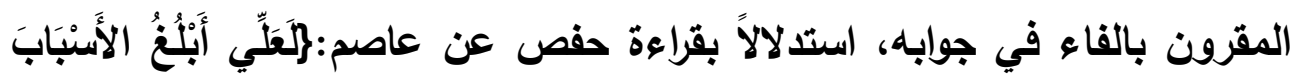

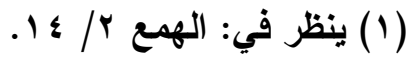

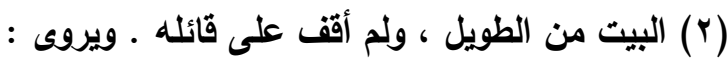

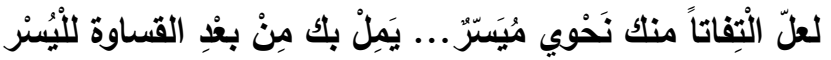

والثاهد : قوله" يملْ " حيث جزم الفعل بـ" لعل" عند سقوط الفاء.

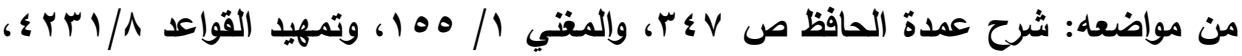

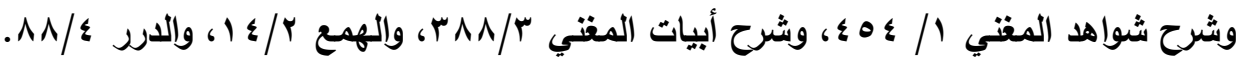

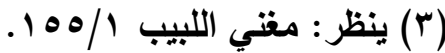

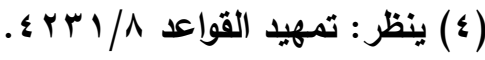

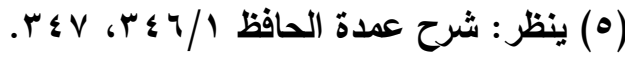

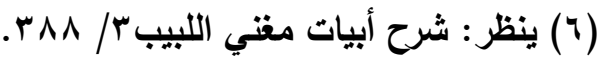

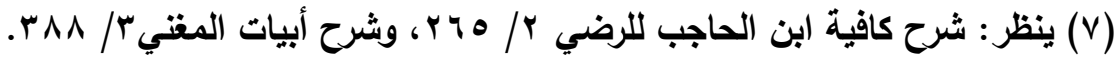




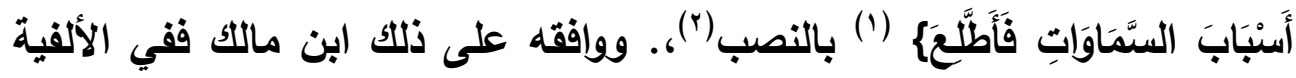

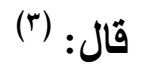

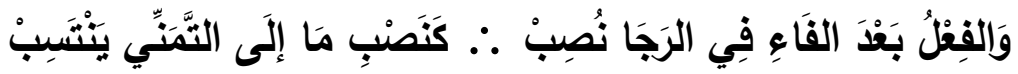

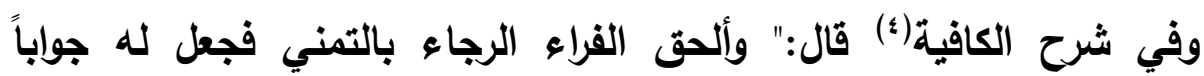

منصوياً ، ويقوله أقول؛ لثبوت ذلك سماعاً..."ومذهب البصريين أن الترجي ليس له

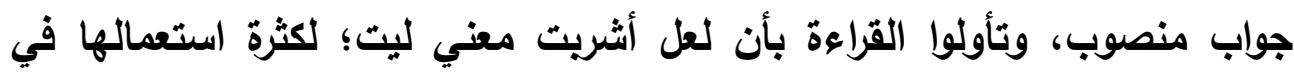

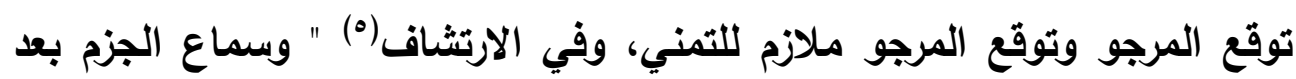
الترجي يدل على صحة مذهب الفراء ومن واقفقه من الكوفيين.

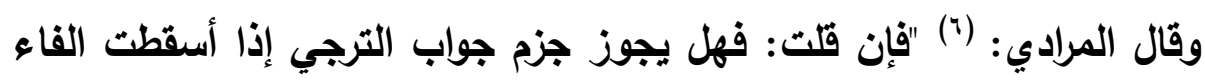

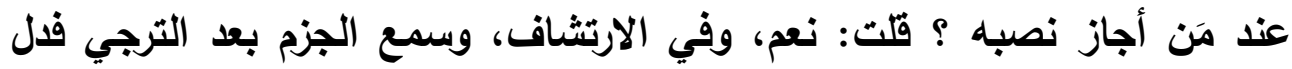

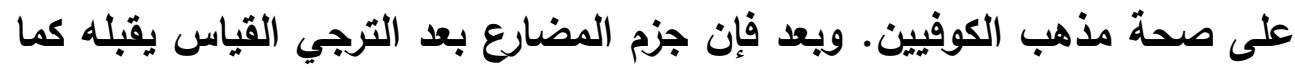

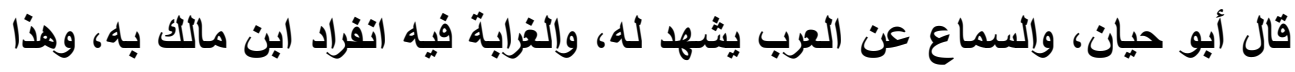
يعد من بدائع ابن مالك - رحمة الله عليه - والله أعلم.

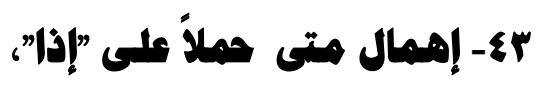

(1) سورة غافر من الآية بكا، ومن الآية Vr.

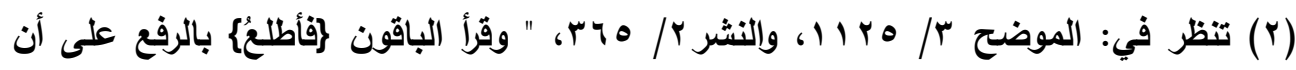
الفعل معطوف على \} أبلغئُ .

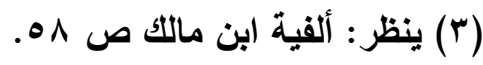

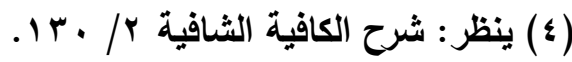

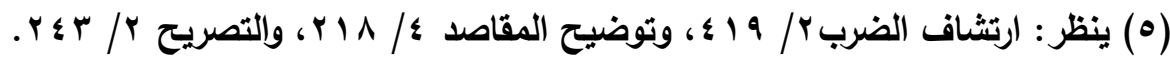

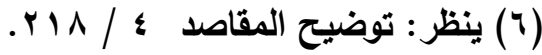


قال ابن مالك في التسهيل:(') "وتهمل متى حملاً على"إذا"، وفي" شواهد

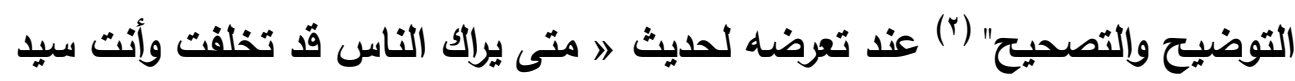

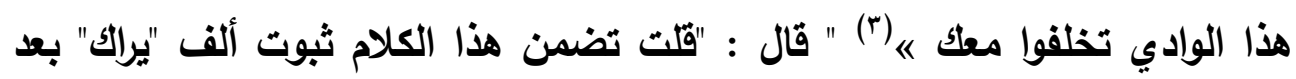

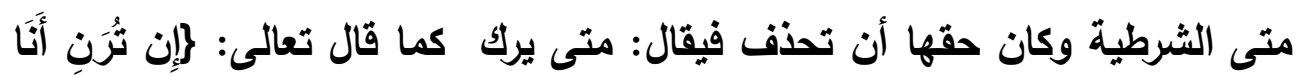

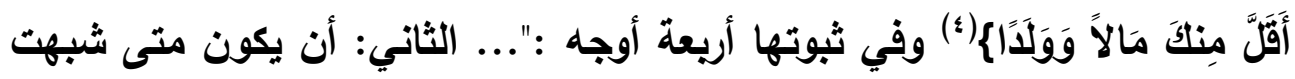

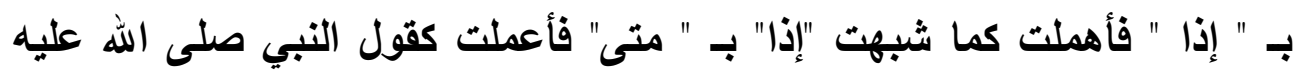

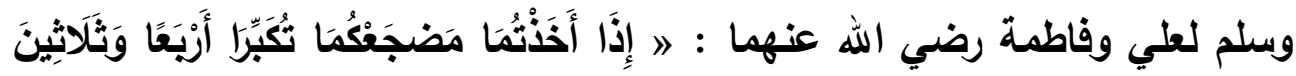

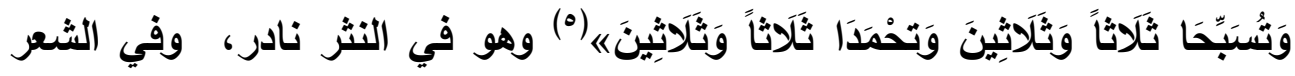

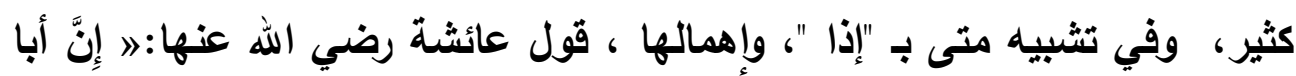

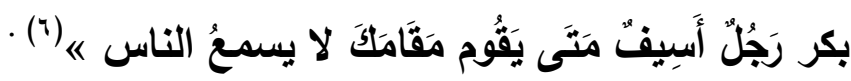

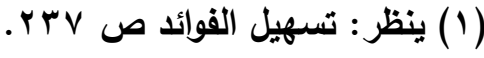

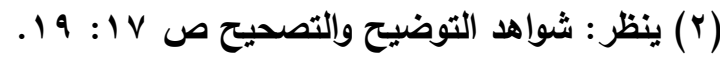

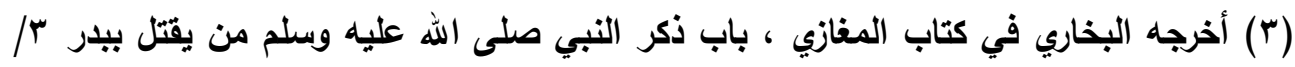

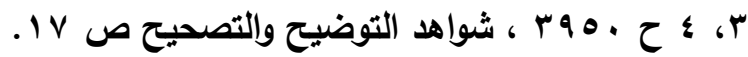

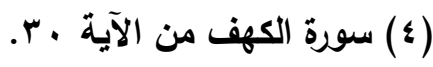
(0) أخرجه الإمام البخاري في كتاب فضائل أصحاب النبي صلى الله عليه وسلم باب مناقب علي الابه

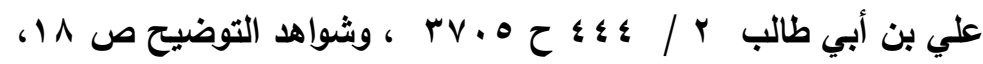

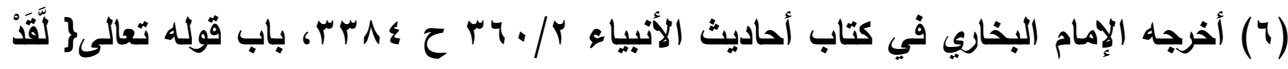

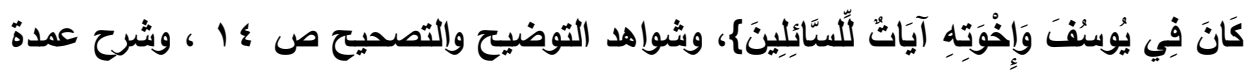

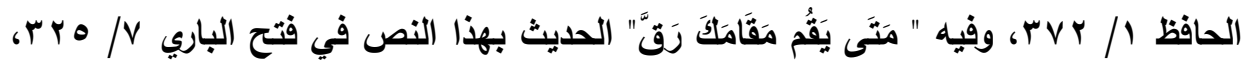

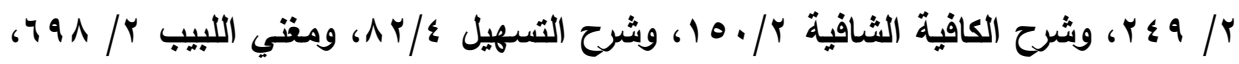

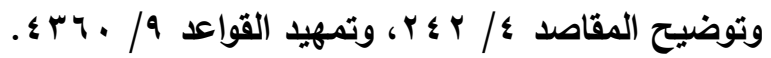


فصل المقال في الغريب من الأقوال النحوية والتصريفية د / عبدالرعوف ثابت أحمد عبدالله

وفي شرح الكافية الثافية:(') "[وشذ إهمال "متى" حملا على "إذا". واستثل

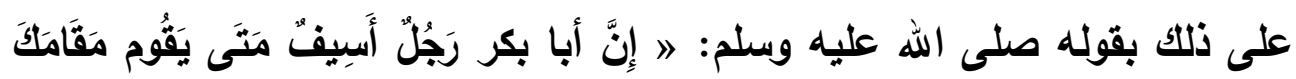
رَقَّ « .

ووسم بدر الدين بن مالك في تكملة "ثرح التسهيل(†)هذا الرأي بالغريب

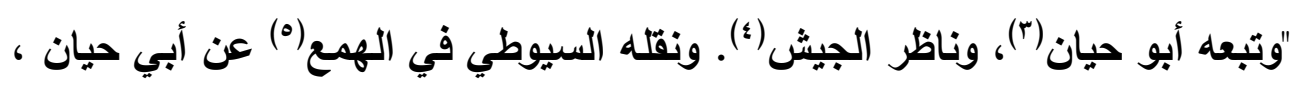

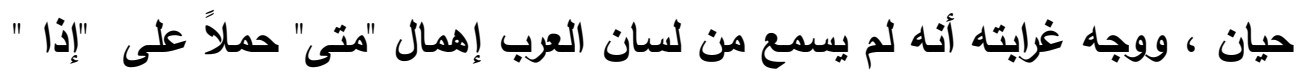

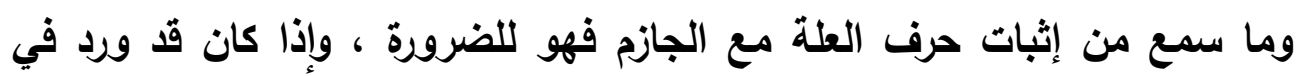

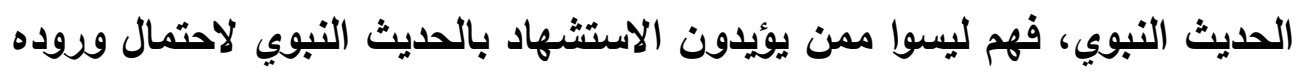
بالمعنى ، وهي قضية خلاف بين النحويين.

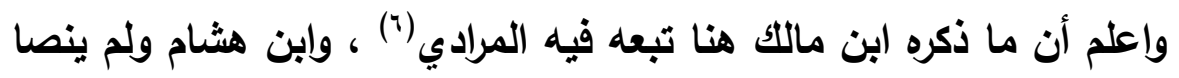

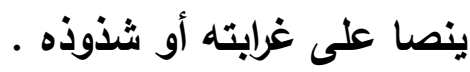

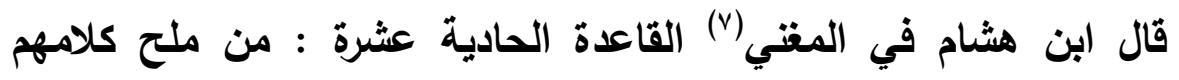
تقارض اللفظين في الأحكام ولذلك أمثله مئ فئ فئ

(1) ينظر : شرح الكافية الثافية r/ / • 10.

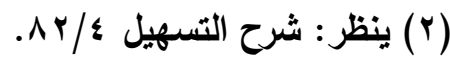

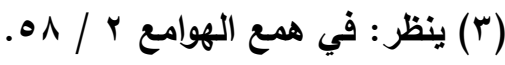

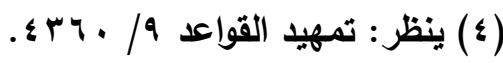

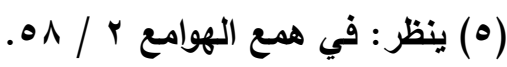

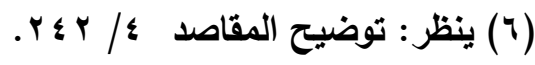

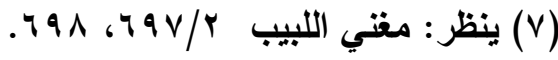


فصل المقال في الغريب من الأقوال النحوية والتصريفية د / عبدالرعوف ثابت أحمد عبدالله

\section{الرابع منها: إعطاء إذا حكم متى في الجزم بها كقوله:(')}

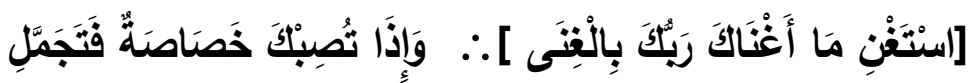
وإهمال متى حكما لها بحكم إذا كقول عائشة - رضي الله تعالى عنها - "وأنها مَتَّى

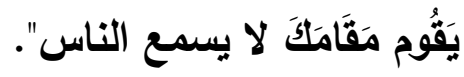
وقال الحافظ بن حجر في فتح الباري:(؟)" قوله: "متى يقوم" كذا وقع للأكثر في الموضعين بإثبات الواو، ووجهه ابن مالك بأنه شبه متى بـ "إذا" فلم تجزم، كما

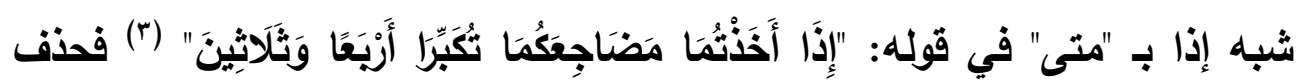
النون. ووقع في رواية الكشميهي متى ما يقم ولا إثكال فيها". وقال الكفوي:(؛) "قلد يشبه متى بـ"إذا" فلم يجزم كما يشبه "إذا" بـ "متى" في قوله: "إذا أخذتما مضاجعكا فكبرا أربعاً وثثلاثين" ويناء على الوارد في الحديث النبوي يكون إهمال متى ليس غريباً، وإنما هو من باب التقارض بين اللفظين كما ذكر ابن مالك ، وابن هشام، ومن تبعهما . والله أعلم.

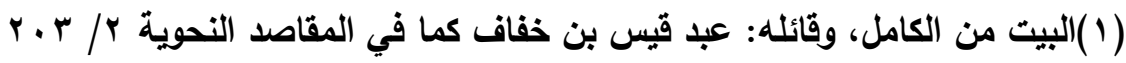

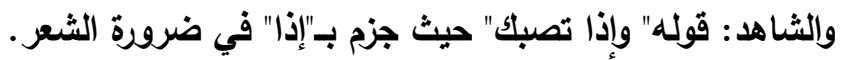

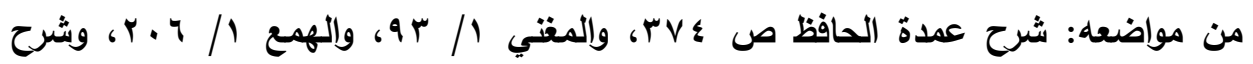

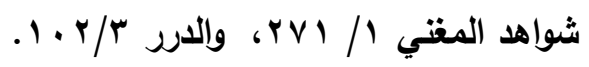

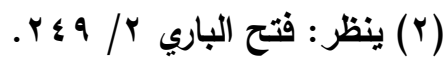

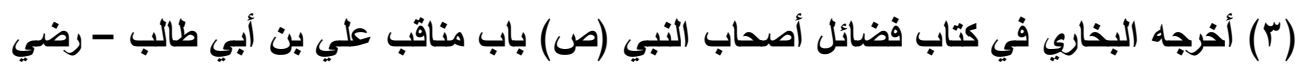

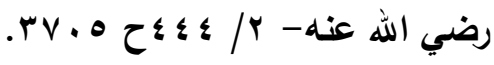

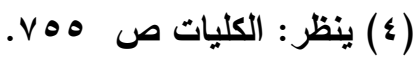


فصل المقال في الغريب من الأقوال النحوية والتصريفية د / عبدالرعوف ثابت أحمد عبدالله

\section{عـ- خروة "مهما " عن الإسمية إلى المرفية}

زعم السهيلي(') أن "مهما" قد تخرج عن الإسمية ، وتكون حرفاً إذا لم يعد

عليها من الجملة ضمير، كقول زهير: (r)

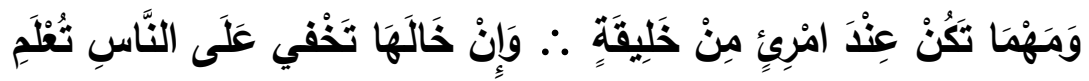

قال المرادي:(ّ) وهو قول غريب". ووجه الغرابة هنا مخالقته لجمهور

النحويين، قال السمين:(؛) " وشَذَّ السهيليُّ فزعم أنها قد تأتي حرفاً ".لأن جمهور النحويين يرون أن "مهما " اسم شرط جازم في معنى "ما" أو "إن" والدليل على اسميتها عود الضمير عليها، قال ابن يعيش:(ه)" والاليل على أن "مهما" فيها فئ

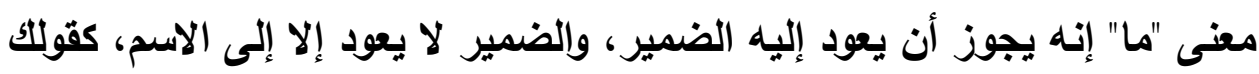

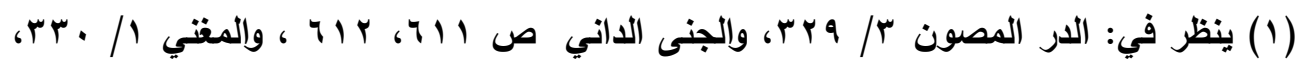

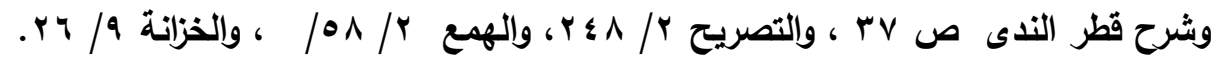

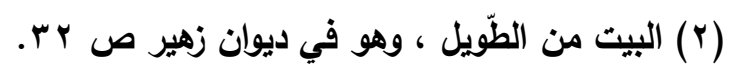

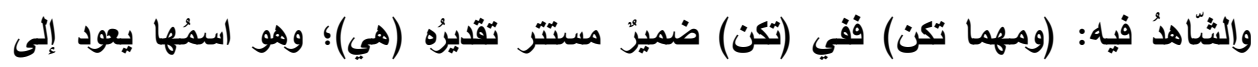

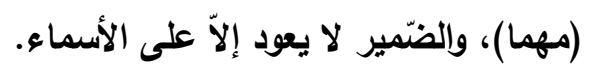

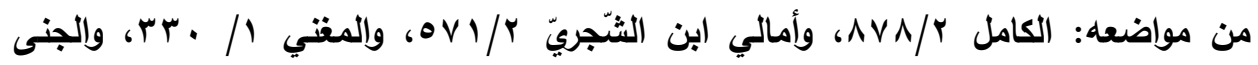

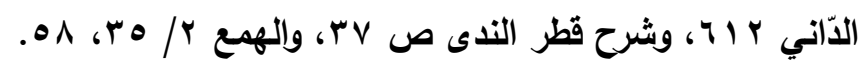

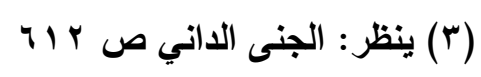

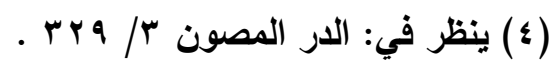

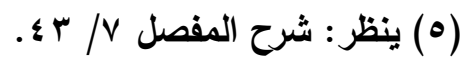


فصل المقال في الغريب من الأقوال النحوية والتصريفية د / عبدالرعوف ثابت أحمد عبدالله

: مهما تعمل من صالح تجاز عليه، فالهاء في عليه يعود إلى مهما، وقال

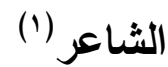

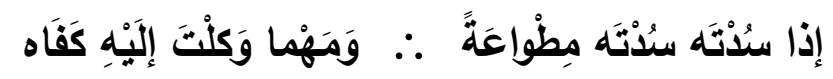

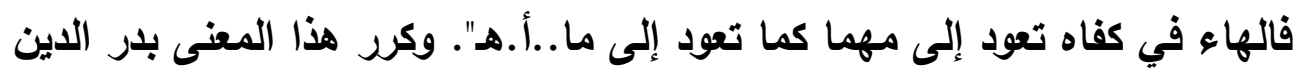

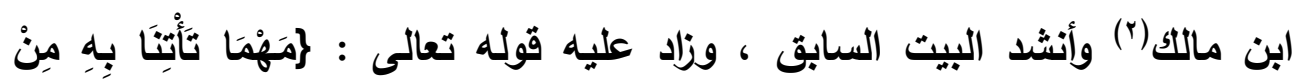

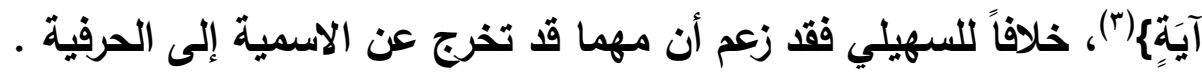

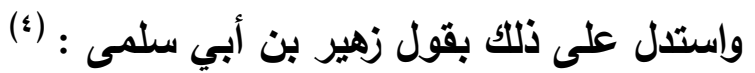

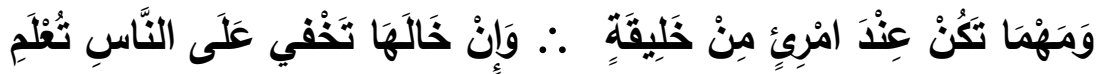

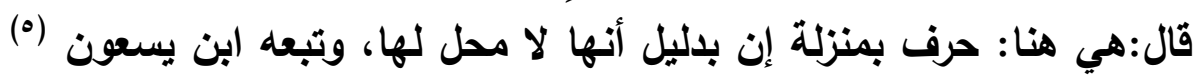

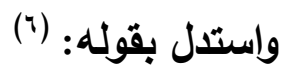

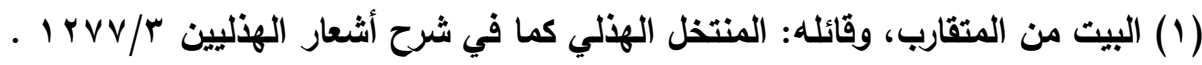

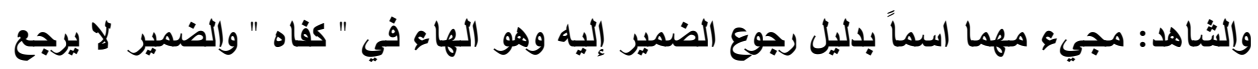

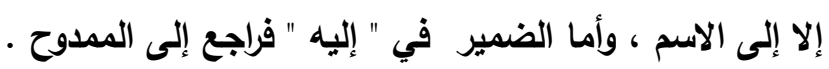

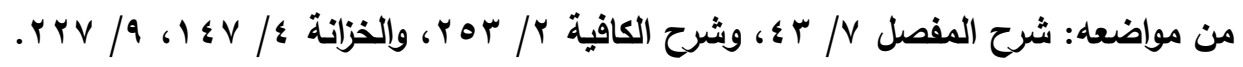

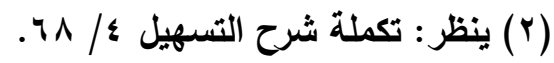

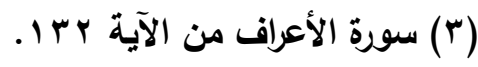

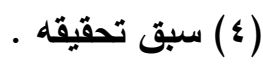

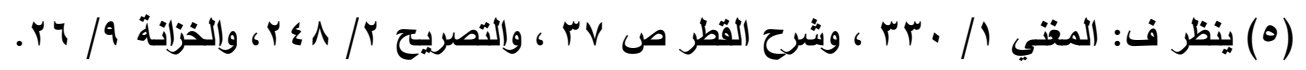
.r4

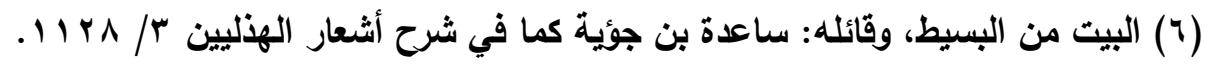

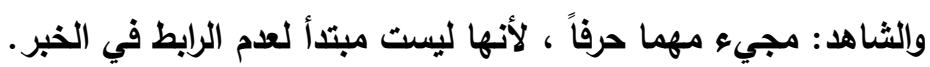

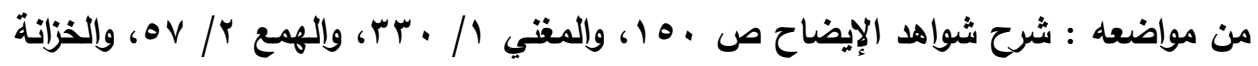

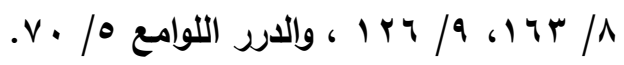


فصل المقال في الغريب من الأقوال النحوية والتصريفية د / عبدالرعوف ثابت أحمد عبدالله

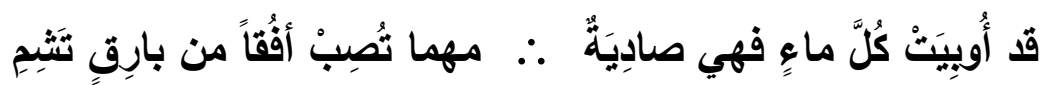
قال:لا تكون مبتدأ ؛ لعدم رابط من الخبر وهو فعل الشرط ولا مفعولاً لاستيفاء فعل الشرط مفعوله. ولا سبيل إلى غيرهما فتعين أنها لا موضع لها." وسبقهما إلى القول بهذا خطاب ألماردي(1)، واعلم أن التحويين (؟).اختلفوا في "مهما": هل هي بسيطة

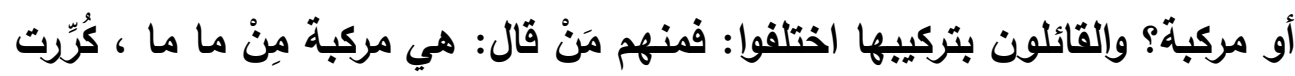

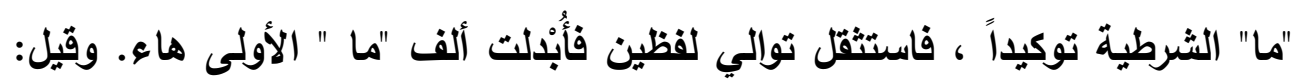

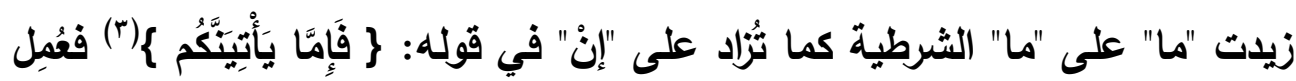
العمل المذكور للثقل الحاصل. وهذا قول الخليل(๕) وأتباعه من أهل البصرة. وقال قوم: "هي مركبة مِنْ : مَلْه، التي هي اسمُ فعلٍ بمعنى الزجر وما الشرطية ، ثم رُكِّبت

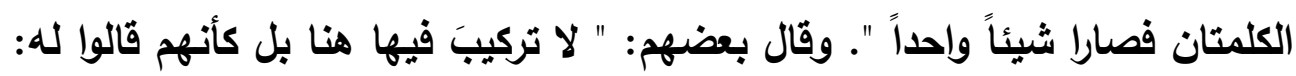

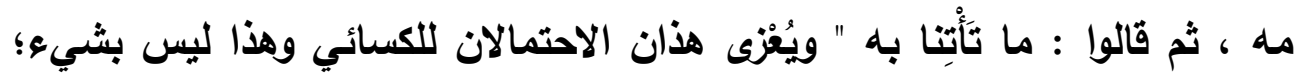
لأن ذلك قد يأتي في موضعِ لا زَجْرَ فيه، ولأن كتابتها متصلة ينفي كونَ كلٍ منهما كلمةًَ مستقلة ، وقال قوم: إنها مركبة من: مَهْ، بمعنى: اكفف، ومَنْ الشرطية، بدليل

قول الشاعر: (•)

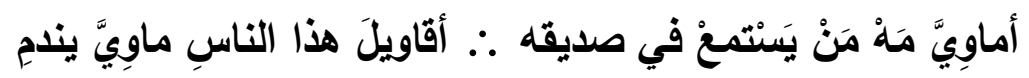

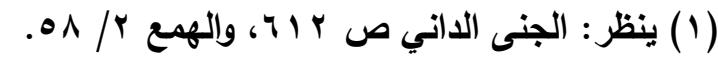

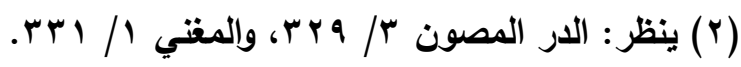

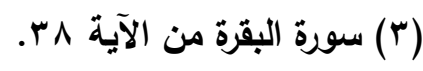

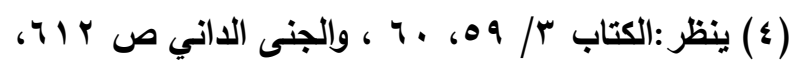
(0) البيتُ من الطّويل، ولم أقف على قائله.

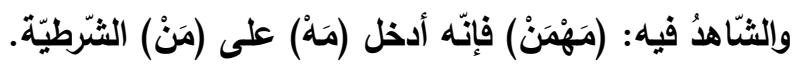

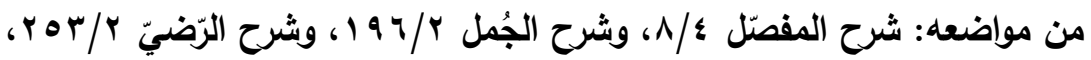


فصل المقال في الغريب من الأقوال النحوية والتصريفية د / عبدالرعوف ثابت أحمد عبدالله

فَأُبْدِتَتْ نونُ "مَنْ" ألفاً، كما تبدل النونُ الخفيفة بعد فتحة، والتتوين ألفاً. وهذا

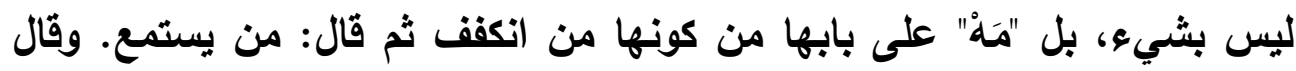

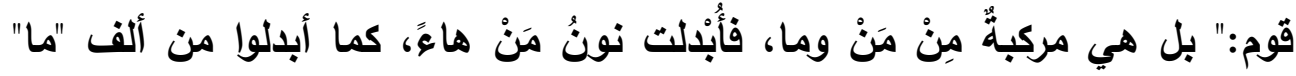

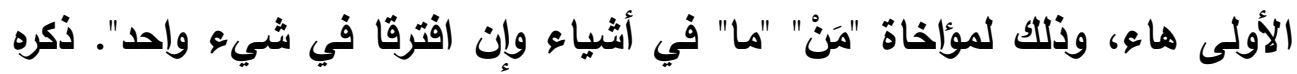
مكي.

ويعد فقد اتضح أن وجه غرابة القول بحرفية "مهما" كما قال السهيلي، ومن

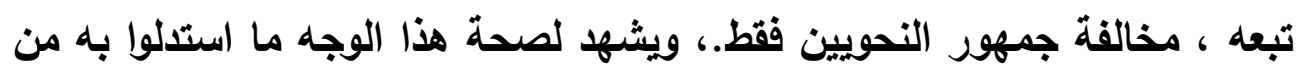

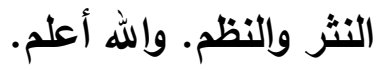


فصل المقال في الغريب من الأقوال النحوية والتصريفية د / عبدالرعوف ثابت أحمد عبدالله

\section{ع - جواب " له" فمل تعمب مقرونك باللامه،

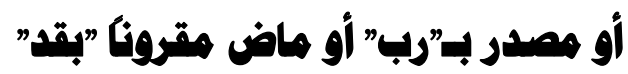

قال أبو حيان:(') "ومن غريب ما وقع جواب دل "لو" فعل تعجب بصيغة أفعل"

مقروناً باللام قال الثاعر: (r)

فلو متُ في قومي ولم آتِ عجزةً . يضعقني فيها امروٌٌ غيرَ عادلِ لأكرم بها من ميتةٍ إن لقيتها ـ.

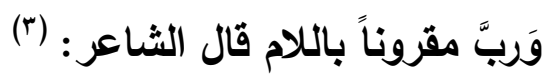

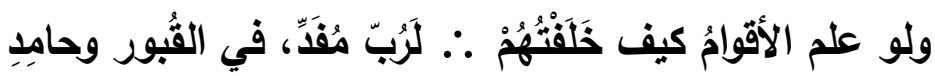

وقال ابن هشام:(؛)" وقد ورد جواب لو الماضي مقروناً بقد، وهو غريب، كقوله(ه)

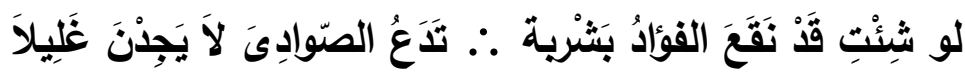

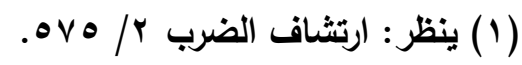

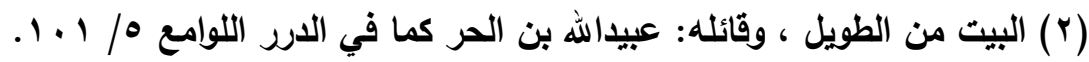

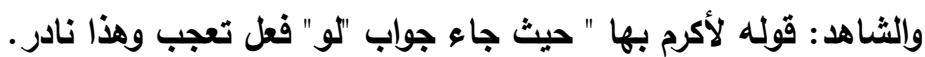

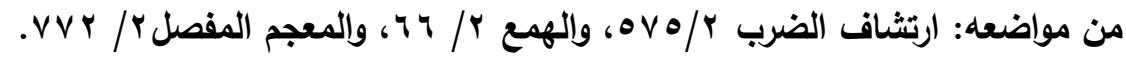

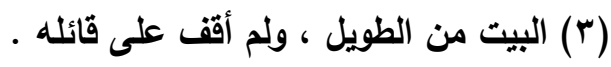

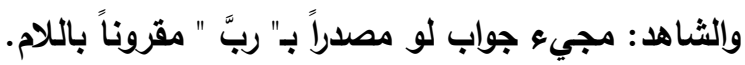

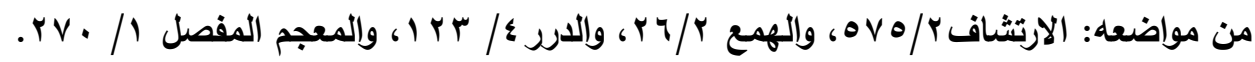

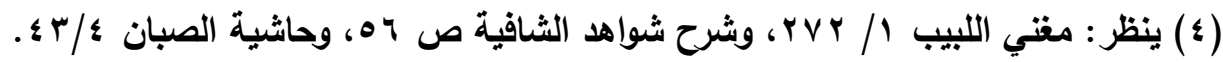

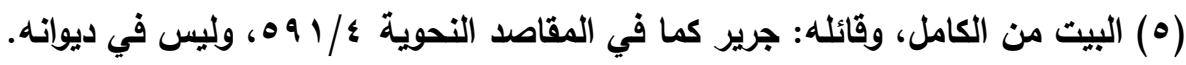

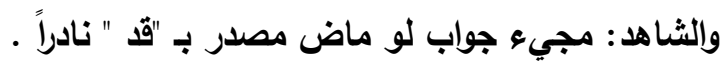

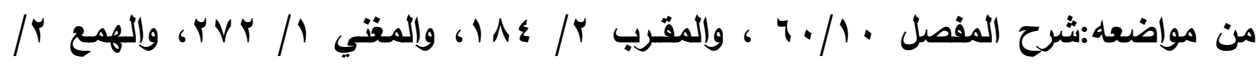


فصل المقال في الغريب من الأقوال النحوية والتصريفية د / عبدالرعوف ثابت أحمد عبدالله

ووجه الغرابة في هذه الأجوية ؛ قلة الاستعمال وندرته، ولهذا عدها السيوطي

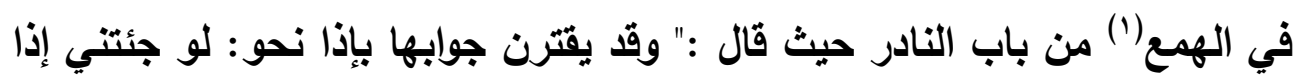
لأكرمتك ، وندر كونه تعجباً مقروناً باللام وأنشد: "لأكرم بها.." البيت السابق. ثم بـ

قال: وندر كونه مصدراً برب أو الفاء كقوله: (ץ)

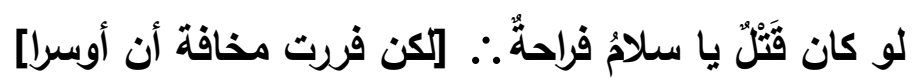

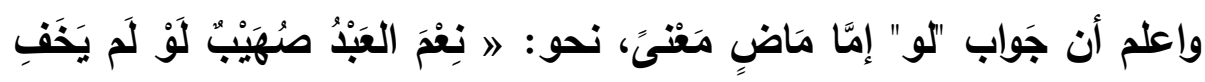

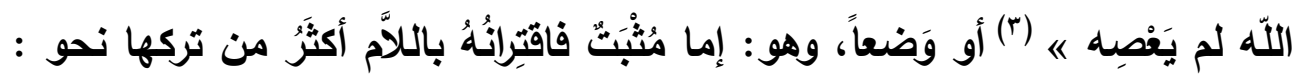

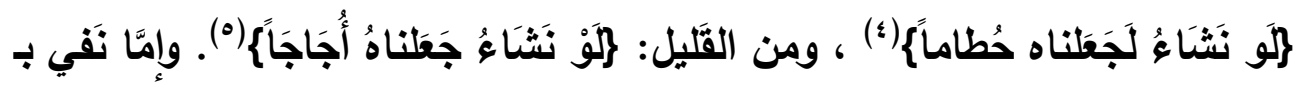

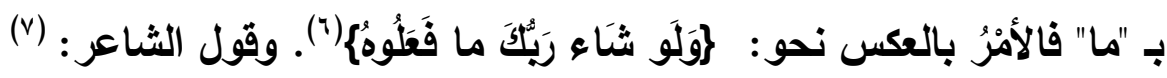

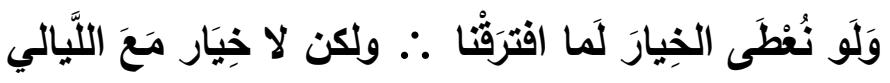

$$
\begin{aligned}
& \text { (1) ينظر: الهمع r/ (1) }
\end{aligned}
$$

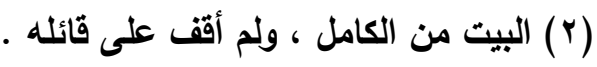

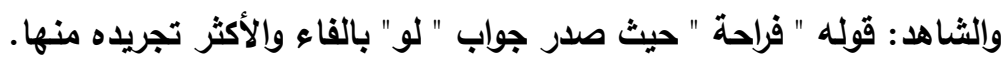

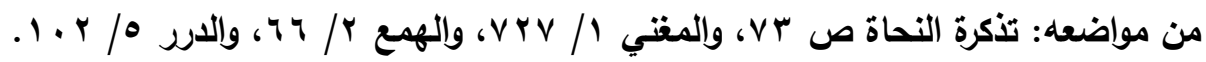

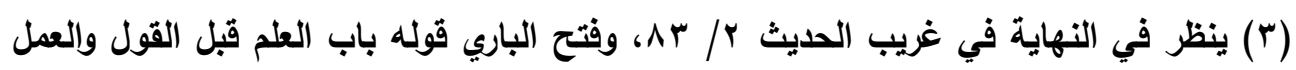

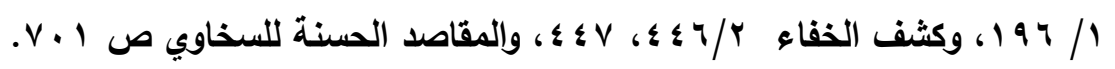

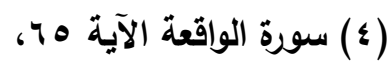

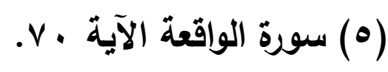

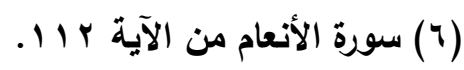

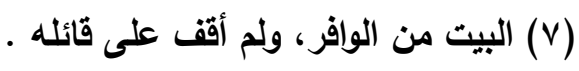
والثاهد: قوله " لما افترقنا" حيث وقع جواب "لو" فعلا ماضياً منفياً بـ" ما" ومقترناً باللام وهذا

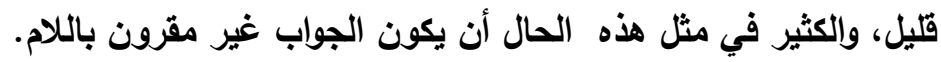

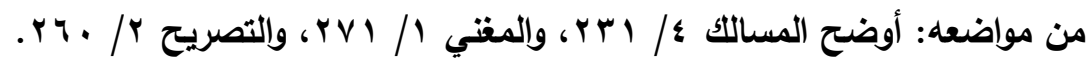




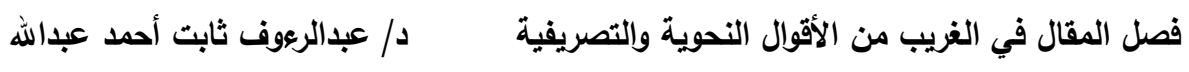

ويعد فإن مجيء جواب "لو" فعل تعجب بصيغة " أفعل"مقروناً باللام، أو

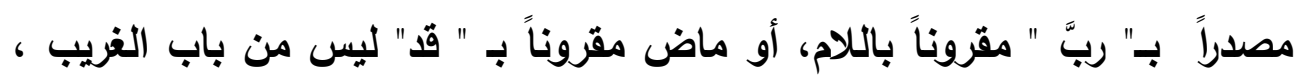
وإنما هو من باب القليل النادر الأي يحفظ ولا يقاس عليه. والله أعلم. 
فصل المقال في الغريب من الأقوال النحوية والتصريفية د/ عبدالرعوف ثابت أحمد عبدالله

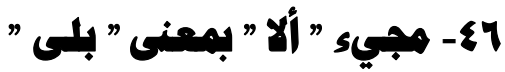

قال المالقي: (1) "الموضع الثالث من مواضع " ألا": تكون جواباً ، وهو

قليل ، فيقول القائل : ألم تقم ؟ ألم تخرج ؟ فتقول: ألا ، وهو شاذ بمعنى: بلى ."

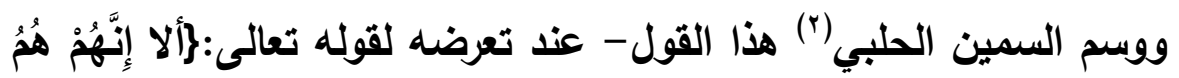
المفسدونج(ّ)- بالغريب حيث قال: "... وأجاز بعضُهم أن تكون جواباً بمعنى: بلى ، يقول القائل : لم يقم زيل ، فتقول : ألا ، بمعنى بلى قد قام ، وهو غريب . ووجه غرابته أنه لم يقل به غير المالقي من المتقدمين ، وقلة استعماله.

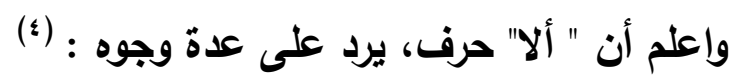

الأول: التنبيه والاستفتاح. وهي تلخل على الجملة الإسمية، نحو: \} أَلا إِنَّ أَوْلِيَاء

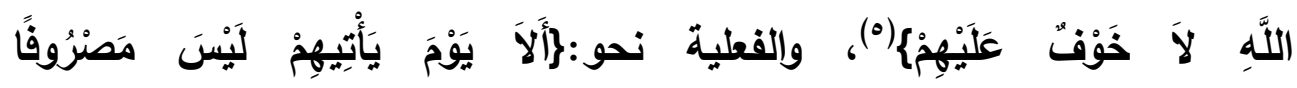
عَنْهُمْ\{(").وعلامتها صحة الكلام بدونها. واختلف فيها: أهي مركبة أم بسيطةٌ فقيل: فقيل: مركبة من همزة الاستفهام ولا النافية. وإليه ذهب الزمخشري.(v) وقيل: هي بسيطة. وإليه ذهب ابن مالك(^). ورد أبو حيان(9) دعوى التركيب، بأن الأصل

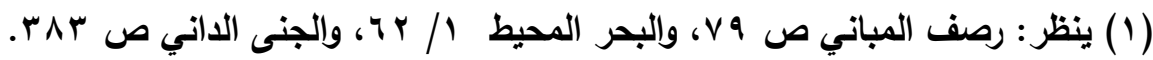

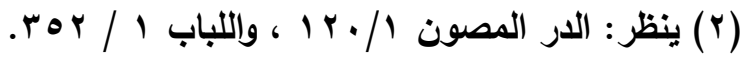

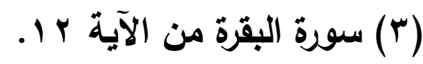

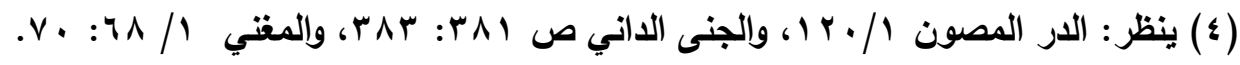

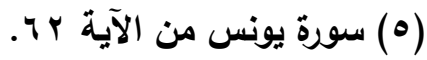

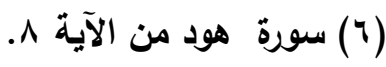

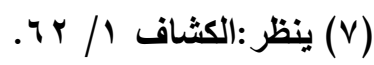

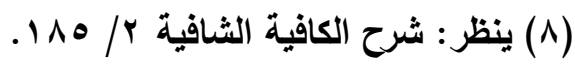

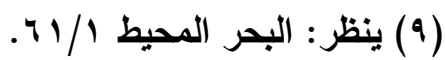


فصل المقال في الغريب من الأقوال النحوية والتصريفية د / عبدالرعوف ثابت أحمد عبدالله

عدمه، ويأنها قد وقعت قبل إن ، ورب ، وليت والنداء، ولا يصلح النفي قبل شيء من ذلك. الثاني: العرض والتحضيض، ومعناها طلب الشيء، والفرق بينهما أن العرض طلب بلين والتحضيض طلب بحثٍ. وهذه مختصة بالأفعال، نحو: ألا تنزل عندنا فتحدث.

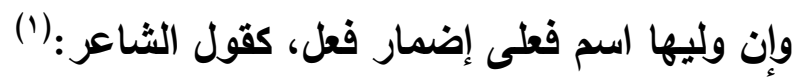

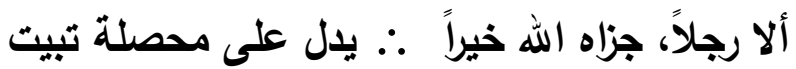
التقدير: ألا تروني رجلاً. هذا قول الخليل(ז) وقال يونس: إنه أراد: ألا رجل، فنون مضطراً... وألا هذه مركبة. قال ابن مالك: (َ) "ألا" التي للعرض مركبة من لا النافية

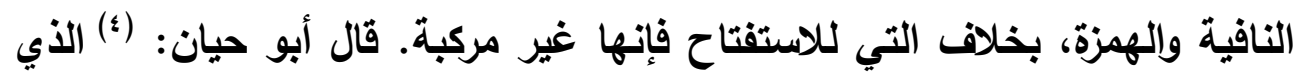
أذهب إليه أنها بسيطة. قال المرادي: (ه) وهو ظاهر كلام صاحب رصف المباني. الثالث: التمني فتجري مجرى ليت في بعض أحكامها، ومن ذلك قول الثاعر: (؟)

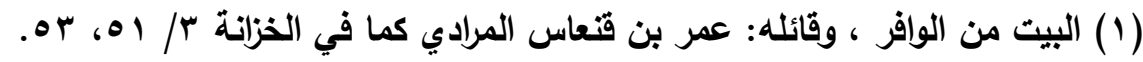

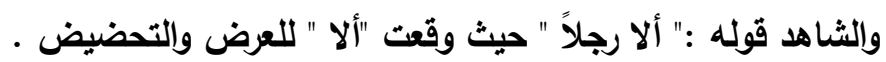

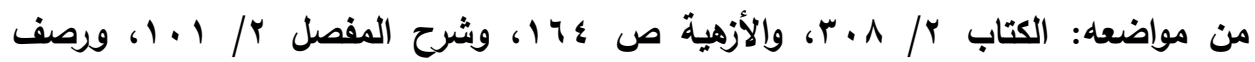

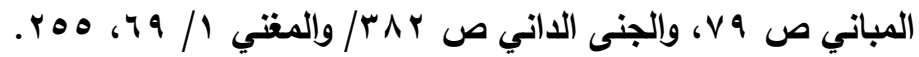

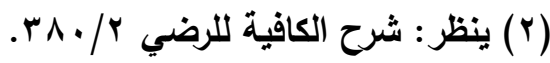

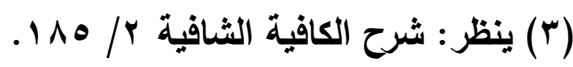

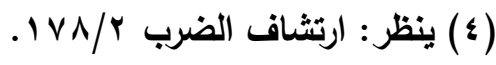

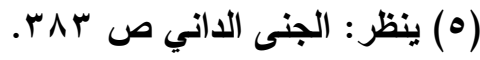

$$
\begin{aligned}
& \text { (7) البيت من الطويل ، ولم أقف على قائله. }
\end{aligned}
$$

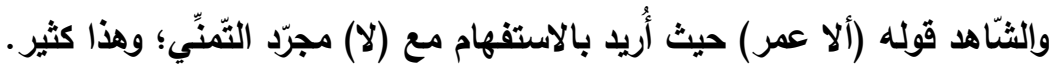

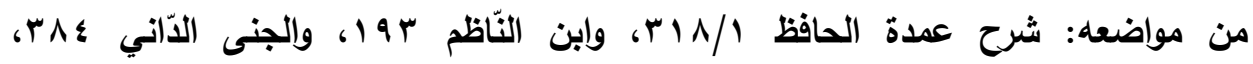

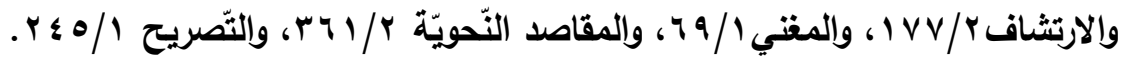


فصل المقال في الغريب من الأقوال النحوية والتصريفية د / عبدالرعوف ثابت أحمد عبدالله

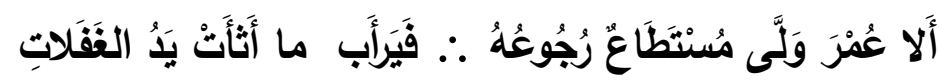

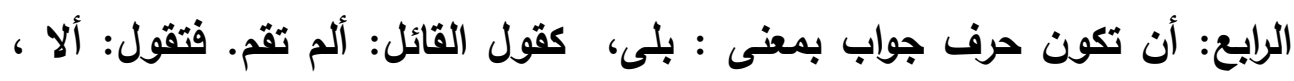

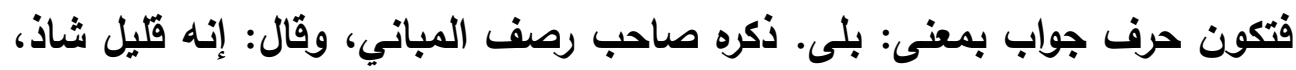

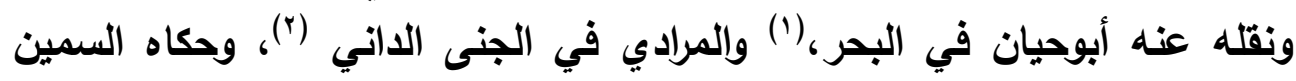
الحلبي في الار المصون (ث) ونعته بالغريب.

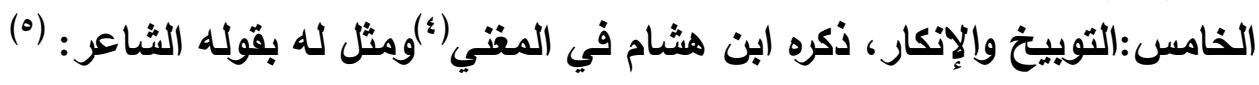

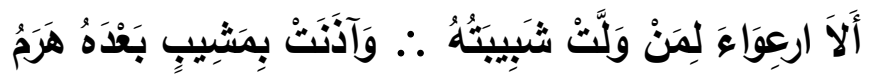

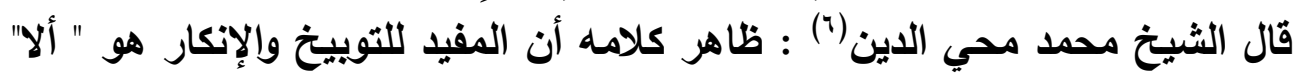

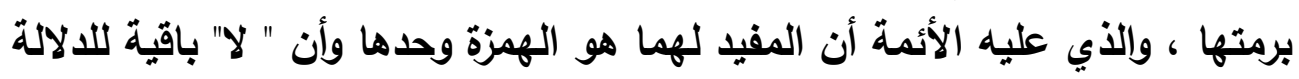

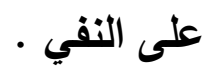

ويعد فقا اتضح أن مجيء "ألا" بمعنى :"بلى" هو وجه من وجوه استعمالات

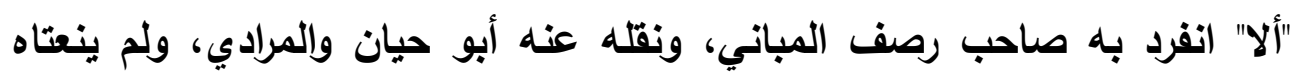

$$
\begin{aligned}
& \text { (1) ينظر: البحر المحيط / / ب T. }
\end{aligned}
$$

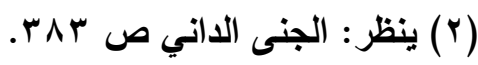

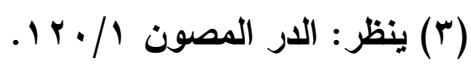

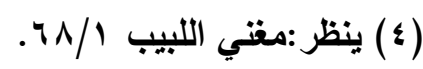

(0) (البيت من البسيط، ولم أقف على قائله.

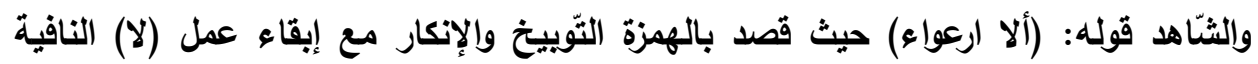

للجنس كما لو كانت مجرّدة من الهمزة.

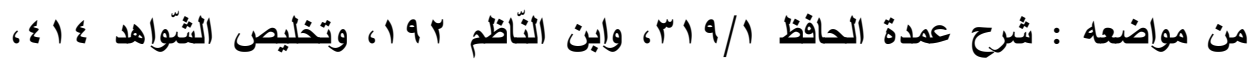

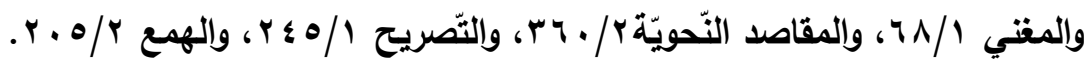

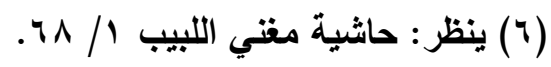


فصل المقال في الغريب من الأقوال النحوية والتصريفية د البدالرعوف ثابت أحمد عبدالله

بالغريب، وإنما هو قليل الاستعمال كما ذكر المالقي، ولعل هذا هو ما دعى السمين الحلبي إلى نعته بالغزيب .والله اعلم.

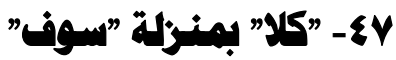

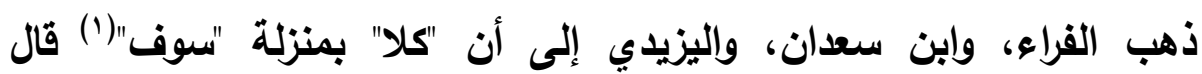

أبوحيان: (ץ) "هذا مذهب غريب." وتبعه في ذلك ناظر الجيش. (־)

وذكر هذا المذهب القرطبي ، وابن الجزري في التمهيد (؛)، وحكاه المرادي (•)، (•)، والسيوطي في "الإتقان"(") ولم يصفه أحد منهم بالغريب.

قال القرطبي: (v) "وقال القراء: (كَلَّلج\{ بمنزلة سوف ؛ لأنها صلة وهي حرف رد رد فكأنها "تعم" و"لا" في الاكتقاء ، قال : وإن جعلتها صلة لما بعدها لم تقف عليها كقولك : كلا ورب الكعبة؛ لا تقف على كلا لأنه بمنزلة : إي ورب الكعبة ، قال الله

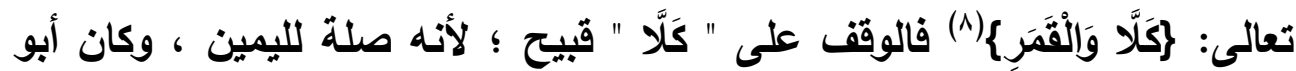
جعر محمد بن سعدان يقول في \}كَلَّلُ مثل قول الفراء.."

واعلم أن ما ذكره الفراء ومن تبعه هو معنى من معان ستة ذكرها النحاة :

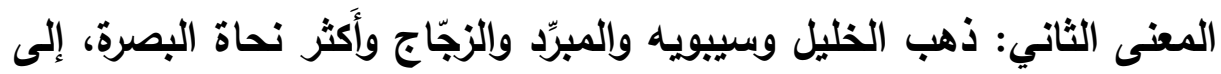
أنها حرف معناه الرَّدّع والزجر، لا معنى لله سواه؛ حتى إنهم يجيزون الوقف عليها

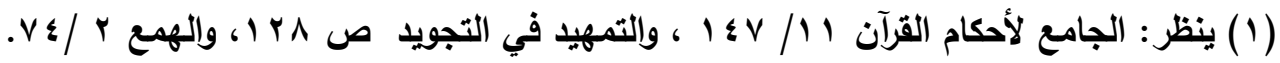

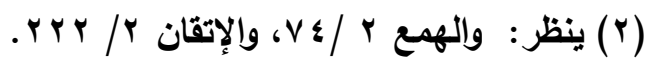

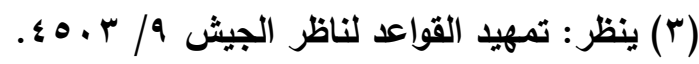

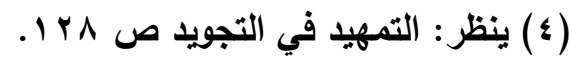

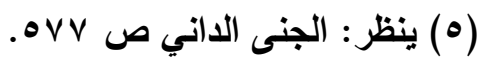

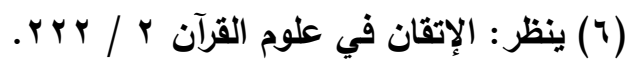

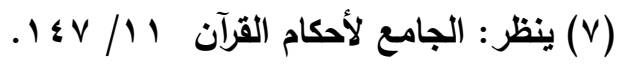

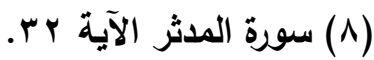


فصل المقال في الغريب من الأقوال النحوية والتصريفية د/ عبدالرعوف ثابت أحمد عبدالله

أَبَداً والابتداءَ بما بعدها، حتى قال بعضهم: إذذا سمعت كَلاَّ في سورة فاحكم بأَنَها

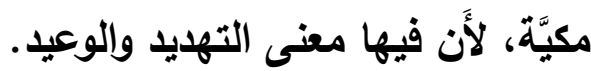
الثالث: أنها تكون بمعنى حقاً وهو مذهب الكسائي، ونصر بن يوسف، وابن واصل،

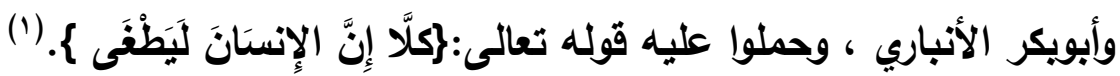
الرابع: أنها حرفُ تصديقِ بمعنى نعم ، فتكون جواباً ، ولا بُدَّ حينئذٍ مِنْ أَنْ يتقدَّمَها شيءُ لفظاً أو تقديراً . وقد تُستتعمل في القسم. وهو مذهب النضر بن شميل (r)،

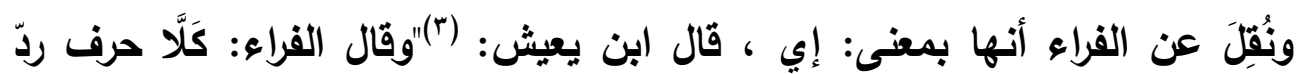
يكتفي بها كنعم ويلى، وتكون صلة لما بعدها كقولك: كَلَّلا ورب الكعبة، بمنزلة إي إئي

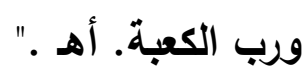
الخامس:أنها حرف استفتاح بمنزلة "ألا" الاستقتاحية التي للتنبيه وهو مذهب أبي حاتم السجستاني، ووافقه الزجاج. السادس: أن تكون رداً لكلام قبلها فيجوز الوقف عليها ، وما بعدها استئناف. ويعد فأن مجيع "كلا " بمنزلة سوف في كونها صلة لما بعدها -وحينئ لا يجوز الوقف عليها- هو معنى من معان ستة ذكرها النحويون ، والفراء ، وابن سعدان ، واليزيلي ، ثلاثة من كبار النحويين · والله أعلم.

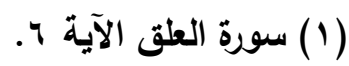

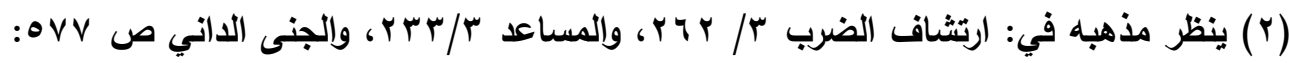
OVV

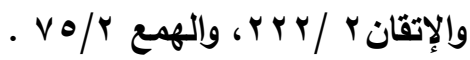

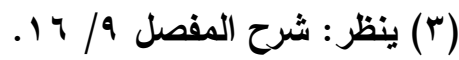


فصل المقال في الغريب من الأقوال النحوية والتصريفية د / عبدالرعوف ثابت أحمد عبدالله

\section{المبمث الثاني \\ الأقوال والآراء التصريفية الغربية}

\section{ا - الفعل اللازم يتعدى بتضعيف اللالم}

حكى أبو حيان (')عن بعض النحويين: أن الفعل اللازم يتعدى بتضعيف اللام

نحو: صعر خده وصعرتيه، ثم وصف هذا القول بالغريب.6ووجه غرابته أن

النحويين نصوا على أن الفعل اللازم يصير متعدياً بتضعيف العين. ففي المغتي(r) وغيره(") يصير اللازم متعديًا بسبعة أشياء :

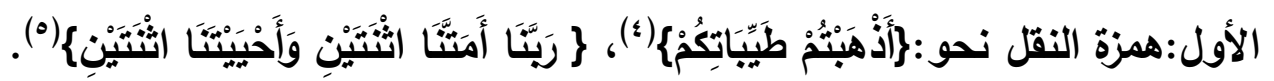
الثاني: تضعيف العين نحو: فرح زيد ، وفرحت زيدًا. وقد اجتمعا في قوله تعالى: \}

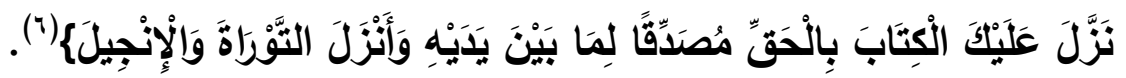
الثالث: المفاعلة تقول في جلس زيد، ومشى وصار: جالست زيدًا وماشيته

وسايرته.

الرابع: استفعل للطلب أو بالنسبة للشيء كاستخرجت المال، واستحسنت زيدًا، واستقبحت الظلم ، وقد ينقل ذا المفعول الواحد إلى اثثين نحو: استكتبته، واستغفرت

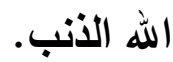

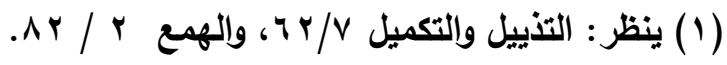

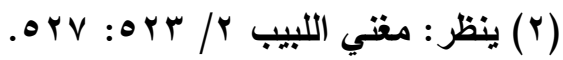

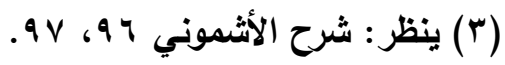

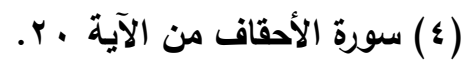

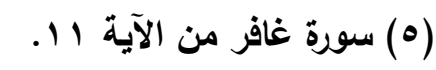

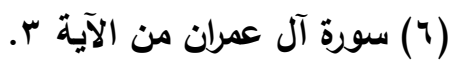


فصل المقال في الغريب من الأقوال النحوية والتصريفية د / عبدالرعوف ثابت أحمد عبدالله

ومنه قوله : (1)

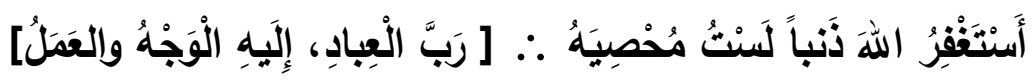

وإنما جاز استغفرت الله من الأنب ؛ لتضمنه معنى استتبث، أي: طلبت التوية. الخامس: صوغ الفعل على فعلت بالفتح أفعل بالضم لإفادة الغلبة تقول : كرمت زيدًا أكرمه ، أي : غلبته في الكرم.

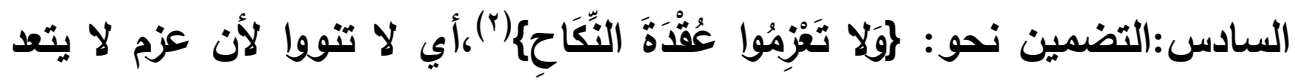
إلا ب"على"، تقول: عزمت على كذا لا عزمت كذا. ومنه رحبتكم الطاعة، وطلع بشر اليمن: أي وسعتكم، ويلغ اليمن.

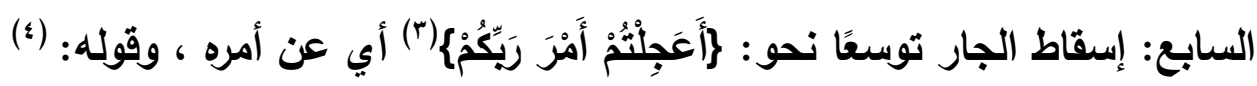

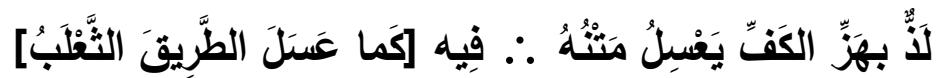

أي من الطرق. وليس انتصابهما على الظرفية، خلافًا للقارسي في الأول، وابن الطراوة في الثاني لعدم الإبهام.، هذا هو المشهور في كتب النحويين غير أني

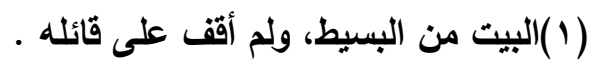

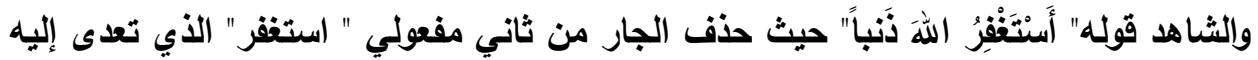
بواسطة الحرف والأصل أستغفر الله من الأنب.

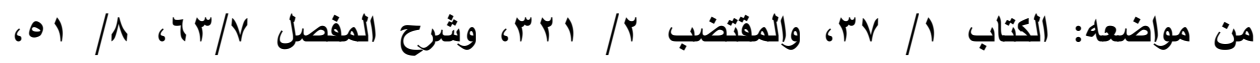

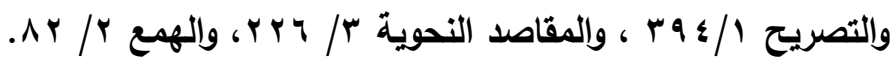

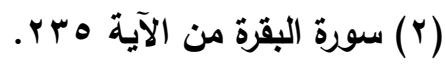

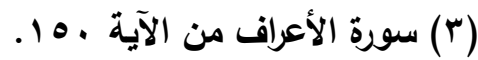

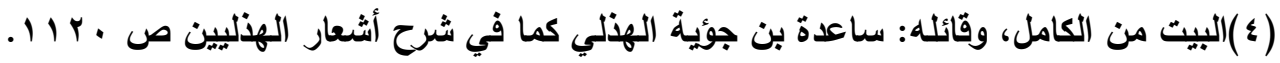
$.11 r$. والثاهد : قوله " عسل الطريق" حيث حذف حرف الجر" في" والأصل كما عسل في الطريق.

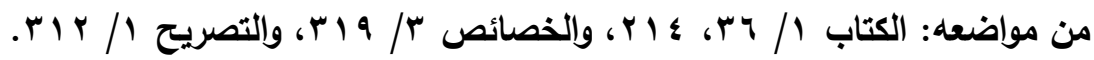


فصل المقال في الغريب من الأقوال النحوية والتصريفية د/ عبدالرعوف ثابت أحمد عبدالله

وجدت سيبويه(1) وابن السراج(r) وابن قتيبة (ץ) نصوا على أن الفعل اللازم قد يصير

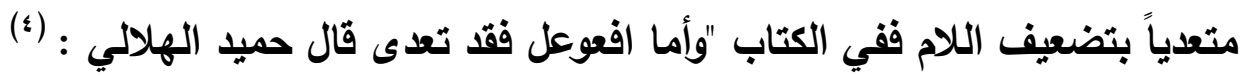

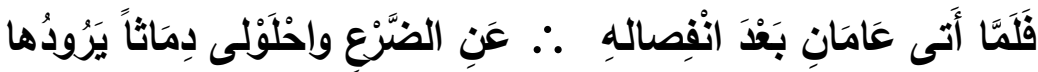
وكذلك افعوَّل قالوا: اعلوطته، وكذلك فعلتنه صعررته ؛ لأنهم أرادوا بناء دحرجته وقال : و

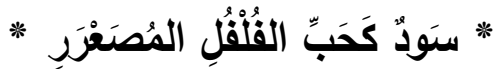

قال الأعلم: (")" المصعرر: وهو اسم المفعول من صعررتُهُ إذا دحرجته فدل هذا على أن فعللت قد يكون لما تعدى". وفي أدب الكاتب:(v) "وفعلَت يتعدى قالوا: "صَمْرَزْتُهُ "فتصعرر وأنشد البيت السابق.ويعد فكيف يكون غريباً وقـ نص عليه أئمة النحاة، ولو قيل: إن التعدي بتضعيف العين أشهر من التعدي بتضعيف التلام

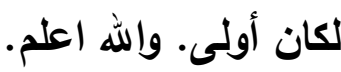

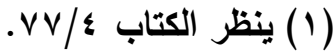

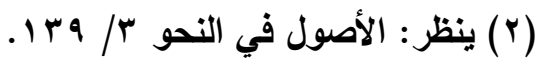

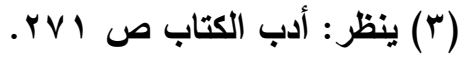

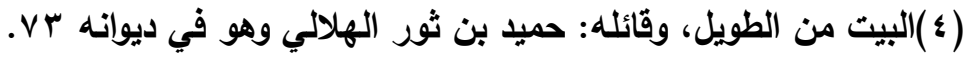

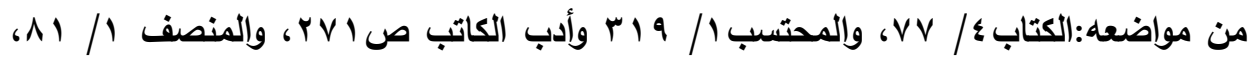

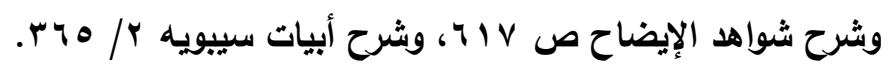

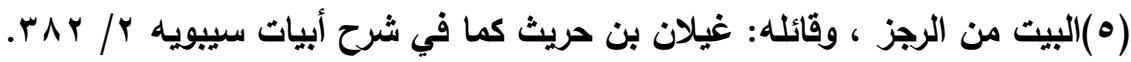

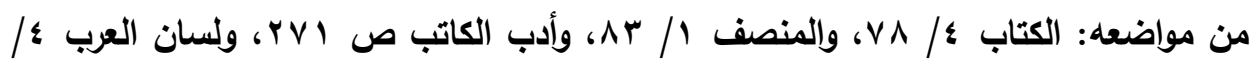

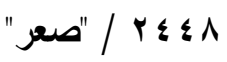

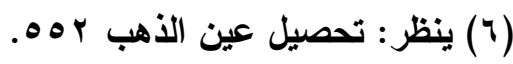
(V) 
فصل المقال في الغريب من الأقوال النحوية والتصريفية د / عبدالرعوف ثابت أحمد عبدالله

\section{r- تعدي الفعل اللازم بدون الهمزة}

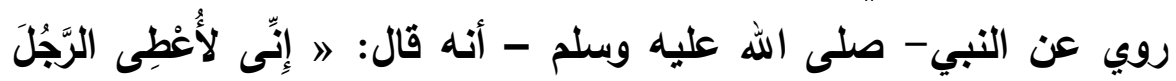

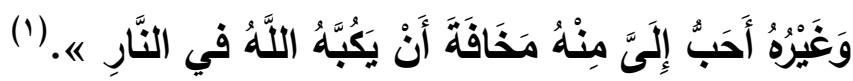

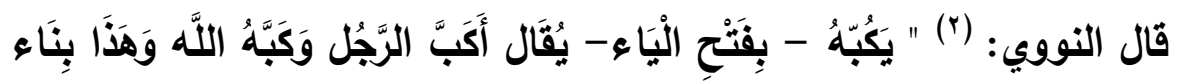

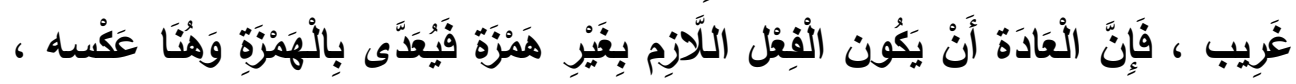

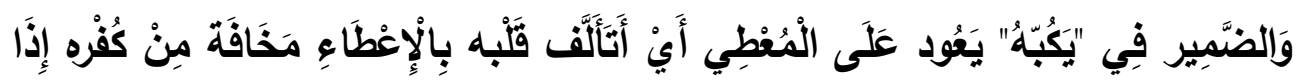

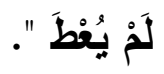

ووجه غرابته مخالفة القياس فالقياس يقتضى أن الفعل اللازم إذا دخلت

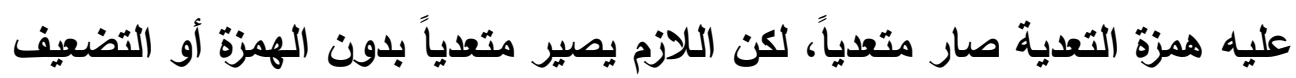


فصل المقال في الغريب من الأقوال النحوية والتصريفية د / عبدالرعوف ثابت أحمد عبدالله

الغيمُ وقشنتََهُ الريحُ وحكى ابن الأعرابي(') في المتعدي كبه وأكبه معاً، وفي"العباب" (r) يقال: كبه الله لوجهه: صرعه على وجهه ، يقال : كب الله العدو ، وأكب على ولى وجهه: سقط ، وهذا من النوادر"

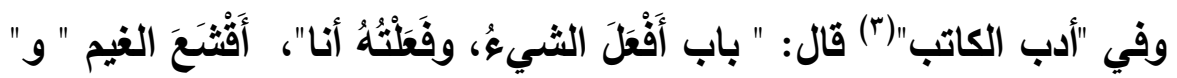

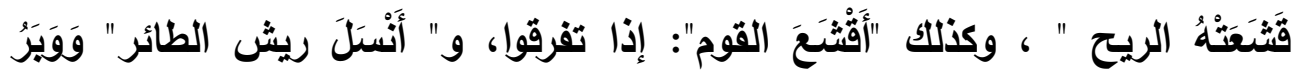

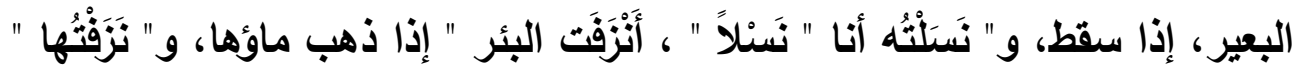

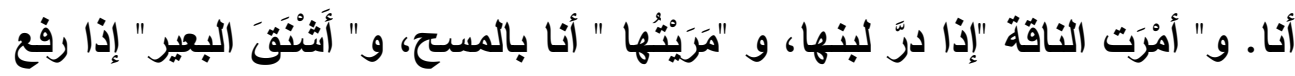

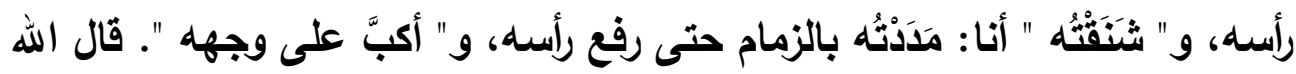

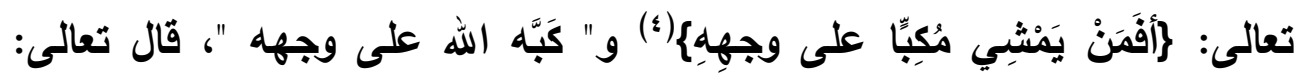

(o).

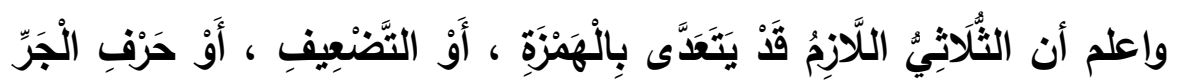

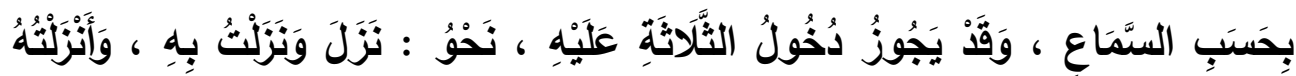
وَنَزَزَنَنُهُ

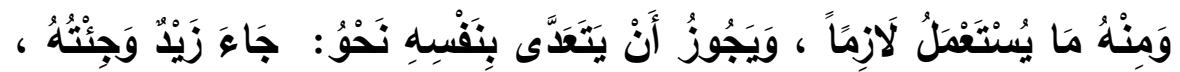

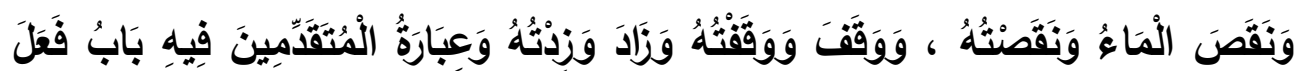

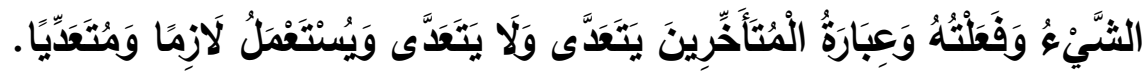

(1) ينظر في: عدة القاري- باب إذا لم يكن الإسلام على الحقيقة / / ب 19 ـ.

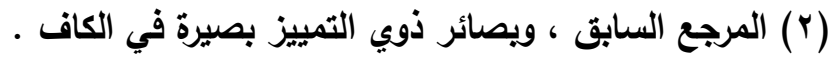

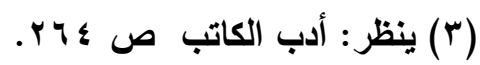

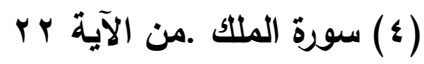

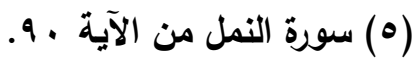


فصل المقال في الغريب من الأقوال النحوية والتصريفية د / عبدالرعوف ثابت أحمد عبدالله

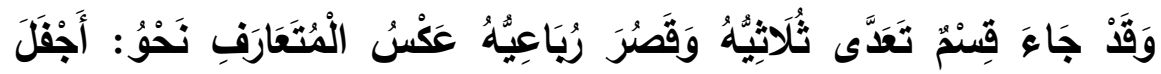

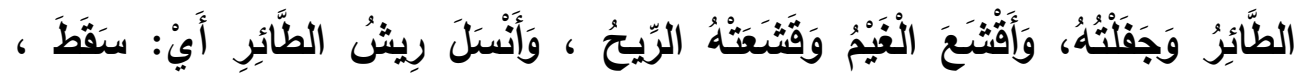

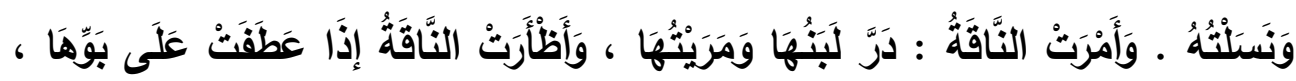

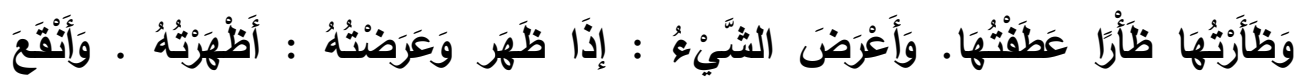

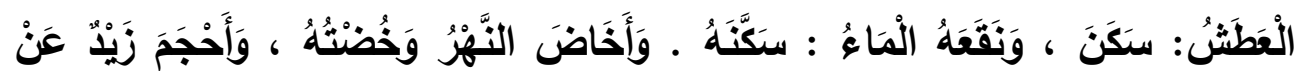

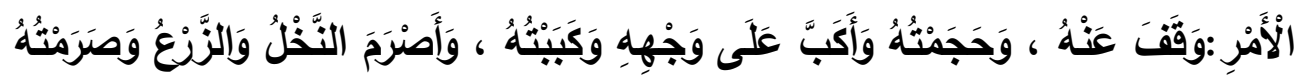

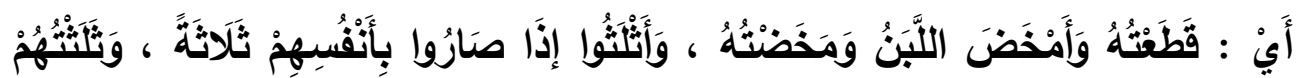

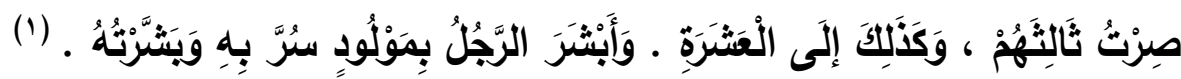
ويذلك اتضح أن الفعل الثثلاثي اللازم على ثلاثة أنواع :

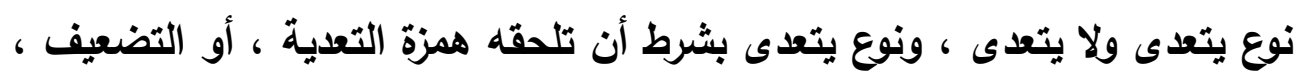

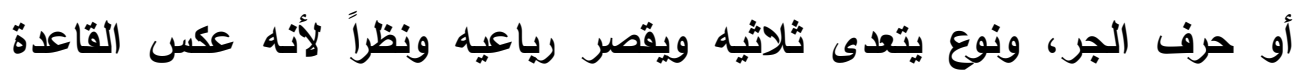

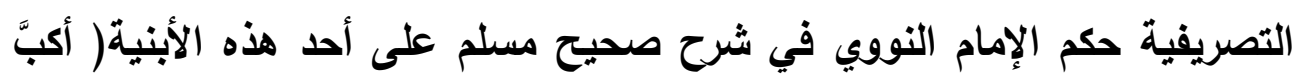

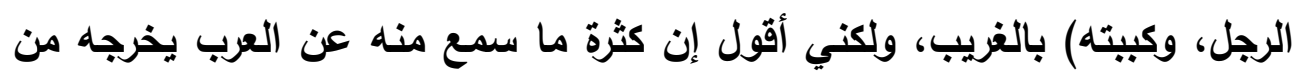

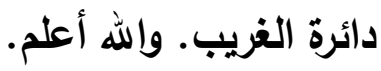

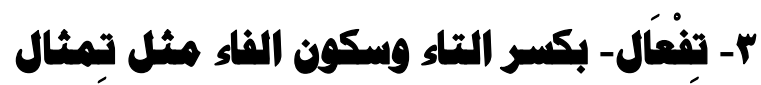

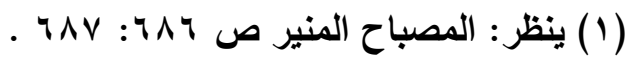


فصل المقال في الغريب من الأقوال النحوية والتصريفية د / عبدالرعوف ثابت أحمد عبدالله

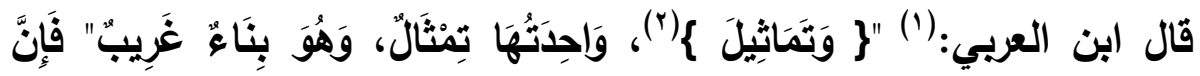

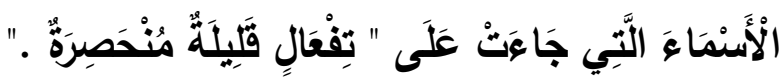
ووجه غرابته كما هو واضح أنه بناء قليل الاستعمال.

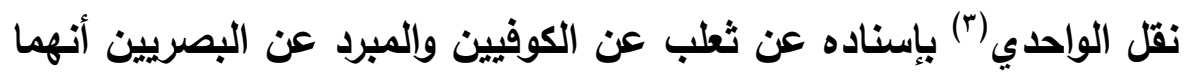

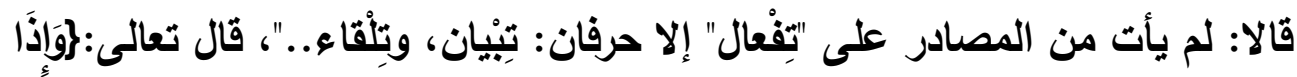

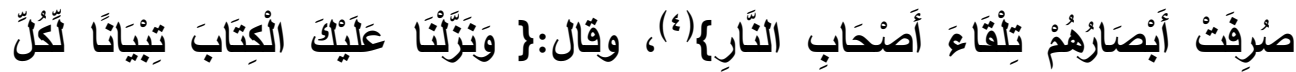
شَنَيِِْ وقال أبو جعفر النحاس في شرح المعلقات:(") "ليس في كلام العرب اسم

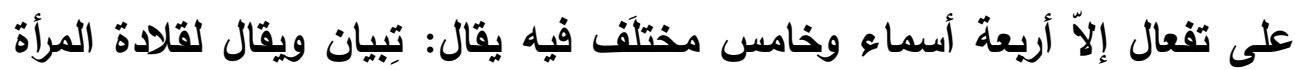

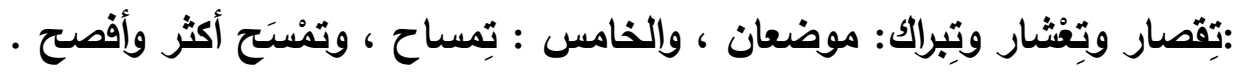

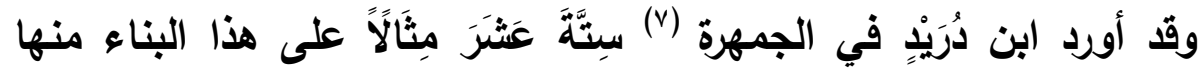

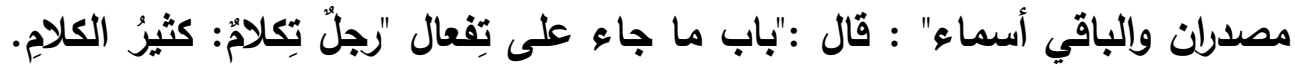

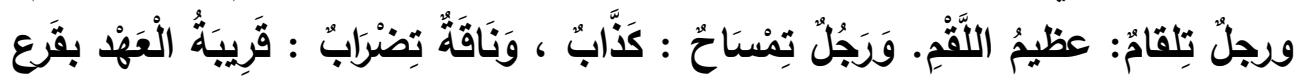

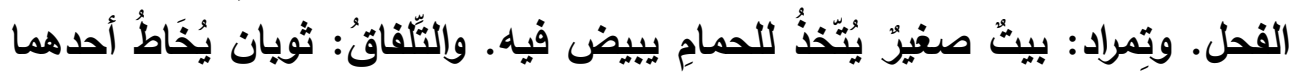

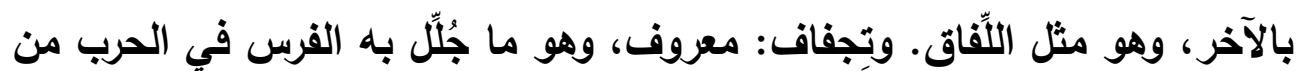

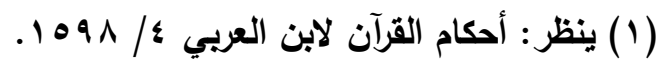

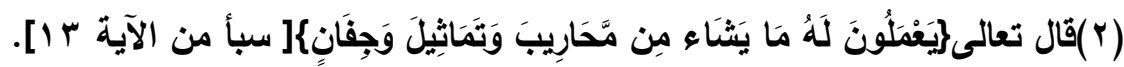

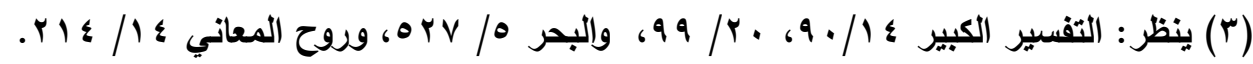

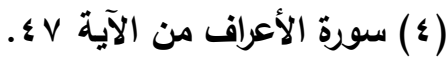

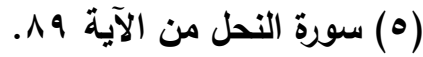

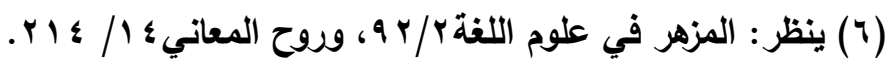

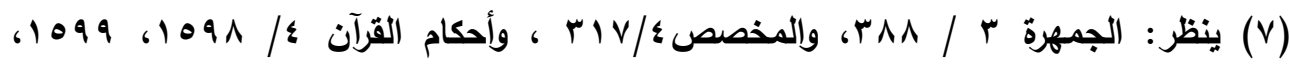

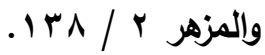


فصل المقال في الغريب من الأقوال النحوية والتصريفية د البدالرعوف ثابت أحمد عبدالله

حديد أو غيره. وتِمثال: معروف. وتبِيان، وهو البيان. وتِلقاء: قِبِالتَكَ. ومرّ تِهواء

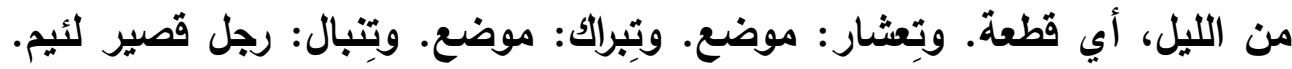

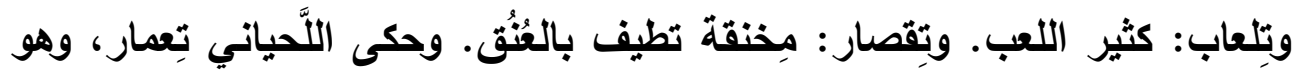

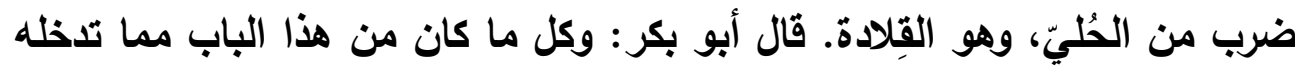

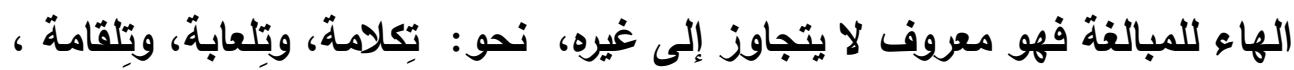

وما أشبهه.

وقال ابن مالك في كتابه نظم الفرائد('): "جاء على تفعال "بكسر التاء" وهو

غير مصدر: رجل تكلام وتلّقام وتلْعاب وتمْساح للكذاب وتضُراب للناقة القريبة العها

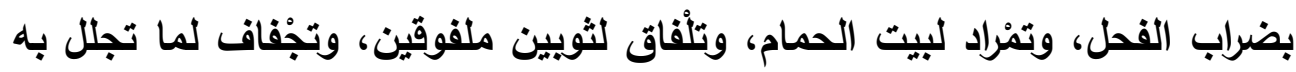
الفرس، وتهُواء لجزء ماض من الليل، وتتبال للقصير اللأيم، وتعشار، وتبرام، وزاد

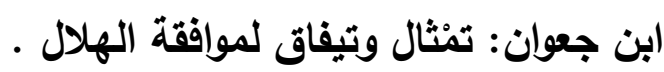

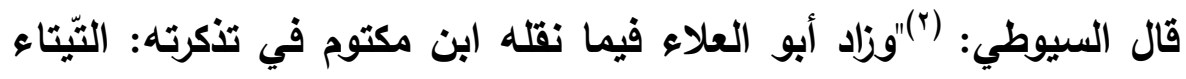

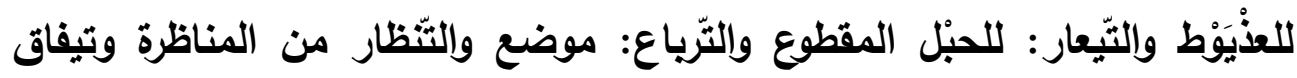

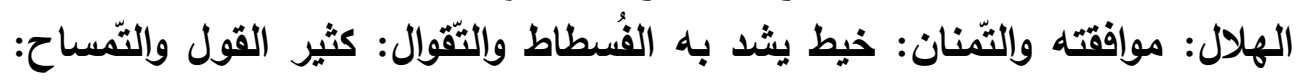
الابة المعروفة، وتزَعام: اسم شاعر والتّمزاح: الكثير المزح والتّيفاق: الكثير الاتفاق." - الأه

والمتأمل في الأبنية السابقة يجد أن بناء "تفْعال" قـ ورد منه في الأسماء ما

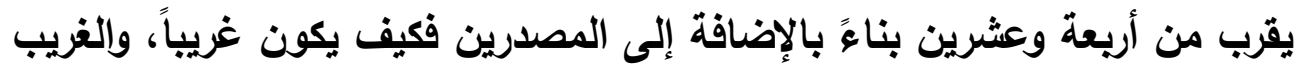

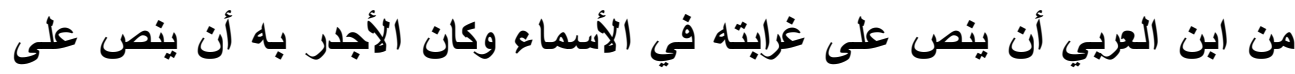
غرايته في المصادر فقد نص أهل الثقة من البصريين والكوفيين على أنه لم يأت الته منه إلا التبيان ، والتلقاء وهما في القرآن الكريم. والله أعلم.

ع- وزن "فيعال" من الصفات مثل "بيناسي"

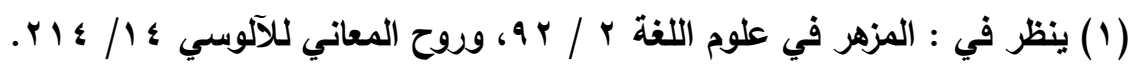

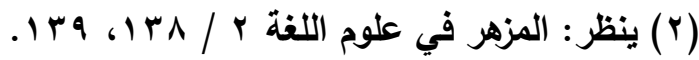




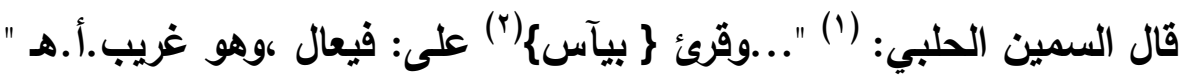

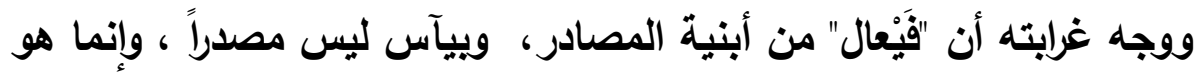
صفة . والحق أن هذا الوزن مسموع من العرب في الأسماء وفي الصفات فمن

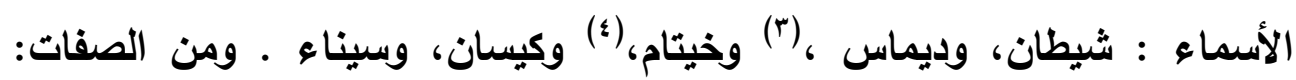

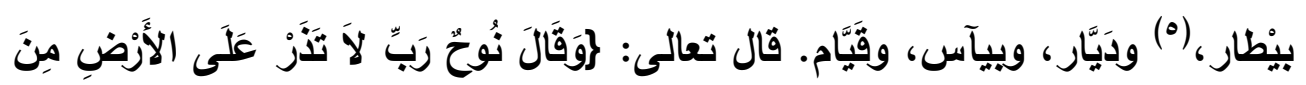

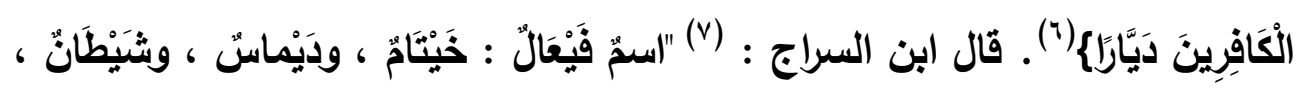

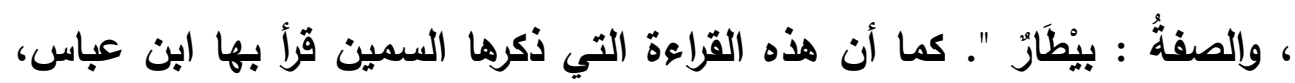

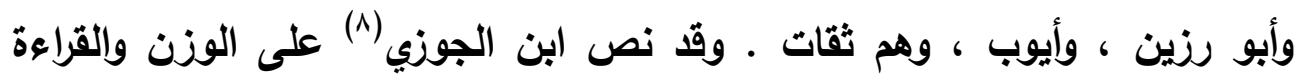

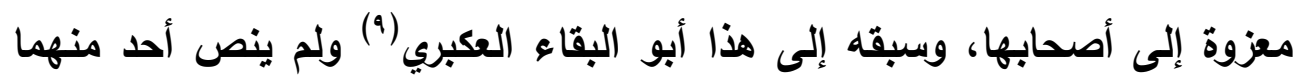

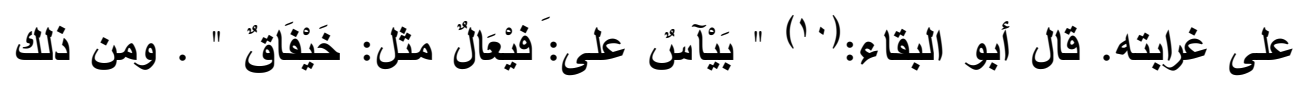

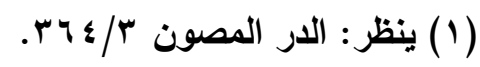

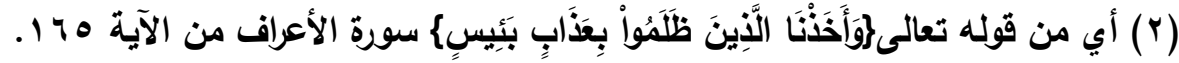

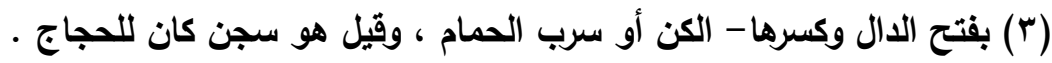

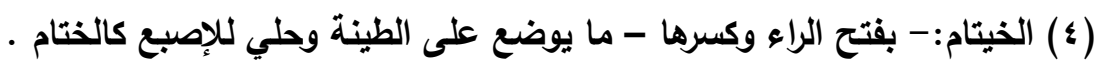
(0) البيطار : من صنعته البيطرة.

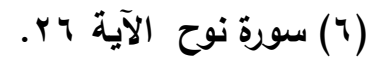

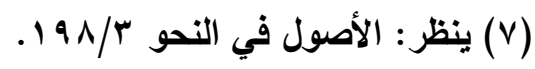

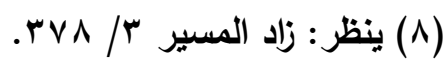

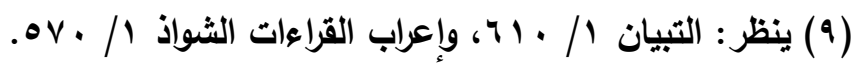

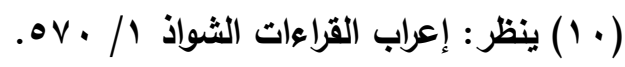


أيضاً قراعة (')عمر بن الخطاب، وعثمان بن عفان - رضي الله عنهما - ، وابن

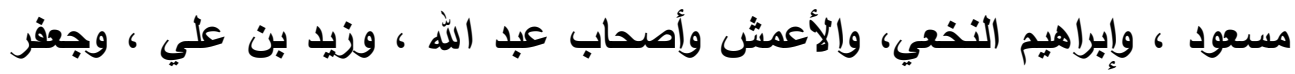

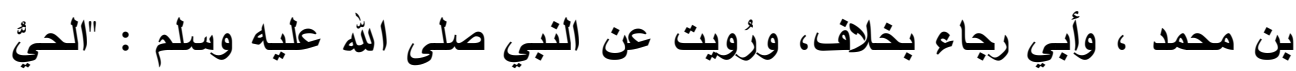

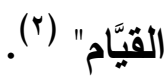

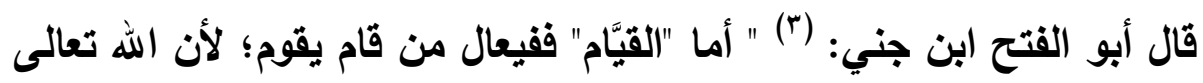

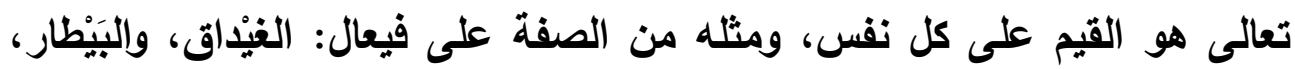

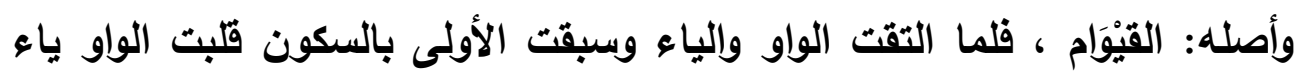

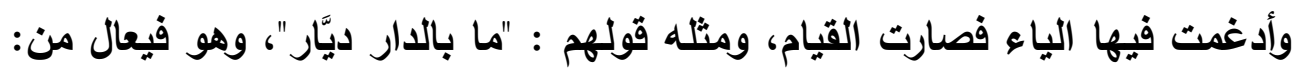

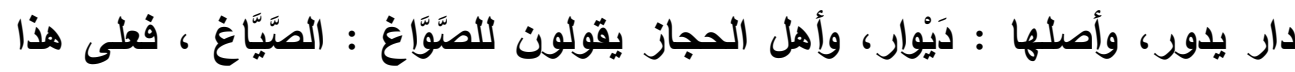

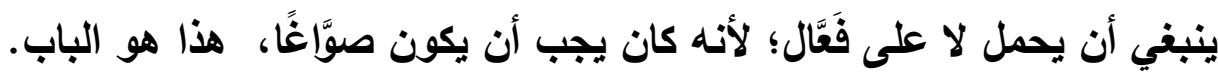

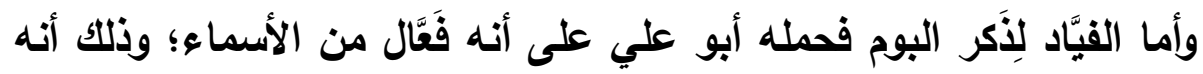

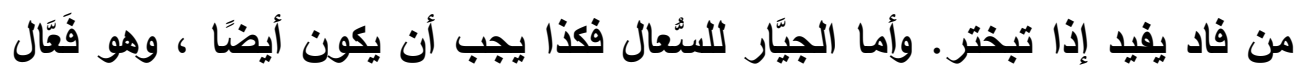

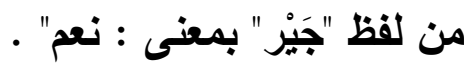
ولعله بعد هذا الإيضاح يكون قد زال وجه الاستغراب، والله أعلم.

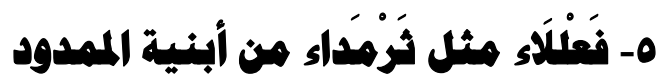

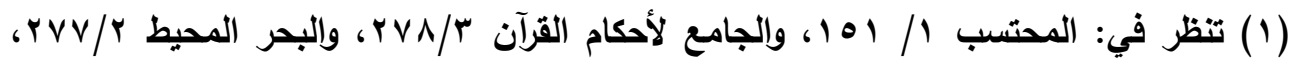

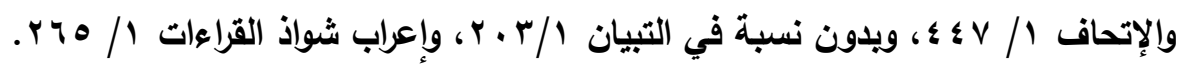

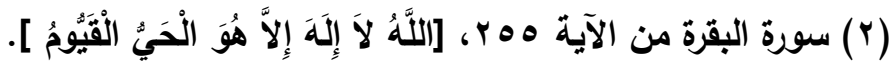

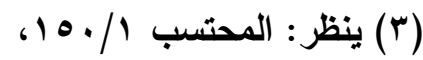


فصل المقال في الغريب من الأقوال النحوية والتصريفية د / عبدالرعوف ثابت أحمد عبدالله

قال الميداني(1) عند تعرضه لقول العرب : "تِعْمَ مَأْوَى المِعْزَ ثَرَمَدَاء "هذا مكان خصيب ،يضرب هذا المثل للرجل الكثير المعروف يؤمر بإتيانه ولزومهه، ويَزَمَدَاءُ : بناء غَريب لاَ أعلم له نظيراً ". ووجه غرابته من وجهة نظره أنه لم يسمع من لسان العرب غيره. وهذا غير

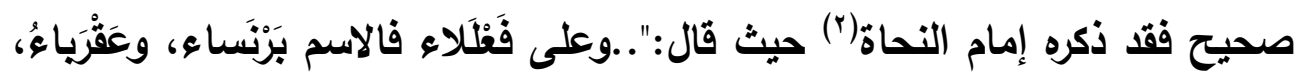

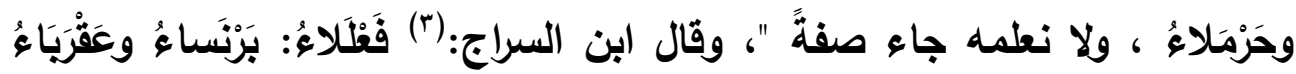
ممدودٌ وغيرُ مصروفٍ ولا يعرفُ وصفاً ".، وذكر ابن سيده(؛) خمسون بناءً للاسم

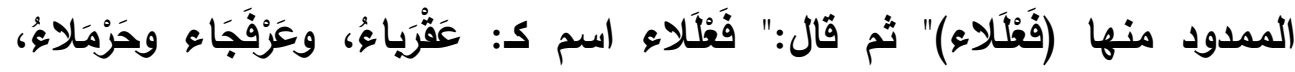

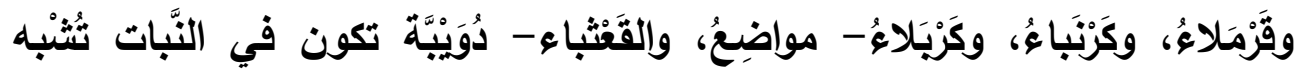

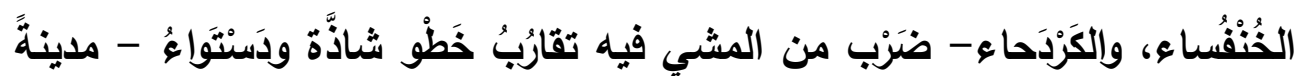

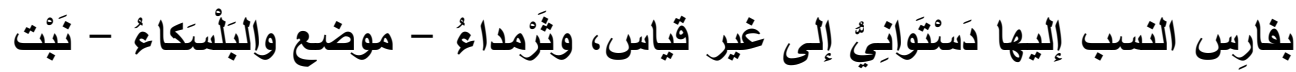
يتعَلَّق بالثوب فلا يكادُ يفارقه.، ومنه أيضاً المَصنطَكاء بالمد نقلاً عن الفراء وابن الأنباري وهو العِلك الرومي وهو دخيل في كلام العرب(ه) ويعد فقد اتضح أن "فعلاء" من أبنية الاسم الممدود وقد سمع منه من لسان العرب ما يرفع غريته عند الميداني.، وهذا إن دل فإنما يدل على أن الميدانيرحمه الله - لم يطلع على هذه الأبنية ـ والله أعلم.

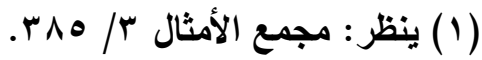

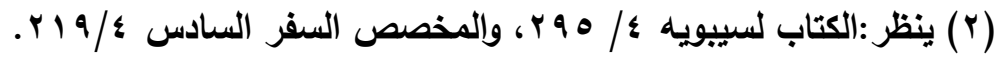

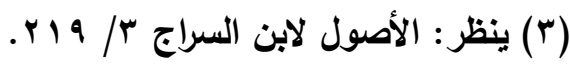

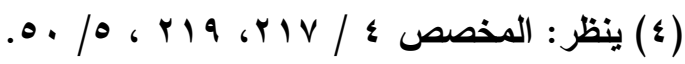

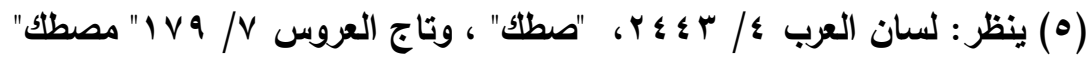


فصل المقال في الغريب من الأقوال النحوية والتصريفية د/ عبدالرعوف ثابت أحمد عبدالله

\section{1- تثنية العلم على وضعه}

قال أبوحيان:(1) "ذكر صاحب البديع خلافاً في كيفية تثنية العلم وجمعه فقال:" منهم من يلحق الألف واللام عوضاً عما سئب من التعريف، فيقول: الزيدان، والزيدون، وهو الأكثر، ومنهم من لم يلخلهما عليه، ويبقيه على حاله قبل التثنية والجمع فيقول: زيدانِ وزيدون " وهذا القول الثاني غريب جداً لم أقف عليه إلا في عي ولي

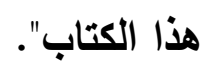

ووجه غرابته أن النحاة(؟) اشترطوا التنكير عند تثية العلم، فلا يثى العلم باقياً على علميته، لأن الأصل فيه أن يكون مسماه شخصًا وإحدًا معينًا ، ولا يثنى أنس إلا عند اشتراك عدة أفراد في اسم واحد، وهذا معنى قول النحويين : "لا يثنى العلم إلا بعد قصد تنكيره"، وحينئ تزاد عليه: "أل" المعرفة بعد التثنية؛ لتعيد له التعريف، أو: يسبقه حرف من حروف النداء - مثل : "يا"؛ لإقادة التعبين والتخصيص أيضًا، بسبب القصد المتجه لشخصين معينين ؛ نحو: يا محمدان، أو إضافة إلى معرفة ، مثل: حضر محمداك. فلا با مع تثنية العلم من شيء مما سبق يجلب له التعريف.؛

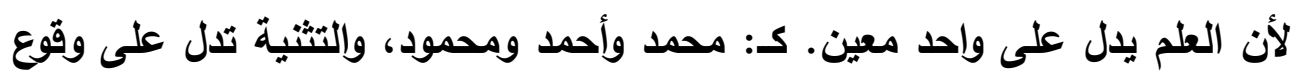
مشاركة بينه وبين آخر، فلا يبقى العلم مقصورً على ما كان عليه من الالالة على لإنى واحد بعينه، بل يشترك معه غيره عند التثية،، وفي هذه المشاركة نوع من الشيوع،

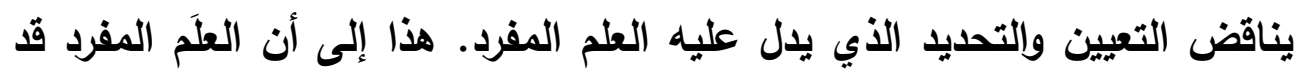

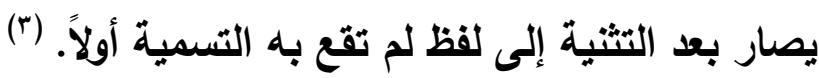

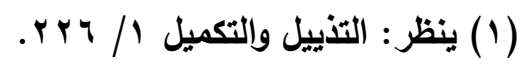

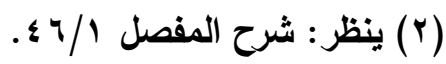

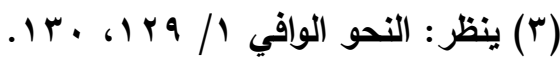


فصل المقال في الغريب من الأقوال النحوية والتصريفية د / عبدالرعوف ثابت أحمد عبدالله

قال السيوطي: (') "ويستثنى نحو: جماديين: اسمي الثهر، وعمايتين: اسمي جبلين، وأذرعات، وعرفات، فإن التثية والجمع فيها لم تسلبه العلمية ،ولذا لم تدخل

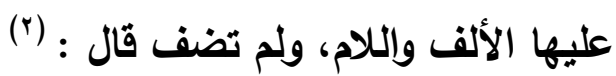
حتى إذا رجب تَََلَّى وانقضى . وقال : (r)

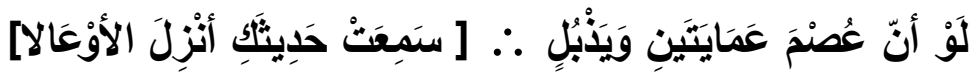

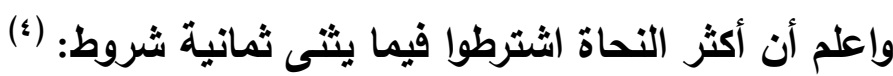
الأول: الإفراد، فلا يجوز تثنية المثنى والمجموع على حدة ، ولا الجمع الأي لا نظير له في الآحاد اتفاقا، وأما غيره من جموع التكسير فظاهر كلام المصنف جواز تثنيته، وقال غيره: إن تثنية الجمع ، واسم الجنس غير مقيسة.

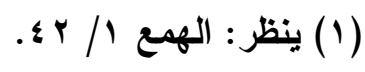

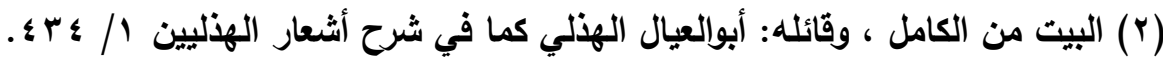
وفي البيت شاهدان :أولهما: أن الواو في "وجماديان" لم تفد الترتيب لأن رجباً يأتي بعد

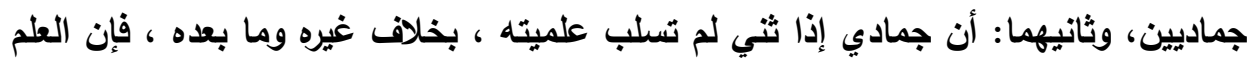
إذا جمع يقدر تنكيره ، ثم يثى ويجمع.

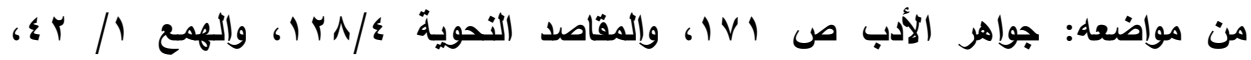

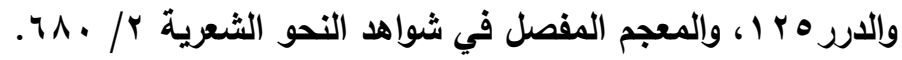

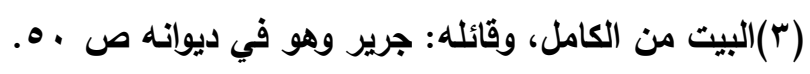

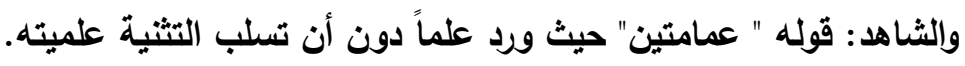

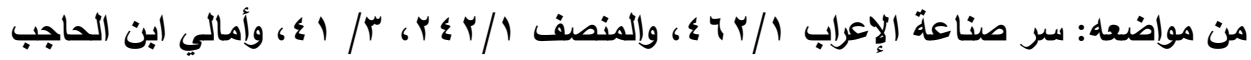

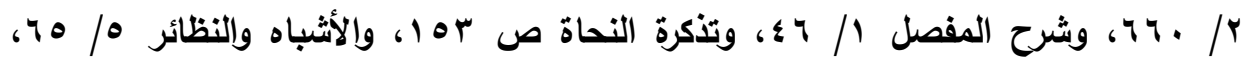

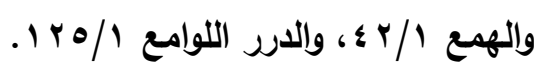

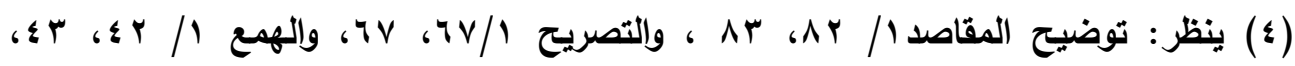

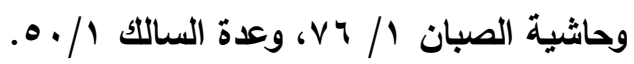


فصل المقال في الغريب من الأقوال النحوية والتصريفية د/ عبدالرعوف ثابت أحمد عبدالله

الثاني: الإعراب، فلا يثنى المبني، وأما قولهمح : "منان ومنَيْن" فليست الزيادة فيهما للتثنية ، بل للحكاية يدل على ذلك "حذفهما" وصلاً، وأما "يا زيدان ، ولا رجلين" فإنما ثني قبل البناء، وأما "هذان واللأن" ونحوهما فصيغ وضعت للمثنى، "وليست" من المثى الحقيقي عند المحققين. الثالث: عدم التركيب، فلا يثى المركب تركيب إسناد اتفاقا، وكذا ما في حكمه كأنما مسمى به، واختلف في تثية المركب تركيب مزج نحو: "بعلبك وسيبويه" ، وصحح أكثرهم المنع ؛ لشبهه بالمحكي ولعدم السماع.

وأما الأعلام المضافة نحو: "أبو بكر" فيستغنى فيها بتثنية المضاف "وجمعه" عن ثثية المضاف إليه وجمعه، وأجاز الكوفيون تثثيتها معاً وجمعهما لبكا معاً فتقول: "أبَوا البكرين وآباء البكرين". الرابع: التنكير. فلا يثنى العلم باقياً على علميته، بل إذا أريا تثنيته قدر تنكيره، ولذلك لا تثنى الكنايات عن الأعلام نحو: "فلان وفلانة" ، فإنها لا تقبل التنكير. الخامس: أن يكون قابلاً لمعنى التثية. فلا تثنى الأسماء الواقعة على ما لا ثاني له في الوجود "كثمس، وقمر" إذا قصدت الحقيقة. السادس: اتفاق اللفظ، وأما نحو: "القمرين" في الثمس والقمر، فمن باب التظليب. السابع: اتفاق المعنى، فلا يجوز تثثية المشترك والحقيقة والمجاز، هذا مذهب أكثر المتأخرين.

قال في شرح التسهيل: (') والأصح الجواز، وممن صرح بجواز ذلك أبو بكر بن الأنباري.

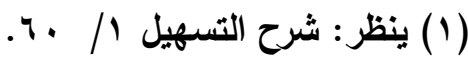


فصل المقال في الغريب من الأقوال النحوية والتصريفية د/ عبدالرعوف ثابت أحمد عبدالله

الثامن: ألا يستغنى بتثية غيره عن تثنيته نحو: "سواء" فإن أكثرهم لا يثنيه استغناء بتثية سي فقالوا: "سيان" ولم يقولوا: "سواعان" على أن أبا زيد حكاه عن لن

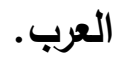

ويعد فقد اتضح أن تثنية العلم على وضعه هو مذهب مخالف لمذهب جمهور التحويين نقله صاحب البديع عن بعض النحويين وإنفرد به ـ والله أعلم. 
فصل المقال في الغريب من الأقوال النحوية والتصريفية د البدالرعوف ثابت أحمد عبدالله

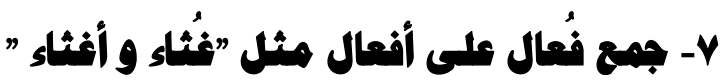

وصف السمين الحلبي جمع غثاء على أغثاء بأنه غريب في أحد قوليه، وذلك عند تعرضسه لإعراب وتفسير قوله تعالى: (') غثاء أحوى\{ حيث قال:(ץ) " قوله

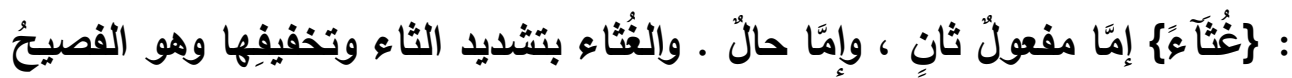

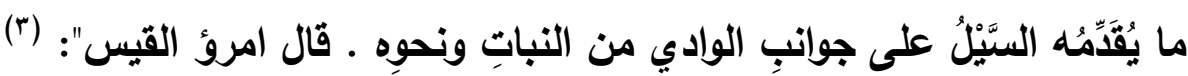

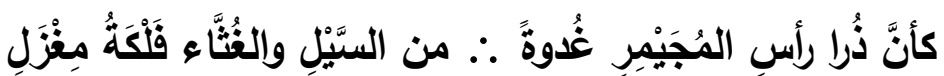

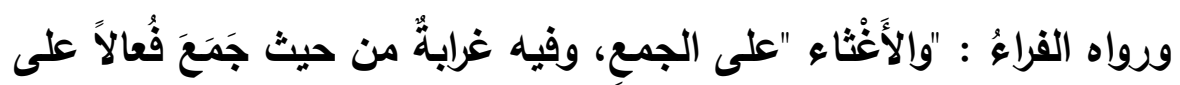

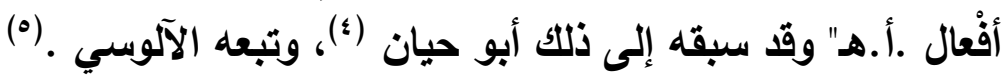
والقول الثاني: للسمين هو وصفه لهذا الجمع بالثذوذ، وكان هذا منه عند تعرضسه

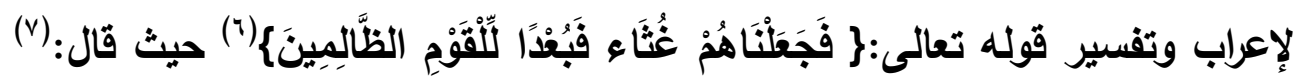

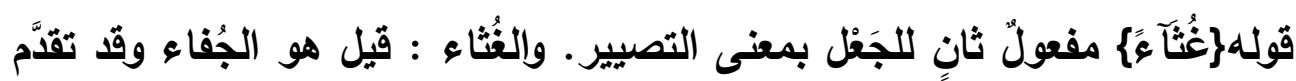

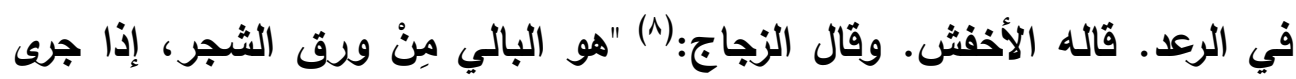

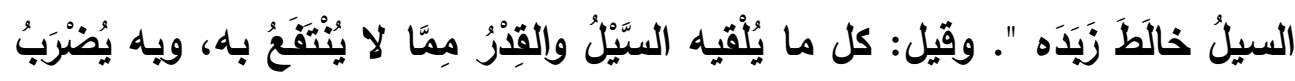

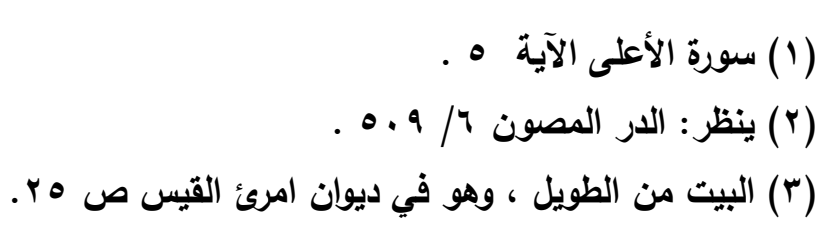

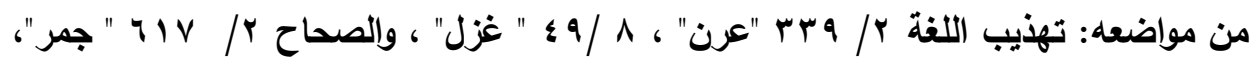

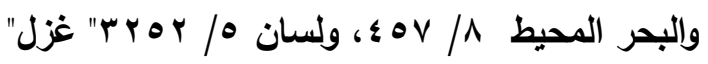

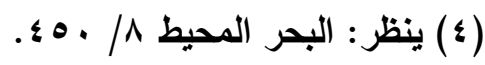

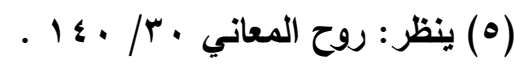

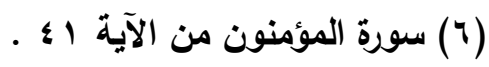

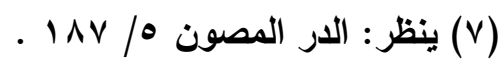

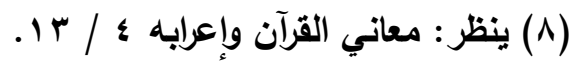


فصل المقال في الغريب من الأقوال النحوية والتصريفية د / عبدالرعوف ثابت أحمد عبدالله

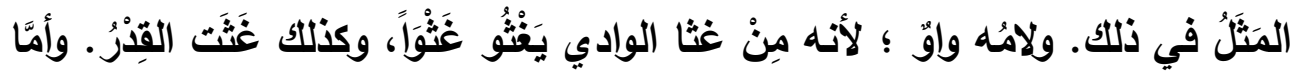

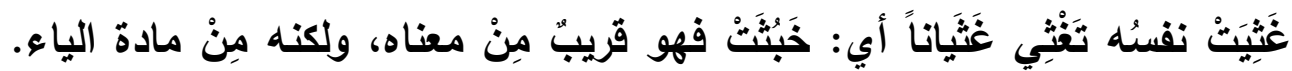

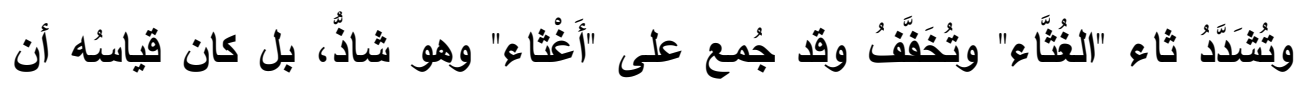

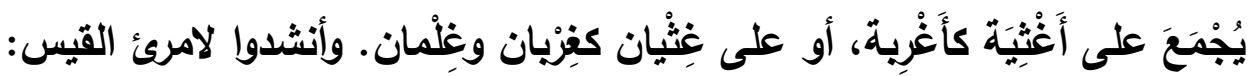

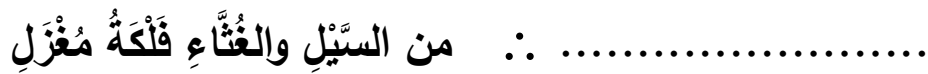

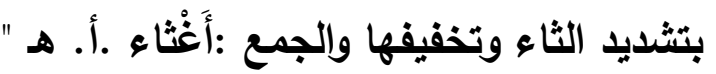

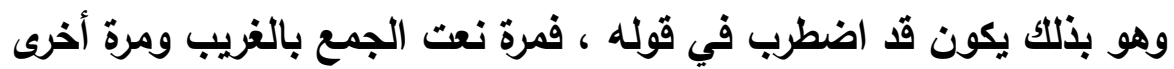

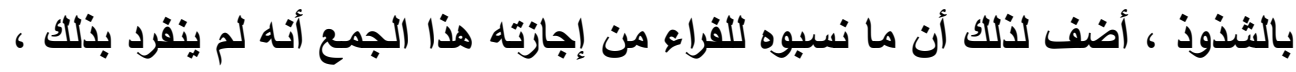
حتى يحكم عليه بالغرابة، بل قال به بعض النحويين كالرضي فقي شرح الثافية،

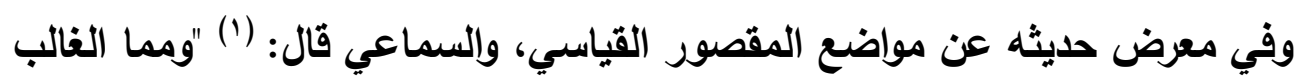
فيه القصر كل مفرد معتل اللام يجمع على أفعال، كندى وأنداء، وقفا وأقفاء، وجاء هواء

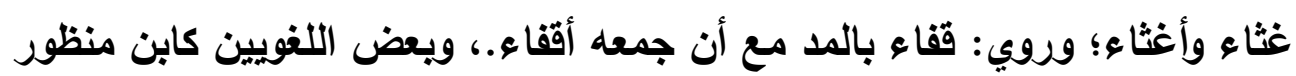

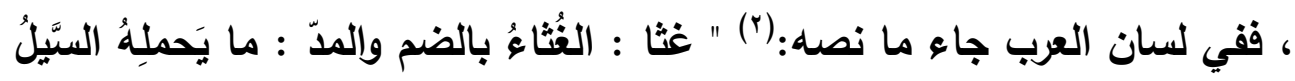

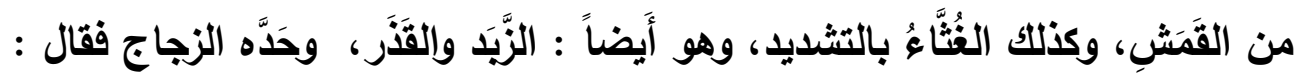

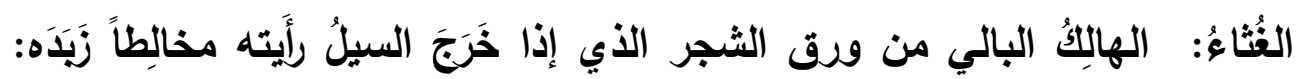

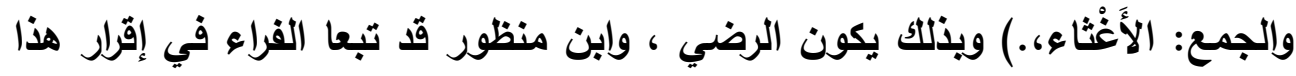

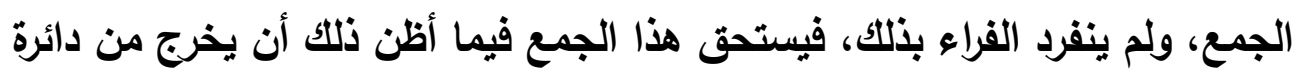

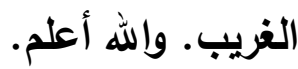

\section{A- جمع فعيل على أفعلاء هثل: هين و أهيناء.}

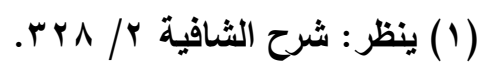

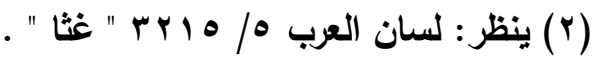


فصل المقال في الغريب من الأقوال النحوية والتصريفية د / عبدالرعوف ثابت أحمد عبدالله

ذهب الزجاج إلى أن أصل هَيَّن: هيين بوزن : فعيل ، وجمعه : أهوناء على وزن : أفعلاء ، مثل : نصيب وأنصباء ، ونعته السمين الحلبي بشدة الغرابة ، وذلك عند تعرضه للحديث عن أصل ، ووزن أثياء، حيث قال: (') "...، ذهب الفراء في هذا الحرف مذهب الأخفش غير أنه خَلَط حين ادَّعى أنها كهيْن، ولَيَّن

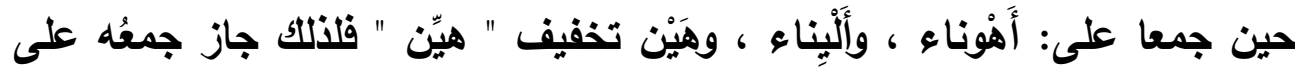

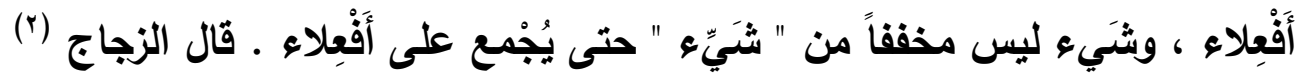

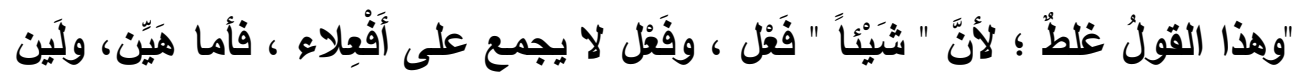

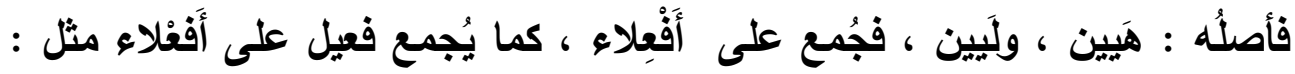

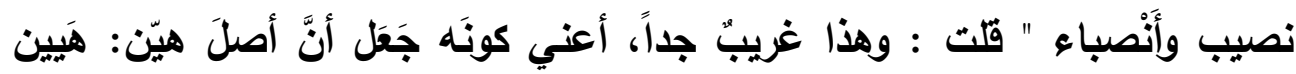

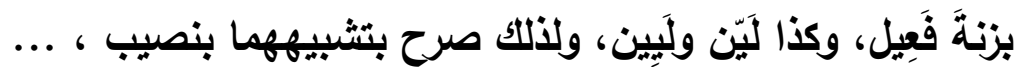
وما ذكره الزجاج سبقه إليه الفراء عند تعرضه لوزن ميت قال الرضي:(ז) "ومذهب الفراء أن وزن "ميث" فعيل كـ "كريم" ، والأصل: مويت أعلت عينه كما أعلت في الماضي والمضارع ، فقدم وأخر، ثم قلبت الواو ياء ؛ لاجتماعهما وسكون الأولى، ... ثم قال: واستدل الفراء على كون ميت في الأصل فعيلاً بنحو: أهوناء، وأبيناء، في هين ويين، والمشهور في أفعلاء أن يكون جمع فعيل،... وما ذهب إليه الفراء في وزن ميت ، والزجاج في وزن هين من أن كلاً منهما على وزن فعيل هو مذهب جمهور النحويين، فالجمهور يقولون: إن هَيّناً

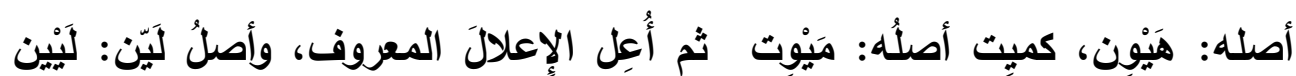

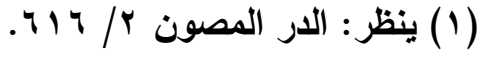

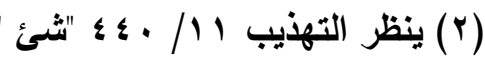

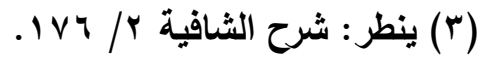


فصل المقال في الغريب من الأقوال النحوية والتصريفية د / عبدالرعوف ثابت أحمد عبدالله

بياعين، الأولى ساكنة والثاينة مكسورة ، فأُدْغت الأولى ، وهو الراجح للأسباب التالية:

الأول: الاشتقاق يشه لهم ، فقد أجمعت كتب اللغة ،على أن اشتقاق اللفظة من

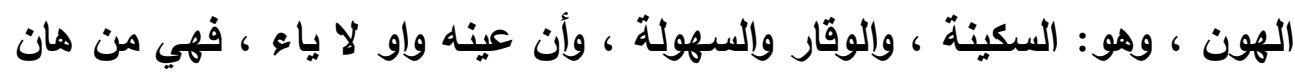

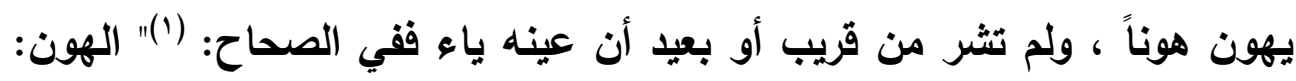

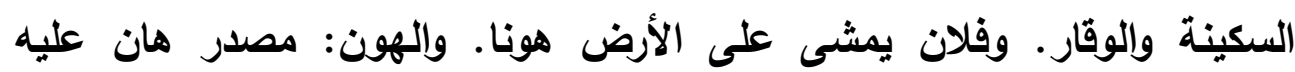

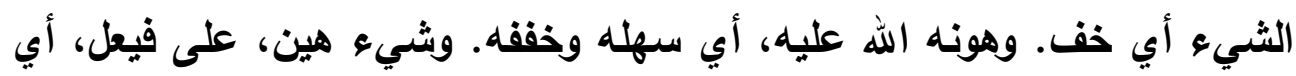

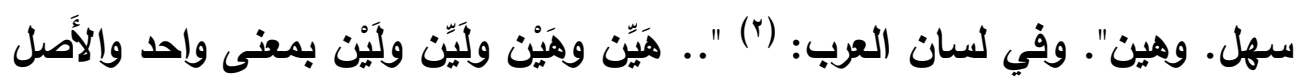

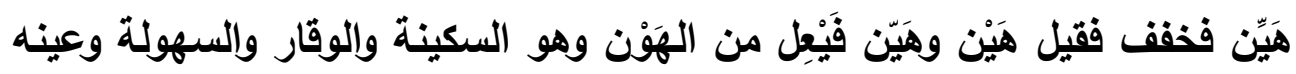

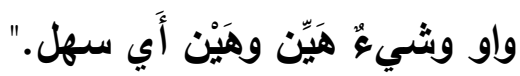
الثاني: الجمع، لأنهر حين جمعوه على أَفْعلاء أظهروا الواوَ فقالوا : أَهْنِاء، بالواو

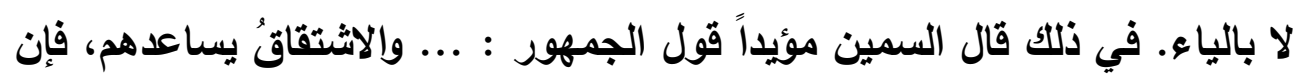

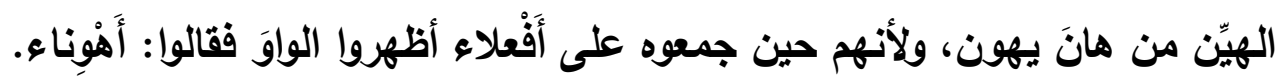
الثالث: الوزن، فمذهب الخليل ، وسييويه، وعليه الجمهور أن وزن مثلن مئل سيد،

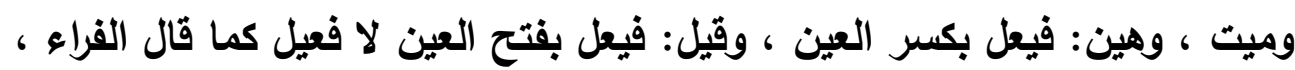

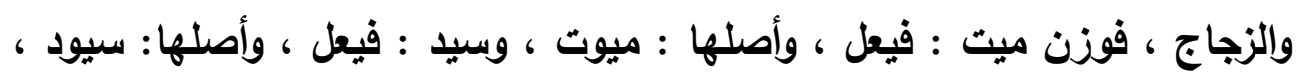

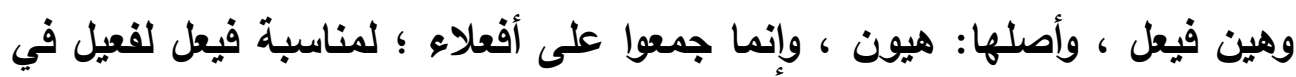

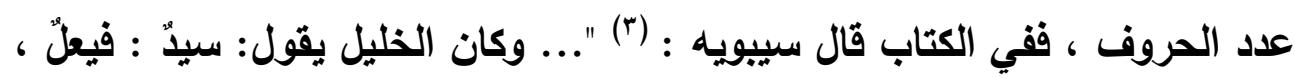

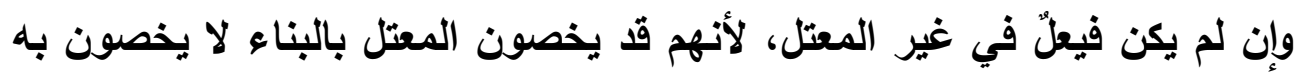

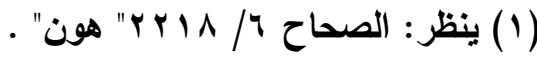

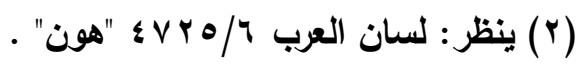

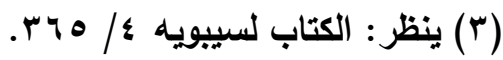


فصل المقال في الغريب من الأقوال النحوية والتصريفية د / عبدالرعوف ثابت أحمد عبدالله

غيره من غير المعتل، ألا تراهم قالوا : كينونةٌ ، والقيدود، لأنه الطويل من غير

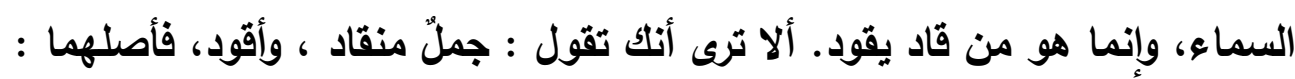

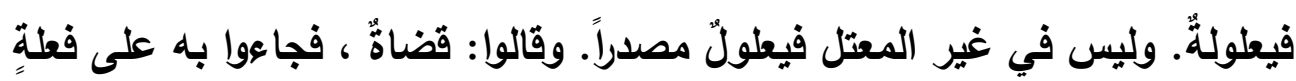

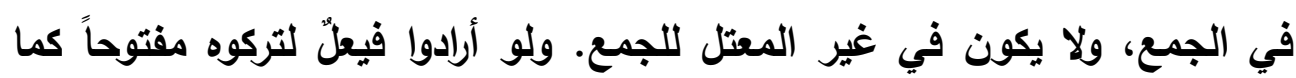
قالوا : تيجان ، وهيبانُ. وقد قال غيره: هو فيعلّ، لأنه ليس في غير المعتل فيعلّ. وقالوا: غيرت

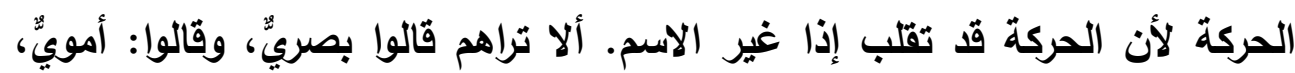

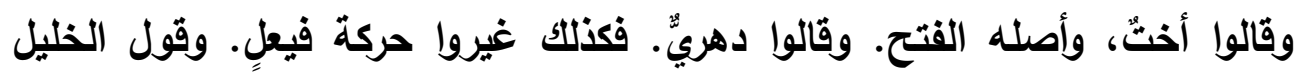
أعجب إلي؛ لأنه قد جاء في المعتل بناءٌ لم يجيء في غيره، ولأنهم قالوا هيبانٌ وتيحانٌ فلم يكسروا.أ.هـ.

ويعد :فقد اتضح أن ما ذكره الزجاج من أن أصل هين: هيين بوزن فعيل

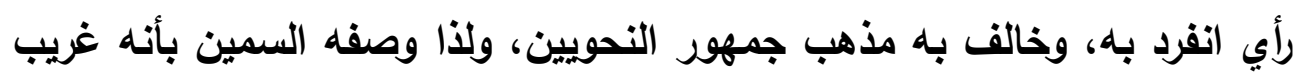

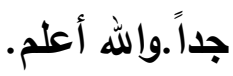

\section{9- هخالفة الجمع لمزرده}


فصل المقال في الغريب من الأقوال النحوية والتصريفية د / عبدالرعوف ثابت أحمد عبدالله

نعت السمين الحلبي مخالفة الجمع لمفرده بالغريب في موضعين من كتابه

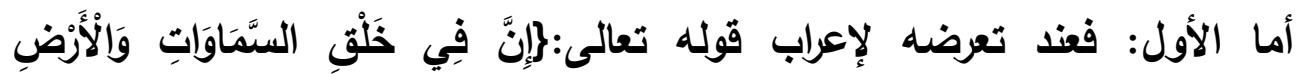

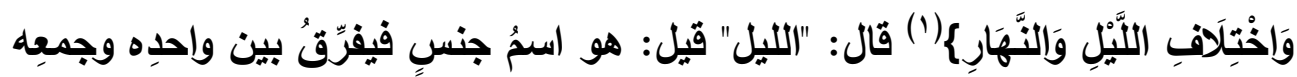
تاءُ التأنيث، فيقال: ليلة وليل كتمرة وتمر، والصحيحُ أنه مفردٌ ولا يُحْفَظظ له جمعُ ،

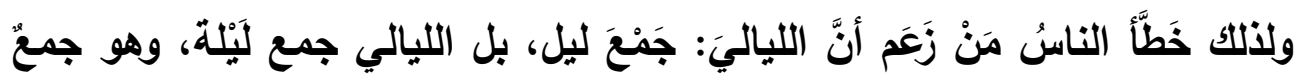
غريب، ولألك قالوا: هو جَمْع: ليلاة تقديراً، وقد صُرّح بهذا المفردِ في قَّل

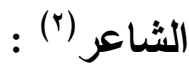

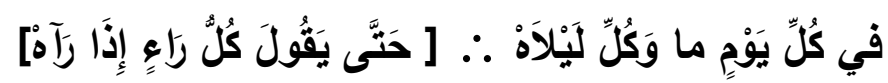

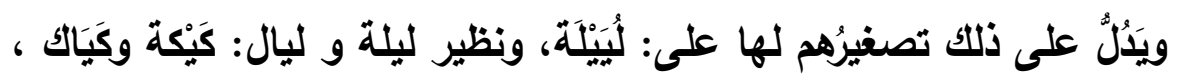

كأنهم تَوَهَّموا أنها كَيْكات في الأصل، والكيكة: البيضة .أ.هـ ـ وهو في هذا الموضع

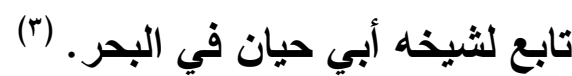

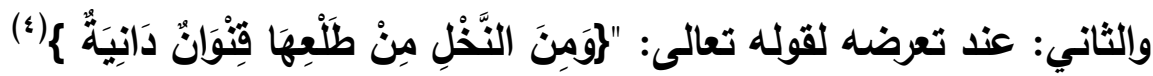

قال: (1) "والقتوان: جمع تكسير ...وفيه لغات : فلغةٌُ الحجاز 》 قِتْوان 《 بكسر القاف ، وهي قراءة الجمهور (r) .

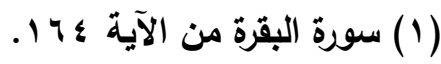

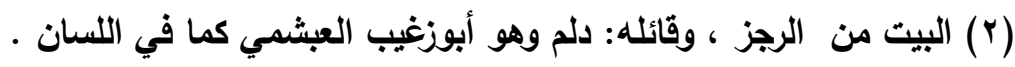

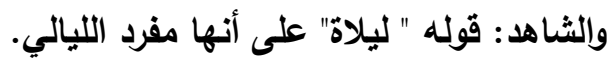

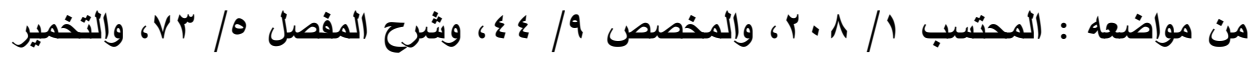

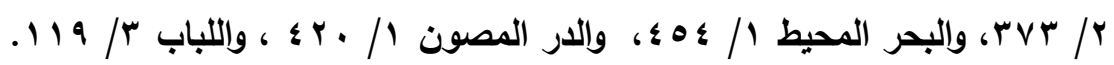

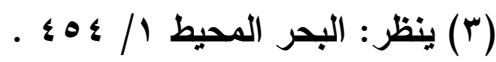
(؛) سورة الأنعام من الآية 99. 
وقرأ (r) الأعمش، والحباب عن أبي عمرو، والأعرج بضمّها ، ...واللغة

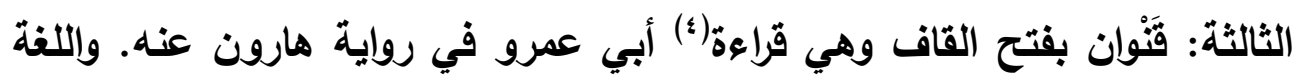

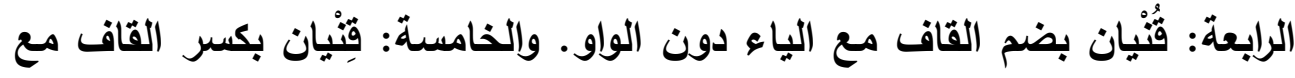

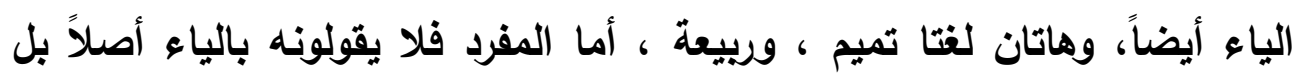

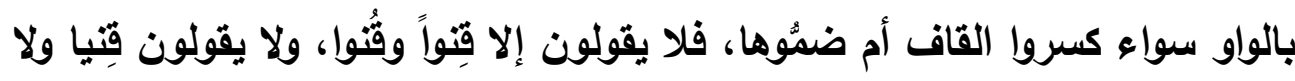
قُنيا، فخالف الجمعُ مفرده في المادة وهو غريب.

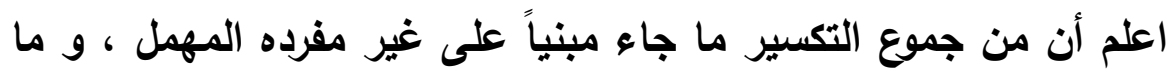

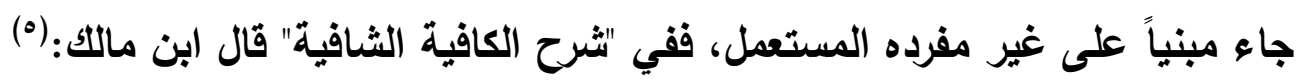

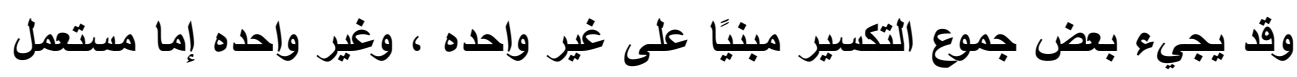

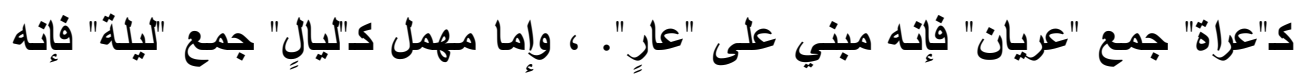
بني على تقدير "ليلاة " وهو مهمل.أ.هـ.

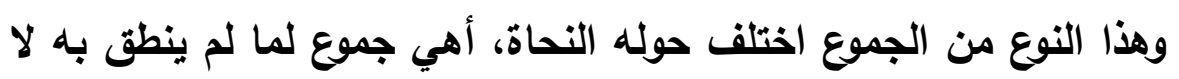

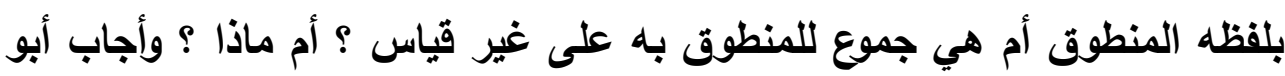

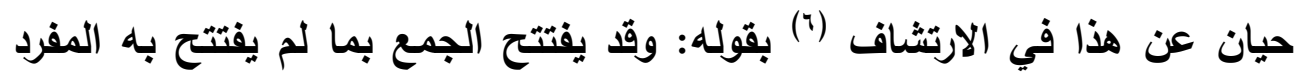

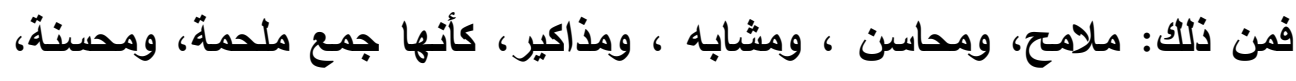

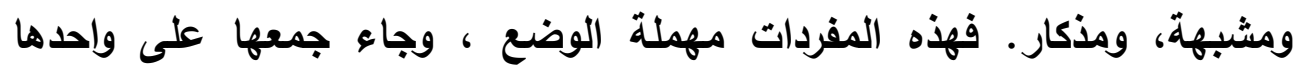

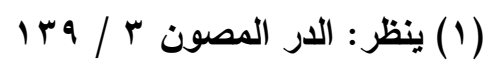

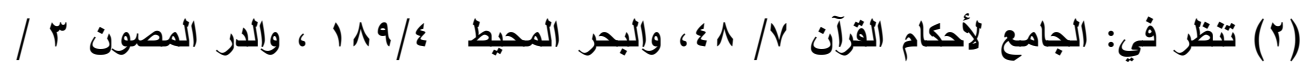

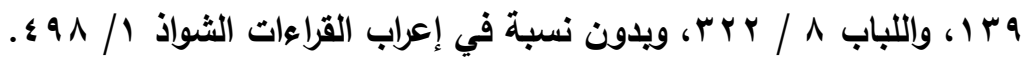

( ) المراجع السابقة.

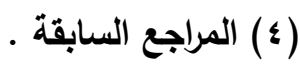

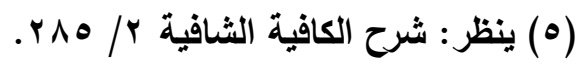

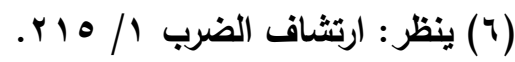


فصل المقال في الغريب من الأقوال النحوية والتصريفية د / عبدالرعوف ثابت أحمد عبدالله

القياس المهمل ، والمسموع في مفردها : لمحة ، وحسنة ، وشبه ، وذكر، ومن ذلك قولهم في جمع استخراج، وإتقار : تخاريج، وفتاقير، كأنها جمع تخراج، وفتقار ، فهما جمع واحد قياسي مهمل جمل ...

ويعد أن عدد أبو حيان باقي هذه الأنواع من الجموع قال: " وهذا الذي

ذهب إليه سييويه من أن هذه جموع لما لم بنطق به لا بلفظه المنطوق به هو قول هول هـ

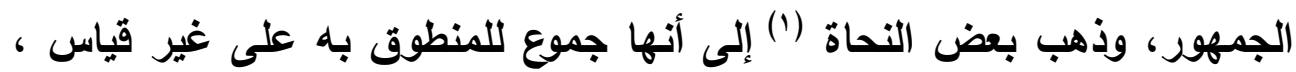
كما ينسب إلى الاسم على تغيير خارج ، وزعم ابن جني أن الاسم بعينه يغير إلى إلى

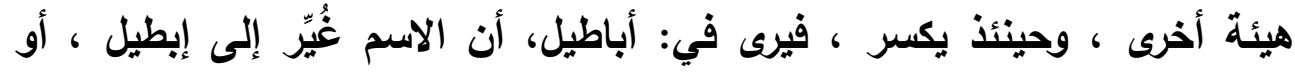
ابطول، ثم كسر، وكذلك سائر الباب ‘ فأما الليالي، والأظافير، فالمستعمل المشهور: ليلة، وظفر ، وسمع: ليلاه ، وأظفور، وكأن هذين الجمعين جاءا على القليل غير

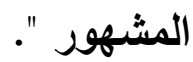

ويمكن أن يكون من هذا الباب قتيان بكسر القاف ، جمع قني الأي لـ ينطق به ، بل المستعمل: قنو بكسر القاف فيكون الجمع جاء على غير مفرده ويعد فقهم من نص أبي حيان في الارتشاف أن جمع ليلة على ليالٍ جاء على القليل غير المشهور هو ما عليه أكثر النحاة ، لا ما ذكره في البحر، وتبعه السمين الحلبي فيه من أن هذا الجمع غريب. وأما قِتيان فجاء على غير مفرده .

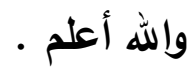

. 1 - وقوع الافرد موقع البممع

(1) كالأزهري في التهذيب 0 // بـ ــ. 
فصل المقال في الغريب من الأقوال النحوية والتصريفية د / عبدالرعوف ثابت أحمد عبدالله

قرأ الحسن ، والأعرج ، وأبوزرعة ، وابن جبير، والأعمش ، وابن مجاهد -

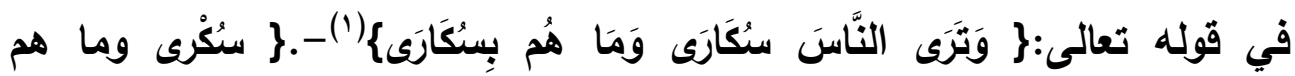
بسُكرى\{ بضم السين (ץ) فيهما من غير ألف ، قال الزمخشرى(") - رحمه الله - :"هو غريب!" - ن

ووجه غرابته أنه اسم مفرد مثُل: البُشُى. وقع موقع الجمع " سُكَارى " وهذا

مما لا يجوز عند جمهور البصريين، وإنما هو مقصور على الشعر، ومن المعهود لاينا أن الزمخشري بصري الاتجاه، وأما الكوفيون فيجيزون مثل ذلك ، قال الفراء:

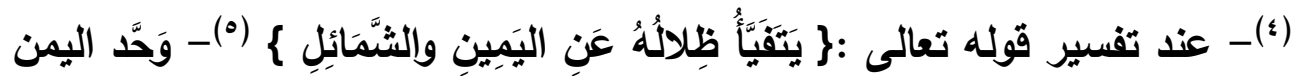
، وجمع الشمائل وكل ذلك جائز في العربية . وفي توجيه القراعة، قال أبوحيان("): " قال ابن جني(v): "هي اسمٌ مفردٌ كاللبُشْرَى · بهذا أفتاني أبو علي". وقال أبو الفضل الرازي:(') "فُعْلَى بضمِّ القاعِ مِنْ صفةِ الواحدةِ من الإناثِ ، لكنها لَمَّا جُعِلَتْ من صفاتِ الناس وهم جماعة، أُجْرِيَتْ الجماعة بمنزلة المؤتثِت

(1) سورة الحج من الآية ب - قرأ حمزة الكسائى " سككرى وما هم بسكرى " بفتح السين من غير

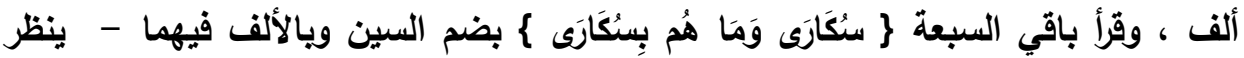

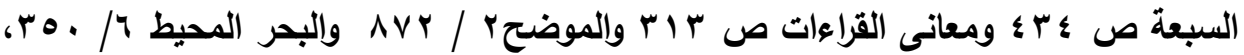

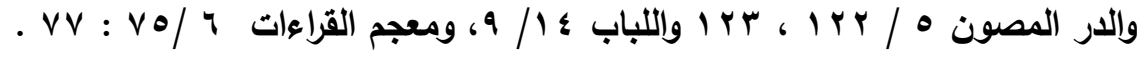

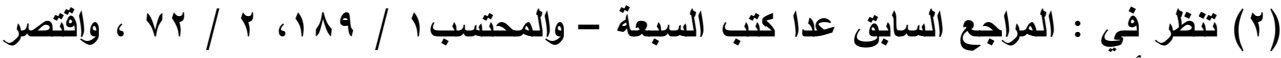

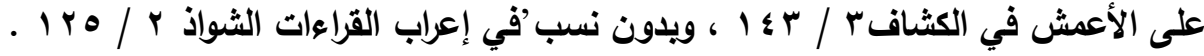

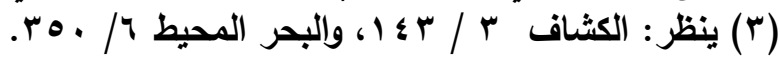

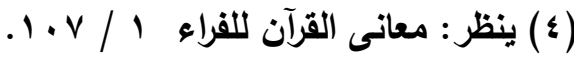

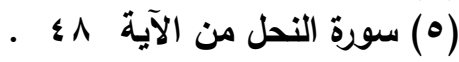

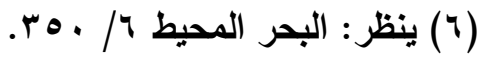

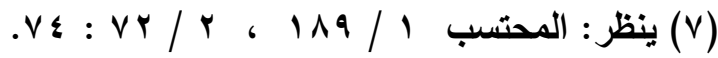


فصل المقال في الغريب من الأقوال النحوية والتصريفية د / عبدالرعوف ثابت أحمد عبدالله

الموحَّدِ "، ورداً على الزمخشري قال السمين الحلبي:()".. قلت: ولا غرابةَّ ؛ فإنَّ فُعلى بضم الفاء كَثُر مجيُُها في أوصافِ المؤنثة نحو: الريى، والحبلى.." ويعد فقد اتضح أنه لا غرابة في وقوع المفرد موقع الجمع فهو مذهب كوفي ، وإن قصره البصريون على الثعر • والله أعلم.

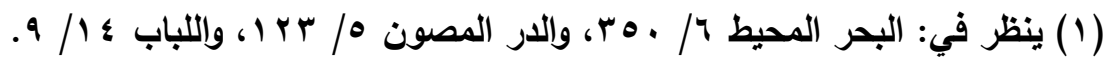

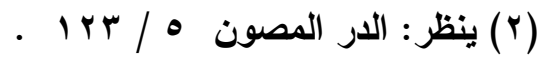


فصل المقال في الغريب من الأقوال النحوية والتصريفية د / عبدالرعوف ثابت أحمد عبدالله

\section{1 - لفظ " الرحمن " بين العربي والمعرب}

قال السمين الحلبي:(') "ومن غريب ما نُقِل فيه- أبي في الرحمن - أنه مُعََّب

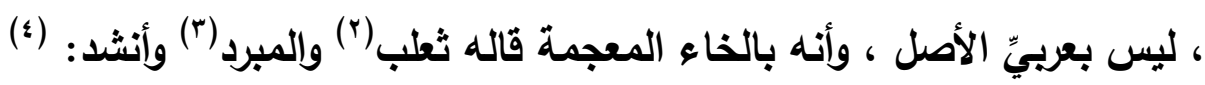

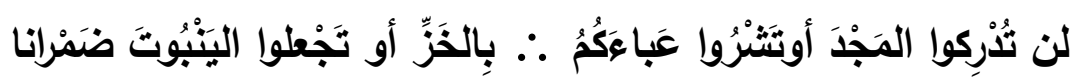

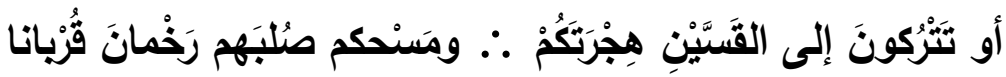

وقال أبويكر بن الأنباري : (0) "سمعت أبا العباس يقول : إنما جمع بين الرحمن والرحيم ؛ لأن الرحمن عبراتي ، فجاء معه بالرحيم العربي وأنشد البيتين

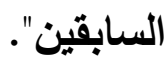

وقال الأزهري: (؟) "قال أبو بكر المنذريٌٌ : سمعتُ أبًا العباس يقول في قوله : الرحمن الرحيم : جمع بينهما ؛ لأنَّ الرحمن عبرانيّ ، والرحيم عربي."

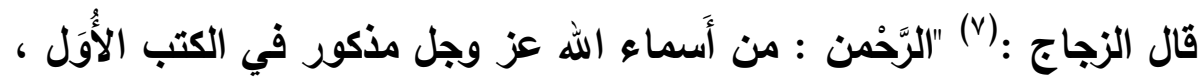

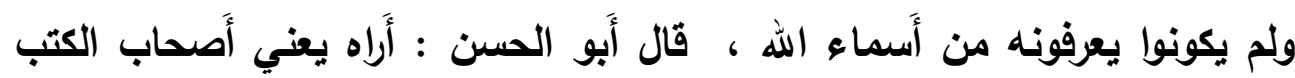

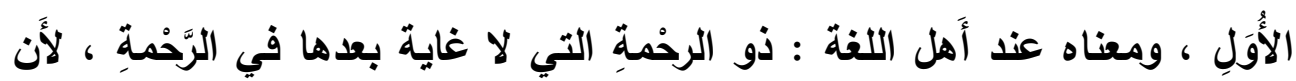

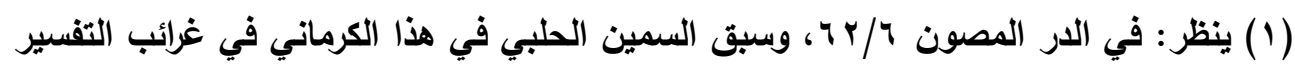

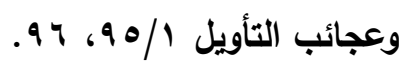

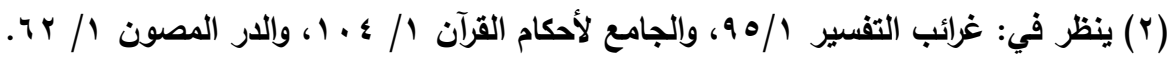

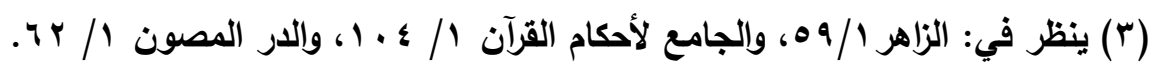

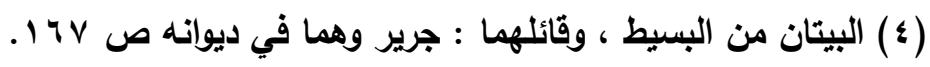

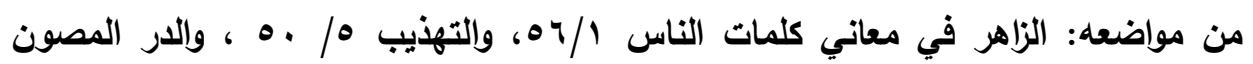

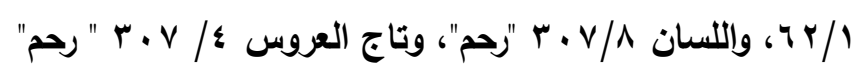

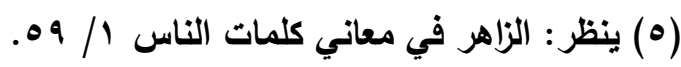

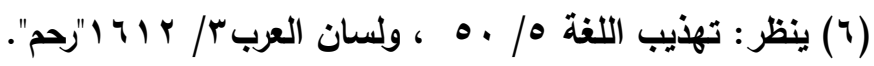

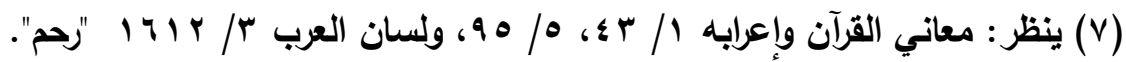


فصل المقال في الغريب من الأقوال النحوية والتصريفية د / عبدالرعوف ثابت أحمد عبدالله

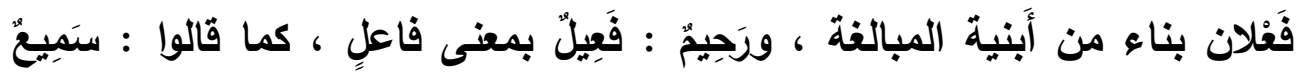

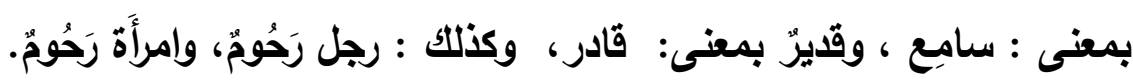

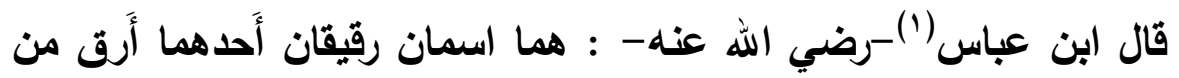

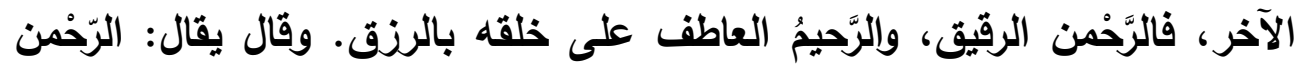

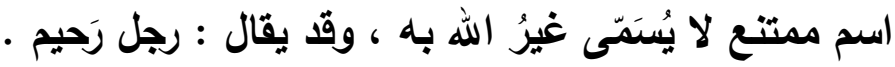

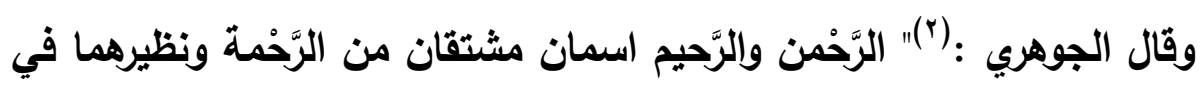

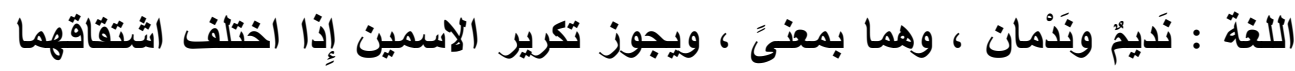

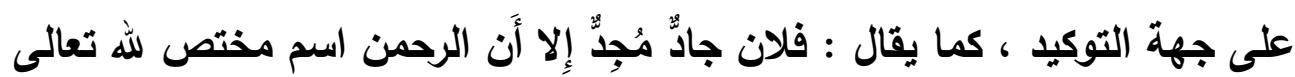

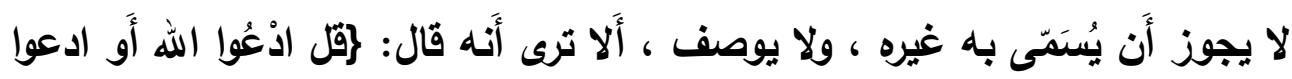

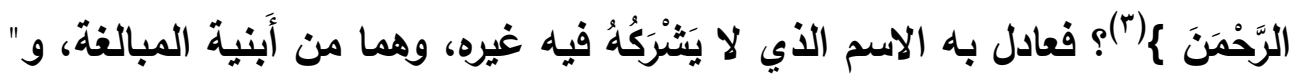

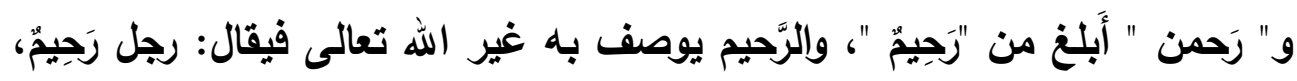

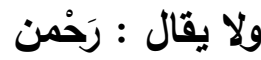

وسبق الجوهري في القول باثتقاقهما الخليل بن أحمد (๕)، وأبوعبيدة (॰)،

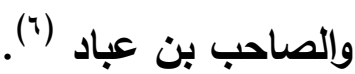

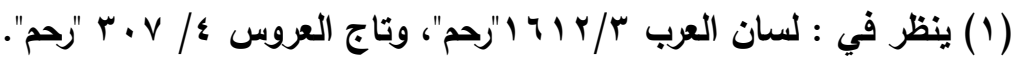

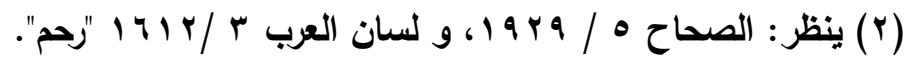

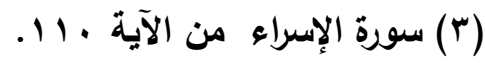

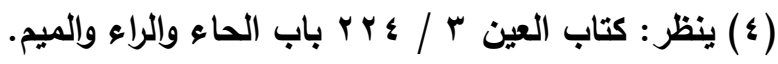

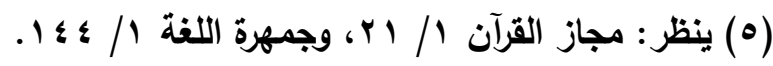

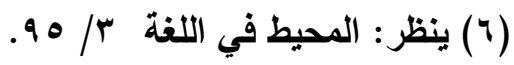


فصل المقال في الغريب من الأقوال النحوية والتصريفية د / عبدالرعوف ثابت أحمد عبدالله

\section{وتبعهم ابن الأثير (') وغيره (r)}

ويعد فقد اتضح أن لفظ "الرحمن" مشتق من الرحمة ، وأنه على وزن : فعلان ، من أبنية المبالغة ، وهو قول أئمة اللغة ، وأن القول بأنه عبراني قول

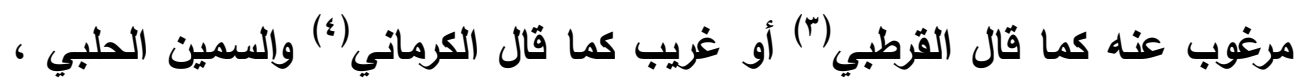
أوشاذ كما قال ابن حجر. (ه) ففي فتح الباري : "ومن الشاذ ما روى عن المبرد وثعلب . أن الرحمن عبراني والرحيم عربي ، وق ضعفه ابن الأنباري ، والزجاج ، وغيرهما وقد وجد في اللسان العبراني لكن بالخاء المعجمة. والله أعلم .

(1) ينظر: النهاية في غريب الحديث r/ / ب و ا" رحم".

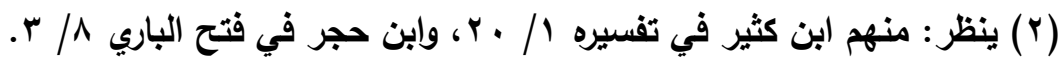

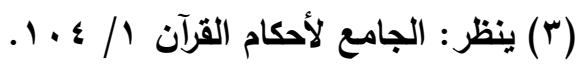

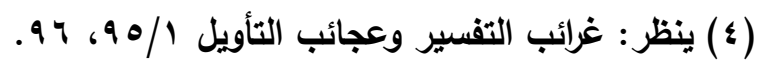

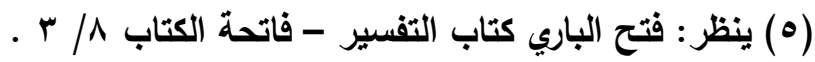


فصل المقال في الغريب من الأقوال النحوية والتصريفية د / عبدالرعوف ثابت أحمد عبدالله

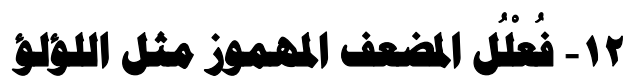

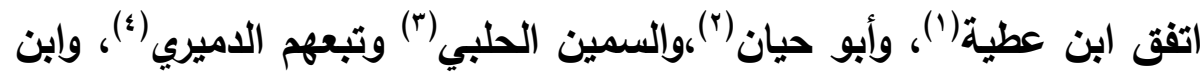
عادل الحنبلي(ه) على أن اللؤلمؤ بناء غريب ولم يرد منه في العربية إلا خمسة ألفاظ.

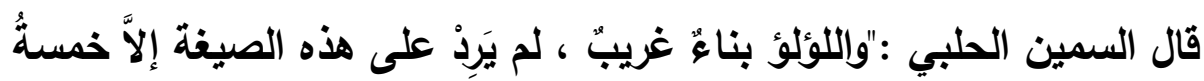

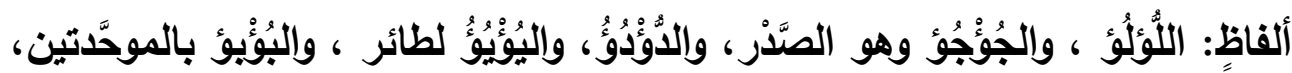

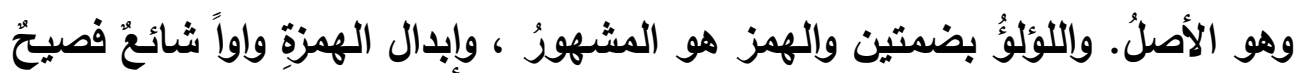
"، ووجه الغرابة فيه الثقل ، وقلة السماع عن العرب . ويالبحث اتضح لي في كتب اللغة غير هذه الخمسة، ومن ذلك الضؤضؤ، قال

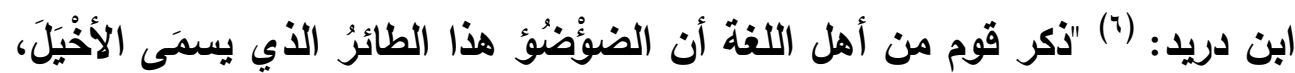

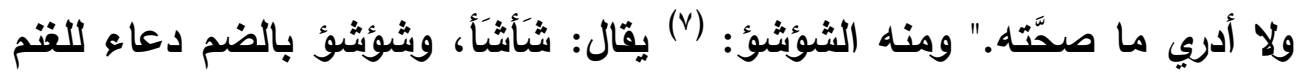
لتأكل أو تشرب." ومنه النؤنّؤ: (^) بالقصر كفدفد : المكثر تقليب الحدقة ، أو العاجز العاجز الجبان الضعيف.

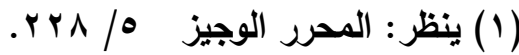

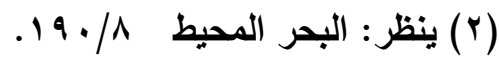

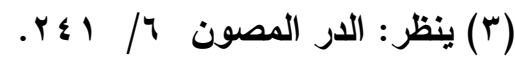

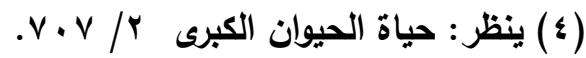

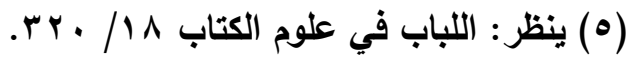

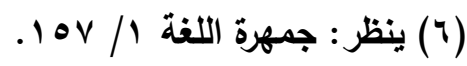

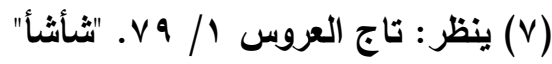

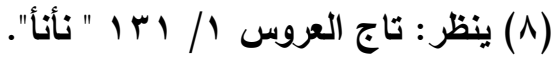


فصل المقال في الغريب من الأقوال النحوية والتصريفية د / عبدالرعوف ثابت أحمد عبدالله

ثم بعد ذلك رأيت الآلوسي(')- رحمة الله عليه- نص على ذلك حيث قال

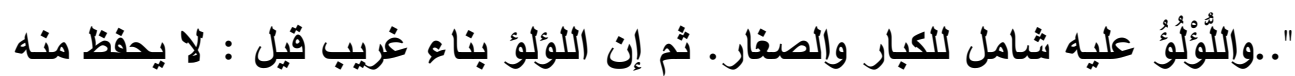
في كلام العرب أكثر من خمسة هو ، والجؤجؤ الصدر وقرية بالبحرين، والدؤدؤ آخر الشهر أو ليلة خمس وست وسبع وعشرين أو ثمان وتسع وعشرين أو ثلاث ليال من آخره، والبوؤيؤ بالباء الموحدة الأصل والسيد الظريف ورأس المكحلة وإنسان العين ووسط الشيء ، واليؤيؤ بالياء آخر الحروف طائر كالباشق ، ورأيت في كتب الب البه اللغة على هذا البناء غيرها وهو الضؤضؤ الأصل للطائر. والنؤتؤ بالتون المكثر تقليب الحدقة والعاجز الجبان، ومن ذلك شؤثؤ دعاء الحمار إلى الماء وزجر الغتم والحمار للمضي. أو هو دعاء للغنم لتأكل ، أو تثرب ". ويعد فإن هذا البناء قليل الاستعمال في لسان العرب لثقله. والله أعلم.

با - "فَعْيلة " من الميغ قليلة الاستعمال

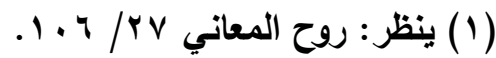


فصل المقال في الغريب من الأقوال النحوية والتصريفية د / عبدالرعوف ثابت أحمد عبدالله

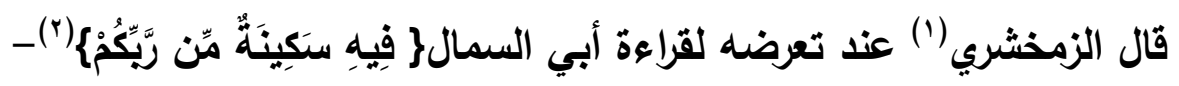

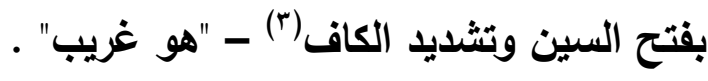

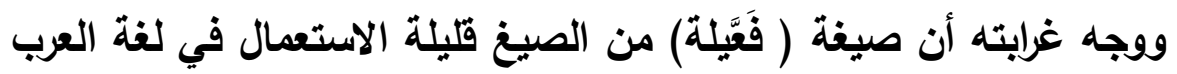

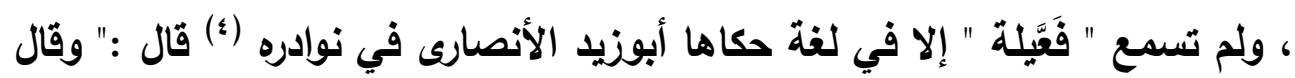

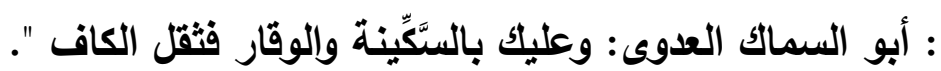

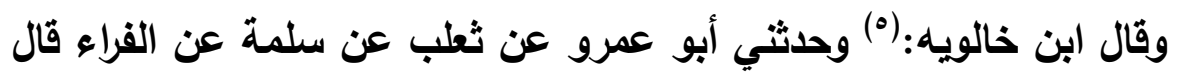

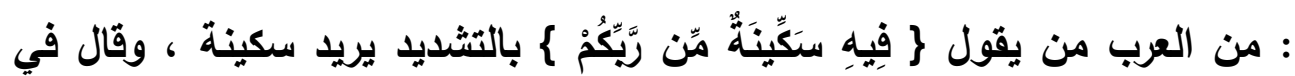

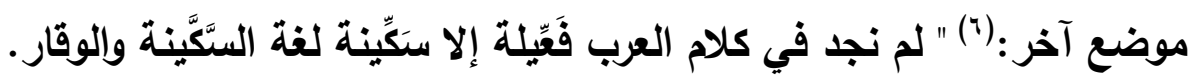

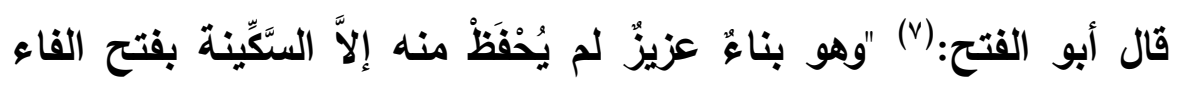

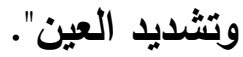

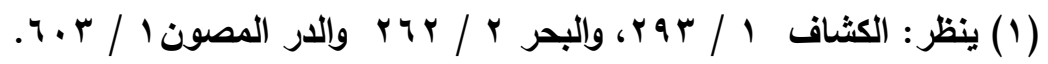

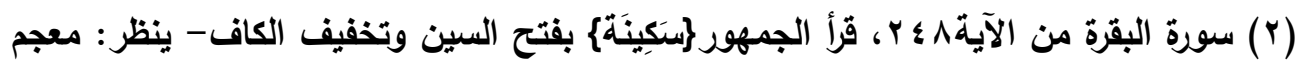

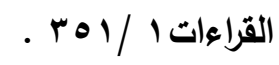

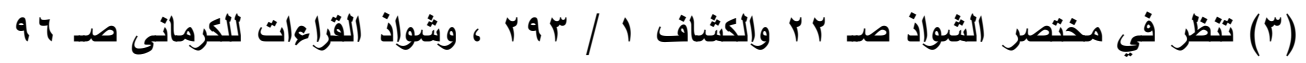

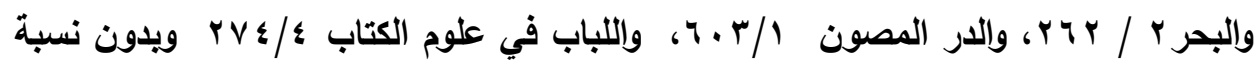

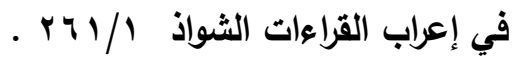

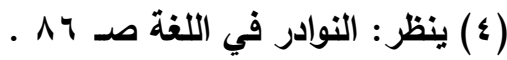

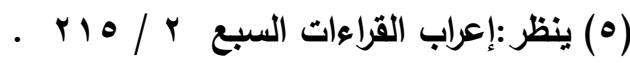

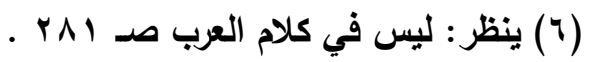

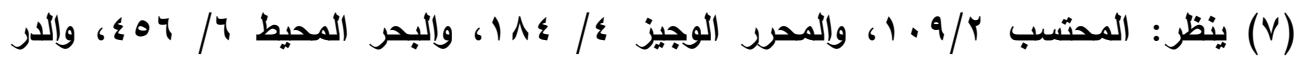

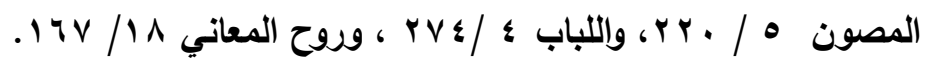


فصل المقال في الغريب من الأقوال النحوية والتصريفية د / عبدالرعوف ثابت أحمد عبدالله

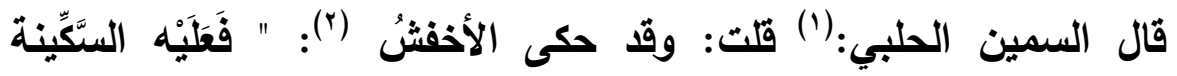

واللوَقَار.."

ويذلك يتضح لك أن تثديد العين في "فعيلة " ليس غريباً ، وإنما هو لغة

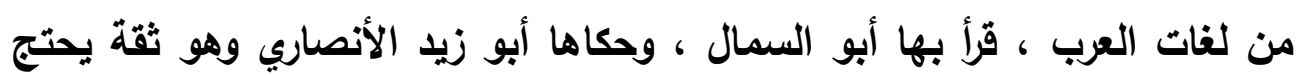

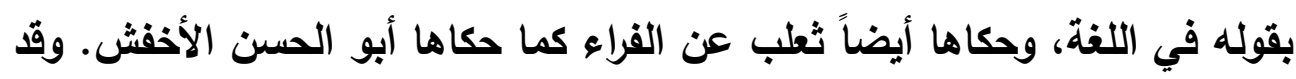

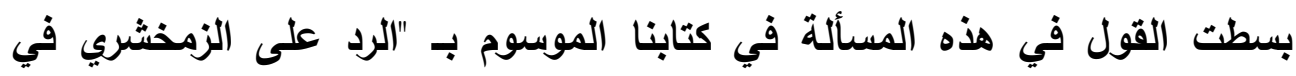

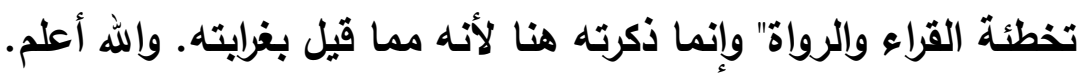

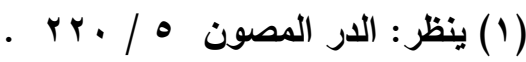

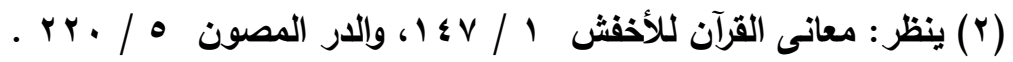


فصل المقال في الغريب من الأقوال النحوية والتصريفية د / عبدالرعوف ثابت أحمد عبدالله

\section{8}

قال أبو حيان: (1) "اليوم هو: المدة من طلوع الفجر إلى غروب الثمس، ويطلق على مطلق الوقت ، وتركيبه غريب، أعني ؛ وجود مادة تكون فاء الكلمة

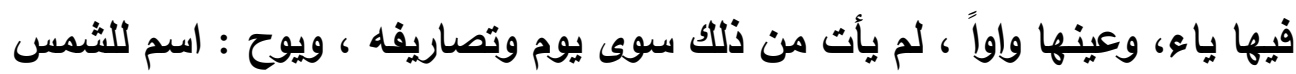
، ويعضهم(r) زعم أنه بوح بالباء ، المعجمة بواحدة من أسفل." وما ذكره أبوحيان

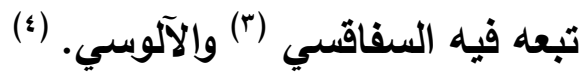

ووجه غرابته ؛ قلة استعمال مثل هذه المادة في اللسان العربي.

قال السيوطي: (•) "ولم يأت مما فاؤه ياء وعينه واو إلاّ يوح ، وعن الفارسي إنكاره، وقيل: هو تصحيف بوح (بالباء)، وإلاّ يوم وما تصرف منه: يوم أيوم وياومه مياومة ويواماً ".

وزاد ابن جني ثالثاً وهو: "يون"، فقي كتاب "التمام "(") أنشد : (v)

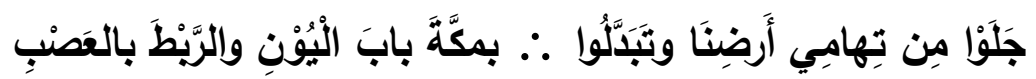

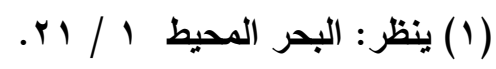

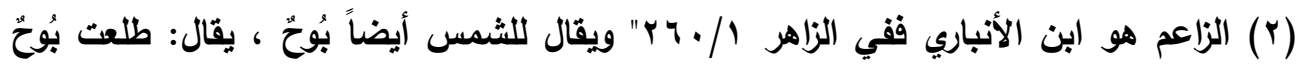

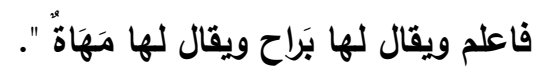

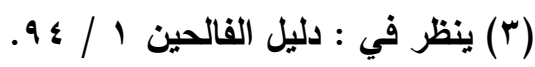

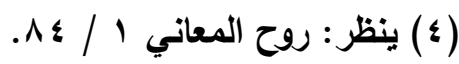

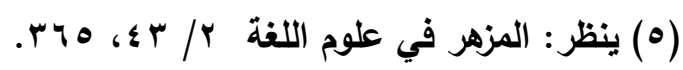

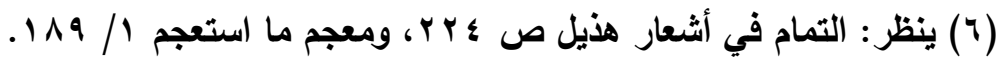

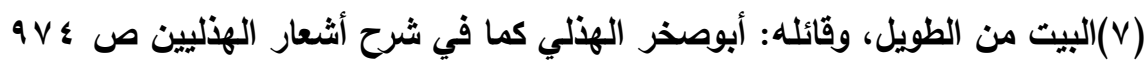

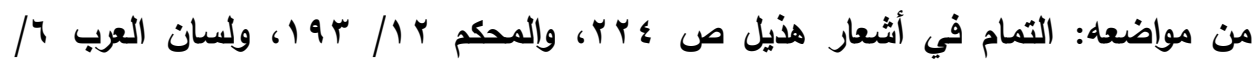

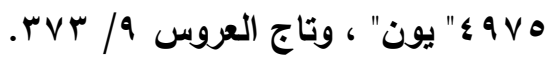


فصل المقال في الغريب من الأقوال النحوية والتصريفية د / عبدالرعوف ثابت أحمد عبدالله

قرأت على الحسين بن علي عن أبي عبد الله محمد بن العباس عن محمد بن

حبيب لكثير : (1)

جرى دون باب اليون والعصب دونه م.

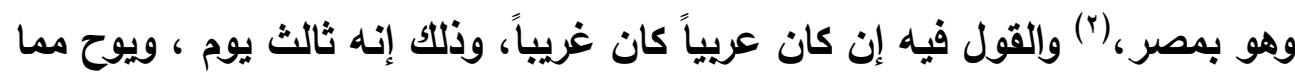

فاؤه ياءُ وعينه واو، وهذا هو الظاهر ".

ويعد فقد اتضح أن تركيب "يوم ، ويوح ، ويون " باعتلال الفاء والعين من

التراكيب قليلة الاستعمال في لسان العرب، وأنه لم يسمع منه إلا هذه الألفاظ

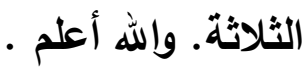

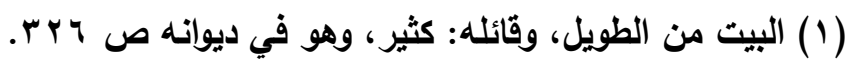

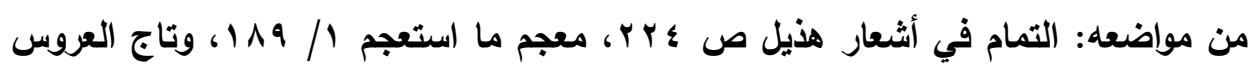

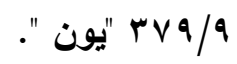

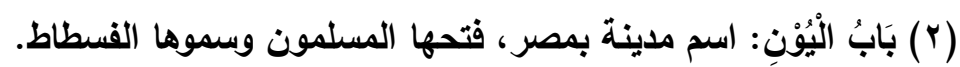


فصل المقال في الغريب من الأقوال النحوية والتصريفية د / عبدالرعوف ثابت أحمد عبدالله

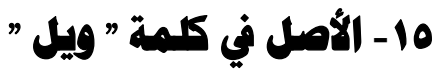

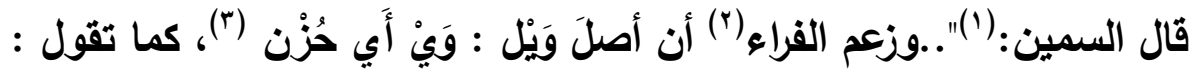

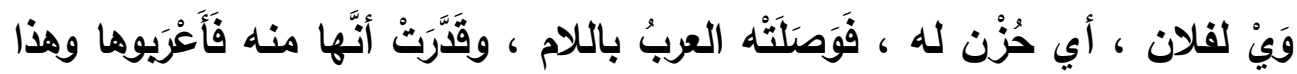

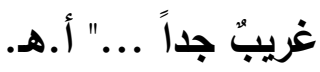
الويل كما ورد في بعض آيات القرآن الكريم كما في قوله تعالى: كَوْلّه

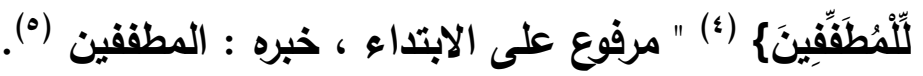
وأصله : مصدر منصوب ساد مساد فعله ، ولكنه عدل به إلى الرفع للالالة

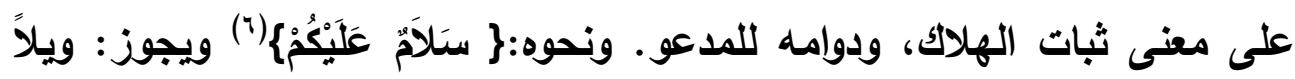

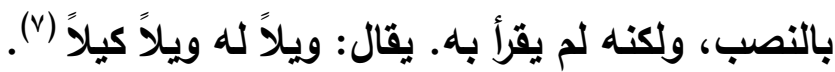
وما قاله الفراء سبقه إليه الخليل بن أحمد، والليث، وأبو طالب النحوي فقد وله روي عن المنذري عن أبي طالب النحوي أنه قال:(^) " قولهه: ويْلَه كان أَصلها:

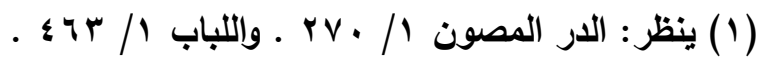

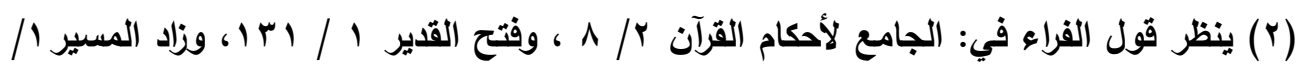

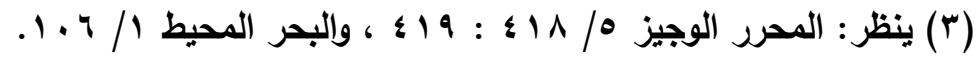

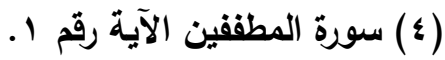

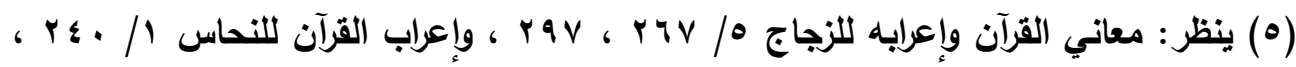

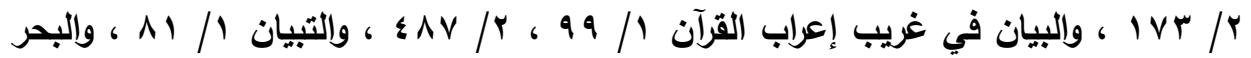

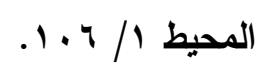

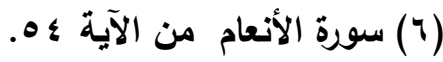

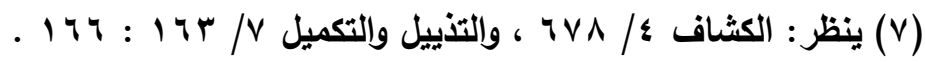

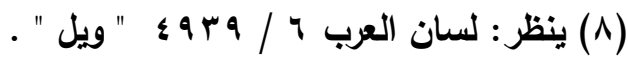


فصل المقال في الغريب من الأقوال النحوية والتصريفية د / عبدالرعوف ثابت أحمد عبدالله

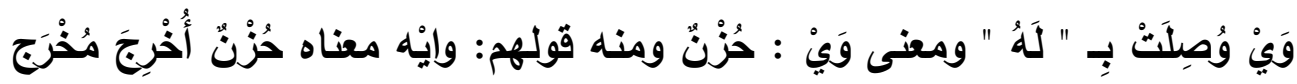

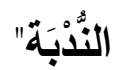

وفي التهذيب: (1) "...الليث: وَي: يكنى بها عن "التويْلِ". وقد تدخل "وي"

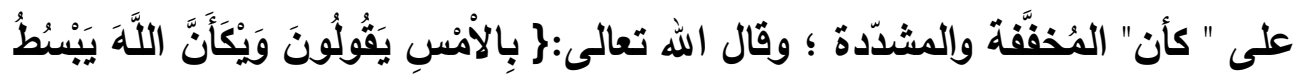

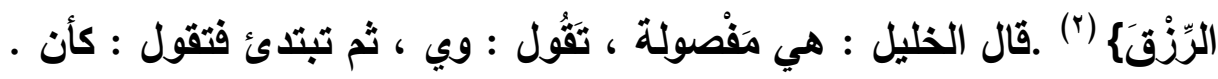
وقد ذكر الفَرَاء قول الخليل هذا، وقال: "ويكأن": "وي" مُنفصلة من " كأن" ،

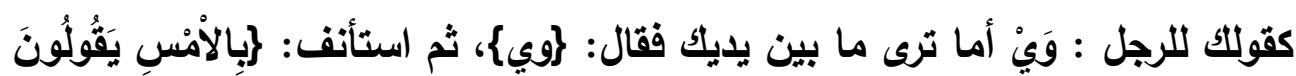

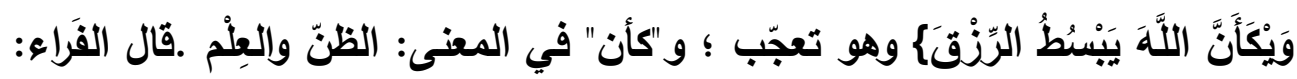
وهذا وجه يَستقيم، ولو تكتبها العربُ مُنْفصلة.، ويجوز أن يكون كَثر بها الكلام فُؤصلت بما ليست منه ، كما اجتمعت العرب على كتاب ( بابنتؤُمّ ) فوصلوها لكثرتها قلت : هذا صحيح ، والله أعلم. أ.هـ"

والذي يتضح من نهاية نص التهذيب تصحيحه لقول الفراء ، كما هو قريب

من قول الليث ، والخليل بن أحمد، وأبي طالب النحوي، كما رواه المنذري عنه ، ونقل قول الفراء كل من: القرطبي، وابن الجوزي، وابن منظور، وغيرهم دون اعتراض، ولعله بهذا يكون قد خرج من دائرة الغريب ـ والله أعلم.

\section{7 - زيادة السين قبل الناء بدون التاء "سفمل"}

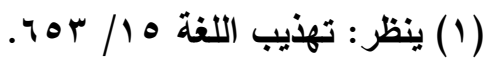

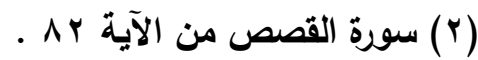


فصل المقال في الغريب من الأقوال النحوية والتصريفية د / عبدالرعوف ثابت أحمد عبدالله

قال أبوعمر الزاهد ('): السيّين في أول سِنْبِس زائدة ، يقال : نبَسَ إذا أسرَعَ

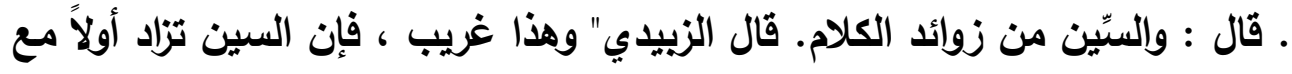
التاء ، كما في استفعل ، وأما بغيرها فنادر .

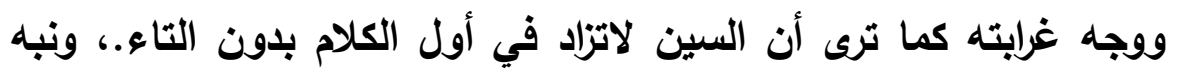

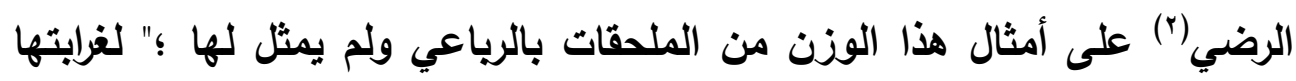

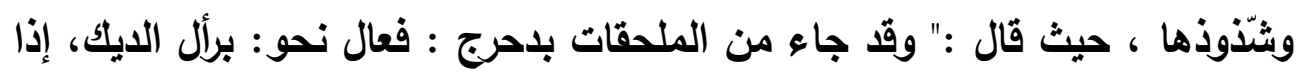

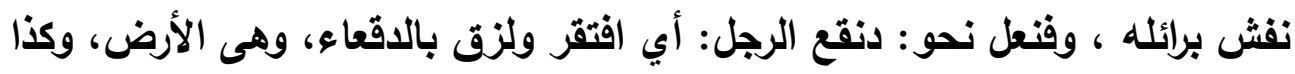

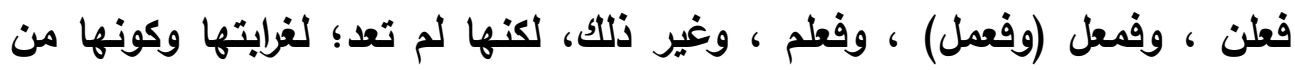

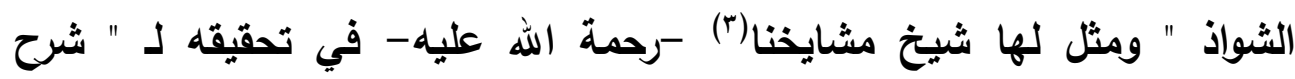
الثافية" ونصه :" وقوله فيما بعد: ونحو ذلك، إلى أوزان أخرى لم يتعرض لأكرها،

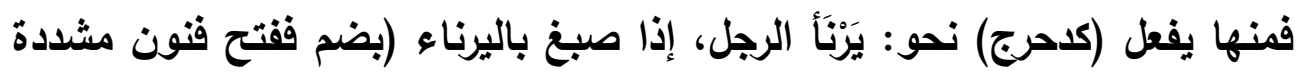
ويعد الألف هزةة) وهى الحناء.، ومنها: تفعل كدحرج نحو: تَزَمَسَ بمعنى رمسه:

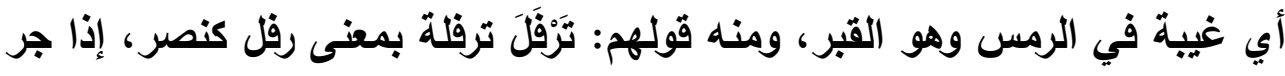

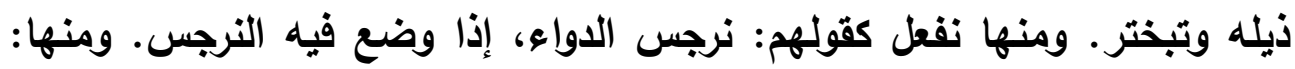

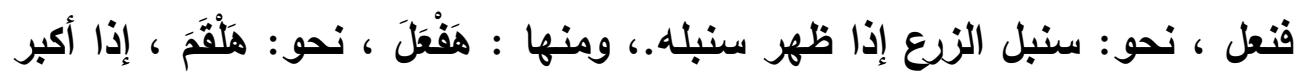
اللقم.، ومنها : سفعل ، نحو: سنبس بمعنى نبس: أي نطق، إلى غير ذللك مما تجده في كتب اللغة.

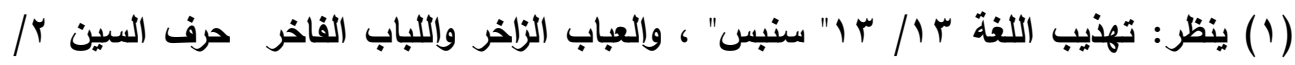

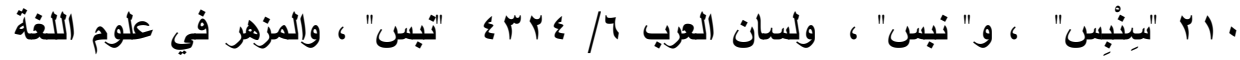

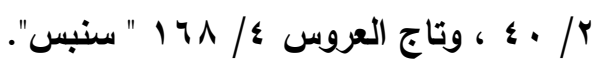

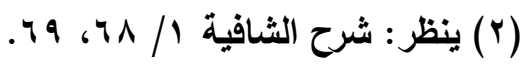
(r) الثيخ محد محي الدين عبد الحميا - حاشية المرجع السابق. 
فصل المقال في الغريب من الأقوال النحوية والتصريفية د / عبدالرعوف ثابت أحمد عبدالله

وما ذكره أبوعمر الزاهد نتله أبومنصورالأزهري(')، والصغاني(؟) وابن منظور (r)، وجزم به ابن القطاع (؛)، ولم يسمه أحد منهم بالغرابة . وجعل السيوطي الزيادة هنا للإلحاق بالرباعي فقي "المزهر في علوم اللغة"(•) قال : "المزيل من الثُلاثي الأصل: ملحق بالرياعي الأصل أو بمزيده وغير ملحق ، فالملحق به : منه ما يكون حرف الإلحاق قبل القاء فيكون علي وزن يَفْعَل ، نحو:

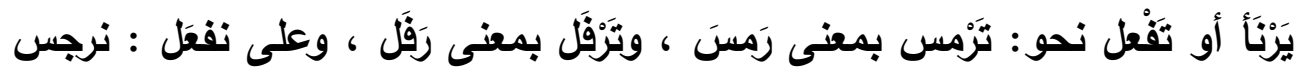

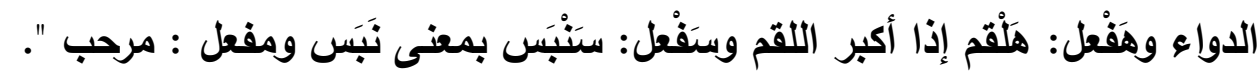
ويعد فإن المشهور لاى العلماء أن السين لا تزاد إلاّ في مَوْضِعِع وإِدِ.

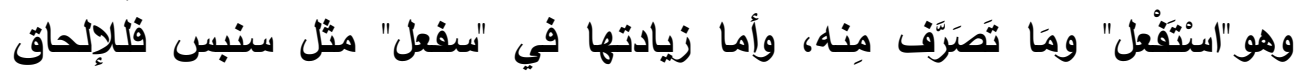
بالرياعي، وقد نص عليه أبوعمر الزاهد المعروف بغلام ثعلب وهو من متقدمي علماء العربية ، وعنه أخذ اللغويون ، ولا غرابة فيه غير أنه انفرد به ، وقل استعماله ، ، والله أعلم.

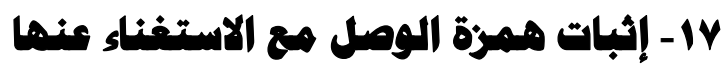

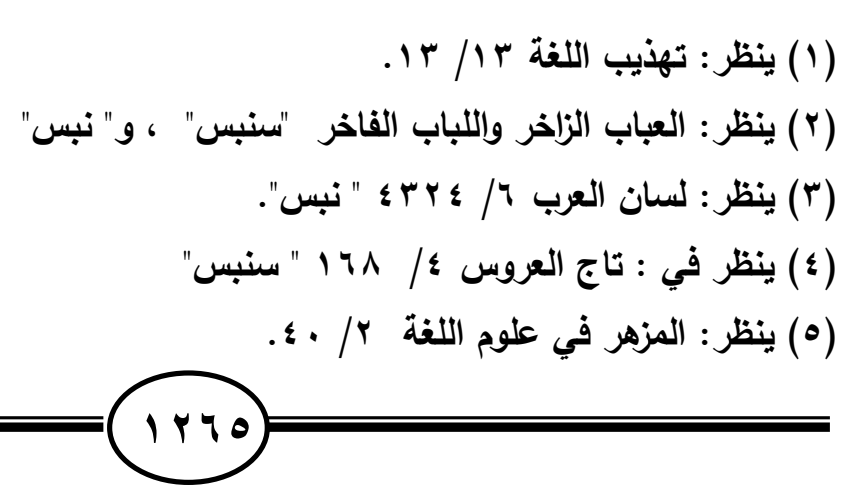


فصل المقال في الغريب من الأقوال النحوية والتصريفية د / عبدالرعوف ثابت أحمد عبدالله

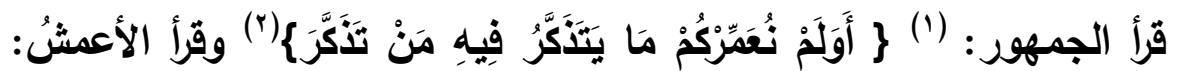

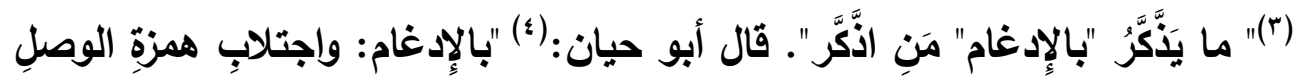

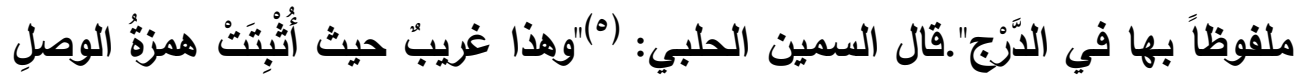

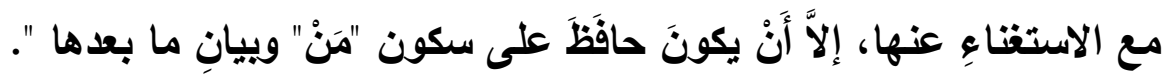

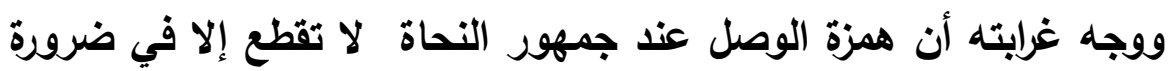

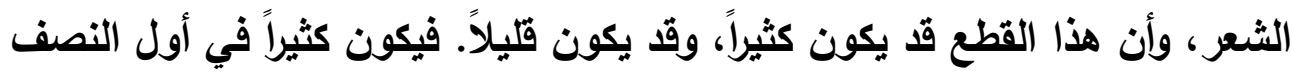

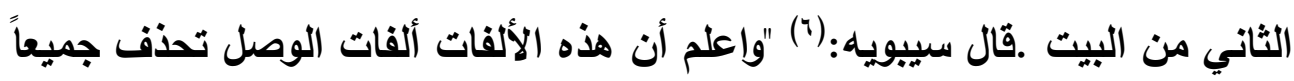

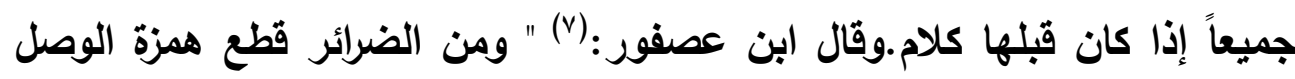

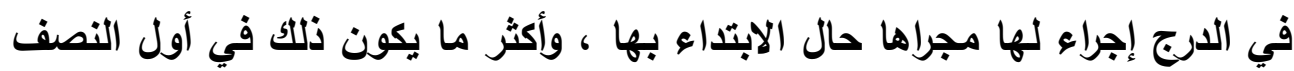
الثاني من البيت، لتعذر الوقف على الأنصاف التي هي الصدور".

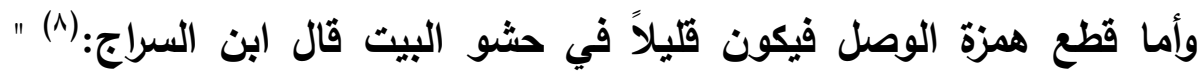

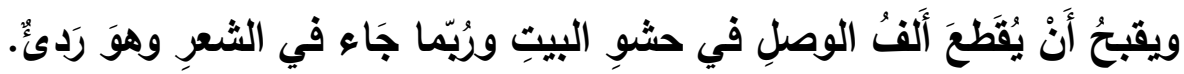

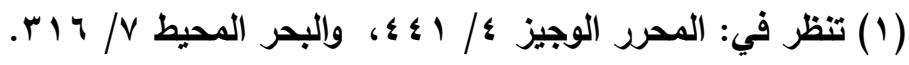

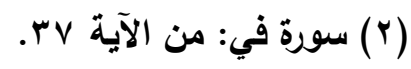

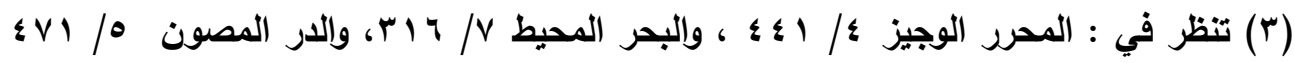

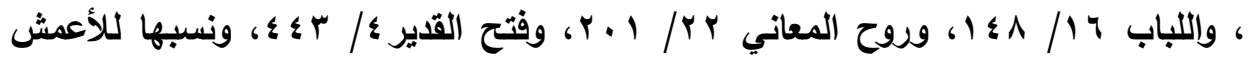
وابن مسعود في مختصر الشواذ ص ؛ ب ا، واقتصر على ابن مسعود في شواذ القراءات ص

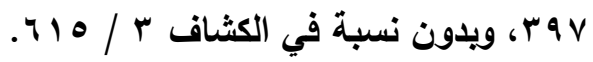

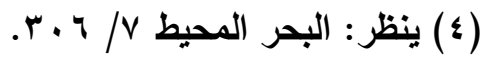

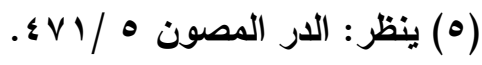

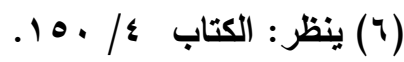

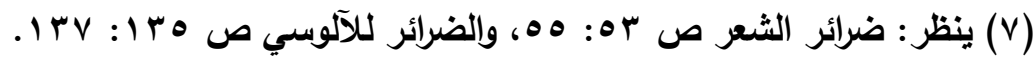

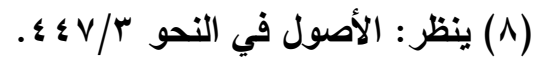


فصل المقال في الغريب من الأقوال النحوية والتصريفية د / عبدالرعوف ثابت أحمد عبدالله

وذهب الأخفش(') إلى أن قطع همزة الوصل قليل، وأنه وقع في الاختيار كما وقع في الشعر حيث قال:" وزعموا أن من العرب من يقطع ألف الوصل. أخبرني من

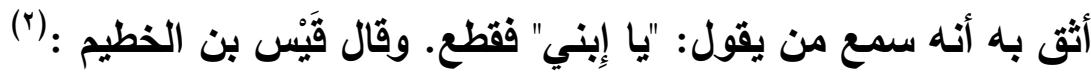

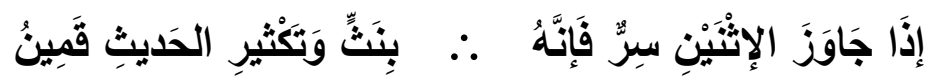

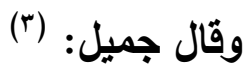

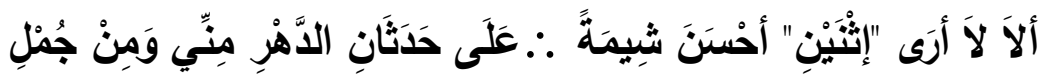
وهذا لا يكاد يعرف. ويذلك يتضح أن إثبات همزة الوصل في موضع القطع

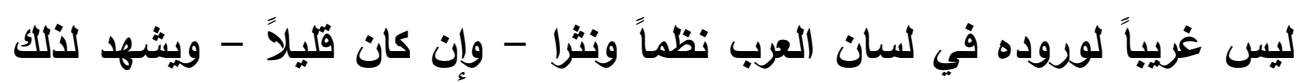

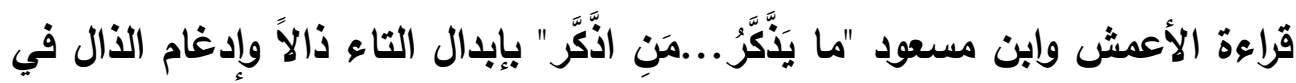

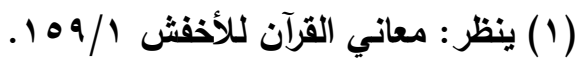

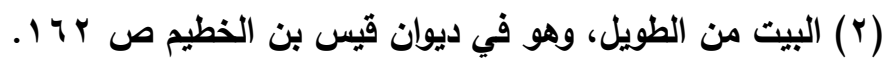

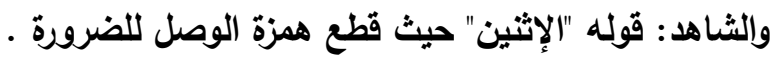

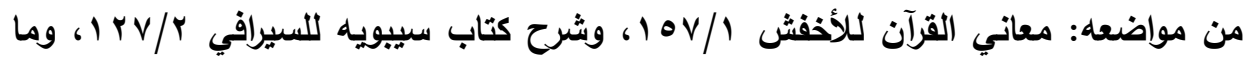

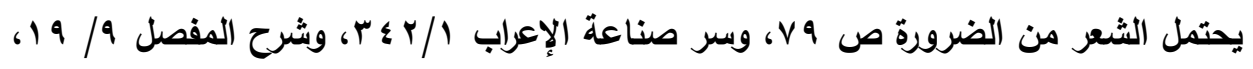

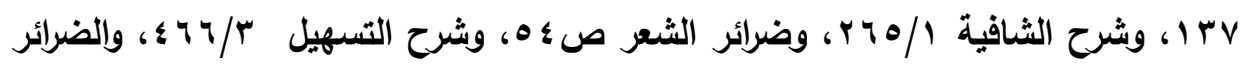

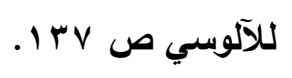

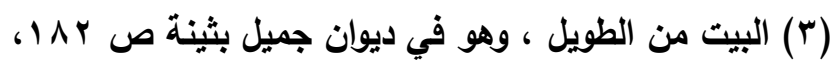

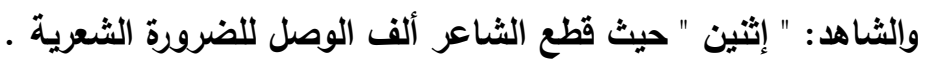

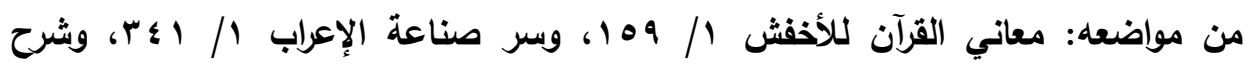

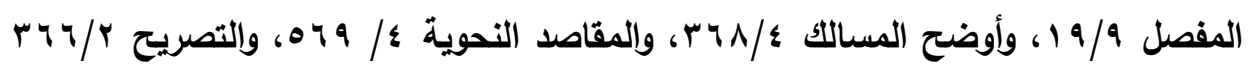

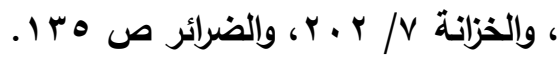


فصل المقال في الغريب من الأقوال النحوية والتصريفية د / عبدالرعوف ثابت أحمد عبدالله

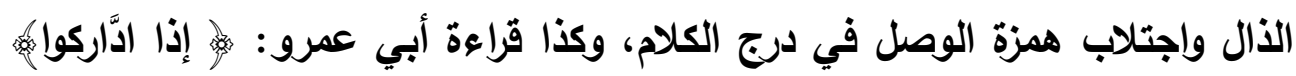

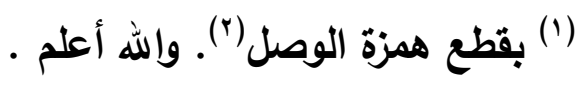

\section{1- إبدال الياء من الهمرة}

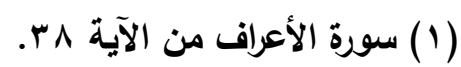

(Y) قرأ الجمهور \} إذا ادَّركوا \{ بوصل الآهـ

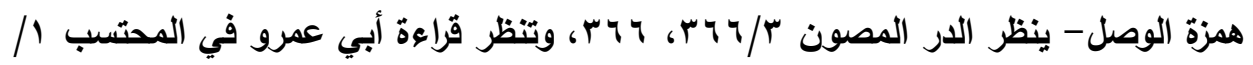

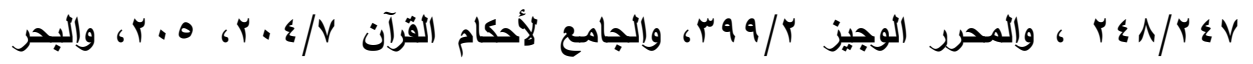

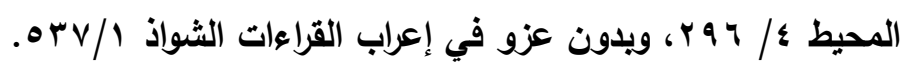


فصل المقال في الغريب من الأقوال النحوية والتصريفية د / عبدالرعوف ثابت أحمد عبدالله

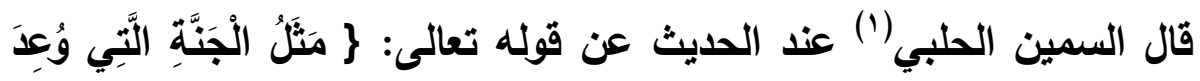

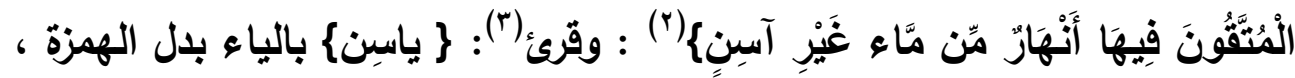

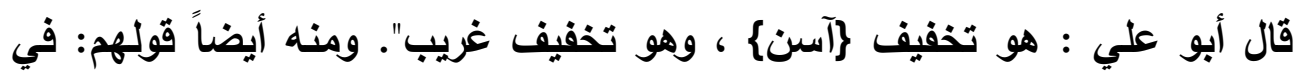

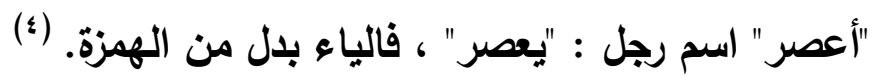

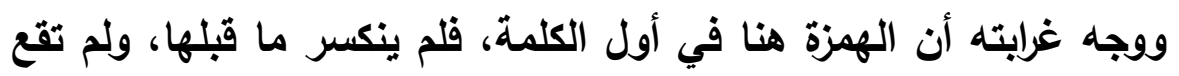
بعد ياء التصغير إلى غير ذلك مما يوجب تخفيفها.

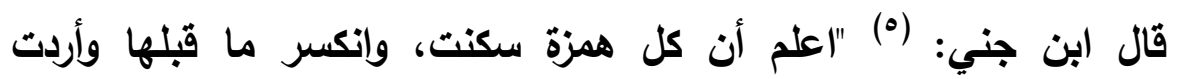

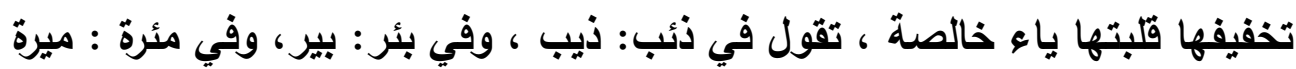
، وكذلك إذا انفتحت وإنكسر ما قبلها، تقول في مئر: مير، وفي يريد أن يقرئك:

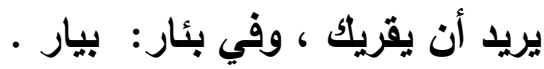

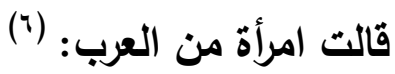

$$
\begin{aligned}
& \text { (1) ينظر: الار المصون } 4 \text { / • 10. }
\end{aligned}
$$

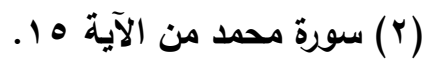

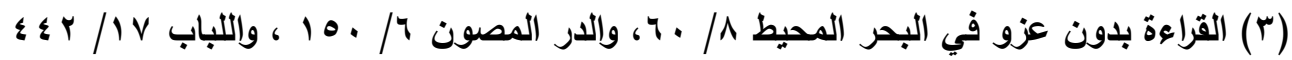

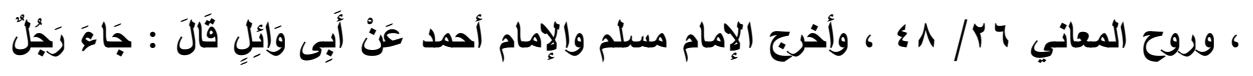

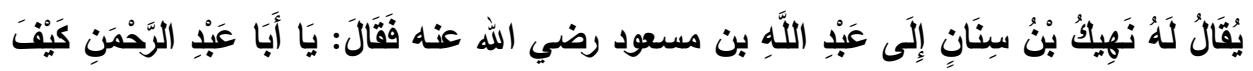

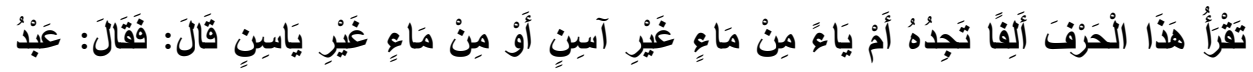

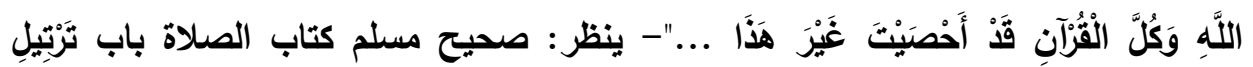

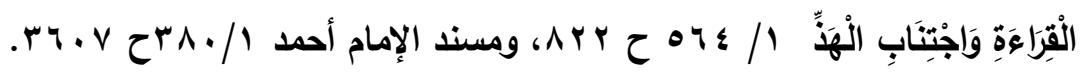

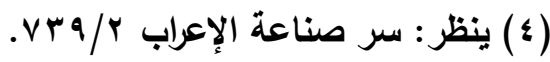

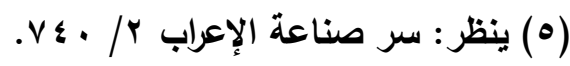

(†) البيت من المتقارب، وقائله: امرأة من العرب لم بعرف اسمها. 
فصل المقال في الغريب من الأقوال النحوية والتصريفية د / عبدالرعوف ثابت أحمد عبدالله

ألم ترنا غبنا ماؤنا . سنين فظلنا نكد البيارا

وكذلك إن وقعت الهمزة بعد ياء فعيل ، ونحوه ، مما زيلت فيه لمد ، أو بعد

ياء التحقير فتخفيفها أن تخلصها ياء ، وذلك قولك في خطيئة : خطية ، وفي نبيء : نبي ، وفي أُقَيَْس تصغير أفؤسس: أفيس ، وفي تخفيف أريئس تحقير أرؤس :

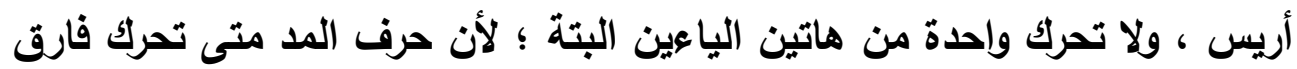
المد ، ولأن ياء التحقير أخت ألف التكسير، فكما أن الألف لا تحرك كذلك أجروا الياء هنا إذ كانت فيه رسيلتها ، على أن بعضهم قد قال في تخفيف خطيئة : خطية

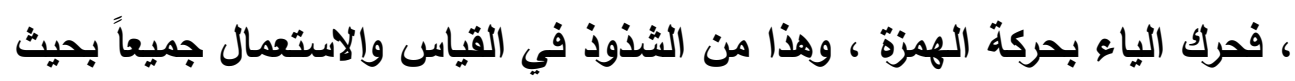
لا يلتف إليه". وقد أبدلوا الهمزة ياء لغير علة طلباً للتخفيف ، وذلك قولهم في قرأت : قريت ، وفي بأت : بليت ، وفي توضأت : توضيت. ويذلك يكون اتضح للك وجه غرابة تخفيف الياء من الهمزة في: يسن من آسن والله أعلم.

\section{|}

والثاهد قوله :" البيارا" حيث خفف الهمزة وقلبها ياء والأصل: "البئارا".

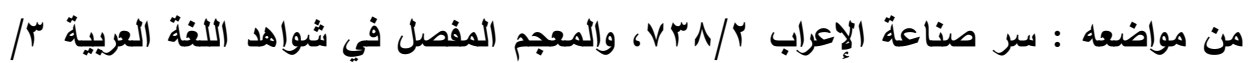


فصل المقال في الغريب من الأقوال النحوية والتصريفية د / عبدالرعوف ثابت أحمد عبدالله

الحمد لله رب العالمين،أحمده سبحانه كما ينبغي لجلال وجه وعظيم سلطانه، وأصلي وأسلم على من تحب يارينا وترضى ، وعلى آله ، وصحبه ، ومن تبعه بإحسان إلى يوم الدين.

\section{وبعد}

فقد انتهيث- بحمد الله وتوفيقه-من دراسة ومناقثة ما تيسر لي جمعه من الأقوال والآراء الموسومة بالغريب في كتب النحو، والتصريف، والتفسير، ومعاني القرآن وإعرابه، وغير ذلك. وكاتت النتائج التالية من أهم ما أسفر عنه هذانه هذا البحث:

أولاً : أن الغريب في كتب النحو والتصريف لا يقصد به البعيد، أو الغامض، كما يتبادر إلى الأهن ، وإنما يقصد به الأقوال والآراء التي انفرد بها أصحابها ، أو التي لا تعرف لغيرهم، وهذا إن جرى على القياس، ونطق به السماع فهو محمود ، وإن لم يشه له قياس ولا سماع فهو مذموم ، ومن أمثلة ذلك: 1- الفصل بين إن واسمها بالحال(') ليس غريباً كما زعم أبوحيان، وإنما هو رأي ولي ولئ انفرد به أبو الحسن بن علي الجلولي ، تشبيهاً للحال بالظرف.

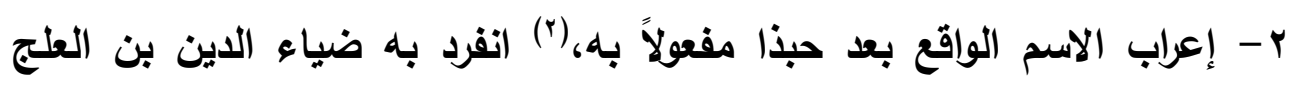

$$
\text { (صاحب البسيط). }
$$

ץ- الواو لا تفيد الترتيب والتواو تفيده(ז) انفرد به الفراء.

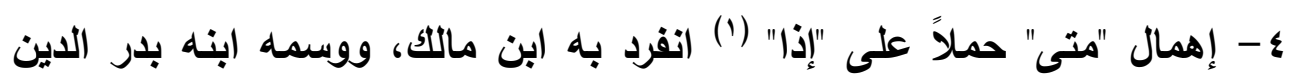
بالغريب ، وتبعه أبوحيان، وناظر الجيش ، ويالبحث اتضح أنه ليس غريباً وإنما

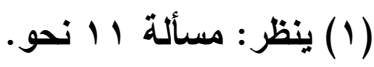

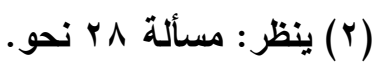

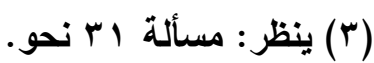


فصل المقال في الغريب من الأقوال النحوية والتصريفية د / عبدالرعوف ثابت أحمد عبدالله

هو من باب التقارض بين اللفظين وتبع ابن مالك في ذلك المرادي في الجنى الداني ،وابن هشام في المغني. ه- جزم المضارع بعد الترجي(r) ليس غريباً كما زعم أبو حيان ، وإنما هو رأي انفرد به ابن مالك رحمة الله عليه. ثانيا : أظهر البحث عن كثير من الأقوال والآراء التي وسمها التحاة بالغريب لأن أصحابها انفردوا بها، أنها ليست غريبة؛ لأن من قال بها يعد من الثقات ، وقا لأرات لا يكون انفرد بها، وإنما سبقه إليها جمع من أهل الثقة ، وحكاها المتأخرون

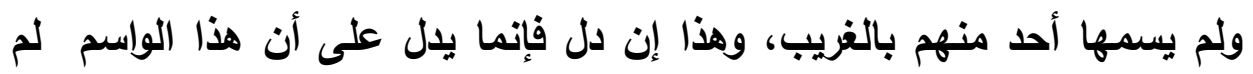
يقف على جوانب هذه القضية وإنما حكم عليها بحسب ما وصله، وهذا غير كاف في الحكم، وقد اتفقوا أن من حفظ حجة على من لم يحفظ .ومن أمثلة ذلك:

ا - عد ابن مالك - رحمه الله - (وني ورام) من أخوات " زال"(") وزعم أن النحويين لايكاد يعرفونهما إلا من عني باستقراء الغريب، ويالبحث اتضح أن ابن عصفور نقل ذلك عن بعض البغداديين. r- روى الأخفش ومن تبعه إعمال "إن" إذا اتصلت بما الزائدة (؛)، ووسمه ابن برهان ويدر الاين بن مالك وابن الصايغ بالغريب، ويالبحث اتضح أنه رواه الثقات كابراً عن كابر عن العرب.

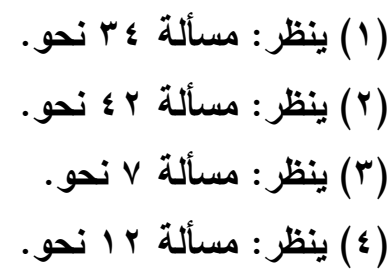


فصل المقال في الغريب من الأقوال النحوية والتصريفية د / عبدالرعوف ثابت أحمد عبدالله

ץ- مجيء "حتى" بمعنى "إلا" الاستثنائية(1) ، قاله ابن هثام الخضراوي، ووسمه المرادي بالغريب والبحث اتضح أنه قال به جمع كبير منهم : صاحب البسيط ، وابن مالك ، وأبو حيان، والسمين الحلبي ، وابن هثام الأنصاري ، والثيخ خالد الأزهري، والسيوطي، وغيرهم.

ثالثه: أن ما قرئ به ولو في الشاذ ، لا يعد غريباً؛ لأن القراءة سنة عن النبي صلى الله عليه وسلم--.، ومن أمثلة ذلك:

1- زيادة الباء في اسم ليس (r)، وسمها ابن هشام بالغريب ، وخرج عليه ابن

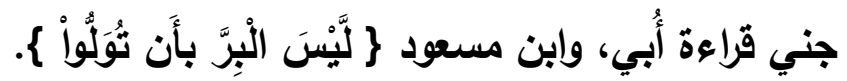

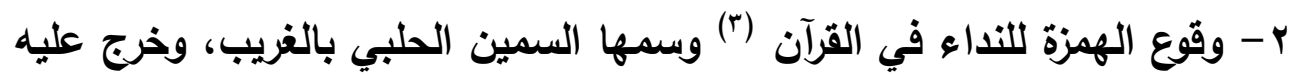

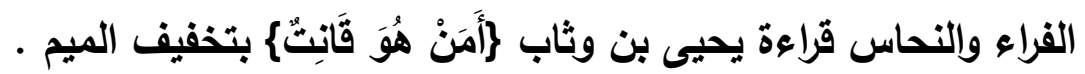
رابهك : قد يطلق الغريب على الأقوال والآراء التي خالف بها أصحابها جمهور النحويين ، وأحياناً جمهور البصريين.، ومن أمثلة ذلكي:

1 - مجيء اللام بمعنى الباء ، أو الكاف بمعنى المبادرة (؛)، ليس غريباً ، وإنما هو من باب إنابة حروف الجر بعضها عن بعض، وهو مذهب الكوفيين، خلافاً للبصريين الذين يمنعون ذلك. ץ- وقوع المفرد موقع الجمع(•)، ليس غريباً، وإنما هو مذهب كوفي، وقصره البصريون على الضرورة.

$$
\begin{aligned}
& \text { (1) ينظر : مسألة . ع نحو. }
\end{aligned}
$$

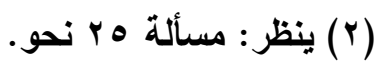

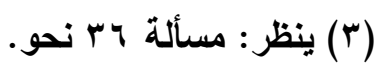

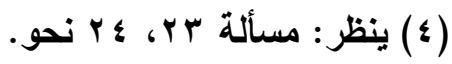

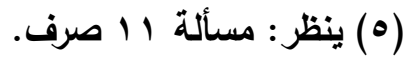


فصل المقال في الغريب من الأقوال النحوية والتصريفية د / عبدالرعوف ثابت أحمد عبدالله

خامسك: قا يطلق الغريب على القليل ،أو النادر، أو الثاذ ، أو على لغة من لغات العرب، ومن ذلك:

1- مجيء خبر عسى اسماً صريحاً (1)، ليس غريباً كما زعم المرادي، وإنما هو من باب القليل النادر؛ لأن الكثير والغالب أن يكون خبرها جملة فعلية فعلها مضارع مقرون بأن.

r- وقوع أن المخفقة بعد فعل التمني، (r) ليس غريباً، وإنما هو من باب الثاذ الأي يحفظ ولا يقاس عليه.

ץ-حذف المقول ويقاء القول، () ليس غريباً كما زعم ابن هشام، وإنما هو قليل في لغة العرب وعكسه هو الكثير.

ع - الجر بلعل(؛) ليس غريباً كما زعم أبو حيان، وإنما هي لغة بني عقيل نقله أبوزيد الأنصاري، وقال به جمع من الثقات، أمثال: الفراء، ومكي القيسي، وابن سياه، وابن بري، وابن منظور ،وغيرهم. سادسك: قيل يطلق الغريب على ما تحتمله الضرورة الشعرية ومن أمثلة ذلك: 1 - زيادة الباء بين عن ومجرورها(ه) ليس غريباً ، وإنما هو من باب الضرورة . r- حذف حرف النداء مع غير العلم (؟)، ليس غريباً، وإنما هو ضرورة عند البصريين ، جائز عند الكوفيين.

$$
\begin{aligned}
& \text { (1) ينظر: مسألة } 1 \text { نحو. } \\
& \text { (r) ينظر: مسألة س ب ا نحو. } \\
& \text { (Y) ينظر : مسألة } 17 \text { (Y) نحو. } 1 \text { (Y) }
\end{aligned}
$$

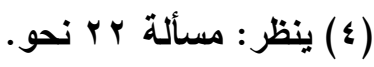

$$
\begin{aligned}
& \text { (0) ينظر : مسألة ه ب نحو. }
\end{aligned}
$$

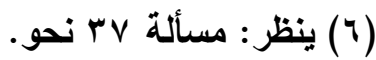


فصل المقال في الغريب من الأقوال النحوية والتصريفية د / عبدالرعوف ثابت أحمد عبدالله

ويعد فذه أهم النتائج، أو النتائج الإجمالية لمضون البحث، وفي البحث

الكثير من القضايا والثوارد النحوية والتصريفية التي تم مناقشتها ومعالجتها ،

فإن أن أكن وقا وفقت فيما قصدت فلله الفضل والمنة، وإن تكن الأخري فحسبي

أنتي اجتهدت والله من وراء القصد، فإنه نعم المولى ونعم النصير •

נكتمر

\section{عبدالرورف ثابت أصمد عبدالالها}

أستاذ الغويات المساعد في كلية البنات الإسلامية بأسيوط. 
فصل المقال في الغريب من الأقوال النحوية والتصريفية د / عبدالرعوف ثابت أحمد عبدالله

1 - إتحاف فضلاء البشر بالقراءات الأربعة عشر - تحقيق : د / شعبان محمد إسماعيل،

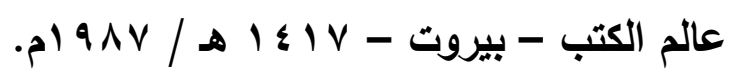

r- الإتقان في علوم القرآن للسيوطي - تح / محمد أبوالفضل إبراهيم - مكتبة ومطبعة

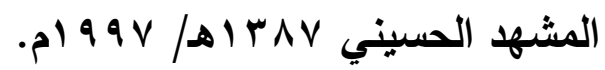

ץ- أحكام القرآن لابن العريي (تشعهـ) تح/ محمد علي البيجاوي - دار المعرفة

$$
\text { بيروت لبنان. }
$$

ع - أدب الكاتب لابن قتيبة- تح/ محمد محي الدين عبدالحميد - دار الطلائع ه . . ب م. ه- ارتثاف الضرب من لسان العرب لأبي حيان الأندلسي - تحقيق - د/ مصطفى أحمد

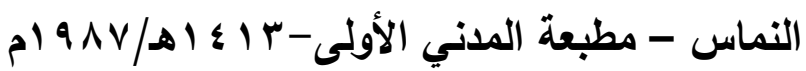

4 - الإرشاد الشافي على متن الكافي للامنهوري - دار إحياء الكتب العربية - عيسى الحلبي وشركاه.

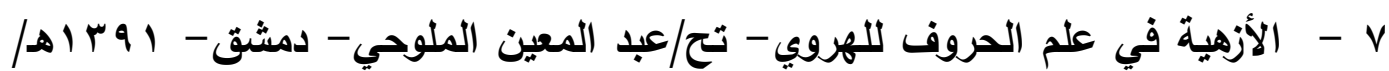
. $) 9 \vee 1$

- الاستغناء في الاستثناء للقرافي- تح/ محمد عبد القادر عطا - دار الكتب العلمية

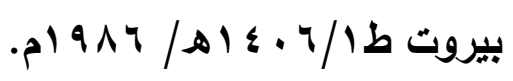

9- الأشباه والنظائر في النحو للسيوطي - راجعه وقدم له د / فايز ترحيني - دار الكتاب

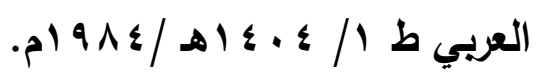

• 1 - الأصول في النحو لابن السراج تحقيق/عبد الحسين الفتلي - موسسة الرسالة -

$$
\text { ه } 1 \leqslant 0
$$

1 - أضواء البيان في إيضاح القرآن بالقرآن محمد للأمين الثنقيطي - دار الفكر

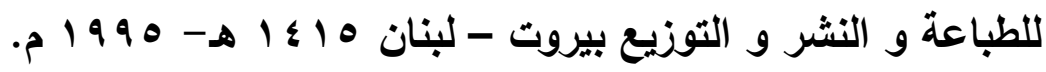

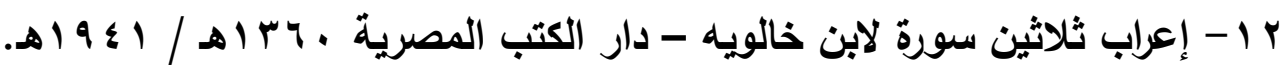


فصل المقال في الغريب من الأقوال النحوية والتصريفية د / عبدالرعوف ثابت أحمد عبدالله

ب ا - إعراب القراعات السبع وعللها لابن خالويه- تح/ عبدالرحمن العثيمين - مطبعة المدني - ط / /

ع ا - إعراب القراءات الثواذ لأبى البقاء العكبري - تح / محمد السيد أحمد عزوز - عالم

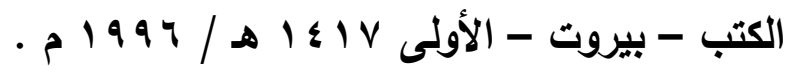

10

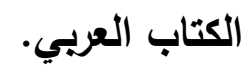

17 - إعراب القرآن للنحاس ، تح : د / زهير غِازي - عالم الكتب - مكتبة النهضة ط

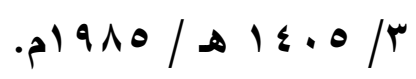

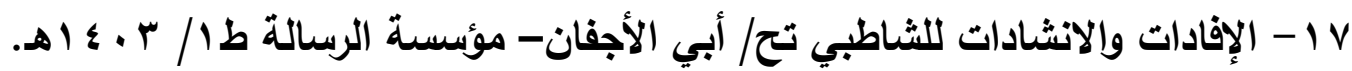
1 1 - الإقتراح في علم أصول النحو للسيوطي - د/أحمد محمد قاسم - 9 V 9 ام. 9 ا 19 ألفية بن مالك في النحو والصرف - مطبعة الحلبي .

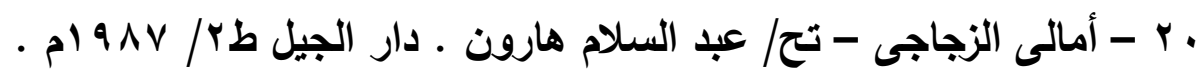

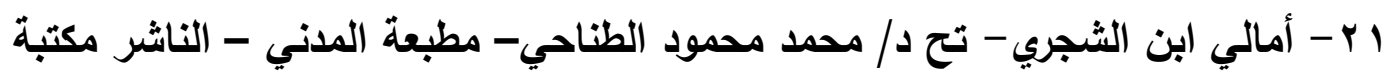

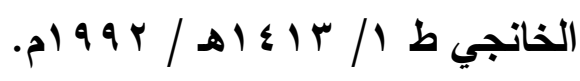

r r - الأمالي لأبي علي القالي ومعه ذيل الأمالي - دار الكتاب العربي - بيروت.

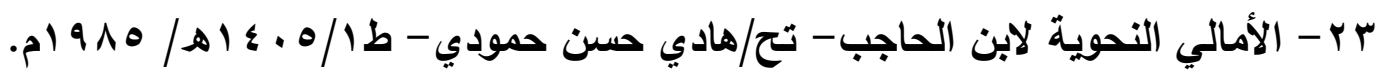

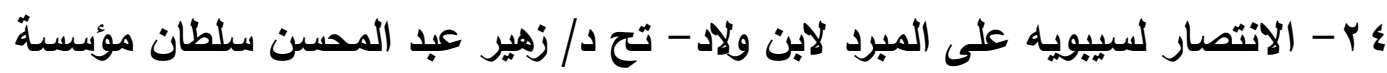

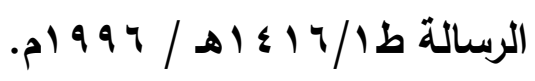

ه - الإنصاف في مسائل الخلاف لابن الأنبارى - تح/محمد محى الدين. دار الفكر צ - أوضح المسالك إلى ألفية ابن مالك - لابن هشام الأنصاري - تح / محمد محيى

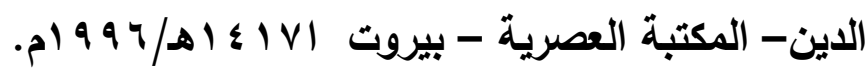


فصل المقال في الغريب من الأقوال النحوية والتصريفية د / عبدالرعوف ثابت أحمد عبدالله

- الإيضاح في شرح المفصل لابن الحاجب- تح/ موسى بناي العلايلي- مطبعة

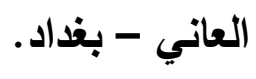

^r - الإيضاح في علل النحو للزجاجي- تح د/ مازن المبارك - دار النفائس- طب/

$$
\text { . } 9 \text { ( } 9 \text { / } / 1 \% 9 q
$$

q - البحر المحيط لأبى حيان - الناشر - مكتبة النهضة الحديثة بالرياض السعودية. • ب- البرهان في علوم القرآن للزركشي- خرج أحاديثه وقدم له / مصطفى عبدالقادر

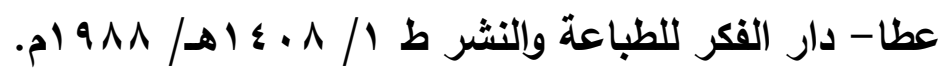
اس- البسيط في شرح جمل الزجاجي لابن أبي الربيع/تح د/عياد بن عيد الثبيتي - دار

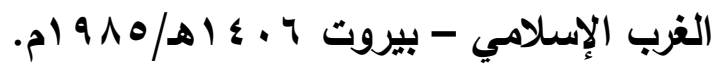

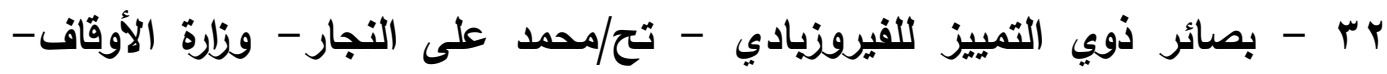

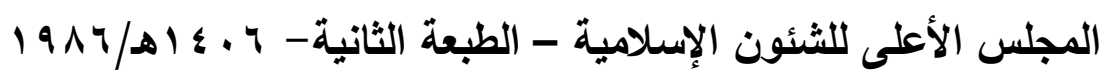

r - البيان في إعراب غريب القرآن للأنبارى- تح. د/ طه عبد الحميا طه- الهيئة

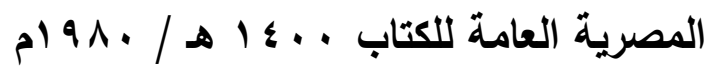

ع ب - تاج العروس للزبيدى - المطبعة الخيرية بمصر - ط الأولى 7 . ب اهـ. هـ- تأويل مشكل القرآن لابن قتيبة- تح/ السيد أحمد صقر - دار التراث بهوس اهـ/ - p) $9 \vee r$

צس - التبصرة في القراءات السبع لمكي بن أبي طالب- تح/ محمد غوث الندوي - الدار

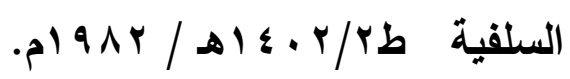

VV - التبيان في إعراب القرآن للعكبري- تح/ محمد على البجاوي - ط/الحلبي 919 ام.

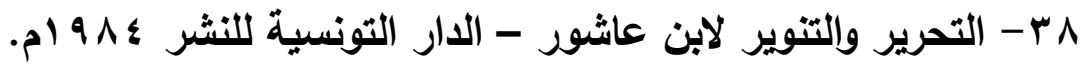
q - تحصيل عين الأهب للأعلم- تح: د/ زهير عبد المحسن سلطان - مؤسسة الرسالة

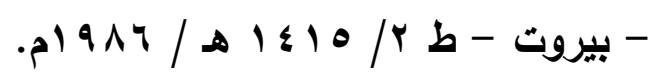


فصل المقال في الغريب من الأقوال النحوية والتصريفية د/ عبدالرعوف ثابت أحمد عبدالله

• ع - تحفة الأحوذي بشرح جامع الترمزي- مراجعة- عبدالرحمن محمد عثمان - المكتبة

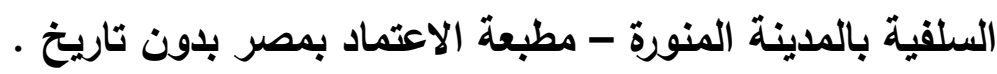

اء - تخليص الشواهد وتلخيص الفوائد لابن هشام الأنصاري- تح د/عباس مصطفي

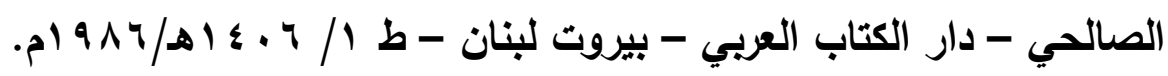

r - التخمير( شرح المفصل في صنعة الإعراب للزمخشري) تأليف صدر الأفاضل الخوارزمي - تح/ عبدالرحمن بن سليمان العثيمين - دار الغرب الإسلامي - ط الإسيري

. 199 .

بـ - تذكرة النحاة لأبى حيان - تح د/عفيفى عبد الرحمن - مؤسسة الرسالة.طا ـ ـ 7 . ع 1

$$
\text { هـ } 919
$$

ع ـ - التذييل والتكميل فى شرح التسهيل لأبى حيان- تح: د/ حسن هنداوى"على فترات. ه ؛ - التسهيل لعلوم التنزيل لمحمد بن جزي الكلبي - دار الكتاب العربي طء/ ب . ـ اهـ/ 1914.

צ ؛ - تسهيل الفوائد وتكميل المقاصد لابن مالك تح: د/ محمد كامل بركات - دار الكتاب

$$
\text { العربي }
$$

V \ - التصريح بمضمون التوضيح للثيخ/ خالد الأزهري- دار إحياء الكتب العربية.فيصل

الحلبي.

^ ـ - تعليق الفرائد على تسهيل الفوائد للاماميني تح د/محمد عبد الرحمن المفدى

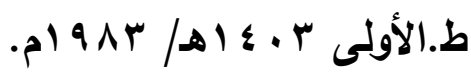

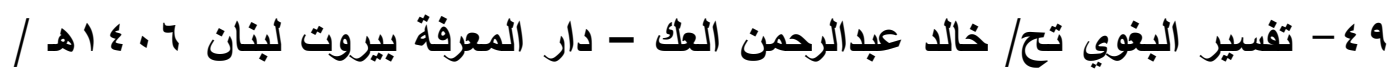

7919

• - - تفسير البيضاوي- تصحيح.محمد سالم محيسن.الناشر.مكتبة الجمهورية- ش. الصناددية بمصر 
فصل المقال في الغريب من الأقوال النحوية والتصريفية د / عبدالرعوف ثابت أحمد عبدالله

اه - التفسير الكبير المسمى (مفاتيح الغيب) للفخر الرازي- دار الكتب العلمية - بيروت. ro - تفسير النسفي-تح الثيخ /مروان محمد الثقار - دار النفائس ط الأولى 7 أـ اهـ

$$
\text { . } 999 /
$$

به - تكملة شرح التسهيل لبدر الدين بن مالك- تح / عبد الرحمن السيد ، محمد بلوى

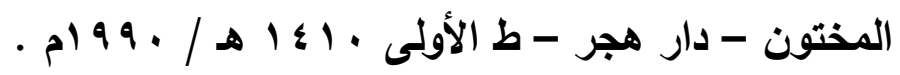

ـه - التمام في شرع أشعار هذيل لابن جني - مطبعة العاني- بغداد- الطبعة الأولى

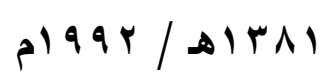

هـ - التمهيد في علم التجويد لابن الجزري - مؤسسة الرسالة قرطبة ط / / ب . . rم. צه - تمهيد القواعد لناظر الجيش تح أ.د/ على محمد فاخر وآخرين - دار السلام للطباعة والنشر ط الأولى ^r \& أهـ/ V . . r م.

- OV تهذيب اللغة للأزهري - تحقيق الأستاذ / عبد السلام محمد هارون - الهيئة

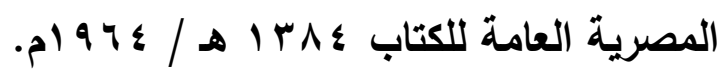

ه - توضيح المقاصد والمسالك للمرادى - تع ـ د / عبد الرحمن على سليمان - مكتبة

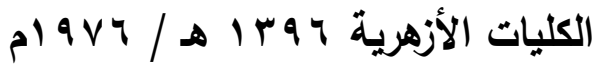

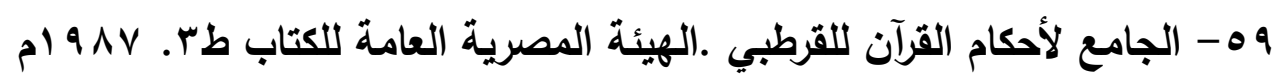
.

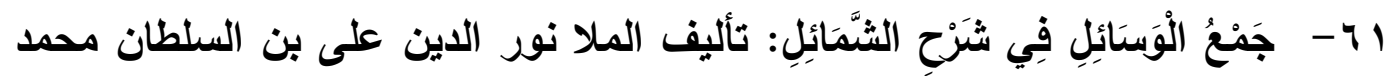

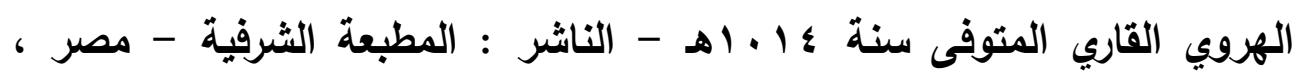
مطبع مصطفى البابي الحلبي.

ب - الجمل في النحو للزجاجي تحقيق د/ على توفيق الحمد - طبع مؤسسة الرسالة -

$$
\text { م) } 997 / \text { / أه }
$$

با - جمهرة اللغة لابن دريد - دار صادر بيروت. 
فصل المقال في الغريب من الأقوال النحوية والتصريفية د/ عبدالرعوف ثابت أحمد عبدالله

צ - - الجنى الدانى في حروف المعانى للمرادى - تح : د / فخر الدين قباوة- دار الكتب

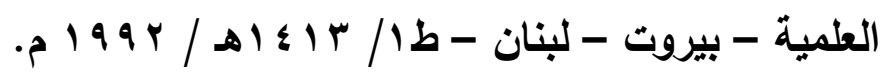

ه - جواب المسائل العشر لابن بري- تح د/ محمد أحمد الدالي - دار البشائر للطباعة

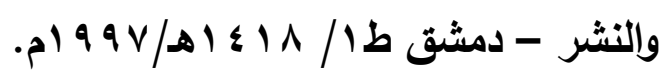

צ - - حاشية الأمير على مغتي اللبيب - دار إحياء الكتب العربية- فيصل الحلبي. Vף - حاشية ابن جماعة على شرح الجاريردي على شافية ابن الحاجب- عالم الكتب بيروت.

1 الحلبي وشركاه.

9 9 - حاثية الصاوي على تفسير الجلاليين قدم له صدقي محمد جميل - دار الفكر

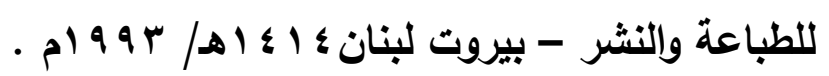
• هشام " المطبعة البهية بمصر .ـ • ب أهـ. 1 حاشية الثهاب الخفاجى على تفسير البيضاوى المسماة " عناية القاضى وكفاية

$$
\text { الراضى " - المكتبة الإسلامية - أردمير - ديار بكر - تركياز. }
$$

VY حاشية الصبان على شرح الأثموني - ط عيسى البابي الحلبي. ك - V - حاثية يس على التصريح - دار إحياء الكتب العربية.فيصل الحلبي. 乏 - حجة القراعات السبعة وعللها لأبى على القارسي - وضع حواثيه/كامل مصطقى

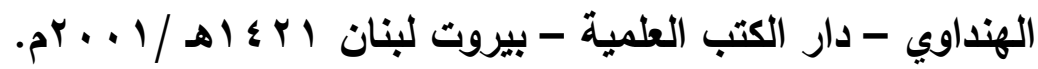
ه - حياة الحيوان الكبرى للاميري - دار التحرير للطبع والنشر 999 ام. 
فصل المقال في الغريب من الأقوال النحوية والتصريفية د / عبدالرعوف ثابت أحمد عبدالله

VY - خزانة الأدب وغاية الأرب لابن حجة الحموي -تحقيق : عصام شعيتو -الناشر :

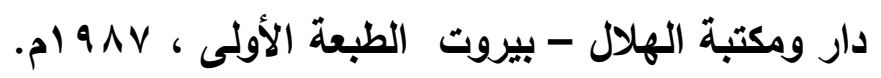

- خV

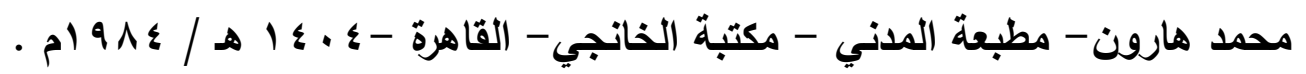
1 - الخصائص لابن جني- تح/ محمد على النجار - الهيئة المصرية العامة للكتاب

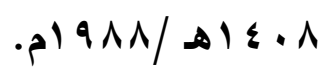

q - دراسات لأسلوب القرآن الكريم تأليف أ.د/ محمد عبدالخالق عضيمة - دار الحديث

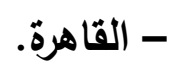
. 1 - الدرر اللوامع على همع الهوامع للشنقيطى- تح د / عبد العال سالم مكرم- دار

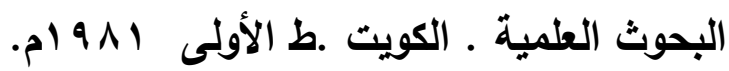
1 - الار المصون في علوم الكتاب المكنون للسمين الحلبي - تحقيق/ على محمد

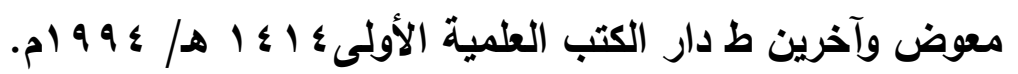
ץ ^ - دليل الفالحين لطروق رياض الصالحين لابن علان الصديقي - دار الكتاب العربي بيروت لبنان.

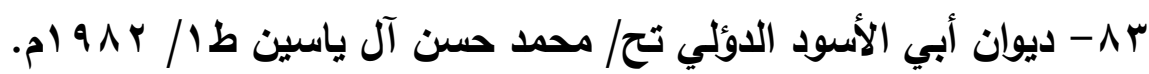
؟ ـ - ديوان الأسود بن يعفر صنعه د/ نوري حمودي القيسي - المؤسسة العامة للصحافة

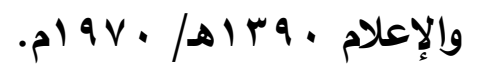

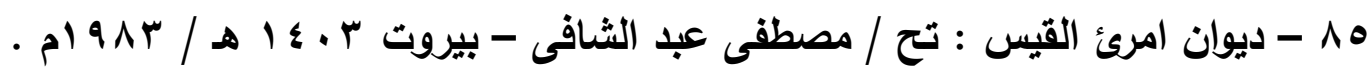
צ

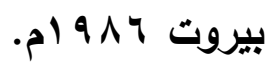

- دv 
فصل المقال في الغريب من الأقوال النحوية والتصريفية د / عبدالرعوف ثابت أحمد عبدالله

^^ - ديوان جميل بثينة ، جمع وتحقيق/ إميل يعقوب- دار الكتاب العربي بيروت طا/ . $199 r$

ه - ديوان ديوان الحطيئة - شرح/ يوسف عيد - دار الجيل بيروت طا/ سا اء اهـ/ -p) $99 r$

• 9 - ديوان حميد بن ثور الهلالي - صنعة عبدالعزيز الميمني - الار القومية للطباعة

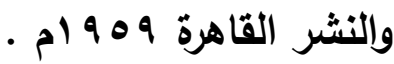

19- ديوان ذى الرمة ( غيلان بن عقبة)- شرح / أحمد حاتم الباهلى تح / أحمد عبد القدوس - مؤسسة الإيمان

r - ديوان روئة بن العجاج - عناية وترتيب / وليم البروسي .دار الأفاق الجديدة .

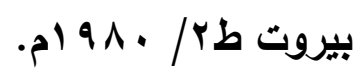

به- ديوان زهير بن أبي سلمى (شرح شعر زهير) صنعة أبي العباس ثُعلب - تحقيق -

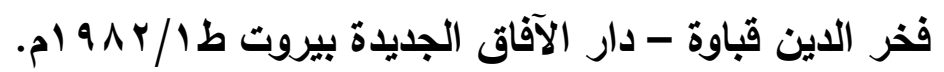
؟ 9 - ديوان أبي زيد الخيل = شعر زيد الخيل الطائي - صنعه أحمد مختار البزرة - دار المأمون للتراث - دمشث.

9 ه - ديوان عبيد الأبرص - دار بيروت للطباعة والنشر ra 9 ام.

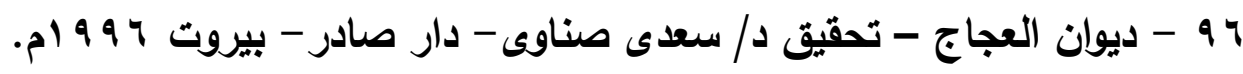
Q V - ديوان الفرزدق دار صادر بيروت .وطبعة الصاوي \&ه أم.، وشرح وطبط أ/ علي

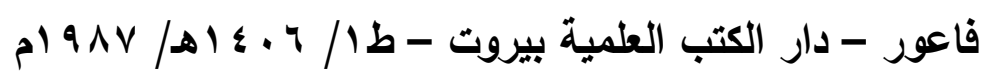
^ه - ديوان ديوان قيس بن الخطيم : تح / ناصر الدين الأسد - دار صادر بيروت . $) 97 V / r b$ 9 9 - ديوان كثير عزة : تح/ إحسان عباس - دار الثقافة بيروت - طا / IV ام . 
فصل المقال في الغريب من الأقوال النحوية والتصريفية د / عبدالرعوف ثابت أحمد عبدالله

. . - . ديوان الكميت بن زيد= شعر الكميث جمع وتقديم/ داود سلوم - مكتبة الأندلس -

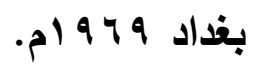

1 - 1 - ديوان لبيد بن أبي ربيعة العامري تحقيق إحسان عباس - نشرة وزارة الإعلام في الكويت مطبعة حكومة الكويت طن/ ع ع 9 ام.

r • 1 - ديوان النابغة الأبياني - تحقيق/محمد أبوالفضل إبراهيم دار المعارف بمصر - p) $9 V V$

r • ا- رصف المباني في شرح حروف المعاني للمالقي - تحقيق /أحمد محمد الخراط مطبوعات مجمع اللغة العربية بلمشث.

ـ • 1 - روح البيان لإسماعيل حقي البرسوي - الناشر - دار إحياء التراث العربى - بيروت

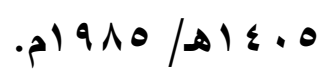

$$
\text { ه . } 1 \text { - روح المعانى للآلوبسي - دار إحياء التراث العربي - بيروت - لبنان . }
$$

7 ـ 1 - زاد المسير في علم التفسير لابن الجوزى - خرج آياته / أحمد شمس الدين -

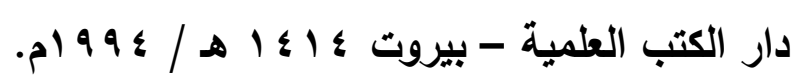

v - ا - الزاهر في معاني كلام الناس لابن الأنباري تحقيق د/حاتم الضامن - مؤسسة

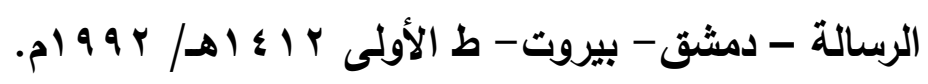

1 . 1 - السبعة في القراعات لابن مجاهد - تحقيق د/ شوقى ضيف - دار المعارف بمصر

$$
\text { - م) } 91 \text {. }
$$

9 . 1 - سر صناعة الإعراب لابن جنى - تحقيق. د// حسن هنداوى - دار القلم للطباعة

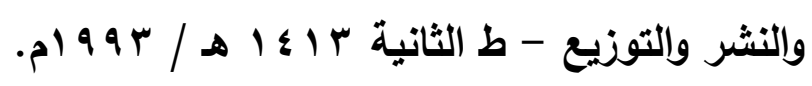

• 11- سنن الترمزي - تحقيق / بشار عواد معروف. الناشر : دار الغرب الإسلامي -

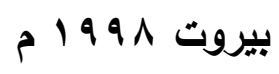


فصل المقال في الغريب من الأقوال النحوية والتصريفية د / عبدالرعوف ثابت أحمد عبدالله

111 - السنن الكبرى للإمام البيهقى - تحقيق / محمد عبد القادر عطا - دار الكتب

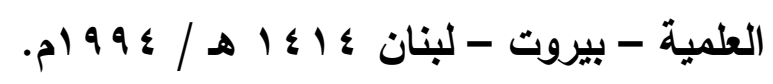

r 11 - سييويه والضرورة الثعرية تأليف الدكتور / إبراهيم حسن إبراهيم - مطبعة

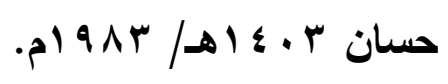

r 11 - شرح أبيات سيبويه للسيرافي - دار المأمون للتراث دمشت بيروت 9 ام. ع 11 - شرح أبيات مغتي اللبيب للبغدادي ت/عبد العزيز رياح- دار المأمون للتراث

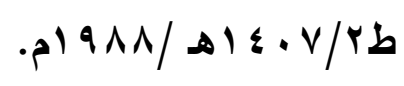

01 1 - شرح أشعار الهذليين للسكري تحقيق /عبد الستار أحمد فراج - مطبعة المدني .

11 ا - شرح التسهيل لابن مالك - ت/ عبد الرحمن السيد ، محمد بلوى المختون - دار

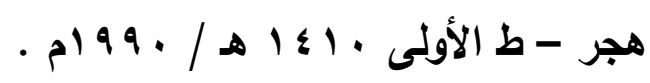

1 V - شرح الجاربردي على شافية ابن الحاجب - عالم الكتب بيروت . 11 ا - شرح جمل الزجاجي لابن عصفور. تح/ صاحب أبوجناح - وزارة الأوقاف العراقية p) $9 \Lambda$.

1 1 1 - شرح ديوان الحماسة للمرزوق - نشر أحمد أمين ، وعبدالسلام هارون - مطبعة

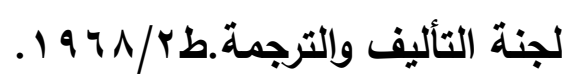
• r ا - شرح ديوان المتببي للبرقوقي - دار الكتاب العربي - بيروت لبنان . . ـ اهـ| . ) $9 \Lambda$. اY ا - شرح شافية ابن الحاجب للرضي - ت / محمد نور الحسن وآخرين - دار الكتب 
فصل المقال في الغريب من الأقوال النحوية والتصريفية د / عبدالرعوف ثابت أحمد عبدالله

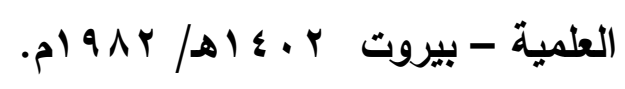

r r r ا شرح شواهد الإيضاح لابن بري تحقيق /عبيد مصطفى درويش مطبوعات مجمع

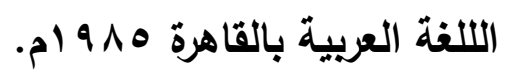

r r ا شرح شواهد الشافية للبغدادي - ت / محمد نور الحسن وآخرين - دار الكتب

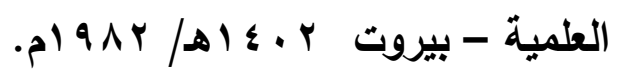

צ ا ا - شرح شواهد المغنى للسيوطى - تصحيح وتعليق / محمد محمود الشنقيطى -

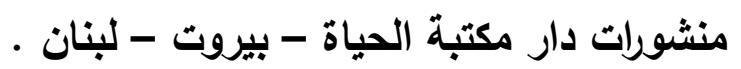

ه ا - شرح صحيح البخاري بشرح الكرماني - دار إحياء التراث العربي بيروت لبنان -

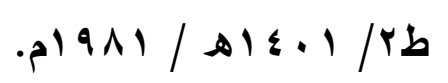

צ I - شرح ابن عقيل على ألفية ابن مالك ، ومعه منحة الجليل بتحقيق/ محمد محي الاين- دار الكتب العلمية بيروت.

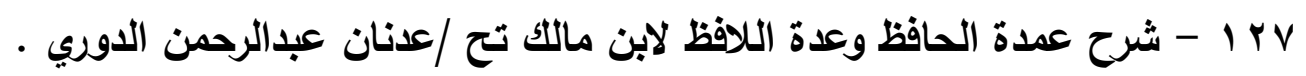
1 1 ا شرح قطر الندى لابن هشام تح/ محمد محي الاين- المكتبة العصرية بيروت. q و ا - شرح كافية ابن الحاجب للرضي - ط دار الكتب العلمية- بيروت - لبنان . • ب ا - شرح كتاب سييويه للسيرافي. تح .د/ رمضان عبدالتواب - الهيئة المصرية العامة

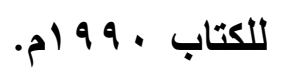

اس ا- شرح الكافية الثافية لابن مالك- دار الكتب العلمية بيروت لبنان. r ا - شرح المفصل لابن يعيش - عالم الكتب ( بدون تاريخ ) .

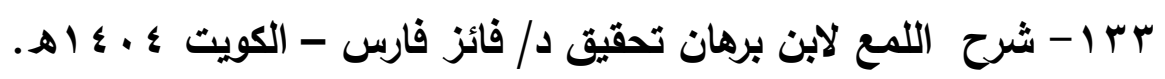
ع ب ا - شرح مغتي اللبيب للاماميني بحاثية المنصف" المطبعة البهية بمصر ع ـ ب اهـ. هـ 1 - شرح ابن الناظم على ألفية ابن مالك تح د/عبد الحميد السيد بيروت. 
فصل المقال في الغريب من الأقوال النحوية والتصريفية د / عبدالرعوف ثابت أحمد عبدالله

צ ا I - شرح النووي على صحيح مسلم - المطبعة المصرية ومكتبتها.

V I V - شواذ القراءات للكرمانى/ تح د/ شمران العجلى - مؤسسة البلاغ - بيروت .

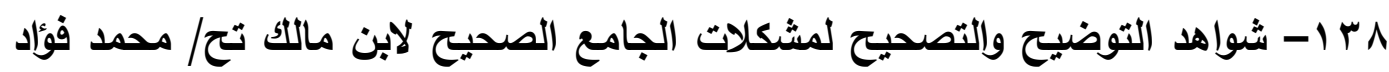

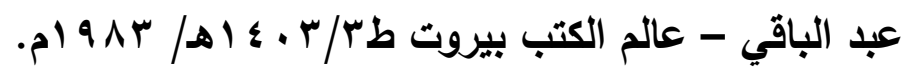
q 1 - الصاحبي في فقه اللغة لابن فارس- تح / السبد أحمد صقر ـ مكتبة ومطبعة دار

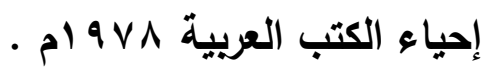

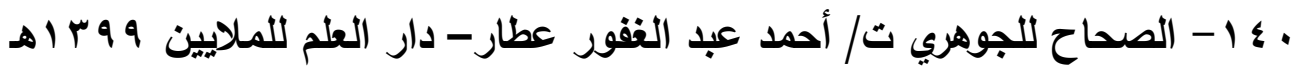
1\& إ صحيح البخاري. تحقيق / طه عبد الرعوف سعد - مكتبة الإيمان بالمنصورة

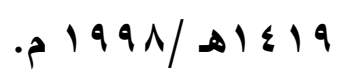

ץ ا ا - صحيح مسلم تح : محمد فؤاد عبد الباقي- دار إحياء التراث العربي - بيروت، وإعداد فريق عمل الطيماوي- دار الجيل بيروت : دار الأفاق الجديدة ـ بيروت.

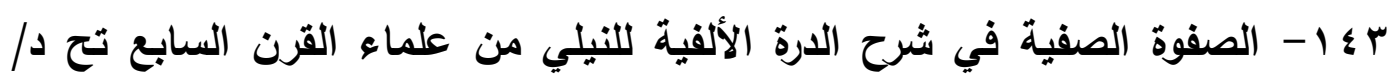

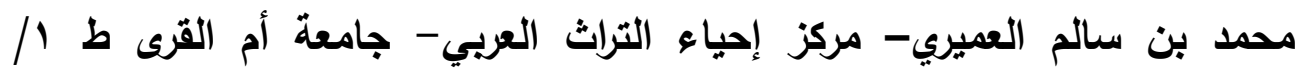
. 19

ـ ـ ا- ضرائر الشعر لابن عصفور الإشبيلي تحقيق/السبد إبراهيم محمد.- دار الأندلس

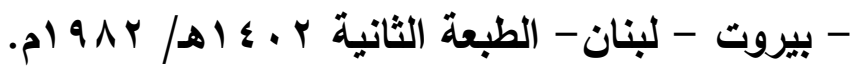

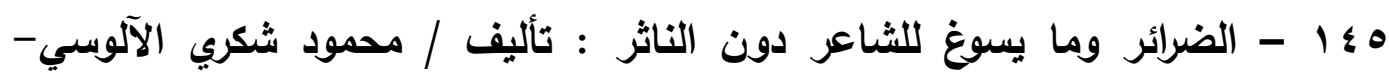

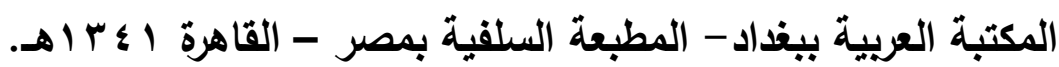
\ء ا - العباب الزاخر واللباب الفاخر للصاغاني - الشئون الإسلامية العامة- دار الآفاق

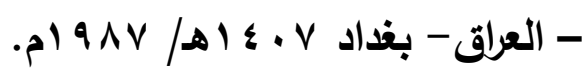
I V V - العين للخليل بن أحمد تحقيق د/ مهدي المخزومي - المكتبة الوطنية بغداد-p) $99 r$ 
فصل المقال في الغريب من الأقوال النحوية والتصريفية د / عبدالرعوف ثابت أحمد عبدالله

^ ا ا - غرائب التفسير وعجائب التأويل لتاج القراء / محمود بن حمزة الكرماني تحقيق د/ شمران سركال يونس العجلي - دار القبلة للثقافة الإسلامية - جدة ، وموئسة

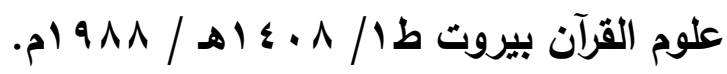
§ ا - الغيث المسجم في شرح لامية العجم للصفدي قدم لله وطبعه- د/ صلاح الدين

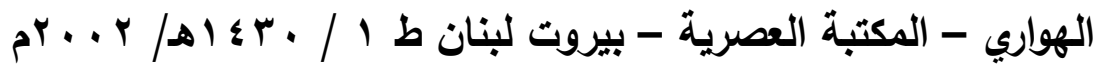
• 1 - الفائق في غريب الحديث للزمخشرى.تح/ محمد أبو الفضل. طץ/ الحلبي. 10 - فتح الباري بشرح صحيح البخاري لابن حجر العقلان تح/ عبد العزيز بن باز ومحمد فؤاد عبدالباقي - دار التقوى للتراث . . . rم. ro 1 - فتح القدير للشوكاني - ضبط/ أحمد عبد السلام - دار الكتب العلمية بيروت- ط - م) $99 \leq / \Delta 1 \leq 10 / 1$

به 1 - الفصول الخمسون لابن معط تح/ محمود محمد الطناحي - مطبعة عيسى البابي الحلبي.

ـه 1 - فيض القدير شرح الجامع الصغير لتاج العارفين بن علي المناوي ث( اس ـ أهـ.

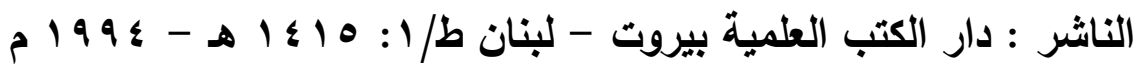

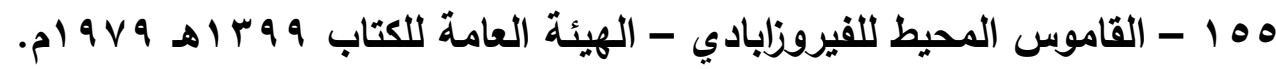
10 10 - الكامل في اللغة والأدب للمبرد تح: د/ محمد أحمد الدالي - مؤسسة الرسالة ط

$$
\text { م) } 99 \mu / \Delta 1 \% 1 \%
$$

10V - الكتاب لسيبويه - تح الأستاذ / عبد السلام محمد هارون - مطبعة المدني -

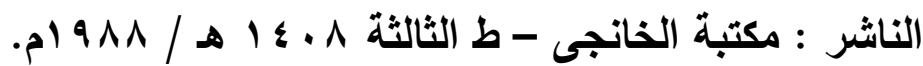

1ه - كتاب الشعر أو شرح الأبيات المشكلة الإعراب لأبي علي الفارسي تحقيق د/

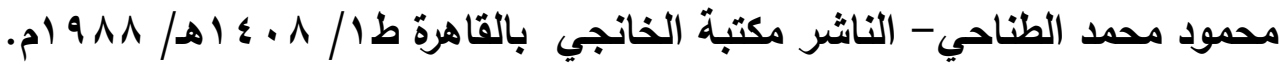


فصل المقال في الغريب من الأقوال النحوية والتصريفية د / عبدالرعوف ثابت أحمد عبدالله

9 ه - الكشاف للزمخثرى - رتبه وضبطه وصححه / مصطقى حسين أحمد - دار

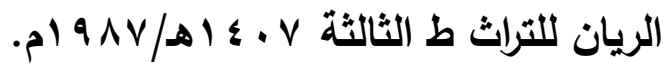

. 1 - الكثف والبيان عن تفسير القرآن للثعلبي - تح/ أبو محمد بن عاثور دار إحياء

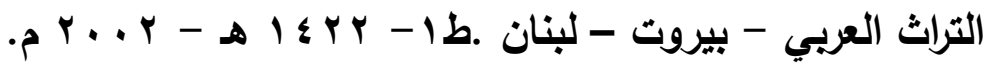

171 - كثف الخفاء ومزيل الإلباس للعجلوني / تصحيح وتعليق/ أحمد القلاسي - نشر وتوزيع مكتبة التراث الإسلامي بحلب .

r 1 - كثف الظنون عن أسامي الكتب والقنون لحاجي خليفة - دار العلوم الحديثة بيروت- لبنان.

با ا- كتاب الكليات لأبى البقاء الكفوى - تح / عرفان درويش ومحمد المصرى -

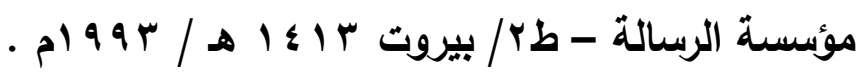

צ 1 - كنز العمال في سنن الأقوال والأفعال للمنتقي الهندي- ضبط / الثيخ بكري

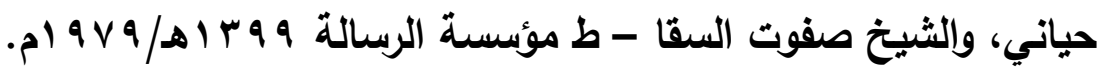
ه 1 - اللامات للزجاجي تحقيق/ مازن المبارلك - دار الفكر - دمشث طץ/ ه ه . ـ اهـ. 7 ا 1 - اللباب في علوم الكتاب لابن عادل الامشقي الحنبلي - تح / عادل أحمد عبد الموجود، والشيخ / على محمد عوض - منشورات محمد على بيضون - دار الكتب

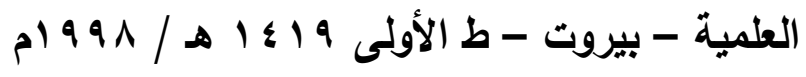

VI 1 - لسان العرب لابن منظور تح /عبدالله على الكبير وآخرين. دارالمعارف بمصر 1 1 - اللباب في علل البناء والإعراب لأبي البقاء العكبري - تح/ غازي مختار طليمات

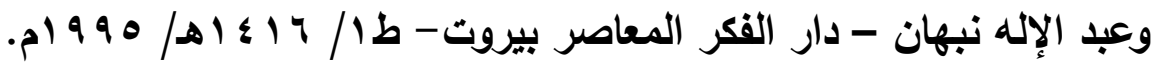

19 1 19

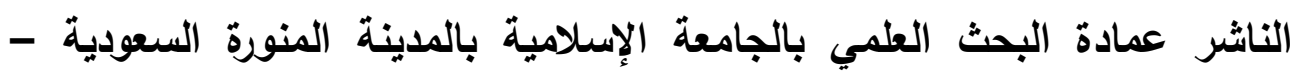

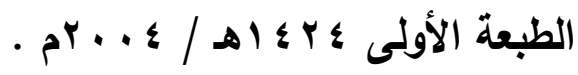


فصل المقال في الغريب من الأقوال النحوية والتصريفية د/ عبدالرعوف ثابت أحمد عبدالله

IV.

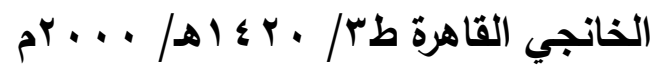

IVI - مجاز القرآن لأبي عبيدة - تعليق/محمد فؤاد سكزين - الناشر مكتبة الخانجي بالقاهرة

IV - مجالس ثعلب شرح وتحقيق/ عبد السلام محمد هارون - دار المعارف بمصر

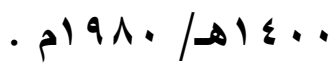

IVT - مجالس العلماء للزجاجي تحقيق/ محمد عبدالسلام محمد هارون - مكتبة

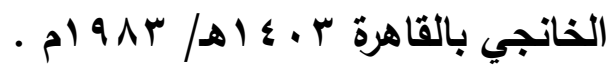

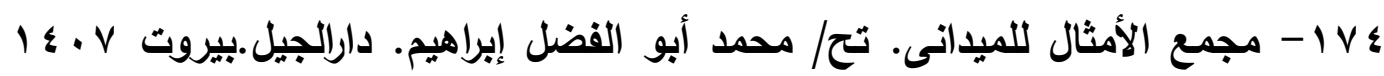
- $19 \wedge \mathrm{V}$

ه l V المحتسب في تبيين وجوه شواذ القراءات والإيضاح عنها لابن جني ، ت / على التجدي ناصف ، وآخرين - طبعة المجلس الأعلى للشئون الإسلامية - لجنة إحياء

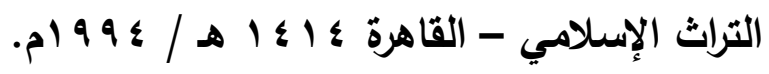

IV ا - المحرر الوجيز في تفسير الكتاب العزيز لابن عطية، تح/ عبد السلام عبد الثافي

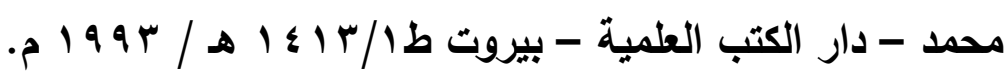
IVV 19VY./

^ ا - المحيط في اللغة لابن عباد، تح. محمد حسن آل ياسين، مطبعة المعارف، بغداد، ط

I V - مختصر في شواذ القراعات من كتاب البليع لابن خالويه - عنى بنشره :

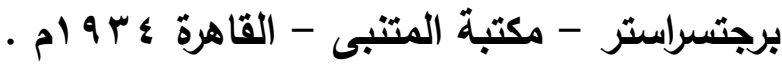
I Vq 
فصل المقال في الغريب من الأقوال النحوية والتصريفية د / عبدالرعوف ثابت أحمد عبدالله

• 1 ا - المزهر في علوم اللغة للسيوطي تح/محمد أبو الفضل إبراهيم وآخرين ط الحلبي דr

1 ا - المسائل البصريات لأبي علي الفارسي تحقيق ودراسة / محمد الثاطر أحمد محمد

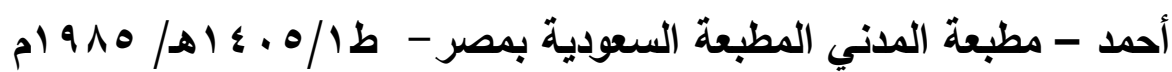
Y Y Y - المسائل الحلبيات للفارسي تحقيق / حسن هنداوي - دار القلم - دمشت . $9 \wedge V / \Delta 1 \leq \cdot V$

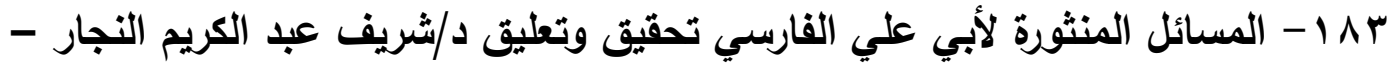

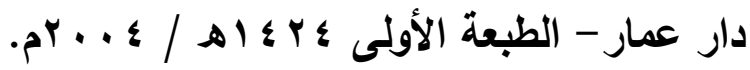

ـ 1 - المساعد على تسهيل الفوائد لابن عقيل ت.محمد كامل بركات - دار المدنى

$$
\text { م) } 91 \leq / 8 \text { \& } 1 \leq 0
$$

ه1 - المستقصي في أمثال العرب للزمخثري - دار الكتب العلمية بيروت لبنان

$$
\text { • } 9 \Lambda V
$$

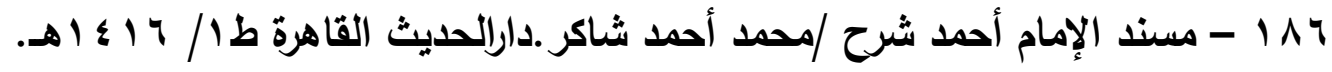

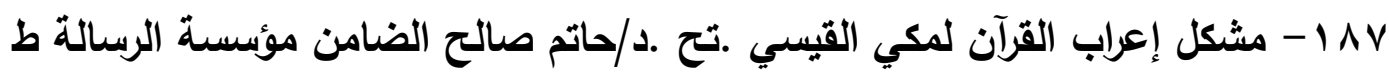

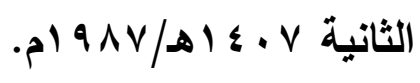

1 1 ا - المصباح المنير للفيومي - تحقيق د/ عبدالعظيم الثناوي - دار المعارف. 1 1 - معاني القراعات السبع وعللها للأزهري- تح / أحمد فريد المزيدى - دار الكتب

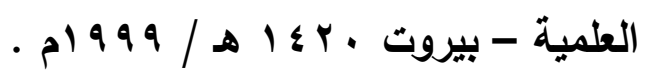

ـ 9 - معاني القرآن للأخفش ت د/فائد فارس-المطبعة العصرية - الكويت ط ـ . . ـ اهـ/

$$
\text { -p) } 9 \wedge 9
$$

19 9 - معانى القرآن للفراء - تح /محمد على النجار - الدار المصرية للتأليف والترجمة. 
فصل المقال في الغريب من الأقوال النحوية والتصريفية د / عبدالرعوف ثابت أحمد عبدالله

r 9 - معانى القرآن وإعرابه للزجاج - تحقيق الدكتور / عبد الجليل شلبى - عالم الكتب

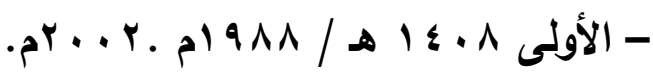

به 1 - معجم القراءات تأليف د/عبد اللطيف الخطيب - دار سعد الدين للطباعة وإلنشر

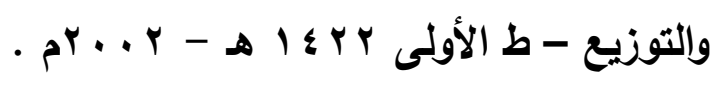

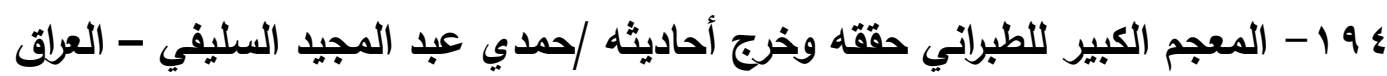

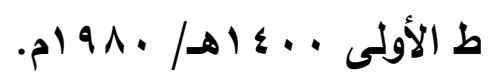

ه 9 - معجم ما استعجم من أسماء البلاد والمواضع للبكري تحقيق/ مصطفى السقا عالم الكتب بيروت.

צ 9 - المعجم المفصل في شواهد النحو الشعرية - إعداد - د/ إميل بليع يعقوب - دار

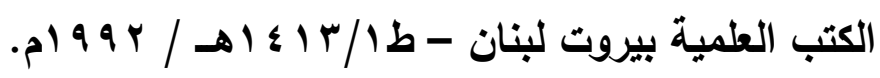

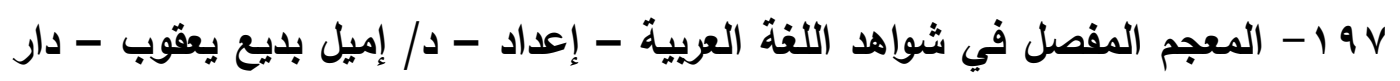

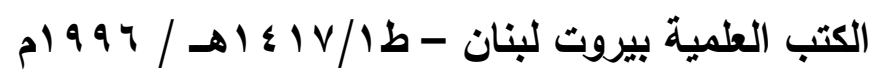
19 1 - مغنى اللبيب عن كتب الأعاريب لابن هشام الأنصاري - تحقيق / محيى الدين عبد الحميد - مطبعة المدني - القاهرة .

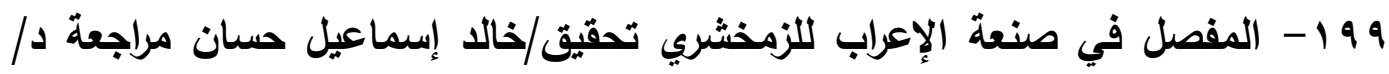

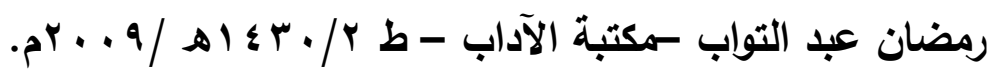

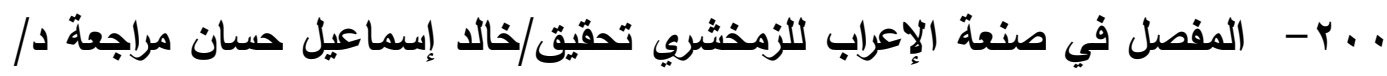

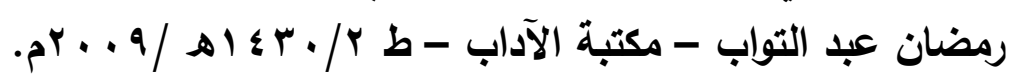

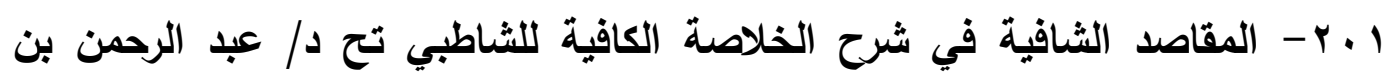

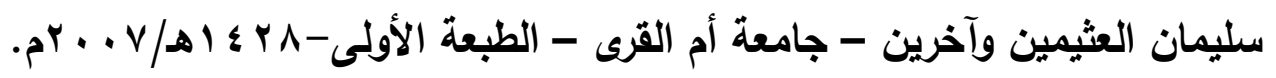

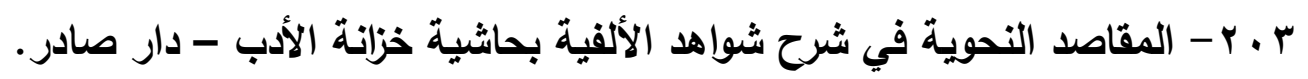

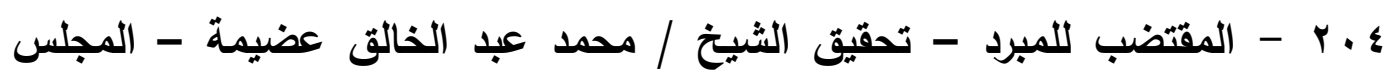

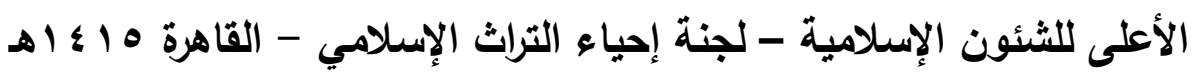

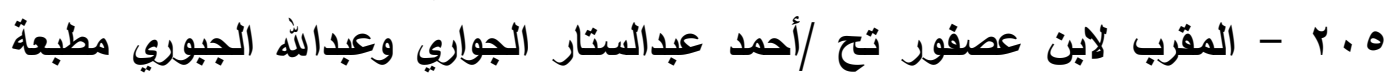

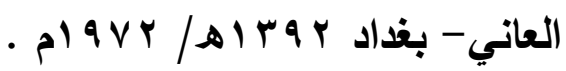


فصل المقال في الغريب من الأقوال النحوية والتصريفية د / عبدالرعوف ثابت أحمد عبدالله

צ · - الممتع في التصريف لابن عصفور - ت / فخر الدين قباوة - منشورات دار

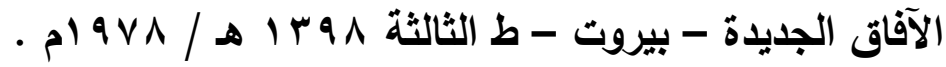

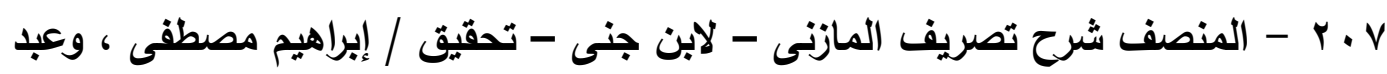

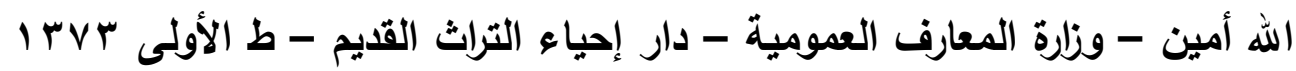

$$
\text { هـ } 90 \text { ه }
$$

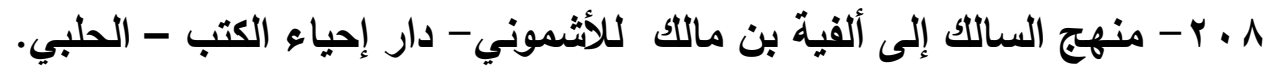

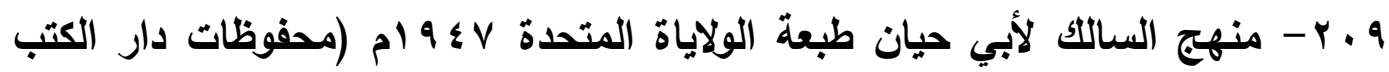

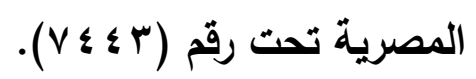

• 1 - موصل الطلاب إلى قواعد الإعراب تحقيق: عبدالكريم مجاهد - مؤسسة الرسالة

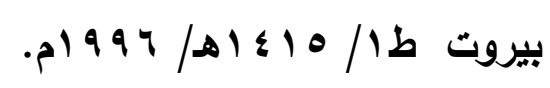

Iا - الموضح في وجوه القراعات وعللها - تأليف / نصر بن على بن محمد الثيرازي

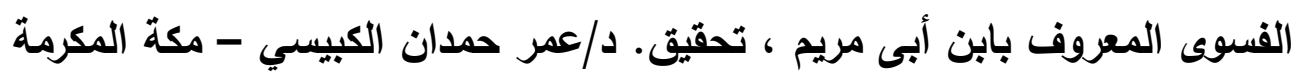

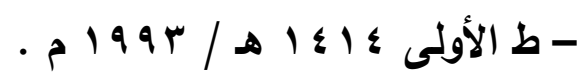

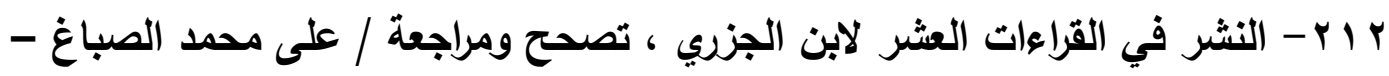

$$
\text { دار الكتب العلمية - بيروت - لبنان. }
$$

ץ ا ץ- نتائج الفكر في النحو للسهيلي تحقيق د/محمد إبراهيم البنا طץ/دار الرياض

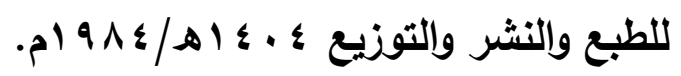

ـ اب - النهاية في غريب الحديث والأثر لابن الأثير تحقيق - أبو عبدالرحمن صلاح بن

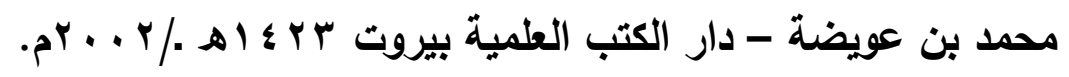

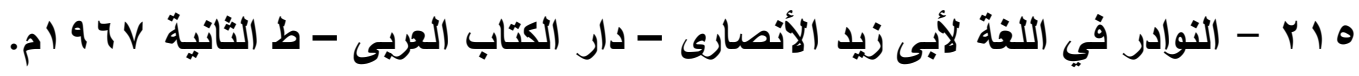
7 ا - همع الهوامع شرح جمع الجامع للسيوطي - عني بتصحيحه :السيد محمد بلر

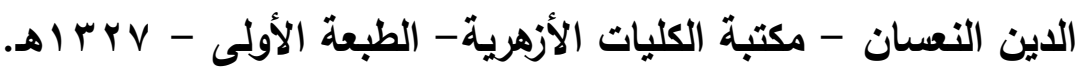


فصل المقال في الغريب من الأقوال النحوية والتصريفية د / عبدالرعوف ثابت أحمد عبدالله

فهرس موضومات البمث

\begin{tabular}{|c|c|c|}
\hline |لصفمة & المضوغ - المو & م \\
\hline & الاقتشمية & 1 \\
\hline & التمهميـــد & r \\
\hline & مفهوم الغريب & $\mu$ \\
\hline & مصطلحات لها علاقة بالغريب & $\varepsilon$ \\
\hline & أولاً : المطرد & $\bullet$ \\
\hline & ثنانياً : الشاذ & 7 \\
\hline & ثنالثاً : النادر & 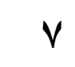 \\
\hline & رابعاً : الضعيف & $\Lambda$ \\
\hline & خامساً : الضرورة & 9 \\
\hline & الأقوال والآراء النموية الغريبة الأول & \\
\hline & 1 - تجريد التاء الاسمية عن الخطاب & $1 \cdot$ \\
\hline & r - تقديم الضمير على مفسره & 11 \\
\hline & r- الضمير في قوله : " رُدُوّهَا عَلَيَّ " للشمس & Ir \\
\hline & צ - إظهار متعلق الظرف والجار والمجرور & ir \\
\hline & 0- حرفية كان وأخواتها & $1 \varepsilon$ \\
\hline & צ- إعمال ليس مع اقتران خبرها بإلا & 10 \\
\hline & v- وني ، ورام من أخوات " ما زال " & 17 \\
\hline & ^- مجيء خبر عسى اسماً صريحاً & iv \\
\hline & 9- " لكن " مركبة من ثلاث كلمات & $1 \wedge$ \\
\hline
\end{tabular}


فصل المقال في الغريب من الأقوال النحوية والتصريفية د / عبدالرعوف ثابت أحمد عبدالله

\begin{tabular}{|c|c|}
\hline . 1- " لكننا " مركبة من " لكن " واسمها & 19 \\
\hline 1 1 - الفصل بين " إن " واسمها بالحال & $r \cdot$ \\
\hline r ا - إعمال إن الداخلة على " ما " الزائدة & Yl \\
\hline س ا -وقوع " أن " المخفقة بعد فعل التمني & $r r$ \\
\hline ع ا - " خُلِقَ " بمعنى " جُعِلَ " في التعدي & $r r$ \\
\hline ه 1-الاشتغال باسم الإشـارة & $r \varepsilon$ \\
\hline צا - حذف المقول ويقاء القول & ro \\
\hline I - حذف المنصوب مع بقاء عامل النصب & rq \\
\hline 1 ا - مجيع " إلا " زائدة ، ويمعنى " بعد " & $r v$ \\
\hline 9 19 - زيادة " لا " في " لا سيما " & $r \wedge$ \\
\hline • . - انتصاب الضمير على الحال & rq \\
\hline ا ب- التمييز المحول عن المبتدأ & $r$ \\
\hline r r - الجر بـ " لعل " & 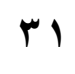 \\
\hline r r - مجيء اللام بمعنى الباء & rr \\
\hline ع ץ - من معاني الكاف المبادرة & $r \varepsilon$ \\
\hline هץ - زيادة الباء بين "عن" ومجرورها - زيادة الباء في اسم ليس & ro \\
\hline ج ץ - حذف التتوين من " كل " وينائها على الضم & r \\
\hline rv - ع عل فعيل ، وفعل من صيغ المبالغة & $\mu v$ \\
\hline ^r - إعراب المنصوب الواقع بعد حبذا & 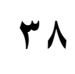 \\
\hline q r - حذف العائد المجرور مع الجار دفعة واحدة & rq \\
\hline سفه نس إعراب " نفسه " توكيلاً د " من سفه " من قوله \} إلا من & $\varepsilon$. \\
\hline
\end{tabular}


فصل المقال في الغريب من الأقوال النحوية والتصريفية د / عبدالرعوف ثابت أحمد عبدالله

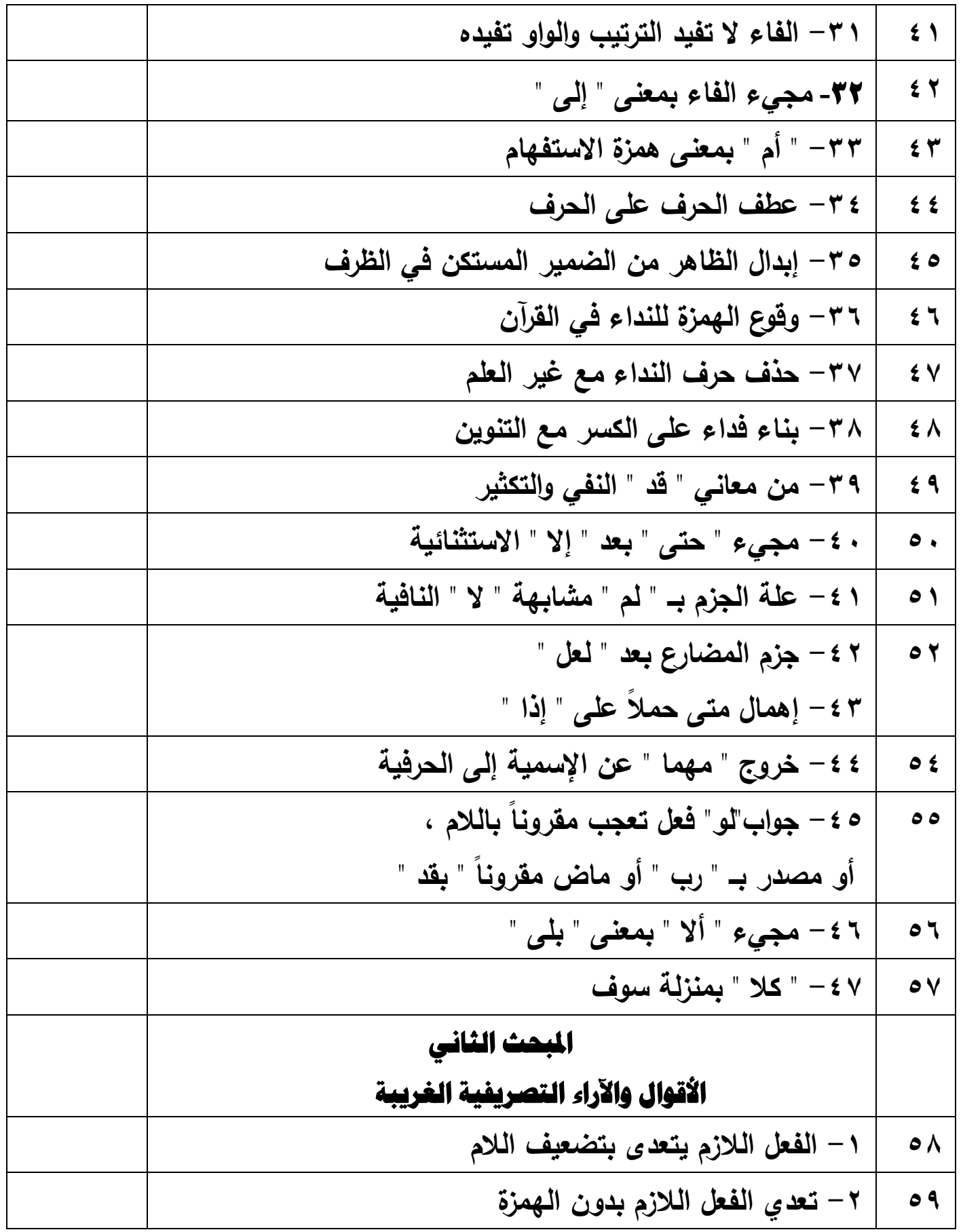


فصل المقال في الغريب من الأقوال النحوية والتصريفية د / عبدالرعوف ثابت أحمد عبدالله

\begin{tabular}{|c|c|c|}
\hline & r- تِفْعَال - بكسر التاء وسكون الفاء & 7. \\
\hline & ع - وزن " فيعال " من الصفات مثل " بيئاس " & 71 \\
\hline & هـ فَعْلَاءع مثثل ثَرَمداء من أبنية الممدود & $7 r$ \\
\hline & ج- تثثية العلم على وضعه & r \\
\hline & - جمع فُعال على أفعال مثل " غُثاء وأغثاء " & $7 \varepsilon$ \\
\hline & 1- حمع فعيل على أفعلاء مثل : هين وأهيناء & 70 \\
\hline & 9 - مخالفة الجمع لمفرده & 97 \\
\hline & . & TV \\
\hline & | 1 - لفظ " الرحمن " بين العربي والمعرب & 91 \\
\hline & 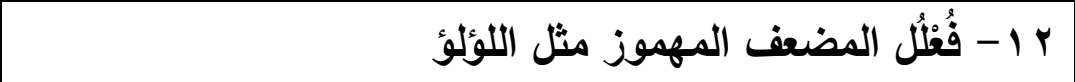 & 99 \\
\hline & ب ا - " فَعيلة " من الصيخ قليلة الاستعمال & V. \\
\hline & ع 1 - تركيب " يوم " & $v_{1}$ \\
\hline & ه - الأصل في كلمة " ويل " & VY \\
\hline & ح 1 - زيادة السين قبل الفاء بدون التاء " سفعل " & VY \\
\hline & IV - إثبات همزة الوصل مع الاستغناء عنها & $V \varepsilon$ \\
\hline & ^ ا - إبدال الياء من الهمزة & $V \varepsilon$ \\
\hline & الخاتمة & Vo \\
\hline & فهرس أهم المراجع والمصادر & $V_{7}$ \\
\hline & فهرس موضوعات البحث & $V V$ \\
\hline
\end{tabular}

